Florida International University

FIU Digital Commons

FIU Electronic Theses and Dissertations

University Graduate School

$11-8-2019$

\title{
Charles A. Dana, the Civil War Era, and American Republicanism
}

Eric X. Rivas

eriva002@fiu.edu

Follow this and additional works at: https://digitalcommons.fiu.edu/etd

Part of the Intellectual History Commons, Political History Commons, and the United States History Commons

\section{Recommended Citation}

Rivas, Eric X., "Charles A. Dana, the Civil War Era, and American Republicanism" (2019). FIU Electronic Theses and Dissertations. 4347.

https://digitalcommons.fiu.edu/etd/4347

This work is brought to you for free and open access by the University Graduate School at FIU Digital Commons. It has been accepted for inclusion in FIU Electronic Theses and Dissertations by an authorized administrator of FIU Digital Commons. For more information, please contact dcc@fiu.edu. 


\title{
FLORIDA INTERNATIONAL UNIVERSITY
}

Miami, Florida

CHARLES A. DANA, THE CIVIL WAR ERA, AND AMERICAN REPUBLICANISM

\author{
A dissertation submitted in partial fulfillment \\ of the requirements for the degree of \\ DOCTOR OF PHILOSOPHY \\ in \\ HISTORY \\ by \\ Eric Rivas
}

2019 
To: Dean John F. Stack, Jr.

Steven J. Green School of International and Public Affairs

This dissertation, written by Eric Rivas, and entitled Charles A. Dana, the Civil War Era, and American Republicanism, having been approved in respect to style and intellectual content, is referred to you for judgment.

We have read this dissertation and recommend that it be approved.

$\begin{array}{r}\hline \text { Jessica Adler } \\ \hline \text { Clement Fatovic }\end{array}$

Darden A. Pyron, Co-Major Professor

Gwyn Davies, Co-Major Professor

Date of Defense: November 8, 2019

The dissertation of Eric Rivas is approved.

Dean John F. Stack, Jr.

Steven J. Green School of International and Public Affairs

Andrés G. Gil

Vice President for Research and Economic Development and Dean of the University Graduate School

Florida International University, 2019 
ABSTRACT OF THE DISSERTATION

CHARLES A. DANA, THE CIVIL WAR ERA, AND AMERICAN REPUBLICANISM

by

Eric Rivas

Florida International University, 2019

Miami, Florida

Professor Gwyn Davies, Co-Major Professor

Professor Darden A. Pyron, Co-Major Professor

When Charles A. Dana bought the New York Sun in 1868, he used it to support the presidential candidacy of Ulysses S. Grant and the Republican Party ticket to unify the post-Civil War nation. After a victory for the Civil War general and Republican Party, though, the first fifteen months of the new administration turned the editor against the president and his party. Dana's Sun criticized Grant and his allies as corrupt, of using the military for political ends, and of growing the size and power of government beyond traditional American practice. Against the backdrop of Reconstruction, Dana also decried the Grant administration's foreign policy, especially regarding the ongoing war in Cuba. This dissertation explores how Dana's interpretation of republican values clashed with the American response to transatlantic politics to justify further criticism of the president and his party between March 1869 and the election of 1872 . 


\section{TABLE OF CONTENTS}

CHAPTER

PAGE

INTRODUCTION

I. CHAPTER ONE: FOUNDATIONAL INTELLECTUAL INFLUENCES FROM BUFFALO TO BROOK FARM (1810 - 1847)

II. CHAPTER TWO: IDEOLOGY AND PARTY POLITICS (1848 - 1856)

III. CHAPTER THREE: BELLIGERENT PARTY POLITICS $(1856$ - 1867) 102

IV. CHAPTER FOUR: ANTI-REPUBLICANISM AND

CRITICISM OF THE GRANT PRESIDENCY (1868 - MID - 1870)

132

V. CHAPTER FIVE: REJECTING GRANT'S FOREIGN POLICY

TOWARD THE CUBAN REVOLUTION (1868 - MID - 1870)

180

VI. CHAPTER SIX: CONTINUTED OPPOSITION

TO GRANT'S RECONSTRUCTION POLICY (MID - 1870 - 1872)

VII. CHAPTER SEVEN: REPUBLICAN VISIONS IN FOREIGN

POLICY INFLUENCE AMERICAN PARTY POLITICS (MID -1870 - 1872)

CONCLUSION

VITA 


\section{ABBREVIATIONS AND ACRONYMS}

*Associationism: a set of ideas/political philosophy associated with the American version of Fourierism, the ideology created by French philosopher Charles Fourier that found followers in the United States between the 1830s and 1840s. These ideas are not connected to the self-labeled Associationalist ideas calling for private and community responses to the Great Depression by Herbert Hoover in the 1920s.

*Communitarianism: a political philosophy associated with the utopian-inspired ideas of Henry de Saint-Simon, Robert Owen, Charles Fourier, George Ripley and others. In the United States, the community at Brook Farm (1841-1847) is an ideal example. Communitarians emphasized the egalitarian spirit of republicanism and often were open to experiments in communal living, alternative family organization popular in the first half of the nineteenth century.

*Communism: a set of ideas/political philosophy that emphasizes the aspects of permanent violent revolution against capitalism and its structural influences. It opposed the ideas of socialism in Dana's time, which insisted on a relatively peaceful transition of the existing capitalist system in a more republican direction.

*Liberalism: a set of ideas/political philosophy associated with the collection of ideas generally included under the banner of the term, like- equality, individuality rationalism, anti-slavery, freetrade, and the state protection of private property.

*Republicanism: a set of ideas/political philosophy associated with civic virtue, communitarianism, egalitarianism, economic nationalism, anti-corruption, and anti-monarchism. It also has strong connections to small government ideologies, and broad fear of standing armies and militarism. The use of the term is not meant to connote any direct connection to the Republican Party at any point in the dissertation. In the Civil War era, however, republican ideas made up a strong segment of the Republican Party platform. During Reconstruction, however, this connection shifted, drawing Dana to make the major changes in political affiliation that make up the majority of the dissertation.

*Socialism: a set of ideas/political philosophy associated with the generally non-violent approach to reforming corporate and industrial capitalism. In Dana's period, the term socialist had wide ranging connotations, but in my employment of the term, I use to describe economic reform of capitalism with republican inspired policies while also embracing the larger structure of the social, economic, and political makeup of the American system of life. 


\section{INTRODUCTION}

As an Undersecretary of War in 1863, Charles Anderson Dana (1819-1897) won a permanent, if minor, place in the history of the Civil War by helping convince his chiefs, Secretary of War Edwin Stanton and president Abraham Lincoln, to salvage General Ulysses S. Grant's career, when many wanted him cashiered. Six years later Dana, now a newspaper editor and owner, helped co-author a campaign biography of the general in support of Grant's candidacy as the Republican Party's nominee for president. Within a year, however, Dana famously refused to continue defending Grant, the administration, or the Republican Party that supported the president instead, becoming its loudest critic. Dana's enemies - including the administration itself — charged Dana as a frustrated job-seeker and cynical newspaperman. This characterization of Dana - a spited, and selfish, ankle-biter to the president — is the standard portrait found in most historiographical accounts of Dana. The editor of the vastly popular New York Sun responded to these charges by insisting that his public record since the 1840 s illustrated a set of steady ideological commitments - transatlantic republican perspectives - that best explained his behavior between 1869 and 1872 . If never really a politician nor a soldier, his life and career as a journalist and public intellectual merit a closer and more detailed examination. Indeed, his biography reflects the complexities of nineteenth century American and transatlantic politics, as well as a myriad of socio-political connections between region, nation, and even international events. This dissertation presents three inter-related investigations: it studies Dana's commitment to the ideas of civic virtue, communitarianism, and egalitarianism in early adulthood; explains how his transition from a pacifist understanding of republicanism in the $1840 \mathrm{~s}$ and $1850 \mathrm{~s}$ transformed into a belligerent defense of those ideas in the Civil War era; and explains how these very ideas informed his rejection of President Grant and the Republican Party during Reconstruction. This project scrutinizes Dana's biography to make this case in detail: Dana's 
established vision for nation and world in the Civil War era fueled his opposition with the policy approaches of President Ulysses S. Grant's administration and its Republican allies.

This dissertation makes the argument that Dana's earliest ideological foundations developed around a classically republican worldview. Dana grew to embrace these ideas while in Buffalo, New York, next at Harvard and the Brook Farm commune, and that these ideas were then further stimulated at the New York Tribune and the War Department during the Civil War, continuing into his purchase of the New York Sun in 1868. Readers familiar with the genealogy of the republican synthesis will know that defining republicanism and its precise role in American history can be difficult. Traditional understandings of the American founding suggested that the Founders most embraced the classically liberal ideas of John Locke, and the other social contract theorists, whose philosophy stressed individualism, the inviolability of private property, the rejection of chattel slavery, and the voluntary understanding of contract-like bonds joining citizens to their government. Scholars propagating a republican synthesis maintained that the founders did, in fact, find inspiration in the Classical period, the Italian Renaissance, the English Civil War, and the Enlightenment. ${ }^{1}$ The works these historians published pointed to those era's fascination with the structure of the republic and concomitant "republican" values of civic virtue, egalitarianism, and community-mindedness. ${ }^{2}$ What followed were heated debates about the extent

\footnotetext{
${ }^{1}$ Bernard Bailyn, The Ideological Origins of the American Revolution (Cambridge: Belknap Press of Harvard University Press, 1967); Gordon S. Wood, The Creation of the American Republic, 1776-1787 (Chapel Hill: University of North Carolina Press, 1969); J.G.A. Pocock, The Machiavellian Moment: Florentine Political Thought and the Atlantic Republican Tradition (Princeton: Princeton University Press, 1975).

${ }^{2}$ Useful summaries of the interplay between these ideas can be found in: Geoffrey C. Kellow and Neven Leddy, eds. On Civic Republicanism: Ancient Lessons for Global Politics (Toronto: University of Toronto Press, 2016); Douglas Moggach, ed., On Civic Republicanism: Ancient Lessons for Global Politics (Toronto: University of Toronto Press, 2016); Ed White, "The Ends of Republicanism," Journal of the Early Republic 30, no. 2 (Summer, 2010): 179 - 199; Paul Weithman, "Political Republicanism and Perfectionist Republicanism," The Review of Politics, 66:2 (Spring, 2004): 285-312; Alan Gibson, "Ancients, Moderns, and Americans: the Republicanism-Liberalism Debate Revisited," History of Political Thought 21, No. 2 (Summer 2000): 261 - 307; Michael J. Sandel, "Liberalism and Republicanism: Friends or Foes? A Reply to Richard Dagger," The Review of Politics 61, no. 2 (Spring, 1999): $209-214$.
} 
of republicanism's influence on the Founding alongside liberalism, and other ideologies. This dissertation does not engage this idea. Instead, it studies how Dana's use, and understanding, of republican themes motivated his understanding of American history and the Civil War era.

Historian John G. Grove, in a recent analysis of the antebellum South Carolina Senator John C. Calhoun's embrace of classical republicanism, provides a cogent summary of what qualities of thought, expression, and action show commitment to the ideology. He explains that "classical republicanism considers the political state to be natural in some essential way," emphasizing the citizen's "role as a citizen of a particular community." The republican believes that the individual "is bound to and by the community into which he is born." ${ }^{3}$ Grove explains that classical republicanism "concerns itself with civic virtue and the prerequisites for free government." Citizens must have "the requisite and intellectual virtue" to show themselves "capable of ruling themselves and acting in the best interests of their community." Grove emphasizes that republicans fear the influence of corruption within individuals or rival factions, and saw these three points as potential checks to demagoguery or corruption in government. ${ }^{6}$ Critically, as well, the classical republican fears the influence of militarism and the role that standing armies have had throughout history in superseding the political power of the citizen. ${ }^{7}$ These themes permeated

\footnotetext{
${ }^{3}$ John G. Grove, John C. Calhoun's Theory of Republicanism (Lawrence: University Press of Kansas, 2016), 6 .

${ }^{4}$ Ibid.

${ }^{5}$ Ibid.

${ }^{6}$ Ibid, $6-7$.

${ }^{7}$ For more on the debate surrounding militarism and standing armies within republican theory, see: Manjeet Ramgotra, "Conservative Roots of Republicanism," Theoria: A Journal of Social and Political Theory 61, No. 139 (June 2014): 22 - 49; Andrew F. Lang, "Republicanism, Race, and Reconstruction: The Ethis of Military Occupation in Civil War America," Journal of Civil War America 4, No. 4 (December 2014): 559 - 589; Daniel H. Deudney, Bounding Power: Republican Security Theory from the Polis to the Global Village (Princeton: Princeton University Press, 2007); Daniel T. Rodgers, "Republicanism: the Career of a Concept," The Journal of American History 79, No. 1 (June 1992): 11 38.
} 
Dana's early intellectual interests and political commitments, requiring any study of the intellectual influences on his life (particularly a study on why he turned so forcefully on President Grant in 1869; or why looked so consistently to examples in international affairs to make points about American politics) to center on the role of republicanism in motivating his choices.

Dana's biographical chronology provides a suitable framework to analyze the change over time in the intensity of his republican beliefs. Born in 1819 New Hampshire to an old New England family, Dana grew up further west — at the centers of Northern New York state's hubs of trade and immigrant culture. ${ }^{8}$ Buffalo, famed for its diverse array of religious, political, social, racial, and national traditions enriched Dana's childhood interest in transatlantic society. His focus on European culture remained one consistent characteristic of Dana's entire life, traceable to the multicultural atmosphere of the Erie Canal corridor in the $1820 \mathrm{~s}$ and $1830 \mathrm{~s} .{ }^{9}$ Dana worked as an accountant at his uncle's dry goods shop, immersed himself in Buffalo's immigrant and Native American life, learned multiple languages, and educated himself in European literature and philosophy in his free time. He yearned to go to Europe, the German states especially, and was said to have a "Continental" bent. ${ }^{10}$ While among Buffalo's competing cultural influences, Dana developed business savvy, transatlantic perspectives, and intellectual and religious skepticism (all without formal schooling). He read the works of Baruch Spinoza, G.W. Hegel,

${ }^{8}$ Elizabeth Ellery Dana, The Dana Family in America (Cambridge: Wright \& Potter Printing Company, 1956).

${ }^{9}$ For more on the multicultural demography and intellectual makeup of Buffalo, see: David A. Gerber, The Making of an American Pluralism: Buffalo, New York, 1825-60 (Champaign: University of Illinois Press, 1989); Donald H. Parkerson, "The Structure of New York Society: Basic Themes in Nineteenth-Century Social History," New York History 65, no. 2 (April 1984): 159-187; Whitney Cross, The Burned-Over District: The Social and Intellectual History of Enthusiastic-Religion in Western New York, 1800-1850 (New York: Harper \& Row, 1950).

${ }^{10}$ James Harrison Wilson, The Life of Charles A. Dana (New York: Harper, 1907), 3. Wilson, Dana's earliest biographer, remembered that as long as he had known him, Dana appeared to have a "slight strain of Continental blood in his veins." 
Friedrich Schleiermacher, Johann Gottlieb Fichte, Emmanuel Swedenborg and the Romantics Samuel Coleridge and Thomas Carlyle - all famed Biblical skeptics and contributors to the republican worldview. ${ }^{11}$ Letters from Dana to friends reveal how deeply he felt religion like these men did, shared their aversion to religious orthodoxy and focused on worldly social reform. Dana embraced the liberal Protestantism and social gospel impulse of the region he lived in (that part of an area in upstate New York lumped into a large midwestern area called the "Burned Over District" because of how quickly new evangelical movements swept through the hearts of residents). ${ }^{12}$ Dana's religious curiosity and scholarly acumen gained him the friendship of prominent Buffalonians (such as Dr. Austin Flint), as well as entry into the city's intellectual circles (the Young Men's Association). Dana took this perspective to Harvard where in 1839 his admission was no small feat given that he was self-educated. The twenty-year old immersed himself further in metaphysics, epistemology, and philosophy of religion, spending considerable time in library stacks stocked with works he could never read back home. Liberal protestant movements, concomitant to a resurgence in Romanticism and social reform Protestantism, spread across eastern Massachusetts in this period. That placed Dana at a philosophical epicenter of the

\footnotetext{
${ }^{11}$ For more on the thought of these thinkers that grasped Dana's attention, see: Nicholas Halmi, "Coleridge's Ecumenical Spinoza," in Spinoza Beyond Philosophy, ed. Beth Lord (Edinburgh: University of Edinburgh, 2012), 189-190; Gary Lachman, Swedenborg: An Introduction to His Life and Ideas (New York: Tarcher/Penguin, 2012); Jacqueline Mariña, The Cambridge Companion to Friedrich Schleiermacher (New York: Cambridge University Press, 2005); Richard Holmes, Coleridge (New York: Pantheon Books, 1999); Thomas A. Howard, Religion and the Rise of Historicism: W.M.L. de Wette, Jacob Burckhardt, and the Theological Origins of Nineteenth-Century Historical Consciousness (New York: Cambridge University Press, 1999); Walter Jackson Bate, Coleridge (Cambridge: Harvard University Press, 1973).

${ }^{12}$ For more on the "Burned Over" District of antebellum America, see: Cross, The Burned-Over District; Glenn Altschuler and Jan M. Saltzgaber, Revivalism, Social Conscience and Community in the BurnedOver District: The Trial of Rhoda Bement (Ithaca: Cornell University Press, 1983); Linda K. Pritchard, "The Burned-over District Reconsidered: A Portent of Evolving Religious Pluralism in the United States," Social Science History 8, no. 3 (Summer 1984): 243-265; David L. Rowe, Thunder and Trumpets: Millerites and Dissenting Religion in Upstate New York, 1800-1850 (Decatur: Scholars Press, 1985); Michael Barkun, Crucible of the Millennium: The Burned-Over District of New York in the 1840s (Syracuse: Syracuse University Press, 1986); Curtis D. Johnson, Islands of Holiness: Rural Religion in Upstate New York, 1790-1860 (Ithaca: Cornell University Press, 1989).
} 
American world. One of the movements exploding across the region, often called

Transcendentalism ${ }^{13}$ (but included many themes that were part of the much broader and

influential Second Great Awakening occurring across the transatlantic), encouraged Christians to

improve the physical world around them as they sought personal communion with their spiritual

God. ${ }^{14}$ The popularity of the movement reflects the extent to which many New Englanders like

Dana sought out new ideas to solve old problems. ${ }^{15}$ One of the scions of the movement - the

Massachusetts preacher, writer, reformer, and Harvard graduate George Ripley — became one of

Dana's favorite contemporary social philosophers (reading his books, listening to his local

speeches, and sitting in on occasional lectures given at Harvard). ${ }^{16}$ Ripley combined Romanticism

\begin{abstract}
${ }^{13}$ For more on the influence of the spread of social reform Protestantism in this period, see: Justin Rowe, "New Wine in Old Wineskins: Social Structure and the Making of $19^{\text {th }}$ Century American Calvinism (PhD diss. Michigan State University, 2015); David Dowling, Emerson's Protégés: Mentoring and Marketing Transcendentalism's Future (New Haven: Yale University Press, 2014); David Morse, American Romanticism (London: Palgrave MacMillan, 2014); Thomas J. Davis, John Calvin's American Legacy (New York: Oxford University Press, 2010); John Witte, The Reformation of Rights: Law, Religion, and Human Rights in Early Modern Calvinism (Cambridge: Cambridge University Press, 2007); Michael T. Gilmore, American Romanticism and the Marketplace (Chicago: University of Chicago Press, 1985); Stephen Prickett, Origins of Narrative: The Romantic Appropriation of the Bible (Cambridge: Cambridge University Press, 1996); Jean Raimond and J.R. Watson, A Handbook to English Romanticism (New York: St. Martin's Press, 1992); Richard A. Grusin, Transcendentalist Hermeneutics: Institutional Authority and the Higher Criticism of the Bible (Durham: Duke University Press, 1990).
\end{abstract}

${ }^{14}$ For more on the Second Great Awakening, see: R. Laurence Moore, Religious Outsiders and the Making of Americans (New York: Oxford University Press, 1986); Jon Butler, Awash in the Sea of Faith: Christianizing the American People (Cambridge: Harvard University Press, 1990); Frank Lambert, Inventing the 'Great Awakening' (Princeton: Princeton University Press, 1999); E. Brooks Holifield, Theology in America: Christian Thought from the Age of the Puritans to the Civil War (New Haven: Yale University Press, 2003); Thomas S. Kidd, The Great Awakening: The Roots of Evangelical Christianity in Early America (New Haven: Yale University Press, 2007); Daniel C. Goodwin, Into Deep Waters: Evangelical Spirituality and Maritime Calvinistic Baptist Ministers, 1790-1855 (Montreal: McGill-Queen's University Press, 2010).

${ }^{15}$ For more on Harvard when Dana attended, see: Stephen Shoemaker, "The Emerging Distinction between Theology and Religion at Nineteenth-Century Harvard University," The Harvard Theological Review 101, no. 3-4, Centennial Issue (Jul.-Oct., 2008): 419; Ronald R. Story, "Harvard Students, the Boston Elite, and the New England Preparatory System, 1800-1876," History of Education Quarterly 15, no. 3 (Autumn, 1975): 281-298; Daniel Walker Howe, The Unitarian Conscience: Harvard Moral Philosophy, 1805 1861 (Cambridge: Harvard University Press, 1970); Samuel Eliot Morison, Three Centuries of Harvard (Cambridge: Harvard University Press, 1936).

${ }^{16}$ For more on George Ripley and his ideas, see: Patrick Labriola, "Germany and the American Transcendentalists: An Intellectual Bridge," The Concord Saunterer 6 (1998): 98-113; Joel Myerson, "New 
and early socialism to make critiques of industrial capitalism and offering communitarian solutions. Dana was sympathetic to the ideals of social justice, economic redistribution, individual and societal perfection, and civic virtue that made up Ripley's worldview. At Harvard Dana cultivated a relationship with Ripley and gained an invitation to the utopian commune Ripley was organizing at West Roxbury, Massachusetts called Brook Farm. Ripley hoped to make the community embody his republican worldview, taking Dana with him.

At Brook Farm, Dana embraced Ripley's republican ethos of social responsibility and communal living. Dana developed this sympathy for these ideas while helping run the utopian community with Ripley, and lived with reformers like Margaret Fuller, Timothy Dwight, and Orestes Brownson. This placed him at the center of some of the highest intellectual circles of New England. A brilliant linguist, Dana, by 1845, had risen to second in command at the collective and helped edit its newsletter, The Harbinger. ${ }^{17}$ He supported the community's movement towards Associationism, an American offshoot of the French utopian philosophy of Joseph Fourier, and became a public advocate of the movement. ${ }^{18}$ Dana's commitment to the

Light on George Ripley and the Harbinger's New York Years," Harvard Library Bulletin 32 (Summer 1985): 313-336; David A. Zonderman, “George Ripley's Unpublished Lecture on Charles Fourier," Studies in the American Renaissance (1982): 185-208; Charles R. Crowe, George Ripley (Athens: University of Georgia Press, 1967); Joseph Slater, "George Ripley and Thomas Carlyle," Proceedings of the Modern Language Association 67, no. 4 (June 1952): 341-349.

${ }^{17}$ Ellis Shookman, "Brook Farm and Beyond: German Thought and Literature in 'The Harbinger,' 18451849," German Studies Review 34, no. 3 (October 2011): 575; Stanley M. Vogel, German Influences on the American Transcendentalists (New Haven: Yale University Press, 1955); Joel Myerson, "New Light on George Ripley and the Harbinger's New York Years," Harvard Library Bulletin 32 (Summer 1985): 313336.

${ }^{18}$ For more on "Associationism," and Fourierism in the United States, see: Carl J. Guarneri, The Utopian Alternative: Fourierism in Nineteenth-Century America (Ithaca: Cornell University Press, 1994); Sterling F. Delano, "French Utopianism on American Soil: Six Unpublished Letters by Victor Considerant," Nineteenth-Century French Studies 13, no. 2/3 (Winter-Spring, 1985): 59-64; Carl J. Guarneri, "Utopian Socialism as a Transatlantic Movement," paper presented to the Charles Warren Seminar for Boston Area Historians of American History, Harvard Univ., April 7, 1982; Robert C. Hauhart, " $19^{\text {th }}$ Century Labor Money Schemes, Self Realization through Labor, and the Utopian Idea," World Review of Political Economy" 3, no. 2 (Summer 2012) 177-190; Lloyd Jenkins, "Fourierism, Colonization and Discourses of Associative Emigration, Area 35, no. 1 (Mar., 2003) 84-91. 
belief that individuals could band together, by choice, to ensure the safety of communities by living with a spirit of sharing and citizenship was at the heart of these efforts. ${ }^{19}$ The economic crises of the late 1830 s and early 1840 s — the Panic of 1837 and its ensuring recession ${ }^{20}$ — had helped inspire Ripley to create the community. The same focus encouraged Dana's embrace of a type of social gospel. Brook Farm began as an alternative to the developing industrial-capitalist system - Ripley rejected the concept of wages and built the commune to have support systems for exchanging labor for goods while prioritizing classical education and training in skilled trades. To accentuate the values of the community Dana and many of the others drew on the ideas of Joseph Fourier. His theories joined various other mid-century theories that proposed alternatives to the developing transatlantic network of industrialism and capitalism that Associationism similarly critiqued. ${ }^{21}$ Unlike the belligerence of some of these ideologies, Associationism disavowed violence as an instrument of change - choosing instead a pacifist alternative to

\footnotetext{
${ }^{19}$ For more on Brook Farm, see: Sterling F. Delano, “'We Have Abolished Domestic Servitude:' Women at Work at Brook Farm," in Toward a Genealogy of Transcendentalism (Athens: University of Georgia Press, 2014); Katherine Burton, Paradise Planners: The Story of Brook Farm (New York: Longmans, Green and Co., 1939); Lindsay Swift, Brook Farm: Its Members, Scholars, and Visitors (New York: MacMillan Company, 1900), $203-260$.

${ }^{20}$ For more on the Panic of 1837, see: Jessica M. Lepler, The Many Panics of 1837: People, Politics, and the Creation of a Transatlantic Financial Crisis (Cambridge: Cambridge University Press, 2013); Alasdair Roberts, America's First Great Depression: Economic Crisis and Political Disorder after the Panic of 1837 (Ithaca: Cornell University Press, 2013).
}

${ }^{21}$ Andrew Zimmerman, "From the Second American Revolution to the First International and Back Again: Marxism, the Popular Front, and the American Civil War," in The World the Civil War Made, ed. Gregory P. Downs and Kate Masur (Chapel Hill: University of North Carolina Press, 2015); Gareth Stedman-Jones, "Radicalism and the Extra-European World: the Case of Karl Marx," in Victorian Visions of Global Order: Empire and International Relations in Nineteenth Century Political Thought, ed. Duncan Bell (Cambridge: Cambridge University Press, 2007), 186 - 214; Maurizio Isabella and Konstantina Zanou, Mediterranean Diasporas: Politics and Ideas in the Long $19^{\text {th }}$ Century (London: Bloomsbury Academic, 2016); Peter Ryley, Making Another World Possible: Anarchism, Anti-Capitalism, and Ecology in Late $19^{\text {th }}$ and Early $20^{\text {th }}$ Century Britain (New York: Bloomsbury Academic, 2013); Colin J. Beck, "The World-Cultural Origins of Revolutionary Waves: Five Centuries of European Contention," Social Science History 35, no. 2 (Summer 2011): 167-207; Roman Szporluk, Communism and Nationalism: Karl Marx and Friedrich List (New York: Oxford University Press, 1988); Paul E. Corcoran, Before Marx: Socialism and Communism in France, 1830-1848 (London: MacMillan, 1983); Theda Skocpol and Ellen Kay Trimberger, "Revolutions and the World-Historical Development of Capitalism," Berkeley Journal of Sociology 22 (1977-78): 101113. 
capitalism. Brook Farm and the Associationist movement transformed the bookish Dana into a radical for republicanism, faithful to the possibilities of peaceful reform. Dana did not remain at Brook Farm for long, as the newly complete phalanstery (or main community house) burned down forcing the community to close. In 1846 he moved to Boston to coordinate the broader Associationist movement. He continued to publish the Harbinger there. He also gave speeches across the northeast promoting Associationist ideas and found additional work at Elizur Wright's Boston Chronicle, where he gained a reputation amongst its readers as a progressive editor eager to shake up the paper's more traditional protestant outlook. ${ }^{22}$ Through his work as a popularizer of Associationism, Dana met the famous newspaper editor and social reformer Horace Greeley, owner of the popular New York Tribune. Collecting activists like Margaret Fuller and Arthur Brisbane as writers, Greeley offered Dana a job as an editor for his paper where he rose rapidly to the post of managing editor, covering both city and international news.

Dana's cosmopolitanism attracted him to use his new post to understand the implications of European crises on mid-nineteenth century American politics. At the Tribune he was at the center of transatlantic intellectual culture. ${ }^{23}$ The issues that drew his interests focused on political economy, communitarianism, and republican ideas. Weeks after he joined the paper republicaninspired revolutions had spread across France, the German states, and a host of other countries. Dana wanted to witness the anti-royalist movement in Paris, most specifically, because there Fourierist ideas he helped propagate in the United States had some part to play in toppling Louis Phillipe. ${ }^{24}$ The tour of duty introduced him to Karl Marx, Friedrich Engels, Joseph Proudhon,

\footnotetext{
${ }^{22}$ Lawrence B. Goodheart, Abolitionist, Actuary, Atheist: Elizur Wright and the Reform Impulse (Kent: Kent State University Press, 1990).

${ }^{23}$ Adam-Max Tuchinsky, Horace Greeley's New York Tribune: Civil War-Era Socialism and the Crisis of Free Labor (Ithaca: Cornell University Press, 2009); Coy F. Cross II, Go West Young Man! Horace Greeley's Vision for America (Albuquerque: University of New Mexico Press, 1995).

${ }^{24}$ For more on Napoleonic France and the causes of the revolution that so gripped the attention of Americans like Dana, see: Fenton S. Bresler, Napoleon III: A Life (London: Harper Collins. 2000); William
} 
Bruno Bauer, Victor Considerant, and other revolutionary leaders across Europe. ${ }^{25}$ This collection of renowned figures made up a seeming pantheon of left-of-center reform. Dana could not have obtained a better set of accounts from which to measure the European conflicts that he was using to test his ideological commitments. The European Revolutions of 1848 changed Dana's life. Critically they weakened his faith in pacifist, Fourierist-inspired ideologies. Peaceful political compromise failed to inspire the and revolution failed across Europe. Was it only the case, he must have thought, that reform needed to come through violence? Did it also require formal political participation? Upon returning to the United States, Dana's experiences observing the tumultuous revolutions reaffirmed the supremacy of the more conservative, pacifistic interpretation of republicanism that stressed working within the American constitutional system. ${ }^{26}$ The revolutions taught him that the utopian aims of the European Revolutions needed to be more

E. Echard, Napoleon III and the Concert of Europe (Baton Rouge: Louisiana State University Press, 1983); Henry Weber Casper, "American Attitudes Toward the Rise of Napoleon III; A Cross Section of Public Opinion" (PhD diss., Catholic University of America Press, 1947).

${ }^{25}$ For more on Dana's time in Europe as correspondent for the Tribune see: Timothy Mason Roberts, Distant Revolutionaries: 1848 and the Challenge to American Exceptionalism (Charlottesville: University of Virginia Press, 2009); Pamela Pilbeam, French Socialists before Marx (Montreal: McGill-Queen's University Press, 2000); Michael Rapport, 1848: Year of Revolution (New York: Basic Books, 2010); Lewis Namier, 1848: The Revolution of the Intellectuals (Oxford: Oxford University Press, 1993). For the published articles that Dana wrote for the paper, see these articles from the Tribune: "Sympathy with the French Revolution in Boston," Harbinger 6 (April 15, 1848): 195; "Response to the French Revolution," 6 (April 8, 1848), 179 - 181; Harbinger 7, no. 14 (July 11, 1848): 109; "The Parisian Insurrection," The Harbinger 7 (July 22, 1848): 89; "The Present and Future of Germany," Harbinger 8, no. 3 (Nov. 18, 1848): 18.

${ }^{25}$ For more on Proudhon, Bauer, Considerant, and other European reformers in the period, see: Alex Prichard, Justice, Order and Anarchy: The International Political Theory of Pierre-Joseph Proudhon (Toronto: Routledge, 2015); Zimmerman, "From the Second American Revolution to the First International and Back Again"; Douglas Moggach, The Philosophy and Politics of Bruno Bauer, Cambridge: Cambridge University Press, 2003); Jonathan Beecher, Victor Considerant and the Rise and Fall of French Romantic Socialism (Berkeley: University of California Press, 2001); Sterling F. Delano, "French Utopianism on American Soil"; K. Steven Vincent, Pierre-Joseph Proudhon and the Rise of French Republican Socialism (Oxford: Oxford University Press, 1984); Rondel V. Davidson, "Victor Considerant and the Failure of La Réunion,” The Southwestern Historical Quarterly 76, no.3 (Jan., 1973): 277-296.

${ }^{26}$ Mischa Honeck, We Are the Revolutionists: German-Speaking Immigrants and American Abolitionists after 1848 (Athens: University of Georgia, 2011); Roberts, Distant Revolutionaries. 
gradually applied in the republic of the United States, where moderate policies could help heal political, economic, and social wounds. Dana used this context to join Greeley and the Tribune in counseling nationalist movements in South America, Canada, Cuba, and the broader Caribbean. ${ }^{27}$ He joined his mentor and his paper in helping a nascent political organization, the Republican Party, which would help fight against the spread of slavery in the $1850 \mathrm{~s}^{28}$ The party's connections to economic nationalism, anti-slavery and free labor movements, and civic virtue attracted Dana to Greeley and made up the basis of their relationship for the next decade and a half.

The tumultuous political environment of the 1850 s encouraged Dana to view journalism and party politics as the best vehicles for progressive change. Prior to joining the Tribune, enrolling at Harvard, or working at Brook Farm, Dana had no interest in party politics. Being in attendance at the failure of communalism to heal revolutionary France, and his subsequent frustrations with popularizing Associationism in the United States. Dana shifted his perspective for reforming the United States. Working with the Tribune expanded Dana's developing conception of anti-slavery politics, communitarian social reform, and transatlantic egalitarian politics. His experiences in Europe appear to have convinced Dana of the importance of partisan

\footnotetext{
${ }^{27}$ For colorful examples of the Tribune's response to filibusters in the Caribbean and Central America, see: New York Daily Tribune, November 18, 1856. The editorial page criticized William Walker and the American filibusters in Nicaragua, "the filibusters generally seem to think it is a great outrage that they cannot be allowed to prosecute in safety under the protection of the American flag. Our government, it seems, is not only to allow, as it does, the free shipment of men, munitions and arms for the subjection of the Nicaraguans and the confiscation of their property, but if any of the speculators who go out to buy happen to get killed by the natives, the whole of Central America is to be held responsible for this violation of the American flag. The filibusters in Nicaragua seem to think that the Government of Washington is just as much bound to protect them in conquering Nicaragua as it is to protect the Missouri Border Ruffians in subduing Kansas - and, indeed, both would seem to have an equal claim, since both have the same object in view, namely, the extension of slavery."

${ }^{28}$ For more on these early Republican Party circles, see: Johnathan H. Earle, Jacksonian Antislavery \& the Politics of Free Soil, 1824-1854 (Chapel Hill: University of North Carolina Press, 2004) and Bleeding Kansas, Bleeding Missouri: The Long Civil War on the Border (Lawrence: University of Kansas, 2013); Michael S. Green, Freedom, Union, and Power: Lincoln and His party in the Civil War (New York: Fordham University Press, 2004), 300-330.
} 
politics in realizing republican ideals, as he returned ready to help Horace Greeley use the Tribune to that very end. The Tribune followed the Whig party, embracing that party's belief in American progress, government activism, policies friendly to workers and capitalists alike, and the championing of economically nationalist approaches. ${ }^{29}$ The Whig party could not, however, withstand the challenge that balancing the political weight of slavery's continued to be on the American political system. The passage of the Compromise of 1850 (with its inclusion of the very unpopular Fugitive Slave Act that allowed Southern slave-catchers wide legal power to enter northern states to recapture runaway slaves), the 1852 publishing of the abolitionist novel Uncle Tom's Cabin by Harriet Beecher Stowe, the Kansas-Nebraska Act of $1854,{ }^{30}$ and the "Bleeding Kansas" crisis ${ }^{31}$ left the Whig Party irreparably fractured. Many Whigs supported slavery (known as "Cotton Whigs") and opposed the abolitionist branch of the party, known as the "Conscience Whigs." ${ }^{32}$ Greeley, Dana, and the Tribune abhorred slavery, sent money and weapons to support anti-slavery forces in Kansas, and helped make slavery a central issue of American party politics. By 1855 enough dissatisfied Whigs had broken away to help form the new Republican Party. ${ }^{33}$

\footnotetext{
${ }^{29}$ For more on the Greeley's connection to the basic ideology of the Whig party, see: Tuchinsky, Horace Greeley's New York Tribune, 39, 184-186, 190, 231; Andrew Wender Cohen, The Right and Labor in America: Politics, Ideology, and Imagination (Philadelphia: University of Pennsylvania Press, 2012), $15-$ 26; Mitchell Snay, Horace Greeley and the Politics of Reform in Nineteenth-Century America (Lanham: Rowman \& Littlefield, 2011); James L. Huston, "A Political Response to Industrialism: The Republican Embrace of Protectionist Labor Doctrines," The Journal of American History 70, no. 1 (Jun., 1983): 35-57.

${ }^{30}$ James A. Rawley, The Kansas-Nebraska Act of 1854 (Lincoln: University of Nebraska Press, 2008).

${ }^{31}$ Michael Fellman, In the Name of God and Country: Reconsidering Terrorism in American History (New Haven: Yale University Press, 2010).

${ }^{32}$ For more on the influence of slavery on the Democratic and Whig party's throughout the 1840s and 1850s: Yonatan Eyal, The Young America Movement and the Transformation of the Democratic Party (Cambridge: Cambridge University Press, 2012); James Alex Baggett, The Scalawags: Southern Dissenters in the Civil War and Reconstruction (Baton Rouge: Louisiana State University Press, 2003); Michael A. Morrison, Slavery and the American West: The Eclipse of Manifest Destiny and the Coming of the Civil War (Chapel Hill: University of North Carolina Press, 1997); Michael F. Holt, The Political Crisis of the 1850s (New York: W.W. Norton \& Co., 1978).

${ }^{33}$ Dana and Greeley in early Republican Party circles again: John R. Commons, "Horace Greeley and the Working-Class Origins of the Republican Party," Political Science Quarterly 24, no. 3 (Sept., 1909): 468-
} 
The editors fundraised material support for anti-slavery forces in Kansas and Missouri in their efforts to secure an abolitionist state constitution there. ${ }^{34}$ Dana campaigned actively for the party's first presidential candidate, John C. Fremont, in his failed 1856 campaign. ${ }^{35}$ He helped organize and rally "Wide Awake" clubs in New York City that used military imagery as a metaphor to represent their belligerent desire to defend anti-slavery politics and the Republican platform. $^{36}$

Dana played a major role in boosting Republican support through the Tribune, and helped Abraham Lincoln gain support in traditionally Democratic Party-controlled New York in the election of $1860 .{ }^{37} \mathrm{He}$ and Greeley encouraged the Republican Party's break from establishment candidates like New York Senator William Seward and towards Lincoln's candidacy. The two argued that the Illinois lawyer was a better fit for the republican goals of the New York Tribune and its progressive readers. Lincoln's victory surprised many across the country and angered

488; Tuchinsky, Horace Greeley's New York Tribune, 126-164; Robert C. Williams, Horace Greeley: Champion of American Freedom (New York: New York University Press, 2006); Janet A. Steele, The Sun Shines For All (Syracuse: Syracuse University Press, 1993).

${ }^{34}$ For more on the Tribune's encouragement of pseudo-filibuster expeditions from the North to Kansas and Missouri to defend the anti-slavery forces going to defeat the Lecompton constitution and establish a republican government based in free labor there, see: Tuchinsky, 156-211. For more on what the Tribune wrote about this maelstrom, while within it, see: New York Weekly Tribune, February 25, March 4, 18, 25, April 15, June 3, 24, 1854; June 2, November 3, December 8, 15, 1855; April 18, 26, May 2,9, July 11, 18, 1857; November 5, December 3, 1859.

${ }^{35}$ For the newest on Fremont, see: John Bicknell, Lincoln's Pathfinder: John C. Fremont and the Violent Election of 1856 (Chicago: Chicago Review Press, 2017).

${ }^{36}$ For more on these community-based political organizations, see: Jon Grinspan, "Young Men For War," The Wide Awakes and Lincoln's 1860 Presidential Campaign," The Journal of American History 96:, no. 2 (Sep., 2009): 357-378 and The Virgin Vote: How Young Americans Made Democracy Social, Politics Personal, and Voting Popular in the Nineteenth Century (Chapel Hill: University of North Carolina, 2016).

${ }^{37}$ For more on Lincoln's support in the leadup to the election, see: John Burt, Lincoln's Tragic Pragmatism (Cambridge: Harvard University Press, 2013); Mackubin T. Owens, Abraham Lincoln's, Esq.: The Legal Career of America's Greatest President (Lexington: University Press of Kentucky, 2010). 
enough Southern states to provoke secession from the Union. ${ }^{38}$ Dana called for swift action, Greeley did not, and the difference in strategic preference terminated their professional partnership.

Dana's belligerent republicanism had no patience for the threats of secession made by Southern legislators. He rebuked those calling for peace and negotiation with the states if the South did secede en masse. The union required vigorous defense, he believed, and that threats to leave the union extra-legally, as the Southern states had done, invited a martial response. Dana believed that the Southern states had crossed a line in rejecting compromise, which, in turn, forced stronger reactions. These were the methods for defending republicanism that Dana first understood in Europe in 1848 and matured across the sectional crisis of the 1850. At some point violence to protect the worldview is warranted, he deduced. ${ }^{39}$ Greeley did not agree with this vision, as he had attempted to strike a peace between the two sides from the moment that the Confederate States of America had been announced on February 8, 1861. The disagreement between Dana and Greeley about whether the Union should use its assumed military advantage to immediately overwhelm the seceded states led to a rift between the two men. Dana wanted the Union army to strike at Richmond quickly; Greeley wanted Abraham Lincoln to strike for a negotiated peace..$^{40}$ The circumstances of Dana's dismissal eventually prompted Abraham Lincoln's Secretary of War, Edwin Stanton to appoint him as his personal agent in the field.

\footnotetext{
${ }^{38}$ For more on the election of 1860 and its effects, see: A. James Fuller, The Election of 1860 Reconsidered (Kent: Kent State University Press, 2013); Michael S. Green, Lincoln and the Election of 1860 (Carbondale: Southern Illinois University Press, 2011).

${ }^{39}$ For more the growing inclination of northerners for violence, see: Joanne B. Freeman, The Field of Blood: Violence in Congress and the Road to Civil War (New York: Farrar, Straus and Giroux, 2018).

${ }^{40}$ For more on this cross-cutting cleavage in Northern sentiment towards the South before the formal start of the war, see: Russell McClintock, Lincoln and the Decision for War: The Northern Response to Secession (Chapel Hill: University of North Carolina Press, 2008).
} 
Stanton and President Lincoln used Dana's observations of general Ulysses S. Grant to promote the latter as commanding general of the Union armies. His reports helped save Grant's job, providing the administration with enough confidence that the general whom Lincoln had yet to meet in person had enough talent and pluck to merit promotion. Stanton appointed Dana as Assistant Secretary of War based on this surveillance of the future lieutenant general of the Union Army.

As one of Stanton's deputies, Dana pressed for equal rights, free labor, and unionism. While Dana worked for the War Department, Stanton designed a controversial domestic policy that challenged American standards of privacy, liberty, and free speech — he suspended habeas corpus (the idea in common law that those under arrest are reserved to avoid unlawful detention), effectively established martial law, and concentrated unprecedented power in the executive branch. ${ }^{41}$ Dana wanted the Confederate conspiracy subdued swiftly and aggressively, in ways that show a complicated lineage from Dana's reflections from the revolutions of 1848. In such ways, he rejected the anti-Bourbonism that he advocated in those missives from Europe that argued that overpowered governments like Louis Phillipe's were threats to liberty. How could he advocate that the northern states stamp out secessionism and slavery without growing to such an illiberal size and an empowered executive office? The Civil War provided Dana with complicated choices. The emergency that was the Civil War, though, pressed him to argue that in times of crisis, temporary abuses could be tolerated. This aggressiveness towards war, and openness towards using state power to fix political problems is a clear lineage from his European trip to

${ }^{41}$ For more on Lincoln and Stanton's war policy, see: John Fabian Witt, Lincoln's Code: The Laws of War in American History (New York: Free Press, 2014); James A. Dueholm, "Lincoln's Suspension of the Writ of Habeas Corpus: An Historical and Constitutional Analysis," Journal of the Abraham Lincoln Association 29, no. 2 (Summer 2008): 47-66; Brian McGinty, Lincoln and the Court (Cambridge: Harvard University Press, 2008); Mark E. Neely, The Fate of Liberty: Abraham Lincoln and Civil Liberties (New York: Oxford University Press, 1991); David L. Martin, "When Lincoln Suspended Habeas Corpus," American Bar Association Journal 60, no. 1 (January 1974): 99-102. 
1848 and subsequent work for the Tribune. Dana's work for the Lincoln administration hardened his conviction that defending these values required martial force in certain cases. Dana was no longer a Fourierist. Dana also handled a wide away of bureaucratic duties for Stanton, and after the formal surrender of Robert E. Lee, Dana oversaw the capture of escaped President of the Confederate States of America, Jefferson Davis, and helped Secretary Stanton stabilize the federal government and Cabinet after Lincoln's assassination. ${ }^{42}$ Lincoln's death, the end of the war, and the promise of swift changes within the government encouraged Dana to return to journalism where he would make his lasting fame.

Dana holds an unambiguous reputation as a giant in journalism and newspaper making. The editor was, and still is, highly respected for his work in journalism and his ability to run an urban newspaper. ${ }^{43}$ Between the 1860 s and the 1880 s Dana stood in the top strata of editors and media moguls. Dana's contemporaries often called him a "radical," a "firebrand," and a "blackguard" for his opinions about political economy and party identification. ${ }^{44}$ His time at Brook Farm, publicizing "Associationism" and "cooperationism" across the Northeast, political activism with the martial Wide Awake clubs popular with young activists, work with Greeley's

\footnotetext{
${ }^{42}$ For more on Dana's work for Secretary Stanton, observations of General Grant, and promotion to Assistant Secretary of War, see: Wilson, Charles A. Dana, chapters 12 - 21; Charles A. Dana, Reminiscences of Men and Events of the Civil War (New York, S.S. McClure, 1898).

${ }^{43}$ For more on Dana's journalistic practice, see: Wilson, The Life of Charles A. Dana; Mayo W. Hazeltine, "Charles Anderson Dana," The North American Review 185, no. 618 (1907): 505-514; Frank M. O’Brien, The Story of the Sun (New York: D. Appleton \& Company, 1918); Edward Page Mitchell, Memoirs of an Editor: Fifty Years of American Journalism (New York: C. Scribner's Sons, 1924); Charles J. Rosebault, When Dana Was The Sun (New York: Robert M. McBride \& Company, 1931); Candace Stone, Dana and the Sun (New York: Dodd, Mead \& Company, 1938); Paul Lancaster, Gentleman of the Press: The Life and Times of an Early Reporter, Julian Ralph, of the Sun (Syracuse: Syracuse University Press, 1992).

${ }^{44}$ Henry Adams provided one of the better of these impressions of Dana's radicalism. In 1907, in The Education of Henry Adams, he wrote that "Charles A. Dana had made the Sun a very successful as well as a very amusing paper, but had hurt his own social position in doing it; and Adams knew well enough to know that he could never please himself and Dana too; with the best intentions, he must always fail as a blackguard, and that at the time a strong dash of blackguardism was life to the Sun." Henry Adams, Ira B. Nadel, ed. The Education of Henry Adams (Oxford: Oxford University Press, 1999), 206.
} 
popular, yet eccentric, Tribune, and role within the Cabinet that passed the Emancipation Proclamation, earned Dana this reputation for intellectual radicalism and "rogue" behavior. ${ }^{45}$ During the Civil War these judgments of Dana's thoughts and character followed the editor. As an Undersecretary of War, he was attached to the hard-handed use of state power to ensure Union victory_-policy positions supported by Radical Republicans in Congress. Dana's subsequent purchase of the Chicago Republican, and weaponizing of the paper to attack President Andrew Johnson's administration, further endeared Dana's behavior to the characterization of radical and firebrand. Dana's support for the passage of the Fourteenth Amendment — the laws granting citizenship and civil rights to former slaves — added further to this impression of his radicalism. It appeared that he wanted drastic change. Further complicating this picture of Dana's objectives, however, was his desire for retrenchment after the war: returning the government to its pre-war size and responsibilities. Dana's historic fear of overpowered governments and heads of state conditioned him to want a trim and efficient federal government. The revolutions of 1848 crystallized an anti-Bourbonism in Dana's thought. The Civil War had allowed a temporary bloat of political, economic, and military power, he argued. His loss of patience with the Grant administration's alleged corruption during Reconstruction pressed Dana to amplify this distaste of monarchism. In the 1870s Dana recommended that the Southern states all be given back power over their elections, and a federal retreat from Reconstruction policy. This was anathema to the Radical Republican faction of the party, already angry that Dana and his newspaper had turned so vociferously against President Grant. Dana's critics accused him of turning his back on freedmen, enabling Southern state legislatures to expand the use of black codes to curb black voting rights, and erasing social gains accomplished during the war and immediately after it. This dissertation

\footnotetext{
${ }^{45}$ Steele, The Sun Shines for All, 29 - 48; Williams, Horace Greeley: Champion of Freedom, 125 - 151; Tuchinsky, Horace Greeley's New York Tribune, chapters 1-7.
} 
provides context to these competing characterizations of Dana to help explain his life during the Reconstruction period that followed the end of the Civil War.

The New York Sun was the most prominent vehicle Dana ever used to communicate his republican vision for Reconstruction. The first edition of The Sun illustrated Dana's intention to use the paper to publicize his vision for an egalitarian American future. In doing so, his newspaper established itself as the representative of a platform that illustrates the ways that transatlantic issues motivated domestic politics during Reconstruction. The period under heaviest scrutiny in this study - $1869-1872$ - represents a critical period in the growth of the circulation of Dana's Sun, the amplification of Dana republican message, and the development of both Dana and his paper as among of the nation's premier editorial voices. Dana often attributed the rapid rise of his newspaper's circulation to the top of New York City's competitive circulation table to his paper's directness, lack of pretention, ideological consistency, political nonalignment, newsgathering objectivity, and editorial independence. Dana presided over the last gasp of the style of American newspaper first popularized by The Sun's creator Benjamin Day — cheap, "penny press," political rags that offered clear, if sometimes too direct, news and opinion in a handful of pages. ${ }^{46}$ The argument can be made that Dana very quickly made the paper the world's most circulated newspaper from 1870 through the mid 1880 s. ${ }^{47}$ It was Dana's standard that

\footnotetext{
${ }^{46}$ For more on the development of the press from its 1820 s and 30s "penny press" version into the monolithic transformation into the Gilded Age that Dana helped influence, see: W. Joseph Campbell, The Gilded Age Press, 1865-1900 (Westport: Praeger, 2003); Gerald Baldasty, The Commercialization of News in the Nineteenth Century (Madison: University of Wisconsin Press, 1992); Michael Schudson, Discovering the News: A Social History of American Newspapers (New York: Basic Books, 1978).

${ }^{47}$ For more on the larger context of the era of journalism that Dana came to champion in the 1870 s and 1880s, see: Arthur Weinberg and Lila Shaffer Weinberg, The Muckrakers (Urbana: University of Illinois Press, 2001); David M. Tucker, Mugwumps: Public Moralists of the Gilded Age (Columbia: University of Missouri Press, 1998); Louis Filler, The Muckrakers (University Park: Pennsylvania State University, 1976); Gerald W. McFarland, Mugwumps, Morals \& Politics, 1884-1920 (Amherst: University of Massachusetts Press, 1975); David Mark Chalmers, The Social and Political Ideas of the Muckrakers (New York: Citadel Press, 1964).
} 
William Randolph Hearst and Joseph Pulitzer, who worked for Dana at The Sun for a time, eclipsed in the 1880s and 1890s. They were rewarded for embracing consumer culture, the illustration as a feature of the newspaper, and the bombastic "yellow" headlines that gave these editors their fame in the build-up to the Spanish-American War of $1898 .^{48}$ The failures to recognize the need for larger printing presses, including images on the front page, and featuring entertainment and popular culture that sunk Dana in the journalism of the later years of the century were not as apparent in the late 1860s. Instead The Sun utilized many of the same approaches to journalism that Dana had used at the Tribune — and like that paper had a circulation that went far beyond New York City. ${ }^{49}$ Like his time at Greeley's paper — a journal with its own national and global renown and scope — Dana sent correspondents across the world, and had permanent reporters embedded across the Northeast, Washington D.C., Cuba, and the major capitals of Europe.$^{50}$ Dana understood the power that newspapers held, through newsgathering, editorial opinion, and practical political organizing. Dana employed his paper to help shape and publicize political movements he supported. Dana actively supported the labor movement - using his transatlantic, and republican, perspective to ground his calls for peaceful

\footnotetext{
${ }^{48}$ For the applicable works on yellow journalism, see: David R. Spencer, The Yellow Journalism: The Press and America's Emergence as a World Power (Evanston: Northwestern University Press, 2007); W. Joseph Campbell, Yellow Journalism: Puncturing the Myths, Defining the Legacies (Westport: Praeger, 2001); Joyce Milton, The Yellow Kids: Foreign Correspondents in the Heyday of Yellow Journalism (New York: Harper \& Row, 1989).

${ }^{49}$ Books on pre-eminence of American journalism and newspaper work in the nineteenth century: Joel H. Wiener, Americanization of British Press (Basingstroke: Palgrave McMillan, 2014); Richard L. Kaplan, Politics and the American Press: The Rise of Objectivity, 1865-1920 (Cambridge: Cambridge University Press, 2002).

${ }^{50}$ Dana also stood at the center of a transatlantic revolution in journalism. For more, see: John J. McCusker, "The Demise of Distance: The Business Press and the Origins of the Information Revolution in the Early Modern Atlantic World," The American Historical View 110, no. 2 (April, 2005): 295-321; Adam-Max Tuchinsky, “'The Bourgeoisie Will Fall and Fall Forever:' The 'New-York Tribune,' the 1848 French Revolution, and American Social Democratic Discourse," The Journal of American History 92, no. 2 (Sep., 2005): 470-497; John A. Britton, “"The Confusion Provoked by Instantaneous Discussion;” The New International Communications Networks and the Chilean Crisis of 1891-1892 in the United States," Technology and Culture 48, no. 4 (Oct., 2007): 729-757.
} 
union organizing. He also went so far as to use influence, and his newspaper, to support extralegal movements like the Fenian Irish nationalist movement, ${ }^{51}$ Cuban nationalism, Canadian separatism, and the Paris Commune. ${ }^{52}$ Dana argued that his newspaper stood atop the crest of a thundering wave of republican civil values. He insisted that The Sun would do what it could to realize the rights that Americans had enjoyed since 1776 — and recently improved in 1865 across the United States and transatlantic. ${ }^{53}$ Dana would insist on the legitimacy of violence when fighting for the preservation of these values.

Dana's immediate rejection of President U.S. Grant, simultaneously after he took office in March 1869, clouded the public's understanding of the motivations behind his choices. Dana had publicly campaigned for Grant as the Republican Party candidate in 1868 and co-wrote a

\footnotetext{
${ }^{51}$ For more on the Fenian movement, see: Mitchell Snay, Fenians, Freedmen, and Southern Whites: Race and Nationalism in the Era of Reconstruction (Baton Rouge: Louisiana State University Press, 2007); Timothy J. Sarbaugh, Post-Civil War Fever and Adjustment: Fenianism in the Californian Context, 18581872 (Boston: Northeastern University, 1992); Wilfried S. Neidhardt, Fenianism in North America (University Park: Pennsylvania State University Press, 1975).

${ }^{52}$ For more on the Paris Commune of 1870, see: Coghlan, J. Michelle, Sensational Internationalism: the Paris Commune and the Remapping of American Memory in the Long Nineteenth Century (Edinburgh: Edinburgh University Press, 2018); David A. Shafer, The Paris Commune: French Politics, Culture, and Society at the Crossroads of the Revolutionary Tradition and Revolutionary Socialism (New York: Palgrave MacMillan, 2005); Martin P. Johnson, The Paradise of Association: Political Culture and Popular Organizations in the Paris Commune of 1871 (Ann Arbor: University of Michigan Press, 1996); Alistair Horne, The Fall of Paris: The Siege and the Commune, 1870-71 (New York: St. Martin's Press, 1966).

${ }^{53}$ Books about growing liberalism and republicanism in the transatlantic world: Don H. Doyle, Jörg Nagler and Marcus Gräser, The Transnational Significance of the American Civil War (Basingstroke: PalgraveMacMillan, 2016); William Palen, The "Conspiracy" of Free Trade: the Anglo-American Struggle over Empire and Economic Globalization, 1846 - 1896 (Cambridge: Cambridge University Press, 2016); Ely M. Janis, A Greater Ireland: The Land League and Transatlantic Nationalism in Gilded Age America (Madison: University of Wisconsin Press, 2015); Kate Flint, The Transatlantic Indian, 1776-1930 (Princeton: Princeton University Press, 2008); Leslie Butler, Critical Americans: Victorian Intellectuals and Transatlantic Liberal Reform (Chapel Hill: University of North Carolina Press, 2007); James T. Kloppenberg, Uncertain Victory: Social Democracy and Progressivism in European and American Thought, 1870-1920 (New York: Oxford University Press, 1986); Michael F. Conlin, "The Dangerous 'isms' and the Fanatical 'ists': Antebellum Conservatives in the South and the North Confront the Modernity Conspiracy," Journal of the Civil War Era 4, no. 2 (June 2014): 205-233.
} 
hagiographic campaign biography of the general. ${ }^{54}$ Weeks after the new president took power in March 1869, Dana used his paper to open a broadside of negative press coverage of the administration. Dana's critics identified patronage rivalries as a major reason for the editor's turn on Grant. They alleged that his rebuffed patronage hopes motivated The Sun's anti-Grant message. ${ }^{55}$ Dana's biographers have debated the extent to which Dana's beliefs guided this transformation or whether it was bitterness over being passed over for patronage that caused the shift. ${ }^{56}$ This dissertation finds that Dana instead directed an increasingly aggressive form of republicanism developing since the 1850 s towards interpreting a wide array of problematic reports about the Grant administration. In these reports, Dana found reason enough to change his mind about the potential for President Grant to protect his republican hopes for the nation. He accused Grant of embracing "Old World" corruption, maladministration, and machine politics in government and pay for play schemes like the allegations of the Long Branch House Scandal and Gold Ring Crisis of 1869. Dana used the term "Grantism" to describe the growth lobbying and the spoils system under Grant's watch. He decried reports of the administration's connections to machine politics visible through its connections with the famous William "Boss" Tweed of the corrupt Tammany Hall of New York City. Dana compared Grant's hiring of friends and family, and broader political approach, to despots like Napoleon III, Robespierre, and Caesar. These comparisons became popular points of comparisons for critics of the president to use to

\footnotetext{
${ }^{54}$ Charles A. Dana and James Harrison Wilson, The Life of Ulysses S. Grant, General of the Armies of the United States (Springfield: G. Bill \& Co., 1868).

${ }^{55}$ For samples of the treatment/interpretation of this episode, see: Harry J. Maihafer, The General and the Journalists (London: Brasseys, 1998), 228 - 231; Mark Wahlgren Summers, The Party Gang: Newspapers and Politics, 1868 - 1878 (Chapel Hill: University of North Carolina Press, 1994), 34, 70.

${ }^{56}$ O'Brien, Story of the Sun, 191. For those that treat Dana, and his turn on his former friends, as a reflection of intellectual disagreement, and not patronage spite, see: Wilson, The Life of Charles A. Dana, 404 - 415; O'Brien, The Story of the Sun, 182 - 195; Charles J. Rosebault, When Dana Was The Sun (New York: Robert M. McBride \& Company, 1931), 189- 196.
} 
emphasize the transatlantic nature of Grant's seeming opposition to republican values. President Grant's commitment to helping the freed slaves find equality before the law notwithstanding, Dana believed that Grant misused the great power bequeathed to the White House by the Radical Republican Congress to reconstruct the South. Grant, he repeated often, abused his power and could not be trusted with a bloated federal government. So much so that it required a movement back towards small, constitutionally mandated, federal relationship between the federal government and the states. The paper spent considerable attention reporting on stories like when the president reportedly used the Enforcement Acts of 1870 - 71 as political cover for using the military to help tilt the congressional elections in 1870 and Republican Party primaries in 1871 in his favor and against reform candidates. ${ }^{57}$ Using the military in such a way was redolent the Old World. Many Americans shared Dana's opposition to the Grant administration's domestic policies in the early $1870 \mathrm{~s}$ - scores leaving the party of Lincoln for the Democrats, upstart parties like the Liberal Republican Party, or elevating principles over party and remaining unaffiliated. This study analyzes Dana's ideological commitments from the 1830 s through the early 1870 s to help explain why he agreed with so many fellow Republicans who renounced the organization altogether. This study also explains why Dana did not just look to domestic policy, but also to foreign policy, when making these judgements. How the nation treated burgeoning republican movements in the Caribbean and Europe mattered greatly to Dana's evaluation of Grant's performance.

This work presents the domestic and foreign context of Dana's republican vision for the United States as explanations for Dana's behavior during Reconstruction. This dissertation builds on Dana's pre-1868 intellectual record to focus on the influence of his earlier experiences on his

\footnotetext{
${ }^{57}$ For more on federal government's role in the New York City midterm elections in 1870, see: David Quigley, “Acts of Enforcement: The New York City Election of 1870," New York City History 83, no. 3 (Summer 2002): 271 - 292; "The Department of Justice and Civil Rights Enforcement, 1870 - 1871," in Robert J. Kaczorowski, The Politics of Judicial Interpretation: The Federal Courts, Department of Justice, and Civil Rights, $1866-1876,62-79$.
} 
late and 1860 s and early 1870 s national and transatlantic commitments. The evidence suggests that a combination of domestic and transatlantic influences directed Dana's personal and editorial view for the post-war country. Dana cared deeply about protecting republican values in places like Cuba, the Dominican Republic, and France, and wanted the Grant White House to follow suit. This work does not debate that Dana may have been deeply disappointed for not receiving some reward from Grant for his help electing him president in 1868. Instead, it argues that Dana's transatlantic understanding of republicanism, combined with the way Grant's administration had begun its work, played the major part in changing his mind about Grant and the Republican Party. Dana never thought of the values of nationhood and republican brotherhood as selfishly American characteristics and hoped that the United States would work to help others realize these values for themselves and he used the pursuit of these values as the guidelines to judge public policy. Dana expected Grant to protect transatlantic republicanism-especially in places that orbited the United States' sphere of influence. Dana's past bears this out—he travelled to Europe in 1848 to test his faith in Associationist and socialist ideas for the United States. He publicized nationalist and republican revolutions around the world in Tribune, like the Cuban rebellions in the $1850 \mathrm{~s}, 60 \mathrm{~s}$, and 70s. Movements that were against slavery - as the Cuban cause wasreceived prime billing in the paper Dana edited. It was not enough for the United States to declare slavery abolished during the Civil War if it still existed in the Western Hemisphere - freedom and republicanism needed to prevail across the Old World. This did not change when Dana bought the New York Sun in 1868 and used its widely read editorial page to critique the policy decisions of President Grant. That administration's failure to protect the developing American exponent of republicanism in Cuba, in Dana's estimation, represented as mortal a wound to his sympathy for Grant as could have existed. The republican perspective Dana employed in debates about American and transatlantic nationalism, national identity, political economy, anti-slavery, 
equal rights, anti-corruption, and small government philosophy illustrate the dual influence of insular and international factors on his thought.

This study incorporates a combination of historical methodologies to make its case. First, it combines traditional biography with cultural, intellectual, journalistic, and political history to elevate the life and work of Charles Anderson Dana. It does so using extensive archival material from Dana's extensive journalistic career. The project uses digitized collections of the newspapers Dana edited or helped edit, the Harbinger, New York Tribune, Chicago Republican and New York Sun. It utilizes the record of Dana's public speeches and interviews, combined with related international sources, including newspapers and pamphlets. ${ }^{58}$ To provide context to Dana's domestic and international ideas and influence, and the broader network he functioned within, this project provides an illustration of the predominance of these broad international conversation about political culture and nationalism Dana participated in. In method, design, and instrumentation, the dissertation alternates between Dana's many perspectives: local and national, domestic and global, international and transnational. It builds on the work of historians who have affirmed the importance of ideas that bridge these legal and analytical boundaries. ${ }^{59}$ Dana used

\footnotetext{
${ }^{58}$ Dana did not leave behind personal correspondence, as he did not preserve letters. Typically, any citation that includes Dana's correspondence includes his response to a letter from the subject of the archives. The perfect example: In 1895 Dana wrote to Marianne Orvis that "it has not been my practice to preserve letters after the subjects on which they were written have been disposed of." This mention of his only exists within the historical record because Ms. Orvis preserved the note, it ended up in Henry S. Borneman's papers at the Illinois Historical Society, historian Carl Guarneri noted it in studies of Dana's participation in Fourierism and Associationism, and alerted Dana biographer Janet Steele of the existence of the sources so that she could cite it in the only modern biography of the editor. See Charles A. Dana to Marianne Orvis, Dec. 31, 1895, Henry S. Borneman Papers, Illinois Historical Society, University of Illinois, cited in Steele, The Sun Shines For All, xxi. In part by necessity, and in part because of just how public a man Dana was, this dissertation is relying squarely on Dana's place as a public figure and the role of his republic vision in forming his outlook on American society.

${ }^{59}$ Recent works this dissertations aspires to in scope and approach, are: Steven Hahn, A Nation Without Borders: The United States and Its World, 1830-1910 (London: Viking, 2017); Don H. Doyle, ed., American Civil Wars: The United States, Latin America, Europe, and the Crisis of the 1860s (Chapel Hill: University of North Carolina Press, 2017); Don H. Doyle, The Cause of All Nations: An International Study of the American Civil War (New York Basic Books, 2015); Gregory P. Downs and Kate Masur, The World the Civil War Made (Chapel Hill: University of North Carolina Press, 2015); David T. Gleeson and Simon Lewis, eds. The Civil War as Global Conflict: Transnational Meanings of the American Civil War
} 
local and international events to guide his understanding. He adopted a geographically expansive version of republicanism that embraced its transnational nature while also reinforcing its ability to foster nationalism. This study allows Dana's interests and perspectives to lead the scope of its analysis and conclusions. It has been guided by his transnational embrace of republican values, in part by paying "attention to networks, processes, beliefs, and institutions that transcend these politically defined spaces" as classic studies of that sort do, but it does not refute Dana's faith in the nation-state or the United States. ${ }^{60}$ Dana was a champion of American unionism and nationalism, but also of its mission to share these ideas with others. This dissertation insists that his expansive worldview helped inspire Dana's belief that ideals like egalitarianism and civic republicanism transcended legal borders in ways that radically impacted domestic politics.

Attempting to combine these various perspectives with the figure comes with various methodological issues. An almost complete record exists of the journalistic products of Dana's life. Contemporaries left much on the record about their opinions about Dana, his newspaper, and his intellectual commitments. Little of Dana's private thoughts—letters, for instance — remain preserved, however. Dana failed to preserve his private correspondence, not allowing a fully comprehensive study of his personal life and inner thoughts. This project is lucky enough to have a major advantage over previous works analyzing Dana: it had access to the fully digitized archives of the major paper's Dana wrote for and edited. The Harbinger, New York Tribune and

(Columbia: University of South Carolina Press, 2014); Stig Förster and Jörg Naler, eds. On the Road to Total War: The American Civil War and the German Wars of Unification, 1861-1871 (New York: Cambridge University Press, 1997).

${ }^{60}$ C.A. Bayly, et al. "AHR Conversation: On Transnational History," The American Historical Review 111, no. 5 (December 2006): 1459. For more on the influence of transnational history, see: Marcus Gräser, "World History in a Nation-State: The Transnational Disposition in Historical Writing in the United States," The Journal of American History 95, no. 4 (Mar., 2009): 1038-1052; Micol Seigol, "Beyond Compare: Comparative Method after the Transnational Turn," Radical History Review 91 (Winter 2005): 62-90; McGerr, Michael E. "The Price of the New Transnational History," American Historical Review 96 (Oct. 1991): 1056-67. 
New York Sun are key-word searchable online. This was not a luxury that previous scholars have had, as Dana biographer Janet Steele noted when lamenting that "there is no index to ease the task of the historian who attempts to reel through thirty years' worth of daily papers." ${ }^{\prime 61}$ The availability of modern technology presented the possibility to study Dana's editorial corpus from different angles. This dissertation, then, makes an explicit choice to embrace the lack of many of Dana's private words by providing new ways to view Dana's beliefs and choices. Using the available archives, and a wave of new scholarship that has enriched the contextual and ideological background of Dana's life, has provided fresh opportunities to illuminate critical parts of his importance to American history in this period. This project no doubt eschews some of the more personal biographical tidbits of Dana's home-life - his marriage, dedication to fatherhood, interest in fine Chinese ceramics (of which his collection was worth hundreds of thousands of dollars upon his death), his various European and Asian trips, or publishing of various translations of European children's story anthologies - in lieu of a close analysis of a specifically chaotic and important period in his life. This dissertation includes an extensive study of Dana's early life and thought as justification for this methodological interpretation of Dana's main passion, vehicle of his time, and ultimate maker of his reputation-The Sun and its editorial policy.

${ }^{61}$ Steele, The Sun Shines For All, xii. 


\section{CHAPTER ONE}

\section{DANA'S FOUNDATIONAL INTELLECTUAL INFLUENCES}

FROM BUFFALO TO BROOK FARM $(1810$ - 1847)

Between 1810 and 1848 American life changed profoundly. Those living within the United States witnessed a thorough restructuring of their former habits and norms as the young nation matured. Fundamental transformations occurred within the nation's economics, demographics, politics, culture, philosophy, and religion. Charles A. Dana, born in 1819, came of age during this reorientation of American culture, and his early years echoed the frenetic pace of early-nineteenth century change. Intellectual tumult characterized his formative years, including his coming of age in upstate New York, college time at Harvard, and experience at the utopian community at Brook Farm. Dana developed a republican vision of the nation, and its place in the world, that emphasized cooperation, egalitarianism, civic virtue, and communitarianism. This chapter illustrates how Dana developed a strong understanding of international politics, global and American political economy framed around a nebula of republican ideals in these early stages of his intellectual development.

\section{Early $19^{\text {th }}$ Century Political Economy}

Dana's early life coincided with dramatic transformations for the nation. Inventions in communications and transportation technology, for instance, revolutionized the global economy. Historians have long explained that the invention of the railroad, the steamship, and the telegraph helped make the nineteenth century more efficient and dynamic than the eighteenth century. ${ }^{62}$

\footnotetext{
${ }^{62}$ For more, see: William M. Fowler, Steam Titans: Cunard, Collins, and the Epic Battle for Commerce on the North Atlantic (New York: Bloomsbury Press, 2017); Wolfgang Schivelbusch, The Railway Journey: The Industrialization of Time and Space in the Nineteenth Century (Berkeley: University of California Press, 2014); Richard Slotkin, The Fatal Environment: The Myth of the Frontier in the Age of Industrialization, 1800-1890 (Norman: University of Oklahoma Press, 1998); Kenneth Warren, Triumphant Capitalism: Henry Clay Frick and the Industrial Capitalism of America (Pittsburgh: University of Pittsburgh Press, 1996).
} 
These innovations drove an increasingly interconnected system of transatlantic economics and trade. ${ }^{63}$ While new technologies helped increase global economic productivity, so did adjustments in how humans worked within this system. In the United States, Brazil, and the Caribbean, for instance, domestic slave markets combined with faster land and sea shipping and new industrial and agricultural technologies radically enhanced profits. ${ }^{64}$

Recent historians have explained how the rapid expansion of the global economy arose within this maelstrom of technological innovation, corporate organization, and industrial management. ${ }^{65}$ This last category may have started with chattel slaves, but also included the broad nineteenth century category of "wage slave." ${ }^{66}$ The products of the Second Industrial Revolution (expanding factories, predominance of low-wage labor, and dominance of industrial work in urban centers) changed the nature of work across the nineteenth century. Workers were leaving increasingly less popular jobs as artisans and farmers in rural areas for dangerous work in cities with low levels of compensation. These workers toiled under the weight of exploitative contracts or unlivable wages in the new urban and industrial centers across the Atlantic world.

\footnotetext{
${ }^{63}$ For more on nineteenth century transatlantic economics and trade, see: Jürgen Osterhammel, The Transformation of the World: A Global History of the Nineteenth Century, trans. Patrick Camiller, (Princeton: Princeton University Press, 2015); Sven Beckert, Empire of Cotton: A Global History (New York: Knopf, 2015); Kevin O’Rourke and Jeffrey G. Williamson, Globalization and History: The Evolution of a Nineteenth-Century Atlantic Economy (Boston: MIT Press, 2000); C.A. Bayly, The Birth of the Modern World, 1780 - 1914 (New York: Wiley-Blackwell, 2003).

${ }^{64}$ Edward E. Baptist, The Half Has Never Been Told: Slavery and the Making of American Capitalism (New York: Basic Books, 2014).

${ }^{65}$ Sven Beckert, Slavery's Capitalism: A New History of American Economic Development (Philadelphia: University of Pennsylvania Press, 2016); Beckert, Empire of Cotton; Michael Zakim and Gary J. Kornblith, Capitalism Takes Command (Chicago: University of Chicago Press, 2011).

${ }^{66}$ For more on wage slavery in this period, see: Seth Rockman and Cathy Matson, Scraping By: Wage Labor, Slavery, and Survival in Early Baltimore (Baltimore: Johns Hopkins University, 2009); Marcus Cuncliffe, Chattel Slavery and Wage Slavery: The Anglo-American Context, 1830-1860 (Athens: University of Georgia Press, 2008); Jonathan A. Glickstein, American Exceptionalism, American Anxiety: Wages, Competition, and Degraded Labor in the Antebellum United States (Charlottesville: University of Virginia Press, 2002).
} 
Critics decried the various categories of workers laboring for a weekly wage - whether in a factory, artisanal shop, or the various other avenues available to both skilled and unskilled workers -which helped form the basis of new ideologies that opposed the prevailing relationship between worker, manager, and the owners of capital. ${ }^{67}$

The popularity of new ideologies across the transatlantic world occurred alongside the exploitation of labor in the early to mid-nineteenth century. Since the "Age of Revolutions" in the late $18^{\text {th }}$ century when monarchies fell, and nations were created, ideas of liberty, freedom, democracy, civic virtue, egalitarianism, fraternity, and communitarianism spread across the transatlantic world. ${ }^{68}$ The fracture of the "Old World" order exposed widespread disagreement regarding what exactly these values meant in different contexts across the nineteenth century. The spread of one of these ideologies, liberalism, played a leading role in this debate. ${ }^{69}$ Economically, liberalism inspired free trade, promoted by the British Empire since the late eighteenth, to early

${ }^{67}$ Nelson Lichtenstein, A Contest of Ideas: Capital, Politics, and Labor (Urbana: University of Illinois Press, 2013); Rosanne Currarino, The Labor Question in America: Economic Democracy in the Gilded Age (Urbana: University of Illinois Press, 2011); Moon-Ho Jung, Coolies and Cane: Race, Labor, and Sugar in the Age of Emancipation (Baltimore: Johns Hopkins University Press, 2006); Victoria Charlotte Hattam, Labor Visions and State Power: The Origins of Business Unionism in the United States (Princeton: Princeton University Press, 1993); Herbert Gutman, Work, Culture, and Society in Industrializing America (New York: Verso, 1976).

${ }^{68}$ Richard Huzzey, Freedom Burning: Anti-Slavery and Empire in Victorian Britain (Ithaca: Cornell University Press, 2012); Timothy Mason-Roberts, Distant Revolutions: 1848 and the Challenge to American Exceptionalism (Charlottesville: University of Virginia Press, 2009); Adam Rothman, "Slavery and National Expansion in the United States," OAH Magazine of History 23, no. 2 (April 2009): 23 - 29; Daniel A. Bell, Communitarianism and Its Critics (Oxford: Clarendon Press, 1995).

${ }^{69}$ Liberalism views every individual as a free actor capable of acting politically, economically, and socially within the marketplace of ideas and products. These concepts emphasized the fairness of an unfettered global market, the positive impact of the rational choices of individuals in the market economy, and the equality of all consumers within the market. For more on these ideas, see: Nancy Cohen, The Reconstruction of American Liberalism, 1865 - 1914 (Chapel Hill: University of North Carolina Press, 2002); Jennifer Pitts, A Turn to Empire: The Rise of Imperial Liberalism in Britain and France (Princeton: Princeton University Press, 2006); Uday Singh Mehta, Liberalism and Empire: A Study in Nineteenth Century British Liberal Thought (Chicago: University of Chicago Press, 1999); Eric Hobsbawn, The Age of Capital: 1848 - 1875 (New York: Vintage, 1996). 
nineteenth, centuries. ${ }^{70}$ Spurred by the ideas of Adam Smith, and the advocacy of Richard Cobden, the British led a campaign to do away with trade restrictions around the world. ${ }^{71}$ The impulse to treat the world as a market of individuals capable of acting in their own best interest had intimate connections with the movement to abolish chattel slavery. ${ }^{72}$ Arguments elevating the freedom, liberty, and rationalism of all individuals, as well as the sanctity of private property, took hold across the Atlantic world. ${ }^{73}$ This defense of private property, however, did not always align with liberal calls for radical freedom.

\section{Republicanism}

Liberal ideas about globalization and political and economic freedom proliferated, however, alongside ideas about citizenship and community, providing an alternative vision for social organization. This ideological cluster, often classified under the label of republicanism, emphasized the power of egalitarianism, communitarianism (rather than the global competition and social atomization that liberalism could encourage), civic virtue, and anti-monarchism. ${ }^{74}$ Historians have explained that republican ideas tend to emphasize "the capacity to place the good

\footnotetext{
${ }^{70}$ For a strong review of the literature of economic liberalism and its relationship to free trade, see: Eric Helleiner, "Economic Liberalism and Its Critics: The Past as Prologue?," Review of International Political Economy 10, no. 4 (Nov., 2003): 685 - 696; "Economic Nationalism as a Challenge to Neoliberalism? Lessons from the $19^{\text {th }}$ Century," International Studies Quarterly 46, no. 3 (2002) 307-329; Patricia Mary Goff, "Invisible Borders: Economic Liberalization and National Identity," International Studies Quarterly 44, no. 4 (2000): 533-562.

${ }^{71}$ Palen, The "Conspiracy" of Free Trade; Patricia Mary Cain, "Capitalism, War and Internationalism in the Thought of Richard Cobden," British Journal of International Studies 5 (1979): 229 - 47.

${ }^{72}$ Britain abolished the slave trade in 1807 with the Slave Trade Act of 1807, and formally abolished slavery across the British Empire in 1833, with the Slavery Abolition Act of that year. For more on the interconnections of abolitionism and free trade, see: Alex Gourevitch, From Slavery to the Cooperative Commonwealth: Labor and Republican Liberty in the Nineteenth Century (Cambridge: Cambridge University Press, 2014); Simon Morgan, "The Anti-Corn-Law League and British Anti-Slavery in Transatlantic Perspective, 1838 - 1846," The Historical Journal 52, no. 1 (Mar., 2009): 87-107.

${ }^{73}$ Appleby, Liberalism and Republicanism in the Historical Imagination, 3.

${ }^{74}$ Michael Schudson, The Good Citizen: A History of American Life (New York: The Free Press, 1998).
} 
of the commonwealth above one's own," and make that idea the "lynchpin of constitutional stability and liberty-preserving order." ${ }^{, 75}$ Republicanism, in this interpretation, is fundamentally anti-monarchist, against economic or political corruption, and wholly in the interests of the community of citizens. These republican ideas often confronted liberal individualism, but also worked with liberal ideas of equal rights. ${ }^{76}$ Republican influenced thinkers like Friedrich List who argued that the ends of republicanism could be realized through economic policy. A German political economist who spent time in Pennsylvania in the 1820s and supported Henry Clay and the Whig party's "American System" of economic nationalism, ${ }^{77}$ List argued that high trade barriers for foreign goods reaching the United States would benefit both workers and the owners of capital. ${ }^{78}$ This economic alternative to economic liberalism embraced high tariffs to protect domestic industries, and the protection of the wages and rights of all workers. Republicanism could also exhibit a potent strain of nativism and xenophobia, as policies supporting high tariff barriers would keep foreign influence, and other forms of potential corruption, at a safe distance. Protectionism of this variety would, the thought went, improve the material lives of the citizens of a thriving republic.

\footnotetext{
${ }^{75}$ Appleby, Liberalism and Republicanism in the Historical Imagination, 21.

${ }^{76}$ Eric Hobsbawn, The Age of Revolution: Europe, 1789 - 1848 (London: Abacus, 1977); Tuchinsky, Horace Greeley's New York Tribune; Ashli White, Encountering Revolution: Haiti and the Making of the Early Republic (Baltimore: Johns Hopkins University, 2012).

${ }^{77}$ Maurice G. Baxter, Henry Clay and the American System (Lexington: University Press of Kentucky, 1995).

${ }^{78}$ For more on List, see: P. Sai-wing Ho, "Distortions in the Trade Policy for Development Debate: A Reexamination of Friedrich List," Cambridge Journal of Economics 29, no. 5 (September 2005): 729 - 745; David Levi-Faur, "Friedrich List and the Political Economy of the Nation-State," Review of International Political Economy 4, no. 1 (Spring, 1997): 154 - 178; Dieter Senghaas, "Friedrich List and the Basic Problems of Modern Development," Review 14, no. 3 (Summer, 1991): 451 - 467; W.O. Henderson, Friedrich List: Economist and Visionary, 1789-1846 (London: Cass, 1983); W.O. Henderson, "Friedrich List and the French Protectionists," Journal of Institutional and Theoretical Economics 138, no. 2 (Jun 1982): 262-275; W.O. Henderson and Hemel Hempstead, "Friedrich List and England," Journal of Economics and Statistics 203, no. 5/6 (October 1987): 532 - 546.
} 
Criticisms of prevailing work conditions across the early to mid-nineteenth century motivated a multifaceted critique of the era's political economy. In Europe, the legacy of socialism is most often tracked to the anti-monarchism and populist French Revolution (17891799), through the abolitionist movements of the early 1810 s and 20 s, culminating with the protosocialist ideas of Henri de Saint-Simon, Robert Owen, Charles Fourier, and Mikhail Bakunin. ${ }^{79}$ These thinkers provided a framework for restructuring the social order. Many offered ways for creating autonomous utopian communities as alternatives to the prevailing norms of society in an industrial capitalist order. Early transatlantic utopianism, communitarianism, and anarchism were ideologies spreading across the world, gaining followers in places like the United States, France, Germany, Britain, and Russia. These ideas helped inform the ideas of Karl Marx and Friedrich Engels. For much of the 1820s and early 1830s, Marx and Engels were comfortable with the developing ideas of utopianism and communitarianism, but by the late 1830s their writing had turned increasingly radical. Marx and Engels levelled their critiques of industrial capitalism, beginning in the $1840 \mathrm{~s}$, and were joined by a long list of thinkers across the transatlantic world hoping to effect change in how the working classes experienced the nineteenth century economy. ${ }^{80}$

In the United States, early vestiges of the push towards socialism, and broader attempts at social democracy, translated into various Working Men's parties that formed around the nation in the 1820 s and 30 s. ${ }^{81}$ The Working Men's parties had their ideological basis in $18^{\text {th }}$ century

\footnotetext{
${ }^{79}$ Hauhart, " $19^{\text {th }}$ Century Labor Money Schemes"; R.J. Ormerod, "The History and Ideas of Marxism," The Journal of the Operational Research Society 59, no. 12 (Dec., 2008): 1573 - 1590; Albert S. Lindemann, History of European Socialism (New Haven: Yale University Press, 1984); Ivan Scott, "Nineteenth Century Anarchism and Marxism," Social Science 47, no. 4 (Autumn 1972): 212-218.

${ }^{80}$ Rolf Hosfeld, trans. Bernard Heise, Karl Marx: An Intellectual Biography (New York: Bergahn Books, 2013); Isaiah Berlin and Alan Ryan, Karl Marx: His Life and Environment (New York: Oxford University Press, 1996).

${ }^{81}$ Seymour Lipset and Gary Marks, Why It Didn't Happen Here: Why Socialism Failed in the United States (New York: Norton, 2000): 20 - 21; Sean Wilentz, Chants Democratic: New York City and the American
} 
artisanal republicanism, egalitarianism amongst citizens and workers, and a mix of community and individual-mindedness. ${ }^{82}$ Historians have explained that they did not "advocate collective ownership, or equality of result." ${ }^{93}$ Instead they promoted policies favorable to workers providing an early expression of working-class centered party politics. ${ }^{84}$ One of these policies, meant to show the possibilities of communitarian cooperation and equality of opportunity, was promoting equality of education between the classes through public schools and workers' colleges. ${ }^{85}$ These parties didn't survive the decade, however, instead having their platform subsumed by larger political parties. ${ }^{86}$ The Working Men's preference for equality of opportunity, rather than the more socialist preference for programs that ensure equality of result, became a feature of a new coalition party, the populist Jacksonian Democrats. This was the coalition that supported the candidacy and then presidency of Andrew Jackson (1829-1837) ${ }^{87}$ Scholars, historians, and contemporaries of the period point to these groups as the reason why American class antagonisms never reached the point of class war in the nineteenth century. They explain the rise of the

Working Class, 1788 - 1850, $2^{\text {nd }}$ edition (New York: Oxford University Press, 2004); Maurice F. Neufeld, "The Persistence of Ideas in the American Labor Movement: The Heritage of the 1830s," Industrial and Labor Relations Review 35, no. 2 (Jan., 1982): 207-220; Bernard Mandel, Labor, Free and Slave:

Workingmen and the Anti-Slavery Movement in the United States (New York: Associated Authors, 1955).

${ }^{82}$ Wilentz, Chants Democratic, $61-103$.

${ }^{83}$ Lipset and Marks, Why It Didn't Happen Here, 20.

${ }^{84}$ Ibid.

${ }^{85}$ Wilentz, Chants Democratic, $177-180$.

${ }^{86}$ Historians still debate why, centering on the critical difference between equality of opportunity and equality of result. Some historians blame the Working Men's parties' choice to the collectivist policies more closely aligned with the often unpopular ideas of socialism as it became later in the century. See: Lipset and Marks, Why It Didn't Happen Here, 20; Joshua R. Greenberg, "'Powerful—Very Powerful is the Parental Feeling": Fatherhood, Domestic Politics, and the New York City Working Men's party," Early American Studies 2, no. 1 (Spring 2004): 192 - 227.

${ }^{87}$ For more on Jacksonianism and its amalgamation of various populist reform movements in the $1830 \mathrm{~s}$, see Lawrence F. Kohl, The Politics of Individualism: Parties and the American Character in the Jacksonian Era (New York: Oxford University Press, 1989). 
Jacksonians and the Working Men as a product of American class politics being too distant from a feudalistic past. These critics argue that the Working Men were too committed to sectarianism in religion, too faithful to liberal individualism, and too beholden to a two-party system that frustrated the development of socialism in the United States. ${ }^{88}$ Stronger expressions of socialism in the United States appeared more forcefully in the American exponents of the transatlantic utopianism movement in the $1830 \mathrm{~s}$ and $40 \mathrm{~s} .{ }^{89}$ Disillusioned with American economics and social mores, Americans increasingly joined utopian communities like those at Oneida, New York, the Brook Farm community at West Roxbury, Massachusetts, and the North American Phalanx in Monmouth, New Jersey. ${ }^{90}$ Many of these utopian communities did not survive longer than a decade. They nevertheless represented the radical and socialist reform spirit in the United States animated by similar values: egalitarianism, cooperation, and republicanism. Dana had a direct part to play in the communications of these republican, communitarian, and socialist experiments across the transatlantic world, and especially in the United States.

\footnotetext{
${ }^{88}$ Werner Sombart, trans. C.T. Husbands, Why Is There No Socialism in The United States? (London: MacMillan, 1976, 1906); Selig Perlman, A Theory of the Labor Movement (Philadelphia: Porcupine Press, 1979, 1922); Irving Howe, Socialism and America (San Diego: Harcourt Brace, 1985); Eric Foner, "Why Is There No Socialism in the United States?," History Workshop 17 (Spring, 1984); Michael Hanagan, "Response to Sean Wilentz, "Against Exceptionalism: Class Consciousness and the American Labor Movement, 1790 - 1920," International Labor and Working-Class History 26 (Fall, 1984): 31 - 36. For more on Marx's opinions about American socialism, see: Henry M. Christman, ed., The American Journalism of Marx and Engels: A Selection from the New York Daily Tribune (New York: New American Library, 1966); Karl Marx and Friedrich Engels., ed. Andrew Zimmerman, The Civil War in the United States (New York: International Publishing Company, 2016).

${ }^{89}$ For more on these movements, see: Guarneri, The Utopian Alternative; Jonathan Beecher, Charles Fourier: The Visionary and His World (Berkeley: University of California Press, 1986); Michael Fellman, The Unbounded Frame: Freedom and Community in Nineteenth Century American Utopianism (Westport: Greenwood Press, 1973).

${ }^{90}$ Deward Spann, Brotherly Tomorrow: Movements for a Cooperative Society in America, 1820 - 1920 (New York: Columbia University Press, 1988); Carl Guarneri, "Reconstructing the Antebellum Communitarian Movement: Oneida and Fourierism," Journal of the Early Republic 16, no. 3 (Autumn, 1996): 463 - 488; Matthew Cooper, "Relations of Modes of Production in Nineteenth Century America: The Shakers and Oneida," Ethnology 26, no. 1 (Jan., 1987): 1-16; Arthur Bestor, Backwoods Utopias: The Sectarian Origins and the Owenite Phase of Communitarian Socialism in America, 1663-1829, $2^{\text {nd }}$ Edition (Philadelphia: University of Pennsylvania Press, 1970)
} 


\section{Dana's Place in an Increasingly Republican World}

Analyzing the interconnectedness and dynamism of the transatlantic world in the early to mid-nineteenth century, and how Dana experienced it, adds to the growing historiography highlighting the role of transatlantic republican values on the development of the early to midnineteenth century United States. Historians highlight the interconnectedness of American and transatlantic trends in slavery, economics, social reform, ${ }^{91}$ party politics, demographic change, ${ }^{92}$ and military strategy and technology. ${ }^{93}$ A flurry of studies since the turn of the $21^{\text {st }}$ century has made a definitive case, combining these categories, of a period of nineteenth century American history that Charles Dana directly lived within and contributed to.${ }^{94}$ Dana's understanding of his

\footnotetext{
${ }^{91}$ For more on transatlantic abolitionism, see: Edmund Morgan, American Slavery, American Freedom: the Ordeal of Colonial Virginia (New York: Norton, 1975); Leonardo Marques, The United States and the Transatlantic Slave Trade to the Americas, 1776 - 1867 (New Haven: Yale University Press, 2016); W. Caleb McDaniel, The Problem of Democracy in the Age of Slavery: Garrisonian Abolitionists and Transatlantic Reform (Baton Rouge: Louisiana State University Press, 2013).

${ }^{92}$ For more on immigration and demographic change in the United States in the Civil War era, see: Hidetaka Hirota, Expelling the Poor: Atlantic Seaboard States and the Nineteenth Century Origins of American Immigration Policy (New York: Oxford University Press, 2017); Raymond L. Cohn, Mass Migration Under Sail: European Immigration to the Antebellum United States (Cambridge: Cambridge University Press, 2010); Joseph P. Ferrie, Yankees Now: Immigrants in the Antebellum United States, 1840 - 1860 (New York: Oxford University Press, 1999); Quintard Taylor, In Search of the Racial Frontier: African Americans in the American West, 1528 - 1990 (New York: Norton, 1998); Bruce Levine, The Migration of Ideology and the Contested Meaning of Freedom: German Americans in the Mid-Nineteenth Century (Washington: German Historical Institute, 1992).
}

${ }^{93}$ For more on the influence of the military strategy and technology of the Union and Confederate armies on the transatlantic world, see: A.D. Harvey, "Was the American Civil War the First Modern War?," History, 97:2 (April 2012): 272 - 280; Wayne Wei-Siang Hsieh, "Total War and the American Civil War Reconsidered: The End of an Outdated 'Master Narrative," Journal of the Civil War Era 1, no, 3 (September 2011): 394 - 408; Forster and Nagler, On the Road to Total War.

${ }^{94}$ These works include, but are not limited to: Don Doyle, American Civil Wars; Daniel Kilbride, Being American in Europe, 1750-1860 (Baltimore: The Johns Hopkins University Press, 2013); Christopher Hanlon, America's England: Antebellum Literature and Atlantic Sectionalism (New York: Oxford University Press, 2013, 2016); Lepler, The Many Panics of 1837; Roberts, Distant Revolutions; Flint, The Transatlantic Indian; Paola Gemme, Domesticating Foreign Struggles: The Italian Risorgimento and Antebellum American Identity (Athens: University of Georgia Press, 2005); Richard Carwadine and Jay Sexton, The Global Lincoln (New York: Oxford University Press, 2011); Andre Fleche, The Revolution of 1861: The American Civil War in the Age of Nationalist Conflict (Chapel Hill: University of North Carolina Press, 2012); Don Doyle, et al., The Transnational Significance of the American Civil War; Robert E. May, ed., The Union, the Confederacy, and the Atlantic Rim (West Lafayette: Purdue University Press, 
circumstances proved no different from the way that Americans had historically viewed themselves as part of a vibrant international system. These relationships permeated the early to mid-nineteenth century, reinforcing the idea that American politics, economics, and culture existed as part of a much larger nexus of events and ideas. Placing Charles Anderson Dana's experiences in the context of this web enriches our understanding of the interconnectedness of the nineteenth-century United States and the impact of ideas like republicanism.

\section{Dana and Upstate New York}

Charles A. Dana's early life reflected the dynamism of the transatlantic world within which he lived and analyzing it helps explain his later intellectual development. A member of a well-known American family, but not a member of the most prominent branch of that family tree, his upbringing was relatively modest. At the time of his birth, Charles' father Anderson was a humble merchant in charge of a warehouse in Gaines, New York along the recently completed Erie Canal. ${ }^{95}$ Charles's mother died in 1828 , when he was nine, forcing father Anderson to split up the family. Dana was sent to his mother's brother's farm in Connecticut. Charles's uncle on his father's side arranged for Dana's education, hiring tutors who helped the bright boy get classed with "boys as much as six and eight years his senior" when he was ten. ${ }^{96}$ Dana had the opportunity to learn multiple languages, and studied Latin grammar and mathematics. Dana's biographer explains that at this point, once Dana had "acquired sufficient education, especially in reading, writing and arithmetic, to earn his own living, and accordingly, with the consent of his uncle and grandfather, he was sent to Buffalo" to live with his benefactor uncle. ${ }^{97}$

\footnotetext{
1996); Edward L. Ayers, "The American Civil War, Emancipation, and Reconstruction on the World Stage," OAH Magazine of History 20 (January 2006): 54 - 60.

${ }^{95}$ Wilson, The Life of Charles A. Dana, 2.

${ }^{96}$ Ibid, 3.

${ }^{97}$ Ibid.
} 
The economic, political, and demographic character of upstate New York influenced Dana's early life. The nation's infrastructural development, economic expansion, and population growth in places like Buffalo were driven by the completion of the Erie Canal in $1832 .{ }^{98} \mathrm{~A}$ feature of the United States' participation in the First Industrial Revolution, the new waterway encouraged residents from the Connecticut River Valley and elsewhere in New England and the mid-Atlantic states to seek new futures in upstate New York towns like Buffalo, Rochester, Utica, Syracuse, and the Gaines he knew. The character of the economic and cultural developments in these cities mirrored the customs and practices of those migrating to the city. New residents from the New England economies of New Hampshire, Vermont, and Connecticut, which were built on transatlantic trade, innovation, and local industry, gave upstate New York a similar character. Across the 1820s, 30s, and 40s, the population of Buffalo grew dramatically. Connecticut Valley settlers, whose families helped found the earliest New England communities, were now moving west in search of new opportunities. ${ }^{99}$ Another set of new migrants were those from Europe, as Germans and other immigrant groups flocked to cities like Buffalo and Rochester where earlier migration of German speakers made upstate New York a welcome area for those looking for a familiar culture. These immigrant groups became pillars of the community where they started

\footnotetext{
${ }^{98}$ For historical treatments of the Erie Canal and its impact on New York, see: Ronald E. Shaw, Erie Water West: A History of the Erie Canal, 1792-1854 (Lexington: University of Kentucky Press, 1990) and Canals for a Nation: The Canal Era in the United States, 1790-1869 (Lexington: University Press of Kentucky, 1990); Roger E. Carp, "The Limits of Reform: Labor and Discipline on the Erie Canal," Journal of the Early Republic 10, no. 2 (Summer 1990): 191-219; Carol Sheriff, The Artificial River: the Erie Canal and the Paradox of Progress, 1817-1862 (New York: Hill and Wang, 1996); Peter L. Bernstein, Wedding of the Waters: The Erie Canal and the Making of a Great Nation (New York: W.W. Norton, 2005); Patrick Vincent McGreevy, Stairway to Empire: Lockport, the Erie Canal, and the Shaping of America (Albany: State University of New York Press, 2009) and Gerard Koeppel, Bond of Union: Building the Erie Canal and the American Empire (Cambridge: Da Capo Press, 2009).

${ }^{99}$ Brian C. Wilson, Yankees in Michigan (Lansing: Michigan State University Press, 2008); Andrew P. Yox, "Bonds of Community: Buffalo's German Element, 1853-1871," New York History 66, no. 12 (April 1985): 140-163.
} 
new businesses, started German-language newspapers like Der Weltbürger founded in $1837,{ }^{100}$ and expanded local trade networks with groups like the local Seneca reservation. ${ }^{101}$ This migration pattern that included both domestic and international refugees into upstate New York gave these budding municipalities a very diverse and cosmopolitan, if also humble and smalltown, ethos. ${ }^{102}$ Buffalo, Rochester, and the greater Erie Canal corridor transformed into hubs of shipping, trade, and commerce motivated by this large influx of migrants - domestic and otherwise - as well as the rapid proliferation of new technology. These influences converged to make Buffalo and greater upstate New York burgeoning economic hubs of the early nineteenth century—markers of the new century's possibilities.

\footnotetext{
${ }^{100}$ Max Heinrici, Das Buch Der Deutschen in Amerika (Philadelphia: Walther, 1909). December 2, 1837 was the birthdate of the first German newspaper in Buffalo. It was a weekly paper called Der Weltbürger [The World Citizen], published by Georg Zahm from Zweibrücken. On the first edition, the paper explained the following about why it was created: "The number of German people in Buffalo has increased significantly in the past four or five years. The commercial and political situation of this city is of such great importance to the Germans living here that people have felt the urgent need for a newspaper in the German language for a long time. Its goal is to inform the German people of this country's politics and to communicate the most important American and European events. Indeed, informing the reader is its prime motive, therefore it will join no particular political party; rather it will attempt to remain independent and non-partisan in order to sustain the fundamental principles necessary to the preservation of the Constitution. In important political issues the platforms of both political parties will be communicated in order to put the reader in the position to form his own opinion. The newspaper will provide a definitive voice against the persecution of immigrant Europeans and it will make these people aware of their rights guaranteed by constitution and law."

${ }^{101}$ For more information on changes conditions in upstate New York during this period, see: Laurence Glasco, "Migration and Adjustment in the Nineteenth-Century City: Occupation, Property, and Household Structure of Native-born Whites, Buffalo, New York, 1855, in Hareven and Vinovskis, eds. Family and Population in $19^{\text {th }}$ Century America (Princeton University Press, 1978); Edward Pessen, "A Variety of Panaceas: The 'Social Problem' and Proposed Solutions to it in Mid-Nineteenth Century New York State," New York History 59, no. 2 (April 1978): 198-222; Mary P. Ryan, Cradle of the Middle Class: The Family in Oneida County, New York, 1790-1865 (New York: Cambridge University Press, 1981); Gerber, The Making of an American Pluralism; Matthew Dennis, Dreams, Dreamers, and Visions: The Early Modern Atlantic World (Philadelphia: University of Pennsylvania Press, 2013).
}

${ }^{102}$ As part of all this, even the Seneca were themselves partly Quaker. For more, see: Matthew Dennis, Seneca Possessed (Philadelphia: University of Pennsylvania Press, 2010); Levinus K. Painter, "Quaker Settlements in Erie County, New York," Quaker History 55, no. 1 (Spring 1966): 24-37. 


\section{The "Burned-Over District" and Romanticism}

Together with the large influx of New Englanders who settled in northern New York state, the region further contended with the religious revolution of the Second Great Awakening. Between 1790 and 1820 a wave of change in religious affiliation and belief changed the nature of religion in the American north. 103Along the Erie Canal corridor, as in many other places, Baptist and Methodist church memberships swelled as religious revivalism took hold. This revivalism is often paired with the Romantic movement in literature and philosophy by scholars because both movements emphasized subjectivism and emotion over the pure rationality of the Enlightenment. 104Buffalo's history in this period represents a good example of the role the Second Great Awakening played in transforming American religious belief. To reflect the role of the religious movement's impact on the city, historians of the region and period use the term given to it by revivalist Charles Finney: the "Burned-over District." ${ }_{105}$ The nickname for the area of Buffalo, Rochester, Ithaca, Syracuse, and south along the Adirondacks and Catskills colorfully described the way that religious sects like the Baptists, Methodists, Mormons, and Millerites caught the attention of redemption-starved and god-fearing residents of the region. The city's

\footnotetext{
${ }^{103}$ There has been a plethora of historical studies addressing the Second Great Awakening, including: R. Laurence Moore, Religious Outsiders and the Making of Americans; Jon Butler, Awash in the Sea of Faith: Christianizing the American People; Frank Lambert, Inventing the 'Great Awakening' (Princeton: Princeton University Press, 1999); E. Brooks Holifield, Theology in America: Christian Thought from the Age of the Puritans to the Civil War (New Haven: Yale University Press, 2003); Thomas S. Kidd, The Great Awakening; Daniel C. Goodwin, Into Deep Waters.

${ }^{104}$ Cross, Burned Over District, 55 - 112.

105 James D. Folts, “The Fanatic and the Prophetess: Religious Perfectionism in Western New York, 18351839, New York History 72, no. 4 (October 1991): 357-387; Douglas M. Strong, Perfectionist Politics: Abolitionism and the Religious Tensions of American Democracy (Syracuse: Syracuse University Press, 1999); Alan Taylor, "The Free Seekers: Religious Culture in Upstate New York, 1790-1835," Journal of Mormon History 27, no. 1 (Spring 2001); Marianne Periaccante, Calling Down Fire: Charles Grandison Finney and Revivalism in Jefferson County, New York, 1800-1840 (Albany: State University of New York Press, 2003); Paul E. Johnson, A Shopkeeper's Millennium: Society and Revivals in Rochester, New York, 1815-1837 (New York: Hill and Wang, 2004); Richard Lee Rogers, "The Urban Threshold and the Second Great Awakening: Revivalism in New York State, 1825-1835," Journal for the Scientific Study of Religion 49, no. 4 (December 2010): 694-709; Rachel Cope, "From Smouldering Fires to Revitalizing Showers: A Historiographical Overview of Revivalism in Nineteenth-Century New York," Wesley and Methodist Studies 4 (2012): 25-49.
} 
broad embrace of various belief-systems as part of one polity made it susceptible to the flood of new religious ideas inspired by the Second Great Awakening. Buffalo during Dana's childhood and adolescence was an international city, and politically and religiously complex; a great place for a young student interested in European philosophy and culture.

Dana familiarized himself with the routines and diverse makeup of the restless city, especially its pluralistic approach to religion, politics, and civic culture. For income, teenage Charles helped keep accounts of "the popular leading dry goods store for fashion of those days," Staats and Dana. ${ }^{106}$ His uncle, and managing partner in the firm, William K. Dana, arranged for Charles's upbringing, employment, and education. ${ }^{107}$ The store stood on a bustling mid-town commercial street popular amongst the city's diverse population. Staats and Dana was profitable enough to have another branch in a neighboring town. ${ }^{108}$ As customers, the store especially attracted German-speaking immigrants and residents from the local Seneca reservations. ${ }^{109} \mathrm{~A}$ keen student, Charles quickly became fluent in both German and Seneca. ${ }^{110}$ His linguistic fluency helped establish his reputation at the store, and also allowed him to travel freely across the city and surrounding Seneca and Iroquois reservations. ${ }^{111}$ Dana's biographers explain that he appeared to have a "slight strain of Continental blood in his veins." 112 As shopkeeper for his uncle's firm,

${ }^{106}$ Welch, Samuel Manning. Home History: Recollections of Buffalo During the Decade from 1830 to 1840 of Fifty Years Since (Buffalo: Peter Paul \& Bro., 1891), 165. Welch's brother worked with Dana for a time as register keeper and shares his remembrances, briefly, in this source.

${ }^{107}$ First Annual Report of the Executive Committee of the Young Men's Association of the City of Buffalo (Buffalo: Press of Oliver V. Steele, 1837). William K. Dana joined the group in 1845. For a good summary of William K. Dana, see Wilson, The Life of Charles A. Dana, 4.

${ }^{108}$ Wilson, The Life of Charles A. Dana, 4.

${ }^{109}$ Welch, Home History, 88-9.

${ }^{110}$ Wilson, The Life of Charles A. Dana, 6.

${ }^{111}$ Ibid, $3-9$.

${ }^{112}$ Ibid, 3. 
Dana's "continental" education also came in the evenings, and reinforced the international nature of his interests and daily interactions. However, these were insufficient resources to send Charles to a preparatory school in Buffalo to groom him for college. At a time when many elite future college-goers attended elite academies, Dana ensured his own academic advancement, studying by candlelight in the evenings (a habit that would help cause Dana's renowned weak vision). After his shifts at Staats and Dana, Charles studied the Latin classics, Greek grammar, history and drama, and the greats of English Romanticism. ${ }^{113}$ Of that list, Dana's relationship to transatlantic Romantic literature and philosophy in this period remained important. ${ }^{114}$ It inspired the proliferation of novels, poetry, and philosophy featuring the power of the individual, and the subjective connection to nature, love, and the divine. Dana read the leading writers of the movement, including Samuel Coleridge, Thomas Carlyle, ${ }^{115}$ and Johan Wolfgang von Goethe. ${ }^{116}$ Dana devoured these thinkers' critical assessment of the relationship between the individual and God. Dana's religious wanderings were as unsettled as that of the region, but also reflected the region's open mind for such questions. One of Dana's biographers explained that Dana had not lived a stable enough life to allow for the maturation of any faith in rigid systems of thought and faith. He explained that "his fortunes were too uncertain, his life too unsettled, to admit of his settling down to the rigid requirements of an orthodox faith." ${ }^{117}$ In lieu of focusing on religion,

\footnotetext{
${ }^{113}$ Wilson, The Life of Charles A. Dana, 3 - 9.

${ }^{114}$ For more, see: Morse, American Romanticism; Gilmore, American Romanticism and the Marketplace; Prickett, Origins of Narrative: The Romantic Appropriation of the Bible; Raimond and Watson, A Handbook to English Romanticism.

115 John Nichol, Thomas Carlyle (Cambridge: Cambridge University Press, 2011); John Morrow, Thomas Carlyle (New York: Bloomsbury Academic Press, 2007).

${ }^{116}$ Wilson, The Life of Charles A. Dana, 7. For recent work on Goethe, see: Rüdiger Safranski and David Dollenmayer (trans.), Goethe: Life as a Work of Art (London: Liveright, 2017); John R. Williams, The Life of Goethe: A Critical Biography (New York: Wiley-Blackwell, 1998).

${ }^{117}$ Wilson, The Life of Charles A. Dana, 17.
} 
Dana continued to explore all manners of literature and philosophy, bringing him closer with Buffalo's intellectual circles.

Dana's intellectuality helped expand his social circle and gained him entrance into one of Buffalo's leading intellectual and community organizations. Both can be traced to Dana's friendship with one of Buffalo's most famous residents, Dr. Austin Flint, a close friend of Dana's uncle, and a leading doctor, researcher, and scholar. ${ }^{118}$ As a reflection of how close the two became, Dana and Dr. Flint, by one account, "spent most of their leisure time together." ${ }^{119}$ Both Flint and Dana's uncle were members of a group called the Young Men's Association, dedicated to intellectual study and the preservation of knowledge for Buffalo's citizens. The two helped Dana gain acceptance into the group of 545 members in 1837. The YMA sought to establish itself as an organization meant for the intellectual enrichment of its members and the larger community. The group's founding documents confirm it sought to establish and maintain "a library, reading rooms, literary and scientific lectures and other means of promoting moral and intellectual improvement." ${ }^{120}$ The YMA subscribed to the nation's academic journals, ensuring its members could refer to the most current scholarship. ${ }^{121}$ Some of William Dana and Dr. Flint's

\footnotetext{
${ }^{118}$ For more on Flint's standing in the medical field recently, see: Warren Winkelstein, "Austin Flint, Clinician Turned Epidemiologist," Epidemiology 18, no. 2 (March 2007): 279; Bruce R. Leslie, "Austin Flint in New Orleans and the Origins of Evidence-Based Medicine," The Journal of the Louisiana Medical Society 154, no. 3 (2002): 144-148; N.J. Mehta, R.N. Mehta, and I.A. Khan, "Austin Flint: Clinician, Teacher, and Visionary," Texas Heart Institute Journal 27, no. 4 (2000): 386-389.

${ }^{119}$ Wilson, The Life of Charles A. Dana, 9. For more on Dr. Austin Flint's role as an important physician in the 1840s and 1850s, and his larger role in medical ethics and philosophy, see: John R. Shook, ed. Dictionary of Early American Philosophers, 2 vols. (London: Continuum, 2012), I, 397 - 398.

${ }^{120}$ First Annual Report of the Executive Committee of the Young Men's Association of the City of Buffalo, with the By-Laws, List of Officers, and Act of Incorporation (Buffalo: Press of Oliver V. Steele, 1837), 5. The Young Men's Association was fairly popular in northern New York. There was another branch of the group in the state capital of Albany. The Buffalo group's minutes clarified that the group's goals to form an intellectual organization in search of establishing a strong library of classics, politics, economics, and social issues that included 2,700 volumes. When Dana was a member, and when Charles would have known the YMA, the group was establishing its library, adding a reading room, and making relationships with other intellectual organizations around Buffalo.

${ }^{121}$ Ibid.
} 
friends from the Young Men's Association of Buffalo also brought Charles into a local breakout group from the YMA called the Young Men's Literary Society, (or as the members informally called it, the "Coffee Club"). Flint and Dana's uncle introduced Charles to the group and helped expose the well-read young man to others like him. The Coffee Club and the Young Men's Association of Buffalo helped bridge Dana's intellectual interests in the 1830s with a community of well-educated men seeking intellectual enrichment and personal growth. The semi-elite, semiformal, discussion and literature club featured some of Buffalo's leading men. Apart from Flint, they included the well-known lawyer Deacon James Crocker, Crocker's student clerk James Barrett, the Reverend James Hosmer, and school master John S. Brown. ${ }^{122}$ The Coffee Club had a similar mission to that of the Young Men's Association and worked in concert with that group in helping complete the library and reading room project. Flint often gave talks in front of the group, and so did Dana. ${ }^{123}$ Historians have explained that the group was a place "where young clerks and bookkeepers could find an outlet for their literary productions in [the] congenial and supportive company" of the city's scholarly and professional community. ${ }^{124}$ Dana's amateur publishing within the group, and attendance at lectures and readings represents one of the earliest instances of Dana's first efforts at being a public intellectual.

\footnotetext{
${ }^{122}$ Roger Whitman, Scott G. Eberle and David A. Gerber, The Rise and Fall of a Frontier Entrepreneur: Benjamin Rathbun (Syracuse: Syracuse University Press and Erie County Historical Society, 1996), 74; Wilson, The Life of Charles Anderson Dana, 18.

${ }^{123}$ Wilson, The Life of Charles A. Dana, 10. On January 29, 1839, Charles gave a lecture to the club titled "Early English Poetry." Biographer James H. Wilson analysis of the lecture's transcript maintained that it showed "the wide range of his reading on the subject of his lecture, and exemplifies his poetical theories, and his canons of criticism." See the text of the paper in In Dana's granddaughter, Ruth Draper's daughter's box, at the Harvard archives in the Schlesinger Library.

${ }^{124}$ Whitman, Eberle and Gerber, The Rise and Fall of a Frontier Entrepreneur, 74; Wilson, The Life of Charles A. Dana, 18.
} 
An economic recession in 1837, driven by bank speculation in gold and silver in London and New York, destabilized Dana's life. The "panic of 1837," as the recession became known across the Atlantic world, lowered wages for Americans and wrecked businesses in the Erie Canal corridor. ${ }^{125}$ The modest citizens of Buffalo saw their wages fall as local shops closed. The economic vitality brought to Buffalo by the Erie Canal could not shelter Charles from the vicissitudes of the transatlantic economy. His uncle's store, like many other businesses in the city, was dependent on the transatlantic commerce brought to the region because of the Erie Canal and by 1838 Staats and Dana was forced to close. ${ }^{126}$ Occurring in the shadow of his eighteenth birthday, the economic depression fractured any hopes Dana would have of staying in upstate New York. Dana had assets to take with him in finding a new direction, however. He now had a keen eye for business, having worked for his uncle for over a decade. Charles had a wide range of literary and philosophical knowledge. Also important was his religious and philosophical skepticism, and intellectual character. He could now prove the ability to thrive in a diverse northern city. Most important, he possessed relentless energy. Knowing all of this about himself, Dana decided to apply for college that fall. This would be no small feat, as he lacked a transcript full of prep-school courses as many other college applicants would enjoy.

\section{$\underline{\text { Dana and a Formal Education }}$}

In 1838, Dana shifted to getting a formal education, with the hopes of gaining acceptance to Harvard College. While it is not clear whether or not Dana had a formal recommendation that guaranteed his entrance into the school (especially considering that he did not have the formal schooling that benefited most Harvard entrants), he did have personal ties to the school that

\footnotetext{
${ }^{125}$ Lepler, The Many Panics of 1837; Roberts, America's First Great Depression.

${ }^{126}$ Wilson, Life of Charles A. Dana, 8-9.
} 
would have helped gain him admission. ${ }^{127}$ For one, the Dana family name was familiar to the Harvard alumni registrars. Perhaps the oldest alumnus in the family, Francis Dana graduated in 1762, was a member of the Constitutional Congress from Massachusetts, and later minister to Russia in John Adams' administration. ${ }^{128}$ Samuel Luther Dana (1763 - 1832), Charles' second uncle, first graduated from Harvard in 1813, and the school's Medical School in 1818. Dana also had relatives with notable positions in higher education and politics. One of Charles' distant uncles Daniel Dana (1771 - 1859), had been president of Dartmouth College in 1820-1821. His great uncle Samuel (1767-1835) was a member of the House of Representatives for Massachusetts's $4^{\text {th }}$ district between 1814-1815, and a member of the Massachusetts House of Representatives and State Senate for various periods across the 1810s and 20s. His great uncle Judah (1772-1845) was senator from Maine between 1836 and 1837, and Judah's son John (18081867) the $19^{\text {th }}$ and $20^{\text {th }}$ Governor of Maine. ${ }^{129}$ Charles also had friends with direct connections to the college. Dr. Flint was an alumnus. ${ }^{130}$ Dr. Hosmer, of the Coffee Club and the Young Men's Association, also had connections at the school being friends with Professor C.C. Felton, who taught Greek literature, and history, and would later become Harvard's president. ${ }^{131}$ On the back of his friends, and his own private academic rigor, Dana successfully gained the opportunity of taking and passing Harvard's entrance exam early in $1838 .^{132}$

\footnotetext{
${ }^{127}$ For more on the expectations of the typical prep school applicant at the time, see: Story, "Harvard Students, the Boston Elite, and the New England Preparatory System, 1800-1876."

${ }^{128}$ Richard Henry Dana, "Francis Dana," Magazine of History and Biography 1 (1877): 86 - 95.

${ }^{129}$ Elizabeth Ellery Dana, The Dana Family in America (Cambridge: Wright \& Potter Printing Company, 1956).

${ }^{130}$ Steele, The Sun Shines for All, 9.

${ }^{131}$ Ibid, 10.

${ }^{132}$ Dana to James Barrett Wilson, October 29, 1840 in Wilson, The Life of Charles A. Dana, 24.
} 
In the late 1830s, Harvard was experiencing as much a process of change as Dana and the nation were. School President Josiah Quincy, who was in his tenth year when Dana arrived, was in the throes of a battle over the school's curricular future. Debates over what the school should be teaching reflected the changes in religion and philosophy occurring outside the college's walls. Quincy was president of the university in the middle of the Second Great Awakening. New England had undergone a critical transformation in its expectations for religion and religious practice. ${ }^{133}$ In the 1810 s and before, the region had been dominated by a conservative, Calvinist, religious impulse. ${ }^{134}$ Harvard's curriculum reflected this: the classics, the Anglo-American literary and political canon, a Protestant "character-building education," ${ }^{135}$ classes that emphasized "the "truths' of systematic theology." ${ }^{136}$ This curriculum became increasingly controversial in the decades after 1820. Historian Stephen Shoemaker argues that Unitarianism encouraged a cultural reorientation towards the reform-minded, decentralized understanding of "religious" practice rather than formal Calvinism. Unitarianism strayed from many of the basic tenets of Calvinism: it rejected Jesus's "god-ness" and the truth of the Trinity, elevated individual spirituality over formal religiosity within a given sect and championed the individual's connection with a non-denominational deity. This brand of liberal Unitarian reform forced Harvard to reconsider its course offerings, syllabi, and textbooks in the $1830 \mathrm{~s} .{ }^{137}$ Unitarianism

\footnotetext{
${ }^{133}$ Morison, Three Centuries of Harvard.

${ }^{134}$ Rowe, "New Wine in Old Wineskins: Social Structure and the Making of $19^{\text {th }}$ Century American Calvinism"; Davis, John Calvin's American Legacy; John Witte, The Reformation of Rights.

${ }^{135}$ George Marsden, The Soul of the American University: From Protestant Establishment to Established Nonbelief (New York: Oxford University Press, 1994), 82.

${ }^{136}$ Stephen Shoemaker, "The Emerging Distinction between Theology and Religion at Nineteenth-Century Harvard University," The Harvard Theological Review 101, no. 3-4, Centennial Issue (Jul.- Oct., 2008): 419.
}

${ }^{137}$ Steele, The Sun Shines For All, 11. "Though the Unitarians had departed from Calvinist orthodoxy over the doctrine of the Trinity, the real conflict had been the nature of human beings and their contribution to their own salvation. Unitarians believed that human reason was a gift from God and that man an infinite 
had, as Dana's biographer explains, become "the church of the Boston establishment." 138 Dana's father, a conservative Congregationalist now living in the frontiers of Ohio, cautioned him about radical Unitarianism spreading through New England and at Harvard upon hearing that Charles had gained admission. ${ }^{139}$ Dana failed to heed the patriarchal advice. His broad intellectual curiosities and his interests and associations suggest that Charles left precisely for the religious and intellectual influences that his father warned him against.

In letters to friends in Buffalo, Dana confirmed the thorough transformation of Harvard by liberal reforms. Dana's entrance exam to the college was still weighted heavily in the traditional Latin and Greek. ${ }^{140}$ The school's professors of natural sciences and religion professors, men like Henry Ware, Sr. with the school since 1805, still taught the systematic theology that Dana and others had hoped would be phased out by the late $1830 \mathrm{~s} .{ }^{141}$ In a letter to his father, then living in the frontier state of Ohio, Dana confirmed that some in the school still held to the old "positive doctrine[s]" of Calvinism. ${ }^{142}$ There was progress, he noted, in that the long-studied

capacity for good. Even more controversial was their rejection of the idea that some sinners were predestined for damnation."

${ }^{138}$ Ibid, 10 - 11. For more on Harvard and Unitarianism, see: Daniel Walker Howe, The Unitarian Conscience: Harvard Moral Philosophy, 1805 - 1861 (Cambridge: Harvard University Press, 1970).

${ }^{139}$ Letter from Anderson Dana, Ohio, to Charles A. Dana, undated, in Wilson, The Life of Charles A. Dana, $16-17$.

${ }^{140}$ A Catalogue of the Officers and Students of Harvard University, for the Academic Year, 1839-1840 (Cambridge: Folsom, Wells, and Thurston, 1839), 23. The Harvard Catalogue of 1839/40, where Dana is listed as Freshman, noted that prospective first-years would be tested in the following by the Latin, Greek, and "Mathematical" Departments: 1), of Latin, "the whole of Virgil and Caesar," "Cicero's Select Orations," "Adam's Latin Grammar (Gould's edition), or Andrews and Stoddard's Latin Grammar, including Prosody, and in writing Latin." 2) from the Greek Department, "Jacob's Greek Reader, the four Gospels of the Greek Testament, Sophocles' Greek Grammar, or the Gloucester, Buttmann's, of Fisk's Greek Grammar, including Prosody, and in writing Greek." 3) of the Math Department, "Lacroix's Arithmetic (Cambridge edition), Euler's Algebra (printed also at Cambridge)," and "Elements of Geography, Modern and Ancient, by J.E. Worcester." (23)

${ }^{141}$ Shoemaker, "The Emerging Distinction between Theology and Religion," 419.

${ }^{142}$ Dana, at Cambridge, to Flint, January 16, 1840 in Wilson, The Life of Charles A. Dana, 19. 
theological ideas of John Locke were being "already laid aside," and he predicted that William Paley's textbook Natural Theology or, Evidences of the Existence and Attributes of the Deity (Philadelphia: John Morgan, 1802) were "about to suffer the same fate." ${ }^{143}$ Textbooks lile Paley's were foundational classics in this Calvinist-directed understanding of theology and natural philosophy. Harvard's curriculum changes reflected broader trends away from these ideas and towards the prevailing popularity of Romanticism. Felton, perhaps the professor Dana remained closest to, was a neo-classicist and hesitant about the trend toward spiritualism and subjectivity. ${ }^{144}$ It is clear from letters shared between Felton and Dana that the growing popularity of Ralph Waldo Emerson and the transcendentalists in the neighborhoods around Cambridge disappointed the old professor, but enchanted the young undergraduate. ${ }^{145}$ A movement gained momentum outside the walls of Harvard led by Emerson and others bringing together English and Germaninspired Romantic ideas about culture that Dana's professors could not always provide. Dana wrote to Flint that "it may be vain to expect a university as far advanced as the age." ${ }^{\text {"146 }}$ Even with that being the case, he embraced the modest reforms in curriculum that he enjoyed at Harvard.

${ }^{143}$ Ibid.

${ }^{144}$ Felton's biography is notable. Born in 1807, Felton graduated from Harvard in 1827, was a member of the Hasty Pudding Club, became a tutor at the school in 1829, and hired as university professor of Greek in 1832. Felton was promoted to the Eliot professorship of Greek literature in 1834. When he knew Dana, Felton was also well published for New England. He had just published a well-read set of English annotations of Friedrich August Wolf's analysis of Homer's Iliad (Homer, Friedrich August Wolf, Cornelius Conway Felton, The Iliad from the Text of Wolf (Boston: Munroe, 1833) and a translation of German poet Wolfgang Menzel's earlier liberal literary criticism. Wolfgang Menzel and C.C. Felton, and George Ripley, German Literature (Boston: Hilliard, Gray, and Company, 1840). He would later publish widely in Greek history, even selling widely purchased Greek language textbooks. Felton would later become the President of Harvard from 1860 until his death in 1862.

${ }^{145}$ In Myerson, Joel. Emerson and Thoreau: The Contemporary Reviews, pg. xiii. Myerson explains that "C.C. Felton warned against 'the super-sublimated transcendentalism of the Neo-Platonistic style'." For more of Felton's critiques of Emerson and these ideas, see: "Emerson's Essay's," Christian Examiner 30 (May 1841): 253-62; Monthly Review 3 (October 1841): 274-9; North American Review 70 (April 1850): 520-524; Graham's Magazine 36 (March 1850): 221-2.

${ }^{146}$ Dana, at Cambridge, to Flint, January 16, 1840 in Wilson, The Life of Charles A. Dana, 19. Dana's note was inspired by his knowledge that Harvard was planning on writing yet another new course for the next year on the History of Philosophy using Locke and Paley texts. 
Dana grew even closer to the age's Romantic spiritualism because his college had also moved in this direction. Harvard's developing embrace of Unitarian ideas under President Quincy reflected his "plan," as historian Stephen Shoemaker argues, "to get out of the theology business." ${ }^{147}$ Shoemaker and other historians have shown that the school intentionally moved away from the theological claims of conservative Christianity, and towards a closer connection to secularization and the spiritualism that Dana hoped to study. ${ }^{148}$ In 1840, President Quincy reiterated this vision for the college that explicitly noted that "Harvard University is not a theological establishment." ${ }^{149}$ His aim to distance Harvard from the debates between Unitarians and the Trinitarian, Calvinist doctrine produced a liberal religious atmosphere that appealed to Dana. In a letter to Dr. Flint in 1840, he explained that "old Harvard is feeling" the influence of "spiritualism," and "the tendency of the age is spiritual." 150 A reflection of Dana's growing comfort at the newly "spiritual" Harvard was his increasing biblical skepticism. The Romantic, German-inspired idealism of Samuel Coleridge's work, as well as his biblical criticism, encouraged the maturation of Dana's non-denominational Christian idealism. ${ }^{151}$ Dana was fascinated by Coleridge's argument for the power of individual faith and the power of cooperation between the individual and the divine. Dana, as Ralph Waldo Emerson and others famous Coleridge readers, ${ }^{152}$ strayed from the Calvinism that dominated northern American

\footnotetext{
147 Shoemaker, "Distinction between Theology and Religion,” 420.

148 Shoemaker, 418 - 420; Julie Reuben, The Making of the Modern University: Intellectual Transformation and the Marginalization of Morality (Chicago: University of Chicago Press, 1996), 13. 
religion and sought out similar Unitarian and Romantic alternatives. Dana read these reformers at Harvard because he shared their doubts about ever truly knowing God through revelation in a traditional church. ${ }^{153}$ Coleridge's "new poetry," as some historians have described it, became increasingly popular in the United States in this period for its liberal arguments in favor of the subjective understanding of God. ${ }^{154}$ In his exploration of Coleridge at Harvard, Dana forged his understanding of the Romantic poet that emphasized the ideal manifestation of the divine within nature and society.

In addition to these writers, Dana's intellectual development also drew from the work of other Romantic idealists. In these thinkers Dana also came to see how Romanticism could translate to communitarianism and republicanism. These ideas continued to keep him distant from traditional religious sects. The pantheist ideas of Dutch philosopher Baruch Spinoza (1632 1677), which had a controversial reputation among Christian scholars, particularly attracted Dana. ${ }^{155}$ Spinozan philosophy fit within the canon of biblical criticism that Dana studied, as Coleridge had read Spinoza too. Spinoza criticized the idea that God was the anthropomorphic being of canon but was also more expansive, as part of the core of all living things. From this Spinoza developed an expansive interpretation of the scope of God's community on Earth. For this Spinoza was often charged with pantheism, and the Church of his own time worked tirelessly to suppress his ideas. Spinoza attracted Dana for reasons that other Romantics found the Dutch skeptic congenial: his biblical criticism and questioning of Enlightenment rationalism and support

\footnotetext{
${ }^{153}$ Ibid. "Gradually the number of reviews of Coleridge picked up in the 1830 s, after beginning in 1800 , as "subjective and idealistic criteria replaced neoclassical prescriptions by the early 1830 s...Early reactions to Coleridge's work make clear the neoclassical current that he and Wordsworth were bucking..." Also see, 7.

${ }^{154}$ Ibid. "Transcendentalism sparked additional discussion, particularly after 1836 - but even before Nature, editors and reviewers worried about the antinomian and pantheistic tendencies in Coleridge's thought. Beginning in 1839 came the sigh of relief and acceptance-more than acceptance, the attempt by rival factions to claim Coleridge as their own...By 1844, Coleridge had become a household word..."

${ }^{155}$ Halmi, “Coleridge’s Ecumenical Spinoza,” 189-190.
} 
for general religious tolerance. In letters home to Dr. Flint, Dana defended Spinoza against attacks from conservatives. He explained "that the common charges against [Spinoza] are false, and that instead of having been an infidel, or pantheist in the ordinary sense of the term, he was in the highest sense a theist." ${ }^{156}$ These affirmative reviews of Spinoza signaled how deeply Dana supported the turn to an emotional, subjective, and egalitarian understanding of religion, philosophy, and the Divine. Another of these writers that Dana followed was Friedrich Schleiermacher, a biblical scholar engaged in hermeneutics, or the higher criticism of the Bible. ${ }^{157}$ Wilhelm de Wette, another German theologian and liberal critic of the Bible, was also on Dana's reading list. ${ }^{158}$ So were works about alternative forms of spirituality and religion, like that of Emmanuel Swedenborg. ${ }^{159}$ An eighteenth century Protestant theologian, reformer, and biblical critic, Swedenborg published a host of texts explaining his interpretation of the spirituality that inspired Biblical verse. ${ }^{160}$ While not a pantheist as Spinoza was perceived to be, Swedenborg held to a Spinozan critique of the established Church, and sought out an alternative remedy to the ills of physical existence in human society. Dana held an incredibly high regard for

\footnotetext{
${ }^{156}$ Dana to Dr. Austin Flint, Buffalo, January 16, 1840 in Wilson, The Life of Charles A. Dana, 20.

${ }^{157}$ For more on Schleiermacher, see: Ulrike Wagner, “Transcendentalism and the Power of Philology: Herder, Schleiermacher, and the Transformation of Biblical Scholarship in New England," Amerikastudien/American Studies 57, no. 3 (2012): 419-445; Jacqueline Mariña, The Cambridge Companion to Friedrich Schleiermacher (New York: Cambridge University Press, 2005); B.A. Gerrish, A Prince of the Church: Schleiermacher and the Beginnings of Modern Theology (Eugene, Or: Wipf and Stock, 2001); Martin Redeker, Schleiermacher: Life and Thought (Philadelphia: Fortress Press, 1973).

${ }^{158}$ For more on de Wette, see: Thomas A. Howard, Religion and the Rise of Historicism: W.M.L. de Wette, Jacob Burckhardt, and the Theological Origins of Nineteenth-Century Historical Consciousness (New York: Cambridge University Press, 1999); John W. Rogerson, W.M.L. de Wette: Founder of Modern Biblical Criticism, An Intellectual Biography (Sheffield: Sheffield Academic Press, 1992).

${ }^{159}$ Wilson, The Life of Charles A. Dana, 27.

${ }^{160}$ For more on Swedenborg, see: Gary Lachman, Swedenborg: An Introduction to His Life and Ideas (New York: Tarcher/Penguin, 2012); Guarneri, 116-117; Clarke Garrett, "Swedenborg and the Mystical Enlightenment in Late Eighteenth-Century England," Journal of the History of the Ideas 45, no. 1 (Jan., Mar., 1984): 67 - 81; Marguerite Beck Block, The New Church in the New World: A Study of

Swedenborgianism in America (New York: Holt, Rinehart and Winston, 1932).
} 
Swedenborgianism, ${ }^{161}$ as did other Romantics. Swedenborg's ideas paralleled the progressing Unitarian reforms of Harvard's curriculum. Dana steeped himself thoroughly in the thought of these liberal Christian philosophers that early biographers described it as a "German obsession." 162 Professor Felton liked to remind Dana and his students about his opposition to the new liberal philosophy. Dana remembered how Fenton remained especially hostile to the popularity of the new ideas that he called "super-sublimated transcendentalism of the NeoPlatonic style." ${ }^{163}$ Dana explained that he sought a type of Platonic unity within society between the individual and the spiritual whole, something that historian Adam Tuchinsky has called "transcendental cultural democracy."164 In a letter to his friend William Barret, explaining why he moved from system to system in search of answers, Dana wrote that "next to the longing for moral freedom, for the subjection of the body to the law of the spirit, my most earnest wish is for a revelation of the truth, for the peace and serenity of an undoubting, a truly religious faith." ${ }^{\text {165 }}$ In a letter to Dr. Flint, Dana explained that he was "in the focus of what Professor Felton calls 'supersublimated transcendentalism,' and to tell you the truth, I take to it rather kindly."166

\footnotetext{
${ }^{161}$ Dana to Dr. Flint, November 21, 1840 cited in Wilson, 27. Dana explained to Flint that "you may think that I speak in superlatives, but superlatives can be applied to Swedenborg. Besides, there is a great deal that appears to me visionary and mystical in his writings, but all that is received by men for whose intellectual strength and acuteness I have great respect."

162 Wilson, The Life of Charles A. Dana, 25, 28. Dana indeed idolized German culture, and spoke about visiting, and even studying, there. In a letter to his friend William Barrett, Dana wrote that "my purpose of going to Germany grows fixed and definite. I am told that I can live there at a university for fifty dollars a year, and can earn something besides by teaching English. If at the end of my junior year, I can get hold of two or three hundred dollars, I shall go, God willing, I shall write you from Germany..." Dana to Barrett, October 29, 1840 in Wilson, 25.

${ }^{163}$ Myerson, Joel, ed. Emerson and Thoreau: The Contemporary Reviews, xiii.

${ }^{164}$ Tuchinsky, 58.

${ }^{165}$ Dana to William Barrett on January 10, 1841, in Wilson, 28-29.

${ }^{166}$ Dana to Dr. Flint on January 16, 1840, in Wilson, 19.
} 
One of the leading American followers of these Romantic thinkers helped Dana see the social, political, and economic ramifications of his search for a "truly religious faith." As Romanticism and Transcendentalism matured in popularity in the $1820 \mathrm{~s}$ and $30 \mathrm{~s}$, one of its leading American proponents was George Ripley (1802 - 1880). An alumnus of Harvard College (1823) and Harvard Divinity School (1826), Ripley developed a liberal interpretation of the Bible centered around the improvement of society. For ten years he was minister at the Purchase Street Church in Boston, instructor at Harvard College, and a published academic in the philosophy of religion. Ripley was on staff when Dana attended, publishing articles and books on the validity of the arguments of the European Romantics and biblical critics. Ripley's and Dana's intersecting intellectual interests would lead their path's to cross. Dana read many of Ripley's books. He enthusiastically recommended Ripley's Letters on The Latest Form of Infidelity, Including A View of the Opinions of Spinoza, Schleiermacher, and De Wette, published in 1840, in letters to friends. ${ }^{167}$ Dana wrote Dr. Flint that the book might change his mind in favor of the pluralistic theism within Spinoza's thought. ${ }^{168}$ Ripley's interpretation of these theologians provided Dana with a particular understanding of the applicability of Romantic and Transcendental ideas within society. ${ }^{169}$ Ripley insisted that because religious inspiration was an intensely personal experience, it was important for society to embrace social responsibility. Unlike other important reformers of the period who concentrated on the conscience, like Ralph Waldo Emerson, Ripley sought

\footnotetext{
${ }^{167}$ George Ripley, Letters on The Latest Form of Infidelity, Including A View of the Opinions of Spinoza, Schleiermacher, and De Wette (Boston: James Munroe and Company, 1840). Specifically cited in Dana to Dr. Austin Flint, Buffalo, January 16, 1840 in Wilson, The Life of Charles A. Dana, 20.

${ }^{168}$ Dr. Austin Flint, Buffalo, January 16, 1840 in Wilson, The Life of Charles A. Dana, 20.

${ }^{169}$ For more on Ripley's intersections with other things that Dana was known to have been reading while at Harvard and before, see: Joseph Slater, "George Ripley and Thomas Carlyle," Proceedings of the Modern Language Association 67, no. 4 (June, 1952): 341-349.
} 
answers in the economic and political questions of the day. ${ }^{170}$ Ripley had become a vociferous social critic in the late 1830s, making the argument that the Panic of 1837, the one that pushed Dana from Buffalo, was caused by the "extravagant worship of wealth." ${ }^{\prime 11}$ Ripley helped introduce Dana to republicanism. He exposed Dana to his interpretation of the personal relationship of the individual with God with a vision of society that embraced the wholesale reform of its glaring issues. The various components of Ripley's worldview strongly attracted Dana while at Harvard. The relationship the two would cultivate in this period would draw Dana away from Harvard and closer into Ripley's circle of social reformers.

\section{$\underline{\text { Brook Farm }}$}

Dana became restless at Harvard and was drawn towards following Ripley to a utopian community being formed in western Massachusetts. This transition in Dana's intellectual focus moved him closer to social reform and applying republican ideas. Dana's struggles to get through his entire undergraduate career at Harvard was one sign that Dana's life would again go through a transition. To start with, Harvard was quite expensive. ${ }^{172}$ Dana could not afford the school, took various leaves of absences, and worked as a school teacher in Scituate, Massachusetts. ${ }^{173}$ Dana also boarded at another uncle's home in Guildhall, Vermont, further cementing his standing as an outsider at Harvard. When combined with his weakening vision, and the increasing difficulties he

\footnotetext{
${ }^{170}$ Steele, The Life of Charles A. Dana, 12. This historian explains that "not surprisingly, the Transcendentalists found it hard to agree on a host of philosophical matters, including the problem of social responsibility and reform. For Emerson, the solitary self was all important; others, including George Ripley, believed that the misery of the Boston slums demanded greater attention to social justice."

${ }^{171}$ George Ripley, The Temptations of the Times: A Discourse Delivered in the Congregational Church in Purchase Street, on Sunday Morning, May 7, 1837 (Boston: Hillard, Gray, and Company, 1837).

${ }^{172}$ Steele, 10; Wilson, Charles A. Dana, 20; Story, "Harvard Students, the Boston Elite."

${ }^{173}$ Steele, 10.
} 
had paying for tuition, Dana decided that leaving Harvard might benefit him. ${ }^{174}$ His attendance at the school was never consistent between September 1839 and late $1841 .{ }^{175}$ Dana's decision to leave Cambridge coincided with George Ripley's decision to resign the pulpit, and start a communitarian experiment at West Roxbury, Massachusetts called Brook Farm. ${ }^{176}$ Dana's close relationship with the famous New England theologian, philosopher, and writer led Ripley to invite Dana to join the Brook Farm community. In a letter to Dr. Flint in November 1840, Dana explained that "apropos of Mr. Ripley, he leaves his church on the $1^{\text {st }}$ of January as I am informed. He is to be one of a society designed to establish themselves at Concord, or somewhere in the vicinity, and introduce, among themselves at least, a new order of things. Their object is social reformation... With these men are my sympathies." ${ }^{177}$ Dana's business knowledge, familiarity of languages and the classics, as well as his Romantic philosophical leanings, made him a good candidate to help Ripley with many of Brook Farm's responsibilities. Ripley arranged for Dana to oversee the community's accounting and shop-keeping, manage the community's schoolhouse, teach the classics and foreign languages, wait at the community cafeteria, and help edit the community's intellectual journal, The Harbinger. Every member had to buy-in to the Brook Farm joint-stock corporation, which Ripley had developed as an alternative to wage slavery by establishing a system where labor acted as currency. ${ }^{178}$ Ripley understood that Dana

\footnotetext{
${ }^{174}$ Dana to James Barrett, July 17, 1841 in Wilson, Charles A. Dana, 30. “...Nevertheless, my eyes improve so slowly that I fear I shall not be able to return to college for a year, in which I propose to return to Massachusetts and work on a farm."

${ }^{175}$ Dana enrolled in September of 1839 and completed the fall and spring . In 1840 he began the fall semester but could not finish through the spring. The same attendance pattern occurred in 1841, where he joined Ripley late in that year.

${ }^{176}$ Steele, The Life of Charles A. Dana, 11-12.

${ }^{177}$ Dana to Dr. Flint, November 21, 1840 cited in Wilson, 26-27.

${ }^{178}$ For more on Dana's role at the school, see: Burton, Paradise Planners; George P. Bradford, "Reminiscences of Brook Farm," Century Magazine 45 (Nov., 1892): 141-148; Arthur Sumner, "A Boy's Reflections of Brook Farm," New England Magazine 10 (May 1894): 309-13. Relative to the shares in the Brook Farm corporation that Dana purchased, he bought 3 of the 24 shares for 50 each. Cited in Steele, 13.
} 
had a very practical sense of the world that joined his idealistic curiosities about the metaphysical and philosophic world. The community, Dana wrote his sister, was nothing more, or less, than individuals joining together for "the purpose of living purely and justly and of acting from higher principles than the world recognizes."

Historians have studied Dana's time at the utopian community and have drawn many conclusions about the importance of these years on Dana's commitment to both social reform and republican ideals. The Brook Farm community has been the subject of widespread analysis and these studies contribute a clear picture of Dana's experience there. Historians maintain that the community developed around a critique of modern commercialism and capitalism in the United States and the broader transatlantic world. Brook Farmers, and especially Dana and Ripley, sought to reorient the relationship between workers and the larger economic system. ${ }^{180}$ The Brook Farmers insisted that competitive capitalism produced overly-predatory relationships between citizens. ${ }^{181}$ For this reason, creating a communitarian system of labor and exchange would elevate the communities' commitment to the republican values of egalitarianism and civic virtue. The development of the American variant of Fourierism, which Dana and the Brook Farmers called “Associationism," provided the Brook Farmers with a systematic alternative to liberal individualism and industrial capitalism. ${ }^{182}$ Historians argue that the group, and especially Ripley,

\footnotetext{
${ }^{179}$ Wilson, Life of Charles A. Dana, 31-32. Letter to Charles's sister Ann Maria Denison. In the note Dana explains that he joined Brook Farm "for the purpose of living purely and justly and of acting from higher principles than the world recognizes." Ann Denison came often to Brook Farm, and would eventually marry the brother of Dana's future bride, Osborne MacDaniel. Steele, 12-13.

${ }^{180}$ Steele, The Sun Shines for All, 19.

${ }^{181}$ Ibid, 17.

${ }^{182}$ Guarneri, The Utopian Alternative, 6. "Opposed both to the free-labor system of northern capitalists and the slave-labor system of the South, their communitarian movement sought to transform both into systems of cooperative labor - and to convince Americans that their mission was to make their nation the socialist Promised Land." For more on this division between individualism and nationalism/communitymindedness, see: Yehoshua Arieli, Individualism and Nationalism in American Ideology (Cambridge: Harvard University Press, 1964).
} 
modeled the community as an attempt to reform capitalism, and not a replacement for it. ${ }^{183}$ The community's financial structure represents one form of evidence for this claim. Ripley created Brook Farm as a joint-stock corporation that required labor in exchange for property for residents to stay in good standing. ${ }^{184}$ In so doing, Ripley envisioned that this structure could form an alternative mode of organizing communities to protect the livelihood of their residents within the hegemonic, and hyper-competitive, capitalist system of the rapidly industrializing 1840s United States. Historians explain that Ripley, Dana, and a majority of Brook Farmers supported a transition of the community's guiding principles to Fourierism, and its American adaptation called Associationism to accommodate the social, and not individual, reform objectives of the group. ${ }^{185}$ Associationism, historians have argued, provided the Brook Farmers with a more strident system of social reform that would compel all in the group to contribute fairly, and thus equitably distribute the community's shared resources. ${ }^{186}$ Scholar Janet Steele described this intellectual system as "radical economics based on Christian principles." 187 She argues that the

\footnotetext{
${ }^{183}$ For more on Brook Farm as an alternative to capitalism, see: Sterling F. Delano, "We have abolished domestic servitude:' Women at Work at Brook Farm," in Toward a Genealogy of Transcendentalism (Athens: University of Georgia Press, 2014); Clarence Gohdes, "Getting Ready for Brook Farm," Modern Language Notes 49, no. 1 (Jan., 1934): 36-39.

${ }^{184}$ For more on this variety of economic, and labor, structure, see: Hauhart, " $19^{\text {th }}$-Century Labor Money Schemes.

${ }^{185}$ Steele, The Sun Shines for All, 15. Steele provides a quick summary of the relatively complicated social philosophy: "Fourierism was a curious combination of economic theory and fanciful futurology that supposedly described 'scientifically' the workings of society. It started with the premise of human perfectibility and, working through a complex system of numerology and 'passional attractions,' concluded with the coming of a millennial kingdom of material well being." Steele explains that "though much of Fourierism sounds absurd today, it nonetheless had the very serious aims of reconciling the individual with the community, creating harmony between labor and capital, and bringing about a more humane society through economic reorganization."
}

${ }^{186}$ Steele, The Sun Shines for All, 13. In a letter from Horace Greeley to Dana in 1842, the Tribune editor wrote that Fourierism would help solve the problem posed by the question: "why shall I labor, when another in wanton idleness consumes the product? Why shall I assume unpleasant functions when others avoid them and in secret laugh at my easy good nature."

${ }^{187}$ Ibid, $13-15$. 
aims of the Brook Farmers resembled the Social Gospel movement common later in the century, intent on bringing the Kingdom of Heaven to Earth by supporting social reform efforts. ${ }^{188}$ They had a "strong spiritual orientation" and that its members, including Dana, "equated the Fourierist utopia with the coming of the Christian millennium. ${ }^{189}$ Alongside Ripley and Dana, scholar of German Romanticism John Dwight played a leading role in the community’s philosophy. ${ }^{190}$ Dwight studied classical German literature and was previously a follower of the philosopher Georg Wilhelm Friedrich Hegel. ${ }^{191}$ Margaret Fuller, a Transcendentalist, abolitionist, and feminist, published a translation of Goethe's "Prometheus" from German. ${ }^{192}$ The community's guiding philosophy had extensive influences from the European thought that highlighted almost all of the members' interests, including those shared by Dana.

Dana helped spread these ideas about social reform and republicanism through Brook Farm's intellectual periodical, The Harbinger. First published in June 1845, the paper acted as a cultural journal but also publicized the cause of Association. Dana worked alongside John Sullivan Dwight and Parke Godwin, helping make The Harbinger one of the best sources to

\footnotetext{
${ }^{188}$ Ibid, 18.

${ }^{189}$ Ibid. In the "Lecture on Association," given in 1844, Dana wrote to a friend that "in Association, then...the promise of Christianity is to be fulfilled - fulfilled by making the incarnation of the great law of love an actual and universal fact."

${ }^{190}$ For more on the connection of the Brook Farmers with German thought, see: Patrick Labriola, "Germany and the American Transcendentalists: An Intellectual Bridge," The Concord Saunterer 6 (1998): 98-113; Thomas J. Wesley, "John Sullivan Dwight: A Translator of German Romanticism," American Literature 21:, no. 4 (January 1950): 427-441.

${ }^{191}$ Some of Dwight's publications in this area include an 1839 publication: Select Minor Poems, translated from the German of Goethe and Schiller (Boston: Hilliard \& Gray, 1839). For more, see: Wesley, "John Sullivan Dwight: A Translator of German Romanticism"; George Willis Cooke, John Sullivan Dwight: Brook Farmer, Editor, and Critic of Music (Boston: Small \& Maynard, 1898).

192 Russell E. Durning, "Margaret Fuller's Translation of Goethe's "Prometheus," Harbuch für Amerikastudien 12 (1967): 240-245.
} 
understand Brook Farm's political, economic, and social philosophy. ${ }^{193}$ These manifested themselves in the book reviews, poetry, philosophical papers, historical analyses, and editorials about contemporary American political, economic, and social issues. The editors of The Harbinger published a translation of Goethe's autobiography edited by Godwin, and translated by Dwight, Dana, and John Henry Hopkins. ${ }^{194}$ Historians have explained that these men often explained the tenets of Associationism through Goethe in the paper. ${ }^{195}$ Dana participated in The Harbinger's connecting of American Association to German, and broader European, communitarian and republican philosophy. Dana saw in the ideas of these European thinkers the ways to implement a republican mode of social organization capable of reshaping the current trajectory of American life. Dana affirmed this legacy in The Harbinger that Swedenborg, Fourier, and Goethe were the "teachers of the Nineteenth century" and could help guide this mission. ${ }^{196}$ Dana's conception of social reform motivated his recommendations about how best to moderate capitalism's negative impulses. He thought that capitalism needed to be reformed to better elevate the working American's standard of living. He especially tried to make clear that his ideas were meant to be taken in opposition to the more aggressive anti-capitalist ideologies gaining popularity across the world. In the August 6,1846 edition of the Harbinger, Dana wrote that he ultimately sought a "peaceful and complete reform which shall bring labor and capital into

\footnotetext{
${ }^{193}$ For more on the Harbinger once it moves to the city in 1847, see Delano, "Boston Associationists," 31, fn 38; Joel Myerson, "New Light on George Ripley"; John R. Wennersten, "A Reformer's Odyssey: The Public Career of Parke Godwin of the New York Evening Post, 1837-1870," (PhD diss., University of Maryland, 1970).

${ }^{194}$ Johann Wolfgang von Goethe, The Auto-biography of Goethe. Truth and Poetry: From my Life, 4 vols., trans. Parke Godwin, ed. Parke Godwin, John H. Hopkins, Charles A. Dana, and John S. Dwight (New York: Wiley and Putnam, 1847-8). Also see Ellis Shookman, "Brook Farm and Beyond: German Thought and Literature in 'The Harbinger,' 1845-1849," German Studies Review 34, no. 3 (October 2011), 575; Stanley M. Vogel, German Influences on the American Transcendentalists (New Haven: Yale University Press, 1955).

${ }^{195}$ Shookman, 581- 582.

${ }^{196}$ Harbinger 1, no. 25 (November 1845) cited in Shookman, 582.
} 
unity." ${ }^{197}$ Fourierists across the world, and Associationists in the United States, were not violent revolutionaries. Peacefully communitarian and socialist, they did not see capitalism as their ideological enemy to the violent end. Dana's comments about a "peaceful and complete reform" of capitalism exposed his republican sensitivity to the safety of fellow citizens. Steele has explained that Dana's pacifism further extended to his opinions about how to best confront the problem of inequality and exploitation. Steele explains that Dana did not believe in the power of strikes, but instead that Associationism "is pacific and not destructive." ${ }^{198}$ Dana argued that Associationism would harmonize the interests of the laboring and owning classes by introducing moral suasion as a force for change. "In offering abundance to all," he explained, Associationism "invades the established rights of none." 199

Dana's republican-inspired criticism of economics in the United States undergirded many of his contributions to The Harbinger. Like other parts of Dana's biography, this feature of his thought has also been well covered by historians. They, as this dissertation does, affirms that Dana generally followed a "producerist," or "artisanal republican," ideology. ${ }^{200}$ By the time Dana was writing for The Harbinger, these ideas were clear and mature. ${ }^{201}$ The championing of republican values was a defining feature of the paper. ${ }^{202}$ Social reformers like the Brook Farmers were repulsed by the negative effects of industrial capitalism and sought answers in

\footnotetext{
${ }^{197}$ Harbinger (August 6, 1846): 142. Also mentioned in Steele, The Sun Shines for All, 18.

${ }^{198}$ Dana, A Lecture on Association, 25. Also mentioned in Steele, The Sun Shines for All, 18. ${ }^{199}$ Ibid.

${ }^{200}$ For more on previous historians' analysis of Dana's connection to pro-labor, producerist interpretations of republicanism, see: Tuchinsky, xi, 15; Steele, 5-6, 26.

${ }^{201}$ For one of the better examples, see: “Commerce," Harbinger 1 (June 21, 1845): 31.

${ }^{202}$ Some examples from the paper include: Albert Brisbane and Osborne Macdaniel, "Gradual Abasement of the Producing Classes," Phalanx 1 (March 1, 1844: 73; William H. Channing, "Labor for Wages,"

Harbinger 2 (May 30, 1846): 396; Parke Godwin, "Wages Slavery," Harbinger 6 (March 25, 1848): 146.
} 
communitarianism and egalitarianism. In the November 8, 1845 edition, for instance, Dana provided readers with a negative review of the future of industrial capitalism. Dana wrote that "the existing system of labor and the relations between the workmen and their employers are full of the foulest wrongs... That gloomy era approaches - in our manufacturing towns we see more than mere premonitions of its coming, - when the pale sky of New England shall look down on men, women, and children ground to the very dust by feudal monopoly." ${ }^{203}$ Dana found many problems within the existing system of wage slavery that alienated the individual from the products of their labor. He thought the market unfairly distributed the fruits of the labor of the producing classes and created an unwanted level of competition between individuals for basic needs. Dana insisted that the Brook Farmers looked to the Associationist system as an experiment in alleviating the conflict between labor and capital. He called this idea "industrial association," a system where the interests of the worker, and the owner of the means of production, more equally profited from the products they helped create. ${ }^{204}$ Steele explained that Dana supported this combination of Associationism and industrial culture as a moderate compromise between the individualism of liberalism and the communitarianism of republicanism. Associationism multiplied on an industrial scale would help moderate the selfish thinking of the individual in the market while still embracing the modernism of the age. Steele explained that Dana believed that "individualism was the poisonous fruit produced by the acquisitiveness and selfish competition of modern society industrial society." 205 She suggests that Dana's previous experiences with his father's and uncle's businesses scarred Charles's expectations of the market economy. ${ }^{206}$ In an

\footnotetext{
${ }^{203}$ Harbinger, November 8, 1845: 350, in Steele, 17.

${ }^{204}$ Ibid, in Steele, 19.

${ }^{205}$ Steele, The Sun Shines for All, 17.

${ }^{206}$ Ibid.
} 
1845 edition of The Harbinger, Dana explained to his readers the extent that this was so. He wrote that "intimate acquaintance of many years with commercial life...[has] constrained [me] to believe that in commerce, absolute and complete honesty...is impossible...The [S]avior was right to throw the merchants out of the temple."207 Dana wrote that his objective in writing anti-market and anti-capitalist editorials was to show "the other side of the picture," the "increasing poverty of the working classes. ${ }^{, 208}$ Dana's republican-inspired criticism of the United States became a consistent feature of his understanding of the nation and its culture.

Dana's advocacy for the rights of workers in the 1840s occurred at a critical stage in his life. Intellectually, Dana's thought had coalesced into a set of ideas developed at Buffalo, honed at Harvard, and matured at Brook Farm. Professionally, publishing in The Harbinger helped make Dana an established member of the New England intelligentsia. Dana had become a wellknown writer, speaker, and reformer with a wide network of professional and personal relationships with some of the century's leading figures. One of these individuals was Horace Greeley, the editor of the New York Tribune, and one of the county's leading supporters of Associationism, the labor movement, and the Whig party. Brook Farm could not have been a better social network. Other notable visitors included Ralph Waldo Emerson, Henry James, Sr., Robert Owen, Theodore Parker, George R. Russell, Francis S. Shaw, Margaret Fuller, William Henry Channing, Elizabeth Peabody, Orestes Brownson, and Amos Bronson Alcott. ${ }^{209}$ This rapid expansion of Dana's professional social network at Brook Farm extended to his personal life. In 1846, Dana married Eunice MacDaniel, the sister of a fellow Harbinger writer Osborne MacDaniel, and a resident of the community. Leaving for a honeymoon later that year, Charles

\footnotetext{
${ }^{207}$ Harbinger, August 30, 1845: 187.

${ }^{208}$ Harbinger, August 6, 1846: 142.

${ }^{209}$ Swift, Brook Farm, 203 - 260.
} 
and Eunice arrived back to find out that a fire had ruined Brook Farm. ${ }^{210}$ The destruction encompassed the Fourierist-inspired common house, or phalanstery building, that the community had saved so long to afford, and had finally completed the very year. ${ }^{211}$ With a low reserve of funds, Ripley and the other leaders of the community decided to not re-build the phalanstery and disbanded the physical manifestation of Brook Farm. Dana, Dwight, and others on The Harbinger staff continued to publicize the group's republican and communitarian ideas, however.

After the closing of Brook Farm, Dana took on a more public role as a critic of establishment thought, extreme commercialization, and as a popularizer of Associationism. The first manifestation of this - he took a job as visiting editor at the Boston Chronotype, then edited by the Congregationalist editor Elizur Wright. ${ }^{212}$ Dana and Wright shared characteristics that help explain their professional connection. To historians, Wright is known as first being a fairly traditional Congregationalist, but with a strong reform streak visible in his commitments to abolitionism. Wright's abolitionism eventually drove his break from the church, and his eventual move towards openly progressive interpretations of religion, leading to his becoming a selflabeled atheist. In the mid-1840s, Wright's was still in the early stages of this transformation, but nonetheless could provide an attractive job opportunity for the young reformer. Dana biographer James H. Wilson explained that the Chronotype was "an orthodox publication, and was therefore a great favorite with the Congregational ministers of Massachusetts." ${ }^{213}$ In one instance, when Wright was away and Dana was left in charge of the paper, the Associationist visiting editor came

\footnotetext{
${ }^{210}$ Wilson, 59.

${ }^{211}$ Ibid.

${ }^{212}$ Wilson, 59. According to Wilson, Dana was hired "to read the exchanges, edit the news, and make himself generally useful. It was also understood that during Wright's absence Dana should act as editor, but all without additional compensation."

${ }^{213}$ Wilson, 59-60.
} 
out "mighty strong against Hell," as Wilson remembered Wright's jovial retelling of this story. ${ }^{214}$ These characteristics helped make the Chronotype a welcome place for Dana to gain additional experience in conventional journalism, as well as understand ways to communicate his ideological positions through the newspaper. Wilson judged that the editorial was "evidence of the young writer's independence of thought, and of his radical departure from the gloomy doctrines of Calvin, as well, perhaps, as an instance of his growing sense of humor." ${ }^{215}$ Across the mid-1840s Dana also spent considerable time helping edit The Harbinger, and traveling around the Northeast speaking to sympathetic regional groups. A late January 1847 Harbinger article recounted one of these lectures given to the Boston Union of Associationists. ${ }^{216}$ This group, one of the better known Associationist clubs across the nation, trumpeted many of the ideas of societal and religious "unity" in the United States, and across the globe, that Dana often used to explain the system. ${ }^{217}$ His talk was titled "The Progressive Development of Society" and explained the ideology's understanding of the various stages of history. A glowing review of the speech noted that the "meaning of history was never unlocked to any audience, we fancy, by so magical a key." ${ }^{218}$ Another speech given to the New England Fourierist Society titled, "A Lecture

${ }^{214}$ Wilson, 59-60. This editorial was printed to the "to the astonishment of the subscribers as well as of the responsible editor."

${ }^{215}$ Ibid. Wilson explained that "in referring to this incident years after Dana had come to be a great editor, Mr. Wright said it gave him a great deal of trouble at the time, as it obliged him to write a personal letter to every Congregational minister in Massachusetts, and to many of the deacons besides, explaining that the paper's apparent change of doctrinal attitude was due to no change of faith on his own part, but to the fact that it had been left temporarily in charge of 'a young man without journalistic experience."”

216 "Lectures on Association in Boston, The Harbinger (January 9, 1847). The program was for one speech a week starting January 7. This was the order: W.H. Channing, "The Destiny of Man upon the Earth" first; Dana second; Horace Greeley, "The Tendencies of Modern Civilization," third; Parke Godwin, "Fourier," fourth; George Ripley, "The Grounds of Association in the Spiritual Nature of Man," fifth; Albert Brisbane, "The Practical Organization of Association," sixth; John S. Dwight, "Integral Education," last.

${ }^{217}$ Guarneri, The Utopian Alternative, 241-46, 282-88, 306-318.

218 "Lectures in Boston," The Harbinger (January 30, 1847). This section of the Harbinger contained a speech Dana gave titled, "The Progressive Development of Society," and was described by a witness to be a "complete and eloquent exposition and application of Fourier's profound review of the progressive 
on Association, In Its Connection With Religion," was a similar explanation of the applications of Associationism to religion, history, and society at large. ${ }^{219}$ Dana went beyond the commune in his enthusiasm for Associationism in speeches and meetings. The work with Brook Farm and associationism placed him within a community of reformers attempting to adapt these ideas with society at large. ${ }^{220}$ These were some of Dana's earliest efforts at covering, analyzing, and participating in Atlantic politics, economics, and culture.

There was a strong connection between Dana's Associationism and the larger relationships he established with influential members of the American political, economic, and social order. Fourierism, and the Associationism that developed in the United States, focused closely on understanding the progression of republican, and metaphysical ideas, across history. The movement paid close attention to how politics and economics defined society, which made it implicitly suspicious of the negative features of political and economic liberalism. The system did not allow for individualism or selfishness to interfere with the needs of the community. Dana's faith in Associationism as a cure for the nation's ills (and indeed those of the Atlantic world) made it an attractive philosophy that others in the American political order also felt could aid the political economy of the United States. Associationism offered Dana a specific strategy for how

developments of Society, through the several periods of Edenism, Savagism, Patriarchalism, Barbarism, and Civilization; dwelling more particularly on the characteristics of the several phases of Civilization, and pointing out the symptoms already appearing of a transition into the seventh period of universal Guarantines. The meaning of history was never unlocked to any audience, we fancy, by so magical a key. Fourier was the first historian," concluded the article. Dana's close analysis of Fourier's stages of progressive history and societal organization illustrates how he remained interested in the French philosopher's ideological application to American history.

${ }^{219}$ Charles Dana, "A Lecture on Association, In Its Connection With Religion” delivered before the New England Fourier Society in Boston delivered on March 7, 1844 (Boston: New England Fourier Society, 1844).

${ }^{220}$ For more on the transatlantic nature of Fourierism, and Associationism, see: Lloyd Jenkins, "Fourierism, Colonization and Discourses of Associative Emigration, Area 35, no. 1 (Mar., 2003): 84-91; Gregory Claeys, "John Adolphus Etzler, Technological Utopianism, and British Socialism: The Tropical Emigration Society's Venezuelan Mission and Its Social Context, 1833-1848," The English Historical Review 101, no. 399 (Apr., 1986): 351-375. 
to achieve a republican, egalitarian, alternative to the existing American system of political economy. It was on these points that it correlated with the politics of the American Whig party, a critical note for the developing intellectual sympathies of Charles Dana. That political party had a close relationship with reformers like the Associationists across the American north. ${ }^{221}$ Whigs strongly opposed the small-government, anti-corporate, rural populism of Andrew Jackson and the Democrats. ${ }^{222}$ Whigs popularized a platform that combined initiatives for corporate welfare, a national bank, trade protectionism, domestic infrastructure spending, and socio-economic reform. They recommended a large, and activist federal government powerful enough to shelter American trade, manufacturing, and labor. ${ }^{223}$ The Whig party's bias for economic producers and regulators (industrialists, manufacturers, bankers, and financiers) did not keep them from gaining support from workers. Northern Whigs opposed chattel slavery, ${ }^{224}$ favored labor unions, and supported a charitable balance between the classes. ${ }^{225}$ From this group came the smaller minority of Whigs favorable to the early socialist ideas spreading across the transatlantic world, including the Brook Farmers. They embraced a communitarian spirit and aimed to moderate the negative effects of

${ }^{221}$ Guarneri, The Utopian Alternative, 36 - 39.

${ }^{222}$ For more on the American Whig party's opposition to Andrew Jackson, see: Jeffrey S. Selinger, "The Second Party System and the Politics of Displacing Conflict," in Embracing Dissent: Political Violence and Party Development in the United States (Philadelphia: University of Pennsylvania Press, 2016), 83 108; Reeve Huston, "The Parties and 'The People': The New York Anti-Rent Wars and the Contours of Jacksonian Politics," Journal of the Early Republic 20, no. 2 (Summer 2000): 241-271; David Brown, "Jeffersonian Ideology and the Second Party System," The Historian 62, no. 1 (Fall 1999): 17-30; Rogers M. Smith, "High Noon of the White Republic: The Age of Jackson, 1829 - 1856," in Civil Ideals: Conflicting Visions of Citizenship in U.S. History (New Haven: Yale University Press, 1997), 197 - 242; Michael F. Holt, The Rise and Fall of the American Whig Party (New York: Oxford University Press, 1999): 28 - 60; Ernest F. Dibble, "'We Could Have Sent the Old Barbarian Back to the Hermitage': Joseph M. White and Anti-Jacksonianism in Territorial Florida, 1821 - 1839," The Florida Historical Quarterly 75, no. 2 (Fall, 1996): $167-182$ ).

${ }^{223}$ Howe, The Political Culture of the American Whigs, 96 - 122.

${ }^{224}$ Ibid, $238-298$.

${ }^{225}$ Ibid, $123-149$. 
industrial capitalism in communistic experiments and policy proposals. The Whig system contained more than just economic and political ideas, as well. Whiggery had cultural, and even epistemological, ramifications. ${ }^{226}$ This cross-section of politics, economics, and culture formed the broad Whig ideology that attracted reformers like those at Brook Farm. ${ }^{227}$ Influenced both by Enlightenment rationalism and the revivalism of the Second Great Awakening, many Whigs believed in human progress and even perfectibility. ${ }^{228}$ Historian Daniel Walker Howe explains that these ideas "supplied Whiggery with a conception of progress that was the collective form of redemption: like the individual, society as a whole was capable of improvement through conscious effort." ${ }^{229}$ The Whigs' insistence on protecting the nation's businesses and workers alike attracted these reformers who lived on the principles of universal brotherhood, communitymindedness, and supported an egalitarian relationship between industry and labor. ${ }^{230}$

Through journalism Dana became connected to parts of the Whig party that he had not previously known in 1840 , when he rejected that party as being too bound up in corrupt elections and patronage-centered machine politics. One major Whig newspaper and its editor, the New York Tribune and Horace Greeley, educated him about many of the reform values of the party. Historians have described Greeley as popularizing "collective capitalism," Carlyle,"232 an "ethic of paternalism and mutual responsibility," "brotherly love to overcome

\footnotetext{
${ }^{226}$ Ibid, $23-42$.

${ }^{227}$ Ibid, $150-180$.

${ }^{228}$ Howe, The Political Culture of the American Whigs, 69 - 95.

${ }^{229}$ Ibid, 152.

${ }^{230}$ Guarneri, The Utopian Alternative, 36 - 37.

${ }^{231}$ Ibid, 36.

${ }^{232}$ Ibid, 41.
} 
class hostility," and an "expressed boundless faith in American progress." ${ }^{233}$ Greeley hoped that the country could embrace a moderate position between liberal individualism and communitarian republicanism. Charles Dana agreed, making a reputation for himself as a popularizer of his position within the pages of The Harbinger and the speaking circuits of the formal Associationist movement. Greeley, like Dana and the Brook Farmers, also supported moderate reforms to the nation's political and economic systems, calling for initiatives like producers' cooperatives and mutual insurance. ${ }^{234}$ This connection helped bring Greeley and Dana together, fostering a relationship that would change the trajectory of Dana's life.

In 1847 Horace Greeley offered Dana a job as the high-placed editor of the paper's city desk, as well as run its foreign affairs division. Dana accepted, and later that year he was working alongside one the United States' leading editors. The Tribune's concomitant role as one of the Whig party's more prominent newspapers (albeit one of its more reform-minded and eccentric ones), helped place Dana at the center of American politics. Greeley's role as one of the American Whig party's major journalistic supporters helped legitimize the Associationist movement. Greeley insisted on showing that Associationism's goals fitted closely with those of the Whig party and especially its professed commitment to bridge the conservatism of economic growth and individual rights with the radicalism of egalitarianism democracy and communal values. ${ }^{235}$ Through the movement, and through Greeley, Dana could see how these reformminded ideas could help the Whig party use cooperationist policies to help fix the problems with capitalism apparent from the recent Panic of $1837 .{ }^{236}$ While Dana's writings within The

\footnotetext{
233 Ibid, 37.

${ }^{234}$ Guarneri, The Utopian Alternative, 8.

235 Tuchinsky, Horace Greeley’s “New York Tribune,” 34.

${ }^{236}$ Guarneri, The Utopian Alternative, 38.
} 
Harbinger remained idealistic, his choices in the late 1840s show how serious he was in trying to find practical answers to the problems plaguing the nation. ${ }^{237}$ His move to the New York Tribune pushed Dana even further away from idealism and towards pragmatism.

\section{Conclusion}

Charles A. Dana had a direct part to play in the profound changes to American life occurring between 1810 and the middle of the 1840s. He experienced the influence that the late First Industrial Revolution had brought to the United States in places like Buffalo, New York. He witnessed, and participated within, the amalgamation of cultures characterizing many of the nation's growing cities. Dana developed a love of learning, but especially a certain branch of thought that emphasized biblical skepticism, a personal relationship with the divine, and a larger sense of the responsibilities of individuals within their larger communities. At Harvard Dana formalized his knowledge of the new ideas shaping the transatlantic world: romanticism, transcendentalism, pantheism and communitarianism. There he also broadened his appreciation for the application of epistemology, metaphysics, and morality to society. At Harvard, and later at the utopian community at Brook Farm, Dana embraced radical egalitarianism, communitarianism, and republicanism. Dana studied the work of Samuel Coleridge, Thomas Carlyle, Baruch Spinoza, Emmanuel Swedenborg, George Ripley, and Charles Fourier, among others. Various differences marked Dana's intellectual interests, but their ideas all converge in emphasizing biblical criticism, religious humanism, and ways to implement these ideas to improve society at large. By the 1830s and 40s, Dana had transformed from an intellectually curious and adept teenager in Buffalo studying on his own, to participating in groups like the Brook Farm commune that emphasized community-engagement, social cooperation, large scale egalitarianism and empathy, alongside individual growth and enrichment. Dana's efforts in explaining Associationist ideas while at Brook Farm helped earn him regional notice. Dana's defense of utopianism and

${ }^{237}$ Ibid, 345. 
republicanism as reflected at Brook Farm helped him see the social, political, and economic application of philosophical ideologies. There he became politically active and broadened his intellectual circle to include politically driven men like George Ripley and Horace Greeley. Greeley and his newspaper reflected many of the same interests that had consumed Dana cross the 1830s, and Dana's decision to accept the offer to join the newspaper added to Dana's transition from an idealist, interested primarily in philosophy, into an idealist more interested in the application of reform to society at large. 


\section{CHAPTER TWO \\ IDEOLOGY AND PARTY POLITICS}

$(1848-1856)$

"They [the 1848 revolutionaries] believe to death that there is a better order possible for man than the current civilization, and they find that the stupidity and faithlessness of the propertied classes hinders the avenues to that promised land. Hence their terrific violence."

- Harbinger 7, no. 14 (July 11, 1848): 109

Much like the half century that preceded it, the period between 1848 and 18563 involved the transformation of American life. These changes also prompted the restructuring of how Europeans and Americans conceived of the applications of ideology, political economy, and culture. Dana expressed the essence of these changes by advocating the republican values of egalitarianism, community-mindedness, and class equality. In this period, he underwent an intellectual sea change of his own which lead him away from the study of religion, metaphysics, and utopianism in the $1830 \mathrm{~s}$, on the one hand, and, on the other, redirected him towards practical republicanism by supporting worker's rights and the abolition of slavery in the late-1840s and 1850s. Central to this metamorphosis was his passion for the work of the New York Tribune, which put him in the metropole of urban American politics. In the process he established himself as a leader in the new Republican Party. Dana transitioned from being a pacifist, committed to an optimistic interpretation of social, political, and economic relations, towards a new identity as an aggressive defender of republican values in the United States and across the transatlantic.

\section{The Tribune and the Revolutions of 1848}

The changes in Dana's perspective came at an auspicious time, as many others across the transatlantic world adopted a similar approach to defending republican values. The European Revolutions sparked this change. This string of political upheavals in Sicily, Denmark, the Netherlands, the Habsburg Empire, Switzerland, Sweden, Poland, Romania, Belgium, Ireland and France shared common assumptions. These included opposition to monarchism, aristocratic 
privilege, and serfdom, the creation of democratic political systems, affirmation of the rights of workers, and the embrace of communitarianism, egalitarianism, and civic virtue. ${ }^{238}$ In the revolutions of the German states and Austria, many revolutionaries supported a working and middle-class coalition to limit the power of the aristocracy. In the Habsburg Empire, antiaristocratic Hungarian revolutionaries attempted to use these ideas to obtain independence from the Austrian monarchy. While these revolutions failed, the had lasting effects worldwide. ${ }^{239}$ The exiles from these movements, especially from German principalities, Austria, Hungary, and Ireland, emigrated in large numbers to the United States, the "Forty Eighters," as they were known here, had their own impact. ${ }^{240}$ The majority of these new American immigrants brought with them a commitment to egalitarianism and democracy alongside a distaste for aristocracy and all forms of slavery, and they appeared in the United States at a critical juncture in American history.

${ }^{238}$ For more on the Revolutions of 1848, see: Peter Jones, The 1848 Revolutions (London: Routledge, 2014); Pamela Pilbeam, French Socialists before Marx (Montreal: McGill-Queen's University Press, 2000); Michael Rapport, 1848: Year of Revolution (New York: Basic Books, 2010); Lewis Namier, 1848: The Revolution of the Intellectuals (Oxford: Oxford University Press, 1993). Influential in many of these movements were a host of young ideas named socialism, Communism, and anarchism. Socialism's dedication to a peaceful compromise between industrial capitalism and the state ownership of industries by workers competed against the anti-capitalist and violent impulses of Communism's objectives for a worker's revolution and anarchism's goals of an über-small government of equals for attention in revolutions across Europe. Perceived as radical by their critics, these ideologies were responses to the growing power of industrial capitalism and political aristocracy in the nineteenth century. For more on the place of these movements in the $19^{\text {th }}$ century, see: Isabella and Zanou, Mediterranean Diasporas; Peter Ryley, Making Another World Possible: Anarchism, Anti-Capitalism, and Ecology in Late $19^{\text {th }}$ and Early $20^{\text {th }}$ Century Britain (New York: Bloomsbury Academic, 2013); Szporluk, Communism and Nationalism; Paul E. Corcoran, Before Marx: Socialism and Communism in France, 1830-1848 (London: MacMillan, 1983); Theda Skocpol, Ellen Kay Trimberger, "Revolutions and the World-Historical Development of Capitalism," Berkeley Journal of Sociology 22 (1977-78): 101-113.

${ }^{239}$ For more on Napoleonic France and the causes of the revolution that so gripped the attention of Americans like Dana, see: Fenton S. Bresler, Napoleon III: A Life (London: Harper Collins. 2000); William E. Echard, Napoleon III and the Concert of Europe (Baton Rouge: Louisiana State University Press, 1983); Henry Weber Casper, "American Attitudes Toward the Rise of Napoleon III; A Cross Section of Public Opinion (PhD. diss., Catholic University of America Press, 1947).

${ }^{240}$ For more on the results of the Revolutions of 1848, see: Eric Dorn Brose, "The Revolutions of 18481849 and Their Aftermath," in Germany History, 1789-1871 (Berghan Books, 2013); Carol Diethe, Exiles from European Revolutions: Refugees in Mid-Victorian England (Berghan Books, 2003). 
A large majority of this generation of immigrants, however, largely supported the Whigs because they supported an anti-slavery position that encompassed both the pro-labor and antiaristocratic goals of the 1848 Revolutions. ${ }^{241}$ The addition of swaths of territory to the United States as a product of victory in the Mexican-American War more than doubled the size of the nation, amplifying the debate about slavery, and the place of democracy and the values of republicanism in it. The nation's two major parties - the Democrats and Whigs - took stronger stands over their visions of these territories as either potentially free or slave states. As was the case in Europe, at the center of the debate were the contested meanings of terms like republicanism, liberty, civic virtue, egalitarianism, and cooperation. Each party's attempt to make these ideals its own - to justify their preferred system of labor - frustrated the American political order. Antislavery advocates joined the Whigs in large numbers in the late 1840 s and early '50s giving rhetorical weight to that rapidly growing wing of the American electorate. Whigs drew prominent '48ers into the American political process. Whigs invited Lajos Kossuth, the Hungarian revolutionary, to tour the United States giving speeches about transatlantic republicanism. This is not to say some Forty-Eighters did not support slavery, or were members of the Democratic Party, because many were. ${ }^{242}$ New antislavery political parties, like the FreeSoil Party and the Republican Party, though, provided compelling alternatives to either the Whigs

\footnotetext{
${ }^{241}$ For more on the influence of slavery on the Democratic and Whig party's throughout the 1840s and 1850s: Eyal, The Young America Movement; James Alex Baggett, The Scalawags: Southern Dissenters in the Civil War and Reconstruction (Baton Rouge: Louisiana State University Press, 2003); Morrison, Slavery and the American West; Holt, The Political Crisis of the 1850s.

${ }^{242}$ For more on the members of the 1848 generation that supported the Democratic Party, and even supported slavery in some instances, see: Thomas E. Rodgers, "Copperheads or a Respectable Minority: Current Approaches to the Study of Civil War-Era Democrats," Indiana Magazine of History 109, no. 2 (June 2013): 114-146; Jason E. Pierce, Making the White Man's West: Whiteness and the Creation of the American West (Boulder: University Press of Colorado, 2016); Dale Baum and Dale T. Knobel, "Anatomy of a Realignment: New York Presidential Politics, 1848-1860," New York History 65, no. 1 (January 1984): $60-81$.
} 
or Democrats, coalescing the anti-slavery vote in new places. ${ }^{243}$ Dana stood at the center of the maelstrom that was the 1850 s in the United States. He did so by working for one of the most recognized Whig newspapers Horace Greeley's New York Tribune.

The time period wherein Dana joined the paper - the late 1840s - marked a critical point for Dana, the Tribune, the American political order, and the transatlantic world. ${ }^{244}$ Greeley's Tribune employed a staff to implement his vision that mirrored his own beliefs, including the Brook Farmers Dana, Ripley, Fuller, ${ }^{245}$ Curtis, Brisbane and Henry Raymond, later editor of the New York Times. ${ }^{246}$ The Tribune supported alternatives to the free market economy in utopian communities, the better treatment and pay of wage workers, the protection of American industry and labor with trade barriers, the opportunities offered by westward migration - and "Manifest Destiny"), and the nationalist desires of republican peoples like those in South America, the Caribbean, North America, and Europe. The Tribune presented ideas to reform both chattel and wage slavery, limit the harmful effects of free trade on American workers, and purify the broader system of crony, corporate and industrial capitalism. ${ }^{247}$ The question of what to do about the

\footnotetext{
${ }^{243}$ For more on the Free-Soil Party, and other abolitionist parties, see: Earle, Jacksonian Antislavery \& the Politics of Free Soil; Leonard Richards, The Free North and Southern Domination, 1780-1860 (Baton Rouge: Louisiana State University, 2000); Ryan Jordan, 'Quakers, 'Comeouters,' and the Meaning of Abolitionism in the Antebellum Free States," Journal of the Early Republic 24, no. 4 (Winter, 2004): 587608; Eric Foner, Free Soil, Free Labor, Free Men: The Ideology of the Republican Party Before the Civil War (New York: Oxford University Press, 1995).

${ }^{244}$ Cross II, Go West Young Man!; Earle D. Ross, "Horace Greeley and the West," The Mississippi Valley Historical Review 20, no. 1 (Jun., 1933): 63-74.

${ }^{245}$ Fuller was a leading light of the Transcendentalist, Feminist, and Abolitionist movement. She had personal relationships with those such as Emerson, Ripley, and Greeley. For more on Fuller, see: Dowling, "Emerson's Hero: Mentoring Margaret Fuller," in Dowling, Emerson's Protégés; Brigitte Bailey, et al. Margaret Fuller and Her Circles (Durham: University of New Hampshire Press, 2013); Jane Duran, "Margaret Fuller and Transcendental Feminism," The Pluralist 5, no. 1 (Spring 2010): 65 - 72; Meg McGavran Murray, Margaret Fuller, Wandering Pilgrim (Athens: University of Georgia Press, 2008); Judith Mattson Bean and Joel Myerson, Margaret Fuller, Critic: Writings from the New York Tribune, 1844-46 (New York: Columbia University Press, 2000).

${ }^{246}$ Maihofer, The General and the Journalists, 51.

${ }^{247}$ Tuchinsky, Horace Greeley’s “New York Tribune," 18 - 57; $126-211$.
} 
growing influence of chattel slavery on American society remained particularly at the center of the debate. The Tribune's demanded commitment to "free-soil" ideology. ${ }^{248}$ It opposed the Mexican War, the admission of Texas as a slave state, ${ }^{249}$ and the annexation of Cuba where slavery flourished. It only advocated passage of the Wilmot Proviso, which disallowed slavery in any new territory won as product of the war. ${ }^{250}$

\section{Dana and a Republican Test in Europe}

Dana delighted in the Tribune's republicanism. One major reason for this is that he entered a community of friends and like-minded colleagues. As at Brook Farm, he found the company intellectually congenial. With Dana, Greeley constructed a staff that shared a close ideological outlook which sought remedies to the pernicious effects of industrial capitalism. ${ }^{251}$ Dana also embraced the Tribune because Greeley allowed him chances to observe these ideas when possible. For instance, when nationalist and republican revolutions spread across Europe in 1848, Dana insisted that he be the man sent to witness them first-hand for the Tribune. The revolutions, especially in France and the German-speaking states, were feeding off ideas that Dana and Greeley had been propagating separately for almost a decade. ${ }^{252}$ They represented a test

\footnotetext{
${ }^{248}$ Williams, Horace Greeley, 112; Tuchinsky, Horace Greeley’s “New York Tribune,” 153 - 157 ; Maihofer, 56.

249 Williams, Horace Greeley, 172-173, 282.

${ }^{250}$ For more on the Tribune's opinion of the Mexican-American War and the Wilmot Proviso see: Williams, Horace Greeley, 105-108; Tuchinsky, Horace Greeley's “New York Tribune," 142-44.

251 Tuchinsky, Horace Greeley’s “New York Tribune,” 1 - 18.

252 “Our Foreign Correspondence," New York Tribune, August 23, 1848. "We give in this morning's Tribune an admirably letter from "H.B," whose letters have attracted much attention. We believe that his letters, in conjunction with those of Mr. Dana, will furnish a more clear and intelligible impression of the present condition of France, that can be obtained from any other source. The letter from Constantinople, a translation of which we have also procured, throws considerable light upon the important movements which are now convulsing Eastern Europe. We can honestly claim for The Tribune the merit of being the only journal which, as yet, has bestowed any attention to these developments, so pregnant with importance to the Future of Europe."
} 
for the Tribune's aim to mediate between individualistic and exploitative market relations as well as help alleviate corrupt political practices. Greeley consented to sending Dana to Europe alongside Arthur Brisbane. Dana's plan was to write for the Tribune, and also send correspondence to the Harbinger and other newspapers across the northeast. ${ }^{253}$ Dana would chronicle his observations and document his opinions of these republican movements as he and Brisbane travelled through London, Paris, Berlin, Cologne, Dresden, Prague, and Vienna.

Dana arrived in London on June 18, 1848, and quickly travelled to France. The revolution challenged his faith in Associationism and pacifistic reform and impelled him to develop a belligerent defense of republicanism. Dana arrived after the deposition of Louis Napoleon, the establishment of the Second Republic, in the middle of a counter-revolutionary move by conservatives against the recent gains of the revolution in France's more radical cities. He attended the heated meetings of the Assembly and heard speeches from the revolution's political and philosophic leaders. ${ }^{254}$ In editorials back to the United States, he described the

\footnotetext{
${ }^{253}$ Apart from the Tribune, Dana also sent notes to the Harbinger, Spirit of the Age, the Philadelphia American, the New York Commercial Advertiser, and the Boston Chronotype. The Tribune's correspondence with Dana was reprinted across the country by the many papers that supplemented their own material with notable news and editorials from the much bigger Tribune. See, Wilson, The Life of Charles A. Dana, 62.
}

${ }^{254}$ These included General Louis Eugène Cavaignac, leader of the French National Guard, the author and philosopher Victor Hugo, politician and transatlantic icon Alexis de Tocqueville, and General Adolphe Thiers. Dana and Brisbane met with the popular philosopher and political economist Joseph Proudhon, utopian socialist Etienne Cabet, and the socialist historian, and politician, Louis Blanc. Marx called Blanc the second coming of Robespierre in the second line of The Eighteenth Brumaire of Louis Bonaparte in 1852. Guarneri, 337; Dana kept a communication with Blanc into 1851. Steele cites a letter of introduction that Dana "wrote to Louis Blanc on behalf of Parke Godwin, December 29, 1851. Steele, 174; Dana also met with Victor Considerant, a Fourierist, member of the National Assembly, and leader of the National Guard. For more on Considerant, see: Beecher, Victor Considerant; Sterling F. Delano, "French Utopianism on American Soil"; Davidson, "Victor Considerant and the Failure of La Réunion". Dana also visited with scholar and historian of French Fourierism, and republicanism Armand Lechevalier and Alexandre-François Baudet-Dulary who had sponsored a well-known Fourierist commune in France. Their pacifistic ideas did not attract workers who sought more aggressive leaders like Considerant, the leader of the National Guard. Dana's despatches confirmed that aggressive leaders like Pierre-Joseph Proudhon, Louis Auguste Blanqui, Armand Barbès and Louis Blanc had the public's heart instead. They offered socialist and communitarian policy ideas alongside a willingness to use violence to force France to return to republican government. For more on these visits see: "The Parisian Insurrection," The Harbinger 7 (July 22, 1848): 89. Also quoted in Guarneri, 338. According to Dana, it was the "radical clubs of agitators such 
uproar as a "social rather than just a political revolution...initiated by the working classes." 255 The election of a conservative National Assembly in the months after the initial revolutionary thrust, however, resulted in the closing of the popular National Workshops in Paris, and a renewal of violence in the streets between republican revolutionaries and law and order conservatives. ${ }^{256}$ The National Guard entered Paris in anticipation of the violent fighting that resulted, now called the "June Days" which inspired Dana's first editorials from Paris, where he explained that the situation was being instigated by communists and anarchists eager to use force to topple the French propertied classes from power. ${ }^{257} \mathrm{He}$ described the movement as more than a change in governments. ${ }^{258}$

Dana's reports from his meetings with reformist leaders illustrated the extent to which the French Revolution of 1848 adjusted his views on the possibilities for labor reform, selfgovernment, and democratic egalitarianism. He explained that even though the Associationists had not gained much traction within the National Assembly, or among the French people, he believed that a good number of socialist ideas were now commonly supported by France's workers. Dana argued that socialism had spread in France and was not "exploded and extinct since the June battles." He considered that French politics had lost its many divisions. Now, he

as Auguste Blanqui and Armand Barbès rather than the utopian socialist sects who held the workers' attention, and the Associative school was 'even more remote than other Socialists from any participation in the whole [popular movement.]"'

${ }^{255}$ Ibid.

256 The announcement of Dana's departure to observe Associationism's potential defense in Europe received the applause of the Harbinger, whom Dana was still helping organize. See: Harbinger 7 (June 17, 1848): 52.

${ }^{257}$ Guarneri, 337. Dana arrived with Brisbane around June 22-23, during the June Days.

${ }^{258}$ In one of his earliest letters from France, Dana explained that he hoped to see a "peaceful transition from absolutism to democracy," which was critically "important to utopians" in his opinion. For Dana's published sentiments to the March revolution in France, see: "Sympathy with the French Revolution in Boston," Harbinger 6 (April 15, 1848): 195; "Response to the French Revolution," Harbinger 6 (April 8, 1848): 179 - 181. Also see: Guarneri, 336. 
wrote that there are "only two ranks in France, the Socialist party, and their opponents," the conservatives. ${ }^{259}$ The variety, "the vent of social publications in Paris," astonished him to the point that he insisted that "the mind of France is itself Socialist, and the well of systems and doctrines is therefore inexhaustible. ${ }^{260}$ Dana's faith in socialist policies flourished in France but at the cost of his pacifist convictions. He argued that from witnessing the revolution, speaking to reformers, and observing sessions of the National Assembly, he had confirmed his suspicion that the lack of class cooperation in the cities (especially Paris) encouraged the decision to forego Associationist pacifism for polarizing and politicized urban violence. ${ }^{261}$

In October and November 1848, Dana and Brisbane travelled across the German states and the Habsburg Empire to report on the revolutions there. What made these visits different from their French experience was that Fourierism played no part in these movements. ${ }^{262}$ In Germany moderates allied with factions of the socialist left to create a different revolutionary dynamic. In

${ }^{259}$ Harbinger 7, no. 14 (July 11, 1848): 109.

${ }^{260}$ Ibid.

${ }^{261}$ Harbinger 7, no. 14 (July 11, 1848): 109. "It is the first battle of the Social doctrines of all kinds against the old order of things, and the desperateness of the first measures the deep reliance of the insurgents on their principles. They believe to death that there is a better order possible for man than the current civilization, and they find that the stupidity and faithlessness of the propertied classes hinders the avenues to that promised land. Hence their terrific violence."

${ }^{262}$ Zimmerman, "From the Second American Revolution to the First International and Back Again," 306-7. "Only in the first year of the revolution in Germany did socialists, like Marx and Engels, cooperate with liberals, who were typically elite property owners. Marx and Engels had recommended such a workingclass alliance with the bourgeoisie in the Communist Manifesto, published just before the revolutions broke out in 1848. In the first year of the revolution, Marx, much to the consternation of many communists, continued to advocate this interclass collaboration. The hopes of Marx and likeminded leftists for a socialist-democratic-liberal alliance in Germany were dashed when, after a year of debate, in 1849, the liberal Frankfurt Parliament proposed a constitutional monarchy for Germany. Even worse, when the proposed head of this monarchy, the king of Prussia, rejected this crown, liberals abandoned the revolution and cooperated with their erstwhile enemies to suppress those socialists and radical democrats who wished to continue the revolution. Marx, Engels, and many others responded to this liberal betrayal by abandoning their calls to participate in a democratic revolution that they had anticipated the bourgeoisie would lead. By 1849 the moderate stage theory of the Communist Manifesto - in which the bourgeoisie vanquished feudalism, produced 'its own gravediggers' in the proletariat, and then stepped aside for socialism - had been replaced by a more directly military and revolutionary model of history." 
the middle of the first year of the German revolution, Dana met Karl Marx and Friedrich Engels in Cologne, the theoretical advocates of the very German view, who had just published the Communist Manifesto. ${ }^{263}$ In 1848 Marx and Engels had still hoped that property owners could cooperate with the republicans and socialists to create an egalitarian constitution beneficial to workers. ${ }^{264}$ Dana found Marx more open to cooperation between the classes in these interviews. In 1848, Marx aligned closer to a type of cooperationism and republicanism that Dana advocated. The three shared enough camaraderie and ideological vision that Dana persuaded the two Communists to contribute to the Tribune. ${ }^{265}$ Dana's relationship with Marx and Engels represent one of the most prominent transatlantic connections to republicanism the Tribune would ever make, but Dana continued to build his network of European reformers. Thus, traveling to Berlin, he met the prominent Young Hegelian, republican, and Biblical skeptic, Bruno Bauer (18091882) ${ }^{266}$ Best known for establishing a republican understanding of philosopher of history Georg

${ }^{263}$ Notable publications by Marx and Engels in the period where Dana and those two developed a professional relationship were: Critique of Hegel's Philosophy of Right (1843); The German Ideology (1845); "Wage Labor and Capital," in Neue Rheineische Zeitung (April, 1849); The Class Struggles in France (1850); and The Eighteenth Brumaire of Louis Bonaparte, 1852). Marx and Engels of course published a long list of articles and books after this period, but in terms of his relationship with Dana, these were the texts that defined the pair that Dana knew.

${ }^{264}$ Zimmerman, "From the Second American Revolution to the First International and Back Again," 307. German liberals, who Marx grouped within the property owning bourgeoisie, were expected to create a "socialist-democratic-liberal alliance" to create a new constitution for the German states. Zimmerman has shown that Marx was still open to peaceful interclass cooperation in 1848.

${ }^{265}$ Across the next fourteen years, Marx would contribute more than five-hundred articles for the newspaper. See: Zimmerman, "From the Second American Revolution to the First International and Back Again," 310.

${ }^{266}$ Bauer studied under Hegel and Schleiermacher while at the University of Berlin. From 1834 to 1839 he lectured at the University of Berlin in Theology and Biblical Texts. From 1839 until 1842 he taught at the University at Bonn until he was dismissed. Bauer was a Right Hegelian, or a follower of Hegel's ideas that viewed theology through a rationalist lens, interpreting miracles as occurring within nature. Bauer openly taught rationalism at Bonn, which encouraged his dismissal. He was initially an ally of Marx and Engels, but his rationalism strayed from their materialism. For this, Bauer, was attacked by Marx and Engels in The Holy Family (1844) and The German Ideology (1845-6). By the time Dana met him, he was a dedicated revolutionary dedicated to social democracy in Germany. He was among the many voices on the socially democratic side of the revolution. For more on Bauer, see: Moggach, The Philosophy and Politics of Bruno Bauer. For more on the Young Hegelians, see: Douglas Moggach, The New Hegelians: Politics and Philosophy in the Hegelian School (New York: Cambridge University Press, 2006); Warren Breckman, 
Hegel (1770-1831), Bauer opposed liberal individualism and orthodox religiosity. Bauer argued that only by transcending the particular interests of individuals could a society become truly republican and community minded. Marx and Bauer traded arguments about the future of socialism, but Dana's interest in both of them grew from their shared distaste for the social atomization that resulted from holding only an economically liberal worldview.

Besides describing actual events, Dana's summaries of his European trip celebrated the communitarian, egalitarian, and empathetic spirit and linked these developments to Western civilization and the United States. One dispatch on the breaking apart of traditional ideas and modes of "spiritual authority" dating to Martin Luther, Voltaire, and the Puritan and Quaker colonists of North America. Their ideas, he noted, began the modern "inauguration of individualism." ${ }^{267}$ Dana explained to his American readers that these thinkers helped institute "the revolt against absolute spiritual authority, and proclaimed the liberty of the individual in matters of faith." In his interpretation, the inauguration of individualism transferred smoothly from religion, "extended to politics," and assumed in the United States "its only logical form, the Republic." ${ }^{268}$ Individualism and its ideological home in classical liberalism, he explained, had helped both the United States and the broader transatlantic world in many ways. For America, Dana wrote, classical liberalism had proven to be "a fruitful principle, this of Individualism and has truth in it.” American “Arts, Industry, Republican Freedom, Liberty of Conscience, Progress," he explained, "are due to it." He warned, however, that individual success and fulfillment, Dana argued, was inadequate for a successful republic if not accompanied by a republican ethos. He insisted that "individualism" had produced a variety of negative effects in

Marx, the Young Hegelians, and the Origins of Radical Social Theory (Cambridge: Cambridge University Press, 1998); David McClellan, The Young Hegelians and Karl Marx (New York: Praeger, 1969).

267 “The Present and Future of Germany," Harbinger 8, no. 3 (Nov. 18, 1848): 18.

${ }^{268}$ Ibid. 
the United States. He wrote that selfish motives motivated by the quest for personal liberty alone "resulted in Political Economy, laissez faire, Usury and the proletariat." ${ }^{\text {269 }}$ Advocating a moderate position between liberal individualism, republican egalitarianism and fraternity, Dana argued that individualism "is imperfect by itself — only a part of the truth," 270 concluding that "liberty and Equality are great blessings; but if not completed by Fraternity, they produce evil as well as good." 271 The European revolutions were good for the United States he insisted. ${ }^{272 ~ " T h e ~}$ millions of Germans in the United States constantly in correspondence with the friends and relatives they had left behind them, have been so many revolutionary agents," he said. ${ }^{273}$ He took from his conversations with German revolutionaries that these letters from German-Americans had been "animated by that sense of dignity and independence which belongs to the Republican citizen." These letters had motivated German friends of Americans, he argued, which "widely and irresistibly undermined the foundations of royal authority and inspired a profound hatred of the feudal institutions of the country" and that "in this way America has had her direct share in this Revolution as she had in that of 1789."274

Dana's hopes for a republican Europe did not bear fruit. Dana returned to France to see Louis Napoleon elected President of the Second French Republic, an indication of the weaknesses of the European revolutions. Indeed the Napoleonic return marked a turning point for Dana and others in the transatlantic world. It represented the failure of pacifism and French Fourierism, and

\footnotetext{
${ }^{269}$ Ibid.

${ }^{270}$ Ibid.

${ }^{271}$ Ibid.

${ }^{272}$ Ibid.

${ }^{273}$ Ibid.

${ }^{274}$ Ibid.
} 
suggested that Associationism had no place in the United States. ${ }^{275}$ Associationism abandoned individual communities and shifted towards broader class cooperation. Instead it argued for broader class cooperation. ${ }^{276}$ In France, Joseph Pierre Proudhon, a politician, social reformer, and anarchist, theorized a new path. His ideas appealed to Dana, according to Guarneri, as a "new, narrower, solution to the problem of industrial labor," ${ }^{277}$ and supported Proudhon's larger goal of making the wage-worker a capitalist to free him from the labor market and democratize the economic system. ${ }^{278}$ This, in a very general sense, had been the objective of the Brook Farm community. ${ }^{279}$ Dana's return from Europe, and his published reactions to what he saw, suggest that he underwent fundamental changes in his perception of republicanism and the means through which to expand it in the United States. ${ }^{280}$

${ }^{275}$ Guarneri, 345. "When the Associationists retreated to gradualist reform in the late 1840 s, they set realistic goals but also risked making their position indistinguishable from that of contemporaries. Jointstock organization, mutual insurance, mutual banking, and apartment living could serve the prevailing competitive system rather than challenge it; in fact, they proved to be easily compatible with private property and corporations. By the 1850s Godwin and Dana had watered down communitarianism to jointstock organization and profit sharing and were advocating a more humane version of corporate capitalism rather than a transformed socioeconomic system. Eternal optimists Greeley and Channing, who believed that the "spirit of the age" and improvements in organization and technology must inevitably lead Americans toward Association, went even further down the accommodationist road."

276 Tuchinsky, 98; Guarneri, $335-347$.

${ }^{277}$ Ibid, 99 - 102. For more on Proudhon, see: Prichard, Justice, Order and Anarchy; K. Steven Vincent, Pierre-Joseph Proudhon and the rise of French Republican Socialism.

${ }^{278}$ Ibid, $50-57$.

${ }^{279}$ Guarneri, The Utopian Alternative, 341, 346. Guarneri explains that Dana "believed that mutual banking could be a useful alternative to the phalanx" and "in the same pragmatic spirit...supported cooperative stores and workshops." He also explained that this willingness on Dana's part reflected how completely, "as a newsman, he deliberately renounced utopia for life as it was." (346)

${ }^{280}$ Guarneri, The Utopian Alternative, 341. Guarneri notes that class antagonisms in France had "rendered Fourierist pleas for reconciliation a utopian delusion." 


\section{Dana and the Sectional Crisis of the $1850 \mathrm{~s}$}

Dana returned from Europe with a punctured faith in utopian reform in the United States. ${ }^{281}$ In February 1849 Dana wrote to his old boss, Elizur Wright at the Boston Chronotype, that he "was no longer a Fourierist," 282 but cooperative work, egalitarianism, and civic virtue could lead to social justice even if the utopian commune was not the vehicle, he believed. The 1848 Revolutions revealed the extent to which he would now focus closer on the way that wage and slave labor were marginalized in the United States. Evidence for this readjustment exists in a series of lectures Dana gave across November and December 1850 called "The Workers of Modern Times." These lectures clarified Dana's argument that both the enslavement and exploitation of labor by the moneyed classes had proven to be the major problem of the American political and economic order. ${ }^{283}$ In these speeches, he offered his understanding of history and social development. He would cover his opinions about the progression of the various stages of world history, the development of labor, capital, and the wage system, and the dependence on slavery, money, wealth, and greed that the modern system of political economy had created. ${ }^{284}$ Dana insisted that Associationism's value rested in its emphasis on the common good of the community and sensitivity to ameliorating the harmful effects of modern society. ${ }^{285}$ The more he

\footnotetext{
${ }^{281}$ See: Roberts, Distant Revolutions, 28, L. Reynolds, European Revolutions, 47 - 48; Guarneri, Utopian Alternative, 336 - 42. The French Revolution's principle of cooperative work leading to social justice had done little to prevent bloodshed between the bourgeois French government and socialists. From Europe, Dana's explanations of the June Days to American readers insisted that the fighting was due to the French Government's "failure to help the workers establish self-run cooperatives."

${ }^{282}$ Charles Dana to Elizur Wright, February 15, 1849, May Collection. Cited in Guarneri, 341.

283 “The Workers of Modern Times; A Lecture,” New York Tribune, November 27, 1850.

284 “Mechanics' Institute-Winter Course Lectures," New York Tribune, November 19-25, 1850; New York Tribune, December 21, 1850. Dana gives this speech again at the Williamsburg Lyceum in late December.

${ }^{285}$ Wilson, The Life of Charles A. Dana, 134 - 135. The quoted but uncited Tribune article that Wilson notes from Dana argued that, "Kansas will soon be either a free or a slave State, and her fate decides that of many which are to come after her. Mexico, Cuba, and Central America proper, the raw material for at least a dozen States, are all probably destined to come to us in time. Shall they come to us as free or slave
} 
spoke publicly about his understanding of society, the more he underwent a shift towards understanding transatlantic and domestic politics. This occurred at a critical period, as the question of slavery's expansion into new western territories in North America consumed the American political order in the late 1840 s and across the 1850 s.

For the next ten years, Dana used direct participation in party politics to expand his ideal of republicanism. He aligned with Horace Greeley's involvement in the Whig party, abolitionism, and socio-economic reform. At the center of Dana's political epiphany was the crisis surrounding the extension of slavery into the new western territories acquired from the 1846-48 war with Mexico. The Missouri Compromise of 1850, the Kansas-Nebraska Act of 1856, and the larger "Bleeding Kansas" crisis helped radicalize Dana into an antislavery member of the Whig party. Greeley and Dana made efforts, for example, to ally with groups aligned under the banner of "free-soil," or the belief that slavery should not be allowed to extend in places further than where it currently existed. The "free-soil" ideology had already proven influential before Dana arrived at the Tribune and matured when he embraced political activism. In the Whig party, it helped motivate a growing split in the faction between anti-slave "conscience" Whigs and pro-business "cotton" Whigs who stressed the importance of slavery to the national economy and who allied themselves with Southern businessmen. ${ }^{286}$ Dana, Greeley, and other anti-slavery, free-soil Whigs distinguished themselves from their enemies in the party by calling themselves "conscience" Whigs. ${ }^{287}$ They called the other half of the caucus the "cotton" Whigs for their appeasement of

States? This question seems to us by far the most momentous and vital of any now affecting our national politics."

${ }^{286}$ Maihofer, The General and the Journalists, 48 - 49, 52. Greeley had been arguing that the Whig party was on the verge of death, and made the same claim during the election of 1848, when he believed that Zachary Taylor, as well as all other candidates was entirely too soft against the spread of slavery. Greeley and Dana were also against the Whig candidate in 1852, Winfield Scott, and concomitantly participated in the split of the party, and then the creation of the new party atop the bones of the old Whig infrastructure.

${ }^{287}$ Commons, "Horace Greeley and the Working Class Origins of the Republican Party," 468-488. 
northern business interests who profited from the Southern slave economy. ${ }^{288}$ Dana's becoming so represented his full transformation from an unaffiliated idealist utopian to a more practical activist committed to a set of reforms inspired by republican social policy. In the Democratic Party, Martin Van Buren led a New York-centered anti-slavery faction to leave the party in the 1840 s, and start an organization in the late 1840 s, the Free-Soil Party. ${ }^{289}$ This bi-partisan group of anti-slavery activists that confronted pro-slavery forces in Kansas Territory. Van Buren wanted the party to pull all the antislavery and abolitionist outcasts of the Democratic Party and resuscitate Jacksonian political equality in the figure of a third party. Dana and Greeley, while never Free-Soil Party members, joined Van Buren in pressing public opinion against the slave power and the Democratic Party. The Tribune's editorial policy never wavered that any new lands added to the United States be free for development in ways that maximized liberty for men of all races. ${ }^{290}$ This was the principal plank of the Free-Soil Party in the late 1840s and first half decade of the 1850s. The rise of the Free-Soil Party encouraged serious fissures in the Whig party. The party could not defend itself from the Free-Soil insurgency, by stealing abolitionist Whig voters, in order to cater to its pro-Southern cotton-Whig minority. The Free-Soilers were advocating a host of similar policies to the Whigs in this period: reform of both the "Slave" and "Money Power," the need for a homesteading law granting free to cheap land for the working

${ }^{288}$ Howe, The Political Culture of the American Whigs, 196, 225 - 250.

${ }^{289}$ Christian Esh, "Martin Van Buren as Statesman: States' Rights and the Rise of the 'Free Soil' party," in Constitutionalism in the Approach and Aftermath of the Civil War, ed. Paul D. Moreno and Johnathan O’Neill (New York: Fordham University Press, 2013).

${ }^{290}$ New York Tribune, November 29, 1850. "Our doctrine about land is that the soil is necessary to the support of life, like air and water, and is accordingly the common property of the human race: such as it is, strictly speaking, not a proper subject of trade between individuals. But improvements in land are the result of labor, and as such are properly individual property, and may be bought and sold without violating the absolute principles of justice." 
class, and broader policy shifts towards egalitarianism between the classes. ${ }^{291}$ After the passage of the Kansas-Nebraska Act in 1854, which stipulated that the fate of slavery in Kansas Territory would be subject to the vote of the residents who lived there, known as the principle of "popular sovereignty," the split in the Whig caucus became permanent. ${ }^{292}$ By the middle of the 1850 s, proand anti-slavery forces swarmed into the territories to cast ballots for their favored system. The "Bleeding Kansas" crisis that resulted from the hundreds dead in Kansas elicited Dana's strongest reaction in favor of reform, and made him a public member of the antislavery caucus exacerbating the differences within the Whig party.

Clarifying that he, like Greeley, maintained that land is always for free men, Dana often spoke at "Free Kansas" meetings to make this case. He connected the present crisis with the ideological struggle of the nation's founding. The struggle in Kansas represented a microcosm of the nation's own struggle for independence in 1776 even as the nation's current struggle symbolized the fight against both wage and chattel slavery. ${ }^{293}$ At one Free Kansas meeting in New York City, Dana insisted that Kansas was "a question in whose hands the solution of the problem whether a Republican Government is possible in the world." 294 "All the wrong that the American people suffered," Dana announced to the crowd, "and which culminated in that Revolution, and which gave birth to this great country—all the tyranny, the wrongs and outrages which they had endured were feeble and trifling compared to the wrongs and outrages of which we have been witnesses in Kansas. ${ }^{295}$ The blood spilled over the issue of slavery, he argued,

\footnotetext{
${ }^{291}$ The most effective encapsulation of their policy platform is Earle's Jacksonian Antislavery \& the Politics of Free Soil, 1824-1854 (Chapel Hill: University of North Carolina Press, 2004). Also see, Eric Foner, Free Soil, Free Labor, Free Men (Chapel Hill: North Carolina Press, 1995).

${ }^{292}$ Howe, $196-200$.

293 “Free Kansas Meeting. Great Gathering At The Tabernacle,” New York Tribune, June 10, 1856.

${ }^{294}$ Ibid.

${ }^{295}$ Ibid.
} 
challenged the very basis of his understanding of republicanism. Dana proclaimed to the meeting that "the great cause of Freedom" that had brought them together, also brought them in defense of a nation that had been established "as an asylum for liberty." 296 The threat of slavery expanding to Kansas and Missouri, Dana explained, would endanger the American republic, and leave it to be "swept away and converted into a mere Slave pen." 297 "We desire that the Republican Government - this fair and hopeful experiment to which, until very lately, the eyes of all nations were turned with such earnest desires and anticipations for its success-we desire that this experiment may not altogether prove a failure," he concluded. ${ }^{298}$ Dana's antislavery went further than just making speeches, but also towards organizing direct material aid for those sympathetic to the republican, free land and labor cause in Kansas. ${ }^{299}$

Dana, Republican Values, and the Birth of the Republican Party

The fate of slavery's spread into new Western territories radically destabilized American party politics, helping create a new party dedicated primarily to stopping slavery's spread: the Republican Party. Dana and Greeley determined that a restructuring of the political order would be necessary. They advocated that Conscience Whigs join with Free-Soil Democrats and other anti-slavery groups to create a new party dedicated to anti-slavery, self-government, and free

\footnotetext{
${ }^{296}$ Ibid.

${ }^{297}$ Ibid.

298 “Free Kansas Meeting. Great Gathering At The Tabernacle,” New York Tribune, June 10, 1856.

299 “Gov. Reeder on Kansas Affairs. Mass Meeting at the Tabernacle," New York Tribune, August 27, 1856. Dana was a member of the National Kansas Committee, the national group of various state "Kansas Committees" that helped collect funds and weapons to support abolitionist groups in Kansas. For more on the National Kansas Committee, see: Jeff Rossbach, "Riding Free Horses": Kansas Funds and North Elba Land," in Ambivalent Conspirators: John Brown, the Secret Six, and a Theory of Slave Violence (University of Pennsylvania Press, 1982); Ralph Volney Harlow, "The Rise and Fall of the Kansas Aid Movement," The American Historical Review 41, no. 1 (Oct., 1935): 1-25.
} 
soil. ${ }^{300}$ The new party could, Dana hoped, be built on principles like republican egalitarianism and cooperation between labor and capital. ${ }^{301}$ It could be a weapon used to halt the spread of chattel and wage slavery into new states. This party could realize radical land reform (free homesteads, communal experiments), and support economic nationalism (high tariffs). The new party could champion widespread labor reforms workers of all varieties and races. ${ }^{302}$ Policies like the homesteading concept, that gave land at low to even free rates to working class Americans, were central to the Associationist, Fourierist, mindset in the United States. ${ }^{303}$ If the federal government could control the speculation of Western territories, by ceding the land to yeomen farmers, then this would ensure the spread of a land free of slavery, while also limiting land accumulation in the hands of the richest landowners and railroad corporations. ${ }^{304}$ Additional policy ideas like homestead "exemptions" would keep working class landowners from losing their land in economic downturns. The point of these reform proposals was to lessen the power of monopolists and suggest that landownership could be guaranteed by the laws of the commonwealth. As one Tribune historian explained of the newspaper's commitment to land reform, Greeley and other

\footnotetext{
${ }^{300}$ Williams, 105-109, 112. Also see, Tuchinsky, 5-6. Tuchinsky argues that "at bottom, it was Greeley's hope that the Tribune could be a journal of Whig democracy that would elicit the sympathy of labor and, in turn, transform the Whig party into a legitimate political alternative to the Democrats."

${ }^{301}$ Williams, 66, 133. “...Marx would later write of the very Fourieristic Tribune for which he labored as a European correspondent that, "under the guise of...philanthropic socialistic anti-industrialism," the paper was the voice of the "industrial bourgeoisie," which explains "the secret why the Tribune in spite of all its 'isms' and socialistic humbug can be the 'leading journal' in the United States." Karl Marx and Friedrich Engels, The Communist Manifesto (New York, 1967), 114-17; Marx to Engels, June 14, 1853, in Collected Works, vol. 39 (New York: 1975), 346.

${ }^{302}$ Greeley and Dana viewed land reform as just as critical to the new party as any other issue. Historian Adam-Max Tuchinsky explains that the Whig party, in the period when Greeley was moving from it, was against the idea of manifest destiny in the broad sense. They "opposed population diffusion on the frontier" siding instead with urbanism. This, Tuchinsky explains, largely shut out the pre-Marxist argument by Greeley, and Dana, that "democratizing" land in the Western territories was "central to labor's emancipation." Tuchinsky, 127.

${ }^{303}$ Ibid, $126-164$.

${ }^{304}$ Ibid, $136-7$.
} 
land reformers pressed for these ideas because they believed "that land is a shared and inalienable endowment of nature, and that rights of property are dependent on a socially guaranteed right to labor." ${ }^{305}$ Dana used the forum of the newspaper to advocate for his interpretation of republican values and the responsibilities of the state to assist its citizens find stable homes. Only then, Dana and Greeley argued, could the working classes raise enough of their own capital to settle the west without it being land reserved for speculators and monopolists. In 1852, Dana spoke at a land reform meeting discussing the merits of one of these bills then in front of Congress. ${ }^{306}$ The 1852 proposal had almost unanimous support in the North, but Southern and corporate land interests repeatedly defeated this effort and subsequent efforts across the 1850s. Many of the homesteading bills that passed the House of Representatives in the late 1840s and early 1850 s failed in the Senate. ${ }^{307}$ If Greeley and Dana hoped that land reform, in the figure of a homestead act, could be a central feature of any new party's plan to balance the rights of workers and capitalists, the two had additional ideas as well.

Dana's republican framework led him to prioritize abolitionism as a priority for the new Republican Party over other issues. He set aside the other planks of the party's platform, like trade and taxes, to focus on liberating the chattel slave. Historians have studied the way that slavery overshadowed many of the economic debates within the early Republican Party caucus.

\footnotetext{
305 Tuchinsky, Horace Greeley's “New York Tribune,” 138.

${ }^{306}$ New York Tribune, May 25, 1852.

${ }^{307}$ Ibid. This article recounts a meeting of land reformers discussing the merits of the Homestead bill being debated in the U.S. Senate of which Dana is speaking. For more on the debate over "Homestead Exemptions," and the free granting of land to settlers in the West, see: Tuchinsky, "Land Reform, Pragmatic Socialism, and the Rise of the Republican Party," in Horace Greeley's "New York Tribune," 126-162; Mark A. Lause, Young America: Land, Labor, and the Republican Community (Urbana: University of Illinois Press, 2005); Sarah T. Phillips, “Antebellum Agricultural Reform, Republican Ideology, and Sectional Tension," Agricultural History 74, no. 4 (Autumn, 2000): 799-822; Paul Goodman, "The Emergence of Homestead Exemption in the United States: Accommodation and Resistance to the Market Revolution, 1840 - 1880," The Journal of American History 80, no. 2 (Sept., 1993), 470-498.
} 
Would the party oppose slavery but also advocate free trade or protectionism? Advocating free trade would benefit Southern agricultural exporters and northern textile mills, while a protectionist platform would show the party favored big business. Dana and Greeley had natural inclinations to the economic nationalism forwarded by high tariff barriers. Free trade, they maintained, mostly benefited slave-owners and industrialists hoping to keep both prices and wages low. The Tribune amplified the economically protectionist message, having gained a reputation as one of the leading protectionist papers within the Whig party in the decade prior to 1856. ${ }^{308}$ Greeley's political hero, Henry Clay, popularized economic nationalism, high tariffs, and the development of American infrastructure as part of his "American System" in the first decades of the nineteenth century. ${ }^{309}$ Whig support of trade protectionism hinged on the idea that it was possible for the federal government to retain enough power to control the market to the benefit of all American citizens. A fellow Tribune staff member and one of the prominent political economists in the country, Henry C. Carey, hoped that the Republican Party could also champion these protectionist Whig principles. Carey believed that high tariffs were in line with republican economic values because they sheltered both American workers and business owners, ensuring a prosperous community of republican citizens. ${ }^{310}$ Carey's ideas had gained popularity across the

\footnotetext{
${ }^{308}$ For more on the support for protectionist ideas within the Tribune, and Greeley's history supporting economic protectionism from the existence of the National Republican Party, the Whig party, and the Republican Party, see: Tuchinsky, Horace Greeley's New York Tribune, 39, 184-186, 190, 231; Cohen, The Right and Labor in America, 15-26; Green, Freedom, Union, and Power: Lincoln and His party in the Civil War, 300-330; Huston, "A Political Response to Industrialism: The Republican Embrace of Protectionist Labor Doctrines," 35-57.

${ }^{309}$ For more on Clay and economic nationalism, see: Mark E. Neely, Jr., "American Nationalism in the Image of Henry Clay: Abraham Lincoln's Eulogy on Henry Clay in Context," The Register of the Kentucky Historical Society 106, no. 3/4 (Summer/Autumn 2008): 537-570; Baxter, Henry Clay and the American Systemx; Randolph B. Campbell, "The Spanish American Aspect of Henry Clay's American System," The Americans, 24, no. 1 (Jul., 1967): 3-17.

${ }^{310}$ Palen, The "Conspiracy" of Free Trade; Andrew Dawson, "Reassessing Henry Carey (1793-1879): The Problems of Writing Political Economy in Nineteenth Century in Nineteenth-Century America," Journal of American Studies 34, no. 3 (Dec., 2000): 465-485; Rodney J. Morrison, "Henry C. Carey and American Economic Development," Explorations in Entrepreneurial History 5 (Winter 1968): 132-144.
} 
industrial north, ${ }^{311}$ as a result of the growing influence of the European political economist Friedrich List. List had been a German student of Alexander Hamilton's, who helped project the famous Revolutionary Era's economic nationalist and protectionist ideas into the late nineteenth century. List supported Clay's American System because it provided much of the Hamiltonian state control of the economy that both thought would shelter both worker and manufacturer. Clay, List, Carey, Greeley, and Dana all argued that enacting economic nationalist policies, like high tariffs and internal improvements, would increase economic growth beneficial to the entire nation. This growth would then be equally distributed among all socio-economic strata, helping alleviate the existing divide between the working and capitalist classes. ${ }^{312}$ Such an arrangement, Dana maintained, would produce a type of republicanism that would bring American citizens together in a joint project of egalitarian economic growth. He insisted that with a system of political economy meant to protect all classes, and not just the wealthiest, the United States could afford to abolish slavery in the name of a more democratic system of labor. Even this, Dana explained, would prove drastically controversial within the party. Dana confided to his friend Carey that prioritizing economic nationalism and the political economy of republicanism over ending slavery was wrong. Letters from Dana to Carey illustrate Dana's fears in splitting the antislavery majority then forming in the growing Republican Party coalition of the early 1850s. Dana wrote that, "it is my conviction that to attempt to put Protection into the platform of any party to-

\footnotetext{
${ }^{311}$ For more on Carey's popularity, see: George Winston Smith, Henry C. Carey and the American Sectional Conflict (Albuquerque: University of New Mexico Press, 1951); A.D.H. Kaplan, Henry Charles Carey (Baltimore: Johns Hopkins University Press, 1931).

${ }^{312}$ Karl Marx did not agree with Carey's interpretation of the class structure in capitalist society, especially in the United States. The popularity of Carey's ideas, which he thought were flawed, proved that Americans were not prepared to institute the level of class revolution that the Marxist system called for. See Karl Marx to Joseph Weydemeyer, March 5, 1852, in Karl Marx and Friedrich Engels, Collected Works, vol.39 (New York: International Publishers, 1975), 62.
} 
day would be equivalent to political suicide." ${ }^{313} \mathrm{He}$ explained to the political economist that "I do not feel like breaking off political connections, which I think are useful to the country, in the hopeless effort to build up a new Protection party." ${ }^{314}$ Dana's decision to prioritize political and social republicanism over economic nationalism as a factor in organizing the Republican Party bore out in his efforts during the election of 1856. By the middle of the 1850s, Dana, Carey, Greeley, and many others were committed to create a new party out of dissatisfied Whigs and Democrats that included both free trade and protectionist ideas. They invited members of the Free-Soil Party, Know Nothings, and Liberty party to join, in order to combat the spread of slavery, expanding rights for workers, making the American market fairer for all classes, and empowering the federal government to regulate this system.

The Republican Party officially formed in 1854 and Dana supported the candidacy of John C. Fremont as its first presidential candidate for the election of 1856. Fremont was chosen, in part, for the central role he played in the development of the American west. He was explorer of the western territories in the 1840s and a notable general during the Mexican-American War. ${ }^{315}$ He joined the Republican Party for reasons similar to Dana, and opposed the election of proslavery Democrat Franklin Pierce, resisted the spread of slavery into the West, and hoped to gain

\footnotetext{
${ }^{313}$ Charles A. Dana to Henry C. Carey, Nov. 16, 1856. Cited in Arthur M. Lee, "Henry C. Carey and the Republican Tariff,” The Pennsylvania Magazine of History and Biography 81, no. 3 (July., 1957): 283.

${ }^{314}$ Charles A. Dana to Henry C. Carey, Nov. 16, 1856. Cited in Lee, 283.

${ }^{315}$ Fremont had a controversial reputation, though, because during that war he was court-martialed for repeated attempts at forcibly gaining control of California without authorization, had his sentence commuted by Democratic President James Polk after war's end, only to later strike it rich during the California Gold Rush and become one of the first Senators elected by the slave-free state of California in 1850. For more on Fremont and California in 1850s: David Roberts, A Newer World: Kit Carson, John C. Frémont, and the Claiming of the American West (New York: Simon and Schuster Books, 2000); Vernon L. Volpe, "The Origins of the Frémont Expeditions: John J. Abert and the Scientific Exploration of the Trans-Mississippi West," The Historian 62, no. 2 (Winter 2000): 245-263; Andrew Rolle, John Charles Frémont-Character as Destiny (Norman: University of Oklahoma Press, 1991); John A. Hawgood, "John C. Frémont and the Bear Flag Revolution: A Reappraisal," Southern California Quarterly 44, no. 2 (June, 1962): $67-96$.
} 
the presidency in 1856 to spread the Republican Party's ideas nationwide. Dana helped organize the party in New York and, later, the creation of a state-wide Fremont campaign. ${ }^{316}$ Dana had become a politico. He joined "Rocky Mountain Clubs," early grassroots organizations aggressively publicizing the message of the young Republican Party and recruiting members. In the case of the Fifteenth Ward's Rocky Mountain Club, Dana served as chairman. ${ }^{317}$ Speakers would come before the group, planned by the club's organizing committee and chairman, to rouse supporters and attract new ones. Dana organized for these local groups, and often served as a speaker at others for the Republican Party. At one Republican meeting in New Haven, Connecticut, Dana spoke for over an hour, was "rapturously received," and brought on stage a "Kansas man who was almost hanged for being a Free State man." 318 At another meeting in the small but bustling upstate New York state town of Batavia, Dana spoke in front of 10,000 townspeople on Fremont's behalf, a large number for the upstate New York region. ${ }^{319}$ This notoriety helped make him one of the leading Fremont men in New York City and state. Dana's experience earned him other roles. He sat on the committee for the Friends of Fremont, a group committed to keeping John C. Fremont's campaign for Presidency in New York financially solvent. ${ }^{320}$ In defense of Fremont's chances, Dana would exclaim to a friend that, "I tell you, John

\footnotetext{
${ }^{316}$ Dana's activities in support of Fremont characterized the culmination of his intellectual and political life since he left Harvard in the late 1830s; towards practical communitarianism and a belligerent defense of republican values. He had disavowed party politics in 1840 and used Brook Farm as an experimental alternative to party politics entirely.

${ }^{317}$ New York Tribune, August 2, 1856. Dana addresses the Rocky Mountain Republican Club "Banner Presentation to the Rocky Mountain Club of the Fifteenth Ward," New York Tribune, September 17, 1856. Parke Godwin and Frederick Conkling will address meeting. Dana is President of the group; "The Rocky Mountaineers," New York Tribune, November 7, 1856. Dana chairman of this Rocky Mountain Club. Addresses group and introduces David Dudley Field; New York Tribune, December 15, 1856. Rocky Mountain meeting.

318 “Great Meeting in New-Haven,” New York Tribune, July 6, 1856.

319 “Mass Meeting in Batavia,” New York Tribune, October 6, 1856.

${ }^{320}$ New York Tribune, September 26, 1856.
} 
C. Fremont is the man for us to beat [Democrat James Buchanan] with, and the only one." ${ }^{321} \mathrm{He}$ used his knowledge of the transatlantic republican rhetoric that joined the United States and the transatlantic world to convince New York City's large immigrant population to vote Republican.

Dana's work for the young Republican Party aimed to attract the Forty-Eighter generation to support a shared vision of republicanism, the Republican Party, and John C.

Fremont. Dana and many European immigrants shared an affinity for the Republican Party that made this process relatively organic. The Republican Party had already made a stand against the expansion of chattel slavery, embraced social reform, and supported egalitarian economic policies like a homestead bill that would help the working classes obtain cheap land out west, while also protecting them from future foreclosure. Historians have studied how the Republican Party's early land reform platform (or at least the Dana-Greeley faction of it) resembled many of the socialist and proto-Marxist reforms being advocated in Europe. ${ }^{322}$ The Tribune was on the forefront of applying these policies to the party's platform. In speeches to immigrant groups, Dana took advantage of his first-hand experience in Europe to draw connections for potential party members. Since Dana returned from Europe in 1848, he had given speeches to immigrant groups explaining which American political parties best defended the radical republican politics they embraced. ${ }^{323}$ In preparation for Fremont's presidential bid in 1856, Dana met with German Republicans in Kings County, and made explicit connections between the Revolutions of 1848 and the goals of the new American party. ${ }^{324}$ In some of these meetings, and in editorials for the

\footnotetext{
${ }^{321}$ Allan Nevins, Ordeal of the Union: A House Dividing, 1852 - 1857 (New York: Scribner's and Sons, 1947), 465.

322 The entirety of Tuchinsky, Horace Greeley's New York Tribune explains this argument.

${ }^{323}$ For a sample of Dana's support of New York immigrant groups, especially those overtly allied to republicanism and liberty, see: New York Tribune, December 16, 1851.

${ }^{324}$ Dana helping bring more Germans into the new party as he had helped do with the local German Whig groups in earlier years. See: "The Germans and Republicans in Kings County in Motion," New York Tribune, October 17, 1856.
} 
Tribune, Dana used the example of Lajos Kossuth, the Hungarian veteran of the 1848 revolution travelling around the United States in the late 1850 s, as a symbol of that interwoven story. Historians have shown the wide-ranging influence Kossuth's trip to the United States had in helping amplify the transatlantic connections of American and European politics. ${ }^{325}$ Dana had welcomed the revolutionary leader to New York in November 1855, hailing him as a symbol of a shared revolutionary experience and republican brotherhood. ${ }^{326}$ Kossuth made stops in many major American cities, and when he came to New York City and attended a "Meeting for the Hungarian Cause" in New York City's tenth ward. The Tribune explained that Dana gave a speech "setting forth the nature of the dispute between Hungary and Austria, and the claims which Hungary has upon our sympathy and practical aid." ${ }^{327}$ These meetings illustrate Dana’s public efforts at recruiting sympathetic immigrants to vote for the Republican Party in the election of 1856 using republican values shared across the transatlantic. Another notable example appeared in the July 29, 1860 edition of the Tribune, which advertised a speech Dana would be giving at a "mass meeting" for "German Republicans" the following night. ${ }^{328}$ The July $30^{\text {th }}$ edition explained that at this very "rally for free speech" organized by the German Republican Campaign Club for the sixteenth, twentieth, and twenty-second wards, Dana spoke alongside prominent leaders from the German immigrant community like Adolph Douai. Dana's reputation with the German-American community had grown to the extent that he could share a stage with

\footnotetext{
${ }^{325}$ Mason Roberts, Distant Revolutions, 146 - 167; Sabine Freitag, Exiles from European Revolutions: Refugees in Mid-Victorian England (Berghahn Books, 2003); Carl Wittke, Refugees of Revolution: The German Forty-Eighters in America (Philadelphia: University of Pennsylvania Press, 1952).

${ }^{326}$ In November of 1855, Dana joined other prominent members of the New York City press in hosting a dinner for the famed revolutionary leader of the Hungarian contribution to the European Revolutions of 1848, Lajos Kossuth. New York Tribune, November 29, 1855.

${ }^{327}$ New York Tribune, November 29, 1855.

328 “A German Republican Mass Meeting,” New York Tribune, June 29, 1860.
} 
Douai, a pre-eminent German Forty-Eighter, abolitionist, and socialist. ${ }^{329}$ The Tribune noted that the meeting attracted "all citizens of German birth opposed to the extension of Slavery, and in favor of Freedom in the Territories, protection of American industry, and free homesteads..."

Dana's role as a grassroots political organizer and local party official coincided with a belligerent period in transatlantic affairs. Russia's attempt to acquire a warm-water port in Crimea sparked war with Britain in 1854, for instance, worsened the existing rivalry between the United States and England. In the United States, President Pierce, Secretary of State Caleb Cushing, and Minister to Russia James Buchanan sided with Russia as a reflection of the widespread antiBritish sentiment across the United States. The Tribune took a relatively neutral approach to the war, with the editorial page emphasizing that the war was only the "petty preludes of the battles of nations," and a war for the benefit of the British bourgeois classes. ${ }^{331}$ The same editorial contented that the Crimean War would serve only as "preludes merely of other battles far more fierce, far more decisive - the battles of the European peoples against the now victorious and secure European despots." ${ }^{332}$ At the same time, the United States and Britain were contending

\footnotetext{
${ }^{329}$ Douai's life is notable. Originally from Dresden, Douai went to the University of Leipzig and the University of Jena where he studied philosophy, philology, and education. Douai was a revolutionary during the Revolutions of 1848, where he was a sitting member on Saxe-Altenberg's council. Douai was a socialist and abolitionist. The failure of the Revolutions forced him to emigrate to the United States, where he settled in Texas. There, Douai's illustrated his commitment to socialist and republican ideas as expressed while he was in Europe. 1850s Texas was not open to Douai's ideas, where he then migrated to Massachusetts, joined the Republican Party, advocated for an end to slavery, and supported the Union during the Civil War. Douai was a prominent member of the German-speaking, '48-er generation, and was often in high demand to attend meetings such as the one with Dana mentioned above. For more on Douai, see: Justine Davis Randers-Pehrson, Adolf Douai, 1819-1888: The Turbulent Life of a German-FortyEighter in the Homeland and in the United States (New York: Peter Lang, 2000); Charlotte L. Brancaforte, The German Forty-Eighters in the United States (New York: Peter Lang, 1989).

330 “German Republicans! Rally for Free Speech,” New York Tribune, July 30, 1860.

${ }^{331}$ For more on the paper's relatively neutral treatment of the war, see: "The Military Power of Russia," New York Daily Tribune, October 31, 1854. This article pointed out the importance of the war would be, with some sarcasm, to the "united Middle Class Liberalism of Europe" dependent on the control of imperial trade routes; Also see: “Crimean Prospects," New York Daily Tribune, February 19, 1855.

332 “The Military Power of Russia,” New York Daily Tribune, October 31, 1854.
} 
over trade and land rights in Nicaragua. The two nations shared a desire to control a prospective canal route through the Central American nation, while also hoping that it could serve as a potential colony from which to extract needed resources. William Walker, an American filibusterer, had engineered a coup in Nicaragua with a band of American mercenaries with the object of creating a slave-friendly colony in Central America. ${ }^{333}$ Becoming the impromptu leader of a nation within Britain's informal economic empire, Walker's actions almost caused a war between the United States and England. President Pierce generally supported Walker's filibustering efforts as a reflection of an aggressive foreign policy premised on geographic expansion in the Caribbean to protect American economic interests and preserve slavery's future. He also openly courted the purchase of Cuba from Spain, for instance, as a partner colony for Southern expansion. ${ }^{334}$ The Pierce administration criticized British foreign policy during the Crimean War and used diplomatic maneuvers like the Ostend Manifesto to empower the Monroe Doctrine to limit British influence in the Atlantic. These foreign policy decisions were popular in a period of widespread anti-British sympathy, helping Pierce and the Democrats retain some level of popularity. The Tribune vigorously opposed Pierce's efforts for their imperialism, and encouragement of the expansion of pro-slavery sentiment. ${ }^{335}$

\footnotetext{
${ }^{333}$ For more on Walker, and the broad filibustering effort in Central America and the Caribbean in the 1940s and 50s, see: Brady Harrison, Agent of Empire: William Walker and the Imperial Self in American Literature (Athens: University of Georgia, 2004); Robert E. May, Manifest Destiny's Underworld (Chapel Hill: University of North Carolina Press, 2002).

${ }^{334}$ Brian Wilson, Heyday: the 1850s and the Dawn of the Global Age (New York: Basic Books, 2016): 186-193.

${ }^{335}$ In this period, as Dana was rallying German-speaking '48ers for the Republican Party, Greeley was on a similar path. Williams explains that Greeley continued his "broad republican strategy, and recalled the republicanism of 1848 in Europe" when he "introduced Jesse White Mario (1832-1906), an Italian republican, when she lectured on the Risorgimento and the cause of Italian freedom in New York. He joined George N. Sanders and other notables trying to raise money for Mazzini." See: Williams, Horace Greeley, 201. For samples of Tribune articles to this effect, see: "Cuba and War," New York Tribune, August 31,1847 . This editorial argues that the annexation is being discussed in the same illegal ways as the annexation of Texas by pro-slavery advocates; "Annexation of Cuba," New York Tribune, November 3, 1847.
} 
The Tribune regretted that the events in Nicaragua reflected the type of conflicts over slavery occurring in Kansas. The rush of pro and anti-slavery supporters into the state to vote on the slavery-friendly Lecompton constitution proposal and the abolitionist Topeka proposal in 1857 came only months after the territory split in two and pro and anti-slavery forces battled openly. ${ }^{336}$ Open electoral fraud produced multiple invalidated elections in Kansas. This aroused Dana, Greeley, and the Tribune to join many activists across New England to pay for the travel of anti-slavery forces to Kansas and to supply them with weapons to establish a republican state government. ${ }^{337}$ The paper had invested considerable funds into covering Kansas and supporting abolitionists there: Greeley spent considerable time there giving speeches to Republicans, and employing reporters like James Redpath, Richard J. Hinton, and John Kagi (one of John Brown's followers), and Hugh Forbes, one of Garibaldi's "Red Shirts," to chronicle the fighting. ${ }^{338}$ Dana and Greeley understood the implications of the fight over slavery's potential spread into Kansas Territory. Slavery had run out of places to expand, and Dana and the Tribune staff knew that without opposition it would expand and by force in places like Kansas, or in the Caribbean. One Tribune editorial emphasized how much the writers there "hate slavery generally and desire its

\footnotetext{
${ }^{336}$ The most famous of these explosions of violence is the Battle of Osawatomie (Aug. 30, 1856), where abolitionist John Brown made his fame before raiding the federal arsenal at Harpers Ferry, Virginia a year later. For more on John Brown, and the Battle of Osawatomie, see: R. Blakeslee Gilpin, John Brown Still Lives!: America's Long Reckoning with Violence, Equality, and Change (Chapel Hill: University of North Carolina Press, 2011); Jeremy Neely, The Border between Them: Violence and Reconciliation on the Kansas-Missouri Line (Columbia: University of Missouri Press, 2007); Zoe Trodd, "Writ in Blood: John Brown's Charter of Humanity, The Tribunal of History, and the Think Link of American Political Protest," Journal for the Study of Radicalism 1, no. 1 (Spring 2007): 1-29; Merrill D. Peterson, John Brown: The Legend Revisited (Charlottesville: University of Virginia Press, 2002).

${ }^{337}$ For more on the Tribune's encouragement of pseudo-filibuster expeditions from the North to Kansas and Missouri to defend the anti-slavery forces going to defeat the Lecompton constitution and establish a republican government based in free labor there, see: Tuchinsky, 156-211. For more on what the Tribune wrote about this maelstrom, while within it, see: New York Weekly Tribune, February, 25, March 4, 18, 25, April 15, June 3, 24, 1854; June 2, November 3, December 8, 15, 1855; April 18, 26, May 2,9, July 11, 18, 1857; November 5, December 3, 1859.

${ }^{338}$ Williams, Horace Greeley, 207.
} 
extinction." ${ }^{339}$ The paper opposed American expansionist aims into Cuba by Southern and proslavery interests organizing filibustering expeditions and vigorously opposing President Pierce's conciliatory approach to the same. ${ }^{340}$ Tribune editorials of the time illustrated Dana and Greeley's opposition to the nation's foreign policy and its anti-republican and illiberal labor systems.

The results of the election of 1856 further entrenched Dana as a part of the Republican Party, however. The country remained unprepared to follow Dana's vision: Buchanan defeated Fremont on the back of a strong showing in the Democrat-friendly swing states of Pennsylvania, New Jersey, and Indiana. ${ }^{341}$ Dana diagnosed the loss as the fault of Fremont campaign managers for not organizing sufficiently. "Had our advice been followed in the outset by the managers of the Fremont cause," the Tribune wrote immediately following the election, "the young eagle of the Rocky Mountains" would have made "a clean sweep of the North, from stem to stern." 342 Fremont's showing in the recent election provided Dana with evidence of a growing fracture in the electorate. ${ }^{343}$ "The hards and softs" of the Democratic Party, the paper wrote, "have been

${ }^{339}$ New York Tribune, April 8, 1859. Cited in Williams, Horace Greeley, 207.

${ }^{340}$ Wilson, Heyday, 186-216. Historians estimate that there were over 60,000 pro-slavery supporters ready and willing to expand slavery into the Caribbean and Central America. For colorful examples of the Tribune's response to filibusters in the Caribbean and Central America, see: New York Daily Tribune, November 18, 1856. The editorial page wrote of William Walker and the American filibusters in Nicaragua that, "the filibusters generally seem to think it is a great outrage that they cannot be allowed to prosecute in safety under the protection of the American flag. Our government, it seems, is not only to allow, as it does, the free shipment of men, munitions and arms for the subjection of the Nicaraguans and the confiscation of their property, but if any of the speculators who go out to buy happen to get killed by he natives, the whole of Central America is to be held responsible for this violation of the American flag. The filibusters in Nicaragua seem to think that the Government of Washington is just as much bound to protect them in conquering Nicaragua as it is to protect the Missouri Border Ruffians in subduing Kansas - and, indeed, both would seem to have an equal claim, since both have the same object in view, namely, the extension of slavery."

341 "The Great Results and the Suggestive Developments of the Presidential Election," New York Tribune, November 8, 1856; "William H. Seward and his Disorganizing party Programme," New York Tribune, November 10, 1856.

342 "The Great Results and the Suggestive Developments of the Presidential Election," New York Tribune, November 8, 1856.

${ }^{343}$ Ibid. 
literally consumed by the Fremont party, like dry stubble under a consuming fire." ${ }^{344}$ Dana and Greeley remained convinced that "certain success awaits the opposition [the Republicans], in a general organization upon the corruption, excesses, and failures of the party in power. Such an organization, North and South, would have carried every Northern state, and half the Southern states..."345 The failures of the party worked in Dana's favor and he elevated his public reputation as a party functionary and community organizer across the next four years. He was appointed to the Republican nominating conventions to select candidates for mayor of New York City and delegates to the Electoral College for the state. ${ }^{346}$ This collection of prestigious posts helped him direct the party's future, and how its candidates aligned to his vision. Dana's elevated standing also earned him the post of chairman for the Sixth District's Republican Party convention in $1860^{347}$ and the New York City Republican Party convention to nominate the party's candidates for city judge, counsel, and governor later that year. ${ }^{348}$ These were positions reserved for highlevel party functionaries - a standing Dana now enjoyed.

\section{Conclusion}

The 1850s represent a critical point of transformation in Charles Dana's intellectual biography. Horace Greeley's New York Tribune embraced the republican idealism that Dana brought with him from Brook Farm and introduced it to the spectrum of the political world, from radical abolitionism to establishment legislative maneuvering. It provided him a chance to explore his desire to better understand transatlantic culture and political economy. Witnessing the

\footnotetext{
${ }^{344}$ Ibid.

345 “Fremont's Defeat and its Causes," New York Tribune, November, 27, 1856.

${ }^{346}$ New York Tribune, November 22, 1859.

${ }^{347}$ New York Tribune, August 23, 1860. Dana on Committee to pick new elector; New York Tribune, September 27, 1860. Dana made Chairman of Convention by the $6^{\text {th }}$ District Republicans.

348 “Republican City Convention,” New York Tribune, October 10, 1856.
} 
failure of Fourierist and Associationist ideas to influence the French Revolution of 1848 pushed Dana towards direct action and conventional party politics in the United States. At the beginning of the chapter Dana was adjusting from a return to Europe, somewhat unsure of how to proceed. The end of the chapter, the scope of half a decade, he had risen to the leadership rungs of a young and exciting Republican Party. In many ways he did not shed the desire to see specific policies implemented to moderate the negative influences of modern industrial life. He just exchanged support for the type of vehicle that would help realize these goals. He focused less on the standards of Brook Farm and Associationism and more on those undergirding Whig and Republican Party activism. He had less support for communitarian expressions of republican values, and developed faith in the possibility of traditional American politics. There was an undeniable tendency toward practicality in Dana's thought in this period. Perhaps the conventional movement towards conservatism that comes with age had its grips on him, but the trend remained clear and bold. In the chapter that follows, focusing on the period between 1855 and the start of the American Civil War in 1861 Dana underwent a profound transformation that lifted him from his previous dedication to the study of religion, metaphysics, and utopianism in the 1830 s. 


\section{CHAPTER THREE}

\section{BELLIGERENT PARTY POLITICS}

$(1856-1867)$

"Though I had seen slavery in Maryland, Kentucky, Virginia, and Missouri, it was not until I saw these plantations, with all their apparatus for living and working, that I really felt the aristocratic nature of it..."

-Charles A. Dana to William Henry Huntington, Milliken's Bend, Louisiana (April 13, 1863)

By 1856, Dana had transformed himself into the republican-inspired politico that he hoped he might become after he returned from Europe in 1848. He had elevated himself within the new party, especially in New York state and city subsidiaries, all the while championing the values he had seasoned while at Brook Farm two decades earlier. The Tribune had proven to be a useful vehicle for Dana to mature his intensifying defense of republican values against the forces of slavery and sectionalism. From 1856 to 1865, Dana further committed himself to advancing republicanism within the party system in yet another period of radical upheaval. During these years the nation fought its bloodiest war, matured - and then destroyed - the most profitable slave economy in the world and restructured both its political party system and constitutional government. These years helped move the United States from the periphery of the transatlantic world to its core. No longer a colony or developing nation, the United States and its citizens participated in, and helped define, a transatlantic debate about the meanings of ideas like republicanism, civic virtue, slavery, and socialism. In the process, these changes propelled Dana to the seat of American political power. His role as a major figure of the New York state Republican Party and Abraham Lincoln's Assistant Secretary of War illustrate the continued influence of his republicanism to his intellectual biography. 


\section{The Late 1850s: Antebellum}

Dana's newfound faith in party politics as the vehicle for spreading his national vision coincided with the highly volatile and divisive late-1850s and the Civil War. The years from 1856-1860 brought increasing tensions over the expansion and continuation of slavery, as well as a major shift in the balance of political power. The debate over slavery permeated national politics and culture while the widening schism between pro-slavery and anti-slavery political and cultural poles in the United States remade the nation's existing political system and exacerbated sectional divisions. ${ }^{349}$ These divisions eventually erupted into the Civil War. Dana played a leading role in encouraging this polarization in New York, a state formerly known for its Democratic Party leaning that took on an increasingly Republican character during the late1850s. He became a vocal advocate of the Republican Party and Abraham Lincoln. He also encouraged vigorous and, if necessary, violent defense of republican values while participating in the "Wide Awake" movement that aimed to recruit young Republicans. He made good on his word when the war erupted, as Dana became the Assistant Secretary of War.

The late-1850s proved seminal in the history of American party politics as the antislavery Republican Party swept the north and Southern Democrats' dedication to the "peculiar institution" remained steadfast. The parties' regional and ideological dichotomy was clearly visible in their rhetoric. In the North, the Republican Party became the hegemonic party of free labor and republican economic development that would be fair to all classes. They had hoped that their upstart party, and fresh candidates like the failed 1856 nominee John C. Fremont, could implement anti-slavery policies across the nation. In the south, some Democratic politicians began openly discussing secession as a valid legal principle (refreshing Senator John C. Calhoun's secessionist arguments from the late 1820s regarding the "Tariff of Abominations").

\footnotetext{
${ }^{349}$ Williams, Horace Greeley, 212 - 213.
} 
Southern Democrats threatened to leave the union if the property rights of slaveowners were violated. These sectional divisions grew after the 1857 Dred Scott case. The ruling protected the property rights of slave-owners in states where slavery was not explicitly legal, and enshrined slaves as a form of constitutionally protected property. ${ }^{350}$ Increasingly vocal pro- and anti-slavery advocates further encouraging polarization of the nation into two ideological extremes. In October 1859, John Brown and a band of abolitionist sympathizers raided the federal arsenal at Harper's Ferry, Virginia, and unsuccessfully sought to provoke a slave rebellion. ${ }^{351}$ Critics of the Tribune's abolitionism, for instance, blamed Dana, Greeley, and the Tribune for helping polarize the political debate and encouraging radical abolitionists like Brown. ${ }^{352}$ This was the state of the paper's editorial positions in the leadup to the most important election in the nineteenth century.

The presidential canvass of 1861 brought competing elements of the Republican arty to the Tribune's doorstep. Observers expected Greeley to consider the candidacy of his old friend and Senator from New York William Seward, whom Greeley had supported since the 1830s. Dana concurred and supported Seward's abolitionism. Also, Dana supported Seward's transatlantic understanding of American values. "He believed," Dana remembered "in the Constitution of the United States, and his one desire was that its blessings should be extended and made perpetual over all the continent." ${ }^{353}$ Dana expressed "intense gratitude" at Seward's foreign

\footnotetext{
${ }^{350}$ Adam Arenson, The Dred Scott Case: Historical and Contemporary Perspectives on Race and Law (Athens: Ohio University Press, 2010); Ethan Greenberg, Dred Scott and the Dangers of a Political Court (Lanham: Lexington Books, 2010); Austin Allen, Origins of the Dred Scott Case: Jacksonian Jurisprudence and the Supreme Court, 1837 - 1857 (Athens: University of Georgia Press, 2006).

${ }^{351}$ For scholarly treatments of Brown, see: Gilpin, John Brown Still Lives!; Louis A. DeCaro Jr., Fire From the Midst of You: A Religious Life of John Brown (New York: New York University Press, 2002).

352 Williams, Horace Greeley, 207-209, 358n90. Also see: the Albany Evening Journal, October 27, 1859; Oswald Garrison Villard, John Brown, 1800-1859: A Biography Fifty Years After (New York: Houghton Mifflin, 1919), 476; Theodore Parker to Francis Jackson (November 14, 1859) in Parker, Collected Works, vol. 14, 426; Seymour Drescher, "John Brown's Body in Europe," in Paul Finkelman, ed., His Soul Goes Marching On: Responses to John Brown and the Harper's Ferry Raid (Charlottesville: University Press of Virginia, 1995), 253-295.

${ }^{353}$ Dana, Charles Anderson. Lincoln And His Cabinet (New York: De Vinne Press, 1896): 29.
} 
policy positions especially because "he proclaimed the principle of continental unity, and that unity he would found in freedom, in progress, and in improvement of ever nature." ${ }^{\text {"35 }}$ Increasingly, however, both found Abraham Lincoln appealing. ${ }^{355}$ Indeed, Dana helped focus Lincoln's popularity among young Republican party progressives.

Abraham Lincoln holds a multifaceted place in American historiography. His biography lends itself to the legend of American exceptionalism and the possibilities for advancement in individual enterprise. His political career reinforced this narrative: a no-name, one term, Whig congressman from Illinois's seventh congressional district between 1845 and 1846, and failed Senate candidate in 1858 , becoming president in 1860 as the representative of a six-year old political party. ${ }^{356}$ This ascent has inspired historical attention since the 1858 debates between Lincoln and Democrat Stephen Douglas garnered national attention. Lincoln gained his reputation for emphasizing his free-soil position on slavery (that it should not expand past its current existence) and unionism (that secession was not the answer to the divisions of the American polity caused over slavery). ${ }^{357}$ Lincoln advanced ideas of economic nationalism at home, and the protection and modeling of American institutions abroad. ${ }^{358}$ To those like Dana who witnessed Lincoln's rapid ascent as a possible nominee for president in 1859 , the reasons for his explosive

\footnotetext{
354 Ibid.

${ }^{355}$ For more on the famous Lincoln-Douglas Debates, see: Rodney O. Davis and Douglas L. Wilson, eds. The Lincoln-Douglas Debate (Urbana and Chicago: Knox College Lincoln Center and University of Illinois Press, 2008).

${ }^{356}$ D. Leigh Henson, “Classical Rhetoric as a Lens for Reading the Key Speeches of Lincoln's Political Rise, 1852 - 1856," Journal of the Abraham Lincoln Association 35, no. 1 (Winter 2014): 1-25; David Zarefsky, "Lincoln and the House Divided: Launching a National Political Career," Rhetoric and Public Affairs 13, no. 3 (Fall 2010): 421-453.

357 J. David Greenstone, The Lincoln Persuasion: Remaking American Liberalism (Princeton: Princeton University Press, 1993).

${ }^{358}$ Laura Smith Porter, “'The Last, Best Hope of Earth,': Abraham Lincoln's Perception of the Mission of America, 1834 - 1854," Illinois Historical Journal 78, no. 3 (Autumn, 1985): 207 - 216.
} 
popularity could be traced to his popularity within the nation's "Wide Awake" movement within the Republican Party.

\section{Dana, the Wide-Awake Movement, and Abraham Lincoln}

Dana's participation in the Wide-Awake movement institutionalized his defense of republican values. The party encouraged Wide-Awake clubs as a means of recruiting and rallying new, young, party members. The movement spread rapidly through New England, and through the towns of the Midwest. ${ }^{359}$ It employed military motifs, fraternalism, and bellicose political activism to popularize the party. In uniforms and marching in torch lit parades, these clubs, as one historian explained, appropriated a militia-like character and "glorif(ied) aggressive political combat." ${ }^{360}$ They aimed for non-violent organizing but were prepared to mobilize belligerently with martial metaphors to defend the Republican Party. Wide - Awakes publicized themselves through pamphlets, editorials, and speeches and employed a communication network built in the shadow of the election of 1856 . Dana and Greeley supported the movement aggressively. ${ }^{361}$ These clubs' bellicosity further reflected Dana's increasing radicalism. In a speech to his fifteenth

\footnotetext{
${ }^{359}$ Grinspan, "Young Men For War,” 357-378.
}

${ }^{360}$ Ibid. Grinspan argues that "youth and militarism distinguished the Wide Awakes from the hundred of other clubs milling around nineteenth-century American elections. The organization appealed to white men in their teens, twenties, and thirties, attracting ambitious upstarts sporting youthful goatees who were "beginning to feel their true power." Using popular social events, an ethos of competitive fraternity, and even promotional comic books, the Wide Awakes introduced many to political participation and proclaimed themselves the newfound voice of younger voters. Though often remembered as part of the Civil War generation stirred by the conflict, these young men became politically active a year before fighting began. The structured, militant Wide Awakes appealed to a generation profoundly shaken by the partisan instability of the $1850 \mathrm{~s}$ and offered young northerners a much-needed political identity. They were also the first major campaign organization to adopt a military motif. Upon enlistment members became soldiers in the Wide Awake army - complete with ranks, uniforms, and duties. The Wide Awakes did not intend to incite actual violence. They chose their symbolism to appeal to the widespread "militia fever" of the era, to glorify aggressive political combat, and to signify the organizational strength and uniformity of the new Republican Party. The Wide Awakes' employment of a martial theme helps shine a light on the use of militaristic symbolism for political ends. More than anything else, this study attempts to examine the concrete impact of this seemingly superficial campaign metaphor."

${ }^{361}$ For a sampling of the Tribune's coverage of the Wide Awake movement in the lead-up to the November election of 1860, see: Tribune, August 13; September 8; September 27; October 22, 1860. 
ward Wide-Awake club in September 1860, he explained this very point. "If anything was calculated to draw forth sympathy," he argued, "it was the Wide-Awake movement — this infusion of new life and strength into the old political ranks." ${ }^{362}$ Estimates by modern historians, citing contemporary sources, placed nationwide Wide-Awake membership at over half a million "soldiers." ${ }^{363}$ Dana argued that Lincoln fit the spirit and mission of the "wide awake" movement within the Republican Party and deserved the support of these political soldiers. He made the case repeatedly in editorials and speeches - that young, aggressive, Republicans had in Lincoln "a candidate and an example a man who had always been wide awake; who, through an unhelped life, had struggled on, determined to make for himself a name, till he had reached a position where he will be the next president." ${ }^{364} \mathrm{He}$ insisted that "not only his example, but also the principles he holds, have stimulated the young men of our country" - in contrast to establishment figures like Seward and Weed. ${ }^{365}$ A Tribune reporter present at a fifteenth ward Wide-Awake meeting in September of 1860 noted how Dana "exhorted" the "young men of our country" that they "might always be on the side of freedom and right," and support Lincoln "against corruption and [the] Democracy." 366

Dana and Greeley's support for Abraham Lincoln riled Seward supporters. Part of the reason for that was that Dana was not alone in his preference for Lincoln over Seward. The Illinois lawyer had caused a major rift. Joined by Horace Greeley, and the editorial force of the Tribune, Dana helped direct the party away from Seward. Dana's reasoning, which he explained

\footnotetext{
362 “Republican Meetings. Fifteenth Ward Wide-Awakes," New York Tribune, September 22, 1860.

${ }^{363}$ Grinspan, "Young Men for War," 141, fn. 9.

364 “Republican Meetings. Fifteenth Ward Wide-Awakes," New York Tribune, September 22, 1860.

${ }^{365}$ Ibid.

${ }^{366}$ Ibid.
} 
publicly in the pages of the Tribune to avoid the appearance of backroom dealing, had everything to do with Lincoln's connection to egalitarian and republican ideas. In an August editorial, he defended the decision as one made on ideological grounds and political calculation, not personal dislike of Seward ${ }^{367}$ Dana wrote that Lincoln had been made "wide awake" and had also had the virtue of a self-motivated, egalitarian, and republican upbringing that would prove more popular to voters. ${ }^{368}$ On February 27, 1860, Lincoln gave a now famous anti-slavery speech at Cooper Union in New York City that Greeley reportedly helped edit. ${ }^{369}$ Dana and Greeley welcomed Lincoln's nomination at the Republican national in Chicago in mid-May 1860. They supported the free soil platform in support of admitting Kansas as a free state, passing a new homestead law, and anti-slavery as a basic goal of the party. ${ }^{370}$ To emphasize that Lincoln had their support, Dana and Greeley re-printed thousands of copies of anti-slavery tracts like Hinton Rowan Helper's, The Impending Crisis of the South (New York, Burdick Brothers, 1857) that showed slavery's economic unprofitability. ${ }^{371}$ Greeley also published a political textbook about the major issues of the upcoming election and how Lincoln stood on these versus the other candidates. ${ }^{372}$ The Tribune declared that "every Wide Awake Club should have a copy" of the Political Textbook for 1860. ${ }^{373}$ Wide Awake clubs spread across the North after the Chicago convention and Dana's numerous speeches in that period before the election put him in conversation with a movement

\footnotetext{
367 “A Word in Reply,” New York Tribune, August 28, 1860.

368 "Republican Meetings. Fifteenth Ward Wide-Awakes," New York Tribune, September 22, 1860.

${ }^{369}$ Williams, Horace Greeley, 211.

${ }^{370}$ Ibid.

${ }^{371}$ Ibid, 213.

${ }^{372}$ Ibid, 213. Greeley published a version of the platform that he helped write through the Tribune. See John F. Cleveland and Horace Greeley, A Political Textbook for 1860 (New York: Tribune Association, $1860)$.

${ }^{373}$ New York Tribune, August 27, 1860.
} 
sweeping the country. Dana's fifteenth ward Wide Awake club marched in New York City while others coordinated similar downtown rallies in Philadelphia, Chicago, Cleveland, and Boston. ${ }^{374}$ In preparation for the march, the Tribune informed New Yorkers that "the hosts of freedom are coming" in the name of the "Republican Wide-Awake Battalion" of the city. ${ }^{375}$ Historians have argued that the efforts of the Wide Awakes excited the electorate in the north behind the Republicans in the lead up to the election in November 1860. The election attracted a high percentage of Americans to the ballot box, and a very large increase in northern voters helped give Lincoln the victory. ${ }^{376}$

The aftermath of Lincoln's election has been the subject of intense study. ${ }^{377}$ Dana forwarded the argument that Abraham Lincoln's election as president in November 1860 guaranteed a crisis. Of that election, Dana would remember that "the great question at issue in that election, although I do not think it was formally stated in the platforms of the parties, was this: Shall the owners of slaves enjoy the right of taking their slaves into the Territories of the United States that are now free, and keeping them there?"378 Dana summarized that as "fundamental question of the election." ${ }^{379}$ Lincoln's election, he explained, "denied this right." 380

${ }^{374}$ Grinspan, "Young Men for War,” 360.

${ }^{375}$ New York Tribune, October 20, 1861; New York Tribune, October 22, 1861.

${ }^{376}$ Estimates of voter turnout suggest that more than of 80 percent of eligible voters cast a ballot. For more see: Lyn Ragsdale, Vital Statistics on the Presidency (Washington, D.C.: Congressional Quarterly Press, 1998), 132-38; Bill Winders, "The Roller Coaster of Class Conflict: Class Segments, Mass Mobilization, and Voter Turnout in the U.S., 1840 - 1996," Social Forces 77, no. 3 (Mar., 1999): 833-862.

${ }^{377}$ For more on the recent work on the election of Abraham Lincoln in November of 1860 and the resulting secession of the South and the start of war, see: A. James Fuller, The Election of 1860 Reconsidered (Kent: Kent State University Press, 2013); Green, Lincoln and the Election of 1860; Russell McClintock, Lincoln and the Decision for War: The Northern Response to Secession.

${ }^{378}$ Charles A. Dana, Lincoln And His Cabinet (New York: De Vinne Press, 1896), 10.

${ }^{379}$ Ibid, 11.

${ }^{380}$ Ibid, 13. 
When the South proved adamant, Dana concluded that the question "was to be determined by war. ${ }^{" 381}$ And then the war came. As it was for the whole country, the hostilities sparked a firestorm in Dana's own life. The upheaval forced Dana to come out more forcefully in favor of war to defend unionism and antislavery in ways that changed his professional relationship with Greeley and the Tribune.

Dana, the Start of the Civil War, and Employment Within the Department of War

Dana's life changed profoundly when he became more committed to a belligerent defense of republicanism in 1861. In the period after Lincoln's election and the first summer campaign of the Civil War, Dana became too aggressive for the more pacifist Horace Greeley. Under normal circumstances, the two handled disagreements quietly. With the Confederate and Union armies organizing in the field, these were not normal circumstances. The breech began when Greeley left Dana in charge of the Tribune when he traveled to Washington D.C. There had been cases such as these in the past where Greeley had objected that Dana failed to keep the Tribune on good terms with its friends when the boss was away. ${ }^{382}$ Greeley's dovishness in the spring of 1861 contrasted with Dana's bellicosity in defense of the rights he deemed foundational. The two disagreed about the Tribune's position - should the editorial call for a preemptive attack and an aggressive prosecution of the war, or should it support compromise and peace.

Dana and Greeley fought for weeks. The republican-fueled heat of European Revolutions, the fears of continental war during Crimea, and the abolitionist bloodletting in

\footnotetext{
${ }^{381}$ Ibid, 13.

${ }^{382}$ In 1854, Greeley produced one of the best examples of his characteristic reprimands of the aggressive Dana. Maihofer reports Greeley thus: "Dana: I shall have to quit here or die, unless you stop attacking people without consulting me." In another note, Greeley complained about Dana's intentional trimming of the size of Greeley's dispatches from Washington. "I wish you could humor would humor my prejudices a little, and when I send two or more dispatches, not make them into one...I would stay here forever and work like a slave if I could get my letters printed as I send them, but the Tribune is doomed to be a second-rate paper, and I am tired." Cited in Hale, Horace Greeley, 169 - 174.
} 
Kansas had radicalized Dana's republicanism. With Greeley gone, and Union armies gathering around Washington, Dana used the Tribune to advocate a first strike against the Confederate capitol at Richmond. Under Dana's supervision, Tribune editorialist Fitz-Henry Warren crafted a short editorial titled "Forward to Richmond." 383 Its tone parroted Dana's aggressive, "WideAwake," approach to the start of the war. Warren's article came at the same time that Greeley was advocating an armistice. ${ }^{384}$ Greeley hoped for an amicable end to a misunderstanding; Dana was advancing republicanism by force of arms. The "Forward to Richmond" article infuriated Greeley very angry, but Dana went further still when he changed the front-page masthead of the Tribune front-page to "Forward to Richmond." 385 The paper called this "the nation's war cry" and demanded that the "Rebel Congress must not be allowed to meet there on the $20^{\text {th }}$ of July!" "By that date," the Tribune commanded that "the place must be held by the National Army." 386 The federal advance in July, fulfilled Dana's aggressive hopes. That early campaign failed miserably. The defeat at Bull Run set up the radicals in the Republican Party, the New York Tribune, and Dana, personally, for the outcome. In a letter to friend Thomas C. Carroll in August, Dana wrote that "Bull Run has knocked the Republican Party pretty badly," leaving him with only "work and trouble" for the rest of $1861 .{ }^{387}$ Greeley played a large part in directing this trouble toward Dana, complaining about the "infernal carelessness" of his aggressive recommendations for the makers of Union grand strategy. ${ }^{388}$

\footnotetext{
${ }^{383}$ Wilson, The Life of Charles A. Dana, 166; Maihofer, The General and the Journalists, 68.

${ }^{384}$ Maihofer, The General and the Journalists, 71.

385 Ibid, 69.

${ }^{386}$ See the New York Tribune editorial page across June of 1861.

${ }^{387}$ Dana to Thomas C. Carroll, August 1, 1861, in Charles Dana Miscellaneous Manuscripts, New York Historical Society, cited in Steele, The Sun Shines for All, 44 fn73.

${ }^{388}$ Horace Greeley to Sam Wilkeson, February 3, 1862, James Wright Brown Collection of Horace Greeley's papers, New York Historical Society, cited in Steele, The Sun Shines for All, 44, fn74.
} 
Dana's aggressive republicanism hurt his (and the paper's) reputation with some but it elevated with others. The figure most attracted by Dana's aggressiveness was Secretary of War Edwin M. Stanton, who had succeeded to the office in January 1862. Secretary Stanton's affinities for Dana arose from the Tribune's hostility to Union generals who failed to prosecute the war aggressively - one of Stanton's major concerns. The Tribune especially opposed the General-in-Chief of the Union army, Henry Wilson Halleck. ${ }^{389}$ Dana similarly pilloried General George McClelland for plodding and lack of pluck. Stanton shared the judgment. ${ }^{390}$ From late 1861 through February 1862, Dana and Stanton grew close. Letters the two exchanged letters weekly in early 1862 show that Stanton saw Dana and the Tribune as partners in the Union's war effort. ${ }^{391}$ Stanton testified that "the Tribune has its mission as plainly as I have mine" even as he reaffirmed that Union Generals like McClellan needed to "fight or run away" and demanded that the rebellion needed to be quelled "with fire and sword." ${ }^{392}$ Familiar with Dana's feelings at the time, biographer J.H. Wilson saw Dana's budding relationship with the aggressive Stanton as representative of the point of disagreement between Greeley and his deputy. "Greeley stood for the abstract and even for the fanciful, while Dana stood for those practical and aggressive measures upon which the nation must necessarily depend for the suppression of the rebellion and the re-establishment of the Union. ${ }^{״ 393}$ By the Spring of 1862 Dana had morphed into a firebrand

\footnotetext{
${ }^{389}$ Maihofer, The General and the Journalists, 88.

${ }^{390}$ For examples, see: Benjamin Wade to Charles A. Dana, February 3, 1862; Edwin M. Stanton to Dana, February 1, 1862 (Dana Papers, Library of Congress), cited in William Marvel, Lincoln's Autocrat: The Life of Edwin Stanton (Chapel Hill: University of North Carolina Press), 155-156.

${ }^{391}$ Edwin M. Stanton to Charles A. Dana, January 24, February 1, 3, 19, 23, 1862 (Dana Papers, Library of Congress). cited in Marvel, Lincoln's Autocrat, 156 - 158; Wilson, The Life of Charles A. Dana, 187 - 188.

${ }^{392}$ Edwin M. Stanton to Charles A. Dana, January 24, February 1, 19, 23, 1862 (Dana Papers, Library of Congress). cited in Marvel, Lincoln's Autocrat, 157.

${ }^{393}$ Wilson, The Life of Charles A. Dana, $187-188$.
} 
defender of republicanism, much friendlier with the aggressive Stanton than with his old friend Greeley. On March $27^{\text {th }}$, Greeley threatened to quit the paper if Dana did not resign and on March $28^{\text {th }}$, the Tribune's board of stockholders approved Dana's resignation. On April $9^{\text {th }}$, Dana wrote to friend and former co-worker James Pike that "Mr. Greeley was weary of seeing letters sent to me by leading men, Senators, Congressmen, Cabinet members, etc.," and "was weary also of seeing other papers speak of me as an essential part of the Tribune. ${ }^{\prime 394}$ Dana made the same claim to Henry Carey. ${ }^{395}$ Leaving the Tribune, regardless of the reason, marked the end of a critical part of Dana's life. Horace Greeley had introduced Dana to the business of journalism. He had also helped qualify Dana as a social reformer and political activist and Greeley's influence had imbued Dana with an appreciation for party politics. At the Tribune, Dana observed the saturation of republicanism in American life while learning to appreciate the need to protect it with force, if necessary.

Dana's break with the paper in 1862 came at the height of his personal and professional life. He had made himself a journalistic powerhouse with a multifaceted resume. He helped the Tribune reach unprecedented levels of success in the 1850s. He was first person to hold title of managing editor in American journalistic history, ${ }^{396}$ owned twenty percent stock in the Tribune corporation, ${ }^{397}$ and received a notable salary. ${ }^{398}$ All these facts made Dana one of the most influential journalists in the country. He practiced more than journalism as represented by the

\footnotetext{
${ }^{394}$ Charles A. Dana to James S. Pike, April 9, 1862. Pike Collection, cited in Steele, The Sun Shines for All, $45 \mathrm{fn} 81$.

${ }^{395}$ Charles A. Dana to Henry Carey, April 8, 1862. Gardiner Collection, cited in Steele, The Sun Shines for All, 45 fn82.

${ }^{396}$ Maihofer, The General and the Journalists, 105-6.

${ }^{397}$ Ibid, 105.

398 Wilson, The Life of Charles A. Dana, 159. Wilson cites that "his salary as managing editor had been increased first to twenty-five, then to forty, and finally to fifty dollars per week..."
} 
New American Cyclopaedia, a sixteen-volume encyclopedia put together by Dana and old friend and Tribune colleague, George Ripley. ${ }^{399}$ He used the time away from the Tribune to finish its last volumes which he had began in 1858. The Cyclopaedia helped cement relationships between Dana and major figures of the age, Marx and Engels, who wrote eighty-one articles for the work - these ranging from military theory, to revolutionary leader biographies, to ideology. ${ }^{400}$ Besides guaranteeing his place with such luminaries, the encyclopedia series made Dana a good amount of money, ${ }^{401}$ and encouraged him to get into the business of publishing anthologies of poetry and children's stories. ${ }^{402}$ Without the Tribune to concern him at home, Dana also took advantage to cultivate his personal and professional friendships.

When considering Dana's professional trajectory in the Civil War era, the most strategic of these relationships was the connections he had developed with members of President Abraham Lincoln's cabinet. Dana's work with the Tribune and friendship with Henry Carey, for instance, helped gain him the ear of the Secretary of the Treasury, Salmon P. Chase, the old Ohio abolitionist, vice presidential candidate and former governor. ${ }^{403}$ While Dana and Stanton were

\footnotetext{
${ }^{399}$ For samples of the reviews, see: The North American Review 86, no. 179 (Apr., 1858): 584-585; The North American Review 87, no. 181 (Oct., 1858): 563-564; The North American Review 88, no. 182 (Jan., 1859): 281; Scientific American, 14, no. 17 (January 1, 1859); Scientific American, 5, no. 3 (July 20, 1861): 45; The North American Review 97, no. 200 (Jul., 1863): 289-290.

${ }^{400}$ Steele, The Sun Shines for All, 38.

${ }^{401}$ Ibid, 38-9. Dana’s biographer explains that Dana, and co-editor George Ripley, made over $\$ 180,000$ dollars from sales of the American Cyclopaedia by 1880.

${ }^{402}$ For more on Dana's American Household Book of Poetry (New York: Appleton \& Co., 1859), see: Steele, The Sun Shines for All, 38; Wilson, The Life of Charles A. Dana, 54-57, 157-58, 174177, 288-289.

${ }^{403}$ For more on Chase, see: Michael W. Pfau, The Political Style of Conspiracy: Chase, Summer, and Lincoln (Lansing: Michigan State University Press, 2005); Herman Belz, "Salmon P. Chase and the Politics of Reform," Journal of the Abraham Lincoln Association 17, no. 2 (Summer 1999): 22 - 40; Stephen E. Maizlish, "Salmon P. Chase: The Roots of Ambition and the Origins of Reform," Journal of the Early Republic 18, no. 1 (Spring, 1998): 47 - 70; John Niven, Salmon P. Chase: A Biography (New York: Oxford University Press, 1995); Louis S. Gerteis, "Salmon P. Chase, Radicalism, and the Politics of Emancipation, 1861 - 1864," Journal of American History 60, no. 1 (June 1973); David Donald, ed. Inside
} 
trading correspondence, Chase contacted Dana to do business for the government buying and trading Southern cotton. Historians have explained how controversial this type of activity was, as Northerners trading confiscated Southern cotton back to Confederate citizens could easily be accused of confiscating property and prolonging war. ${ }^{404}$ Dana's biographer, James Harrison Wilson, reported that Chase proposed to pay Dana handsomely to "purchase and bring out cotton from such parts of the Mississippi Valley as had been occupied by the Federal Army." ${ }^{405}$ Still in New York City, Dana decided to leave Eunice with the four children in the spring of 1862 to travel to Washington to meet with Chase, Stanton, and Lincoln. After meetings in the West Wing of the White House Dana decided that their previous idea of dealing in contraband Southern cotton would be too dangerous a post for Dana to begin any potential government employment. Secretary Stanton had other ideas. ${ }^{406}$ In the months that passed between Stanton's appointment and Dana's leaving the Tribune, the secretary had clarified his priority of reforming the quartermaster system of the army. Stanton sent Dana to disentangle the wide extent of financial corruption in the Union quartermaster corps. ${ }^{407}$ The war's cost had grown to levels that were

Lincoln's Cabinet: The Civil War Diaries of Salmon P. Chase (New York: Longmans, Green and Company, 1954).

${ }^{404}$ For more on the Union government's attempts to buy and trade in confiscated Southern cotton, especially at the direction of the Treasury Department, see: David G. Surdam, "Traders or Traitors: Northern Cotton Trading During the Civil War," Business and Economic History 48, no. 2 (Winter 1999): 301-312.

${ }^{405}$ Wilson, The Life of Charles A. Dana, 183.

${ }^{406}$ Ibid, 185-186.

${ }^{407}$ For more on the U.S. Army's Quartermaster corps in the early months of the Civil War, see: Robert O'Harrow, Jr., The Quartermaster: Montgomery C. Meigs, Lincoln's General, Master Builder of the Union Army (New York: Simon \& Schuster, 2016); Mark R. Wilson, "The Business of Civil War: Military Enterprise, the State, and Political Economy in the United States, 1850 - 1880," Enterprise \& Society 4, no. 4 (December 2003): 599 - 605; Ira Katznelson, "Flexible Capacity: The Military and American Statebuilding," in Shaped by War and Trade: International Influence on American Political Development, ed. Ira Katznelson and Martin Shefter (Princeton: Princeton University, 2002); Paul A.G. Koistinen, Beating Plowshares into Swords: The Political Economy of American Warfare, 1606 - 1865 (Lawrence: University of Kansas Press, 1996). 
injuring the perception of the Union among the people. On June 16, 1862, Secretary of War Stanton formally hired Dana as an agent of the Department of War, as part of a commission investigating claims against the army quartermaster in the bustling rail hub of Cairo, Illinois. ${ }^{408}$

Dana would be a war commissioner for the Army, an accountant and anti-corruption agent for the federal government. In this role he joined a cohort of well-known politicians: former Governor of Massachusetts George S. Boutwell [later Congressman] (1863-1869), Secretary of the Treasury (1869-1873), Senator (1873-1877) and former member of the Illinois House of Representatives Shelby M. Cullom, later a Congressman (1865-1871), Governor of Illinois (1877-1883), and Senator from that state (1883-1913). Dana and the rest of the group were assigned to "audit unsettled claims against the quartermaster's bureau..."409 The work amounted to the inspecting "sixteen hundred and ninety-six claims, aggregating $\$ 599,219.36$, were examined and adjusted," of which Dana delivered the report to Stanton early in August." Dana's previous accounting history helped qualify him for such work. Dana's skills as an observer and ombudsmen suited the task, too. The commission proved to be only an introductory post for a much brighter future, however. After returning from Illinois, Stanton decided to send Dana on a higher priority assignment where his skills of observation and judiciousness would be put to the test. Stanton hoped that Dana could also help him with another problem. The secretary needed an experienced observer to serve as the eyes of the administration in the field. Dana's desires to see republicanism aggressively defended, combined with his reputation for judiciousness, made him Stanton's and, consequently, Lincoln's preferred evaluator as Grant was the subject. The primary general the two had in mind for Dana to report on was General Ulysses

\footnotetext{
${ }^{408}$ Wilson, The Life of Charles A. Dana, 190.

${ }^{409}$ Wilson, The Life of Charles A. Dana, 190.

${ }^{410}$ Ibid, 201.
} 
S. Grant, as Lincoln had never met the general. The latter was preparing a major campaign south from Cairo, Illinois to take all the major Confederate forts along the Mississippi River. The most formidable of these was the impressive fortifications at Vicksburg, Mississippi.

\section{Dana as Lincoln's Military Observer and Assistant Secretary of War}

Neither Lincoln nor Stanton trusted Grant completely. "From October, 1862, to June, 1863 , or for a period of eight months, Grant's tenure of command was uncertain, and that at times he was in imminent danger of being removed...," according to one source. ${ }^{411}$ Wilson, who worked with the general in Vicksburg and later in the war, admitted that Grant was a "successful general," but "was a poor correspondent" of his intentions and movements. ${ }^{412}$ Wilson's appraisal hit the mark. Thus Henry Halleck, for example, believed that Grant was ruining the Mississippi Campaign and failed to reassure him in letters or in the field. Even after his victories at Fts. Henry and Donelson, Halleck had actually suspended him from command. Part of the issue here was that Grant and his subordinate, General William T. Sherman, had experienced some difficulty in securing a flanking movement along the Yazoo River. Grant underwent an embarrassing defeat at Holly Springs in early December and Sherman later suffered a particularly one-sided defeat at the Battle of Chickasaw Bayou. ${ }^{413}$ Grant and Sherman were also fighting off the eternally crafty General Nathan Bedford Forrest, with his famous cavalry who played havoc with Grant's supply lines, as at Holly Springs. ${ }^{414}$ Indeed Grant needed better relations with the White House as much as the administration needed information about the taciturn general. "[Grant] had but few friends

\footnotetext{
${ }^{411}$ Wilson, The Life of Charles A. Dana, 201.

${ }^{412}$ Ibid.

${ }^{413}$ Ronald C. White, American Ulysses: A Life of Ulysses S. Grant (New York: Random House, 2016), 251. "For Grant, the last days of 1862 marked a personal nadir in the war. Halleck telegraphed on December 27, 'I think no more troops should at present be sent against Vicksburg. I fear you have already too much weakened your own forces."

${ }^{414}$ Ibid, 248.
} 
and no intimates connected with the government," Wilson wrote, "and notwithstanding his great victories was more or less in disfavor." "415 "The general was clearly in need of friends who could command the attention of both the President and the Secretary of War," he explained. They hoped Dana could help remedy this. Dana remembered years later that "whenever an important campaign of the armies began Mr. Lincoln liked to send me, because when I went, with my newspaper experience, he got a clear report of everything that happened." It would be Dana's duty then, Wilson explained, "to keep them [Lincoln and Stanton] correctly informed on all matters of importance connected with him and the forces under [Grant's] command." ${ }^{\text {416 }}$ He would explain years later that "the generals didn't like to sit down, after fighting all day, and write a report, and they were always glad to have me come to them." ${ }^{417}$ In March 1863, as Grant directed his major campaign to take the entire Mississippi River under Union command, Dana arrived in Memphis to join the force. ${ }^{418} \mathrm{He}$ described his responsibilities to a friend. He was to serve "as a 'special commissioner' of the War Department, a sort of official spectator and companion to the movements of this part of the campaign, charged particularly with overseeing and regulating the paymasters, and generally with making myself useful." ${ }^{219}$

Dana had other duties as well. He would do more than audit the army's supply procurement system as he had done before. It was at Cairo that Dana met the high command: Ulysses S. Grant, his Adjutant General and Chief of Staff, John A. Rawlins and his Inspector General, James Harrison Wilson, later a biographer and historian. ${ }^{420}$ Wilson remembered that

\footnotetext{
${ }^{415}$ Wilson, The Life of Charles A. Dana, 198.

${ }^{416}$ Ibid, 200.

${ }^{417}$ Dana, Lincoln and His Cabinet, 43.

${ }^{418}$ Wilson, The Life of Charles A. Dana, 203 - 204.

${ }^{419}$ Ibid, 212.

${ }^{420}$ Wilson, The Life of Charles A. Dana, 192 - 201.
} 
Dana's real duty was to report daily "what he might see and learn" about General Grant. ${ }^{421}$ While Dana had no military experience to merit such a post, he was an expert chronicler, an able outdoorsman, and skilled war correspondent. Along with his belligerent republicanism, these skills qualified him to serve the White House's needs.

He was the perfect witness to Grant's unprecedented victory at Vicksburg. ${ }^{422}$ Dana explained in his reports that Grant had a plan for a two-pronged attack-Sherman would take his divisions down the Mississippi and Yazoo Rivers with the assistance of Admiral David Dixon Porter and the Navy, while Grant would harass the Confederates on land. One Grant biographer described that Grant's intent was to "hold the Confederates in front while Sherman came in from the rear. ${ }^{, 423}$ Dana documented all aspects of this famous campaign for the War Department. ${ }^{424}$ An eager camp-hand and go-getter, Dana did everything that his camp guide, James Harrison Wilson, did on the approach to Vicksburg, including "riding our lines, visiting the hospitals, or going to our base of supplies at the Landing." ${ }^{, 425}$ Dana marched alongside Grant and Wilson, helped build bridges, and reportedly became a "great expert at framing and deciphering coded Confederate

${ }^{421}$ Ibid, 200.

${ }^{422}$ For the most recent analysis of the Vicksburg Campaign, see: Michael B. Ballard, The Civil War in Mississippi: Major Campaigns and Battles (Jackson: University Press of Mississippi, 2014, 2011).

${ }^{423}$ White, American Ulysses, 248.

${ }^{424}$ Dana's letters to Stanton relative to Vicksburg included "full accounts of the siege operations, the explosion of the mines under the works of the enemy, the movement of troops, the co-operation of the gunboats, the precautions against a sortie, the necessity for reinforcements, [and] the condition of the enemy inside and outside of Vicksburg." (Wilson, The Life of Charles A. Dana, 226)

${ }^{425}$ For more on the responsibilities of the army that Dana joined Wilson in doing, see: Wilson, Life of Charles A. Dana, 221-222, 230. "Never a day passed without riding our lines, visiting the hospitals, or going to our base of supplies at the Landing. In this way Dana became familiar with every detail of army administration as well as the actual military operations." 
messages." "426 "It is not too much to say that he got a better idea of the real merits of our generals," Wilson wrote, "and gained a more practical knowledge of actual military operations, in the final ten days of that campaign, than would have been possible in any other period of the war." ${ }^{, 27}$ At no other point was this knowledge as important as when he had to evaluate the effectiveness of the Vicksburg Campaign. He began by evaluating the generals for the White House, and he found Brigadier General John A. McClernand problematic, ${ }^{428}$ and the "genius" of Grant's famous subordinate, General William T. Sherman, formidable. ${ }^{429}$ Of Grant, Dana had especially prized his aggressiveness in battle.

Dana's dispatches secured Grant's reputation with the administration. They depicted him as headstrong, courageous, and humble. Grant, by Dana's measure, deserved his job and not the rumors of his inability, carelessness, of alcoholism swirling around the national press. ${ }^{430}$ The final stages of the campaign won his highest encomia. The combination of the successful pincer movement around Vicksburg, the start of the siege, and Dana's positive reviews of his

${ }^{426}$ Dana joined the men in marching and building bridges. (Wilson, The Life of Charles A. Dana, 223); "Dana, as well as can be understood, became a great expert at framing and deciphering code messages..." (Wilson, The Life of Charles A. Dana, 206).

${ }^{427}$ Wilson, The Life of Charles A. Dana, 223.

${ }^{428}$ Ibid, 227-8. Wilson's impressions of Dana's negative, but respectful, review of the politically-connected general McClernand: "I have dwelt upon this episode first because it well illustrates Dana's independence in the performance of a public duty no matter how important the persons concerned might be, and next because McClernand, without reference to his real merits or his political influence, was the only officer of high rank in that entire army who was not on good terms with Grant...”

${ }^{429}$ Ibid, 212. Dana to Stanton, April 13, 1863. "Sherman especially is a man of genius and of the widest intellectual acquisitions."

${ }^{430}$ Wilson, The Life of Charles A. Dana, 239. Dana felt similarly of Grant, the general, in 1897 as he did in 1864. Dana would, almost three decades later in his Civil War memoir, Remembrances of the Civil War, remember him "as an uncommon fellow - the most modest, the most disinterested, and the most honest man I ever knew, with a temper that nothing could disturb, and a judgment that was judicial in its comprehensiveness and wisdom. Not a great man, except morally; not an original or brilliant man, but sincere, thoughtful, deep, and gifted with courage that never faltered; when the time came to risk all, he went in like a simple-hearted, unaffected, unpretending hero, whom no ill omens could deject, and no triumph unduly exalt." 
performance, secured Grant the confidence of his superiors. In early May of 1863, Stanton wrote to Dana that he should instruct Grant that he had "the full confidence of the government." ${ }^{431}$ The administration was satisfied that the beginning of the siege signaled the last stages of a successful campaign. "General Grant has full and absolute authority to enforce his own commands," Stanton's note instructed Dana to communicate to Grant, imploring the general "to remove any person who, by ignorance, inaction, or any cause, interferes with or delays his operations. ${ }^{\circledR 432}$ As Stanton was want to do, however, he also left Dana with a bitter warning to be taken alongside the assurances of confidence delivered to Grant. The Major General, Stanton wrote to Dana, "is expected to enforce his authority, and will be firmly and heartily supported, but he will be responsible for any failure to exert his powers. You may communicate this to him." ${ }^{433}$ The show of support from the White House, motivated by Dana's positive reports, arrived just as Grant completed some of his most successful maneuvers of the war. Grant's columns enveloped the fortifications and began what would become a two and half month siege — a stunning and successful campaign that realized one of the major goals of the Union's grand strategy: the control the Mississippi River and the splitting of the Confederate Army in half. This result realized Dana's desire to see American republican values vigorously defended by the Union army and its leadership. Dana's validation of Grant with the Lincoln administration served this end. Dana pressed for an intrepid Union strategy that valued offense over defense, taking advantage of Union advantages in manpower, technology, and resources. Abandoning the pacifism of his past, a republican future in the United States, Dana now insisted, could come only with force of arms. General Ulysses S. Grant prosecuted the war in just such a fashion and deserved Dana's recommendation.

\footnotetext{
${ }^{431}$ Stanton to Dana, May 5, 1863. Cited in Wilson, 218.

${ }^{432}$ Ibid.

${ }^{433}$ Ibid.
} 
Dana's reports from Vicksburg helped him gain another assignment in 1863, as well as an expanded role within the Department of War. Dana's practical experience of urging military strategy as a defense of republican values continued. The first of these new assignments was another observational post in the field with similar objectives. Lincoln and Stanton wanted to understand the choice made by General Rosencrans to give up the strategically valuable mountain city of Chattanooga. Dana's reports could allow the administration to decide whether a more “forward-thinking” replacement, like Rosencrans' subordinate George Thomas, would be necessary to expedite operations against Confederate forces in the Smoky Mountains. ${ }^{434}$ While encamped with the Army of the Cumberland, Dana's reports regarding Rosencrans' disastrous performance during the Union defeat at the Battle of Chickamauga sealed his doom. Wilson explained that "Dana's vigorous despatches had the immediate effect of so arousing the government that it at once put forth its best efforts to reinforce the army now gathered at Chattanooga by troops from every quarter that could spare them. ${ }^{, 435}$ Dana's reports, Wilson explained, “...laid bare with a pitiless hand the incapacity, the imbecility, and the utter lack of firmness which characterized the conduct of Rosencrans." ${ }^{, 36}$ Both Lincoln and Stanton agreed to put Thomas in charge, and to execute an aggressive campaign that would eventually leave Lookout Mountain and the nearby Nashville area in control of the Union's Army of the Tennessee. Again Dana's correspondence illustrates his ambition to defend republican values in ways that matched the administration's military war strategy.

It is important here to note other Civil War experiences that helped mold Dana's intellectual development and commitment to republicanism. Dana's work as Stanton's agent on

\footnotetext{
${ }^{434}$ Wilson, The Life of Charles A. Dana, 254-6. "The government at Washington had been clearly outgeneraled by the government at Richmond..."

${ }^{435}$ Ibid, 268.

${ }^{436}$ Ibid, 269.
} 
the ground exposed him more directly to the ways that slavery influenced the republic. Dana insisted since the start of the war that the nation's generals needed to aggressively prosecute the war to end slavery, restore the union, and preserve historic American values. If viewed through the prism of republicanism, Dana's war strategy manifested from his belligerent, post-1848 defense of free labor and unionism. This type of aggressive approach to combating slavery's existence, and propagating broader ideas of free labor, focused Dana's understanding of republicanism since the Bleeding Kansas controversy. During the 1850 s he spoke to various "Free Kansas" meetings, often equating the plight of slavery with the major problems within the republic. Dana, though, did not travel widely across the South before the war. He lacked firsthand experience of chattel slavery. His knowledge was theoretical and abstract. Following Grant down the Mississippi River valley allowed Dana to witness large-estate slave plantation life. Moreover, his witness came in the Spring of 1863, just months after the Emancipation Proclamation took effect. "During the eight days that I have been here," he wrote to friend William Henry Huntington from Milliken's Bend, Louisiana, "I have got new insight into slavery, which has made me no more a friend of the institution than I was before..." ${ }^{\text {437 }}$ He explained to a friend that it was on the campaign down the Mississippi and Yazoo Rivers, en route to Vicksburg, that he understood slave life in the Deep South. "Though I had seen slavery in Maryland, Kentucky, Virginia, and Missouri," he wrote," it was not until I saw these plantations, with all their apparatus for living and working, that I really felt the aristocratic nature of it..."438 Grant's units travelled through some of the most slavery-dense areas in the Confederacy andrunaway slaves would follow the army, which Grant organized as "pioneer units" which played a major role within Grant's army during the Mississippi Campaign in the complex engineering feats

${ }^{437}$ Charles A. Dana to William Henry Huntington, Milliken's Bend, Louisiana (April 13, 1863). Cited in Wilson, Life of Charles A. Dana, 213.

${ }^{438}$ Ibid. 
required to surround Vicksburg. ${ }^{439}$ Dana developed a strong and clear support of these unitseven declaring his support for the forming of black combat units. ${ }^{440}$

His experience was transformational, as he became a rigorous advocate of the Thirteenth Amendment to the Constitution to ban slavery. Thus Lincoln asked Dana to help whip votes for the late January vote in the House of Representatives and early April Senate vote. ${ }^{441}$ Dana described how Lincoln wanted pass such an amendment through Congress before the war's end to make a definitive rhetorical shift in the Union war effort. The Thirteenth Amendment, he argued, was proposed during 1864 "as a means of affecting the judgment and feeling and the anticipations of those in the rebellion." Passing such a forceful reform of the Constitution would serve as an "intellectual army" in the field, "an intellectual force that would tend to paralyze the enemy and break the continuity of his ideas." ${ }^{442}$ Lincoln often walked from the White House to the War Department building a few blocks away to discuss the amendment's passage with Dana ${ }^{443}$ On one occasion the president asked Dana to lobby congressmen on his behalf for their affirmative votes. ${ }^{444}$ Dana described the president's influence on the passage of the amendment, while also directing the war effort, as a "little piece of side politics [that] was one of the most judicious, humane, and wise uses of executive authority that I had ever assisted in or witnessed." 445 As a government agent Dana helped coordinate policies between the executive and legislative

\footnotetext{
${ }^{439}$ White, American Ulysses, 246-7.

${ }^{440}$ Wilson, The Life of Charles A. Dana, 235.

${ }^{441}$ For more on Dana's recounting of the work he did for the President, see: Dana, Lincoln and his Cabinet, $51-58$.

${ }^{442}$ Dana, Lincoln and his Cabinet, 52.

${ }^{443}$ Ibid, 54.

${ }^{444}$ Ibid, 57.

${ }^{445}$ Ibid, 58.
} 
branches. As a reflection of his republicanism, no position could have made more sense, as the experience of the Civil War further radicalized Dana's defense of the values of egalitarianism, free labor, and civic virtue.

Dana's duties for the Department of War elevated him to the highest levels of the nation's bureaucracy. The promotion represented a monumental rise in responsibility, since Dana's residence at Brook Farm. On January 20, 1864, Congress officially confirmed by Dana as Assistant Secretary of War. ${ }^{446}$ This recalibration of Dana's professional life should not be seen as one devoid of his commitment to republicanism. Instead, provided Dana with a look at the institutional underbelly of a nation-state's attempt to enforce these values at a time of political and constitutional crisis. Now fully embedded within the government, spending most of his time in Washington, Dana joined an office noted for controversy. If Dana was being exposed to the process of defending egalitarianism, civic virtue, and free labor during times of war, he was also spending more time in a department with a reputation for hard-handedness, vindictiveness, favoritism, and arrogance. ${ }^{447}$ Stanton tended to distribute justice unevenly and avoid army regulations when convenient to him. ${ }^{448}$ Chief Clerk of the War Department Albert E. H. Johnson described Stanton as a would-be "tyrant." ${ }^{449}$ The more Dana associated with the department, the more he developed a similar reputation. Journalist Charles F. Benjamin charged the now

\footnotetext{
${ }^{446}$ Dana finally gets confirmed by the Senate on January 20, 1864; much later then when Stanton named him to the post. Cited in Wilson, Life of Charles A. Dana, 194-198, 248.

${ }^{447}$ Charles F. Benjamin, "Recollections of Secretary Stanton," Century Magazine 33, no. 5 (March 1887): 758-768; Benjamin, "Recollections"; Benjamin to Horace White, June 1, 1914, White Papers, Abraham Lincoln Presidential Library and Museum. Cited in Marvel, 159, 502.

${ }^{448}$ Marvel, Lincoln's Autocrat, 156.

${ }^{449}$ Albert E.H. Johnson, "Reminiscences of the Hon. Edwin M. Stanton, Secretary of War," Records of the Columbia Historical Society 13 (1910): 88-89; Charles F. Benjamin, "Recollections of Secretary Stanton," Century Magazine 33, no. 5 (March 1887): 758-768; Benjamin, "Recollections"; Benjamin to Horace White, June 1, 1914, White Papers, Abraham Lincoln Presidential Library and Museum. Cited in Marvel, 502 .
} 
Assistant Secretary of War as being one of Stanton's "petty tyrants" ${ }^{\text {" } 50}$ As a "petty tyrant," Dana had various posts and responsibilities. Each centered on the tasks Dana had done previously. For instance, Wilson explains that it was up to Dana, another Assistant Secretary of War, to "supervise the contracts for horses, mules, wagons, harness, tents, clothing, camp, equipage, arms, ammunition, drums, fifes, flags, and every other article used by the army." ${ }^{451}$ It is almost as if Dana's life's journey - from clerk and accountant at his uncle's firm, through Harvard, Brook Farm, the Tribune, and as a part of the Union war machine - allowed him to realize his ideological and nationalist goals. Throughout, he remained committed to the civic and financial virtue of the war effort, continuing to act as a type of inspector general of the Department of War, searching out fraud, also included prosecuting outstanding cases by military commission. ${ }^{452} \mathrm{He}$ investigated those "caught cheating the government" and established a system of purchasing that guaranteed that all war supplies were received before moneys were paid to military contractors. ${ }^{453}$ Dana's success at anticorruption work, both as a journalist and government agent, represented his continued attempt to realize a republic founded on civic virtue.

Dana served in this role as Assistant Secretary of War through the end of the war. His role continued acting as a conduit between the White House and critical members of the Army

\footnotetext{
${ }^{450}$ Marvel, Lincoln's Autocrat, 319.

${ }^{451}$ Wilson, The Life of Charles A. Dana, 185; 305-308. Wilson explains that it was Dana, and the other Assistant Secretary of War Watson, to "supervise the contracts for horses, mules, wagons, harness, tents, clothing, camp, equipage, arms, ammunition, drums, fifes, flags, and every other article used by the army. Also see: Dana to Wilson, January 24, 1865, in Wilson, The Life of Charles A. Dana, 353.

${ }^{452}$ Ibid, 307-308. Wilson, who had directly witnessed his time in the War Department, wrote that "fraud was everywhere rampant, and everywhere those engaged in it had their friends among the governors of the States, the members of the Senate and of the House of Representatives. Many of those gentleman were almost as impatient and overbearing as the Secretary himself, but fortunately most of them stood in wholesome awe of his authority, and gave him a wide berth in their effort to serve their friends."

${ }^{453} \mathrm{Ibid}, 309$. "Every contractor had to be watched, and when it is remembered that the quartermasters and inspectors were not always honest, but frequently stood in for a share of the profit, it will be readily understood that Dana's time, as well as that of the first assistant secretary, was constantly employed..."
} 
leadership. For instance, Dana hand-delivered the promotions for Sheridan to major general. ${ }^{454}$ He continued to serve as the "eyes and ears" of the administration, joining Grant and his army after the Battle of the Wilderness in early May $1864 .{ }^{455}$ Dana remembered this period clearly years later, explaining that "when General Grant went out for the campaign in the Wilderness, that was the last great campaign, which ended in the surrender of Richmond, - for two days we had no reports." ${ }^{456}$ Lincoln sent for Dana, explaining him to that he was "troubled about this business down in the Wilderness" and that he and Stanton "don't know what is going on" and "would like [Dana] to go down." ${ }^{57}$ Dana also joined Grant as his columns approached Richmond in the spring of $1865 .{ }^{458}$ By Wilson's measure, Dana was one of the best qualified civilians on military matters in the whole Union war effort. ${ }^{459}$

Lincoln's murder did not affect Dana's enthusiasm for the administration. Of that night, Dana remembers that he was "awaked from a sound sleep with news that Mr. Lincoln had been shot, and that the Secretary wanted him at Manager Ford's house." Dana found "the President lying unconscious, though breathing heavily, on a bed in a small side room, while all the members of the cabinet, and the Chief Justice with them, were gathered in the adjoining parlor. ${ }^{, 460}$ As Assistant Secretary of War, he took on an integral role in maintaining order in the

\footnotetext{
${ }^{454}$ Wilson, The Life of Charles A. Dana, 347.

${ }^{455}$ Ibid.

${ }^{456}$ Dana, Lincoln and his Cabinet, 43.

${ }^{457}$ Ibid, 43-44.

${ }^{458}$ Steele, 57.

${ }^{459}$ Wilson, The Life of Charles A. Dana, 306. "No civilian till the end of the war had been so constantly with the army, or had become so intimately acquainted with the active generals in the field as Dana had, and no one can read his despatches without perceiving that he had many qualities and much information which would have been most useful in the higher position."

${ }^{460}$ Ibid, 68.
} 
aftermath of the shooting of the president, and the attempted murder of Secretary of State William Seward. Through the night, up until about 3 a.m. of the $15^{\text {th }}$, Secretary of War Stanton effectively controlled the government. Dana executed his orders. ${ }^{461}$ "All those orders, he wrote, "were designed to keep the business of the government in full motion [until] the crisis should be over." ${ }^{\prime 42}$ The most immediately pressing of these orders was the apprehension of the assassin and inquiry about a conspiracy. ${ }^{463}$ Thus Dana oversaw John Wilkes Booth's capture and the arrest of conspirators Samuel Arnold, George Atzerodt, David Herold, Michael O’Laughlen, Lewis Powell, John Surratt and Mary Surratt. ${ }^{464}$ After their capture, Dana gave witness testimony to the court on May $18^{\text {th }}$, explaining his contribution to the arrests, and helping play critical role in the prosecution and eventual execution of the Lincoln assassination conspirators. ${ }^{465}$ Stanton also tasked Dana with helping direct the search for the fleeing former-President of the Confederate States of America Jefferson Davis. Dana assigned his friend James Harrison Wilson, now a Major General, to lead the cavalry units meant to find Davis. After Davis's capture, Stanton sent Dana to Fort Monroe in Southern Virginia to oversee the former Confederate president's

\footnotetext{
${ }^{461}$ Wilson, The Life of Charles A. Dana, 370. Also see: Wilson, 358-9. “...Stanton, who had been from the day of the appointment as Secretary of War the strong man of the government, at once took charge. His first thought was to send for Dana, and it was to him that he dictated all the orders and telegrams that were sent out that night. They closed their work and parted with each other at about three o'clock the next morning.... [Lincoln] died a few days later, and almost immediately afterwards the secretary sent an order to Dana directing him to arrest the commissioner who had been the last object of the good man's solicitude."

${ }^{462}$ Dana, Lincoln and his Cabinet, 69.

${ }^{463}$ Wilson, The Life of Charles A. Dana, 359. "Dana at once put the machinery under his control in motion for that purpose, but this was far from being his most important duty in that emergency. He made every effort not only to apprehend the murderer of the President, but to detect and bring to justice all persons suspected of having co-operated with him in the accomplishment of his crime...the preliminary measures set on foot by the War Department, and largely conspiracy was developed, and the conspirators were arrested and brought to trial. Dana had gathered many letters and much information showing the details of the conspiracy, and on May $18^{\text {th }}$ gave his testimony in the case..."

${ }^{464}$ Ibid, 367.

${ }^{465}$ Ibid, 359.
} 
confinement. ${ }^{466}$ Dana did his part, as well, to organize the demobilization of the army. With that, Dana's participation as a government agent came to a close.

\section{$\underline{\text { Conclusion }}$}

The end of the Civil War marked the end of a critical period in his intellectual development but also provided Dana with professional opportunities. After returning to Washington to watch the "Review of the Armies" on May $23^{\text {rd }}$ and $24^{\text {th }}$, Dana began to look for his next challenge. Government work did not hold Dana's continued interest. By the end of May he a lucrative journalism post offer in Chicago awaiting his acceptance. In a letter to Wilson, Dana explained that was making plans to leave the War Department and "undertake there the editorship of a new daily journal." ${ }^{467}$ Dana viewed it as both a pecuniary, professional, and political opportunity. ${ }^{468}$ It represented the reorientation that Dana, as the rest of the nation, was forced into with the war's end. Ideologically, Dana's experience working for the Department of War matured his progressive approach to political economy and social reform that he developed since 1848. Even though Dana entered the post of Assistant Secretary of War as a novice in the practical inner workings of the federal government bureaucracy, he learned how to implement his intellectual outlook through government policy. Growing close to President Abraham Lincoln and Secretary of War Edwin Stanton provided Dana with models for implementing reform in times of

${ }^{466}$ Wilson, The Life of Charles A. Dana, 359-360.

${ }^{467}$ Charles A. Dana to James H. Wilson, Macon, Georgia, May 30, 1865. Cited in Wilson, The Life of Charles A. Dana, 261. In this note, Dana wrote that "the report which you have probably seen in the newspapers, that I have left the department, is only partly true. I have not yet left it, but propose to do so by July $1^{\text {st }}$. I have agreed to go to Chicago to undertake there the editorship of a new daily journals which is about to be established. As you are aware, it has not been my wish to return to my old profession on retiring from office, but to find some sphere of practical or industrial activity; but as nothing of this kind offered itself, and as the inducements to take this place at Chicago were satisfactory, I have waived all scruples and made an agreement to go there."

${ }^{468}$ Charles A. Dana to James H. Wilson, June 2, 1865. Cited in Wilson, The Life of Charles A. Dana, 367368. Dana wrote to his friend that "they inform me from Chicago that my new paper is very successful at the start. I send you the first number, in the making of which I have had no share; if, however, I can make twenty thousand dollars a year by it, while I exert a wholesome and honest influence on the politics of the country, and on its general progress, I shall be content." 
political crisis. He gained further understanding of the types of reform possible when pragmatic, and not idealistic, concerns were at play. Dana had an insider's look at the realization of policies that he called upon as a later newspaper editor and grassroots political organizer. On July 1, 1865 Dana left his job as Assistant Secretary of War. His decision to leave the Department of War marked yet another major transition point in his professional and intellectual life.

Since he decided to leave his uncle's home in Buffalo, Dana had undergone many such transformations that culminated in his desire to work within Lincoln's Cabinet. Dana believed in peaceful attempts at socio-economic reform until he witnessed the Revolutions of 1848 for himself. He remained uninterested in partisan politics until this same time, and after he returned from Europe, he became instrumental in the creation of the Republican Party. All along, Dana carried with him a developing understanding of the republican values that inspired the new party: egalitarianism, free labor, civic virtue, communitarianism, and cooperation between the working and capitalist classes. Working for the Tribune helped introduce Dana to the change brought upon by war, and the weaknesses of pacifism. None of this stopped when the Civil War started in 1861. Dana's work for Edwin Stanton's War Department represented the culmination of the previous stages of Dana's intellectual maturation - especially the stage resulting from his witnessing of the Revolutions of 1848. Dana returned from Europe aggressive, belligerent, and pragmatic. Working at Horace Greeley's Tribune in the whirlwind of the 1850s was a perfect place to hone this new frame of mind. Dana abhorred slavery's influence on the nation's politics, and during the "Bleeding Kansas" and antebellum secession crisis he proved more than willing to provide tinder to the fires of war being stoked around him. The Dana of the 1850 s believed that defending republican values required force in certain cases. Rejecting the influence of slavery on the American republic was such an example. His work for the Union government during the Civil War was not a deviation from the prevailing trends in Dana's life, but instead the culmination of them. Dana could not get much closer (considering his half-blindness from his youth) to helping 
realize the republican goals he saw for the country than in the jobs he took for Secretary Stanton. Now he took with him yet another perspective on the social, economic, and political issues plaguing his nation. 


\section{CHAPTER FOUR}

\section{ANTI-REPUBLICANISM AND THE CRITICISM OF THE GRANT PRESIDENCY $(1868$ - MID-1870)}

Dana's decision to reenter journalism after the war's end - first in Chicago to run the Chicago Republican between 1866 and 1867 - placed him at the center of one of the most chaotic times in the history of American politics and journalism after Lincoln's assassination in 1865. Andrew Johnson's lenient stance on former Confederates and obstruction of the radical's plan for Reconstruction further exacerbated political tension. Dana opposed Johnson's reversal of Lincoln's policies but the paper he used to communicate his radical vision for Reconstruction, the Chicago Republican, proved to be a frustrated experiment. Disagreements with the other stockholders prompted him to sell out and return to New York City where he purchased a historic American newspaper, the Sun, in 1868 - in part to support the Republican candidate for President, Ulysses S. Grant. Dana, who had saved Grant's professional reputation in 1862 even coauthored a campaign biography to support the general's election as president with James Harrison Wilson. ${ }^{469}$ Within a year of Grant's election, however, Dana had already become one of Grant's foremost critics. Although both contemporary and historical critics have offered various explanations of Dana's turn away from Grant in 1869, ideology provides the best explanation. This chapter offers a new understanding of early Reconstruction politics by viewing through the prism of Charles A. Dana's republican worldview. It presents Dana's republican motivated opposition to financial and political corruption as a compelling explanation of his refusal to support a party he helped found and a president he once defended to Abraham Lincoln.

\footnotetext{
${ }^{469}$ To review previous mentions of the campaign biography and Dana's support for Grant in 1868 by this dissertation, see chapter 3 .
} 


\section{$\underline{\text { Context }}$}

Lincoln left a mixed record for his successor and for Congress as well. On the one hand the war had prompted to exercise unprecedented power which most Southerners and many Northerners considered tyrannical. On the other hand his actual policy for the political reintegration of the rebels into the national polity aroused opposition from other segments of the political system, especially radicals who opposed its leniency. The administration implemented its policy forcefully — suspending habeas corpus, effectively establishing martial law, maximizing its use of the executive order, spending money without congressional approval, and blockading Southern ports. To many like Dana these were means to a larger end, but stayed a contentious point of debate in the nation's heated political circles. The process of Reconstruction began first in 1863 in Louisiana, Tennessee, and Arkansas, the first states that the Union army conquered. This plan called for a return to normalcy when ten-percent of the eligible voters on the 1860 census took an oath of allegiance to the federal government and agreed to the end of slavery. In return, the administration would pardon all former Confederates - except for the political leadership and protect all former Confederate property minus slaves. The reaction to the administration's proposal revealed the serious disagreements between the radical Republicans, who sought a harsh Reconstruction policy, and moderate Republicans like Lincoln, who sought reconciliation more than retribution. Radical Republicans, under the leadership of Thaddeus Stevens, the veteran Pennsylvania Congressman, and Charles Sumner, the Senator from Massachusetts, pre-empted Lincoln's plan with a draconian measure meant to cripple the South and disenfranchise drastically larger number of former Confederates. This Wade-Davis bill passed Congress in 1865, which Lincoln vetoed. Lincoln's assassination on April 15, 1865 unhinged all these plans. 
Andrew Johnson's administration strayed from the Lincolnian vision for

Reconstruction. ${ }^{470} \mathrm{He}$ was a veteran Democrat politician from Tennessee, acting as Congressman and Governor before the Civil War and Military Governor during the conflict. He had bipartisan support for some of his favorite policy ideas such as a homestead act giving western lands to poor farmers. Johnson, however, believed that slaves were legally protected property and opposed efforts to ban slavery in western territories. He remained committed to unionism during the sectional crisis of the late $1850 \mathrm{~s}$, sided with the North during the war, and earned the nomination as Lincoln's vice president in 1864 to attract the border-state, unionist, Democrat vote. ${ }^{471}$

Assuming powers in April nine months before Congress convened he instituted his own plan for reconstruction through executive order. Johnson immediately decreed amnesty for all but the wealthiest Confederates (with postwar assets valued over $\$ 20,000$ ) even as he issued numerous pardons for these. He also mandated that former Confederate states call constitutional conventions. He ignored issues of voting rights. Allies of Johnson's "Presidential" plan cited the high support for the former and high support for the latter in some Northern states Minnesota, Wisconsin, New York and Massachusetts which had just voted down black suffrage. The Southern states began reformed their governments, included Black Codes limiting the civil rights

\footnotetext{
${ }^{470}$ His background was like that of many other poor whites in the mountains of Tennessee: Andrew and his brother were sold into proto-slavery because his family was too poor to provide for him. Johnson ran away from an 11-year indenture contract in the $5^{\text {th }}$ year, taking his brother with him. He subsequently made a name for himself as a local mayor and continued to win elections - serving as Congressman from Tennessee for ten years (1843 - 53), governor of that state for four (1853-1857) - with eventual appointment as Military Governor during the Civil War (1862-1865). Johnson was popular for his populism. He was principal supporter of the Homestead Act, meant to offer cheap to free land in the western territories to poor Americans. Johnson's belief that slavery was legally protected property within the Constitution made him a popular Democrat in the border state of Tennessee. Johnson refused follow those who left the Democratic Party to create the Free-Soil Party. Johnson opposed the Wilmot Proviso closing the western territories to slavery. He, however, was the only senator not to resign his post when the Civil War began, gained Lincoln's trust, and served as a politically expedient choice for Lincoln to choose to run with him in 1864 .

${ }^{471}$ For more on the contentious election of 1864, see: Larry T. Balsamo, “"We Cannot Have Free Government without Elections': Abraham Lincoln and the Election of 1864," Journal of the Illinois State Historical Society 94, no. 2 (Summer, 2001): 181-199.
} 
of freedmen and elected senators and congressmen when the Congress reassembled in December.

A political war erupted on Capitol Hill.

\section{$\underline{\text { Johnson's "Presidential" Reconstruction }}$}

Ultimately, the Johnson approach to Reconstruction unified the Republican conference and led to his impeachment. ${ }^{472}$ The basis for these accusations was that Johnson stood in the way of the passage of bills to extend the charter of the Freedman's Bureau and confer citizenships to black Americans - clear and logical legacies of the Civil War's promise in the eyes of Republicans. Meanwhile the Radicals implemented their own Reconstruction policy. They refused to seat the rebel congressmen, disallowed the new state governments, and created the Joint Committee on Reconstruction to investigate and draft legislation. Radicals passed the Freedmen's Bureau bill consolidating support for freedman suffrage in the $14^{\text {th }}$ Amendment. In 1867 the Radicals passed the Military Reconstruction Act that dissolved all existing Southern state governments and forced each to reconvene constitutional conventions where ratification of the amendment was required. They also passed the Tenure of Office Act giving Congress power over the president's right to fire subordinates. Johnson vetoed both, and Congress overruled each. Johnson particularly opposed the Tenure of Office Act because he wanted to make major changes to his Cabinet against the wishes of the radicals. When Johnson fired Secretary of War Stanton and replaced him with Ulysses S. Grant (still commanding general of the Army overseeing the continued deployment of troops in the South), radicals drafted articles of impeachment against

${ }^{472}$ For more on the widespread party fractures and divisiveness, see: Erik B. Alexander, "The Fate of Northern Democrats after the Civil War: Another Look at the Presidential Election of 1868," in Gallagher, Gary W. and Rachel A. Shelden, A Political Nation: New Directions in Mid-Nineteenth Century American Political History (Chancellorsville: University of Virginia Press, 2012), 189-213; Heather Cox Richardson, The Death of Reconstruction: Race, Labor, and Politics in the Post-Civil War North, 1865-1901 (Cambridge: Harvard University Press, 2002); Jean Harvey Baker, Affairs of Party: The Political Culture of Northern Democrats in the Mid-Nineteenth Century (New York: Fordham University Press, 1998); Edward L. Gambill, Conservative Ordeal: Northern Democrats and Reconstruction, 1865-1869 (Ames: Iowa State University, 1981); Allan G. Bogue, The Earnest Men: Republicans of the Civil War Senate (Ithaca: Cornell University Press, 1981). 
Johnson. The House of Representatives voted the president's trial on March $3^{\text {rd }}, 1868$ and the Senate deliberated but by one vote to find him not guilty. His power and influence restricted, the lame duck president watched the campaigns for president in 1868 without him. The office Ulysses S. Grant sought against Horatio Seymour, however, was in a period of fundamental transformation alongside the rapid expansion of the powers of Congress. The very process of Reconstruction entailed changes as profound as the drafting of the original Constitution. Many of these challenged Dana's most fundamental values and assumptions.

\section{Reconstruction Era Political Lobbying}

The increasing size and influence of the federal government during Reconstruction effected a dramatic test for American bureaucracy and republican commitments to civic virtue. As historian of government and political lobbying during the early years of Reconstruction, Margaret Susan Thompson, argued, "skyrocketing demands for routine services" changed the responsibilities and functioning of the federal government in the period. ${ }^{473}$ Her work explained that Civil War and Reconstruction presidents encouraged the "unprecedented boom in the size and range of the national public sector." ${ }^{, 74}$ The post-war government's growth, especially, responded to other trends inherited from the war: the need to compel the South to obedience, ${ }^{475}$

${ }^{473}$ Margaret Thompson, The "Spider Web:" Congress and Lobbying in the Age of Grant (Ithaca: Cornell University Press, 1985), 45.

474 Thompson, The "Spider Web," 45.

${ }^{475}$ For more on Reconstruction, its debates, proposals, and policy, see: Mark Wahlgren Summers, The Ordeal of the Reunion: A New History of Reconstruction (Chapel Hill: University of North Carolina Press, 2014); Douglas R. Egerton, The Wars of Reconstruction: The Brief, Violent History of America's Most Progressive Era (New York: Bloomsbury Press, 2014); Paul A. Cimbala and Randall Miller, eds., The Great Task Remaining Before Us: Reconstruction as America's Continuing Civil War (New York: Fordham University Press, 2010); Eric Foner, Reconstruction: America's Unfinished Revolution, 18631877 (New York: Harper and Row, 1988); John Hope Franklin, Reconstruction: After the Civil War (Chicago: University of Chicago Press, 1961). For more on the administration and Congressional efforts at bringing the repentant former confederate states like Georgia, Virginia, Texas, and Missouri back into the Union, see: Richard L. Hume and Jerry B. Gough, Blacks, Carpetbaggers, and Scalawags: The Constitutional Conventions of Radical Reconstruction (Baton Rouge: Louisiana State University Press, 2008). 
the desire to clear out Confederate-allied Native American tribes in the West, ${ }^{476}$ and the call to settle and develop these Western territories. ${ }^{477}$ These factors encouraged Congress to create new government offices. These included the Department of Justice to adjudicate claims of political violence in the South, ${ }^{478}$ the Freedman's Bureau to review claims from, and protect, freed slaves, ${ }^{479480}$ the Bureau of Indian Affairs, and the Department of Agriculture. ${ }^{481}$ The geographic reach of the post-war government bred new layers of federal bureaucracy. Western settlement and Southern Reconstruction required additional customs agents, police, courts, and postal services, expanding the reach and visibility of the federal government. ${ }^{482}$ Washington D.C.'s regulatory

${ }^{476}$ For military treatments of the "Indian Wars" See: Bill Yenne, Indian Wars: The Campaign for the American West (Westholme Publishing, 2005). For more conventional treatments see: Donald A. Grinde and Quintard Taylor, "Red vs. Black: Conflict and Accommodation in the Post-Civil War Indian Territory, 1965-1907," American Indian Quarterly 8, no. 3 (Summer 1984); Stephen Longstreet, War Cries on Horseback: The Story of the Indian Wars of the Great Plains (Doubleday \& Co., 1970).

${ }^{477}$ For new historiography about Western settlement in the post-war period, see: Amy Bridges, "Managing the Periphery in the Gilded Age: Writing Constitutions for the Western States," Studies in American Political Development 22 (Spring 2008): 32-58.

${ }^{478}$ For more on the Department of Justice during Reconstruction, see: Robert J. Kaczorowski, The Politics of Judicial Interpretation: The Federal Courts, Department of Justice, and Civil Rights, 1866- 1876 (Fordham University Press, 2005).

${ }^{479}$ For more on the Freedmen's Bureau and other broad freedmen's aid movements, see: Mary FarmerKaiser, Freedwomen and the Freedmen's Bureau (Fordham University Press, 2010); Carol Faulkner, Women's Radical Reconstruction: the Freedmen's Aid Movement (Philadelphia: University of Pennsylvania Press, 2006); Paul A. Cimbala, Under the Guardianship of the Nation: The Freedman's Bureau and the Reconstruction of Georgia, 1865 - 1870 (Athens: University of Georgia Press, 1997).

${ }^{480}$ More on the establishment of the Department of Education, and education more broadly, see: Hilary Green, Education Reconstruction: African American Schools in the Urban South, 1865-1890 (Fordham University Press, 2016); Michael David Cohen, Reconstructing the Campus: Higher Education and the American Civil War (Charlottesville: University of Virginia Press, 2012); Robert Charles Morris, Reading, 'Righting, and Reconstruction: the Education of Freedmen in the South, 1861-1870 (Chicago: University of Chicago Press, 1981).

${ }^{481}$ For more on the Bureau of Indian Affairs, and Grant's Indian policy, see: Douglas Firth Anderson, “'More Conscience Than Force,': U.S. Inspector William Vandever, “Grant's Peace Policy, and Protestant Witness," The Journal of the Gilded Age and Progressive Era 9, no. 2 (April 2010): 167-196); Claudio Saunt, "The Paradox of Freedom: Tribal Sovereignty and Emancipation during the Reconstruction of Indian Territory," The Journal of Southern History 70, no. 1 (Feb. 2004): 63-94.

${ }^{482}$ For scholarly analyses of the drastic rise in government power in the post-war American political order, see: Richard Bensel, Yankee Leviathan: The Origins of Central State Authority in America, 1859-1977 
responsibilities grew to unprecedented levels in the late 1860 s and early 1870 s. In trying to yoke these other changes, the growth in government became a force in its own right changing the character of the nation's political order. Along with this divisiveness came general governmental inexperience. ${ }^{483}$ Various un-reconstructed states remained barred from Congress and scores of pre-war committee veterans not re-elected or allowed to serve left the federal government low on expertise. ${ }^{484}$ Because of this, one of the last critical forces changing the nature of Reconstructionera American politics was the corruption and graft saturating the system. It provided an incontrovertible symbol of the degenerative trends apparent in America's commitment to republican values.

The demands placed on the government encouraged the American political order's historic penchant for lobbying and patronage-seeking to expand in the late 1860s. Historians have shown that the high volume of business being transacted through the offices of inexperienced government officials in the late 1860s encouraged patronage seeking and machine politics. These studies identify lobbying, and not-yet-regulated forms of nepotism, cronyism and graft as more visible parts of Gilded Age politics than may have been the case in earlier periods. ${ }^{485}$ Many scholars cite the post-war federal government's reliance on lobbying to staff the government, in an age before strident civil service law, encouraged the growth of patronage as the unifying force

(Cambridge: Cambridge University Press, 2003); Paul D. Moreno, The American State from the Civil War to the New Deal: The Twilight of Constitutionalism and the Triumph of Progressivism (Cambridge: Cambridge University Press, 2013).

${ }^{483}$ For more on inexperience of government officers in Congress and around the country see: Thompson, Spider Web, 51 - 52. For a contemporary opinions of this, see, Henry Adams, "The Session," 59 - 60.

${ }^{484}$ For more on the concept of time-lag during the $41^{\text {st }}$ and $42^{\text {nd }}$ Congress during the first Grant administration, see: Thompson, "The Spider Web, " 51 - 52, 66, 73, 110 - 115, and $142-144$.

${ }^{485}$ For more on traditional analyses of Gilded Age nepotism, cronyism, and graft, see: Kenneth J. Meier and Thomas M. Holbrook, "'I Seen My Opportunities and I Took 'Em:' Political Corruption in the American States," The Journal of Politics 54 (February 1992): 133-55; Richard Hofstadter, "The Spoilsmen: An Age of Cynicism," in The American Political Tradition and the Men Who Made It (New York, 1948), $164-185$. 
for political parties. ${ }^{486}$ Historians cite the widespread influence of railroad lobbying interests within the government that encouraged the saturation of patronage-related employment during Reconstruction. ${ }^{487}$ Political "machine" politics, realpolitik-style-organizations or "rings," dominated the characterizations of the American government in the period. ${ }^{488}$ The post-war radical Republicans, the Southern Republican Party, or the New York City Democratic Party are other examples often by scholars of the period. ${ }^{489}$ Organizations like William "Boss" Tweed's Tammany Hall serve as one of the best-known groups. The Tweed Ring dominated New York City politics and won considerable influence in the state legislature. ${ }^{490}$ In late 1869 and early 1870 , they used their patronage influence to tamp down reform efforts across the state from both parties and re-write the New York City charter to preserve the patronage system. ${ }^{491}$ Tammany consolidated its power over New York City and state in 1869 and 1870 and brought Grant Republicans into their patronage orbit in exchange for offices and favors. ${ }^{492}$ Attempting to reform

${ }^{486}$ For more on civil service reform in the late 1860s see: Ari Hoogenboom, Outlawing the Spoils: A History of the Civil Service Reform Movement, 1865 - 1883 (Urbana: University of Illinois Press, 1961).

${ }^{487}$ Robert Wiebe, The Search for Order, $1-10$.

${ }^{488}$ Additional information on the Reconstruction era press, and its strong connection to these stories of scandal, whether hyping them as signals of Grantism, or writing them off as business as usual, can be found in Summers' The Press Gang: Newspapers \& Politics, 1865 - 1878.

${ }^{489}$ For more on the role of patronage systems and machine politics as part of the post-Civil War political order see: Steven Erie, Rainbow's End: Irish-Americans and the Dilemmas of Machine Politics, 1840-1985 (Berkeley: University of California Press, 1988); Michael McGerr, The Decline of Popular Politics: The American North, 1865-1928 (New York: Oxford University Press, 1986).

${ }^{490}$ For more on Tammany Hall in the late 1860s see: E. Vale Blake, History of the Tammany Society, or, Columbian Order, From its Organization to the Present Time (Souvenir Publishing, 1901); Terry Golway, Machine Made: Tammany Hall and the Creation of Modern American Politics (New York: W.W. Norton/Liveright Publishing, 2014); Gustavus Myers, The History of Tammany Hall (New York: Burt Franklin, 1968); Kenneth D. Ackerman, Boss Tweed: The Rise and Fall of the Corrupt Pol Who Conceived the Soul of Modern New York (New York: Carroll \& Graf, 2006).

${ }^{491}$ For more on the New York City Charter see: Golway, Machine Made, 84 - 88; Wallace C. Sayre and Herbert Kaufman, Governing New York City: Politics in the Metropolis (Russel Sage Foundation, 1960).

${ }^{492}$ For more on the response to the Grant administration across 1869 and into the middle of 1870 within the Democratic Party, including within New York, see: Thomas S. Mach, "Gentleman George" Hunt Pendleton: party Politics and Ideological Identity in Nineteenth-Century America (Kent: Kent State 
patronage corruption through the civil service encouraged the same critics to demand independent political reform and organize new movements to win political office. The corruption and the solution resonated with Dana's fundamental ideas, and he lept into the ideas of his past to help respond to the issues of the present via the medium a New York City newspaper.

\section{Dana's Reconstruction-Era Hopes for Civic Virtue}

Dana's earlier experiences and public life while at Harvard and the Brook Farm community, with the New York Tribune and the Lincoln War Department, included a consistent hope for an honest and representative American political system. From the late 1830s forward, his philosophic and political interests coalesced around ideas of community centered-government, religious moderation, ideological diversity, ethnic inclusivity, widespread ownership of property, the harmony of competing classes and interests, political liberty and civic virtue. ${ }^{493}$ To Dana, these ideas manifested the traditions of the country's founders. They also reflected the broader transatlantic Enlightenment thought that advocated self-government and equality for all. Dana's embrace of transatlantic Romanticism, Transcendentalism, and Fourierism encouraged him to find a useful outlet in the utopian experiments at Brook Farm. The communal living offered, Dana said, the ideal expression of democratic life, egalitarianism, civic virtue, and human progress. In his letters, he argued that Brook Farm and the larger work of American Associationists represented an alternative to the corruption of the political and economic order. Such initiatives could, he argued, restructure the corrupt nature of American politics, as well as

\footnotetext{
University Press, 2007); David Quigley, Second Founding: New York City, Reconstruction, and the Making of American Democracy (New York: Hill and Wang, 2005); Baker, Affairs of Party. For more on the response to the Grant administration across 1869 and into the middle of 1870 within the Republican Party, see: Summers, The Ordeal of the Reunion, 83 - 86; Heather Cox Richardson, To Make Men Free: A History of the Republican Party (New York: Basic Books, 2014); Andrew Slap, The Doom of Reconstruction: The Liberal Republicans in the Civil War Era (New York: Fordham University Press, 2006).

${ }^{493}$ For a closer analysis of Dana's relationship to these ideas, and the broader purpose of politics, and political parties, see the introduction and chapter 1 of this dissertation.
} 
the aims of existing parties. Horace Greeley, who agreed with Dana's critique of the existing political order, provided Dana with new ways of understanding the applicability of idealist politics.

Dana's ideas matured during his employment at Greeley's Tribune. The idealist values that he brought to work encouraged his condemnation of establishment politics and society. The Tribune also forced Dana to reconcile Greeley's idealist politics and the less than ideal world of pre-war politics. ${ }^{494}$ Greeley’s support of Whig congressman from Kentucky, Henry Clay, provided Dana with one model of how this could be done. ${ }^{495}$ Greeley and Dana championed Clay's criticism of the overuse of power and corruption in government and encouragement of national economic and social reform. The paper argued that the purpose of politics and political parties stood only to help realize these ideas, but sectional politics prevented the realization of egalitarian vision that Dana and Greeley espoused. The corrupting influence of slavery, Greeley and Dana agreed, required new parties. Greeley, Dana, and the Tribune's jump to support radical abolitionist, and veteran of the late Mexican War, Gen. John Frémont in 1856, provided Dana with evidence of the potential of American party politics. Here was a party and a candidate fighting for the realization of self-government, egalitarianism, and legal equality. The Republican Party's creation as a diverse coalition capable of embodying a range of idealist politics changed the way Dana thought about the work of parties. In the Republicans, Dana found a group insisting that American politics could nurture the abolitionist, protectionist, cooperationist, and Associationist ideas that the Tribune had championed since the 1840 s.

\footnotetext{
494 This dissertation covered the influence of the Tribune and Greeley on Dana's intellectual and political development. See chapter 1.

${ }^{495}$ For more on Clay, see: David and Jeanne Heidler, Henry Clay: the Essential American (New York: Random House, 2011); Kimberly Shankman, Compromise and the Constitution: The Political Thought of Henry Clay (Lanham: Lexington, 1999); Baxter, Henry Clay and the American System; Merrill D. Peterson, The Great Triumvirate: Webster, Clay and Calhoun (New York: Oxford University Press, 1987).
} 
Dana's commitment to the Republican Party arose from the party's reflection of what virtuous politics could be. The party that formed in the 1850 s aligned with Dana's position that any expression of popular politics in the United States needed to guarantee for the legal equality of its citizens, respect intellectual and religious curiosity, protection for political processes, and safeguard their jobs and wages through "American System" protectionism. ${ }^{496}$ His service in Lincoln's administration summarized his commitments for equal rights and honest selfgovernment. Former Whigs like Dana could enter Lincoln's War Department under the Democrat Secretary of War Edwin Stanton and form strong relationships because of the multi-faceted Lincolnian interpretation of government's purpose. This experience encouraged him to think of politics in new ways. Working as an anti-corruption agent was one expression of this, as were the broad responsibilities he had as Assistant Secretary of War. As one of Stanton's "petty tyrants" Dana came to understand how the federal government used individuals like him to keep government business honest. Defeating the influence of sectional politics brought on by slavery also solidified Dana's understanding of the purpose of politics behind the goal of extending freedom to slaves and preserving the egalitarian American spirit. ${ }^{497}$ The Civil War victory simply reiterated the success of the party's message. Yet the performance of the party at the onset of Reconstruction contrasted poorly with its earlier responsibility of preserving self-government and guarding against corruption and the unnecessary overuse of power.

Post war politics frustrated Dana's Civil-War era hopes for bipartisan and honest government. As early as 1866 Dana lost faith in the partisan union that Lincoln's term had brought to the federal government. Political disfunction in the Johnson years challenged his

\footnotetext{
${ }^{496}$ For more on Dana and Greeley's connections to Henry Carey, and his Whiggish "American System" style, protectionism, see: Palen, The "Conspiracy" of Free Trade; Tuchinsky, Horace Greeley's New York Tribune, 38-40, 161, 184; Dawson, "Reassessing Henry Carey," 465-485.

${ }^{497}$ Steele, The Sun Shines For All, 43.
} 
commitment to party politics to maintain honest government. ${ }^{498}$ The party represented a vehicle of cooperation and the general preservation of equal rights to Dana ${ }^{499} \mathrm{He}$ bought his newspaper in Chicago to advance these values in the Republican party: to promote equal rights, civic virtue, social egalitarianism, party unity, and honest government. ${ }^{500}$ If he found allies across Chicago that supported the Civil Rights Act of 1866 and the Fifteenth Amendment, this failed to bolster his faith in the party's potential to embrace a post-war vision of a truly "republican" party. ${ }^{501}$ Both the radical's efforts to wrest control of government and Johnson's sectionalism chafed with Dana's old Whiggish distaste for the over-use of power, patronage abuse, and influence in peacetime government. His frustrations over the nature of the political landscape since Lincoln's assassination, Johnson's patronage and pardon abuses, the subsequent impeachment trial, ${ }^{502}$ and the inability of either party to find a consistently moderate tone antagonized his readers and prompted his departure to New York. ${ }^{503}$ The paper he purchased there in 1868, The Sun,

${ }^{498}$ Ibid, 66-71, 88.

${ }^{499}$ Charles A. Dana to James Harrison Wilson, May 30, 1865, cited in Elmer Gertz, "Charles A. Dana and the Chicago Republican,” Journal of the Illinois State Historical Society 45 (1962): 125.

${ }^{500}$ Chicago Republican, June 23, 1865. "The Republican will never forget the duty of keeping alive and glowing that sacred fire of enthusiasm, and that spirit of patriotic and fraternal cooperation under God's Providence has given to the great Union party its momentous victories at the pools, and have thus enabled it to vindicate the integrity of the Republic, and make the Starry Banner of Liberty the only stand that waves overall... With the safety of the Union, the dearest hopes of humanity are still identified..." For one of Dana's biographer's similar interpretation, see: Steele, The Sun Shines For All, 67-69.

${ }^{501}$ For more on the rivalry Dana found with the radical Republican papers and politicians of the city, like the Chicago Tribune, and the way that both sides of the rivalry supported the spirit proposed $15^{\text {th }}$

Amendment, see: letter from C.A. Dana to James Harrison Wilson, May 30, 1865, cited in Elmer Gertz, "Charles A. Dana and the Chicago Republican," 125. Also see Chicago Republican, January 1866, in Gertz, 130-1. Here Dana argued that, "But, like the Bourbons, these unhappy people have forgotten nothing and learned nothing; and probably to the end of time they will continue to declaim against the radicals, even when they are taking the course which most certainly insures the triumph of radical ideas." Other articles sampling Dana's support for suffrage rights for the freed slaves, see: Chicago Republican, February $9,1866$.

${ }^{502}$ See letter from C.A. Dana to James Harrison Wilson, April 30, 1866, cited in Gertz, "Charles A. Dana and the Chicago Republican," 133.

${ }^{503}$ Gertz, "Charles A. Dana and the Chicago Republican," 133. 
represented Dana's best opportunity to control and disseminate his own recommendations for the American political order. ${ }^{504}$

Dana's efforts to organize The Sun, the daily journal he bought in early 1868 , coincided with a frenzied phase in American political history and his standard for honest government took on particular importance in the period between Grant's Inauguration to the middle of 1870 . One issue that concerned him particularly was what he detected as a drift towards tyranny and his fear of European “Old World," personal, government. ${ }^{505}$ In Dana's eyes, these types of systems encouraged large bureaucracies that bred corruption, an overpowered federal government that acted as hegemon to the desires of local communities, and active foreign policies that fostered imperial growth and colonial protectorates in the New World. He wanted the next leader to avoid the problems of the Johnson administration, which appeared very much like the heavy-handed policies of Old World despots. ${ }^{506}$ Dana supported Grant's candidacy in large measure from his personal observations of the general's modesty - the antithesis of the tyrant's mode.

His campaign biography cowritten with Wilson, summarized Grant as the embodiment of Dana's values. Should he be elevated to Chief Magistracy in November next," they wrote, the

\footnotetext{
${ }^{504}$ Dana was also in a financial battle with the Republican's publisher, leading to his exit from the paper. For more on the financial motivations that added to Dana's decision to leave, see: Gertz, "Charles A. Dana and the Chicago Republican," $128-135$.

${ }^{505}$ The character of the nation's leaders had long been a feature of the Dana's Whiggish opposition to aggressive peace-time Presidents that seemed to function like Old World monarchs. For more on Dana's anti-corruption, and critique of overuse of government power, see Dana's experience at Brook Farm, the Tribune, and as Assistant Secretary of War. For a quick restatement of Dana's faith in Grant's up-rightness in The Sun, see: "Conversations With Grant," The Sun (N.Y.), January 8, 1869.

${ }^{506}$ The Sun (N.Y.), January 27, 1868. The prospectus for his newspaper, printed Dana's first edition behind the helm on January 27, 1868, clarified each of these points. Also see: Dana and Wilson, The Life of Ulysses S. Grant, 389. Dana and Wilson noted that, "Subsequent events have proved that Johnson, in the suspension of Stanton, intended to keep him out of the War Office permanently, in spite of the law of the Senate, and to obtain the control of the Department for ulterior motives." They vowed that Johnson's "purpose was fixed. His mode of accomplishing it was sinister. He sought his ends by hypocrisy and double-dealing. Pretending to yield to the requirements of the act, he practically disregarded it. Professing to respect the authority of the Senate, he meant to defy it."
} 
nation "will not entertain the slightest fear that the Union and the Constitution will suffer detriment at his hands." ${ }^{507}$ Grant's "enlightened counsels," they continued, "the actual services he rendered in regard to civil, social, legal and financial matters of unprecedented character and transcendent importance, affecting the interests of large populations and the destinies of powerful States, prove that he possesses abilities and attainments that entitle him to a place among the wise and prudent statesmen of the country." ${ }^{, 508}$ The campaign biography reiterated that Grant would betray no trappings of Old World government corruption. ${ }^{509}$ The way he had handled the episode over the Tenure of Office Act with Johnson had helped prove this point, where Grant had shown himself "scrupulously obedient to law. He is the soul of honor, and never forfeits his word." 510 To the authors, Johnson's actions hinted at autocratic abuse of power, leaving Grant as the virtuous protagonist. ${ }^{511}$ The authors found Grant's performance during the beginning of Reconstruction, first as General-in-Chief of the armies to be of the highest caliber. ${ }^{512}$ For this

${ }^{507}$ Dana and Wilson, Life of Ulysses S. Grant, 397.

${ }^{508}$ Ibid, 424.

${ }^{509}$ This included nepotism, cronyism, financial corruption, machine government, use of the military for political ends, standing armies, or use of the government for personal ends. For more on where Dana, and his co-author on the bio, made these claims in The Life of Ulysses S. Grant, see: 380-1, 406-410, 424. For similar arguments made in The Sun, see: “Grant's Acceptance," The Sun (N.Y.), June 2, 1868; The Sun (N.Y.), September 1, 1868.

${ }^{510}$ Dana and Wilson, The Life of Ulysses S. Grant, 391.

${ }^{511}$ Ibid, 395. "Prudently resolving to leave those upon whom the Constitution had devolved the responsibility of initiating and determining this complicated case, to discharge their several duties" they began, "[Grant] attended to the performance of the manifold trusts committed to his keeping as General-inChief. Continuing to enforce retrenchment and reform in all branches of the service, he devoted himself with untiring energy to the completion of the plan of reconstruction. The fruits of his labors in this field were early seen in the adoption of Constitutions, and the election of State Officers and members of both Houses of Congress, in a large majority of the ten Southern States, leaving it no longer doubtful that, under the vigorous and conciliatory policy and measure of Grant and his faithful coadjutors, all the lately rebellious States may be prepared to crown the work of restoration by participating, in common with the rest of the Union, in the next Presidential election."

512 Ibid, 395. “...throughout these proceedings, Grant pursued the same wise course that had marked his conduct during the entire period of the collision between the President and Congress. Prudently resolving to leave those upon whom the Constitution had devolved the responsibility of initiating and determining this complicated case, to discharge their several duties, he attended to the performance of the manifold trusts 
reason, Dana and Wilson also believed that Grant stood as a beacon for bipartisan compromise and national unity. "Though doubtless concurring in sentiment with the leading principles of the Republican Party," they wrote, "he had never been a member of it, nor voted its ticket, and, so far as he was a politician at all, he was known as a War Democrat." They reminded their readers that many Democrats had "united with the Republicans in presenting the name of Grant to the country, not because they had ceased to be Democrats, but because they believed him to be the best and safest man with whom to entrust its destiny in the pending emergency, and to secure this end they naturally coalesced with the largest body of his supporters to carry out their common object." ${ }^{513}$ Grant's bipartisan resume qualified him, the biography concluded, to soothe Washington's partisan rancor. ${ }^{514}$ Grant would not have to "vacate the position of political independence which he had always occupied; and though Republicans will support him with fidelity and enthusiasm, he will still be regarded as the candidate of other organizations as well as theirs and will be sustained by a large and influential body of those who are distinctively known as War Democrats..." 515

Victorious in1868, Grant tested Dana's commitment almost immediately. ${ }^{516}$ Dana advised the president-elect on various issues, mostly about staffing. One of these

committed to his keeping as Commander-in-Chief. Continuing to enforce retrenchment and reform in all branches of the service, he devoted himself with untiring energy to the completion of the plan of reconstruction.

${ }^{513}$ Ibid, 396-7.

${ }^{514}$ Dana and Wilson, Life of Ulysses S. Grant, 424. The authors wrote that "standing at the close of the eventful epoch we have been surveying, we need not hesitate to affirm, that to play the part in this great drama which Grant has performed, has required talents of a very different kind, if not of a higher grade, than those which produce the mere soldier, however illustrious." Also see: The Sun (N.Y.), September 3, 1868.

${ }^{515}$ Ibid, 397.

${ }^{516}$ Grant defeated Democrat Horatio Seymour of New York 214 electoral votes to 80 . The popular vote was somewhat closer, $52.7 \%$ to $47.3 \%$, but still a considerable margin in the history of Presidential elections. For more on the election, see: William C. Harris, Two Against Lincoln: Reverdy Johnson and Horatio Seymour - Champions of the Loyal Opposition (Lawrence: University Press of Kansas, 2017); 
recommendations was to put himself forward for the lucrative job as Collector at the New York Customs House then appointed by the executive. Grant rebuffed him. Biographers allege that he took offence and turned on his old associate. That interpretation is not unreasonable, but that personal motive was radically reinforced by Dana's most ancient commitment to civic virtues, symbolized most critically by his hatred of corruption.

Even before the inauguration, Dana had argued that the success of the Grant administration hinged on the general's ability to avoid being corruption by the old political order. ${ }^{517}$ While corruption had "stained" and "wounded" some administrations, traditional virtue lay with those executives who, "refused to receive presents as testimonials of regard for public services," $" 18$ never "bestowed office upon a relative," and "rebuked the practice with marked emphasis. ${ }^{" 519}$ Dana used precedents to judge contemporary politicians. Dana's editorials also called for the administration to limit executive and federal power, ${ }^{520}$ guarantee equal suffrage, ${ }^{521}$ check government maladministration, ${ }^{522}$ and to act honestly to preserve the Union and its

\footnotetext{
Alexander, "The Fate of Northern Democrats after the Civil War: Another Look at the Presidential Election of 1868"; Decanio, Democracy and the Origins of the American Regulatory State, 78 - 91; James G. Dauphine, "The Knights of the White Camelia and the Election of 1868: Louisiana's White Terrorists," Louisiana Territory: The Journal of the Louisiana Historical Association 30, no. 2 (Spring 1989): 173-190.

${ }^{517}$ Dana and Wilson, The Life of Ulysses S. Grant, chapters 38 and 39.

${ }^{518}$ Ibid.

${ }^{519}$ Ibid. For more on Dana's use of Jefferson as evidence of this precedent in Executive administration, see: The Sun (N.Y.), August 3, 1869.

520 “Too Many Executive Departments," The Sun (N.Y.), February 6, 1869.

521 "The Lesson of History," The Sun (N.Y.), November 5, 1868. "Once more Radical ideas have received the support of the majority. Universal suffrage is henceforth the established and irreversible law of the reconstructed States, and will gradually become the law in all the others. Thus we see that in American politics it is Radicalism that always triumphs. Conservative and retrograde ideas may sometimes gain a temporary success but it is illusive and evanescent."

522 “Congress Needs To Spend Less," The Sun (N.Y.), January 28, 1869.
} 
republican foundations. ${ }^{523}$ The new administration ignored these strictures, Dana believed, and he increasingly regretted his earlier enthusiasm.

Five issues illustrate Dana's disillusionment: first, corruption and bureaucratic abuse; second, the weakened reputation of the presidency; third, the disarray of the Republican Party; third, the association of Grant with the Tweed Ring's corruption; and finally, the defection of idealists in New York's Republican party in particular. The first three cases reflect Dana's occupation with republican anti-corruption ideology, not personal spite. The last two examples contextualize the durability and transportability of Dana's opposition to "Grantism" in state and local politics. Combined they provide one angle, that of opposition to corruption, from which to understand Dana's principled rejection of Grant and establishment politics.

Reports of government corruption and bureaucratic abuse within the administration triggered Dana's first criticisms. In July, he broadsided the administration's "gift-giving," nepotism, cronyism, and "personal government." 524 He condemned Grant's association with the rich and financial corruption. He attacked the administration's poor bureaucratic organization and performance. Each of these criticisms provided The Sun with different facets to craft the case exposing the corrupting nature of the activities of the president and the broader political system. ${ }^{525}$ The gift-giving, nepotism, and cronyism offended him particularly. This issue

${ }^{523}$ The Sun (N.Y.), January 27, 1869; "Effect of Grant's Election on the Southern Lands," The Sun (N.Y.), September 24, 1868.

524 Dana used the term to describe any time a government leader acted in his or her best interests rather than that of the people. He most often used the term to describe European monarchs like France's King Napoleon III, for instance. In the period, Dana would begin to interchange descriptions of Grant's supposed selfish approach to both staffing, and running, the government with the actions of monarchs like Napoleon. While this specific subject, of the intersections of Dana's analysis of international politics and American Reconstruction during the first Grant administration does not come up until the next chapter, for a good sample of Dana's use of the term, see: The Sun (N.Y.), July 7, 1868.

525 "Office-Seeking in Washington," The Sun (N.Y.), March 17, 1869; "Corruption Among Public Men," The Sun (N.Y.), March 22, 1869. 
represented one of Dana's most persistent complaints into the middle of $1870 .^{526}$ The Sun described an administration unconcerned with acting honestly or frugally. The paper highlighted examples of supporters endowing President Grant with gifts including houses, carriages and horses. Editorials criticized Grant's hiring of relatives and friends, and his keeping former military aides as unelected advisors on salary. ${ }^{527}$ It categorized many of these activities under the banner of personal government, as in Europe where rulers acted in their own interests rather than those of the state. ${ }^{528}$ One such scandal covering the paper's front page early in the administration was the gifting of a home in the beach town of Long Branch, New Jersey to the president by a group of high placed friends who eventually received important government posts. The group donating the "summer White House" included Gen. William T. Sherman, ${ }^{529}$ future Secretary of the Navy Adolph Borie and future Assistant Secretary of Treasury, and Civil War hero, Daniel Butterfield. ${ }^{530}$ The Sun maintained that Butterfield and Borie had especially gained their offices

526 "A Few Words to a Few Fools," The Sun (N.Y.), June 20, 1870. "The President is incompetent, neglectful of his duties, unable to comprehend them, and careless about performing them. He appoints men to office simply because they have made him presents, or are his relations, or because some foolish caprice prompts it.

${ }^{527}$ For a sample of The Sun's argument that offering the President a gift would help gain anyone an office, see: “A Good Opinion, but Bad Advice," The Sun (N.Y.), April 16, 1869. “...there is every reason to believe that if we had sent the velocipede to Gen. Grant, we should have got the office."

528 "How Things Go At Washington. What Sort of an administration it is," The Sun (N.Y.), December 12, 1869. "Gen. Grant interferes even in the smallest matters which touch his prejudices, or partialities, or his family interests, and in a matter wholly unknown before."

529 "A Principle not to be Neglected," The Sun (N.Y.), April 26, 1869. "There is a principle which we trust will not be overlooked or forgotten, either by the President or the gentlemen whom he may hereafter invite to take places in his ministry. It is briefly: No man who has ever contributed to give Gen. Grant a house or any other valuable present, or who joined in the recent great present to Gen. Sherman, ought to be invited to take any place of power, emolument, or honor under this administration." "Or, to state it conversely: No man having the proper sense of delicacy, who has given Gen. Grant a present, or who shared in the late present to Gen. Sherman, will accept any such office if it should be offered to him. And if such a man should be nominated and should accept the place, it will be the imperative duty of the Senate to reject the nomination, no matter what the character or the capacity of the nominee."

${ }^{530}$ The Sun (N.Y.), July 26, 1869; "Partial Removal of the Capital to Long Branch," The Sun (N.Y.), March $7,1870$. 
because of the "influence" of this gift and others like it. ${ }^{531}$ The president's subsequent hiring of men who offered him gifts prior to employment, the paper argued, reinforced the perception of the executive's personal corruption. ${ }^{532}$ Receiving such a gift also exposed the president and his advisors of violating Article I, Section 9, Clause 8 of the Constitution - the Emoluments Clause. ${ }^{533}$ The second example of nepotism and cronyism from Grant and his administration involved Grant's father, his wife's relatives, and other friends who obtained government jobs. Their appointments drew a continuous broadside of criticism from the Sun's editorial page ${ }^{534}$ The third example, of the president's close reliance on former military advisors now placed on public salaries, activated Dana's opposition to selfish, and military, influences on the centers of government. ${ }^{535}$ Thus the editor complained bitterly when the president and his former military

531 “The Reason Why,” The Sun (N.Y.), March 4, 1869.

532 "Then and Now—-The Earlier and the Later Presidents," The Sun (N.Y.), April 24, 1869. Dana's list of Grant's initial grievances in this editorial: After discussing Jefferson and Jackson, the editorial continues, "We have fallen on other times. Are they better times? On Wednesday, the 3d of March, 1869, the President elect accepted $\$ 65,000$ out of a sum on money raised in New York at his own pressing solicitation for Gen. Sherman, to pay him (the President) for a house which he desired to sell. On Thursday he took the oath of office, and in his inaugural address pledged himself to the rigid execution of all laws, whether he liked them or not. He then spent nearly the entire first week of his term in trying to evade the plain provisions of salutary statues, because they blocked the way for the admission to the most important seat in his Cabinet of the almoner who had bestowed this dazzling present. Baffled in this by the firmness of the Senate and the frowns of the public, he nevertheless installed among his constitutional advisers other individuals who, though not obnoxious to this particular objection, were chiefly distinguished for having conferred upon him costly and valuable benefactions. Along with other appointments bearing this sort of trade mark, he appointed as his Secretary of the Navy a gentleman wholly incapable of filling the place, who had taken the lead in giving him a fifty thousand dollar house in Philadelphia, some three years before; and he surrounded the baton of General of the Armies to a renowned solider, who, with his knowledge and approbation, lifted one-hand to take the oath of office, while receiving with the other a tempting gift valued at $\$ 100,000$, of which the sixty-five thousand dollar house in Washington formed a part. Not to go back to Jefferson, or Adams, or Jackson, for virtuous examples, even Andy Johnson had sense and decency enough to refuse the present of a carriage and horses with the Presidential oath lingering on his lips."

533 “A Principle not to be Neglected,” The Sun (N.Y.), April 26, 1869.

534 “The Stupidity of the Democratic Leaders," The Sun (N.Y.), July 19, 1869; “A Republican Editor on his Knees Before Grant," The Sun (N.Y.), July 26, 1869; "Reconstruction Completed-Its Effect upon the Republican Party," The Sun (N.Y.), February 1, 1870.

535 "How Things Go At Washington. What Sort of an administration it is," The Sun (N.Y.), December 12, 1869. "President Grant intends that his Cabinet shall be a sort of military staff, who are to carry and execute orders, without having either discretion or opinion of their own. They are rarely consulted in the large and 
aides and unelected friends worked at the Long Branch residence at the taxpayer's expense. ${ }^{536}$

Pursuing the administration's alleged corruption and misadministration across the first fifteen

months of its tenure encouraged The Sun to point out other types of mismanagement and abuse.

Other reports of Grant's association with wealthy individuals alarmed Dana enough to justify turning against the White House. The Sun's reports of the president's close relationship with affluent financiers and speculators connected to illegal manipulations of specie and currency trading, in particular, drew major concern. The Sun reported, for instance, that Grant had become close with corporate magnates and utilities tycoons like Jay Gould. An antebellum investor in railroad companies, Gould gained a reputation as a shrewd financial mind with a predatory corporate philosophy. In the summer of 1868 Gould engineered a corporate takeover that would make his reputation — he muscled out millionaires Cornelius Vanderbilt and Daniel Drew to become majority shareholder and president of the mammoth Erie Railroad. Dana feared that the über-influential Gould could entrance Grant with the spell of new money and push the policy

proper sense, though by cunning and pertinacity any one of them can bring the President to adopt his views on any difficult question where Gen. Grant has no real opinion of his own. But on Cabinet days they merely make routine reports to their chief, and in matters of mere administration are of very little account, and have very little account, and have very little idea what the President means to do. When Gen. Belknap was recently appointed Secretary of War, no member of the President's intentions, until the choice was made and announced in the newspapers...Gen. Grant interferes even in the smallest matters which touch his prejudices, or partialities, or his family interests, and in a matter wholly unknown before. The President's house is no longer what it used to be. The Chief Magistrate is approached only through a line of 'Generals.' There is Gen. Dent, who is sort of chief usher, and stands in undress to admit or reject visitors, as they may be of the faithful or suspected stripe. One class is handled by Gen. Porter, another by Gen. Babcock, and a third by Gen. Somebody Else, until the President is reached. All these Generals are drawing pay, rations, horse feed, servants' wages, and other allowances, in the most delightful way for themselves. Who cares, since Uncle Sam pays the piper? The Generals buy big houses, sport fine carriages, live on the fat of the land, and sing paeans to the Commander-in-Chief, as the King's friends ought to do."

${ }^{536}$ For a good run-down of The Sun's objections to Belknap's being made Secretary of War after the death of Gen. John Rawlins, see the paper's editorial on the day after Belknap's hiring, "The New Secretary of War," The Sun (N.Y.), October 20, 1869. "The appointment of Gen. Belknap-with the exception that it is not tainted by pecuniary donations - is a political blunder of the same sort as the appointment of Mr. Stewart, Mr. Hamilton Fish, Mr. Borie, and Mr. Robeson. It adds nothing to the political weight of the administration...it proves that we are not to expect any check to that process of constitutional transformation which was commenced by Andrew Johnson." 
agenda of the financiers from the White House. The accusation was not without merit. Gould's attempts to curry favor with the president came as he expanded the Erie Railroad's political lobbying capabilities. Gould retained controversial investment banker James Fisk to help him run the railroad and recruited the help of Tammany Hall to curry favor for the railroad in the state legislature. The paper reported that Gould brought in Boss Tweed to sit on the board (including stock options) ${ }^{537}$ The stink of corporatism and machine politics surrounding the arrangement entered the president's orbit in precisely the ways Dana hoped to avoid. What ensued was a bureaucratic scandal turned economic recession brought on by the leery relationships described above. Sun reports found out that Gould and agents for Fisk approached members of Grant's administration, including members of his extended family, about forming a ring to manipulate gold prices using insider knowledge of government currency trading. One of the president's economic advisors (and brother-in-law), Abel Corbin, and Assistant Secretary of the Treasury Daniel Butterfield reportedly met with the financiers. They planned to offer inside information on incoming reductions in American gold offered on the global market, whereupon Gould and Fisk would buy up large amounts of the metal before the announcement to corner the market in anticipation of higher prices. When Gould and Fisk bought their shares, prior to any government buyup, they precipitated an inflationary currency bubble that shook the price of the dollar. ${ }^{538}$ "Black Friday of 1869 " or "the Gold Crisis of 1869 " looked initially as if the president, his brother-in-law, and the assistant Secretary of the Treasury colluded with financiers to manipulate the stock market. The scandal cut to the core of The Sun's recent censure of the president's inability to pick able political bureaucrats, avoid government connections to nebulous financiers,

\footnotetext{
537 “A Talk With Gov. Seymour,” The Sun (N.Y.), October 5, 1869.

538 The Sun (N.Y.), October 25, 1869. "Though President Grant has not formally repudiated his brothers-inlaw, or shown in any manner that he has withdrawn from them his fraternal regard, they are held in general disesteem just at present...In short, the President's brothers-in-law have made themselves objects of universal distrust and contempt, and we dare say they deserve it."
} 
and to run the nation frugally and transparently. ${ }^{539}$ The paper eventually helped exonerate Grant as being directly involved, ${ }^{540}$ while maintaining that the president had encouraged the crisis by allowing these relationships to exist in the first place. ${ }^{541}$ The Sun insisted that White House's bureaucratic failure created "all-pervading and most damaging suspicions" of corruption throughout the Grant administration. ${ }^{542}$

These reports of government fraud encouraged The Sun to interpret each new report of wealth interacting with the president as another reason for Americans to remove their support. To justify its growing opposition, Dana's paper argued that Grant's character had changed since leaving the military in ways that were damaging to the nation and its republican foundations. The aspirational political world of Washington had elevated the president's tastes, bent his compass, and fluffed his ego. One editorial, for example, recalled when "the time was when Gen. Grant has common sense, and displayed it in a remarkable degree." ${ }^{, 543}$ Dana remembered "when he (Grant)

\footnotetext{
${ }^{539}$ For more on The Sun's coverage of the story across 1869 and early 1870, see: "Conspiracy to Raise the Price of Gold," The Sun (N.Y.), September 20, 1869; "Down with the Gold Gamblers!," The Sun (N.Y.), September 27, 1869; "Facts Already Ascertained about the Gold Combination," The Sun (N.Y.), October 11, 1869; The Sun (N.Y.), November 10, 1869; The Sun (N.Y.), October 25, 1869; "The Reason Why," The Sun (N.Y.), November 15, 1869. "The truth is, that everything that can properly be described by that epithet was against Gen. Butterfield's appointment. In fact, the circumstances are such that people generally believe that Butterfield was made Assistant Treasurer because he had aided largely in giving Gen. Grant a house, and because he had also aided in raising money to pay Gen. Grant an advanced price for the same house for Gen. Sherman. It is almost universally understood that this was the influence that secured his appointment, and that the matter was manipulated by the now notorious A.R. Corbin." For more on The Sun and Corbin see: "The Case of Mr. A.R. Corbin," The Sun (N.Y.), October 4, 1869.

540 "Who Is There That Can Be Trusted," The Sun (N.Y.), November 3, 1869. "Gen. Grant has been foolishly persuaded that The Sun was hostile to him. This is an entire mistake. We have always ben his friend, from the time when we saved him from being sent back to Illinois from his canal digging opposite Vicksburg, down to the time when, seizing upon the opportunity afforded by his letter to Mr. Bonner, we vindicated him from the ill-founded but all-pervading and most damaging suspicions of complicity in the Gold Ring."

541 "Some Curious about the Gold Conspiracy," The Sun (N.Y.), March 4, 1870. The paper noted that "Mr. Gould's signal talents for a part of the task he undertook are amply proved by his success in bending the proverbially stubborn will of President Grant to a conformity with his desires."

542 "Who Is There That Can Be Trusted," The Sun (N.Y.), November 3, 1869.

543 “Nothing like Foolishness," The Sun (N.Y.), June 18, 1870.
} 
was an unpretending soldier...not above following the advice of a man of noble intellect and character." ${ }^{544}$ Since Grant's promotion from generalship, The Sun maintained that "flattery and lucre have turned his head." ${ }^{" 545}$ The Sun pointed to reports of the president insisting on discounted rates on trains and Mrs. Grant's redecoration of the White House as small parts of a much larger change. ${ }^{546}$ Dana and The Sun used the growing list of financial scandals to inform their changing opinions of the new president. They described the long list of corruption scandals and shows of wealth by Grant and his as the "evil practices of men in high places" who "tend to demoralize the public service, and debauch public opinion.. ${ }^{, 47}$ The actions of the president and his partners, The Sun argued, created an atmosphere unhealthy to the virtuous execution of public office.

"Corruption and venality will walk unabashed and almost unrebuked through every department of the Government if left unchecked," the paper explained to readers. Corruption reached the "placeholders," the wealthy political classes, and possibly "the very roots of society." 548 The actions of the president and his allies, stewards within traditionally self-less offices, "inflame the young men of the land with a passion for wealth as the great object of life." Grantism elevated the pursuit and "the possession of riches" as "the sole passport to power, eminence, of even respectability." 549 The paper asked its readers, and the nation's politicians if it was "not high time that the masses of

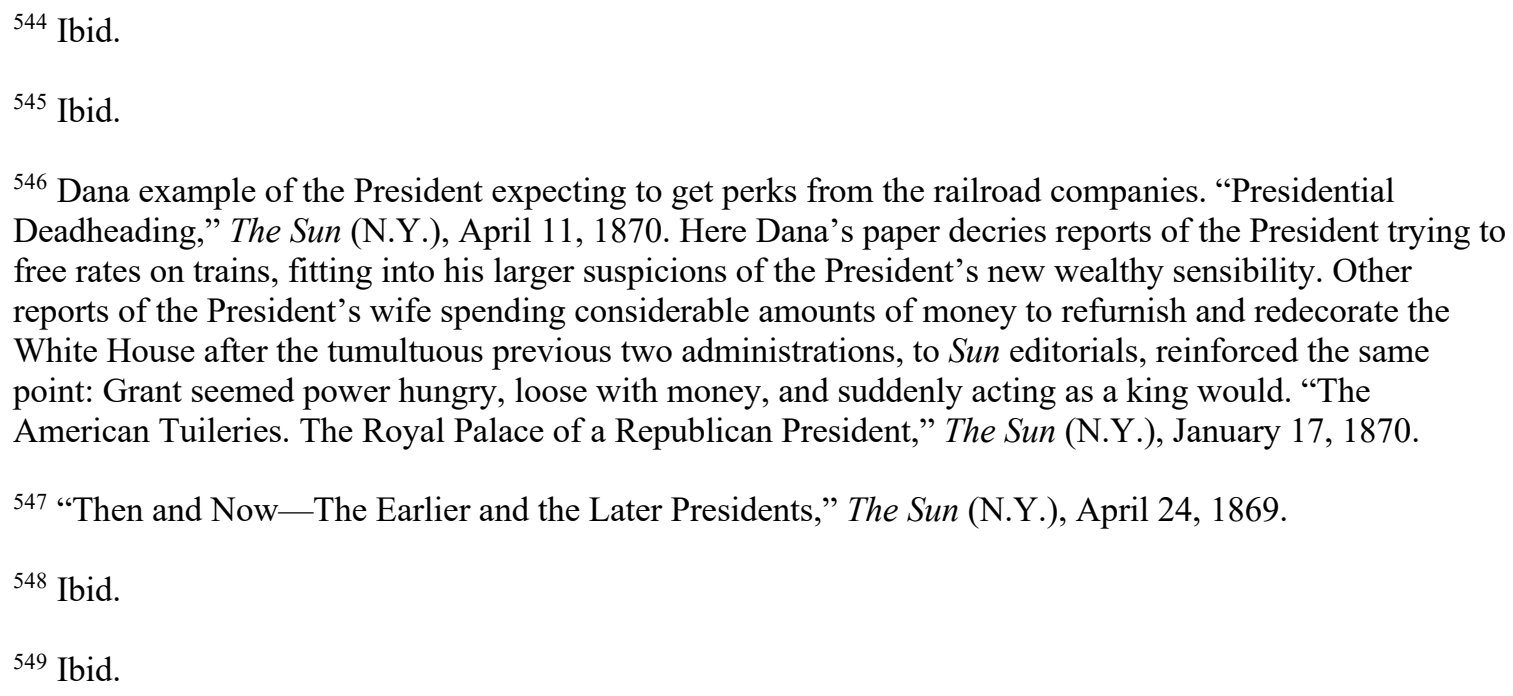


the people, who neither seek nor hold office, should labor for the return of the good old times of republican simplicity." 550

Dana's third justification for his opposition to the president developed from the argument that Grant corrupted the functions of government by tolerating poor management sense and departmental maladministration. As examples, Sun editorials pointed to the poor performance of the president's patronage choices and the mishandling of entire offices, like the Department of the Navy. As often was the case with Grant's tenure, scandal surrounded bureaucratic issues. Dana, the former Assistant Secretary of War, remained sensitive to staffing decisions in the military branches. From the beginning of Grant's tenure, The Sun argued that the department stood crippled by crony patronage choices embodied by the appointments of Adolph Borie and George M. Robeson as successive Secretaries of the Navy. These choices, the paper argued, manifested the White House's inability to shake Grantism and corruption, and represented "one of those blunders that are worse than crimes." ${ }^{551}$ According to the paper, these choices encouraged

${ }^{550}$ Ibid.

551 "Not Borie, but Humbug," The Sun (N.Y.), June 14, 1869. Dana's aggressive denunciation of anything having to do with the Secretary of the Navy arose from his belief that Mr. Borie managed by his job because he put in money to help purchase the Long Branch house for the President. That, and he also knew that Mr. Borie was sick, and that his immediate subordinate Admiral David Dixon Porter was Grant's real choice to run the department, but did not want to try and get Adm. Porter confirmed through Congress. Sec. Borie's appointment, then, was complicit in Grant's schemes for "personal government." This same article made the point: "Mr. Borie is not able to be Secretary of the Navy. He is afflicted with a chronic malady of the nervous system, such that he cannot do any regular work whatever, cannot even read for an hour at a time. And yet he allows himself to be called the Secretary of the Navy and draws the pay, while Admiral Porter does the work - and very pretty work he makes of it sometimes. This, we say, is a scandalous imposition upon the country, which cannot be too earnestly or too loudly condemned. If Gen. Grant wants to keep Admiral Porter at the head of the Navy, let him nominate him for the office like a man, and let the Senate say whether he shall be confirmed. But this way of accomplishing the same end by making a dummy of poor Mr. Borie is neither honorable nor decent. He took the lead in giving Gen. Grant a house, and his appointment to high office may have seemed to the President a proper return for that favor; but before the transaction is completed the parties to it will doubtless understand that if they have not been guilty of a crime, they have committed one of those blunders that are worse than crimes." For more on Dana's reiteration of this same point, see: "The Corrupt and Discreditable Appointment of Secretary Borie," The Sun (N.Y.), May 31, 1869. Dana called this "the most scandalous and indecent transaction in which a President was ever arranged." Dana analyzes how the Republican press covered it." 
inefficiency within the department. Sun editorials argued that the example of David Dixon Porter stood out from its other coverage. The paper argued that Grant's old friend, appointed Assistant secretary of the Navy, informally ran the department under both Secretaries Borie and Robeson. Dana's newspaper insisted that this reinforced the idea that the president used his friends to run government without regard for existing bureaucratic precedent. ${ }^{552}$ If Grant wanted Porter to run the department, he should respect protocol and allow the Senate to approve the appointment. Instead perceptions of cronyism led to grand suspicions on Dana's part. Sun editorials detailing potential frauds undertaken by Navy paymasters, ${ }^{553}$ the use of Navy ships for private trips and events, and the increasing cost of this supposedly inefficient and corrupt department, ${ }^{554}$ confirmed the Navy Department's place within Grant's corrupt and mismanaged circle. ${ }^{555}$ This level of deception, the paper maintained, "outrages the moral and religious sentiment of the country."556

\footnotetext{
${ }^{552} \mathrm{Ibid}$. "Mr. Borie is not able to be Secretary of the Navy. He is afflicted with a chronic malady of the nervous system, such that he cannot do any regular work whatever, cannot even read for an hour at a time. And yet he allows himself to be called the Secretary of the Navy and draws the pay, while Admiral Porter does the work - and very pretty work he makes of it sometimes. This, we say, is a scandalous imposition upon the country, which cannot be too earnestly or too loudly condemned. If Gen. Grant wants to keep Admiral Porter at the head of the Navy, let him nominate him for the office like a man, and let the Senate say whether he shall be confirmed. But this way of accomplishing the same end by making a dummy of poor Mr. Borie is neither honorable nor decent. He took the lead in giving Gen. Grant a house, and his appointment to high office may have seemed to the President a proper return for that favor; but before the transaction is completed the parties to it will doubtless understand that if they have not been guilty of a crime, they have committed one of those blunders that are worse than crimes."

553 "Frauds of Navy Paymasters," The Sun (N.Y.), December 13, 1869.

554 “Increase in the Current Expense of the Navy," The Sun (N.Y.), January 17, 1870.

555 "How Things Go At Washington. What Sort of an Administration it Is," The Sun (N.Y.), December 12, 1869.
}

556 "The Ancient Mariner Robeson Ought to Go," The Sun (N.Y.), November 29, 1869. "In the first six months of his administration Gen. Grant changed his Secretaries of the State, Treasury, and Navy Departments. This is a larger number of changes in the Cabinet than was ever made in so short a time by any President except Tyler, all of whose Cabinet resigned on one day with the exception of Mr. Webster. This is hardly a parallel case, however, because Tyler's first Cabinet was not selected by himself, but by Gen. Harrison...Notwithstanding the changes made by Gen. Grant give an air of instability to his Cabinet, he ought to make one or more without delay. He should remove Robeson from the Navy Department at all events, because he is merely its nominal and not its real head, and because the Department as now conducted outrages the moral and religious sentiment of the country. Though stability, under normal circumstances, may be regarded as a virtue, it is better for the President to change his Cabinet a hundred 
Dana argued that Grantism's devaluation of the presidency itself also justified his opposition to his government. Historical treatment of the Grant administration generally agrees that "Grantism," at its best, exhibited only the president's inexperience and inclination for military aides and friends as advisors. At its worst, Grantism's “organizational mode" exhibited all sorts of financial and political corruption harmful to the Reconstruction-era federal government. ${ }^{557}$ Some of the better-known scandals Dana focused on during Grant's first fifteen months included: the Gold Ring scandal, ${ }^{558}$ the various "gifts" given to the president, his employing friends, family, and "gift givers," and using patronage threats to bend congressman and senators, ${ }^{559}$ alongside the difficulties of staffing the government with effective and honest bureaucrats. The idea that financial and administrative "corruption" ran unchecked across the country motivated a strong reaction against establishment politics, the establishment Republican Party, and the Grant White House in the late 1860s. A glut of examples existed of The Sun highlighting the deleterious influence of the administration's proximity to scandal hampering its popularity and success. One exchange between The Sun and the Troy Daily Times, a Grant paper from the city in upstate New York, appearing in The Sun in June 1870, particularly illustrates

times rather than to allow its members to persevere in ill-doing. The country will hold him responsible for the conduct of Robeson."

${ }^{557}$ For more positive to traditional treatments of the scandal surrounding the President, see: William S. McFeely, Grant: A Biography (New York: Norton, 1982); White, American Ulysses. For those treatments that associate "Grantism" with both mismanagement and political and financial corruption, see: Slap, The Doom of Reconstruction; Thompson, The Spider Web.

${ }^{558}$ For more on the historiographic treatment of the Gold Ring Scandal of 1869 see: Ronald White, American Ulysses, 463 - 485; Kenneth Ackerman, The Gold Ring. Jim Fisk, Jay Gould, and Black Friday, 1869 (New York: Dodd, Mead, \& Co., 1988); Larry T. Widmer, "The Gold Crisis of 1869: Stabilizing Speculation under Floating Exchange Rates?" Explorations in Economic History 12 (April 1975): 105-122.

${ }^{559}$ In his study of the Republican and bi-partisan opposition to the President in the late 1860s and early 1870s, Andrew Slap calls this sort of activity on the part of the President, "party despotism." Slap, The Doom of Reconstruction, 123-4, 130. 
Dana's judgment of the president's perceived sabotage of his office. ${ }^{560}$ The Daily Times accused the editor of holding a grudge against the chief executive, "a spite to gratify, a revenge to satisfy." 561 Dana asked the Times how it "affect[ed], one or the other, the great historical truth that Grant's civil administration is a failure - a dreadful, deplorable, shameful failure?" The Sun affirmed that its editor reserved a close respect for the Grant he used to know. ${ }^{562}$ The real change had to do with Grant in the White House. The June editorial reminded the Times, and Sun readers, of Dana's service to Grant's reputation at the Battle of Vicksburg in 1863, and his support during the later presidential campaign in $1868 .{ }^{563}$ "Few men who had taken more stock in him than we had," The Sun wrote. Since then, Dana's paper admitted that "toward Gen. Grant as President we confess that we cherish a very profound feeling of disappointment and dissatisfaction." 564 The

560 "A Few Words to a Few Fools," The Sun (N.Y.), June 20, 1870. The Times published an article referencing Dana's frustrated attempt at gaining the New York City Customs House post and correlated it with The Sun's current criticism of the Grant administration.

${ }^{561}$ Ibid.

${ }^{562}$ Ibid. "As for Gen. Grant personally, we have neither spite, grudge, nor revenge. He never refused us any personal favor, for we never asked anything of him, save only the appointment of Horace Greeley as Minister to England; and as he sent a man there who isn't half as fit for the place as Mr. Greeley, we have never borne him any grudge on that account."

${ }^{563}$ Ibid. "During the war, when he was digging canals at Vicksburg, and was on the point of being relieved from his command, Mr. Dana did what he could to have him retained at the head of the Army in the Mississippi Valley; and the effort was successfully. But for his agency Grant would then have been sent back to Galena; and in that event he could neither have become Commander-in-Chief of the army nor President of the United States. Next, when he was a candidate for the Presidency, we did what we could to secure for him the nomination of the Republican National Convention; and then we helped to get him the votes of a majority of the American people. All this we did simply because we thought it best for the country; and all we demanded of Gen. Grant was an honest, sensible, disinterested, and patriotic administration of his office."

${ }^{564}$ Ibid. "It is alleged that Mr. Dana wanted the New York Custom House. Bah! What if he did, or what if he didn't? Does that affect, one or the other, the great historical truth that Grant's civil administration is a failure - a dreadful, deplorable, shameful failure? How ridiculous! What has Mr. Dana or the New York Custom House to do with all this? If he has ever mildly disapproved of the appointment of Moses $\mathrm{H}$. Grinnell to that office, how many Republicans are there in the State who have not bitterly cursed the administration for making it? And now, once for all, if Gen. Grant would walk into the Sun office in person to-day, and tender with his right hand to the editor a signed and sealed commission as Collector for this port, offering in addition to the fees of the office a duplicate sum made out of the contributions which he has received from A.T. Stewart and other rich importers, that offer would be declined. Years ago, Robert J. Walker said that he considered the position of editor of a great leading paper-like that of the Herald, 
feeling had little to do with Moses Grinnell, the Customs House officer preferred by Grant for that sinecure Dana wanted, but instead with Grant's corruption of the office of the president. "His administration is bad, foolish, weak, cowardly, corrupt" and "anti-American," the paper insisted, continuing that "it is impossible to speak the truth and deny that this is so." ${ }^{, 65}$ The Sun wrote that "the man who saved the nation as a soldier is covering us with shame as a president." Dana's editorials maintained that it was impossible for "an independent journalist, anxious to discharge his obligations to the people, to conceal or palliate facts so fearful and so notorious." ${ }^{566}$ A paper making charges like this had no choice but to argue that these political liabilities also translated to the party sponsoring his power.

The Sun claimed that political corruption weakened the unity of the Republican Party across the country between March 1869 and the middle of 1870. Dana knew that the Republican Party suffered from widespread division before Grant took office in the lead up to the election of 1868 and before. ${ }^{567}$ At that stage, Dana publicly argued how Grant's election could bring bipartisan peace, but since then the administration's bureaucratic abuses changed the editor's impression. ${ }^{568}$ The long list of potential conspiracies and corrupt appointments the paper referred

which he then mentioned - as far superior to that of the President of the United States; and certainly we consider it far superior to that of Collector of New York."

${ }^{565}$ Ibid. "The President is incompetent, neglectful of his duties, unable to comprehend them, and careless about performing them. He appoints men to office simply because they have made him presents, or are his relations, or because some foolish caprice prompts it.

${ }^{566}$ Ibid. "Must we forbear to tell the truth about him because it is unpleasant to him and his satellites? Must we prophesy only smooth things because a few fools charge us with personal animosity? We do not so understand our office. In our judgment, if there is any man who has the right to speak the whole truth in this case, to state all the facts, and to urge them upon public attention until the mind of the country is entirely aroused to the subject, that right is ours. Nor is it a right alone; it is a duty.

${ }^{567}$ For more on Grant's ideas about disharmony within the Republican Party before Grant's election in 1868 , see chapter one of this dissertation.

568 “The Policy of the Future-The President's Message," The Sun (N.Y.), November 29, 1869. "If he should prove unequal to the task, he could be ignored and allowed to pass quietly into the oblivion which has kindly sheltered so many ex-Presidents; but if, because of his incapacity, he should succeed in breaking down his party, it might change the entire current of affairs for a quarter of a century. The President is 
to almost daily negatively influenced the paper's review of the White House's performance.

Whereas Dana had previously championed the potential of the new executive, editorials now described the president as a principal cause of the Republican Party's continued fragmentation. ${ }^{569}$ The paper argued that Grant's use of "party despotism," as historian Andrew Slap described the process of rigid internal political party control, split the party by encouraging public spats with Republican Party leaders through forceful management of the caucus. ${ }^{570}$ Grant was forcing his vision for the Republican policy, as one centered around his patronage orbit, with remarkable force. Dana was objecting to what another historian, Eric Foner, has described as a shift from an ideological to an organizational mode within the Republican Party that elevated the role of patronage, with Grant as the leader. ${ }^{571}$ Examples that The Sun cited often included the public battle with Congress about the Tenure of Office Act in March 1869, with Edwin Stanton over the secretary of war position, ${ }^{572}$ and with Horace Greeley over the position of ambassadorship to

about to pass through the severest ordeal of his life, and it is hardly too much to say that the destiny of the great party which elevated him to power in his hands. Let him rise above the consideration of gratitude to those who have given him presents, shun a feeble policy, and beware of false friends."

569 “Will The Republican Party Live?," The Sun (N.Y.), April 22, 1869.

570 Slap, The Doom of Reconstruction, 123 - 4, 130.

${ }^{571}$ Historian Eric Foner once described this developing character of the party as the result of many in the Republican Party's growing impatience "with the ideological mode of politics that had shaped the party at its birth and been further strengthened by the crises of war and Reconstruction." As a result, a new group within the party advocated for an "organizational" core to the party that called on more advocacy for party goals, as opposed to hard ideological goals. Foner, Reconstruction, 523.

${ }^{572}$ For the Sun's early hopes that the repeal of the law, which took away power from the President to remove his own subordinates, would be handled well by Grant, see: "Repeal of the Tenure of Office Act," The Sun (N.Y.), February 15, 1869. For the paper's subsequent criticism of the President's choices with Stanton, see: The Sun (N.Y.), April 5, 1869. "The Threatened Doom of the Republican Party," The Sun (N.Y.), April 3, 1869. "If Gen. Grant can preserve throughout his Presidency the extraordinary confidence and respect with which he entered upon his civil duties, we shall regard him, and he will regard himself, no doubt, as a fortunate man. That his path is beset with difficulties is evident. The tenacity of the Senate in holding on to the Tenure of Office act is a specimen of the embarrassments he will have to contend with, and they will be aggravated by the fact that they proceed from the bosom of his own party" 
England. ${ }^{573}$ One August 1869 editorial argued that these actions helped foreshadow "the conspicuous failure of the Grant administration." The "Republican Party seems to be passing through a most dangerous crisis," the paper concluded. ${ }^{574}$ Dana's coverage of the president's appointments clarified that these decisions were causing major problems within the Republican Party. The president had shown himself "destitute of high statesmanlike qualities, and in regard to leadership is too often but the willing instrument of charlatans and adventurers," it explained. ${ }^{575}$ As a result, The Sun predicted a hazy future for the party, reporting that "General Grant is filling the ranks of the party with dissatisfied members. ${ }^{, 576}$ Remember, The Sun, wrote to its readers, "Mr. Lincoln is no more, and it will be well for the party that gave him power and prestige to take heed lest it also soon pass into history and be known among living men no more."577 The existing divisions in the Republican Party between liberals, moderates, conservatives, and Radicals when Grant took office, Dana argued in The Sun, had only deepened with the president's partisan activity since then. This widespread questioning of the president, and his negative influence on the party, contextualizes the breadth of the party shuffling based on these issues of political corruption and maladministration.

\footnotetext{
${ }^{573}$ Dana really wanted to get Greeley appointed to some post within the Grant administration as a symbol of deference to a party leader. After John Lothrop Motley received the office, the paper provided public criticism of the choice. For a sample, see: "How Mr. Greeley Lost the British Mission," The Sun (N.Y.), April 19, 1869. "We have failed-The Sun and Mr. Young have failed together-and now let us together mingle our tears for a few moments, and then look on and gather wisdom from studying the next act of drama. No public man ever yet wronged Horace Greeley without conspicuous retribution, and Ulysses S. Grant cannot now avoid his resentment if he would."

574 "The Crisis of the Republican Party—the Causes of its Danger," The Sun (N.Y.), August 9, 1869.

575 Ibid.

${ }^{576}$ Ibid.

577 "American Political Parties-Their Historical Names and Prominent Leaders," The Sun (N.Y.), June 24, 1869.
} 
Sun editorials explained the paper's opposition to the president weakening of the party. The tenuousness of Republican Party unity drove The Sun to caution the party about the behavior of the executive. The paper warned readers that Grant voters "will feel no special attachment to him or his party" because they "are independent citizens, who never support a party merely for the good it has done." 578 The Sun pointed to these very problems with "corruption" and "folly" that were splitting the group into interminable tribes. The "doctrinaires of the party," the paper explained of former Whigs, Democrats, or Free-Soilers, subordinated all other causes to abolitionism and full equality for former slaves after the passage of the Fifteenth Amendment. The more critical group for Dana remained those "following close behind these" as a "long procession of dissatisfied Republicans." ${ }^{579}$ These latter members of the party of Lincoln were "disgusted with the administration because of its nepotism, its favoritism, the unworthy character of many of its agents, and its disregard of the claims to consideration of distinguished members of the party." 580 One of the paper's evaluations of the Republican Party forewarned that "though the bond which has united these classes to the party is not yet severed, it is seriously weakened, and may snap at the first severe strain." 581 These critiques coincided with Dana's claims that in breaking with the president and his former party he reaffirmed his and newspaper's political independence and commitment to republican virtue.

Dana's analysis of his, and his newspaper's, perceived political and journalistic independence reflects the durability of his republican ideology as a vehicle for opposing the president. The Sun's anti-corruption platform, and lack of financial connection to the major

\footnotetext{
578 "Reconstruction Completed—Its Effect upon the Republican Party," The Sun (N.Y.), February 1, 1870.

${ }^{579}$ Ibid.

${ }^{580}$ Ibid

${ }^{581}$ Ibid.
} 
parties, allowed the paper to position itself as independent, unaligned to either party's patronage orbit. To do this it had to explain that its financial and journalistic independence made it a more reputable evaluator of the Grant administration. Responding to a characterization of the paper as "radical" by a smaller paper, for example, The Sun welcomed the "compliment...all the more because it is true." ${ }^{982}$ "The Sun is Radical," the paper explained, because "it goes to the roots of things," "with the concealed, underlying strata," "not alone the apparent truth, but the real essence and certainty of things." Dana explained that a "Radical" paper "bring $[\mathrm{s}]$ to light the hidden germs of good and expose the lurking poisons and frauds of evil." ${ }^{, 583}$ The allusions to Grantism's corrupting influence stand out here. In the same editorial, Dana's paper anticipated the retort that its editor's anti-corruption drive, and new-found opposition to Grant, resulted from spite or cynicism. Dana's editorial page explained that The Sun "applies to the questions of the day the tests of enduring principle, and not the devices of shifting policy." 584 The enduring set of principles, The Sun's anti-corruption in this instance, illuminate the paper's independence from the patronage orbits of both parties. ${ }^{585}$ Dana insisted that his Sun "is not partisan, and we never trust will be." ${ }^{586}$ In a call to its readers, the editorial reiterated the paper's commitment to honest government and virtuous republican institutions. Dana's paper promised that it "let in the light upon the good deeds and the bad deeds of all parties, heedless whether it hurts or helps either

\footnotetext{
${ }^{582}$ The Sun (N.Y.), June 14, 1869. "Our distinguished friend Mr. J.A. McMaster, who conducts with so much piety and forbearance the Freeman's Journal and Catholic Register, does us the honor to describe The Sun as a Radical journal. This is a compliment that we appreciate all the more because it is true."

${ }^{583}$ The Sun (N.Y.), June 14, 1869.

${ }^{584}$ Ibid.

${ }^{585}$ The Sun (N.Y.), June 14, 1869. "No partisan journal, whether Democratic or Republican, can be Radical," The Sun explained, "for they are all obliged to keep back part of the truth, or to modify it and disguise it, out of regard to the exigencies of party management and the schemes of politicians."

${ }^{586}$ Ibid.
} 
class of intriguers, and careful only of the welfare and the progress of the whole people. ${ }^{, 587}$ The paper popularized a platform committed to broad civil service reform, equality enshrined in law, and self-government for all, whether at the national, state, or municipal levels.

Other examples of Dana's anti-Grantism illustrate that The Sun's fight against corruption contributed to the perception of the paper's independence in opposing the president and establishment politics. One Sun response to an accusation of having "enmity to Gen. Grant" by the Albany Evening Journal in the middle of 1869 highlights this point. The Sun responded to the Journal's indictment of Dana's reputation by reaffirming its own independence and impugning the Journal's support of Grant. ${ }^{588}$ By mid 1869, The Sun's anti-corruption message in New York City had helped propel it leagues above the previously popular Journal, both in terms of circulation and public influence when the Whig politico Thurlow Weed owned it. The Journal remained a strong Republican voice. Weed's protégé George Dawson and assistant editor George W. Demers used it to support the president. The Sun, ascendant in popularity, called this Grant paper "some of the small fry of the press" under "unfortunate management." claim of an anti-Grant bias, The Sun then argued that it, unlike the former Weed paper, was "a thousand times more his friend than the party sycophants who fawn around him." ${ }^{" 590}$ Dana described Republican papers like the Journal as "organs of servility who make it their duty to laud his worst errors as if they were the fruit of the ripest statesmanship.. ${ }^{, 51}$ The Sun avowed it could be both critical and fair, but Grant's allies like Dawson and Demers failed to point out

\footnotetext{
587 "What is True Friendship for General Grant," The Sun (N.Y.), June 28, 1869.

${ }^{588}$ Ibid.

${ }^{589}$ Ibid.

${ }^{590}$ Ibid.

${ }^{591}$ Ibid.
} 
Grantism when they saw it. ${ }^{592}$ Independent papers committed to honest government, The Sun insisted, told the president "most plainly his faults, and well nigh fatal mistakes." $" 593$ They told him when his actions looked corrupt or mismanaged. An independent paper could make a better objective measure, Dana maintained, of "why the President has thus been led wide astray from the noble principles of his inaugural address, and has measurably lost the glory of his military career." ${ }^{994}$ The Sun's attempts to bridge national, state, and local politics in these debates with rival newspapers reflected its editor's ability to transmute his opposition to Grantism to the politics of his neighborhood.

Dana's break with president Grant and the Republican Party are visible parallels between his opposition to federal-level political corruption and bureaucratic abuse at the state and city level. The analogies established between national, state, and municipal political corruption and misgovernment helps contextualize the durability and transportability of Dana's demands for civic virtue. Specifically, in the lead up to the November 1869 state and municipal elections,

592 "Who Is There That Can Be Trusted," The Sun (N.Y.), November 3, 1869. "Gen. Grant has been foolishly persuaded that The Sun was hostile to him. This is an entire mistake. We have always ben his friend, from the time when we saved him from being sent back to Illinois from his canal digging opposite Vicksburg, down to the time when, seizing upon the opportunity afforded by his letter to Mr. Bonner, we vindicated him from the ill-founded but all-pervading and most damaging suspicions of complicity in the Gold Ring." Also see: "The Sun and Gen. Grant," The Sun (N.Y.), October 18, 1869. "Has The Sun treated Gen. Grant fairly? Soon after Gen. Grant became President, he made so many appointments to office of persons who had made large pecuniary donations to him, that he seemed to have adopted the system of bestowing office in return for money. This was a shocking innovation on all former practices and traditions in this country. The whole American people felt it to be such. The Sun gave expression to that feeling. Has there ever been one serious effort, from any quarter, to controvert the views of The Sun on this subject? "We speak of these three points to illustrate the principles of independence and fairness upon which The Sun is conducted. Unlike the party organs, we have no interest to consult but those of the people at large."

593 "What is True Friendship for General Grant," The Sun (N.Y.), June 28, 1869. Also see: "Who Is There That Can Be Trusted," The Sun (N.Y.), November 3, 1869. "Since that, we have endeavored to lift his cause in this State by identifying with it the popular name of Horace Greeley. We have condemned in his administration only such measures as all men at heart condemn — such as the brave Rawlins, his best friend, condemned. Let Gen. Grant learn to discriminate between friends and flatterers, and he will be relieved from his present embarrassment, and will know whom to trust.

${ }^{594}$ Ibid. 
Dana used his opposition to Grant to explain his support of the "independent" candidate for New York State Comptroller, none other than Horace Greeley. Sun editorials noted that Greeley's reputation for honesty, frugality, and political savvy qualified him to be the state's chief financial officer. ${ }^{595}$ They noted that Greeley's political instincts, and combination of republican opinions, could help improve the legislature's reputation for corruption and mismanagement. The Sun's support of Greeley's candidacy aligned a decades-long political alliance on issues of fraud, civil service, and political and journalistic independence. ${ }^{596}$ The paper's editorials defined parts of this political and journalistic independence in both Dana and Greeley's penchant for writing and acting as their beliefs directed, and not where the patronage jobs were offered. Because Greeley stood on an explicitly party-less platform for comptroller against establishment candidates, The Sun interpreted this fight against corruption as helping define Greeley, and the paper's, mutual political independence. The paper's claims in this regard were not without some merit.

The Sun's support for Greeley as an at-large candidate for comptroller in 1869 exemplified the paper's estrangement from main-stream party politics. Historians have argued that Dana's support for Greeley was a joke, ${ }^{597}$ or simply "peculiar." ${ }^{, 598}$ Indeed, Dana in the early

${ }^{595}$ The Sun (N.Y.), November 1, 1869; “Out of Work,” The Sun (N.Y.), November 10, 1869. "No Inquisitorial Tax," The Sun (N.Y.), November 1, 1869.

${ }^{596}$ Not only that, Dana had also supported Greeley's very early attempt to run for Governor against the Tammany candidate in this very election. For The Sun's editorial offering "good wishes" to Greeley's effort to "harmonize the party, now divided into warring squads," see: "A New Candidate-The Conservatives for Horace Greeley," The Sun (N.Y.), June 10, 1868.

${ }^{597}$ Steele, 112. Amos Cummings, one of Dana's managing editors at the time, said that, "Mr. Dana started Greeley's candidacy for the Presidency merely as a joke. I warned him that his efforts would be taken seriously, but up to the very morning of the day the Cincinnati Convention met, he insisted that Greeley had no chance of getting a nomination. Of course, he had to support him, as he wanted to defeat Grant, but he must have known it was no use." (Cummings typescript, James Harrison Wilson Collection, Historical Society of Delaware); Rosebault, When Dana Was The Sun, 200 - 205.

${ }^{598}$ Ibid, $112-115$. The characterization as peculiar is Steele's own, and of Dana's later endorsement of Greeley for President in 1872. Unfortunately, Steele does not spend much time describing Dana's analysis of Greeley's earlier candidacies for State Comptroller, and later Governor, that this section is covering. 
1870s noted that he had a complicated relationship with his former boss, but had also remained ideologically close to Greeley, and thought that he could be a good political representative of the people in this period of machine-style politics. ${ }^{599}$ This dissertation, though, finds that Dana's commitment to Greeley's candidacies for comptroller and governor appear ideologically consistent with his past and quite genuine (even if intentionally done as a "long shot" as some of Dana's own employees describe of his intentions). ${ }^{600}$ When one appreciates how long, and consistently, Dana supported Greeley's repeated attempts to get elected between 1868 and 1872, and how close Greeley's candidacies reflected his broader political goals, it is easier to see how Dana's treatment of Greeley in The Sun was sufficiently authentic. Dana cited his decades-long relationship with Greeley to readers to recommend his honest, and humble government, and could unify the Republican Party, or create a better one. Scholars rarely describe Dana's focus on Greeley's serious candidacies for these state elections in 1869 and 1870, or how Dana viewed Greeley as a real check on the potential power of Tweedism and Grantism. Greeley had republican chops. Dana's support for Greeley as New York State comptroller magnified the way that corruption and mismanagement in the White House and Congress had influenced Dana's stand against crooked party politics nationwide. Editorials from the months before the November 2nd elections show The Sun arguing that Grant's patronage orbit too closely pulled in papers like

\footnotetext{
599 There are sources that do equate Dana's support to Greeley as being genuine in this manner. The best representative of this class includes Dana's first biographer James Harrison Wilson in The Life of Charles A. Dana, 428. "(Dana) and those who stood with him, believed thoroughly in the necessity of taking the government out of the hands of the Republican Party, as well as in the honesty and capacity of Greeley, and spared no effort to make the country believe in him as well." To the claims that Dana did not take Greeley seriously, Wilson says the following, "it has been suggested that Dana's earlier advocacy of "the Philosopher of the Tribune' began in a spirit of fun and that it could not be sincere, and that the campaign for his election was hopeless from the start. To this Dana paid little attention till after the campaign had ended in Greeley's defeat and death." Wilson also provided the following regarding Dana's place in supporting Greeley, and the larger movement to reform the party: "To such as look below the surface, Dana's course at this time appears to have been not only genuine and disinterested, but exceedingly useful to the country at large." Unfortunately, sentiments of this sort sentiments don't appear in the more recent treatments of Dana's support for Greeley in the late 1860s and early 1870s.
}

${ }^{600}$ Rosebault, When Dana Was The Sun, 199 - 201. 
The New York Times, the Newark Journal, the Albany Journal, the Troy Times, the Rochester Democrat, and the Rochester Chronicle. As a result, these organs understood Greeley's attraction to voters and readers alike. ${ }^{601}$ As for itself, The Sun's editorial page boldly declared that it "cares not a copper for the Republican ticket as such." ${ }^{\circ 02}$ The paper opposed, for instance, many on the Republican ticket, such as Henry Smith, running for supervisor of New York City. ${ }^{603}$ The Sun affirmed that its general critique of political malpractice and anti-republicanism nationwide proved that it "is not a party hack, but an independent journal."604 "Unlike the party organs, we have no interest to consult but those of the people at large," the paper wrote. ${ }^{605}$ After all, The Sun argued, the people only desired that "honest, independent, incorruptible men should be elected to office." 606 "Grantism" soured Dana's opinion of party politics, especially within the Republican Party, no matter whether nationally or locally. At every turn, the paper's encountering of resistance to its support of Greeley reinforced its perception of independence by political establishment's embrace of government corruption. Dana's insistence on the paper's political independence, and anti-corruption stance, translated into its call that Greeley should receive bipartisan support.

Dana often used the Greeley candidacy to explain the bipartisan nature of The Sun's anticorruption platform. "The nomination of Horace Greeley for Comptroller of the State has aroused

${ }^{601}$ The Sun (N.Y.), November 1, 1869. "Such Republican journals as the New York Times, the Albany Journal, and the Rochester Democrat are giving Mr. Greeley only an apparent support, while they are more than suspected of desiring his defeat. This makes it the more necessary that the real friends and admirers of the great journalist should make an enthusiastic rally in his behalf. The independent press especially should hang their banners on the outward wall, inscribed, "We fight mit Greeley."'

602 “The Reason Why,” The Sun (N.Y.), November 1, 1869.

603 "Who Shall Be Supervisor," The Sun (N.Y.), November 1, 1869.

604 “The Reason Why,” The Sun (N.Y.), November 1, 1869.

605 “The Sun and Gen. Grant,” The Sun (N.Y.), October 18, 1869.

606 “The Reason Why,” The Sun (N.Y.), November 1, 1869. 
a popular enthusiasm in his behalf which knows no party bounds," the paper maintained the day before the election. ${ }^{607}$ Refreshing its consistent hopes for bipartisanship, The Sun insisted that this independence should attract free-thinking New York Democrats to join Republicans and independents to vote for Greeley. The definition of independence the paper employed matched its uses in other contexts: for instance, New York City Democrats who voted against their party, or the establishment part of their party, based on principle, counted as independent. The Sun maintained that New York City had many of these voters considering the reported divisions within the city and state Democratic Party. The paper pointed to the traditionally Democratic New York Evening News' support for Greeley as such a case. The "independent Democratic" Evening News, as The Sun called it, joined Dana's paper in printing election day ballots that included straight Democratic selections other than Greeley for Comptroller. ${ }^{608}$ Calling it the "Horace Greeley Democratic ticket," Sun editorials argued that it knew better than Republican papers of Greeley's cross-over appeal within the city's typically Democratic working class neighborhoods. ${ }^{609}$

Dana's argument that The Sun's booming popularity grew, in part, from the paper's republican perspective and independent stance against corruption and party influence, continues

607 "The Popular Rally for Horace Greeley," The Sun (N.Y.), November 1, 1869. "The nomination of Horace Greeley for Comptroller of the State has aroused a popular enthusiasm in his behalf which knows no party bounds. To meet the wishes of independent Democrats in this adjoining counties who intend to vote for Mr. Greeley, The Sun has printed regular Democratic tickets of the counties of New York, Kings, Queens, Suffolk, and Richmond, with the name of Mr. Greeley for Comptroller. Copies of these ballots may be obtained, by individuals or committeemen, at the publication offices of The Sun, on application in person, by letter, or by telegraph." Also see: The Sun (N.Y.), November 1, 1869. "Democrats of New York who intend to vote for Horace Greeley, and have not yet procured ballots, may cut them out of the Evening News to-night. We fight mit Greeley."

${ }^{608}$ Ibid. Also see: The Sun (N.Y.), November 1, 1869; “The Returns,” The Sun (N.Y.), November 2, 1869.

609 “The Returns," The Sun (N.Y.), November 2, 1869. Also see: "Cut the Horace Greeley Democratic Ticket Room our Advertising Columns this Morning, and Vote It!," "It Goes Everywhere," The Sun (N.Y.), November 1, 1869. This article chided its rival paper, noting that, "the New York Times is too mean to come out for Horace Greeley"; The Sun (N.Y.), November 1, 1869. These articles emphasized that Greeley is the man both for the educated, and the "unlettered classes." 
to show the durability and extent of Dana's commitments against government malpractice. The paper noted for readers the dramatic rise in The Sun's circulation for 1869 into mid-1870 from around 35,435 in January 1869 to about 116,500 in July $1870 .{ }^{610}$ In articles comparing the circulation of The Sun with the other major New York City papers, Dana explained that the paper's definitive circulation lead in New York City (the world's leading newspaper market) existed because of its stubborn opposition to corruption and the support for Greeley, among other issues. For instance, editorials from the week before the election show Dana comparing the returns from the city's major news dealers as proof that his pre-election coverage outpaced his local, establishment, rivals at the World, Times, and Herald. One late October 1869 count from eighteen New York City newspaper distributors by The Sun revealed the paper sold 5,790 copies that day versus the 465 individual receipts of the Republican-leaning Times and the Democratfriendly World.$^{611}$ The paper insisted that its position against corruption in government, and within New York city and state, had not been "controverted" by his rival papers, and thus

${ }^{610}$ The Sun (N.Y.), July 27, 1870.

${ }^{611}$ For another example of the paper doing this during this election, see: The Sun (N.Y.), November 1, 1869. In the days before the election, the paper took a count from four of the city's notable news dealers. The reports came back with The Sun selling 576 papers, the Herald 297, the Tribune 77, and the World at 58. The paper continued the small un-named editorial asking "the World and Times" to "please copy the foregoing statistics." For a place where the paper called out Marble's World, see: The Sun (N.Y.), October 20, 1869 and The Sun (N.Y.), October 25, 1869. "Poor Mr. Manton Marble of the World is not so much to blame, perhaps, for adopting the style of the blackguard and resorting to abusive epithets as the only mode of expressing his ideas. The contrast between the declining popularity of the inaccurate, pedantic, tedious sheet which he conducts, and the ever-growing favor of the accurate, brilliant, interesting Sun, is the reason why he breaks out in improper language. For instance, within the past few days we have published reports that have been spontaneously sent us of the daily sales of morning papers by eighteen newsmen, with the name and address of each. These eighteen newsmen, all them in this city and the immediate vicinity, sell every morning: Sun: 5,790; Times, 465; World, 433." Also see: “It Goes Everywhere," The Sun (N.Y.), November 1, 1869. "The New York Times says, in language whose coarseness we will not copy, that The Sun circulates more than other papers in the most disreputable places." "On this subject the Times undoubtedly speaks from personal observation, and on this account there could be no better authority." "We knew before that The Sun went everywhere else; and now we learn this interesting fact from the editors of the Times about its circulation in such quarters." "We hope that all those who read it, including the Times men, profit by it, and that, like us, they will all fight mit Greeley." 
encouraged The Sun's boom in popularity. ${ }^{612}$ The results of the election buoyed Dana's belief that the support of honest government within the pages of The Sun had gained traction. Greeley lost the election, but The Sun saw his candidate's vote count as vindication that its anti-Grant, proGreeley independent platform gripping a major segment of the electorate. Greeley's showing at the polls, despite the defeat he eventually suffered, encouraged Dana to argue that he and his independent allies in the press made Greeley's competitive showing compelling for the future. "It was all done by the free, independent press," The Sun wrote. The paper noted that many Democrats had in fact decided to vote for Greeley, "in accordance with The Sun's advice."613 Dana used the weight of The Sun's increasing circulation in 1869 as proof of his ability to boost political candidates like Greeley and the attractiveness of perceived political independence. ${ }^{614}$ "That is the power which has now put Horace Greeley's vote so far ahead," the paper insisted. ${ }^{615}$

612 “The Sun and Gen. Grant," The Sun (N.Y.), October 18, 1869.

${ }^{613}$ The Sun (N.Y.), November 8, 1869. "With his usual blundering, the arithmetic man of the World attempts to account for the large vote given in this city to Horace Greeley by suggesting that Mr. Greeley had repeaters at work for him. In support of his preposterous idea he cites the returns from fourteen Democratic wards, showing 44,639 votes from Nelson, against 22,119 for Sigel, while Allen had by 42,758 against Greeley's 24,144. It is as plain from these figures as the nose on Moses Marble's face, that 2,000 good Democrats who voted for Nelson for Secretary of State, also voted for Horace Greeley for Comptroller, instead of Allen, in accordance with The Sun's advice."

${ }^{614}$ In one fanciful editorial, a day after the election, Dana argued that the impressive numbers that reformers like Greeley and Franz Sigel received suggested that he made have had something to do with it, and could possible bump Greeley to Governor in 1870. See: "Horace Greeley for Governor," The Sun (N.Y.), November 6, 1869. "It was all done by the free, independent press. That is the power which has now put Horace Greeley's vote so far ahead, and that will lead the way in making him Governor in $1870 . "$

615 "Horace Greeley for Governor," The Sun (N.Y.), November 6, 1869. Dana envisioned his support for Greeley as part of a broader, but not always well defined "independent party" that The Sun led. The Returns," The Sun (N.Y.), November 2, 1869. "As fast as the votes are canvassed they will be forwarded to The Sun office and displayed on transparencies from our windows this evening. We hope by this means to be able to announce before 10 AM that Mr. Greeley's has run largely ahead of his ticket in this city, and that the Tammany Ring has been smashed by the independent party of The Sun... Remember this: Vote for Horace Greeley to-day, and by The Sun to-morrow, which shines for all...Democratic ballots, with the name Horace Greeley for Comptroller, can be procured from at The Sun office to-day." Also see: "The Great Democratic Movement," The Sun (N.Y.), November 2, 1869; "The Office and the Man," The Sun (N.Y.), November 2, 1869; "Watch the Canvass," The Sun (N.Y.), November 2, 1869. 
Perhaps the influence of the independent press, The Sun explained, "could help lead the way in making him Governor in 1870." ${ }^{\circ 16}$

The persistence of Dana's opposition to corruption in city and state politics remained a feature of The Sun's political coverage after Greeley's November defeat. It especially extended into the early 1870 New York City charter debate over municipal services that followed the next spring. Tammany had dominated the election that Greeley lost, and thus won the right to oversee the debate within the state legislature regarding the charter offered by the state to the city. This victory showed Dana that Tammany Hall could replace August Belmont as the leader of the Democratic Party, and could potentially pull money-hungry Republicans to his side with promises of patronage and legislation. This would create an insurmountable supermajority in the state legislature to rubber stamp Tweed's desires. Tweedism's comprehensive overwhelming of the Democratic Party in the months after their victory in November elicited alarm from Dana and The Sun. The paper decried the corruption used by Tammany Hall to dismantle the influence of the Democratic Party chairman August Belmont's political machine, the Manhattan Club, within the party. ${ }^{617}$ The Sun reported on Tammany's successful seduction of New York Republicans in the legislature with promises of pork barrel projects. Tammany Hall now had free reign to lessen the restrictions placed upon its own interests in New York City. The Sun's position within the debate features the fifth source of Dana's break with the Grantism, Tweedism, and the mainstream parties: the increasing political corruption of New York State "Ring Republicans" in early to mid-1870. The failure of The Sun's local anti-corruption campaigns in November of 1869 , and for Greeley, emboldened the paper's continued use of republican themes to criticize the state of New York politics.

\footnotetext{
616 “Horace Greeley for Governor,” The Sun (N.Y.), November 6, 1869.

617 “The Tammany Ring Sneaking Away from the Contest," The Sun (N.Y.), March 29, 1870.
} 
The subsequent passage of the "Tweed Charter" heightened The Sun's commitment to combating perceived public corruption. The situation's resemblance to the scandals in the federal government encouraged Dana to continue equating his opposition to Grantism to New York's problems with Tweedism. Thus, Dana's paper insisted that Tammany's favored plan for the charter helped keep the major parties closely tied it into the political machine's orbit. ${ }^{618}$ The paper applauded some parts of the new government's efforts, however. The Sun supported their plan to reform control over the city to city legislators, for example. Soon after, nonetheless, the paper argued that Tammany's orbit continued to grow after the election in ways that were predictably dangerous. ${ }^{619}$ The Sun accused Tweed of collusion with New York Republicans to gain legislative support for a Tammany-friendly charter that alienated various Democratic groups hoping for a different arrangement with the state. ${ }^{620}$ Dana's paper argued that the alliance Tammany created with Republican legislators resulted in a proposed charter that failed to consider many of the critical civil service and voting reforms The Sun hoped would curb future corruption in New York City and Albany. ${ }^{621}$ Not only that, this alliance gave Tammany and its allies direct control over

${ }^{618}$ The Sun described Tammany and the Republican "Ring's" political orbit as, the "slough of disrepute and imbecility by pretenders, charlatans, and corruptionists."; "Shall we have Honest Elections?," The Sun (N.Y.), February 28, 1870. Also see: "The Tammany Ring Sneaking Away from the Contest," The Sun (N.Y.), March 29, 1870. In a discussion of the meeting for the Democratic General Committee convened to discuss the charter, the Sun editorial noted that non-Tammany Democrats "found the doors closed against them, and guarded by a thousand policemen sent there by the Republic Commissioners, who are leagued with the Ring...Henry Smith and Benjamin F. Manierre attended to its enforcement."

619 “The New Era for the New York Democracy,” The Sun (N.Y.), November 10, 1869.

${ }^{620}$ Ibid.

621 "Two Essential Points in any New Charter," The Sun (N.Y.), March 28, 1870. "Both factions of the Democratic Party now contending for the control of the city profess an ardent desire to give us a good charter and a pure and efficient government. The sincerity of their professions will be tested by the practical measures they adopt... It may be set down as a fundamental proposition that no new charter will be the slightest improvement over the present one, unless it provides for choosing, as often at least as once in two years, every one of our principal city and county officers at a single election. These officers must be responsible to the people, and they must be responsible in a body and not in detail so that when their administration outrages the rights of the people in any way, a clean sweep may be made of them. Now, any particular corrupt or incompetent officeholder by himself does not excite sufficient indignation to bring out a full vote of condemnation, and the Ring, by scattering the election of its members along at different 
the city's finances and tax policy, ${ }^{622}$ and enhanced the power of the Tammany-allied Board of Supervisors and Mayor's office. ${ }^{623}$ The situation with corruption had gotten worse. The centrality of the patronage system to New Yorker's attachment to their political parties reminded Dana of the corrupt system in Washington D.C. The party despotism and organization mode of politics that characterized Grant's national party had also animated Tammany Hall to condense power in a similar fashion in New York. The paper argued that the new charter doled out patronage to Tammany supporters in both the state Democrat and Republican parties like "Grantism" did nationally. The election pulled in "some for the least worthy among the unclean copartners on the Republican side... in return for their personal services in securing the passage of this charter," the

periods, escapes justice. Let us therefore have one general election, and no lapping of terms of office one upon another... In the next place, this general election must by all means be held in the spring, so as to separate it as far as possible from the State and national elections in November. Of course, the nominations made will be made by parties based on State and national politics, but the fervor of party spirit kindled by an exciting contest on great political issues will be wanting, and the people will make their choice more calmly. The consideration of this fact will compel both parties to put up their best candidates, and there will be more chance for splits and combination, by the aid of which to defeat rogues and elect honest and capable men. The merits of each candidate, too, will be more carefully weighed than they can be in the hurly-burly of a November election... If these two points are not secured, there will be little use in tinkering the charter in other respects. If our city government is not to be compelled to come before our citizens for judgment as a body, at frequent intervals, it is in vain to enlarge or restrict the powers of this or that individual official. Rings will continue to be formed and maintained, and it will be impossible to shake off their grip. And if our city and county officers are to continue to be elected as they now are, under cover of exciting State and national issues, the struggle against the trickery of primary meetings and the adroit manipulation of party machinery will be a hopeless one."

622 "The New Charter and the Tax Levies," The Sun (N.Y.), February 7, 1870.

623 “Are There any Honest Republicans in the State Senate?," The Sun (N.Y.), April 4, 1870. According to the reporting of The Sun, the new charter proposals would preserve the existing Board of Supervisors of the city (currently staffed principally by Tammany men), push back elections for Mayor keeping Tammany support A. Oakey Hall in office, give the sitting mayor the power of appointing city Commissioners and Heads of Departments, hold sway over four appointees to a new oversight board independent of the city's elected Common Council, as well as control the city's finances. Continuing its assault on the charter reforms, the paper explained that "there can be no reform in a scheme which sustains the hybrid Board of Supervisors, and in which the present Mayor is not only retained in office but endowed with immense and unlimited power." Also see: "The New York Democrats-Who is Sufficient for These Things?," The Sun (N.Y.), January 1, 1870; "Is He a Coward," The Sun (N.Y.), April 8, 1870; "Mr. O'Hall's Appointments," The Sun (N.Y.), April 11, 1870. "The Ring is in full possession of the city." 
paper wrote. ${ }^{624}$ The paper could not help but judge that as a vehicle for honest government, the Tweed charter was a "sham and a fraud." 625

Dana's plea for the Republicans in the New York State Senate to oppose Tammany's charter proposal further demonstrates how far Dana's enduring anti-corruption platform had taken the paper by 1870 . Dana's editorials noted that the previous November's electoral losses left a small number of allies of independent Democrats to oppose the proposed New York City charter with the state legislature in early $1870 .^{626}$ This redoubled Dana's commitment to his platform for honest government. Unrepentant in his anti-corruption stance, the editor continued to emphasize that the few legislators representing the "Young Democracy" in the legislature "stand firm" against the corruption embodied by the Tammany "Ring's" proposals for the charter. ${ }^{627}$ This dedication to supporting anti-corruption paralleled his stance against Grantism and Tweedism. ${ }^{628}$

624 "Are There any Honest Republicans in the State Senate?," The Sun (N.Y.), April 4, 1870. For another sample of Dana explicitly accusing Tammany and Tweed of explicit election buying, see: New York Sun, April 2, 1870.

${ }^{625}$ Ibid.

626 "The New York Democrats—Who is Sufficient for These Things?," The Sun (N.Y.), January 1, 1870. "Are there any Honest Republicans in the State Senate?," The Sun (N.Y.), April 4, 1870. "There are in the Senate thirteen Ring Democrats, five Young Democrats, and fourteen Republicans. The Ring cannot carry its charter without at least four Republican votes. If the Republicans refuse to be seduced ether by bribes of money or by the influence of corrupt office-seekers, they can compel the enactment of such amendments of the charter and the passage of such an election law as will give to the city exemption from official robbery, and to the Republican Party a fair chance of carrying future State elections. The alternative is before the Senators; let them take their choice."

${ }^{627}$ For more on the "Young Republican" platform that Dana and The Sun supported see: "Now for the Republicans," The Sun (N.Y.), April 4, 1870. "The Young Democracy in the Senate will stand firm. They will insist on amending the Tweed charter substantially as follows: I No man shall hold more than one office; II All important city officers shall hold their places for identical terms, being elected together and going out of office together; III There shall be no Board of Supervisors; the Alderman shall perform the functions of Supervisors; IV All city elections shall be held in the next Spring; and at the first one, in May next. The entire city government shall be reconstructed. For more on Dana's argument that the only reason Tammany pressed so hard for a new charter, see: The Sun (N.Y.), February 22, 1870. "The fact is, the Ring are weary of the conflict, and would be glad to retire with their stealings if they could only be assured that they might enjoy them with impunity. But they fear the future.

628 "Republicans and Democrats Alike Corrupt," The Sun (N.Y.), December 23, 1869. 
This year-long emphasis of state politics over national politics exhibited a growing distrust of Tweed's influence within the Republican Party which translated to his coverage of the New York state party. Thus Dana's paper argued that, like its national manifestation, the New York Republican Party remained "so blindly corrupt as to overlook the public interests in their eager pursuit of personal wages." ${ }^{\prime 29}$ "The vast expenditure the Ring have thus far made to corrupt legislation and nullify the popular will," The Sun argued. ${ }^{630}$ Dana's paper implored state Republicans to renounce their previous alliance with Tammany even as many came out in support of the proposed charter in 1870, "with all its atrocities." ${ }^{931}$ The Sun implored state Republicans to help amend the charter to "secure good and honest government to this unfortunate city," not unlike its similar calls for the administration to curb Grantism. ${ }^{632}$ Not doing so, Dana's paper wrote, tied the state Republicans to Tweedism and Grantism; a "Ring of public robbers bent upon riching themselves out of the taxpayers." 633 "The Republican Senator who votes" for the Tweedinfluenced charter, the paper wrote, "betrays his party." 634 The Sun's pleas again could not turn the tide against "Tweedism," and thus "Grantism."

The Sun's reaction to eventual passage of the so-called "Tweed Charter" with considerable Republican support affirmed Dana's claims that the Republican Party had changed. The result crystallized The Sun's argument that these systems of political manipulation and

\footnotetext{
629 "Are There any Honest Republicans in the State Senate?," The Sun (N.Y.), April 4, 1870; Also see, "Is it Constitutional?," The Sun (N.Y.), April 9, 1870. "Why are repeating and illegal voting to be expressly permitted at the first election under the new charter, and ever afterward forbidden? Why are party challengers to be protected at the polls at future elections, but not at this first one?"

630 “Are There Any Honest Republicans in the State Senate?," The Sun (N.Y.), April 4, 1870.

631 "Now For the Republicans," The Sun (N.Y.), April 4, 1870.

${ }^{632}$ Ibid.

${ }^{633}$ Ibid.

${ }^{634}$ The Sun (N.Y.), April 2, 1870.
} 
corruption required opposition nationwide. "Corruption rather than cowardice, venality rather than stupidity" sunk the charter, The 'Sun groaned. ${ }^{635}$ Dana's paper argued that the new charter was "abandoned to the Democrats in pursuance of a corrupt bargain, or series of bargains whereby some of the Republicans in the Legislature received cash." It argued that some Republicans specifically "received promises of Democratic support for their pet schemes, such as an appropriation of a million and half of dollars to the Midland Railroad..." ${ }^{636}$ The parallels drawn by the paper between the Tammany Ring's corruption to Grantism reinforced Dana's opposition to bureaucratic abuse within the Republican Party. Thus after the charter vote, The Sun argued that New York Republicans "devised and carried through this stupid, dastardly, disgraceful surrender of their party to the Tammany Democracy." ${ }^{637}$ In the same period The Sun called the president's "civil administration" a "failure—a dreadful, deplorable, shameful failure. ${ }^{938}$ Dana's perception of the saturation of corruption within the American political order encouraged his turn against Grant and any candidate, elected official, and party that fostered highlevel government corruption and bureaucratic abuse.

635 "Mr. Littlejohn and the Republican Nomination for Governor," The Sun (N.Y.), May 23, 1870. For an example of another of The Sun's related analysis of the infiltration of Tammany in the city's politics, see: "The Tammany Ring Sneaking Away from the Contest," The Sun (N.Y.), March 29, 1870. “A reorganization of the party is promised. Northing is more necessary. But it should be a reorganization which should insure to the masses perfect freedom of opinion and of action. It should put an end to the monopoly of power in the hands of Peter B. Sweeny and William B. Tweed, and give a free chance to every honest and independent Democrat. Against any other reorganization the only decent course is uncompromising rebellion."

${ }^{636}$ Ibid.

${ }^{637}$ Ibid.

638 "A Few Words to a Few Fools," The Sun (N.Y.), June 20, 1870. "It is alleged that Mr. Dana wanted the New York Custom House. Bah! What if he did, or what if he didn't? Does that affect, one or the other, the great historical truth that Grant's civil administration is a failure-a dreadful, deplorable, shameful failure? How ridiculous!; The Sun (N.Y.), March 28, 1870; "Are There any Honest Republicans in the State Senate?," The Sun (N.Y.), April 4, 1870. 


\section{$\underline{\text { Conclusion }}$}

This chapter has argued that Dana's re-evaluation of the president and the political order had more to do with principles deriving from his experiences and ideas, than from personal rivalry. The former grew from the commitments to ideas of community centered-government, religious moderation, ideological diversity, ethnic inclusivity, widespread ownership of property, the harmony of competing classes and interests, political liberty and civic virtue that Dana had developed prior to purchasing The Sun in 1868. The claim that Dana acted only from spite over failed attempts to get lucrative government jobs dominated the characterization of his life. This chapter has attempted to present a multi-layered picture of Dana's opposition to the government corruption and maladministration of his time as a more convincing explanation for this seemingly drastic turn in Dana's life and thought. It has sought to show that the development of an anticorruption platform, and specific interpretation of the purpose of politics and political parties, were integral to almost every stage of his early life. By initially presenting this early context of Dana's commitment to republican values, the chapter attempts to show that Dana's later turn on the president had deep intellectual connections to his long-term thought. The White House's early performance, and close association with scandal, corruption, and maladministration entirely surprised Dana. The onset of Grantism, of the Republican Party's organizational mode during Reconstruction, startled Dana to the point of using his paper to estrange himself from many of his earlier political allies including the president. The chapter used some of The Sun editorial page's favorite examples of poor performance in the federal government to show the depth of Dana's anti-corruption message. The chapter unpacked Dana's sense of his and his newspaper's political independence and ideological republicanism as being the explanation for its rise to the top of the city circulation charts. It shows that the paper used the term independent to describe individuals, politicians, parties, or newspapers who opposed corruption, political despotism, the organization mode of the new political order, and machine politics in ways that it approved of. On the national 
level, Dana convincingly maintained that his ability, and willingness, to indict his former friends, party leadership (indeed, or other parties) on issues like corruption made him a legitimate voice of independent political thought in the United States. The chapter reinforces this position by showing the parallels between Dana and The Sun's republican opposition to corruption in New York state and city politics. Dana's opposition to Tammany Hall and their allies the Republican "ring" is contrasted with support for independent movements like the Young Democracy and candidates like Horace Greeley. The chapter attempted to show Dana's, and his paper's, durable and consistent commitment to fighting corruption at all levels. The paper's recurring use of similar language, themes, and references further connected the paper's concomitant fights against party despotism. This chapter has attempted to take Dana's words, and those of his newspaper, at face value, analyzing the process whereby the editorial pages of The Sun embarked what appeared to look like a drastic change of course against Grant. This chapter also attempts to present the case as Dana's Sun saw it. That is, it was not that Dana's republican principles underwent drastic transformations, or had been cheapened after Grant's election with his bitter sense of disappointment, but rather that everyone else's moral and political compass had shifted. The Sun's circulation rise to the pinnacle of circulation in the same period shows that many others saw things as Dana did. 


\section{CHAPTER FIVE}

\section{REJECTING GRANT'S FOREIGN POLICY TOWARD THE CUBAN REVOLUTION}

$$
\text { (1868 - MID-1870) }
$$

"The United States [stands] better able than ever to enlarge the domain of republicanism by cordially supporting an American State in its attempt to overthrow the tyrannical rule of Europe."

— “Aid and Comfort to Spanish Slavery," The Sun (N.Y.), July 8, 1869.

Dana's public demands for republican government guided by civic virtue stood in sharp contrast to his perception of the Grant White House. The Sun's analysis of ethics violations and corruption in the Grant administration helped gain Dana's newspaper a wide readership. Claims of maladministration in domestic politics were not the only ones informing Dana's change of heart, though. In young adulthood Dana had shown a consistent tendency to use a transatlantic perspective to analyze American political economy. This continued most vividly in his response to the Cuban revolution that broke out in 1868 simultaneously with Grant's presidential campaign that especially agitated his first term in office. This chapter analyzes how the White House's Cuba policy offended Dana's republican scruples just as the government's negative ethical reputation had in the first fifteen months of Grant's presidency. It begins with an introduction to the Cuban revolt against Spain. Next it recounts the White House's response to these events, and finally, it describes Dana's interpretation of the revolution and disappointed expectations for Grant's foreign policy. By the end of the chapter, it should be clear that Dana's sudden opposition to Grant's program arose from both domestic and foreign policy issues. Dana became, by the middle of 1870, a hardened member of the opposition to Grant and the Republican Party because of its position against American intervention in Cuba, and his transatlantic understanding of republicanism. 


\section{The Ten Years War}

Cuba is unique in Latin American history for many reasons. Not least, it alone remained loyal to Madrid when other Latin American peoples revolted at the beginning of the nineteenth century. ${ }^{639}$ If its disengagement from Spain came late, it came fitfully. One effort at independence - the Ten Years War (or la Guerra Grande; Guerra de los Diez Años), the one critical to the Grant administration, failed with Cuban independence only being achieved a generation later with considerable transatlantic assistance - and American intervention. ${ }^{640}$ The Spanish-American War of 1898 marked the end of one chapter, with the revolution of 1959 and the Castro dictatorship culminating the century-long upheaval. ${ }^{641}$ Historians have chronicled each of these episodes, although the first, unsuccessful episode one has attracted the least attention. ${ }^{642}$ The Ten Years War began in October 1868. On the tenth of that month, Carlos Manuel de Céspedes, ${ }^{643}$ from his

${ }^{639}$ For more on the 1820 s and 30s Spanish-American wars of independence, and their connection to American liberalism and republicanism, see: Janet Polasky, Revolutions without Borders: The Call to Liberty in the Atlantic World (New Haven: Yale University Press, 2016); John Lynch, The SpanishAmerican Revolutions, 1818 - 1826 (New York: W.W. Norton \& Company, 1986).

${ }^{640}$ Bonnie M. Miller, From Liberation to Conquest: The Visual and Popular Cultures of the SpanishAmerican War of 1898 (Amherst: University of Massachusetts Press, 2012); Thomas D. Schoonover, Uncle Sam's War and the Origins of Globalization (Lexington: The University Press of Kentucky, 2013); Angel Smith and Emma Aurora Dávila Cox, The Crisis of 1898: Colonial Redistribution and Nationalist Mobilization (New York: St. Martin's Press, 1999); David F. Trask, The War With Spain (Lincoln: University of Nebraska Press, 1981).

${ }^{641}$ For some of the most recent treatments of the revolution, see: Marifeli Pérez-Stable, The Cuban Revolution: Origins, Course and Legacy (New York: Oxford University Press, 2012); Joaquin Roy, The Cuban Revolution (1959 - 2009): Relations with Spain, the European Union and the United States (New York: Palgrave MacMillan, 2009); Teo A. Babun and Victor Andrew Triay, The Cuban Revolution: Years of Promise (Gainesville: University Press of Florida, 2005); Geraldine Lievesley, The Cuban Revolution: Past, Present, and Future Perspectives (New York: Palgrave Macmillan, 2004).

${ }^{642}$ Stephen McCullough, "Foreshadowing of Informal Empire: Ulysses S. Grant and Hamilton Fish's Caribbean Policy, 1869 - 1877," (PhD. diss., University of Alabama, 2007); Vanessa Michelle Ziegler, “"The Revolt of "the Ever-Faithful Isle': The Ten Years' War in Cuba, 1868 - 1878," (PhD. diss., University of California, Santa Barbara, 2007).

${ }^{643}$ For more on Céspedes' remembrance of this period, see: Carlos Manuel de Céspedes, Escritos, ed. Fernando Portuondo, vol. 1 (Havana: Editorial de Ciencias Sociales, 1974). 
plantation in Yara, Oriente Province, Cuba, announced the start of a revolution to bring about Cuban independence - "el Grito de Yara."

The causes of the Cuban rebellion against Spain were varied. Both Spanish and Cuban politics in the 1860 s were especially complicated. Spanish policy towards Cuba dating from the $18^{\text {th }}$ century - high taxes on production and trade, imposition of slavery, lack of consistent representation in the Spanish national assembly known as the Cortes, and forced payments toward Spanish colonial wars as in the Dominican Republic between 1861 and $1865^{645}$ - aroused working and middle-class Cubans to revolt in October 1868. The Spanish Revolution of 1868 did not bring reforms Cuban creoles believed were due them. For years prior, the Cortes had entertained discussions and recommendations for improved relations with Cuba and Puerto Rico. Progressive forums like the Junta de Información de Ultramar (Overseas), created in 1865 to advise the Cortes, recommended liberalizing Spanish policy towards the Caribbean. ${ }^{646}$ Members of the Cuban Reformist party formed in the same year - individuals who would join Céspedes to revolt three years later - dominated the Junta Ultramar, and enjoyed the support of popular newspapers in Cuba like El Síglo. ${ }^{647}$ A conservative shift in Spanish policy in February and

\footnotetext{
${ }^{644}$ For more on the start of the war, see: Enrique Collazo, Desde Yara Hasta el Zanjón: Apuntaciones Históricas (Havana: Instituto del Libro, 1967).

${ }^{645}$ James W. Cortada, "A Case of International Rivalry in Latin America: Spain's Occupation of Santo Domingo, 1853-1865," Revista de Historia de América 82 (July-December, 1976); “Antecedentes Económicos de la Guerra de los Diez Años," Economia y Desarollo 13 (September - October, 1972): 155 162; Pérez, Cuba: Between Reform and Revolution (Oxford: Oxford University Press, 1988), 120.

${ }^{646}$ For more on the Junta de Información de Ultramar, see: Información Sobre Reformas en Cuba y Puerto Rico, volume I and II (New York: Hallet \& Breen, 1867). Also see: Ziegler, "The Revolt of 'the Ever Faithful Isle," 12, 100-122; Domingo Dulce, Informe presentado por el Excmo. Se. D. Domingo Dulce, Marqués de Catellflorita, al Ministro de Ultramar en Enero de 1867 (Madrid, 1867); René González Barrios, Los Capitanes Generals en Cuba (1868 -1878) (Havana: Ediciones Verde Olivo, 1999). For more on the Cuban labor movement, and its influence in these movements for reform, see: Joan Casanovas, "The Cuban Labor Movement of the 1860s and Spain's Search for a New Colonial Policy," Cuban Studies, 25 (1995): $83-99$.

${ }^{647}$ Ibid.
} 
October 1867 - again raising taxes on Cuban economic property, production, and trade enflamed Cubans in eastern and central Cuba in revolt the following year. ${ }^{648}$ In its own way the victory of the Union during the American Civil War provided a model for the Cubans of the vitality of abolitionist republics. According to historians Ada Ferrer and Louis Perez the Cubans actively connected their efforts with the nationalist trends of the nineteenth century. ${ }^{649}$ Ferrer notes that the Cuban version of abolition — which adopted a "gradual" approach from 1869 - 70 — muddies the exact parallel. ${ }^{650}$ The rebels aim for eventual abolition nevertheless attracted

American support for a new republican neighbor as an improvement over Spanish rule in the Caribbean. ${ }^{651}$ Cuban historian Gerald Poyo argues that the Cuban-American separatist leadership

${ }^{648}$ Arthur F. Corwin, Spain and the Abolition of Slavery in Cuba, 1817-1886 (Austin: University of Texas Press, 1967): $185-220$.

${ }^{649}$ Ada Ferrer and M. Ferrandis Gerrayo, "Esclavitud, Ciudanía, los Límites de la Nacioladidad Cubana: la Guerra de los Diez Años," Historia Social 22 (1995); Pérez, Jr., Cuba, Between Reform and Revolution; Tom Chaffin, "'Sons of Washington': Narciso López, Filibustering, and U.S. Nationalism, 1848 - 1851," Journal of the Early Republic 15, vol. 1 (Spring 1995): 79 - 108.

${ }^{650}$ Ferrer and Gerrayo, "Esclavitud, Ciudanía, los Límites de la Nacioladidad Cubana," 101- 125; Ada Ferrer, Insurgent Cuba: Race, Nation, and Revolution (Chapel Hill: University of North Carolina Press, 1999), $1-70$.

${ }^{651}$ The most prominent group was Jose Morales Lemus' New York Cuban Junta. The group had the largest following and influence, and had developed alliances with other sympathy groups like the Cuban League in New York City. The agents of the late 1860s Junta resuscitated Maximo Gomez' 1850s efforts on the part of the group to get supplies, guns, ammo, and men to help Cuban separatists. With Lemus' takeover of the Junta in early 1869, the group appealed to its network of Cuban expatriates across the American northeast and South. It called out to allies for ships to make clandestine runs to central and eastern Cuba through the Bahamian passes. On the way they could pick up more guns and friends in Philadelphia, Charleston, New Orleans, Ybor City, Fernandina Beach, Jacksonville, and Key West. The Junta long cultivated friendships with sympathetic American newspapers to publicize rallies, fundraisers, recruiting information, and the filibustering expeditions themselves. Newspapermen developed close relationships with Cuban revolutionaries in the United States and on the island through these efforts. The group used these networks to successfully pierce the cordon of Spanish and American ships patrolling the Caribbean to deliver men, guns, and cargo to the Cubans. A significant number of former Confederate soldiers, Northerners, CubanAmericans, and Irish-American Fenian nationalists signed up. They transported American rifles, artillery, clothing, and foodstuffs delivered to small Cuban port cities like Nuevitas, Camagüey Province, in eastern Cuba. The Spanish colonial government in Cuba publicly decreed, on numerous occasions, its intention to arrest and prosecute any individual and detain any ship, from any country, assisting the revolutionaries. For a quick background of American interaction with Cuba, see: Jules R. Benjamin, The United States and the Origins of the Cuban Revolution: An Empire of Liberty in an Age of National Liberation (Princeton: Princeton University Press, 1990); Herminio Portell Vilá, Historia de Cuba en sus relaciones con los Estados Unidos y España 2 (Miami: Mnemosyne Publishing, Inc., 1969); Louis A. Perez, Cuba and the 
"believed that this [Cuban independence] could be accomplished only under the guidance of North American constitutional structures." ${ }^{952}$ By 1869 the Spanish Captain General in Cuba, Francisco Lersundi, witnessed tens of thousands of eastern plantation owners, middle and working-class creoles, and freed slaves taking territory and declaring themselves a free nation like the United States. ${ }^{653}$

United States: Ties of a Singular Infancy (Athens: University of Georgia Press, 2003). For more on Goméz, see: Benigno Souza, Máximo Gómez: El Generalísimo (Havana: Editorial de Ciencias Sociales, 1986). For more on the historic role of the Junta in organizing filibustering efforts, see: Basil Rauch, American Interest in Cuba, 1848 - 1855 (New York, 1974), chapter 10; C. Stanley Urban, "The Abortive Quitman Filibustering Expedition, 1852 - 1855, The Journal of Mississippi History, 18:3 (July 1956): 175 - 196; Gerald Poyo, "With All, and the Good of All:" The Emergence of Popular Nationalism in the Cuban Communities of the United States, 1848 - 1898 (Durham: Duke University Press, 1989); Gerald Poyo, "Evolution of Cuban Separatist Thought in the Emigré Communities of the United States, 1848-1895," Hispanic American Historical Review 66:3 (Aug., 1986) 485-507.

${ }^{652}$ Poyo, "Evolution of Cuban Separatist Thought in the Emigré Communities of the United States," 487 488.

${ }^{653}$ The Cuban rebellion's most critical events across the next fifteen months can be divided into three phases: In its earliest phase, from October 1868 to April 1869, an aggressive Cuban revolutionary army spread across central and eastern Cuba overwhelming underprepared, undermanned, and outgunned Spanish colonial forces. Loyalist Cubans in western Cuba, in Havana and Matanzas, made up for Spanish failures in the field by cracking down on rebel sentiment in the island's larger and wealthier urban centers. The next stage from April 1869 to later that year saw the unification of the up-to-then fractured Cuban movement. This stage began with the Cuban drafting of a Constitution, new Commander-in-Chief Manuel de Céspedes' formalizing of military strategy, and the arrival of new Spanish leadership and military reinforcements. The political establishment of a revolutionary Cuban state in May 1869 coincided with successful Spanish military efforts on and off the island. The Spanish colonial leadership actively prevented filibustering efforts aimed at supplying and reinforcing the Cuban Liberation Army from the United States and the wider Atlantic world. In this period, the Spanish commandeered numerous American and British ships. In the process they arrested and executed numerous American citizens on suspicion of filibustering in favor of the rebels. Curbing the Cuban revolution did not entirely shift the military advantages gained by the Liberation Army. The third phase in 1870 may have solidified the Cuban military gains but also encouraged Spanish wrath. The Cubans thus managed to rebuff Spanish efforts to retake the central-Eastern port city Puerto Principe and, furthermore, took the fort at la Nueva. The Spanish Navy sent 30 ships to patrol the Caribbean in response. The war's brutal nature swept the entire island with civilians, women, children, and "traitors," being violated, and arrested, and property destroyed. The Cuban government and the Cuban Liberation Army cultivated outside assistance to make up for debilitating supply issues. Their primary loci were the separatist communities in New York City, New Orleans, and various Cuban communities across Florida. The Cubans managed to establish their young nation but neither side gained a definitive advantage across 1870. The outside assistance reaching the Cuban Liberation Army drew the attention of the American government, and the administration of Ulysses S. Grant. Further information on the provisional Cuban system of checks and balances, see: Ziegler, "The Revolt of "the Ever Faithful Isle," $45-59$. 


\section{The Grant White House and the Ten Years War}

Grant, like the previous Johnson administration, ${ }^{654}$ had clear foreign policy goals to economically and geographically expand American interests. ${ }^{655}$ Grant's White House sought to advance expansionist ideas in places like Nicaragua, the Dominican Republic, ${ }^{656} \mathrm{Haiti},{ }^{657}$ and Canada. Historians have recorded the importance of these initiatives in elevating Grant's popularity as an enforcer of American economic interests - especially in the Caribbean and Central American “canal zone." ${ }^{\prime 658}$ Cuban leader Manuel de Céspedes’s decision to rebel in the shadow of revolution in Spain, then, saddled the White House with a unique foreign policy concern. The Department of State's overarching goal was to keep international trading routes as peaceful as possible, and to maintain trade relationships as profitable as possible to the United

\footnotetext{
${ }^{654}$ Johnson's Secretary of State, William Seward, secured the purchase of Alaska, sought to buy the Dutch West Indies, tried to annex parts of Canada, and came close to securing territory in the newly independent Dominican Republic. For quick reviews of Seward's foreign policy, see: David E. Shi, "Seward's Attempt to Annex British Columbia, 1865-1869," Pacific Historical Review 47, no. 2 (May, 1978): 217-238; Norman B. Ferris, Desperate Diplomacy: William H. Seward's Foreign Policy, 1861 (Knoxville: University of Tennessee Press, 1976); Walter LaFeber, The New Empire: An Interpretation of American Expansion, 1860-1898 (Ithaca: Cornell University Press, 1998): 28; Hoffman, American Umpire, 144-160; Kinley J. Brauer, "Seward's 'Foreign War Panacea': An Interpretation,” New York History 55, no. 2 (April 1974): $132-157$.

${ }^{655}$ For more on Johnson's foreign policy, see: Jay Sexton, "Toward a Synthesis of Foreign Relations in the Civil War Era," American Nineteenth Century History 5 (Fall 2004): 50-73; Ernest N. Paolino, The Foundations of the American Empire: William Henry Seward and U.S. Foreign Policy (Ithaca: Cornell University Press, 1973).

${ }^{656}$ For more on the American attempts to annex the Dominican Republic during the Grant administration, see: Nicholas Guyatt, "America's Conservatory: Race, Reconstruction, and the Santo Domingo Debate," Journal of American History 97 (March 2011): 974-1000; Milery Polyné. "Expansion Now!: Haiti, 'Santo Domingo,' and Frederick Douglass at the Intersection of U.S. and Caribbean Pan-Americanism," Caribbean Studies 34, no. 2 (Jul. - Dec., 2006): 3-45; Harold T. Pinkett. "Efforts to Annex Santo Domingo to the United States, 1866-1871," Journal of Negro History 26, no. 1 (January 1941); Hoffman, American Umpire, $148-155$.

${ }^{657}$ Matthew Pratt Guterl, American Mediterranean: Southern Slaveholders in the Age of Emancipation (Cambridge: Harvard University Press, 2008); Andrew Heath, "'Let the Empire Come': Imperialism and the Reconstruction South," Civil War History 60, no. 2 (June 2014): 152-189.

${ }^{658}$ Jackson Crowell, “The United States and a Central American Canal, 1869-1877," The Hispanic American Historical Review 49, no. 1 (Feb., 1969): 27-52.
} 
States. ${ }^{659}$ This would not be easy in the popular routes around South Florida, North of the busy port of Havana. Understanding the goal of seeking peace for the economy's sake explains Secretary of State Fish's subsequent strategy between July and September of 1869, where the U.S. State Department organized negotiations with General Juan Prim, the President of the Council of Ministers of Spain, for Cuban independence and the abolition of slavery, ${ }^{660}$ and a guarantee that the new Cuban government would favor American trade in exchange for $\$ 150$ million dollars. ${ }^{661}$ The secretary then controversially selected businessman Paul S. Forbes, a friend of both Fish and General Prim, to represent U.S. interests in Madrid. ${ }^{662}$ This plan to buy Cuban independence and trading preference fell through, so Secretary Fish subsequently helped formalize a declaration of neutrality for the United States based on American neutrality laws

\footnotetext{
${ }^{659}$ Vanessa Ziegler argues that the secretary "pursued U.S. hegemony over Cuba in his tenure in office" in such an indirect way that "authority over Cuba did not necessitate annexation." Fish - in other words hoped to preserve American financial and political interests in Cuba without unduly extending the parameters of risk for the United States. For more, see: Ziegler, "The Revolt of 'the Ever Faithful Isle,"'180; Benjamin, The United States and the Origins of the Cuban Revolution, 16-18; Pérez, Cuba and the United States; Foner, A History of Cuba, vol. 2 (New York, 1962): 202 - 204.

${ }^{660}$ For more on the process of abolition in Cuba, both for the new Cuban government and the Spanish authorities, see: Raúl Cepero Bonilla, "Azúcar y abolición: Apuntes para una historia crítica del abolicionismo," in Escritos históricos (La Habana: Editorial de Ciencias Sociales, 1989); Franklin Knight, Slave Society in Cuba during the Nineteenth Century (Madison: University of Wisconsin Press, 1986); Aline Helg, Our Rightful Share: The Afro-Cuban Struggle for Equality, 1886 - 1912 (Chapel Hill: University of North Carolina Press, 2000); Karen Robert, "Slavery and Freedom in the Ten Years War, Cuba, 1868 - 1878," Slavery \& Abolition 13, no. 3 (1992): 181 - 200; Ferrer, Insurgent Cuba; Thomas Orum, "The Politics of Color: The Racial Dimension of Cuban Politics During the Early Republican Years" (PhD., New York University, 1975).

${ }^{661}$ Ziegler, "The Revolt of 'the Ever Faithful Isle,"”188-192.

${ }^{662}$ Forbes' appointment highlighted the extent to which concerns about business corruption could seep into American foreign policy. For more, see: Ziegler, "The Revolt of 'the Ever Faithful Isle,"”182. She cites: Soulère, Historia de la insurrección de Cuba, vol. 1, 167, 169 - 170; Telegram to the Secretary of State from Forbes, dated 7/20/1869, and telegram from Forbes, dated 9/14/1869, both in USNA, "Depatches from Special Agents of the Department of State, 1794 - 1906," Microfilm Publication M37, Roll 11, Vol. 24.
} 
dating from $1818 .{ }^{663}$ This radically changed the way the United States and its citizens could legally approach either Spain or Cuba. ${ }^{664}$

Fish had his reasons for preserving American neutrality towards Cuba. The American assistance to the revolutionaries would damage the ongoing Alabama claims negotiations with Britain over the latter's building of ships and selling of guns to the Confederacy during the Civil War. ${ }^{665} \mathrm{He}$ argued that the American Army and Navy had also suffered in manpower and ship readiness and was not ready to fight again so soon after the Civil War. ${ }^{666}$ Fish is also reported to have had low opinions of the Cuban capacity for self-government and democratic institutions. ${ }^{667}$ He did not want the United States engaged with the Cuban revolution in any fashion except to end it on American terms. ${ }^{668}$ Attorney General Ebenezer Hoar supported Fish's position of nonintervention in meetings with the president. Hoar also did not believe that the recognition of the belligerent rights of the rebels aligned with existing international law. ${ }^{669}$ They, however, were not the only advisers with Grant's ear. Grant listened as the president's old friend from Galena,

${ }^{663}$ Ziegler, "The Revolt of 'the Ever Faithful Isle,"”182 - 183.

${ }^{664}$ These neutrality laws specified that no American soldiers or ships could interfere in external affairs at a time of peace and Fish hoped this would keep the U.S. simultaneously disengaged and economically prosperous. American trade vessels could presumably travel the Caribbean straits unencumbered.

${ }^{665}$ The British wanted clear trade passages, too. Fish had maintained that the prospect of intervention in Cuba could hurt American economic interests in the Caribbean and larger Atlantic. For more, see McCullough, "Foreshadowing of Informal Empire."

${ }^{666}$ Bradford, The Virginius Affair, 135; Ziegler, 182.

${ }^{667}$ Ziegler, "The Revolt of 'the Ever Faithful Isle,"” 179.

${ }^{668}$ Nevins, Hamilton Fish, Vol. 1, 183 - 184.

${ }^{669}$ White, American Ulysses, 506. 
Illinois, the Secretary of War John A. Rawlins, competed directly for attention when it came to foreign policy in Cuba. ${ }^{670}$

The secretaries of war and state had a rivalry that illustrated the early divisions in the administration's foreign policy as both pursued divergent policies insofar as Cuba was concerned. Rawlins, a West Point graduate, Mexican War veteran, and Grant's subordinate during the Civil War, could not have been closer to the president. He wanted Cuba free and Spain expelled from the Western Hemisphere. Historians have further confirmed Rawlins' dedication to intervention through his purchase of bonds to help fund the Cuban Junta. ${ }^{671}$ Scholars have studied how Rawlins repeatedly came close to convincing the president to offer the Cubans the rights of belligerents in July and August $1869 .{ }^{672}$ Rawlins' death, however, stifled the hopes for American intervention in Cuba. The foreign policy portfolio of Secretary Fish included a broad Atlantic and even Pacific - range of concerns suggesting he would never authorize intervention. ${ }^{673}$ These concerns - especially the ongoing negotiations with the British government — motivated Fish's argument for no more than diplomatic intervention in Cuba. ${ }^{674}$ Secretary Fish's influence eventually overshadowed that of the secretary of war in thwarting American intervention in Cuba

\footnotetext{
${ }^{670}$ Also in Rawlins camp, in support of recognizing the rights of belligerents for the Cuban rebels, was Postmaster General Cresswell and Secretary of the Interior Jacob Dolson Cox. White, American Ulysses, 506.

${ }^{671}$ Benjamin, The United States and the Origins of the Cuban Revolution, 17.

${ }^{672}$ Allan Nevins, Hamilton Fish: The Inner History of the Grant Administration (New York: F. Ungar Publishing, 1957), 183 - 184; Fish's diary, September 16, 1873, in John Simon, ed, The Papers of Ulysses S. Grant, vol. 24 (Carbondale: Southern Illinois University Press, 2000), 209. Mentioned also in Ziegler, $183-184$.

${ }^{673}$ Ziegler, "The Revolt of 'the Ever Faithful Isle,"” 178 - 181.

${ }^{674}$ Ibid, 179 - 180. In this regard Fish reflected the foreign policy goals of the post-Civil War U.S. as described by historian Andre M. Fleche - fighting for "stability in international politics." Fleche, The Revolution of 1861, 4.
} 
and Secretary Rawlins' sudden death in September 1869 made it easier for Hamilton Fish to direct the president's foreign policy.

\section{The Grant Administration, the Laws of Nations, and the Meaning of Neutrality}

The White House's policy regarding the Ten Years War changed dramatically after the death of General Rawlins. His death allowed the secretary of state room to work in favor of nonintervention and formal American neutrality. ${ }^{675}$ This included Fish's encouragement of the president to clarify that the Cuban revolt did not count as a formal, legal war. The Cubans' guerilla tactics troubled the president's sense of proper battle. The irregularity of the Confederate effort in the late war - which clearly resonated within Grant's comments on Cuba - was analyzed by Grant's most influential subordinate during the Civil War. ${ }^{676}$ In the Memoirs of General William T. Sherman, the general noted that Southern irregulars, more than any other group, posed the greatest threat to law and order both during and after the war. ${ }^{677}$ The question of irregular fighting consumed the broader Union military leadership and then General Grant worked with President Lincoln, Secretary of War Halleck, and international lawyers and scholars including Franz Lieber (who was also known as Francis in the United States), to help define a new handbook to clarify the rules of guerilla and civil war in the modern period. ${ }^{678}$ Lieber, who helped

\footnotetext{
${ }^{675}$ For more on the broader movements to use neutrality as a diplomatic tool to ensure global peace and commerce, see: Maartje Abbenhuis, An Age of Neutrals: Great Power Politics, 1815-1914 (Cambridge: Cambridge University Press, 2014).

${ }^{676}$ Bruce Catton, U.S. Grant and the American Military Tradition (Boston: Little \& Brown, 1954).

${ }^{677}$ Ibid. Also see William T. Sherman, Memoirs of General William T. Sherman (New York: D. Appleton and Co., 1875).

${ }^{678}$ Rotem Giladi. "Francis Lieber on Public War," Gottingen Journal of International Law 4 (2012): 2, 447-477; Hartmut Keil, "Francis Lieber's Attitudes on Race, Slavery, and Abolition," Journal of American Ethnic History 28, no. 1 (Fall 2008), 13 - 33; David Bosco. "Moral Principle vs. Military Necessity: The First Code of Conduct During Warfare, Created by a Civil War-Era Prussian Immigrant, Reflected Ambiguities We Struggle With To This Day," The American Scholar 77, no. 1 (Winter 2008), 25-34; Gerhard Weiss, "The Americanization of Franz Lieber and the Encyclopedia Americana," in Lynne Tatlock and Matt Erlin, and German Culture in Nineteenth-Century America: Reception, Adaptation,

Transformation (Boydell \& Brewer, Camden House, 2005).
} 
draft new rules for domestic and international law during war, also helped clarify the legality of guerilla and irregular warfare. ${ }^{679}$ Lieber's work for the government clarified, for instance, the new American position that armies required uniforms to distinguish themselves from civilians and that prisoners of war should be treated fairly. Much of the fighting in Cuba resembled the type of fighting that Grant, Secretary Fish, and the new American military rules would have considered illegal. ${ }^{680}$ Rawlins, if alive, may have pointed out that the Cubans did not have enough supplies for regular uniforms or enough arms for traditional tactics. ${ }^{681}$ With Rawlins gone Fish reminded the president that the Cubans had not managed to seize the world's attention by beating the Spaniards in a mass battle or overwhelmed any loyalist Western cities and ports. Their rebellion remained contained to the Eastern part of the island, if fiercely defended from incursions by Spanish forces. Fish also counseled the president to withhold assistance because the rebels had not settled on a formal capital and employed a transitory government to oversee its jurisdiction in Western Cuba. As a manifestation of this change in perception, Grant's foreign policy also curtailed outside assistance, especially via the filibusters from the United States.

A major feature of Grant's Cuba policy was the curtailing of outside assistance from Americans in Cuba. The administration's belief was that curtailing filibusters would show that the United States was serious about enforcing neutrality. The president believed this was necessary to ensure good faith negotiations with Britain over the Alabama claims. ${ }^{682}$ Fish implored to Grant

\footnotetext{
${ }^{679}$ For more of Lieber's work for Sec. of War Halleck, and in private work, see: Franz Lieber, Guerilla Parties Considered With Reference To The Laws And Usages Of War. Written at the request of MajorGeneral Henry W. Halleck, General-in-Chief of the Army of the United States (New York, D. Van Nostrand, August 1862).

${ }^{680}$ Summers, The Ordeal of Reunion, 218, 222.

${ }^{681}$ Pletcher, The Diplomacy of Trade and Investment: American Economic Expansion in the Hemisphere, 1865 - 1900 (Columbia: University of Missouri Press, 1998), 152 - 4.

${ }^{682}$ White, American Ulysses, 506. In one April 1869 Cabinet meeting, the President noted that he had earlier desires to help the Cubans, but that the ongoing negotiations with the British over the Alabama issue prohibited strong action in Cuba. Grant's biographer notes that Grant declared that "strict justice would
} 
that to get a deal done with Britain the United States could not be seen to be acting similarly to the trifling British by helping the Cubans. ${ }^{683}$ Fish announced the government's hard stance in an executive order signed by Grant on July 14, $1869 .{ }^{684}$ The directive clarified the illegality "of the carrying on of any such expedition or enterprise from the territories or jurisdiction of the United States against the territories or dominions of Spain with whom the United States are at peace." $" 685$ To enforce American anti-filibustering law in the epicenter of Cuban sympathy - the Southern District of New York State — Fish appointed States' Attorney Edwards Pierrepont and U.S. Marshal Francis C. Barlow to escalate investigations, arrests, and prosecutions of filibusters in the nation's largest city. ${ }^{686}$ Sources cite Fish's anti-filibustering forces patrolling New York City harbors and the length of the Atlantic seaboard with upwards of forty ships ${ }^{687}$ Fish's blockade could not stop all filibustering efforts, as many expeditions managed to make it to Cuba and back. The anti-filibustering effort had more success on the streets of New York City. There the New York City police department, Barlow's Marshals, and Pierrepont's government lawyers rounded

justify us in not delaying action on this subject, but too early action might prejudice our case with Great Britain in support of our claim."

${ }^{683}$ For more on the influence of the Alabama claims as a reason to hold up any recognition of the Cuban rebels because of how similar the arming of the Cubans, and the British arming of the Confederates, looked, see: Adrian Cook, The Alabama Claims: American Politics and Anglo-American Relations, 18651872 (Ithaca: Cornell University Press, 1975); Nevins, Hamilton Fish, vol. 1, 180- 181; Bradford, The Virginius Affair (Boulder: Colorado Associated University Press, 1980): 15; Ziegler, "The Revolt of 'the Ever Faithful Isle,"” 179-180.

${ }^{684}$ Simon, The Papers of Ulysses S. Grant, $210-211$.

${ }^{685}$ Simon, The Papers of Ulysses S. Grant, 210 - 211; Ziegler, "The Revolt of 'the Ever Faithful Isle,"” 182 -183 .

${ }^{686}$ Ziegler, “The Revolt of 'the Ever Faithful Isle,"” $182-183$.

${ }^{687}$ This proto-blockading force had some success as the October 1869 arrest the Hornet, being outfitted to be used by the Cuban Liberation Army as the Cuba. See: Ziegler, "The Revolt of 'the Ever Faithful Isle,"” 183. 
up Cuban rebel leaders. ${ }^{688}$ The combination of this strong prosecution of the Cuban cause in New York City and the coastal Atlantic - and the administration's refusal to concede the war's validity - illustrated just how comprehensively Fish had come to dominate the public face of the White House's Cuba policy. ${ }^{689}$

White House foreign policy towards Cuba, and Congress' discussion of the issue elevated the issue to national prominence and impacted American party politics in 1869 and 1870. Cuba became a major policy interest when the American press took note of Céspedes' "grito" the day after its proclamation. It achieved still greater preeminence as Fish became involved in discussions with the Spanish minister over lost property in Cuba and the Caribbean. Congress, alerted to Secretary Fish's trouble striking a deal, asked for all the State Department

${ }^{688}$ Their notable indictments included individuals like former Confederate general Thomas Jordon (who led a column of the Cuban Liberation Army) and General Goicouria (who led a filibustering operation as well as soldiers on the island and also Cuban ambassador to Mexico alongside other Junta luminaries). For more on these filibustering expeditions, see: Ziegler, "The Revolt of 'the Ever Faithful Isle,"” appendix C, 277 279.

${ }^{689}$ The progression of the administration's opposition to intervention in Cuba from 1869 to 1870 can be concisely reduced to a list of critical events and speeches that evidence the changes in Grant's Cuba policy. Secretary Fish's attempts at mediation to restore American property and buy peace and discuss potential annexation between July and September of 1869 are the first point of evidence of a changing White House foreign policy. The second was Rawlins's attempt at getting Grant to offer the Cuban rebels belligerency status in August 1869. Rawlins's death in September 1869 marked the third, and particularly critical, incident spurring a change in Grant's Cuba policy. The fourth was Fish's maturing policy against the New York City Cuban Junta and Fenian Irish-nationalists with U.S. State Attorney Edwards Pierrepoint and Marshal Francis Barton starting in July of 1869. The fifth was the Spanish commandeering of U.S. property and murder of U.S. citizens which prompted the U.S. Congress to get involved and to monitor State Department communications after July 1869. Grant's State of the Union Speech in October 1869, where he clarified that the Cuban Revolution not a "war" and could not merit U.S. attention, was the sixth. The seventh was Grant's repetition of these same themes in two speeches in December 1869 and January 1870. Grant and Fish's lobbying of Congress upon the failure of discussions over offering Cuban government the rights of belligerency between April-July 1870 represents the last of these transformative steps in American foreign policy towards Cuba. As a historian of American foreign relations, Elizabeth Cobb Hoffman, notes, mid to late nineteenth century "literate publics increasingly demanded that governments solve humanitarian crises in foreign countries" but that "leaders found themselves pressed to intervene in conflicts where they had little desire to run such risks." This was the case regarding the American political order and the push for intervention in Cuba (at least for the Grant administration and its allies). 
correspondence between Spain and the Secretary. ${ }^{690}$ Between June 1869 through June 1870 both the House and Senate Committees on Foreign Relations investigated U.S. - Spanish relations over Cuba. ${ }^{691}$ Ensuing debates about interfering in the Ten Years War exacerbated divisions within the ruling Republican Party. The administration's non-interventionist allies — Attorney General Hoar, U.S. States Attorney Edwards Pierrepont, ${ }^{692}$ Mark Twain, Francis Train, ${ }^{693}$ the New York Times ${ }^{694}$ New York World, Cincinnati Gazette, and the Nation, ${ }^{695}$ as samples — sided with the White House's position and fought Republicans who thought otherwise. The president's rivalries with congressional party leaders like Charles Sumner, the head of Senate Committee on Foreign Relations, came to a head in this period as a result. Grant's behind-the-scenes lobbying for the removal of Sumner from the committee in 1869, combined with Grant's broader foreign policy, estranged many Republicans across the country and in Congress. ${ }^{696}$ Sumner was beloved by many in Congress, and the prevailing seniority system in Congress assumed that Grant was exercising

${ }^{690}$ Correspondence of the United States Department of State in relation to The Seizure of American Vessels and Injuries to American Citizens during the Hostilities in Cuba. Transmitted to the Senate in Obedience to a Resolution (Washington: Government Printing Office, 1870).

${ }^{691}$ Ibid.

${ }^{692}$ As New York States Attorney Edwards Pierrepont argued that "the Cubans and the Spanish and the Negro race....are not yet fitted for a free government like ours...I have little faith in the Spanish race under free institutions." Edwards Pierrepont to Fish, March 17, 1870, Fish papers, letter book, box 203, vol. 68, ff. 9713, 9715 - 17. Cited in Pletcher, The Diplomacy of Trade and Investment, 153.

${ }^{693}$ The Sun (N.Y.), May 8, 1869.

${ }^{694}$ For a sample of the Times position on Cuba, see: New York Times, March 24, 1869; New York Times, April 8, 1869; New York Times, July 8, 1869; New York Times, September 24, 1869. In these articles the Times argues that the Cubans are a revolting group like the Confederates were and that Americans should let Spain do with her colony as she pleases. The Times also parroted many of the administration's opinions about the Cuban rebellion's deficiencies as a military operation.

${ }^{695}$ For a sample of Godkin's position see: Nation, 9 (April 15, 1869).

${ }^{696}$ Nicholas Guyatt has also argued that the "personal rancor" between the two men "destroyed the party unity that had shepherded the Fifteenth Amendment into law." See: Guyatt, "America's Conservatory," 999. 
undue power in authorizing such a political hit in a body where chairmanships in prestigious committees like Foreign Relations are treasured. Cuban sympathizers in the House of Representatives and the Senate thus began investigating the possibility of aid to the new Cuban rebel government in spite of the administration. Various Congressmen began expressing public sympathy for Cuban independence and the offering of the rights of belligerents to the rebels. In late 1869 , early 1870 and mid-1870, the Congress formally discussed the Cuban question on the floors of both the House and Senate. ${ }^{697}$ In each case the Department of State actively lobbied House members and Senators over the benefits of non-intervention, and the illegality of the Cuban rebellion and the Republican majority in Congress never authorized intervention in Cuba under the weight of White House's threats. In one instance Secretary Fish threatened to resign if the president did not reiterate the administration's opposition to intervention. ${ }^{698}$ As a sign of Grant's increasing sympathy with Fish and his opinion on Cuba, the president subsequently sent a message to Congress on June 13, 1870 reminding the Republican Party of the Cuban Revolution's deficiencies. ${ }^{699}$ Unwilling to move against the White House, Congress was disinclined to approve intervention in Cuba in any of the 1869 or 70 sessions.

These contentious battles over Cuba within the West Wing, in Congress, and within the American social order, did not help the Republican Party. Divisions between - and within — the major parties in the period were exacerbated by the foreign policy crisis caused by the Cuban Revolution. ${ }^{700}$ Non-interventionists spanning both parties desired neutrality for various reasons.

\footnotetext{
${ }^{697}$ Pletcher, The Diplomacy of Trade and Investment: American Economic Expansion in the Hemisphere, $1865-1900,154$.

${ }^{698}$ Ibid, $154-155$.

${ }^{699}$ U.S., $41^{\text {st }}$ Congress., Second session, House Executive Document 160, 13 - 17; U.S., $41^{\text {st }}$ Congress., Second session, House Executive Document 80; Richardson, Messages and Papers, volume 7, 63 - 70.

${ }^{700}$ For more on the administration's open lobbying for non-intervention in Cuba, see: Pletcher, 152 - 157.
} 
Secretary of State Fish was the most prominent of these characters. A long list of influential supporters of neutrality from N.Y. State Attorney Edwards Pierrepont, the New York Times, ${ }^{701}$ Edwin Godkin's Nation, Mark Twain, and Democrat newspapers like Manton Marble's New York World, helped the secretary of state bring Grant round to neutrality. In the process, the Grant presidency estranged many friends, further disillusioned those only marginally behind them, and brought bad press to a White House already receiving poor coverage for other reasons. Many Republicans were already angry about the president's policy towards the Dominican Republic with reports of corruption and bond-trading in the administration. ${ }^{702}$ Domestic reports of patronage, nepotism, and financial fraud also stained the Republican leadership's credibility. The administration's noninterventionism in Cuba but not the Dominican Republic added another category for critics to negatively evaluate the new president and his influence on his party. ${ }^{703}$ Charles A. Dana's support for American assistance to the Cuban rebellion made him one of these estranged former Republicans in 1869 and $1870 .^{704}$

\footnotetext{
${ }^{701}$ For more on the New York Times and Cuba James W. Cortada, "The New York Times, Spain and Cuba, 1851-1869," Revista de Historia de América 77/78 (Jan. - Dec., 1974): 61-75.

${ }^{702}$ For more on role of Dominican issue and differences within the Republican Party, and the influence of the negotiations, see: Hoffman, American Umpire, 149.

${ }^{703}$ The most prominent fissures appeared between interventionists and non-interventionists across both parties. Interventionists split in two camps. The first were annexationists like Grant's Minister to Spain and former Union General - Dan Sickles, Céspedes, many Junta members, and others who openly thought that Cuba needed to be added to the U.S. for economic and military reasons. Other interventionists hoped to achieve liberty for the Cubans - giving them the power to decide what to do with their island. These interventionists prioritized the sovereignty of Cubans, firstly to be independent, and then to allow them to decide if they wanted to be annexed. This group argued however that if anyone was to annex the island, it had to be the United States! Democrats, overwhelmingly interventionist in Cuba, provided an outlet for disaffected Cuban sympathizers in the Republican Party to look for allies. Prominent northern Democrats men like New York Senator Reuben Fenton, congressman Fernando Wood, William "Boss" Tweed, former Sec. of War Simon Cameron, congressman Samuel "Sunset" Cox, and former New York City Mayor George Opdyke - joined these Republicans in publicly opposing the President's anti-interventionist policy in Cuba.

${ }^{704}$ Republicans like Grant's close ally, congressman from New York, Roscoe Conkling - his friend, Secretary of War Rawlins, congressman William T. Evarts, former New York Governor and Republican Party chair Edwin D. Morgan, Congressman Benjamin Wade, editor Horace Greeley, William Cullen Bryant of the New York Post, and Charles A. Dana, also actively supported Cuban independence against the
} 


\section{Dana on the Grant Campaign and the Cuban Revolution of 1868}

Dana's responses to both the Cuban Revolution of 1868 and Grant's policy towards it are notable for many reasons. They reveal the vitality of republican themes in helping Dana interpret the world. The previous chapter documented how Dana's domestic anti-corruption position impelled him against Grant. The administration's behavior enflamed Dana's historic republican scruples for honest government and civic virtue. This chapter introduces Dana's response to the policy towards Cuba as another reason he turned against the president in 1869 and 70 . The Cuban episode has not enjoyed much in the way of historical attention for explaining Dana's disaffection with U.S. Grant and his allies, though. ${ }^{705}$ This is unfortunate, considering how rich of a source this stance is in helping contextualize his thought. Dana had showed interest in Cuba and republican revolutions of a similar character since the late $1840 \mathrm{~s}$ and $50 \mathrm{~s}$. As an employee of the New York Tribune, Dana had, of course, travelled to Europe to cover the Revolutions of 1848 and ran the paper's foreign desk that directed the paper's reporting on Cuba's tumultuous 1850 s. $^{706}$ Even before that, at Buffalo, Harvard, and Brook Farm, Dana showed an enduring interest in the intersections of American and European culture and thought. It is no surprise, then, that he argued that the transatlantic conflicts of the mid-nineteenth century, like the early wars of German Unification, the Spanish Revolution of 1868, the civil war in the Dominican Republic, or the

administration's policy. A good number of these men also held financial interests in the separatist movement. Secretary of War Rawlins financially supported Cuban Junta, as did many other of these other Cuban sympathizers at the highest rungs of American politics. Money flowed on both sides of the debate, however, exacerbating to further encourage existing party divisions in a fight for Cuba. For more on the financial interests on both sides of the debate, see: Summers, The Ordeal of the Reunion, 222.

705 Janet Steele's study of Dana does make mention of Dana's strong opposition to the administration's Cuba message in this period, but allows considerable room for more study of the exact role the Cuban rebellion played on Dana, and the larger American political order, in this period. Much of the other historiography on Dana and his opinions on foreign affairs similarly allow for a close analysis of Dana's commitment to the Cuban issue, and the part it played in his disaffection with Grant and the Republicans. See: Steele, The Sun Shines For All, 102 - 104; Wilson, The Life of Charles A. Dana, 114, 125 - 133, 402, 416, 420, $477-479$. 
Cuban Revolution of 1868 could drastically impact American politics. The Caribbean examples, and particularly the Cuban one, particularly added to Dana's motivations for opposing the president and establishment politics. His historic observance of republican attempts at nationalism, both failed and successful, translated into his support for the Cuban rebels when he purchased The Sun in 1868. He implored the president-elect to support the Cuban rebels by offering them the rights of belligerents and allowing them access to American weapons manufacturers and ports of entry. ${ }^{707}$ Dana suffered profound disappointment when the White House did not help the Cubans when Grant took power in March 1869.

Dana became clearly oppositional to the White House as a result. Particularly, he responded negatively to the government's response to reports of the confiscation of American ships and cargo, the arrest of American citizens, and the execution of Americans caught on the high seas. The State Department's subsequent defense of non-intervention based on the Neutrality Act of 1817 added to Dana's oppositional stance. Fish's attempts to negotiate directly with Spain between July and September 1869 (talks that included preliminary negotiations for U.S. annexation without including Cuban leaders) further enflamed Dana's disillusionment. Dana, for instance, became more oppositional still when the administration sent U.S. Attorney Edwards Pierrepont and U.S. Marshal Francis C. Barlow to New York City to arrest Cuban Junta leaders, and known filibusterers. Dana accordingly supported the New York Cuban Junta. The Justice Department's prosecution of the Junta intensified Dana's opinions of the president although Congress's involvement in late 1869 and early to mid 1870 offered Dana hope that the Radical Republicans would pass legislation through Congress to help Cuba. The president and Secretary Fish's lobbying of these same Congressional leaders to reject intervention, though, reinforced

\footnotetext{
${ }^{707}$ For one sample of Dana's argument before the President-elect took office, see: "Belligerent Rights for Cuba," The Sun (N.Y.), February 3, 1869.
} 
Dana's anger. It appeared as if Grant and his staff were standing in the way Cuban liberty at every turn.

Dana's opposition to this approach towards Cuba developed from his republican ideological foundation. Grant's Cuba policy failed to receive his approval because it acted against Dana's expectations over the United States' role in the world (but especially in the Caribbean). In his newspaper and in public speeches Dana supported the Cuban rebels' claims over selfdetermination and anti-authoritarianism. He argued that American values should be defended across North America and the Western Hemisphere. The editor's public words directly compared the Cuban effort with the American Revolution and the American Civil War where Dana interpreted a shared lineage in the desire for self-determination, national sovereignty, antiauthoritarianism, anti-slavery, and free labor. Dana held an historic antipathy for Old World monarchy and colonialism — visible in his writing since the $1840 \mathrm{~s}$ — grounding his late $1860 \mathrm{~s}$ opposition to Spanish designs in the Caribbean. ${ }^{708} \mathrm{He}$ took an aggressive approach to defending what former President John Quincy Adams called the "Republic of North America." Dana agreed with Adams that American political hegemony in the Western Hemisphere relied upon its republican commitments to self-government, civic virtue, and egalitarianism. ${ }^{709}$ It was the responsibility of the United States to defend these values in the Americas. Dana called upon the history of Thomas Jefferson, James Monroe, and Henry Clay to contextualize this position. The editor also used terms like the "American Union" to explain this informal region of republican

\footnotetext{
708 “The March of Empire,” The Sun (N.Y.), April 6, 1869.

${ }^{709}$ Dana, like many of the Founding Fathers and leading politicians of the early Federal period, argued that the Western Hemisphere represented the home liberty loving people joined in a defense of republican institutions. At one March 25, 1869 pro-Cuban meeting at Steinway Hall, for example, Dana invoked this idea to reiterate the regional sympathies for the liberal idea of self-government in the face of European influence. See: "The Steinway Hall Mass Meeting for Free Cuba," The Sun (N.Y.), March 26, 1869. "We, as citizens of the Republic of North America and near neighbors of the island," Dana announced, that all in the group "recognize a special obligation toward the patriots who are toiling and fighting for its emancipation from European tyranny."
} 
ideas. ${ }^{710}$ Like William Seward, Dana thought the Republican Party had a responsibility to defend these values whenever and wherever necessary. Dana argued that the late 1860s Spanish influence in Cuba - even in its revolutionary state - represented the antithesis of these regional American values. The Sun insisted that the Spanish "desire to hold Cuba in a state of colonial dependence is inconsistent with their own professed devotion to liberty." ${ }^{, 111}$ Dana's editorial page explained that "even now, when the Spaniards at home have overthrown their monarchy," they "positively refuse to allow the Cubans to share with them their newly acquired liberty of selfgovernment." 712 Spanish policy on the island had left the island a place of "nothing but despotism and enmity against liberal institutions" 713 and "in a state of things entirely repugnant to the civilization of the nineteenth century." ${ }^{, 714}$ Dana's insistence that Spain's newfound antimonarchism — in ousting Isabella II—only replaced one form of despotism for another in Cuba and reflects his ideological support for the Cuban revolution.

\section{Dana's Opinion of the Cuban Revolutionaries}

The second part of Dana's support for Cuba resulted from the editor's commitment to self-determination, equal rights, and free labor. Dana's historic support for "free soil, free labor, free men" helps explain his public support of the Cuban effort to establish a similarly-founded

710 “The Revolution in Cuba-A Regular Government Formed," The Sun (N.Y.), May 5, 1869. Also see: "The Cuban Anniversary. The Revolutionary Struggles from 1819 to 1869," The Sun (N.Y.), October 11, 1869.

711 "Recognizing the Independence of Cuba," The Sun (N.Y.), April 13, 1869. For a similar argument made months later by Dana, see: "The State of Cuban Negotiations," The Sun (N.Y.), September 21, 1869.

712 "Why Cuba Desires Independence," The Sun (N.Y.), March 18, 1869. "It cannot be endured that any set of men shall thus dispose of the lives and property of another set, in all respects their equals, without their consent."

713 “A Healthy Sign," The Sun (N.Y.), May 7, 1869. "Is it not the duty of the United States to interfere to prevent such barbarous proceedings? Spain has no right to make Cuba howling wilderness in order to gratify her malignity against the Cuban patriots. She has no right to obliterate all the work of modern civilization there in a hopeless effort to avenge a despotism which she cannot maintain."

714 “Why Cuba Desires Independence,” The Sun (N.Y.), March 18, 1869. 
republic based on the ideals of equality and liberty. ${ }^{715}$ Editorials in The Sun illustrate that Dana called on these values to justify the Cuban, "home-born," desire to break their colonial compact with the Old World. Harkening back to the ideas of former President James Monroe and his "Monroe Doctrine," Dana argued that "Spain had no right to rule any spot in this hemisphere for one moment longer than the majority of the home-born inhabitants" of Cuba "thereof desire."716 Dana's argument paralleled that Jeffersonian defense of the American "right of revolution" refreshed for the Cuban example. ${ }^{717}$ The Cuban desires for self-government and to abolish slavery fitted into Dana's argument that the Cubans aligned with modern abolitionist principles. In The Sun he argued that the Cuban dedication to abolitionism and self-determination provided "conclusive evidence" of the revolt's association with "the most substantial ideas of modern democracy.","118 The Cuban rebels expressed simple republican hopes, Dana argued - to "abolish slavery," "establish impartial freedom," and "the inalienable privileges of managing their own affairs." ${ }^{719}$ Dana's commitment to self-determination for the Cuban revolutionaries dominated his coverage of their rebellion. It is important, though, to explain Dana's nuanced opinion of the

\footnotetext{
${ }^{715}$ One reprinted note sent to The Sun summarized Dana's broad editorial position towards Cuba. See The Sun (N.Y.), October 11, 1869. “...The flag of Cuba represents the noblest political principles that men ever lived and fought for. They are universal liberty, equal rights, and self government. We have sought to serve the cause of Cuba because it is identified with those principles. It has proclaimed the abolition of slavery; it promises equal rights to all men; it contends for self government, and perils life, fortune, and honor in the effort to get it. This is why we are for Cuba and cannot be otherwise."

716 “The March of Empire,” The Sun (N.Y.), April 6, 1869.

717 “American Aspirations for New Acquisitions," The Sun (N.Y.), April 6, 1869. "The American doctrine on this subject was first proclaimed in the Declaration of Independence, and it constitutes the basis on which our Constitution rests, as well as that whereon stands every Government in the Western Hemisphere which has thrown off the yoke of European monarchies... Tested by this primordial principle, the soundness of which no genuine American will dispute, neither England nor Spain has any right to rule any spot in this hemisphere for one moment longer than the majority of the home-born inhabitants thereof desire. The flap of their flag for a single instant beyond this period is a clear usurpation which warrants an uprising of the people to tear it down."

718 “Why Cuba Desires Independence,” The Sun (N.Y.), March 18, 1869.

719 “Are All Rebellions Bad?,” The Sun (N.Y.), March 22, 1869.
} 
future of a Cuban republic and his opinion about the question of Cuban annexation. He understood that the question of annexation exposed the United States to the very claims of authoritarianism and anti-self-determination he leveled against Spain — and later the nation's foreign policy leaders. His justification of Cuban annexation therefore infused the same values to defend the potential for a Cuban entrance into the American union.

Dana argued that, once free of Spain, the Cubans could decide to join the United States in ways that accorded with ideas of self-determination and anti-authoritarianism. A successful Cuban fight against illiberal Spain qualified the Cubans to decide their own fate. All the better, as Dana also maintained, that the Cubans had already exhibited a sympathy with the liberal and republican values foundational to the modern Western Hemisphere. Dana's argument included elements of the geographical determinism found in the arguments of many pro-Cuban sympathizers. At one point in May 1869, he insisted that Americans "could not afford to let that island, holding the keys to the Gulf of Mexico, and keeping guard at the mouth of Mississippi, pass into possession of any other power. We would go to war rather; not from any love of war, but because in the order of geography Cuba forms a part of the United States... [it] is a natural element of our system." ${ }^{, 720}$ At absolute minimum, a new Cuban republic would have to be allowed to have "most favored nations" trading status, and have an offensive and defensive alliance, with the United States. ${ }^{721}$ In Dana's mind this position on annexation stemmed from his larger desires

\footnotetext{
720 “Has Cuba Held a Congress?” The Sun (N.Y.), May 6, 1869.

721 "Spain and Cuba-Weak Inconsistency on the Part of the Negotiations," The Sun (N.Y.), July 19, 1869. "Why should the Cubans pay any millions to Spain for an island which in the natural course of things will be theirs for nothing within a year? Or who has presumed to pledge them to such payment? Certainly not President Céspedes, for he was elected solely to carry on the war of independence. Certainly not Mr. Morales Lemus, the only Cuban representative with whom Mr. Fish has had any opportunity of conferring... Why should we pay fifty millions for Cuba, or agree to do so in any contingency? When her people have gained their independence, if they desire to be annexed to the United States, we shall all be for letting them in on the terms of the most favored nations. But that is no reason why we should pay Spain a great sum of money for the privilege of making one or two States of the Union out of her late colony. Why should we give our money for that which, if we are to have it all at present, we can get for nothing?"
} 
to see republican ideals spread based on the declared will of the Cuban rebel government. Dana clarified that he was not proposing "to annex them unless by purchase, or in payment of our claims, or by conquest in honorable war, until their people have dissolved their connection with foreign rulers, and expressed a wish to unite with this republic." ${ }^{722}$ Dana believed the benefits of this almost anti-imperialist annexation scheme could greatly improve the freedom and liberty of the Cubans. Editorials in The Sun noted that they would "be a great deal more independent, more secure, more free to manage their own affairs in their own way, as one of the United States, than as a small separate organization." 723 From these values Dana connected the Cuban rebellion for his readers with American historical events that were familiar to them.

Dana called on the legacy of 1776 to justify the legitimacy of the Cuban rebellion. Publicizing this parallel in speeches and editorials in The Sun made the case for the ideological linking of both revolts. In front of a large March 1869 crowd at New York City's Steinway Hall, Dana argued as much. "The present struggle of the Cubans for independence and selfgovernment," he explained, "belongs in the same category with the American revolution of 1776." 724 Dana repeated this argument in The Sun's editorials. There he asked readers to consider "when the Americans rebelled against England" based off a list of "specific grievances to complain of, and a specific redress to obtain." Creating the parallel, Dana's paper asserted that the Cubans were doing the same. ${ }^{725}$ The paper maintained that the Cubans were "endeavoring to imitate what we regard as the glorious beginning of our national history, the separation from the mother country, and the foundation of independent self-government." ${ }^{726}$ In some cases, Dana

\footnotetext{
722 “American Aspirations for New Acquisitions," The Sun (N.Y.), May 10, 1869.

723 "Has Cuba had a Congress?" The Sun (N.Y.), May 6, 1869.

724 “The Steinway Hall Mass Meeting for Free Cuba," The Sun (N.Y.), March 26, 1869.

725 “Why Cuba Desires Independence,” The Sun (N.Y.), March 18, 1869.

${ }^{726}$ Ibid.
} 
argued that the Cubans were "worse treated by Spain than our ancestors were by England." ${ }^{27}$ The causes of the Cuban revolt, The Sun declared, were "caused by extortions, oppressions, and wrongs of a far graver character than those which prompted the rebellion of the North American colonies in 1776." 728 Sun readers found a parallel of assumed fact between Cuba in 1868 and 1776 and the same went for connections to the not-too-distant American Civil War.

\section{Dana, Cuba, and the Memory of the American Civil War}

Dana justified the Cuban rebellion in the context of the late Union Army's victory in 1865. Dana's newspaper publicized his understandings of the Civil War's republican underpinnings and their connections to the Cuban revolt. Editorials in The Sun compared both conflicts' anti-slavery foundations. Sun editorials reminded readers that the nation had "just closed a long a costly war against the perpetuation of slavery"729 while in Cuba "the same contest is pending.,"730 The Cubans "have cut the knot by decreeing absolute and immediate emancipation" and represented "slavery's knell" across the Atlantic, The Sun explained. ${ }^{731}$ Dana insisted that the Spanish government represented an assault "to the broad principles of human rights and political freedom." 732 The Confederate government then, like the Spanish government, represented an "attack" on the "rights of man."733 Both the Spanish and the Confederates, Dana insisted, deserved to be "put down by the public police of the world." 734 The very action of the

\footnotetext{
727 “Belligerent Rights for Cuba,” The Sun (N.Y.), February 3, 1869.

728 “Are All Rebellions Bad?,” The Sun (N.Y.), March 22, 1869.

729 “Spain and Cuba_-Weak Inconsistency of the Administration,” The Sun (N.Y.), July 19, 1869.

730 Ibid.

731 Ibid.

732 “Recognizing the Importance of Cuba,” The Sun (N.Y.), April 12, 1869.

733 “Are All Rebellions Bad?,” The Sun (N.Y.), March 22, 1869.

734 Ibid.
} 
putting down of a pro-slavery insurgency made the United States "one of the most respected and formidable powers of the world." ${ }^{735}$ The Cubans deserved the same international recognition. The Cuban rebellion, Dana insisted, could not be equated with the Confederate rebellion. He did not think that the rebels plan for gradual abolition weakened this claim. The fact that Céspedes himself a former slaveholder — worked towards full abolitionism (or even the gradual approach that it became) was enough for Dana. The rebel plans provided a clear alternative to the regressive Spanish colonial authority. For that reason, the Cubans took the part of the Union and the Spanish that of the Confederates for the editor. Dana argued that Cuban republicans paralleled the Union government in the United States - employing democratic values to abolish slavery and protect self-government for all (men). Dana could not think of the Cuban rebellion other than as a reflection the republican institutions that had animated the victorious Union forces.

Dana's insisted that the difference between the Cubans and the repressive Confederacy mattered to how the United States should approach diplomacy with Europe. The best example of his position was his demand that American diplomacy should first, before anything else, champion self-government, egalitarianism, and legal equality in places like Cuba before considering the feelings of European governments. Dana's commentary on the ongoing Alabama claims with Great Britain illustrates this point. Particularly, the editor explained that prioritizing American assistance of anti-colonial movements in the Caribbean needed to supersede smooth relations with the British - a position Dana knew the secretary of state opposed. Dana disputed the opinions of British conservatives that American assistance in Cuba would look like the very British assistance to the Confederates in the late war - the very issue up for debate during these negotiations over the Alabama. The Sun explained that this analogy "between the Cuban and the

\footnotetext{
735 "What Does He Think Of It Now," The Sun, (N.Y.), July 8, 1869. "One of the most respected and formidable powers of the world."
} 
Southern struggle is about as identical as that between freedom and slavery."736 Dana's republicanism motivated his opposition to "the theory that the annihilation of the Cubans is necessary to clinch the logical bargain in regard to the Alabama claims." ${ }^{737}$ Dana firmly held to the idea that the United States could and should defend republican institutions in the Western Hemisphere against any European interference - even that of nominal allies. The paper thus argued that "if Great Britain were to withhold reparation for the depredations of her cruisers in the event of our conceding belligerent rights to the Cubans, it would only damage her cause and not ours." ${ }^{, 738}$ Prioritizing British diplomatic relations with the United States over Cuban republicanism and abolitionism, The Sun argued, "is disgraceful to this country — to its sense of logic as well as of justice." 739 Dana strongly opposed the way that Secretary Fish seemed to prioritize the Alabama claims negotiations with Great Britain over other foreign policy concerns and Cuba in particular. ${ }^{740}$

Dana's republicanism motivated his opposition to the administration's opinion about the Ten Years War in Cuba and international law, irregular war, and filibustering. The editor began with the position that the rebellion was legitimate under international law. Various of Dana's statements across 1869 and the middle of 1870 illustrate his grand thinking about the potential for American and international assistance for Cuba. Dana often argued that the post-war nation was "in the zenith of its power" after the Civil War. ${ }^{741}$ President Grant and the nation stood "better

\footnotetext{
736 “The Administration Cuts Loose from Precedents and is Adrift," The Sun (N.Y.), July 5, 1869.

${ }^{737}$ Ibid.

${ }^{738}$ Ibid.

${ }^{739}$ Ibid.

${ }^{740}$ Ibid; “A Preposterous Rumor of a Treaty between France, England, and Spain,” The Sun (N.Y.) May 13, 1869.

741 “Aid and Comfort to Spanish Slavery," The Sun (N.Y.), July 8, 1869.
} 
able than ever to enlarge the domain of republicanism by cordially supporting an American State in its attempt to overthrow the tyrannical rule of Europe." world" that it was "always on the side of those who contend against despotism and oppression. ${ }^{.743}$ His editorials in The Sun argued that the president should insist that this ideological objective also be addressed through international law. The United States, Dana pressed, needed to insist on the supremacy of republican values in international cases like Cuba's. He insisted that the "laws of nations" need to better defend the "moral truth and justice" of nationalist movements as embodied by the Cuban Revolution. ${ }^{744}$ Dana insisted that the conflict "rous[ed] the indignation of mankind" and had become an example of the inherent right of national sovereignty for colonial peoples. ${ }^{745}$ His paper maintained that "if the law of nations utters anything contrary to this doctrine, then, on this point, the law talks nonsense, and is not entitled to either respect or obedience." ${ }^{, 76}$ Dana called for a friendlier interpretation of international law by the nation's chief foreign policy officials. He argued that republican-inspired cases like that of Cuba should encourage the Grant administration to act freely. They would not have to feel as if they were insulting other countries, like the British, in affirming the rights of the Cuban liberty. Did not the British also want to expand republicanism? Dana thought the British would understand the new international baseline for the recognition of republican rebellions. Thus he often argued that "a recognition of the belligerent rights of a revolted colony, by any neutral power, is not of necessity to be regarded as a hostile act against the mother country." ${ }^{, 747} \mathrm{He}$

\footnotetext{
${ }^{742}$ Ibid.

743 “The Steinway Hall Mass Meeting for Free Cuba," The Sun (N.Y.), March 26, 1869.

744 “The Administration Cuts Loose from Precedents and Is Adrift," The Sun (N.Y.), July 5, 1869.

745 “The Steinway Hall Mass Meeting for Free Cuba," The Sun (N.Y.), March 26, 1869.

746 “The March of Empire,” The Sun (N.Y.), April 6, 1869.

747 The Sun (N.Y.), May 7, 1869.
} 
reminded his readers that during the America Revolution, the Netherlands and France recognized the nascent nation with the English "in force in the colonies and besieging American ports." The White House's refusal to make these demands of the international community sabotaged Dana's belief in the ideological mission of the nation under Grant. Dana maintained that previous administrations had set a precedent in this regard that Grant's Cuba policy had reversed.

Dana justified the recognition of the Cuban rebels by looking to previous American foreign policies. For example, an early 1870 editorial hoped that the president and congressional leaders would look to the 1820 s for models as to how previous administrations had dealt with rebelling Spanish colonies. Dana chose cases where American leaders like President James Monroe and Secretary of State Henry Clay had encouraged American assistance to South American colonies declaring independence from Spain. The editorial explained the niceties of the American recognition of South American nations in the 1820s within the context of regional American values. The Sun insisted that, like Cuba, these subjects had also fought the "weak, perfidious, oppressive power" of Spain. ${ }^{749}$ Taking the minimum step of recognizing their belligerency, Dana explained, illustrated how “our country acted nearly half a century ago in the cause of liberty and republican government in this hemisphere." ${ }^{, 750}$ Spain also remained the colonial power unwilling to relinquish hegemony then as before. Dana used the examples of Monroe and Clay as foils to the Grant and Fish policy. ${ }^{751}$ The latter's refusal to recognize the

\footnotetext{
748 “The Administration Cuts Loose from Precedents and is Adrift," The Sun (N.Y.), July 5, 1869.

749 "Cuban Independence-Monroe and Clay Contrasted with Grant and Fish,” The Sun (N.Y.), January 17, 1870.

750 Ibid.

751 “The Administration Cuts Loose from Precedents and is Adrift," The Sun (N.Y.), July 5, 1869. "The speedy recognition of most of the South American Governments by the United States, long before the acknowledgment of their independence by the countries from which they had separated, constitutes a precedent which seems to have escaped the attention of President Grant in his attitude toward Mr. Lemus, the official representative of the Cubans."
} 
Cuban rebellion, The Sun argued, "proved treacherous to the cause of freedom and representative freedom." ${ }^{\text {752 }}$ These policies were unlike those of Monroe and Clay who had not "cower[ed] at the footstool of a crumbling despotism." ${ }^{, 753}$ Dana argued that previous American leaders understood that no hard line existed between the internal and foreign fight for self-government in the Western Hemisphere. Dana argued that the Grant's decision to draw this line in Cuba was "at war" with "all precedents of the foreign policy of the United States." The administration's policy suggested a change from this stance of assisting rebellious colonies - "cut loose from all history and its precedents." 754 Dana insisted that Grant's Cuba policy signaled that "the liberal policy which we pursued during the weakness of the United States would be abandoned in the days of our strength." "W55 "Who could have foreseen," The Sun asked readers, "that the hand of fellowship extended to revolted colonies in the days of our puny infancy would be palsied at the moment of our national manhood?" 756

Dana called forward these examples of previous - perhaps more egalitarian — foreign policies in the hopes of distancing the White House from historic American values. He did this also by showing the qualifications of the rebels who the Grant administration refused to assist. An analysis of Dana's editorials between October 1868 and the summer of 1870 shows that he openly refuted the White House's lack of recognition of the Cuban constitution, government, courts, and diplomacy. The rebellion's establishment of these institutions, Dana argued, made the

\footnotetext{
752 "The Recognition of Cuba. Who is Responsible for the Attitude of the United States," The Sun (N.Y.), February 25, 1870.

${ }^{753}$ Ibid.

754 “The Administration Cuts Loose From Precedents and is Adrift," The Sun (N.Y.), July 5, 1869.

755 “What Does He Think of It Now!,” The Sun (N.Y.), July 1869.

${ }^{756}$ Ibid.
} 
movement legitimate. He insisted that the Cubans had successfully begun their project of republican nation-building. In that vein the paper declared, the day after it learned of the Constitution, that "with this event the revolution passed from the condition of a series of scattered and more or less disconnected risings into a unitary and comprehensive movement." ${ }^{, 757}$ Dana had previously argued that if the Cubans could organize "and put into form a government" that "there is no reason why belligerency should not be conceded to them, if, indeed, their independence should not be immediately acknowledged." ${ }^{758}$ Dana contended that the Cuban accomplishments in the face of a colonial oppressor - deserved open embrace, not scrutiny. The Cuban constitution and emulation of American government earned it, by Dana's estimation, the "ultimate admission" into the informal, republican "American Union." 759 Dana fought Grant's claim that no revolution, and no republican institutions, existed in Cuba to merit recognition. The best example of this was Dana's response to the president's December 1869 speech where, as The Sun reported, Grant rejected the legitimacy of the Cuban rebellion and its new government. Dana argued that the opponents of republican institutions - who believed the conflict "at no time assume the conditions which amount to a war in the sense of international law, or which would show the existence of a de facto political organization of the insurgents sufficient to justify a recognition of belligerency" — had "too much control over" Grant's "mind." ${ }^{\text {760 }}$ Sun editorials insisted that the enemies of Cuba incorrectly "represent the whole movement to have been from the beginning nothing but a scattered insurrection" with no "established government among them." He insisted that it was "discreditable to our administration and to our people" to ignore the evidence of

\footnotetext{
757 “The Revolution in Cuba-A Regular Government Formed,” The Sun (N.Y.), May 5, 1869.

758 “Facts About the Revolution," The Sun (N.Y.), March 30, 1869.

759 “The Revolution in Cuba-A Regular Government Formed,” The Sun (N.Y.), May 5, 1869.

760 “Cuba's Right to Recognition,” The Sun (N.Y.), December 20, 1869.
} 
nation-building on the island. ${ }^{761}$ Dana swore the Cuban rebels had constructed a government that abundantly "fulfills all the conditions requisite to entitle a nation to recognition and fair treatment." 762 Just as important was Dana's insistence that the Cuban rebels military efforts also fell under this category.

\section{Dana and Guerrilla Warfare's Legitimacy}

Dana justified the Cubans' use of guerrilla warfare as means to facilitate the victory of republican institutions. He did this in three ways. First, Dana defended the Cubans' use of guerrilla warfare because it helped the Cubans realize their strategy of defending the constitution that they had created. The editor and his paper insisted that the issue of how the Cubans fought should not be central. Rather, the argument should concern what they are fighting for. Dana thus applauded the Cuban plan to "proceed cautiously, taking no chances that they can avoid... keeping always in view their object, to use up their opponent without ever giving them a chance to use up the revolution." ${ }^{, 763}$ Dana defended the Cubans' use of guerrilla warfare because he understood it to be a thought-out plan seeing results in the field, not desperate terrorism. Those that did not see it so - like the secretary of state — needed to refer to the Spaniards' constant dispatching of reinforcements to understand the success of rebel strategy. One late 1869 editorial noted that Secretary Fish "pretends that there is no revolution in Cuba." It noted that Fish did not believe the conflict to be "anything more than a band of robbers coming down from the mountains now and then." ${ }^{764}$ Dana rejected as un-American the incorrect analysis of the "want of regularity in the military operations of the Cubans." ${ }^{, 765}$ Spanish responses to the Cubans' tangible

\footnotetext{
761 Ibid.

762 Ibid.

763 “Another Great Statesmen against Cuba,” The Sun (N.Y.), January 3, 1870.

764 “Secretary Fish on Cuba," The Sun (N.Y.), December 12, 1869.

765 “Cuba’s Right to Recognition,” The Sun (N.Y.), December 20, 1869.
} 
successes, he insisted, reflected their republican institutions. "What occasion," the paper asked the Secretary, had Spain to then send "twenty-five thousand new troops, or procure thirty gunboats in New York, to put them down" if not for the threat of further, successful, military operations. ${ }^{766}$ In keeping aid from the Cubans, Dana insisted, the Secretary and the president "impose upon people who have an equal right with them to freedom, the same odious tyranny" that they were fighting. ${ }^{767}$

The Cuban Liberation Army's want of supplies represented the second reason Dana cited to defend the Cuban use of guerrilla warfare. The army's lack of formal uniforms, provisions, guns, and ammunition, various Sun editorials argued, validated the Cubans' controversial strategy. One Sun editorial argued that "if the Cubans could have obtained an unlimited supply of arms and other materials of war, if they could arm a hundred thousand men for active campaigning, they could make shorter work of it but that is out of the question." ${ }^{\text {768 }}$ The White House's efforts, The Sun explained, left the Cubans, "not sure of being able to get any more guns or ammunition." Dana explained that the Cubans only had "small forces...only 40,000 men armed with guns to cover their vast territory — and with their limited and precarious resources. ${ }^{, 769}$ Dana argued that because of this, they had to fight in a specific way and use the machete more often than they might prefer. He insisted that the "fact that the Cubans have not fought nor attempted a great a decisive battle" should not matter. ${ }^{770}$ Dana's paper conceded that "such battles are no doubt more showy than the guerilla [sic] warfare which they have

\footnotetext{
766 "Secretary Fish on Cuba," The Sun (N.Y.), December 12, 1869.

${ }^{767}$ Ibid.

768 “Another Great Statesmen against Cuba," The Sun (N.Y.), January 3, 1870.

${ }^{769}$ Ibid.

${ }^{770}$ Ibid.
} 
adopted." ${ }^{771}$ In order to preserve their rebellion, the paper maintained, they needed to resort to irregular warfare to fund the revolution and feed, clothe, and arm soldiers. The revolution could only live on if the Cubans "wear out their enemy by constant alerts and harassments, and not attempt to crush him by any grand operations." 772 Dana called this the only "safe policy" for the Cubans to best defend the gains of their rebellion. ${ }^{773}$ "It would be criminal folly, insanity, for their leaders to peril all" - especially their republican institutions - "upon the issue of any single conflict." Dana insisted that the Cubans understood that they "cannot afford to take any risks" proof "that their wisdom is equal to the exigency of their situation." 774 The editor comprehended that "this is a tedious method" but "is eminently satisfactory to all who wish for the emancipation of Cuba, because it is the only way that is sure to win." ${ }^{, 775}$ Dana's multifaceted defense of the Cuban rebellion encouraged his support of the less than legal transatlantic paramilitary efforts coming from New York City and other American port cities.

\section{Dana and Direct Assistance to the Cuban Junta}

Dana's primary goal in 1869 was to defend the Cuban effort to gain independence in the field. This is one of the reasons he refused to support Fish's proposal to buy Cuban independence as a trade for American hegemony as he believed that the Cubans could win the fight. ${ }^{776}$ Dana illustrated his support of sympathetic groups including the Cuban Junta's fundraising and filibustering apparatus to counter Fish's efforts. At no other point did Dana act so contrary to the

\footnotetext{
${ }^{771}$ Ibid.

772 Ibid.

${ }^{773}$ Ibid.

${ }^{774}$ Ibid.

775 Ibid. Dana joked that he did not care if this strategy was "not satisfactory to soldiers on the ground on the grand scale like Mr. Twain and Mr. Fish."

776 “Aid and Comfort to Spanish Slavery," The Sun (N.Y.), July 8, 1869.
} 
White House's stated policies towards Cuba. His understanding of the war motivated Dana to support paramilitary operations in support of the rebels as a replacement for diplomatic intervention. He personally helped the Junta and other groups fundraise at meetings and directed his newspaper to aid the fiduciary, lobbying, and military arms of Cuban separatist groups. Dana justified his support for the Cuban Junta because the Cuban Liberation Army needed American help to realize their freedom. The paper received direct inquiries from readers looking for information about where to join the rebellion and publicized the location of the Cuban Junta's recruiting stations. ${ }^{777}$ Dana used his network of Cuban connections within the Junta, and on the island, to better advertise the rebellion's needs to New York City readers. ${ }^{778}$ The Sun reiterated calls Dana received from Cuban leaders that guns and cartridges, more than men, were needed. The paper, for instance, reported that at one point in August 1869 some "60,000 good volunteers are waiting for arms." ${ }^{, 79} \mathrm{He}$ sent his reporters to cover every aspect of the filibustering process. Sun correspondents noted that "the patriots do not need men from the United States... but require arms and ammunition." ${ }^{780}$ On other occasions Sun correspondents stood on board filibustering ships as they embarked under the cover of darkness. After a report for one of these, Dana's editorial page "cheered the patriotic recruits of the Cuban Junta, now steaming their way down the coast to aid in the spread of freedom and republican institutions!"781 The paper kept close

\footnotetext{
777 “The Cuban Expedition Under Col. Ryan Safely Embarked,” The Sun (N.Y.), June 29, 1869.

778 "Information for Those Wishing to Serve in Cuba," The Sun (N.Y.), May 13, 1869. Dana explains that they got many applications to go to Cuba, but notes that the issue is not about regular fighters, but supplies, weapons, and ammunition. "What is wanted there is not more men, but more muskets and more cartridges."

779 “The Cuban Anniversary. The Revolutionary Struggles from 1819 to 1869," The Sun (N.Y.), October $11,1869$.
}

${ }^{780}$ The Sun (N.Y.), July 5, 1869. “A correspondent direct from the sugar plantation of a Spanish resident of Cuba confirms The Sun's assertion that the patriots do not need men from the United States. He says that they have enough men on the island. All they require are arms and ammunition. He also avers that the insurgents would have received much sympathy even from the Spanish residents, had they made a declaration of gradual instead of absolute emancipation."

781 “The Cuban Expedition Under Col. Ryan Safely Embarked,” The Sun (N.Y.), June 29, 1869. 
track of the success and failure of filibustering missions almost as a scorecard of the hopeful prospects of republicanism in the Atlantic world. ${ }^{782}$

Dana explained to readers that the White House was using the Navy and merchant marine to arrest sympathizers fighting for self-government. Dana's defense of Cuban sympathizers painted the administration as an ally of the Spanish efforts to blunt republicanism and abolition. One editorial in The Sun argued that "instead of commanding the Spaniard to loosen his grip on Cuba, they actually abet him in tightening it." ${ }^{, 783} \mathrm{He}$ interpreted Fish's policy as one creating a "blockading" force "harassing" ships at the mouth of the Port of New York and across the Atlantic. ${ }^{784}$ Dana pointed to evidence of the State Department working together with the Spanish — and especially their spies in New York City — to effect witch hunts of Cuban-Americans and Cuban separatist sympathizers. ${ }^{785} \mathrm{He}$ indicted the State Department's suppression of filibustering in New York City as reflecting "Spain's rule in New York."786 The Secretary had States" Attorneys and Deputy Marshals playing the "part of the bloodhound" for Spain against republican values in Cuba. ${ }^{787}$ Editorials in The Sun argued their prosecution of Cubans in this fashion made "the traditions, the precedents, the noble, liberal ambition of America, the laughing stock of mankind." 788 Fish's prosecution of filibusters therefore enflamed Dana's opposition to the

\footnotetext{
${ }^{782}$ For a detailed example of The Sun's close coverage of these filibusters, see: "The Cuban Anniversary. The Revolutionary Struggles from 1819 to 1869. Bloodshed under the Rule of Spain," The Sun (N.Y.), October 11, 1869.

783 “Aid and Comfort to Spanish Slavery," The Sun (N.Y.), July 8, 1869.

${ }^{784}$ The Sun (N.Y.), June 29, 1869; The Sun (N.Y.), July 8, 1869.

785 The Sun (N.Y.), June 30, 1869.

786 “Spain’s Rule in New York,” The Sun (N.Y.), July 7, 1869.

${ }^{787}$ The Sun (N.Y.), July 7, 1869.

788 “Aid and Comfort to Spanish Slavery,” The Sun (N.Y.), July 8, 1869.
} 
government's foreign policy. Dana's growing dissatisfaction continued with the White House's attempts to use diplomacy to end the conflict on American terms.

Dana further justified his criticism of the White House's false commitment to republicanism through their inconsistent treatment of American neutrality towards Cuba. This became another of the editor's points of evidence for the administration's preference for stability with Spain over protecting self-government in Cuba. Of Grant's posture towards the two sides, The Sun explained that "our government appears determined... to assist Spain in the retention of her colony, not only to the most punctilious point of international etiquette, but to the utmost of its power." 789 He decried the "false and hypocritical ground taken by Gen. Grant [and] Mr. Fish." ${ }^{790}$ The editor measured the administration's lack of commitment to nationalism by pointing to their breaking of existing statutes to aid the Spanish, not the Cubans. The paper explained that "in violation of the Neutrality Act of 1818 " the administration "has allowed open shipments of arms and ammunition to the Spaniards of Cuba for over a year, and is about to send them a fleet of gunboats, partly manned by American citizens."791 Dana insisted that "Spain can as little be allowed to violate the neutrality act as can the Cubans." ${ }^{, 792}$ Reports from across 1869 to 1870 detailed the connection between the refusal to support Cuban independence and the choice to prosecute Cuban sympathizers. These editorials explained that the White House's selective

\footnotetext{
789 “If One Party Is Indicted, Why Not The Other?,” The Sun (N.Y.), June 19, 1869.

${ }^{790}$ The Sun (N.Y.), March 14, 1870.

${ }^{791}$ The Sun (N.Y.), December 20, 1869. This piece of legislation, meant initially to curb American filibusterers and mutineers helping anti-imperialist Spanish American movements led by Simon Bolivar, were cited here by Dana to point out the hypocrisy of the White House's selective enforcement of these acts in the 1860s. For more, see: David Head, Privateers of the Americas: Spanish American Privateering from the United States in the Early Republic (Athens: University of Georgia Press, 2015); Kevin Arlyck, "Plaintiffs v. Privateers: Litigation and Foreign Affairs in the Federal Courts, 1816-1822," Law and History Review, 30:1 (February 2012): 245-278.

${ }^{792}$ The Sun (N.Y.), March 14, 1870.
} 
employment of the Neutrality Acts of 1818 resulted in "the Cubans, on the contrary... dogged by Government spies and arrested on the least suspicion of an effort to aid their countrymen in the field." ${ }^{, 793}$ Dana's opposition to the strong prosecution of paramilitary organizing developed from similar criticisms of hypocrisy and misplaced priorities in the nation's foreign policy.

\section{Dana, the Grant White House, Corruption, and Collusion with Spain}

Dana's critique of Ulysses S. Grant's job as president between 1869 and 1870 contained a long list of perceived domestic and foreign policy missteps. The government's response to the Cuban rebellion blended these two. Dana retained serious concerns about the potential spread of the president's alleged connection to corruption in domestic politics to international relations. He found the State Department, for instance, to be mired in unethical conflicts of influence. One of these allegations that earned considerable space in The Sun was the previous employment of Secretary of State Fish's son-in-law Sidney Webster by the Spanish crown. While his employment was years before Grant's election, or Fish's supervision of the State Department, Dana feared the potential influence of nepotism and corruption on the administration's Cuba policy. Dana alleged that the arrangement allowed Americans to think that Fish did not want to "place in jeopardy the income which his son-in law Webster derives from the stability of the Spanish dictatorship."794 Dana argued that the connection appeared incredibly ethically suspect. At the minimum it provided the appearance of an infelicitous connection at a time of international crisis. Dana also criticized the State Department's hiring of J.C. Bancroft Davis - a former Erie Railroad employee found guilty of fraud in 1868 - as assistant secretary of state. ${ }^{795}$ These associations between the White House and cronyism encouraged Dana's wholesale reappraisal of the abilities of the American State Department to defend republican government around the

\footnotetext{
${ }^{793}$ The Sun (N.Y.), December 20, 1869.

${ }^{794}$ The Sun (N.Y.), October 17, 1870.

${ }^{795}$ The Sun (N.Y.) December 6, 1869.
} 
world. The Sun called them the "firm of Fish, Webster, and Davis" and the perpetrators of a “...revolting history of the prolonged efforts of Secretary Fish and his son-in-law and associates, aided by Spanish money and Spanish intrigue, to injure the cause of freedom in Cuba, and to fasten anew the Cuban people the bloody manacles of Spanish despotism..."796

Dana did not trust that such a conflicted Department of State could be trusted to ethically deal with other nation, no less Spain. Unfortunately for Dana, Fish and his deputies had been in negotiations with the Spanish Cortes to allow Cuba's independence in exchange for guarantees on American trade preferences and $\$ 150$ million dollars. The negotiations failed and Dana suspected the worst: the Grant administration was colluding with the Spanish government to keep Cuba Spanish, keep the economic status quo in the Caribbean, and stage negotiations between each country as conciliatory gestures for critics across the Atlantic world. One August article explained that "the leading Spaniards... and especially the rich ones, are all very anxious for the arrangement devised by Mr. Fish; and it is in their interest that he is acting.",797 "Nothing could be possibly more at variance with the Declaration of Independence and the spirit of the American people," the paper argued, "than this barefaced attempt to make the national independence of a heroic people, struggling against slavery and despotism, dependent upon the intrigues in which the diplomatic agent of the oppressors may outwit our Secretary of State."798 The slow pace of the White House's only substantive attempt to help the Cubans further soured Dana's opinion of the

\footnotetext{
796 "The Case of the Hornet," New York Sun, October 25, 1870.

797 “A Scheme that Won't Wash,” The Sun (N.Y.), August 3, 1869.

798 “Aid and Comfort to Spanish Slavery," The Sun (N.Y.), July 8, 1869.
} 
president and his advisors. ${ }^{799}$ Dana called Fish "the master of inactivity" $" 800$ and his failed negotiation policy "free America's shame." ${ }^{\text {" }}$ Sun editorials reiterated Dana's claim that the secretary and the president's Cuba policy "places this country in the ridiculous and disgraceful position of shutting the door against the progress of liberty on this continent." 802 Dana argued that "the incompetence and inadequacy which have prevailed in Gen. Grant's administration of foreign affairs are most conspicuously illustrated in this very transaction. ${ }^{" 803}$ Their failure to press the Spanish ministry for an end to the war in Cuba, Dana argued, is "quickly giving aid and comfort to Spanish slavery" and represented "a reversal of the spirit of the American people." 804 Dana insisted that Secretary Fish and the White House hypocritically favored the supposed republicanism of the Spanish Revolution over that of the Cuban example. Sun editorials criticized the American recognition of the new Spanish "republic" but not that of the Cuban

\footnotetext{
799 "Spain and Cuba-Weak Inconsistency on the Part of the Negotiations," The Sun (N.Y.), July 19, 1869. "Why should the Cubans pay any millions to Spain for an island which in the natural course of things will be theirs for nothing within a year? Or who has presumed to pledge them to such payment? Certainly not President Céspedes, for he was elected solely to carry on the war of independence. Certainly not Mr. Morales Lemus, the only Cuban representative with whom Mr. Fish has had any opportunity of conferring. It is plain that neither Céspedes nor Lemus can have pretended to bind Cuba to any such conditions; and that the proposition which Mr. Fish has authorized Gen. Sickles to lay before the Spanish Cabinet is one which will not satisfy the Cubans, and which they will reject as soon as it is offered them. And how foolish they would be if they should agree to an armistice with an enemy who is almost on the point of exhaustion, and who will soon be obliged to abandon the field? The only policy for them is to push things, and that they will likely to do, notwithstanding Mr. Fish's delusive negotiations. It is even more probable that our Congress will reject the proposed guaranty of Cuban bonds. Why should we pay fifty millions for Cuba, or agree to do so in any contingency? When her people have gained their independence, if they desire to be annexed to the United States, we shall all be for letting them in on the terms of the most favored nations. But that is no reason why we should pay Spain a great sum of money for the privilege of making one or two States of the Union out of her late colony. Why should we give our money for that which, if we are to have it all at present, we can get for nothing?"

800 “Mr. Fish’s Masterly Inactivity,” The Sun (N.Y.), August 30, 1869.

801 "Aid and Comfort to Spanish Slavery," The Sun (N.Y.), July 8, 1869.

${ }^{802}$ Ibid.

803 “Do Not Blame Gen. Sickles for Mr. Fish's Blunders," The Sun (N.Y.), November 15, 1869.

${ }^{804}$ Ibid.
} 
government. Dana insisted that the Spanish state represented a more retrograde form of representative government in comparison to the more enlightened Cuban revolutionaries. The Spanish government, by Dana's estimation, remained "only a temporary makeshift... by no means decided whether they will finally form themselves into a republic or into a limited monarchy with a new king." 805 The Sun explained that the Spanish "have attempted to form a new government, as a substitute for that which they had thus summarily overthrown, but as yet have not had much success in the effort." The paper quickly compared the constitutional - but not republican Spanish revolution — with a Cuban rebellion made military and political progress. The editor lamented that Secretary of State Fish's preference for this Spanish government over the Cuban republic forced the nation at-large "to take the side of one, and to show itself bitterly hostile to the other." ${ }^{806}$ As evidence, the paper used the close diplomatic relationship between the State Department and Spanish ministers. One Sun editorial explained that the difference in the diplomatic treatment illustrated the administration's indifference to the republican effort in Cuba. "The Minister of the Spanish rebels is recognized at Washington," Dana's paper explained, "and he is permitted to use all our naval force and all our civil officers on behalf of his employers." The result of Fish's selective policy, Dana explained to readers, was that "instead of commanding the Spaniard to loosen his grasp on Cuba, they actually abet him in tightening it." ${ }^{" 808}$ The paper continued that the Cubans are instead "denied recognition and their friends here are treated as

\footnotetext{
805 "Spain and Cuba—Weak Inconsistency of the administration," The Sun (N.Y.), July 19, 1869.

${ }^{806}$ Ibid.

${ }^{807}$ Ibid.

808 “Aid and Comfort to Spanish Slavery,” The Sun (N.Y.), July 8, 1869.
} 
felons for trying to assist them." ${ }^{\text {"09 }}$ The secretary of state - by Dana's estimation — was

"disgracing the reputation of the country by its weak pandering" to the Spanish ministry. ${ }^{810}$

\section{Dana, Grant's Cuba Policy, and a Fractured Republican Party}

Dana's last reaction to the Grant administration's Cuba policy produced his criticism of the policy's negative impact on the Republican Party. Dana's claim that the president's Cuba policy severely weakened the Republicans' domestic vitality is further evidence that the editor drew no sharp lines between domestic and foreign policy. Historians have shown that other examples of Grant's foreign policy, in places such as the Dominican Republic, also did not receive the necessary support of the president's party. ${ }^{811}$ Dana joined many of these critics of the White House's policy towards the Dominican. He argued that the president's belligerent attempts to annex the western portion of Hispaniola, his efforts to force annexation bills through Congress, and reports of State Department corruption, left the Republican Party exposed to challenge. Sun editorials argued that politicians opposed to the use of power to acquire land in places like the Dominican Republic had reason to defeat Grant and other Republicans in domestic elections. ${ }^{812}$ Historians have shown that Congress' rejection of Dominican annexation treaties encouraged candidates to use the Dominican issue in state and national elections across the early $1870 \mathrm{~s} .{ }^{813}$

809 "Spain and Cuba_Weak Inconsistency of the administration," The Sun (N.Y.), July 19, 1869.

${ }^{810}$ Ibid.

${ }^{811}$ Summers, The Ordeal of the Reunion, 220 - 227.

812 "St. Domingo - Approaching Rupture of the Republicans with the President," The Sun (N.Y.), July 7, 1869. "If Andrew Johnson had been concerned in it as Gen. Grant is, no human power could have prevented the success of impeachment. The instruments and means employed, together with the secret and suspicious character of the transactions, demand the sternest treatment. More than one hundred and fifty dollars have been sunk, to say nothing of the expenses charged to the secret service fund, which will never appear. Besides those facts, ships of war were withdrawn from Cuba, where they might have protected American citizens against brutal murder, and sent to St. Domingo to enforce annexation and see it voted as a free expression of the people.” Also see: "Good Authority,” The Sun (N.Y.), June 17, 1870.

${ }^{813}$ Summers, The Ordeal of the Reunion, 220 - 227; James W. Cortada, "A Case of International Rivalry in Latin America: Spain's Occupation of Santo Domingo, 1853-1865," Revista de Historia de América, 82 (July-December, 1976); Besada Ramos, "Antecedentes economicos de la Guerra de los diez años," 158 - 
The situation in Cuba, by Dana's estimation, similarly influenced the party. ${ }^{814}$ The best place to see the interaction of domestic party politics regarding Cuba is in his analysis of the June 1870 House of Representatives vote on recognizing Cuban belligerency. Dana's blurred internal and foreign policy perspective analyzing this debate shows three things: first, Dana justified his demand for the Republican Party to aid Cuba because of the ideological motivations of the Cuban rebellion; second, Dana hoped that Congress would recognize the Cuban's rights of belligerent's in defense of "American" values in the Western Hemisphere; and third, Dana's reaction to the defeat of the Cuba bill in June 1870 - citing corruption in the State Department, Congress, and the Spanish Cortes - reinforcing his larger claims that unethical practices and repression saturated the Grant administration, and weakened the "party of Lincoln." Sun editorials predicted that the mid-June 1870 House of Representatives vote would show that Congress appreciated the Cubans' turn towards self-government even if the administration did not. One January essay asked if congressional Republicans could "bring Congress up to the line of its duty." ${ }^{\text {"15 }}$ To Dana this duty meant exhibiting the "strong sense of the obligations they owe to the cause of liberty and republican institutions on this continent." ${ }^{, 16}$ The Sun supported the Cuban writing of a Constitution, the development a bi-cameral, three-branched government on the American model, and the fight against their colonial rulers with an organized military effort. The Republican

161; Pérez, Cuba: Between Reform and Revolution, 120; Nicholas Guyatt, "America's Conservatory: Race, Reconstruction, and the Santo Domingo Debate," Journal of American History 97 (March 2011): 9741000; Millery Polyné, “Expansion Now!: Haiti, 'Santo Domingo,' and Frederick Douglass at the Intersection of U.S. and Caribbean Pan-Americanism," Caribbean Studies 34, no. 2 (Jul. - Dec., 2006): 345; Harold T. Pinkett, "Efforts to Annex Santo Domingo to the United States, 1866-1871," Journal of Negro History 26, no. 1 (January 1941).

814 “St. Domingo-Approaching Rupture of the Republicans with the President," The Sun (N.Y.), July 7, 1869.

815 "Cuban Independence—-Monroe and Clay Contrasted with Grant and Fish,” The Sun (N.Y.), January 17, 1870.

${ }^{816}$ Ibid. 
Congress had to see the regional parallels in what the Cubans had accomplished, and hoped to accomplish, if the White House remained unmoved. Dana argued that the Republican-majority Congress had to fix the administration's foreign policy that "spar[ed] the proud" and "bully[ed] the weak." ${ }^{817}$ Grant and Fish, Dana explained, failed to recognize the essence of the Cuban rebellion. Dana insisted that Grant's Republican supporters did not understand Cuban goals: "self government, the right to think, discuss, and publish their opinions, political social and religious, the right to educate their children, and the right to disencumber themselves of the cursed institutions of negro slavery. ${ }^{" 818} \mathrm{He}$ wanted everyone in the legislative body, and its Republican majority, to prioritize a free Cuba because they embraced these American values since the founding of the country. A vote recognizing Cuban belligerence in June 1870, the Sun agreed, would affirm the national commitment to the regional protection of transcendent American values.

Dana publicized the growing rift in the Republican Party between those who refused to be swayed, and those entirely swayed, by the "American" ends of the Cuban rebellion. In so doing Dana hoped to show a groundswell of support from major figures in the party to change the minds of anti-interventionists. Just as the party was fracturing over Grant's domestic blunders, so would the Cuban issue split the party. One February 14, 1870 editorial applauded the preliminary support for Cuba from Republican Senators Matthew Hale Carpenter and Timothy Otis Howe from Wisconsin, Oliver P. Morton from Indiana, and John Sherman from Ohio. ${ }^{819}$ Other editorials noted that other Republicans in the House of Representatives, Nathanial Banks from Massachusetts, General John A. Logan from Illinois, and Thomas Fitch from Nevada would defy

817 "Sparing the Proud, Bullying the Weak," The Sun (N.Y.), March 4, 1870.

818 "What Cubans and Spaniards Are Fighting For in Cuba," The Sun (N.Y.), May 16, 1870.

${ }^{819}$ The Sun (N.Y.), February 14, 1870. 
the president and "fight for human liberty" in Cuba ${ }^{820}$ Dana dealt personally with many prominent Republicans regarding the case for Cuba. At one April 1870 meeting attended by over nine thousand New Yorkers, Dana sat as vice-president for a group of Cuban sympathizers that included prominent Republicans. A Sun editorial describing the meeting noted the attendance of former Republican Senator from New York and chairman of the Republican Party Edwin Denison Morgan, Grant's former Treasury Secretary Alexander T. Stewart, Republican politicians from New York William M. Evarts and Frederick A. Conkling, Lincoln's international law advisor Franz Lieber, and the radical Republican President Pro Tempore of the U.S. Senate Benjamin Wade. ${ }^{821}$ This was a group of prominent leaders in Congress. The Sun took every effort to publicize those Republicans openly resisting the administration's attempt to keep the nation neutral in this larger conflict attracting Dana's protection of regional liberal and republican institutions.

The editor explained that growing Republican support of the Cubans in mid-1870 would expand the party's abolitionist and republican objectives to include Cuba. As it stood, Dana argued that since the summer of the preceding year, the White House defended slavery and repression in Cuba by avoiding intervention. Sun editorials maintained that their policy towards Spanish slavery looked no different than a policy that Confederate general Robert E. Lee and Confederate President Jefferson Davis might have created. Considering the continued existence of slavery in Cuba, the paper maintained that a Lee-Davis foreign policy "could not be more adverse" to the nation's Cuban policy as Grant's "now is to the cause of human freedom." 822 For an original Republican like Dana there may have been no lower comparison than to equate Grant

\footnotetext{
820 "The Republicans are on the Side of Spain, The Sun (N.Y.), June 17, 1870.

821 "New York for Free Cuba," The Sun (N.Y.), April 5, 1870.

${ }^{822}$ The Sun (N.Y.), June 4, 1870.
} 
with the former star general and President to the Confederate States of America. Sun editorials argued that if Andrew Johnson had been so involved in the Caribbean as Grant was "no human power could have prevented the success of impeachment." ${ }^{\prime 823}$ For a Reconstruction-era Republican like Dana there may have been nothing less powerful that could have been alleged. Dana wanted Republicans to consider the heritage of their party when deliberating on whether to support Cuban belligerency. The party had succeeded in defeating slavery and spreading freedom in 1865 . It championed the citizenship and voting rights of freedmen by 1868 . Dana wanted it to do the same for Cuba in 1869 and 1870. Grant's policy frustrated Dana's regional hopes for the party's protection of republican institutions. Critically, Dana argued that Grant's policy frustrated the health of the party. "If the President perseveres in this ignominious policy," The Sun explained, "the party that lifted him into power will be grievously punished." 824 The paper reported that the Democratic Party could easily take advantage of the blunders and come out for abolition in Cuba to gain voters. ${ }^{825}$ Dana predicted that when the Republican Party received electoral blow-back for its Cuba policy that "poor Mr. Fish will vainly deplore his efforts in behalf of Spanish tyranny and slavery." ${ }^{926}$ The president would regret his policy’s impact on the party that chose to sponsor his candidacy, he claimed. Editorials in his paper argued that Grant's popularity "is walking on the verge of a precipice, and that [the health] of his party will black, sudden, and beyond remedy, if he does not speedily arouse himself to the realities around him." ${ }^{\text {"27 }}$ The administration's "fatal policy towards the Cubans," he explained, put "this great country into

\footnotetext{
${ }^{823}$ The Sun (N.Y.), July 7, 1869.

824 “Aid and Comfort to Spanish Slavery," The Sun (N.Y.), July 8, 1869.

825 “The Democratic Manifesto,” The Sun (N.Y.), June 28, 1870.

826 “Aid and Comfort to Spanish Slavery,” The Sun (N.Y.), July 8, 1869.

827 “What Does He Think Of It Now?," The Sun (N.Y.), July 8, 1869.
} 
the sad and revolting position of a spy and policeman of Spanish despotism, laboring for the perpetuation of slavery in Cuba." ${ }^{928}$ Dana called on Congress to remedy this situation in the middle of 1870 by expanding the legacy of the Civil War victory over slavery by offering to protect "American" values in Cuba.

Dana's reaction to the defeat of the bill - prompting accusations of corruption in the State Department, Congress, and the Spanish Cortés - reinforced his larger claims that corruption saturated the Executive Branch and would weaken the fractured Republican Party. "The Cuba bill has met with a temporary repulse to-day," the paper reported of the "nay" vote in the House of Representatives on June $18^{\text {th }}, 1870 .{ }^{829}$ Editorials the day after the vote lamented the spurning of democratic institutions in the House by the Republican Party. Dana continued to insist that many friends of Cuba still resided in Congress, but that many previous sympathizers had been enticed by bribes to forsake the island. The result of the vote, the editor concluded, was a "sad ... illustration of the power of corruption in republican government." ${ }^{\prime 830}$ Dana, along with some others, insisted that the White House threatened the establishment Republican Party in order to secure the vote against Cuba. Sun editorials explained that "members of the Committee on Foreign Affairs have been tampered with. ${ }^{" 831}$ Dana admitted he had misjudged those Republicans in the House he thought unimpeachable regarding Cuba. He explained to his readers the reason: "that men who were allied to the cause of freedom in Cuba... were seduced from their allegiance by the promises of glittering prizes held out by the executive." ${ }^{\circledR 32}$ The Sun argued that the vote

\footnotetext{
${ }^{828}$ Ibid.

829 “The Cuban Question in the House," The Sun (N.Y.), June 18, 1870.

830 “The Republicans are on the Side of Spain," The Sun (N.Y.), June 17, 1870.

${ }^{831}$ Ibid.

${ }^{832}$ Ibid.
} 
confirmed that the "Republicans are on the side of Spain." "333 "The Republican President stands today a pitiably poltroon on the side of Spain and slavery; and the Republican House is with him,” Dana's paper wrote.

Dana's indictment of the Republican Party's Cuba policy did not mask his hopes that self-government could be spread across the Western Hemisphere and Atlantic world (even without the American government's help). "The end is not yet" one Sun editorial consoled readers. "The Republican Party may commit suicide; but the rights of man cannot be killed," Dana insisted. Sun editorials maintained the editor's now months-long argument that the administration ignored the public's support for Cuban intervention. "The people of the United States hate despotism and love liberty," the paper wrote aiming directly at the White House. ${ }^{834}$ Dana exhorted the White House and the House of Representatives to understand that "if the Republicans had spoken an honest, earnest word for Cuba, they would have all hearts with them." ${ }^{935}$ In support for Cuba "the Republican Party had a chance to keep the lead of the country. ${ }^{836}$ Now, though, everyone associated them with suppressing Cuban freedom, Dana argued, and as the stooges of Spanish interests. Immediately after the failed Cuban vote Dana called Grant the "watchdog of monarchical interests in this hemisphere." He indicted Republican foreign policy leaders for failing to protect "the weak from the strong" or doing "anything to promote freedom or save Cubans from massacre, or women from outrage." ${ }^{\circledR 37}$ One letter written to The Sun from a reader in New Jersey took Dana's side and ably recaps this chapter of the

\footnotetext{
${ }^{833}$ Ibid.

${ }^{834}$ Ibid.

835 “The Republicans are on the Side of Spain," The Sun (N.Y.), June 17, 1870.

${ }^{836}$ Ibid.

${ }^{837}$ The Sun (N.Y.), June 20, 1870.
} 
dissertation. Written in the shadow of the Congressional vote, the reader writes, "I am a Republican, and always have been since the organization of the party; but it is with burning shame that I witness the cowardly and un-American conduct of my party on this question." "With you," the letter continued, "I feel that the days of the party are numbered unless they arouse themselves to cut loose from the leadership of such men as Grant, Fish, and Sumner, men who love Spain and slavery better than America and freedom."

\section{Conclusion}

By the middle of 1870 , Dana had already become a hardened member of the political opposition to the Grant White House, and the ruling majority of the Republican Party in Congress on the back of his transatlantic perspective. The coverage of the Ten Years War and Cuban independence in The Sun across the first fifteen months of the Grant administration illustrates how closely Dana associated domestic and foreign affairs when judging the republican standards of the White House. Historians, as the chapter explained, have a good sense of how the Grant administration's policy in places other than Cuba influenced American politics in this very period. The president's attempts to annex the Dominican Republic became a major political issue in the United States in the late 1860s and early 1870s. Historians have explained that the issue helped destroy the unity in the Republican Party that had just recently been encouraged by party leaders to pass the Fifteenth Amendment, and the various Reconstruction Acts of $1870-71 .^{839}$ The Dominican Republic annexation issue became a critical part of the platform of the growing "liberal Republican," ${ }^{440}$ and Democratic Party, movements that were developing to oppose the

\footnotetext{
838 "Voices from the Republican Rank and File," The Sun (N.Y.), June 15, 1870. "They are but our servants. Then why do they not respect the sentiment of the public?...I and many Republicans cannot be led by the nose at the tail of Spain, by party discipline or Spanish gold."

${ }^{839}$ Guyatt, “America’s Conservatory,” 999.

${ }^{840}$ I put the term in quotes to denote the formal and informal reform movement within the Republican movement that would eventually orbit around the Liberal Republican Party in the early 1870s.
} 
president. This chapter showed that a similar process occurred regarding the administration's policy toward Cuba and the Ten Years War in the same period. The chapter featured Charles A. Dana's personal commitment to Cuban independence, and the role that his Atlantic perspective regarding republican values played in encouraging his disillusionment with his old party and political allies. For Dana, attempting to get the United States to assist the Cuban rebels obtain their independence from Spain intersected with the ideological strain of self-government, egalitarianism, and democracy that the United States had just fought for during the Civil War, and earlier still during the American Revolution. His elevation of the Ten Years War to compare to these American landmark events illustrated parts of Dana's motivations for interpreting potential American intervention to republican values in the Atlantic world as a duty for the nation.

The White House's Cuba policy enflamed Dana's transatlantic political opinions in the first fifteen months of Grant's presidency and stood strongly along Dana's criticism of the president's domestic politics. The "Grantism" and "Tweedism" that an earlier chapter has explained dominated Dana's characterization of the president and his bureaucratic performance also translated to his analysis of the administration's controversial policy toward Cuba and Spain. This has chapter explained that Dana's opposition to this policy joined his ethical repulsion with the issues of corruption and misadministration plaguing the White House since March of 1869 when Grant entered the White House. Dana's support for Cuban independence, and potential annexation to the United States, developed from the commitment to republicanism that Dana had exhibited since his early adulthood. He lived through the period where the United States confronted all of these issues in various forms from the 1830s through the Civil War and Reconstruction. Because the world was undergoing its own confrontation with these issues at this very period, Dana interpreted them together. While these chapters have presented parts of these domestic and foreign intersections separately for the sake of detail and organization, The Sun treated these republican concerns of its editor equally. Across the first fifteen months of Grant's 
term, Dana justified his growing opposition to the president and his allies in the Republican Party by considering domestic and foreign affairs together. The walls closing in on his republican visions for what the nation could be were varied, and he used his newspaper to address corruption within the United States, as well as outside of it. Dana thought of corruption in the expansive way that so many others in the nineteenth century thought of it; as the corruption of a republican ideal based in a specific interpretation of the American Revolution (the American Civil War and the 1870s). By adding the issue of Cuban independence to the portfolio of Dana's building criticisms of the administration, these last two chapters have attempted to show that by the middle of 1870 Dana had developed a very mature opposition to his former allies in the president and the Republican Party.

The decision that Dana made to oppose his president in this period (the decision that has single-handedly influenced his perception among contemporaries and historians since), remained more about Dana's political "independence" and transatlantic perspective than about his earlier desires to gain a patronage post from Grant. These characteristics of his remained salient features of Dana's outlook and continued to show their influence in the positions that Dana took in reaction to the administration policy, as well as his newspaper's efforts to reform the American political party system. Dana's republicanism and transatlantic outlook encouraged him to reject parts of the vision for the nation being forwarded by the mainstream Republican Party in the late 1860s and early 1870s. Indeed, much of Dana's problem with Grant and his allies had to do with the tools and approaches that they used to codify the republican values won in the late Civil War. This produced a complicated web of positions that left Dana outside of the normal bounds of each party. Dana had rejected Grant's Republican Party because he had moved the party towards a new "organizational mode" (as Foner explained it) centered around patronage and away from service to the party's traditional ideology. Dana had also rejected the forceful, militaristic, and statist fashion with which Grant and the mainstream Republican Party executed the reconstruction of the 
nation. He supported parts of the spirit of the administration's policy but rejected the means through which Grant and his allies attempted to realize them. Dana's estrangement from the Republican Party on this point alone was illustrated in chapter three. For Dana, then, the White House's Cuba policy only produced more concerning issues. For one, it proved especially confusing. The White House claimed to be against slavery, and for the establishments of republican-inspired states across the South where new constitutional rights were supposed to flourish. In Cuba, however, the administration remained aloof about a war for these very values ninety miles off American shores. There, one side stood clearly on the side of republican values and in strong alignment to traditional American values. Dana's editorials in The Sun reflect his utter disappointment that the general who helped lead the Union armies defeat the slaveconspiracy of the Confederacy, and enshrine free labor as an American right, would allow his administration (and indeed his secretary of state) to ignore the cries of a burgeoning republican revolution asking for the help of the United States. More criminal still, in Dana's eyes, was the White House's direct intervention in blocking assistance from reaching these Cuban republicans. Dana rejected each of the administration's reasons - economic, diplomatic, and legal - for avoiding intervention. He hated more that it looked as if the Republican Party's turn toward a corrupt "organizational mode" also inflicted the decision-making behind these policies. State Department employees had all variety of financial connections with the Spanish Government, embezzlement and fraud in the United States, or insider trading on annexationist rings for both Cuba and the Dominican Republic. 


\section{CHAPTER SIX}

\section{CONTINUTED OPPOSITION TO GRANT’S RECONSTRUCTION POLICY}

(MID-1870 - 1872)

"The usurpations of Caesar, of Cromwell, and of the two Napoleons were not the work of a day... A heedless people were gradually prepared for the culminating acts by specious pretexts which they failed to detect at the time, and... had not the courage to resist until it was too late. They sat idly, too eager in the pursuit of wealth and pleasure," and remained, "too subservient to factious leaders, too unmindful of individual duty." Without action at the "critical moment, they fell as prey to plausible pretenses, to fraud, to force."

— "Resist Beginnings," The Sun (N.Y.), August 22, 1871.

Dana's opposition to the president's domestic and foreign policy across 1869 and the first half of 1870 reinforced The Sun's position as a critical part of the American political community. ${ }^{841}$ The paper's historic place in American newspaper lore, as perhaps the first widely popular and cheap newspaper of the 1830s "penny press" era, had been brief and it was not to recover its appeal until Dana entered the editor's office. Dana used the paper to help install him as a leading newspaperman of the country, one of the foremost critics of the president, and an authority on questions about public policy, economics, and social equality. Dana built a decadeslong curriculum vitae advocating for republican-inspired policy in these areas across the Atlantic world. This chapter presents an updated argument for how his domestic policy visions, and his republican expectations for good government - hardened across decades - solidified his opposition to the president and the Republican Party in the early 1870s. The chapter contextualizes the policy debates surrounding Dana's republican interpretation of economic and political questions, and how his interpretation of American domestic and foreign policy motivated

\footnotetext{
${ }^{841}$ Dana's in-house circulation counts had The Sun leading the other New York City newspapers by large margins - almost as much as the next four papers combined (the Times, Herald, Tribune, and World. Historical analysis of these numbers suggest Dana's numbers would not have been far off.
} 
the editor's continued break with the Republicans. The chapter shows that Dana's decades-old commitment to transatlantic reform became yet one of the other inspirations to explain his visceral opposition to the Grant administration.

The elevation of Dana and his paper's popularity, and infamy, in 1869 and early 1870 coincided with the continued agitation of American Reconstruction. Dana's life and ideas in the period continued to reflect the frenetic nature of his time. Previous chapters have focused closely on the change in Dana and his newspaper's reversal in support of the president and the Republican-dominated political order. They have highlighted how reports of the governmental fostering of nepotism, financial corruption, and overuse of power in domestic affairs, enflamed Dana's liberal and republican fears of tyranny and militarism. These chapters analyzed the republican underpinnings of Dana's trans-Atlantic thought to show how intensely he supported the cause of the Cuban rebels fighting for self-government from Spain. They showed how Dana revoked his support for the president and the Republican Party when the latter failed to support the Cuban revolutionaries. This chapter continues the project's broader focus on Dana's republican-inspired criticism of the president between 1868 and 1872. From the middle of 1870 forward, Dana's transformation of opinion relative to Grant stemmed from domestic issues of nepotism, corruption, and overuse of power. The editor, though, also emphasized other reasons for his disillusionment with his former political allies. These included disagreements about economics, trade, immigration, labor, and Reconstruction policy between the summer of 1870 and early 1872 . As he did so, Dana again featured republican themes to explain the popularity of the new, and independent, party movements opposing the ruling Republican coalition. Before exploring Dana's plans for the nation in the early 1870s, it is important to first analyze the vehicle Dana used to communicate his proposals for the nation and reasons for his disappointment with the administration: his newspaper. 


\section{The Popularity of The Sun}

The Sun's circulation rose rapidly in the period from January 1869 to July of 1870 , concomitant with Dana's opposition to the president and the Republicans. By the paper's own count, The Sun's average, daily circulation dramatically rose from about 35,435 to $116,500 .{ }^{842}$ The paper's circulation numbers grew as Dana popularized his republican vision for the early 1870s country. The Sun's editorials illustrated Dana's continued commitment to equality before the law, egalitarian civic culture, and republican self-government in a period where these ideas were ascendant. One July 1870 editorial boasted that sales had "more than trebled our circulation, till it is now equal to that of all the four-cent old-fogy (sic) morning blanket sheets combined." 843 Still selling at two-cents, The Sun claimed that its ascendance over the Times, Herald, Tribune, and World made it then, "the most successful newspaper in the world." 844 Dana set the pace in circulation, while also criticizing the corruption and personal government within the Grant administration. His paper's high circulation numbers occurred as he aligned The Sun's resources to evaluate the government's commitment to civic virtue and self-government. The editor maintained that the abolition of slavery in 1865 , and the push for universal manhood suffrage in the late 1860 s remained reflections of these ideals. ${ }^{845}$ Grant's first term conflicted with many of Dana's ideals reflected in The Sun's coverage. Part of the paper's popularity stemmed from Dana's paper becoming an independent critic of Grant, the establishment Republican Party, and

\footnotetext{
${ }^{842}$ The Sun (N.Y.), July 27, 1870.

843 Ibid.

${ }^{844}$ Ibid.

${ }^{845}$ Reconstruction came to represent for Dana a symbol of the nation's liberal and republican identity. Reconstruction forced Dana to again call to his collection of arguments about the nation's republican past: a Jeffersonian-Republican commitment to small government, civic virtue, and community-level egalitarianism alongside a Whiggish fear of the potential influences of Old World style despotism, tyranny, and personal government. For more on Dana's pre-1860s history of supporting the expansion of republican values across the Atlantic world, see chapter one of this dissertation.
} 
the pro-administration Republican press. For instance, The Sun knew that its recent rejection of the Republicans made it one of the president's least favorite papers. ${ }^{846}$ The differences that The Sun developed with both the president and the Republican Party, arose from opposition to Reconstruction and foreign policy, and Grant's embrace of patronage as a political weapon. Dana's vision for the nation's economics and labor relations, though, also diverged with the image for the nation communicated by the president and his allies. To that end, Dana embraced various strategies inspired from his republicanism that the nation should employ to improve the lives of Americans in the early 1870s.

If the Grant administration and the Republican controlled Congress wanted to improve its reputation with the country Dana recommended that they should prioritize the creation of a robust American economic market that protected immigrants, workers, and producers alike. Dana's policy recommendations in 1871 and 1872 can be traced directly to Dana's employment at the Tribune, where he worked with one of the most prominent nineteenth century political economists, Henry C. Carey, who helped focus his ideas. In the early 1870 s, as in the 1850 s and 1860s, Dana followed Carey and the Tribune's Whiggish economic nationalism and republicanism. ${ }^{847}$ Dana's attraction to Carey's ideas continued, as he supported updated versions of his economic platform in this period: the abolition of the Civil War-era income tax to encourage investment, ${ }^{848}$ a commitment to a gold standard as the foundation of a stable

\footnotetext{
${ }^{846}$ Grant, The Sun reprinted in December 1871 reports from its fellow reformer paper, Halstead's Commercial, paid an intern to check each's editorial page for insults. The Commercial report also noted that the New York Times, a paper The Sun openly criticized for elite, corporate, global capitalist, corrupt, and illiberal tendencies, remained the President's first option in newspapers. See: "Going to See Grant. Adventures of a Newspaper Correspondent. Correspondence Cincinnati Commercial," The Sun (N.Y.), December 21, 1871. Recounting a Commercial reporters attempts to see Grant. Explains that Grant has someone read the Commercial and The Sun to keep him abreast of what the critics say and that most of the papers who have correspondents in Washington are anti-Grant. Correspondent: H.V.R.

${ }^{847}$ For more on Dana's history of protectionism, see chapter one and two of this dissertation.

${ }^{848}$ Dana often called the income tax unconstitutional — a reflection of his tender relationship with both small government conservativism, and liberal egalitarianism. Dana also argued that the federal government
} 
international market, and a high tariff to shelter American artisans, workers, and consumers. ${ }^{849}$

Drawing on the Carey-ite ideas that Greeley cultivated at the Tribune, Dana advocated that these policies would help moderate the corrupt excesses of the Grant administration. ${ }^{850}$ Dana's approach to revenue in the 1870s sought to minimize any risk for the Reconstruction nation while alleviating its citizens of further regulatory burdens. Dana also sought a system that could help insulate all Americans from the shocks of economic dislocation and rapid industrialization brought on by free-market capitalism. Proposals for the economic health of the nation, he found, further related intimately to his opinions about American labor rights and role of immigrant culture. Building on his advocacy for the rights of labor and capital and pressing for the benefits

should avoid using initiatives other than taxes to reduce the debt. For a strong summary of Dana's opinions on American taxes, see: "Our Destructive Taxes-Funding the Debt," The Sun (N.Y.), March 6, 1871. "According to Mr. Boutwell, 'the large revenues of the Government have been the chief means by which the public credit has been improved, and our paper currency appreciated materially in value as compared with coin.' He also thought 'that the change which has taken place in the financial system of the country during the last ten years renders the preservation of the public credit a duty of the highest importance inasmuch as every business enterprise and every financial undertaking rests finally upon the public credit.'

... "While the business of the country is ruined by absurd and impracticably taxes, so that the Treasury may make a fictitious show in order to help the Secretary to borrow money at a lower rate, the published details of the funding scheme that has been devised are worthy of such a preposterous and lunatical policy. There are already some fifteen or twenty different classes and denominations of the public debt and it is proposed to add to them three more; and now that the whole world is borrowing, and money is dear, the Secretary expects to sell bonds bearing four per cent. and four and a half per cent interest! And in order to sell them he mixes them up with five per cent bonds is mixed with molasses. What can come of it? Nothing but confusion worse confounded. With the mania for high taxes this passion for multiplying the denominations of our national securities is not inconsistent. Meanwhile business is declining, industry of every kind is strangled, and the farmers borrow the money to pay their taxes. The country is rapidly approaching such a paralysis as it has not dreamed of since 1837. That crisis produced a political revolution which swept the Democrats out of sight. What does Mr. Boutwell expect will happen to him and his party in 1872?"; Also see: "Protest against the Income Tax," New York Sun, August 4, 1870. Notable quote from this editorial: "The income tax is unconstitutional as well as unjust; and it will certainly be set aside as soon as the question can properly be brought before the courts."

849 “Common Sense on the Tariff," The Sun (N.Y.), March 31, 1871.

${ }^{850}$ Ibid. Dana supported using gold to help pay down the debt as the first responsible policy to help spark economic growth and free moneys for American investment in manufacturing. Dana hardened his stance supporting the gold standard versus inflationary greenbacks across the middle of 1870 and into the lead-up of the election of 1872. For a few examples of Dana's support for Gold over silver or greenbacks to pay down the debt, see: "Gold and Greenbacks," The Sun (N.Y.), August 5, 1868; "Gen. Butler's Currency Bill," The Sun (N.Y.), January 13, 1869; "Light on Dark Subjects," The Sun (N.Y.), February 27, 1869; The Sun (N.Y.), March 12, 1869. 
of cooperation between the working and capital owning classes, ${ }^{851}$ he maintained that the nation's immigration, labor, and trade policies needed to work together to realize the republican-ideal inherent in American political culture. Sun editorials argued that the nation's political economy needed to cooperate more with the American working classes to protect the interests of the entire American economic system. ${ }^{852}$

From the middle of 1870 forward, The Sun publicized the importance of the growing labor union movement across the country as a critical feature of the future health of the nation and its political parties. Dana's editorial page particularly emphasized the labor movement's ties to his republican interpretations of cooperation in economic, trade, and immigration policy. In the Civil War period, but especially in the late 1860s and into the first years of the 1870s, a thriving domestic labor movement developed that Dana had known since his time organizing labor in the $1840 \mathrm{~s}{ }^{853}$ The attention Dana's Sun offered the movement reflected this trend. The paper focused on groups like the Workingmen's Union, the National Labor Union, ${ }^{854}$ the National Labor party, ${ }^{855}$ or the Workingmen's League in New York City, which pointed to an American precedent for friendship between American industry, artisans, and common labor. Dana had long championed the development of cooperative schools and housing complexes by workingmen's

\footnotetext{
${ }^{851}$ For more Dana and cooperation, see chapters one and two of this dissertation.

852 "A Workingmen's Ticket. The Union Going Into the Next Canvass with its Banners Inscribed for the Eight-Hour Law-Trouble for Tammany," The Sun (N.Y.), July 22, 1871; "Legislation for Labor. Shall There Be a Commission on Hours and Wages?," The Sun (N.Y.), December 20, 1871.

${ }^{853}$ For more on Dana's time working with labor, especially while he was advocating Associationism during and after Brook Farm, see chapters one and two of this dissertation.

${ }^{854}$ For more on this federation of trade unions, see: Summers, The Ordeal of the Reunion, 231. Summers argues that by the late 1860 s and early 1870 s, the group "claimed 200,000 to 400,000 members."

855 "The Political Utopians. Principles of the National Labor party-How to Adjust the Differences between Labor and Capital, and Restore the Government to its Original Purpose," The Sun (N.Y.), August $11,1871$.
} 
groups to guarantee that labor groups could create their own opportunities. ${ }^{856}$ Dana's paper argued that these policies would encourage higher rates of property ownership by workers and enrich the nation from its foundations. ${ }^{857}$ But wages had been consistently stagnant since before the Civil War, The Sun reminded readers in July 1870, while commodity prices had risen after the 1840s and 50s gold discoveries on the west coast. If workers wanted to change their circumstances, The Sun wrote, they had to employ unions demand wages to match the rising standard of living, and working hours lowered to match the elevated political and social expectations of the age. ${ }^{858}$ Dana's Sun explained that this cooperationist program could only succeed if employers and politicians supported fair wages and considered pro-labor reforms like the eight-hour work day, worker's injury compensation, and health insurance. ${ }^{859}$ Other policies

${ }^{856}$ Chapter one of this dissertation presents some of Dana's earliest experiences, and ideas, advocating these worker's cooperatives. In its own way, Brook Farm was a reflection of one of these experiments in the manifestation of a utopian commune. Dana also had in mind many of the European labor union cooperatives that were centered directly around worker's communities. Dana viewed these as an alternative for workers to take, hopefully with some government support, to fill in the gaps in wages and opportunities left by the expanding industrial capitalist economy of the early 1870s. Also see: "Capital and Cooperation," The Sun (N.Y.), August 19, 1868; "Cooperation, Education, and Trade," New York Sun, December 12, 1868.

${ }^{857}$ For more on The Sun's recent position on this labor question, see: "Do the Workingmen Own Themselves?," The Sun (N.Y.), October 25, 1869.

858 “Trades Unions," The Sun (N.Y.), December 1, 1870. "The object sought in the organization of trades unions is one which must commend itself to every reflecting thing; for it is an unquestionable truth that labor is the foundation of all our wealth. Every measure that tends to the elevation of labor in any of its relations is deserving of commendation, as the more honorable labor is made to appear and the more remunerative its results, the greater will be the number of intelligent men who will devote themselves to the occupations of productive industry, and the greater will be prosperity of the country."

${ }^{859}$ Also see chapter one of this dissertation for Dana's earlier calls for this sort of cooperation between labor and the owners of capital. Then, as in the early 1870s, Dana argued that one of the potential remedies to the current animosity between workers and their managers was that there was not enough of a spirit of harmony between the classes. Dana, ever the idealist, had always had issues with the wage system as a general concept, and even had alternative ideas about how individuals should be compensated in an ideal system that chapter one also covers. In another footnote in this chapter, Dana questions if non-slave labor in the United States even "owned" their very selves when considered as parts of the larger structure of "wage slavery" that had become so entrenched in many of the nations major industrial cities by the early 1870s. In part because of his opposition to much of the basic machinery of the developing economic system in the United States in this period, Dana may have had an over-inflated hope that workers would be able to "cooperate" so closely with the manager class to arrive at a set of wage scales and benefit packages that both sides would find amenable. The decades of the 1880s, and 1890s, would serve as evidence of the utter 
like the banning of cheap convict labor, safe and affordable housing, worker-friendly immigration and tariff policy, and a living wage to match rising prices would also ameliorate the calls of labor leaders. ${ }^{860}$ Otherwise, The Sun explained to readers, the nation's workers would have to band together, and cooperate with unions around the nation to strike peacefully for these concessions. ${ }^{861}$ Strident debates over what allowances to offer American workers, skilled and unskilled, dominated the pages of the Sun during the first Grant administration. The labor movement provided Dana with a means through which to judge the electoral chances of the nation's parties.

Sun editorials from late 1870 and across 1871 explained to New Yorkers that global discrepancies in the standards of living for the working classes, relative to the propertied classes,

failure of hopes like these as the gulf between labor and the owners of capital in the United States only got larger. This notwithstanding, in the early 1870s, all of these movements were still young enough where Dana's voice remained a moderating influence on the debate raging about the conflict between the rights of labor and the need for industrial growth and profit.

860 “The Mill-Owners' Strike, How the Rich Men Spring a Reduction upon the Spinners," The Sun (N.Y.), September 2, 1870.

${ }^{861}$ For a sample of Dana's use of these arguments in previous years, see: "Trades Unions and Apprentices," The Sun (N.Y.), May 1, 1869. "The Sun, it is known, has always defended the course of the workingmen in forming themselves into trades unions for mutual protection. It has supported their right to fix such a price for their services as they may decide upon, and to name the conditions which they will render them. And it has always insisted, and will always insisted that what are called strikes, and which many unthinking persons condemn almost as if they were forbidden by the laws of God, are but legitimate steps by which alone men who have labor to sell can ascertain its fair market value. Of course, this position, has brought us more or less into controversy with those who are, or suppose themselves to be, interested in keeping wages down, and workingmen under subjection to their employers. It has been our endeavor to give a candid consideration to their arguments, and to deal with them fairly. The truth needs no other assistance then to be placed in contrast with error, to ultimately win its way to victory; and the workingmen rest, in general, on such impregnable grounds that they need fear nothing from the arguments of their adversaries. Still, they are, like other men, liable to make mistakes, and it would be strange if they did not in some minor points lay themselves open to objection... We insist on a proper education for lawyers, doctors, and clergymen; why not do as much for the workers in wood, metal, brick, and stone, upon whom we depend for our household necessaries and comforts, and even for health and life itself? For a house badly built, or machinery badly constructed, sometimes causes quite as much mischief as bad advice in law, physic, or divinity. We commend this subject to the earnest consideration of all classes of our readers. It is for the interest of the country to have as large and well-trained a body of skilled laborers as possible, and equally the interest of every parent to have the range of employments, among which his children can choose their means of livelihood and usefulness, embrace those of every mechanical occupation practicable to human hands. And to both it is important that whatever is done in the matter should be well done." 
also had a part to play in the popularity of the labor union movement spreading across the United States. It also tied closely to European political philosophy, and with ideas of egalitarianism and republicanism that had interested Dana since his teenage years. ${ }^{862}$ Most obviously, these themes appeared clearest in Dana's demand to cover the 1848 revolutions for the Tribune and in his recruitment of correspondents like Marx and Engels to write for the paper in the $1850 \mathrm{~s} .{ }^{863}$ Dana had sympathized with the ways that the growing international debate around labor and capital inspired American workers across the nineteenth century. He argued that there was much to be adapted from European socialism and Communism that might be of use in an American context. Editorials in The Sun highlighted the republican inspirations of the revolutionaries' ideas of selfgovernment, worker's rights, and national sovereignty in the socialist and cooperationist underpinnings of the American labor movement. ${ }^{864} \mathrm{He}$ applauded the transnational support of these values in the United States and Europe during episodes like the Paris Commune of 1870

\footnotetext{
${ }^{862}$ Refer to chapters one through three of this dissertation for more on Dana's enduring Atlantic perspective regarding issues of labor and political economy. In that chapter, I note that Dana had a preclusion for Continental philosophy of a very particular variety. It led him towards theories of social organization and economics that focused transnational and materialist understandings of the relationship between the individual and his participation within society. Dana's direct experience with how these philosophies could be potentially carried out while reporting on the European Revolutions of 1848 only immersed him further into the position that republican values remained a transatlantic problem not isolated to Europe, or the United States. Dana remained an ardent nationalist and republican that had a strong desire to see the same combination propagated around the transatlantic World, and the world.
}

${ }^{863}$ Also see chapter one for more on the relationship that Dana developed with the famous journalists and philosophers in that period as a reflection of his similar structural interpretation of republicanism. Like Marx and Engels, Dana saw that the rights of labor, and the results of the industrial and capitalist system spreading across the Western world, often clashed. While they each had different interpretations about whether violence should be used to overcome these conflicts (that I will cover a bit more closely in chapter 5), they remained professional acquaintances until Marx's death in 1871. Dana had an idealistic conception of labor and global republicanism that attracted him to Marx. While Marx famously had a poor opinion of American labor organizers (precisely because, like Dana, they often tried to work within the system, rather than topple it with a violent worker's revolution), he still often wrote to Dana and The Sun as the International Workingmen's Association became a transatlantic phenomenon immediately after its establishment in 1866.

864 “The Workingmen's Union Joining in the Obsequies,” The Sun (N.Y.), December 16, 1871. 
where, as in 1848, protests centered around labor rights and demands for self-government, even if they devolved into violent riots. Dana insisted that the Commune's ideological interpretation of society did not have to be immediately interpreted as anti-American because of this. These prolabor policies, The Sun wrote, could be molded for uses more suitable to American senses of republican government and class cooperation rather than class revolution. One letter reprinted within The Sun documented from a Workingmen's Union meeting summarized the paper's support, and the adoption of the argument. This letter paralleled directly Dana's historic argument that the movement for the rights of labor equated closely with pure republicanism, but just not with wholesale revolution. The Sun's article particularly featured a French immigrant Communist living in Newark, New Jersey who limited his definition of Communism, and the International movement, to "pure republicanism," the concept of the secret ballot, and limiting the power of "avaricious monopolies." 865 After some analysis of the letter, The Sun editorial highlighted the French Communist, Mr. Nifferg's, insistence on the conservative direction for the movement. Nifferg's interviewer noted that "if Communism meant a general disruption of the tenet and customs of society, which would produce general anarchy, he wanted none of it; he was no International under such circumstances. ${ }^{966}$ This more conservative branch interpretation of the labor movement's place in the United States attracted Dana in 1870, just as it had for decades prior. Dana was one of those Americans who believed that these ideas could be employed without violence to realize change in ways that were not as controversial as their European variants. ${ }^{867}$

\footnotetext{
865 Ibid.

${ }^{866}$ Ibid.

${ }^{867}$ An interesting example of this can be found in this editorial: "The Mill-Owners' Strike," The Sun (N.Y.), September 2, 1870. The article describes between Millowners and Spinners. The article supported the Spinners' Association decision to support a peaceful strike. The Sun noted that the strikers disclaim complicity in any riotous demonstrations. The mule Spinners' Association supported The Sun's support for their strike. The same article notes that the Spinner's association meeting of August 31, 1870 where they voted, and resolved the following resolution: "That the New York Sun, as the impartial and fearless exponent of public sentiment, differing as it does in this particular from the more venal and subsidized
} 
The Sun publicly supported the efforts of labor movements attempting to publicize the liberal, republican, and American interpretations of European socialism and Communism. ${ }^{868}$ The domestic labor movement's ideas encouraged the type of cooperationist, democratic, socialism that Dana had supported, in some form or another, since his time at Brook Farm, later the New York Tribune, and into the early days of The Sun ${ }^{869}$ Dana equated this family of ideas with "pure republicanism" and understood them to be part of the existing American intellectual tradition without an Marxist, or Blanquist civil upheaval or anti-nationalism. The implication is clear here that he believed that violent interpretations of republicanism could indeed be impure manifestations of the ideology. Throughout the early 1870 s, Dana insisted that the labor movement needed to avoid calls for the violent overthrow of society to gain nationwide popularity in the United States. This is a clear legacy of Dana's almost full embrace of the political system after the Civil War. Previously, his witnessing of the revolutions of 1848 had shown him that pacifistic approaches to politics could not be counted on to topple monarchs. His immediate immersion in the politics of sectionalism and slavery after his European sojourn had made Dana belligerent, though. He had underwent a break in his faith for a peaceful revolution in American politics while at the Tribune. The experience of the Civil War changed this trajectory, turning Dana back in the direction of realizing change peacefully within the bounds of the political system.

portion of the press of our country, merits the hearty approval of the entire body of mule spinners of Fall River; and we cordially recommend it to the consideration of all labor unions of the United States."

868 “Trades Unions," The Sun (N.Y.), December 1, 1870. "There are many able men engaged in the organization and management of societies whose object is the advancement and protection of their interests; and it would be well for them to consider the question whether, in some respects, their method of proceeding in this country has not been modelled too closely upon that of similar organizations in England, where the conditions and aims of the laboring community are very different from those obtaining here."

869 “A New Triumph for Labor,” The Sun (N.Y.), November 15, 1869. 
The war humbled Dana's opinions regarding the utility of state sponsored violence, but made clear the opportunity for the rabid use of journalism and politics to see the reforms of reconstruction through. It is no surprise, then, that now in 1870 Dana is imploring workers to press for its reform through peaceful movements and established political processes. This position reflected in The Sun is another mark of consistency from his days advocating cooperation and associationism. Then Dana argued that strategies for labor activism, like labor stoppages, had to remain respectful to American socio-political institutions. Dana bemoaned that the mass strike, an inherently peaceful protest, had devolved into a symbol of rambunctiousness, violence, and revolutionary activity because of $1848 .{ }^{870}$ Through his conversations with Marx and Engels while in Europe in 1848, and with the Tribune for years after (and later still at The Sun), Dana developed substantive criticisms of Marxism's conception of persistent violent class struggle and wholesale worker's revolution for the United States of the $1870 \mathrm{~s} .{ }^{871}$ This is part of the reason that Dana and Marx kept the two men from developing a closer correspondence. Even as Dana and Marx maintained a professional relationship across the Atlantic, he regretted that the international movement continued to advocate for the type of violence outlined by Marx and Engels in earlier articles the Tribune, The Sun, and in their other published work. Dana's position against violent labor organizing strategies dated to his reactions to the 1848 reactions and before. ${ }^{872}$ Instead, The Sun advocated that the American labor movement should work within the American political

\footnotetext{
${ }^{870}$ In the middle of 1871 , Dana made efforts to explain that the movement explicitly made a distinction between socialism and communism, and republican ideas. See: The Sun (N.Y.), April 18, 1871.

"Republicanism has taken root in England and threatens to send forth vigorous branches into every part of the country... Neither socialism, communism, and any other ism dared to appear, and the only resolution of importance voted upon was 'that Republicanism be taken to mean repudiation of the hereditary principle as found in monarchical and aristocratic institutions, and of all artificial distinctions and privileges depending upon birth."

${ }^{871}$ The Sun (N.Y.), April 18, 1871.

${ }^{872}$ For more on Dana's previous connection to the international labor movement, and European politics, see chapter one and two of this dissertation.
} 
system to break apart the concentration of capital and property in the hands of a few. ${ }^{873}$ Peaceful critiques of the concentration of power and ideas about international pacifism, mutual aid societies, universal education, cooperation between labor and capital, and an egalitarian distribution of the nation's industrial wealth aligned with Dana's historic objectives for the American worker. He remained hopeful that the American voting process endured as a relatively more democratic system than those in Europe, and remained a viable way for the American working classes to elect their representatives pacifically and overwhelm Congress. ${ }^{874}$ With that said, he concluded that the period left no doubt that the principal obstacle plaguing the American system, inhibiting it from reaching its true republican potential in size and duties to the people, remained the questionable political and financial ethics of the American political and economic classes.

Dana's attempt to present policy alternatives to those of the president and the Republican Party and suggest ways to humble the size and power of the federal government, remained clouded by the administration's problematic reputation for corruption and party despotism. Previous chapters have covered how reports of misuse of power and political in-fighting dogged the nation's domestic and foreign politics almost immediately upon Grant's arrival in office.

${ }^{873}$ Dana often argued that much of the United States' immigrant past came with an inherent support for the working class that helped establish the nation's early commitment to the rights of workers. For an example of how Dana often attempted to use American history to argue that American identity is working class, and should be made more so in the early 1870s, see: "Aristocracy - the Knickerbockers," The Sun (N.Y.), May 3,1871 .

${ }^{874}$ Dana's larger disillusionment with the American political system that "Grantism" had encouraged had not necessarily been extended to the vote. Dana had always been a strong supporter of expanding voting rights as widely as possible. He was in favor of women's suffrage, and was largely in support of every voting initiative put forward in this period. If anything, he argued that it was Grantism that was attempting to interfere in the voting process in ways that are dangerous. While Dana agreed that the voting rights of blacks should have been protected in the South, he also argued that the Enforcement Acts also appeared to give President political cover to interfere both in the voting process of all the states in the union, but also in the nominating processes of the party the President was the head of. Dana, as the preceding chapters have attempted to show, argued that the Grant administration and the Radical Republican Party had pressed their advantage and potentially abused the voting rights of many while attempting to protect the voting rights of others. 
Dana had focused on these problems, and published extensively about them, since the $1840 \mathrm{~s}$. In the early 1870s, The Sun's editorial page remained focused on similar themes: it described the controversial workings of political machines and bosses, reports of fraud and graft within the administration, and evidence of a bloated, over-mighty federal government. ${ }^{875}$ After almost three years into Grant's term, the Republican Party, and Tammany Hall running the various national, state, and local governments surrounding Dana, his paper sustained its aggressive critiques of government malfeasance. The Sun's editorial page wanted readers to reevaluate the country's age-old commitments to equality under the law, an egalitarian political culture, and republican self-government. Dana's editorials asked readers this while also considering the evidence that special interests and graft were saturating the public sphere, its political functions, and the broader debate about civic identity. His notion of the size and responsibilities of government remained heavily filtered through his conceptions of civic republicanism. If the nation wanted to return to any semblance of self-government without the stain of financial and political manipulation, the paper argued, it needed to return the government to a smaller size, rid itself of corruption, and implement a system of political economy and equal rights that realized the nation's liberal and republican traditions.

Dana saw the Grant administration's use of the Force Acts as an extension of the corruption in other parts of its domestic policy strategy. ${ }^{876}$ Dana's desire to see civic virtue in the

\footnotetext{
${ }^{875}$ For a sample of Dana's argument, see: “Tweedism as Practiced By a Grantist,” The Sun (N.Y.), November 30, 1871.

${ }^{876}$ For more on the Enforcement Acts, see: Summers, The Ordeal of Reconstruction, 244-245, 270-71, 276, 370-371, 395; Robert J. Kaczorowski, The Politics of Judicial Interpretation: The Federal Courts, Department of Justice, and Civil Rights, 1866-1876 (New York City: Fordham University Press, 2005): 6279; David Quigley, “Acts of Enforcement: The New York City Election of 1870," New York History 83, no. 3 (Summer 2002): 271 - 292; Xi Wang, “ The Making of Federal Enforcement Laws, 1870-1872," in The Trial of Democracy: Black Suffrage and Northern Republicans, 1860 - 1910 (Athens: University of Georgia Press), 48 - 92; Stephen Cresswell, "Enforcing the Enforcement Acts: The Department of Justice in Northern Mississippi, 1870-1890," The Journal of Southern History 53, no. 3 (Aug., 1987): 421 - 440.
} 
White House continued to guide his opinions of Grant and the Republican Party's strategies at reconstructing the nation. Dana had historically republican (and American) fears of militarism, and the use of the regular army to influence politics in times of peace. This anxiety at creeping political despotism exponentially heightened after the passage of the First and Second Enforcement Acts in February and May 1871. ${ }^{877}$ The Sun argued that the legislation threatened democratic institutions across the country, even if it helped solve the problem of political violence caused by the Ku Klux Klan and other paramilitary outgrowths of the late war spreading across Appalachia and the southwest. ${ }^{878}$ The act created the Justice Department as a new cabinetlevel office, authorizing the Executive Branch to use the military to curb the Klan's activities, with the aim that the voting rights of former slaves were not further infringed in the South. Dana's paper spent considerable time explaining that the Force Acts instead provided the president with unprecedented power to intervene in issues constitutionally delegated to the states. ${ }^{879}$ Thus, these legal provisions empowering the president to use military force to protect voting positioned Dana even further against Grant because he chose to use them in ways that threatened the nation's tradition of civic virtue and the prevalent fear of the standing army. To Dana it appeared as the Enforcement Acts had hardened an arrangement in the South where Republican governments and the administration overused their powers and fostered political and financial corruption. ${ }^{880}$ This is not what the Civil War was fought for, he thought. Corruption cannot be traded for corruption and called virtue. Dana's history of having Whiggish expectations

\footnotetext{
877 “The Ku-Klux Klan,” The Sun (N.Y.), March 10, 1871.

878 “Grant's Rebellion,” The Sun (N.Y.), March 27, 1871.

879 "The Southern Vultures: A Vivid Picture of the Situation in Arkansas. No Ku-Klux Legislation from Congress, but a General Amnesty-The Carpet-Baggers Going for all the Money in the State," The Sun (N.Y.), March 27, 1871.

880 “The Great Question in the South," The Sun (N.Y.), March 28, 1871.
} 
for a modest, honest, efficient, and progressive national government did not sit well with the president's Reconstruction policy. An analysis of The Sun's editorials across 1871 illustrates that Dana's position joined his earlier warnings that the president and the Republican Congress had rapidly increased the federal government's size and influence to unacceptable levels.

Dana's ideas to solve some of the nation's various problems conflicted with other portions of the Grant White House's policy program. One of these was The Sun's suggestions to return political rights and general stability to those states most influenced by Grant and the Republican Party's Reconstruction policy since March 1869. The initiatives included pushes for amnesty and reconciliation with former Confederate veterans and states, and a closer commitment on the part of the federal government to embrace federalism. The paper argued that amnesty for former Confederates would ameliorate the animus of aggrieved Southerners, help disband the Klan, reinstall republican government and citizenship in the South, affirm Grant's commitment to self-government, and improve the Republican Party's reputation across the nation. ${ }^{881}$ Dana affirmed that the federal government absolutely needed to require stricter expectations of these states to uphold the recent amendments to contain violence, but that the army need not engage in physical enforcement. ${ }^{882}$ Dana argued that it was the federal government's duty to help the states fight militias like the Ku Klux Klan, but that interfering in party politics, for instance, violated core American values. He insisted that after the army had been removed from the Southern states (the first time between 1867 and 1868), it should not be returned again. ${ }^{883}$ To this end, Dana's Sun recommended a renewed commitment to the preservation of the balance between the federal

\footnotetext{
881 "Issues for the Campaign,” The Sun (N.Y.), December 1, 1871.

882 “The Congressional Election Law,” The Sun (N.Y.), November 10, 1870.

${ }^{883}$ Ibid.
} 
government and the states as delineated by the Constitution. ${ }^{884}$ One of the major reasons Dana did not think that the "carpetbag," 885 radical-led, Reconstruction governments should stand was that Grant and the radicals encouraged corruption within them. ${ }^{886}$ The previous chapters highlighted some of the past fifteen months' worth of criticism of administration political malpractice. ${ }^{887}$ This context saturated The Sun's coverage of the Reconstruction legislatures in early 1870 . The paper's editorials highlighted the rampant corruption and political malpractice connected to Reconstruction policy and recommended that the right of self-government be returned to former Confederates. There could be no other way without creating yet another mid-nineteenth century constitutional crisis. Issues of political violence and voter fraud, the paper maintained in this period, should not be abused by the federal government to benefit the party in power. Grant's connections with political maneuvers of this sort in 1871 and 1872 helped motivate Dana's emphatic commitment to self-government and civic virtue and his opposition to the Grant administration.

Dana charged that the White House improperly used the regular army to oversee political functions under the Enforcement Acts of 1870 and 1871 as a tool to help the president gain the Republican Party's nomination for president in 1872. The laws, which Dana understood were meant to curb political violence, voter fraud, and corruption across the country, also appeared to

\footnotetext{
${ }^{884}$ Ibid. "A still more serious objection is that it is an interference of Federal authority in matters which the Constitution does not intend to have subject to Federal authority. It is an extension of the power of the President. It is something wholly alien to our political system - something which must be stopped, unless the republic is to be transformed."

${ }^{885}$ For more on the history of the term "carpetbagger," as a slander of northerners who travelled into former Confederate states during Reconstruction, see: K. Stephen Prince, "Legitimacy and Interventionism: Northern Republicanism, the "Terrible Carpetbagger," and the Retreat from Reconstruction," Journal of the Civil War Era 2, no. 4 (December 2012): 538-563 and Ted Tunnell, "Creating 'The Propaganda of History': Southern Editors and the Origins of "Carpetbagger and Scalawag,"” The Journal of Southern History 72, no. 4 (Nov., 2006): 789-822.

886 “The Congressional Election Law,” The Sun (N.Y.), November 10, 1870.

${ }^{887}$ For more regarding this see chapter two of this dissertation.
} 
the editor as becoming a tool to ensure the president's reelection by legitimizing collusion between the federal government, the military, and Grant's political allies. While Dana understood that the reports of violence across the country were of the most serious nature, he did not trust that the president would not use his new powers to intervene in the proceeding of the nation's political parties. ${ }^{888}$ Three related episodes took up a considerable portion of The Sun's editorial page at the end of the year. Federal intervention at the New Orleans Republican Party nominating convention, the military expeditions in the Carolinas, and the intervention at the Republican state nominating convention at Syracuse pierced Dana's republican visions for the 1870 s to their heart. In lieu of the larger context of corruption and illiberalism that Dana claimed tainted the government across 1869, these events forced Dana even further away from the Republican establishment. First, Dana maintained that the administration's intervention in the New Orleans Republican Party nominating convention presented one example of the improper use of the Enforcement Acts. The circumstances of the event enflamed Dana's republican fears of militarism and despotism. Of these actions Dana's Sun argued that the president's actions, "surround[ing] political conventions with soldiers in order to exclude from them those citizens who are opposed to his renomination," puts "the liberties of the people...in danger." ${ }^{\text {" }} 89$ The threat posed by the president and the Republican-majority Congress using the military to secure political goals in Louisiana represented a sinister form of Old World political corruption to The Sun. ${ }^{890}$ The president and the governor of Louisiana were related, and the latter's request for military assistance in presiding over the state's Republican nominating convention in 1871

\footnotetext{
888 "The Republican Ku-Klux," The Sun (N.Y.), April 24, 1871. "It would be a singular thing if the KuKlux force bill, which, as is claimed by its framers, was intended to suppress disorder throughout the South, should after to do something toward accomplishing its purpose, in an indirect way, by removing the cause of those disturbances in the persons of dishonest officials and scalawag adventurers."

${ }^{889}$ The Sun (N.Y.), August 22, 1871.

890 "Stacking the Cards in Louisiana," The Sun (N.Y.), August 1, 1871.
} 
elevated Dana's suspicion of foul play. ${ }^{891}$ The paper argued that "this is but one of numerous indications that Grant intends to force his reelection by placing the whole South under bayonet rule should he receive the Republican nomination." 892 Just months earlier, Dana's editorial page maintained that the "Ku-Klux Force Bill" had the sole object to "enable President Grant to send troops into the Southern States to dictate what shall be done in the elections, under the pretext of putting down the Ku-Klux. It is nothing but an electioneering device." ${ }^{\prime 893}$ The events then occurring in places like Louisiana matured Dana's misgivings about the Grant administration's commitment to republican values and civic virtue. ${ }^{894}$ The continued association of the executive with nepotism, corruption, and party despotism (alongside these various other similar scandals surrounding formal political party functions disrupted by the military) only amplified The Sun's tone.

Dana pointed to other examples in the Carolinas as evidence of the president's suspicious use of the Force Acts after New Orleans. Sun editorials from September 1871 illustrated Dana's

${ }^{891}$ The Sun (N.Y.), August 25, 1871. "What a painful alternative this presents for Grant! He is required either to turn out of office his own brother-in-law, who has done nothing but employ the troops and Gatling guns of the United States to secure for Grant the delegates of Louisiana in the National Republican Convention, or else he must himself take upon the responsibility of this outrage."

892 "How it is to be Put Through," The Sun (N.Y.), November 16, 1871. "The Washington organ of Grant says that it will require not less than ten thousand regular troops, judiciously distributed through the Southern States, to insure a free and fair election in those States in 1872; and that it may be necessary for Congress to increase the army. This is but one of numerous indications that Grant intends to force his reelection by placing the whole South under bayonet rule should he receive the Republican nomination. Such a method of insuring a free and fair election certainly deserves the credit of originality... If Grant runs for President in 1872 he is determined to have a free and fair election, even if it should be necessary to bayonet every man in the Southern States who opposes him. What would be deemed a free and fair election by a man who has used United States troops and Gatling guns to control the action of a Republican Convention at New Orleans may easily be imagined."

893 “The Ku-Klux Bill No Remedy for the Real Evils of the South,” The Sun (N.Y.), May 8, 1871.

894 "Grant the Chief Actor in the New Orleans Conspiracy," The Sun (N.Y.), August 24, 1871. "With facts like these, established so that they cannot be disputed, President Grant's easy-going remark that "the muddle down there is almost beyond his fathoming," is simply the confession of the chief conspirator that he dare not squarely face the truth. The people, however, know it, and they will hold him to the full measure of his responsibility." 
prediction that Grant would use the regular army at nominating conventions not to just protect voting rights, but to help sway party members to nominate the president to represent the party over other choices (such as Dana's ally Horace Greeley, who had entered the race to gain the nomination of the Republican Party). In these editorials, The Sun cited reports that artillery had been sent to Raleigh, North Carolina by order of the War Department. ${ }^{895}$ Dana claimed that they were there to reinforce the national guard meant to police state nominating conventions for the Republicans. Similar reports of the potential misuse of power in South Carolina encouraged Dana to use that state to exemplify the president's suspicious political motives. "That there are violations of law and order in portions of the South no well-informed person can deny," the paper first explained. ${ }^{896}$ Dana did not refute the reality of the reports of racial and political violence in the South, or the voter suppression in the North, but wanted to provide additional context for his readers regarding the government's approach ${ }^{897}$ In this vein the paper insisted of these reports

${ }^{895}$ The Sun (N.Y.), August 24, 1871. "The War Department has ordered two batteries of artillery from Maryland to Raleigh, North Carolina. Is this because a Republican Convention is about to be held in that State, from which it is deemed necessary to exclude all anti-Grant Republicans?"

896 "More Bayonets in South Carolina," The Sun (N.Y.), September 4, 1871.

${ }^{897}$ For a sample of Dana's impressions of the Carolinas and the impact of the Ku Klux Klan laws there, see: "The North Carolina Trials," The Sun (N.Y.), October 16, 1871. "The manner in which the North Carolina Ku-Klux trials have been conducted, looking at them in the most favorable light, affords a sufficient evidence of the dangerous character of the powers bestowed by the Ku Klux law upon the United States officials, who may be violent partisans, and thus incapable of doing justice. It has not been doubted by any sensible man that the Ku-Klux have existed as an organization in North Carolina, nor that outrages have been committed by their members. It is not probable that any one can be found to deny that the barbarities perpetuated by these men merit condign punishment. It is likely that some of the person who have been convicted in Judge Bond's Court have been guilty of all that has been alleged against them; it may be that all of those so convicted deserved their fate, but it is certain that entirely innocent people, who from personal malice or other cause should be wrongly accused of participation in such offences, taking the North Carolina trials as an example of the way in which the law is to be administered, would have very little ground to hope that their innocence would save them from conviction and punishment. What is popularly known as the Ku Klux law was passed for partisan purposes, and it is administered in a partisan manner. While its ostensible object was to suppress the Ku-Klux organization it has been so framed as to render it an instrument under cover of which Gen. Grant may use the most revolutionary means to force his renomination and election; for it can be applied to the North as well as the South, and its terrors may be brought to bear against political societies in our own State, organized for patriotic purposes, as effectually as against the members of the Invisible Empire and kindred associations in the South. In North Carolina its execution has been comparatively mild; yet even there wholesale and indiscriminate arrests have been made, often without warrant; people on mere suspicion have been carried hundreds of miles from their 
"that their number and atrocity are sometimes overstated for partisan purposes, is doubtless equally true." 898 The paper explained, though, that something was "not go[ing] right just now in South Carolina. In that state, as also in Louisiana, prominent Republicans are hostile to Grant's renomination; and they are sowing discord in the Republican field." 899 The same editorial insisted that "Gen. Grant and his supporters intend to take advantage of the existence of these real and reported outrages to put some of the Southern States practically under martial law." ${ }^{900}$ After, they would secure "the appointment of delegates to the Republican National Convention who will vote for his nomination to the Presidency," which "admits of no question."901 Dana's argument that the president and his party used the violence in South Carolina to coalesce the Grant faction's control of the party elicited comparisons to other patterns of potentially un-republican political maneuvers elsewhere.

The administration's approach to protecting the American political process across the country continued to confront Dana's assumptions about how the nation's politics should work. One case was the federal intervention in the New York state Republican Party nominating convention, given particular import for Dana because of its geographic proximity to his physical and political home. The Sun's coverage of the lead-up to the October 1871 convention in

homes, denied bail, and kept for months in prison without any opportunity being afforded them for defense; and in many cases, after long imprisonment, such suspected persons have been set free without a particle of evidence having been brought forward to connect them with the offences with which they had been charged... With violent partisans as prosecuting officers, a packed jury, and a hostile Court against them, it is no wonder that these men were convicted by dozens. They may all have received only their just deserts in the end; but no one can pretend that the manner of their conviction was anything but a mockery of justice and an outrage on judicial propriety."

898 "More Bayonets in South Carolina," The Sun (N.Y.), September 4, 1871. Also see, "The Ku-Klux Report," The Sun (N.Y.), August 2, 1871.

899 “More Bayonets in South Carolina," The Sun (N.Y.), September 4, 1871.

${ }^{900}$ Ibid.

${ }^{901}$ Ibid. 
Syracuse, New York began with indictments that New York Republicans allied to the president had been attempting to sway political enemies with patronage offers in the weeks prior to the convention's organization. ${ }^{902}$ It would be here where the state's Republican leaders would select who the state party would nominate its candidate for president. As early as August, The Sun had been predicting that the convention at Syracuse would be another place where the president's wing of the party would intervene improperly to keep delegates who supported Grant's opponents outside of the convention. ${ }^{903}$ The Republican Party of New York state would here vote on its representative for national election. If these patronage offers did not work, the paper predicted, the president would send the army to tilt the election in his favor there. Dana provided readers with reports of a party on the verge of collapse because of the weaknesses that the president had exposed in his office by taking these actions, and also of the strength of the state's reform candidates like Horace Greeley. ${ }^{904}$ The convention at Syracuse featured numerous candidates that better reflected Dana's republican position on political economy, foreign policy, and civil service who he thought had a good chance to steal the nomination from the president. The Sun anticipated that the president would attempt to maneuver for his nomination at Syracuse, in part, because the Grant wing of the party, including the president himself, downplayed these late-1871 divisions within the New York state Republican Party. ${ }^{905}$ One August Sun editorial reminded the president

902 "Fraud in Nominating Conventions," The Sun (N.Y.)., July 7, 1871. "The extent to which the Tammany system of political management has recently been adopted in the manipulation of Democratic State Conventions is startling... This is a sort of fraud that must be stopped. No party can tolerate it with safety. Honest elections are the only sure foundation for a republican government."

${ }^{903}$ Ibid.

904 "War in the Republican Camp," New York Sun, August 25, 1871. "The ultimate object is to put out Dr. Greeley, Gov. Fenton, Marshall O. Roberts, Gen. Cochrane, Gen. Merritt, and their Republican coadjustors in the State, and with a packed Convention pass resolutions approving of Grant, with all the follies and crimes since he has committed since he became President. This being done, the way will be opened for a seemingly regular, but really bogus, set of Grant delegates to the National Convention of next year."

${ }^{905}$ The Sun (N.Y.), August 23, 1871. "Gen. Grant recently said to a reporter of the Herald at Long Branch, that he did not think there was any real lack of harmony among the Republicans in New York; that some men there who are Republicans in name claim that there is discord, 'but they don't mount to much.'” 
that New York "state Republicans Horace Greeley, Gov. Fenton, Marshall O. Roberts, and hundreds of others in this State of like character and influence...object to his use of the Federal patronage and the regular army to obtain a renomination. ${ }^{\text {906 }}$ Editorials in The Sun predicted that only a repeat of the corruption of elections past would doom Greeley. ${ }^{907}$ Dana's Sun accused Grant's agents of organizing the convention “to pack the Republican State Convention with delegates favorable to Gen. Grant and hostile to Dr. Greeley." ${ }^{908}$ The same editorial noted that these proceedings helped confirm the maxim that "great is the power of money and patronage." 909 The Syracuse convention happened just as Dana expected it would. The armed expulsion of the supposedly rambunctious Greeley delegates ensured Grant's selection as candidate for the New York State Republican delegation. A Sun editorial explained that "this year, and by the same corrupt means, Grant...proved too much for Greeley...again." ${ }^{910}$ Dana’s coverage made the case

\footnotetext{
906 Ibid.

${ }^{907}$ Dana insisted that this was just like the scandals of the last few years replayed again at Syracuse this year. "Last year Grant...overcame Horace Greeley...in the Convention by the use of money," noted one editorial. "The Grant and Murphy Ticket," The Sun (N.Y.), October 2, 1871.
}

\footnotetext{
908 "Packing the Republican State Convention," The Sun (N.Y.), September 25, 1871. The Sun called upon a budding politician familiar to Dana's readers, Horace Greeley, as one manifestation of the developing anti-Tweedism and anti-Grantism across the country. One reason Dana directed The Sun to support Greeley's candidacy for New York Governor in 1870 was the resemblance of the Tribune editor's platform and that of his former charge. Sun editorials during the party nominating season into late 1870 highlighted how Greeley's platform contrasted favorably against the incumbent — the Tammany Hall backed Republican Governor John T. Hoffman. Tammany had been leading a divisive ethnic and patronage campaign to consolidate power since gaining power in the city and state in 1871. The scion of New York Whig and Republican politics, Thurlow Weed, came out of proto-retirement to informally guide Greeley's campaign against the corrupt machine. The Sun supported this candidacy, along with a large portion New York's German residents, who aligned with Greeley in their opposition to corruption and overuse of power in state and city government. See: “The Farmers' Candidate for Internal Improvements," The Sun (N.Y.), July 13, 1871; New York Sun, September 3, 1870. Good story about Greeley and Thurlow Weed possibly getting together. He ends article with "Let us have peace!"; "Woodford Must Resign-Marshall O. Roberts for Governor," New York Sun, September 15, 1870. "It seems to be proved that Mr. Greeley was defeated at Saratoga by the bribery of delegates."; "Shall Horace Greeley be Nominated?," The Sun (N.Y.), September 3, 1870. Also see, “The Republican Nomination for Governor,” The Sun (N.Y.), September 8, 1870;

909 “Packing the Republican State Convention,” The Sun (N.Y.), September 25, 1871.

910 “The Grant and Murphy Ticket,” The Sun (N.Y.), October 2, 1871.
} 
for the affair's un-republican character by continuing to emphasize the weapons being brandished by federal officials to intervene in New York politics. One editorial after the Syracuse Convention noted that "among the many instructive incidents... which ought to excite the most serious reflection was the introduction upon its platform by Mr. Surveyor [and former Gov.] Cornell, at a turning point in the proceedings, of a body of policemen armed with clubs and revolvers." ${ }^{11}$ In his coverage, Dana submitted his hopes for an honest, peaceful, cooperative political process for the nation that the White House rejected by its political use of the Enforcement Acts within New York State's political party functions. The paper insisted that the "measures relied upon to perpetuate the power of the present administration" had a "despotic character." "912 The despotism was "manifested by the unscrupulous use of money," The Sun explained, and continued that other forms of evidence were the "federal patronage to control the action of Republican Conventions in the North" 913 Only a despot, Dana charged, would "overawe such Conventions of the Republican Party as will not do his bidding with the batons and revolvers of the local police, and the bayonets and Gatling guns of the regular army." 914 The Sun called it a "spectacle, at once humiliating and full of peril" because it "revealed the depth of degradation to which Grant's tactics for controlling Republican Conventions have reduced the party." argued that the president's use of force during the Syracuse meeting clearly opposed the ideals of civic republicanism that the nation had strived for since the Founding, and had reaffirmed with the Union victory in the late Civil War. For the editor, the imposition of federal troops to intervene in the political party nomination process did more to tilt the political calculus in

\footnotetext{
911 "Batons and Bayonets," The Sun (N.Y.), October 2, 1871.

912 “A Pleasant Prospect,” The Sun (N.Y.), October 2, 1871.

913 “Ibid.

914 “Batons and Bayonets," The Sun (N.Y.), October 2, 1871.

915 Ibid.
} 
suspicious ways, than guarantee equality and safety as the law was supposed to ensure. Dana's characterization of Grant's behavior as despotic drew the paper to make broader comparisons of the American president with European leaders with equally questionable records.

In a feature editorial from late August 1871, published amid these party convention crises, The Sun compared the president's recent activity to some of ancient and recent history's most controversial authoritarians. This put Dana in league with anti-Grant Republicans and Democrats who used similar language, a characteristic that historians have studied closely. ${ }^{916}$ The comprehensive critique argued that "Grant is not exactly a Caesar," and "far below the first Napoleon as a soldier," but "in great parts he dwindles by the side of stout old Oliver" and "quite as unscrupulous in the use of military power to secure political objects" as Bonaparte. Of Napoleon III, Dana's editorial alleged, Grant's behavior evidenced him as "every inch the peer" in "selfishness, greed, nepotism, and duplicity." "117 The editorial reminded readers of the ways these leaders usurped popular power from legislatures and conventions as the examples of New Orleans and Syracuse suggested was happening now. ${ }^{918}$ Of the comparisons of Grant to the "usurpations of Caesar, of Cromwell, and of the two Napoleons," The Sun reminded readers were not "the work of a day." "19 "A heedless people," it continued, were "gradually prepared for the

\footnotetext{
${ }^{916}$ For more analysis on the use of republican language by those opposing the President, see: Slap, The Doom of Reconstruction, xi, xxii - xxv.

917 “Resist Beginnings,” The Sun (N.Y.), August 22, 1871; “1870,” The Sun (N.Y.), January 2, 1871. "While the President urges in his annual message to Congress the reform of the civil service, he has opened the doors to hypocrisy and corruption by disregarding fitness and propriety in his appointments and regarding only the claims which persons who are related to his family, or who make him presents, or who assist him in his personal schemes, may have upon his recognition. Corruption thus emanating from the head of the Government exercises a baneful influence throughout the country; and those who denounce the condition of France under Louis Napoleon are repeatedly reminded by Gen. Grant's acts of the familiar proverb respecting people who live in glass houses."

918 “Resist Beginnings," The Sun (N.Y.), August 22, 1871.

${ }^{919}$ Ibid.
} 
culminating acts by specious pretexts which they failed to detect at the time, and... had not the courage to resist until it was too late." They "sat idly...too eager in the pursuit of wealth and pleasure," and remained, "too subservient to factious leaders, too unmindful of individual duty." Without action at the "critical moment," "they fell as prey to plausible pretenses, to fraud, to force." 920

The paper argued that the administration's behavior threatened the republican expectations of the nation for the office of the president and the federal government. The interventions in these conventions remained at the center of these concerns, In August 1871 the scandal surrounding the federal intervention in the New Orleans Convention elicited an almost visceral reaction in the editorial pages of The Sun. The paper wrote, for instance that "the man who does not see this is stupidly or willfully blind." 921 The Sun called on its readers to respond strongly against Grant's “creatures," because if not, he will have "established a precedent by force of which some future Caesar, Cromwell, or Napoleon, backed by a great army, will overthrow the Republic and erect a monarchy on its ruins." 922 The paper continued its allusions to history by arguing that "the daring outrage at New Orleans is full of warning to the American people." The Sun wrote that, although "we do not live in times nor in a country which affect monarchical institutions," and that Grant had not wanted to "put on the purple," or "be called Lord High Protector, nor wear an imperial crown," he had taken the nation closer to that

${ }^{920}$ Ibid.

921 "Resist Beginnings," The Sun (N.Y.), August 22, 1871. "If the people allow him to achieve a second term by such means, what will prevent his obtaining a third term, or even a fourth, through like means?"

922 Ibid. "Grant will never put on the purple now be called Lord High Protector, nor wear an imperial crown. But if he is suffered to carry a party Convention into a United States Custom House, and then summon national troops, armed with rifles loaded with ball cartridges, and supported by Gatling guns, to expel the regular delegates from the Convention, and pack it with his creatures, and in this mode obtain a renomination to the Presidency, then he will have established a precedent by force of which some future Caesar, Cromwell, of Napoleon, backed by a great army, will overthrow the Republic and erect a monarchy on its ruins." 
reality. ${ }^{923}$ Dana reminded readers that Caesar "had crossed the Rubicon with his legions in defiance of the decree of the Senate," Cromwell had "dispersed the Long Parliament with his armed Ironsides, took the mace from the Speaker's table, locked the door of the hall, and then became Lord High Protector of the English Commonwealth," and that the "first Napoleon, surrounded by his tall grenadiers, drove out the Five Hundred at the point of the bayonet, and so became Consul for ten years, then Consul for life, and finally Emperor of the French." ${ }^{924}$ The use of the regular army, in all of these instances, to secure political office elevated Dana's fears of Grant's potential threat to republicanism by doing similar things. Dana asked the American people to "heed...the lessons" his paper offered. The Sun editorial recommended for Americans to apply "the exigency the wise Roman maxim," and "let them 'resist beginnings' by striking down the Dictator now." 925 "It is the unrebuked precedent that begins the mischief," the paper warned, "the failure to arrest the first step in the wrong direction that finally conducts into the road to ruin. ${ }^{926}$ These negative metaphors also came with Dana's critique of Grant's military record. Back to his old role as General Grant's evaluator, Dana again attempted to assess the General's performance. This time, though, he did this for the American people, and not simply President Lincoln and Secretary of War Stanton. Critical to the argument he made here was that Grant was a strong general, but that he also never singlehandedly delivered the Union their victory. Against the idea that the president acted as an un-replaceable champion, Dana's Sun argued that "Gen. Grant was a useful man, and did his work well as long as was a General; but he did not save the Union." 927 "That was done by the people," The Sun declared. The editorial

\footnotetext{
${ }^{923}$ Ibid.

${ }^{924}$ Ibid.

925 “Resist Beginnings,” The Sun (N.Y.), August 22, 1871.

${ }^{926}$ Ibid.
} 
insisted that the Union's saving "would have been accomplished just as certainly if Grant had not been saved from being sent back to Galena to get his living for the rest of his life on his salary as a tanner's clerk." ${ }^{\text {928 }}$ Sun editorials insisted that the administration could rise no higher than the "dead level of mediocrity" after these setbacks. The president, The Sun wrote, has only "avenged himself by petty indignities and humiliations. ${ }^{" 929}$ This discontent with the president and the Republicans led Dana to follow other third-party movements more closely aligned to his political values.

As with so many of those making comparisons between Grant and aggressive European statesmen, Dana actively supported the efforts of any group or candidate capable of avoiding these anti-republican foreign policies of the early 1870s. As an outgrowth of this hope, Dana called on the Democrats to develop into a party that could affirm the rights of legal equality and self-government. "A real Democratic Party must be a progressive one,” the paper maintained. ${ }^{930}$ Democrats committed to black rights would show the country that the party stood behind the idea of "genuine Democracy" with a liberal and "heroic defense of the equal rights of all classes of

\footnotetext{
927 The Sun (N.Y.), June 19, 1871.

${ }^{928}$ Ibid.
}

929 “A Feeble President, A Feeble Administration,” The Sun (N.Y.), September 18, 1871. "It does not follow necessarily or as a matter of course, because the head of an administration knows nothing of constitutional law, is an ignoramus in all civil matters, and stumbles and blunders in political management, that his subordinates in the Government, heads of departments and officials and inferior rank, must be incompetent and unfit for the places they fill. And yet it is natural, if not inevitable, that the character of an administration should partake of that of its chief; that its individual members should think and act in conformity with his views, and that its average intelligence and statesmanship should not rise much above his scope and comprehension. Occasionally an inferior or commonplace President has called into his Cabinet men of uncommon wisdom and sagacity. This was the case with Polk and Pierce. The towering intellect and consummate judgment of Marcy gave tone and dignity to their administration; but in both instances the President was rebuked by his superior abilities, and avenged himself by petty indignities and humiliations. Grant has taken special care to avoid any embarrassment of complication of this description. Not a man has he invited into his political household who rises about the dead level of mediocrity. There is not a Secretary among them all who has a national reputation, or whose brilliancy contrasts strikingly with the dullness of the President. There is not a feature in the policy of this administration which he might not have moulded himself."

930 “Resist Beginnings," The Sun (N.Y.), August 22, 1871. 
people." $" 931$ The run-up to the coming presidential election of 1872 encouraged Dana to

recommend to the Democrats many other broadly supported policy reforms that could align them with anti-Grant Republicans. ${ }^{932}$ He had a track record of doing this. He had supported local prolabor Democrats in New York City as early as the 1840s. Dana had reported on the attractiveness of the ideas of a group of reformers within the Democratic Party calling themselves the Young Democracy in 1869 , for instance, that had disowned machine politics and accepted the equality and voting rights of African Americans and naturalized immigrants. Dana's editorial page also lent considerable attention to the ideas of "New Departure" Democrats like Clement Vallandigham in the early 1870 s, who similarly supported acceptance of equal rights and hoped to move on to issues of economic and civil service reform. Dana attempted to bridge these reform movements by attempting to form a new front against the president and the Radical Republicans. ${ }^{933}$ Reformers like Dana pressed them to avoid a military or Tammany nominee, ${ }^{934}$

931 “Afraid of a Name!,” The Sun (N.Y.), July 18, 1871.

932 “The Unchangeable Democratic Party,” The Sun (N.Y.), December 1, 1871.

${ }^{933}$ For good samples of Dana's coverage of Vallandigham and the "New Departure," see this sample of Sun articles: The Sun (N.Y.), July $2-6,1871$; "Is the New Departure an Old Departure?," The Sun (N.Y.), July 28, 1871. "We have never doubted the wisdom of the now accepted policy of the Democratic Party. It was but the last step in the process of a development that has been going on ever since the close of the war, and which has now reached its climax."; Afraid of a Name!," The Sun (N.Y.), July 18, 1871. "A few shortsighted, thin-skinned, so-called Democrats shrink from the application of the term 'new departure' to the line of policy which the party is certain to pursue in the coming Presidential election. This sensitiveness springs both from want of sympathy with genuine Democracy, and ignorance of the history of the Democratic Party of this country." "The fundamental article in the creed of a genuine Democracy is a hearty recognition and a heroic defense of the equal rights of all classes of the people. Every political organization which stops short of this, yet proclaims to call itself Democratic, is a sham and a fraud, and ought to be treated accordingly. A real Democratic Party must be a progressive one, because it will find occasion at short intervals to apply its principles to a new order of things. While its cardinal doctrines will, therefore, ever remain the same, its measures must frequently change. Viewed in the light of the latter, its history will necessarily be characterized by a series of new departures, which will sometimes be so conspicuous as to practically amount to a reorganization. So much for the new departure in the interests of the slavery propagandists. Is it not high time that the Democracy took up another line of departure - a departure from the slough of pestilent heresies wherein Calhoun, Davis, and Toombs whelmed them, to the solid ground of principle where-on stood Jefferson, Jackson, and Wright, who did not believe that Democracy and slavery were synonymous terms? Such a step is a new departure, and why not call it by that name?" 
avoid "blubber[ing] about the Lost Cause," 935 and side with the protectionist economic platforms of mid-West Democrats like George Pendleton and William Groesbeck. ${ }^{936}$ These reform efforts joined the broader "New Departure" inspired movement, and the northern and western Democratic reformers, to accept equal rights and move to new economic and social issues. One Sun editorial argued that the entire Democratic Party would be smart to accept a platform of equal rights, general amnesty, universal obedience to the constitution and laws, low taxation, moderate tariffs and honest finances. ${ }^{937}$ Dana wrote that whoever became the Democratic candidate, for instance, "will be supported by half the old Republican Party" on this platform. ${ }^{938}$ The party, the paper concluded, needed this sort of platform to form a better opposition. ${ }^{939}$ There had to be change, as Dana remained unsure that the "old-fogey" Democrats in the South or across the country could effectively carry this progressive platform. ${ }^{940}$ Any failure by the establishment

${ }^{934}$ The Sun (N.Y.), June 30, 1871. The Mobile Register of John Forsythe goes for Hancock, but Dana says that no military man should be elected until the nation, "we," "forget" Grant.; "The Opportunity Lost," The Sun (N.Y.), July 5, 1871. "Tammany Hall yesterday was not equal to the exigencies of the time. She uttered but a feeble and uncertain voice upon the great question of Democratic reconstruction." "This settles it that Tammany cannot furnish a Presidential candidate for the Democracy. Weak, commonplace, timid men, however shrewd in the management of ward politics and in the manipulation of jobs, will not do for leaders in such a crisis as is present. Tammany stood badly with the Democracy of the nation before - as badly, to borrow a kindred illustration, as Thurlow Weed and the Albany lobby stood with the Republicans in 1860 - and this Fourth of July celebration will not improve the case."; "The Cowards!," The Sun (N.Y.), July 13, 1871. "The Democracy of the nation ought to spew Tammany Hall out of their mouths."

935 “Jeff. Davis on the Stump,” The Sun (N.Y.), May 29, 1871.

936 “Democratic Candidates for the Presidency," The Sun (N.Y.), July 8, 1871.

937 “The Lesson,” The Sun (N.Y.), April 10, 1871.

${ }^{938}$ Ibid.

939 "How to Use One's Foes," The Sun (N.Y.), May 15, 1871. "Soon after the election of Grant the tables were turned, and the Democracy began to profit by his general incapacity; and they have since owed much to that long series of blunders by which Grant has gradually diminished the strength of the party that placed him in power. If, then, the Democrats will only show as much skill in taking advantage of the follies of Grant's administration as the Republicans did in profiting by those of Buchanan's, they may possibly win the next Presidential election."

940 "Jeff. Davis on the Stump," The Sun (N.Y.), May 29, 1871. Also see: "The Blunders of the South," The Sun (N.Y.), July 21, 1871. The Democracy of the North and West, and to a large extent in the South, have determined to take the New Departure. A small but influential portion of the old ruling element of the 
Democratic Party to represent progressive Democratic platform demands, The Sun wrote, would be viewed by "the masses of people... as the death-wail of worn out political organizations." 941

Dana put forward various recommendations for candidates for the party to choose. The candidates Dana directed his newspaper to follow, and sometimes endorse, matched closely with Dana's policy vision for the nation. One of these candidates was Lyman Trumbull, someone Dana had covered closely for decades. Trumbull, a Senator from Illinois, was an ally of this pro-labor, high protectionist-tariff part of the old-western Democracy hoping to grab the nation's attention. ${ }^{942}$ Trumbull advocated a progressive platform that was reflected in Dana's republican ideas for how the nation should be run. ${ }^{943}$ Trumbull and others alleged the Democratic Party

south, led by such men as Davis, Stephens, and Toombs, refuse to adopt this line of policy. They do not propose to fight against it, but they avow their determination to resist it at the polls in the Presidential election... And now, with this fatal record of the last eleven years to serve as an admonition, a portion of these same incorrigible Bourbons turn their backs on the New Departure and propose to continue on in the old road to ruin. In the light of these facts, impartial observers can hardly fail to reach the conclusion that such men as Davis, Toombs, and Stephens do not desire the success of the Democratic Party at the next Presidential election. Let the party therefore treat them accordingly."

941 "Fun Ahead," The Sun (N.Y.), July 20, 1871. "It is highly probably therefore that we shall see four or five Presidential candidates in the field for 1872, as was the case at the great break-up of parties, under circumstances very similar to those now existing, in 1824. On the one hand we may have a regular Democratic nominee, and an Aleck Stephens ultra States Rights nominee. On the other hand, we may have an office-holders' candidate in the person of Gen. Grant, and an independent Republican candidate. Then, too, there may be a Labor Reform candidate, a Hibernian candidate, an Orange candidate, and a Woman's Suffrage candidate. In this troubled state of things the bewildered masses, discarding all these factions, may make up their minds to rally around the Hon. Horace Greeley of Chappaqua and Buchtel, and carry him into the White House with a unanimity that will revive the halcyon era of James Monroe." Also see: "The Lesson," The Sun (N.Y.), April 10, 1871. "Are the Democrats wise enough, patriotic enough, free enough from narrow prejudice to understand and accept this lesson? It is very doubtful. They have been madmen so long that perfect sanity is too much to expect from them with any confidence."

942 "Bound to Come," The Sun (N.Y.), July 6, 1871. "The wriggling of some of the old fogy Democrats of the East under the operation of Vallandigham's New Departure reminds us of an anecdote." (...) "The Eastern Democracy had better accept the situation with good grace, for the Western Democracy are earnestly intent upon their work, and in spite of grimaces here or elsewhere the beard is bound to come off."

943 "Labor Candidates," The Sun (N.Y.), October 3, 1871. "One of the utopian ideas entertained by our artisans is that a workingmen's party will be a universal panacea for all their ills. On Saturday evening, for about the tenth time, an attempt was made to form such an organization in this city. These movements always lead to the same result. Labor candidates are elected who become mere catspaws of the politicians, and in the end the workmen find that their friends betray them. The mistake is in supposing that because a man is a mechanic he will be any more competent or scrupulous than a member of another profession. Our 
remained too committed to men like General Winfield Hancock, rather than adopt non-military options less directly comparable to President Grant. ${ }^{944}$ Running under the banner of the regional National Workingmen's party, Trumbull organized an alternative to the Democrats and Republicans. Dana supported Trumbull's candidacy because the Democratic moderate could attract various disaffected western and northern Democrats open to labor reform and opposition to Grant's policies. Reports in reform papers, including The Sun, linked the party and Trumbull's candidacy to rising (but disenchanted) stars in the Democratic Party like Samuel Tilden. The support of the New York City lawyer popular in the New York Democratic Party helped expand the young National Workingmen's party's reach. Dana publicized the National Workingmen's party's platform, and its commitment to social, economic, and political reform, above his featured editorial across 1871 and $1872 .{ }^{945}$ He appreciated that the Democrats were continuing to advocate for the rights of labor. The Sun's support for breakaway movements within the party system

laborers should learn that their safeguard is in electing thoroughly honest men, without regard to their calling or social position."

944 "The Proposed Nomination of Hancock-A Foolish Project," The Sun (N.Y.), July 3, 1871. "Are the Democratic Party mad? Have they been driven by long and sore defeat into an insane condition, or a state bordering on insanity? The proposed nomination of Gen. Hancock for President looks like it... The strongest one of all the grounds of opposition to Gen. Grant is his tendency to convert the Government into a military establishment. He has in fact already in a great degree accomplished this conversion... To put an end to this dangerous system of military government requires a civilian and not a military man. The Democracy must nominate a civilian and not a military man."

945 "Issues for the Campaign," The Sun (N.Y.), December 1, 1871. "1 One term of office for the President, and no more; the Constitution to be amended to secure this reform; 2 Both Grantism and Tweedism to be abolished in national affairs by laws for the summary punishment of present-taking and bribe-taking as well as public robbery; 3 Universal amnesty and restoration of political rights to all persons concerned in the late rebellion; 4 Reform in the Civil Service, so that appointment to office will no longer depend on party patronage, and cannot be used as a means of corrupting the politics of the country and perpetuating unworthy men in high places; and so that the President cannot appoint his own relations of those of his wife to any office whatever; 5 Reform of the revenue: reduction in the number of revenue officers and the expenses of collecting duties and taxes; fixed salaries for all revenue officers; the abolition of import duties on all the necessaries of life, and the reduction of other duties to a consistent, rational, and moderate system; the abolition of unconstitutional and superfluous internal taxes, leaving only stamps, tobacco, and distilled spirits as the subjects of such taxation; 6 Legislation to prevent the levy of blackmail upon clerks and other public officers for party political purposes, and for the summary punishment alike of those who demand and those who pay such contributions." 
reflected Dana's larger unhappiness with the available options. He demanded that the party take on new positions better suited to respond to the nation's other pressing issues or make a deal with insurgent groups like the National Workingmen. Dana made similarly forceful recommendations for the Republican Party.

Dana argued that the Republican Party also needed to take a close look at its ideological approach or suffer from the type of defections that Trumbull's movement represented for Democrats. In The Sun he contended that the "flagrant error" that Republicans had made in their policy ideas had been their persistence in applying antebellum and war-time hyper-reform enthusiasm and idealism to the early 1870 s. They needed, in his opinion, to stop "believing that because the party has been a party of doctrinaires" that "it must continue to be so." $"$ "It is true, The Sun conceded, that during the war the party "triumphed by bearing aloft the flag of a cause whose strength consisted in the radical nature of its ideas." 947 By Dana's estimation, the party had accomplished the realization of its most closely held "equality positive dogmas," with the passage of the equal-rights amendments. Dana had, after all, been a part of that faction advocating for their passage. As an original adherent to the Republican Party in the early 1850 s, the editor's estrangement from the Reconstruction-era version of the party signaled various ideological splits occurring in the larger coalition. This alienation reflected the very same fractures dividing the party over the scope of government interference in national reform. A liberal in terms of the broad scopes of legal rights then and since, Dana's commitments to the conservative preservation of federalism and republican self-government chafed at the direction of the expansive and bureaucratic post-war Republican Party. A sign of Dana's increasing awareness of politics "as it was" since he returned from Europe in 1848, as historian Carl Guarneri described it, ${ }^{948}$ was The

\footnotetext{
946 “Advice to the Republicans,” The Sun (N.Y.), January 19, 1871.

${ }^{947}$ Ibid.

${ }^{948}$ Guarneri, The Utopian Alternative, 346.
} 
Sun's argument that the country did not demand the "striking schemes" or "sharp edged radical policies" of post-bellum congressional Republicans. ${ }^{949}$ "On the contrary,” Dana's editorial page recommended "wise, cautious, conservative measures, that will best comport with the tone of public sentiment." 950 "The country is wearied of its high excitements," the paper argued, and "now, most of all, demand repose." "We beseech the Republican Party to drop their foolish leaders and their various rank schemes," The Sun counseled, demanding the party "come plainly out upon the broad platform of moderate and judicious measures." 951

The middle of 1870 through early 1872 saw the manifestations of the weakening Republican Party caucus that Dana predicted would materialize as early as 1868 . Because of this, Dana enjoyed more opportunities to connect with other estranged Republicans. This community more closely shared Dana's vision for the nation, and distaste for Grant and the establishment Republican Party. ${ }^{952}$ His paper solidified relationships with other formerly mainstream Republican politicians, newspapers, and organizations pressing for reform, civic virtue, and a

\footnotetext{
949 “Advice to the Republicans,” The Sun (N.Y.), January 19, 1871.

${ }^{950}$ Ibid.
}

${ }^{951}$ Ibid. These recommendations, the "moderate and judicious" ones, matched Dana's broader economic platform asking for "financial policy looking to an abatement of the present excessive taxation, and tending directly toward the resumption of specie payments." The paper also asked the "tariff pruned by the application of a little vigorous common sense, and rates of duty adopted which, if not perfect, will at least not be so absurd, so oppressive, or so partial as to excite derision and animosity."

952 "Is the Republican Party in New York to be Preserved?," The Sun (N.Y.), May 1, 1871. Dana applauded the speech of Senator Fenton, whom Gen. Grant has recently been trying to minimize. Grant running candidates against him, and using Force Acts to subvert Fenton's authority. "It would be well for the Republican cause if the counsels of this experienced statesman could be adopted. The Republican Party can only grow smaller and weaker with the spirit of vindictive animosity and factional malignity which President Grant has introduced into its management. The work of reducing its ranks and disorganizing its machinery has gone far enough, if it is to remain in existence at all. It can only become united and powerful again by adopting the platform set up by Senator Fenton's speech, and by living up to the principles he has laid down." Senator Fenton's platform remained very close to Dana's: "the peace of the nation, the protection of the loyal, the security of equal rights, the maintenance of constitutional guarantees, the rights of the public creditor, and the preservation of the public faith." 
renewed commitment to self-government. One group The Sun and Dana supported was a group of mid-western politicians hoping to reform the Republican Party or create a new party altogether. Liberal German and Austro-Hungarian veterans of the Revolutions of 1848, the formation of the Republican Party, and the Union effort during the Civil War, The Sun explained, had helped motivate large hubs of reformism in Cincinnati, St. Louis, and Chicago. Dana supported one cluster of 1848-ers in the Midwest: Governor B. Gratz Brown and Senator Carl Schurz from Missouri, ${ }^{953}$ General Franz Siegel and editor Josef Pulitzer of the Staats-Zeitung in St. Louis. ${ }^{954}$ One Sun editorial from May 1871 documented a Schurz speech for the Central Republican Association of Cincinnati that communicated his desire to "secure certain necessary reforms within the Republican Party." The paper applauded that these Republicans from the Midwest to which Schurz spoke sought "civil service reform, revenue reform, and a greater freedom of criticism upon the measures and leaders of the party." 955 Back in November 1870, The Sun explained that "the Democracy of Missouri had the good sense to yield their enthusiastic support" to liberal Republican B. Gratz Brown's initial campaign for Governor. ${ }^{956}$ The resulting bipartisan

\footnotetext{
953 "Let Gen. Grant Mind his Business," The Sun (N.Y.), September 26, 1870. "The modesty of Gen. Grant in writing a letter to a Missouri revenue collector, reading the Hon. Gratz Brown and Carl Schurz out of the Republican Party, is neither apparent nor real. Both of these gentlemen aided in the organization of the Republican Party, both have been able and eloquent advocates of its principles for the past fifteen years, and each has represented Missouri in the Senate of the United States with marked distinction... For the President of the United States to entre upon such a task as this, is disreputable, unseemly, and wholly aside from any duties imposed upon him by the great office which he thus degrades. Rather let Gen. Grant quit the watering places, where he is the dead-head of tavern keepers and railway conductors, and the associate of adventurers and tricksters, and return to Washington, where his official oath requires him to be, and where the public business suffers from his absence."

954 "The Sun the Best Newspaper in the World," The Sun (N.Y.), August 24, 1871. "The Hon. Joseph Pulitzer, one of the editors of the Westliche Post, and member of the Missouri Legislature, in a letter to a friend in New York, writes thus of The Sun which shines for all: "I read The Sun regularly. In my opinion it is the most piquant, entertaining, and, without exception, the best newspaper in the world."

955 “Ideas that Cannot be Gainsaid," The Sun (N.Y.), May 22, 1871.

956 “The Elections-Their Results and their Lessons,” The Sun (N.Y.), November 10, 1870.
} 
victory "is likely due to the independent course, alike bold and magnanimous." $" 957$ Dana understood that these men could settle the nation on a course of civic virtue, even if he may not have formally allied so closely with some of them in decades past. The supremacy of the New Departure and the Young Democracy, and the general acceptance of the Fifteenth Amendment and legal equality, allowed Dana to ally with them now with the goal of honest government and government retrenchment in mind.

The Sun explained that these Republican and Democratic Party exile groups could improve the federal government's, and executive's, commitment to ideologically republican values. One reflection of this is the editorial support received by these candidates from many of the other anti-Grant editors in the press. Papers like the Cincinnati Commercial and the Chicago Tribune, for instance, reflected Dana's positions through the opinions of their editors and other politicians like Greeley, Trumbull, Gratz Brown, Schurz, and others. By the middle of 1871, Murat Halstead, editor of the Commercial, had undergone a similar transition from sympathizer to critic that brought him close to The Sun's orbit. Since September 1870, The Sun wrote, the president's public complaints at these new Republican interlopers like Halstead were "to the last degree presumptuous and arrogant, were it not superlatively ridiculous and contemptible." $" 958$ There were also groups of impostors that were beginning to organize, hoping to form parties

${ }^{957}$ Ibid.

958 "Let Gen. Grant Mind his Business," The Sun (N.Y.), September 26, 1870. "The modesty of Gen. Grant in writing a letter to a Missouri revenue collector, reading the Hon. Gratz Brown, and Carl Schurz of the Republican Party, is neither apparent nor real. Both of these gentlemen aided in the organization of the Republican Party, both have been able and eloquent advocates of its principles for the past fifteen years, and each has represented Missouri in the Senate of the United States with marked distinction. To undertake to proscribe such men because they see fit to express independent opinions because they see fit to express independent opinions on certain political measures relating solely to the State of Missouri, and which have no connection whatever with Federal affairs, would be beyond the jurisdiction of the party when assembled in a national Convention. But for a single individual to assume to do this, and that individual one who was never a Republican at all till he became a candidate for the Presidency, even if he was then, and who never voted for but two candidates for the Presidency in his life, namely, James Buchanan in 1856, and himself in 1868 , would be to the last degree presumptuous and arrogant, were it not superlatively ridiculous and contemptible." 
ready to run against the president, that attracted Dana's attention. The Missouri Liberal Republican organization represented one of the breakaway groups that The Sun openly supported (outside of their free trade ideas that kept him at arm's length from the party's inner circle). Another was Dana's repeated popularization of Horace Greeley's attempt to make civil service reform, pro-labor policies, and high protectionist tariff barriers to force his entry into national politics in 1871 . Greeley had been frustrated by corruption, machine rule, and the radical Republican caucus in previous attempts at entering New York state politics. The Sun continued to float Greeley's name as a strong anti-Grantism, and anti-Tweedism, candidate who should run for office again - and maybe even for president this time.

Greeley's public criticism of Grant, featured in a summer 1871 editorial in The Sun, established his name next to the other anti-Grant candidates Dana and his paper popularized as presidential alternatives to the current officeholder. ${ }^{959}$ The Sun celebrated Greeley's efforts, in part, because Dana argued that he could be more transparent, and committed to republican values, than Grant. Dana could put aside his previous Civil War era rivalry with Greeley if his old boss could unset the current president. One editorial from The Sun asked readers to consider the question if "Horace Greeley should be elected President, how many shiftless and worthless relations would he quarter on the Treasury?" 960 The editorial answered for the readers, in italics for emphasis, that "not one" of his family members or personal friends would be employed by the government. The Sun insisted that Greeley "is not that kind of man." "661 Greeley would not "take

\footnotetext{
959 “The Presidency. Mr. Greeley Avows Himself as Hostile to Grant's Renomination," The Sun (N.Y.), May 8, 1871.

${ }^{960}$ The Sun (N.Y.), June 19, 1871.

${ }^{961}$ Ibid.
} 
presents" and "begin by turning out President Grant." 962 Dana's paper helped popularize

Greeley's platform and went so far to claim that Greeley could also attract the farmer's vote, dating back to Greeley's time editing the Jeffersonian in the late 1830s through the recent publishing of his popular farmer's almanac. ${ }^{963}$ The Sun often called Greeley the "Farmer's Candidate," or the "Farmer of Chappaqua. ${ }^{964}$ The Sun often made similar claims about Greeley being the pro-labor candidate, friend to labor. To that end the paper also often called Greeley the "Mechanics' Candidate," a “democrat of the real type." ${ }^{965}$ Dana also believed that Greeley’s position on a strong tariff, while anathema to most Democrats and the larger liberal Republican movement, would bring together a broad reform coalition of disaffected Republicans and independents. ${ }^{966}$ Sun editorials trumpeted Greeley's commitment to the nationalist and

${ }^{962}$ The Sun (N.Y.), July 6, 1871. "To reform the civil service, begin by turning out President Grant and putting in some man, like the Farmer of Chappaqua, who will not take presents or appoint worthless relatives to office."

${ }^{963}$ The Sun (N.Y.), July 6, 1871.

${ }^{964}$ Ibid.

${ }^{965}$ For an example of The Sun's argument about Greeley's history of supporting labor, and qualifications to represent them as a candidate for the Republican Party, see: "Do the Workingmen Own Themselves?," The Sun (N.Y.), October 25, 1869. The following blurb of the article illustrates Dana's argument that Greeley is a champion of workingmen, and a democrat of the real type. "Slavery is supposed to be abolished in this country. The blacks are said to be free. But are the whites free-really free? Do the workingmen of New York actually own themselves today? Are they free to exercise the right of suffrage according to their own volition, and to vote for whomever they please? ... The working men have [put] up before them, as a candidate for office, one of their own number; a life-long champion of their interests; a friend whose fidelity is vouched by every act of his long career as one of the foremost conductors of the public press. Horace Greeley has always been their advocate. Will they now give him their support? We have no doubt that if the real preference of all the voters in the State were to be expressed, Mr. Greeley would be elected by a large majority. The only question is whether the workingmen will generally vote as they really wish to vote, or whether, under the direction of party leaders, they will vote for the opposition candidate... It cannot be denied that the people nowadays act with altogether too little independence, and too much under the despotism of party leaders. We hope in the case of Mr. Greeley to see Republicans and Democrats unite in his support, and vindicate their freedom from mere partisan enslavement. Let every workingman resolve to-day, when he reads this article — we mean every one is entitled to vote - that, come what will, he will vote for Horace Greeley; and when election day arrives let him carry this resolution into effect. The readers of The Sun alone can easily turn the result in his favor. They can elect him. Will they do it? He is a workingman - man of the people. Will the workingmen, the people, stand by him?"

${ }^{966}$ The Sun (N.Y.), July 3, 1871. 
protectionist thought of economist Henry Charles Carey, even calling back to Carey's time working for both of the editors at the Tribune. ${ }^{967}$ As the year progressed, The Sun advertised the growing Greeley support, and framed it as a manifestation of a loud independent political spirit developing across the nation. ${ }^{968}$ Dana's paper enjoyed that the "Greeley movement" had developed "spontaneous" power, and that interested New Yorkers should meet at New York City's Lincoln Club on the evening of June 12, $1871 .{ }^{969}$ Dana emphasized the meeting's intentional anti-partisanship: "People should go without any distinction of party, Democrats as well as Republicans as Independents - everybody should go." ${ }^{\text {970 }}$ The Sun's editorial about the meeting noted that the proceedings left no doubt Greeley is for "every lover of justice and hater of wire-pulling." ${ }^{971}$

The Sun's bi-partisan, and even extra-partisan, defense of Greeley's candidacy gained additional vitality after the death of the Copperhead Democrat, and New Departure soundboard, Clement Vallandigham on June $17,1871 .^{972}$ The broad reform sympathies of the Maryland Congressman, The Sun wrote, could be made more progressive and better popularized by

\footnotetext{
${ }^{967}$ For more on Dana's relationship with Carey, especially regarding their time at Greeley's newspaper, see chapter two and three of this dissertation.

968 “Good Advice for any Candidate," The Sun (N.Y.), April 21, 1871.

969 “The Great Greeley Meeting To-Night,” The Sun (N.Y.), June 12, 1871.

970 Ibid. Also see: "A Sound Platform," The Sun (N.Y.), February 2, 1872. "That able organ of the New York Democracy, the Brooklyn Eagle, lays down a very succinct and practical platform for the approaching Presidential campaign...This is the feeling of the best portions of the people, and of intelligent Republicans as well as Democrats. The sort of President we have now they are sick and tired of. They want a gentleman, a statesman, and man of honor. And they will have him."

971 “All Good Men in 'Favor of the Farmers' Candidate,” The Sun (N.Y.), June 21, 1871.

${ }^{972}$ Dana pointed to the contrarian Maryland congressman as one symbol of the desired post-war reform of the Democratic Party that Greeley could draw on for support. Vallandigham's "New Departure," though, received checkered support from The Sun for its less than enthusiastic of all the brands of reform Dana desired. For one, it cow-towed a bit too closely to the Southern Democracy.
} 
Greeley. ${ }^{973}$ One June 1871 editorial, for instance, suggested that discontented Republicans and progressive Democrats should immediately organize a new party built on economic nationalism, civic virtue, and self-government. ${ }^{974}$ Dana described it as the potential "newest departure" of disaffected voters capable of aligning behind "Uncle Horace." "975 "The Democrats shall make no

973 "The Death of Vallandigham," The Sun (N.Y.), June 19, 1871. What follows is a small part of the editorial page's eulogy of him. This small part helps illustrate Dana's argument that Vallandigham's turn toward reform was laudable, if he himself was part of the reason the reform needed to go farther. "Mr. Vallandigham has not been regarded as a great man, and yet he had elements of real greatness. First of all, he was governed by intense and sincere convictions. Nothing but principle, deeply mistaken but yet perfectly earnest, could have been carried him through the war of the rebellion an apostle of State Rights, but of the Confederacy - a believer in the Union, but antagonist of the dread struggle for its preservation. Next, he was a man of courage, never hesitating to utter his opinions or shrinking from their defence. This noble quality was impressively exhibited in the last great act of his life, when he came forward to direct the Democracy in the New Departure, unsaying his own old ideas, and advocating a policy he had before resisted...his mind will continue to act in our politics long after his grave is closed; and if the Democracy continue, as they doubtless will, to follow the path into which he has led them, they will owe what success they may gain first of all to the foresight, the wisdom, and the firmness of Vallandigham."

974 "A New Departure in Earnest," The Sun (N.Y.), June 26, 1871. "Why do not the discontented Republicans and progressive Democrats combine together and form a new party? They have an excellent candidate for the Presidency in the person of the Hon. Horace Greeley. All the farmers and all the mechanics are for him already, because he is the Farmers' and Mechanics' Candidate."

975 “The Newest Departure," The Sun (N.Y.), November 24, 1871. "The proposition in brief is this: Admitting the impossibility of electing a Democrat, and assuming that Gen. Grant will be the nominee of the Republicans, it is proposed that the Democrats shall make no nomination for the Presidency, but give their support to whoever may be selected as a candidate by that portion of the Republican Party who are opposed to usurpation and corruption in office; who object to the present method of administering the United States Government for the personal benefit of the Grant and Dent families and their friends; and who do not propose to permit Grant's army of greedy and unscrupulous officeholders to control their exercise of the elective franchise. It is urged that by such the coherency which Democratic opposition gives to the Republican Party would be immediately destroyed, and the powerful Republican opposition to Grant would take form as the aggressive party of the hour, supplemented and reinforced by a compact and irresistible reserve of Democrats; and that as the inevitable consequence a liberal, competent, and honest Republican would be chosen President by a majority so overwhelming that it would be folly to contest the result. In short, the glorious victory won in this city would be repeated in the nation... It is certain that Gen. Grant, if nominated, would fail to receive the support of the best and ablest men in the Republican Party. The popularity he attained through his military achievements has been utterly destroyed by the discovery that he is not only unfit to discharge the high duties that have devolved upon him in his civil capacity, but that his personal characteristics are such as to give offence to all decent people. His lawless favoritism, his excessive love of money, and his bestowal of his offices in return for presents; his abject truckling before the rich and powerful, and his supercilious contempt for the masses who have placed him in power; his arrogant disregard of legal restriction; his encouragement of bribe-taking; his suspicious connection with the money-getting schemes of disreputable speculators and adventurers; his support of the slave-traders of Cuba against the patriots who are struggling for their own freedom and that of half a million of enslaved Africans; his disgraceful and illegal action in placing the commanders of American ships of war under the orders of the mongrel imposter Baez, and his general recklessness and incompetency, have all combined to produce a revulsion in public feeling which will make itself manifest at the proper time in a most effectual 
nomination for the Presidency," the editor predicted, "but give their support to whoever may be selected as a candidate by that portion of the Republican Party who are opposed to usurpation and corruption in office" ${ }^{976}$ One recommendation Dana had to create this type of independent ticket was to nominate Greeley as president and William Groesbeck, the mid-western Democrat aligned with Schurz, Gratz Brown, and Pulitzer, as vice president. ${ }^{977}$ If the discontented Republicans and progressive Democrats would also combine to support him," The Sun wrote, Greeley would "be sure of a bigger majority than was ever received by any former President." 978 Dana had long highlighted the need for new options for voters, and again, in mid-1871, argued that "it is time for a new party." ${ }^{979}$ Dana's turn against the president had consolidated to such a point between the middle of 1870 through 1871 that competing newspapers could not always take it seriously. ${ }^{980}$

manner. The ablest of the Republican statesman feel the deep humiliation of serving under a President of so low an intellectual grade; while the great mass of the intelligent people of America are ashamed to see the highest office in the nation filled by a man who is so dull that to save his life he could not write a commonplace formal Thanksgiving proclamation in good English, and whose poverty of ideas is such that he cannot make a speech of three sentences without rendering himself an object of derision." "There can be no doubt that an honest, patriotic, and really able Republican statesman, of enlarged ideas and liberal views, nominated in opposition of Grant and receiving the support of the Democracy of the country, would be elected by an unprecedented majority; and that the adoption of such a policy by the Democrats would be evidence of profound political sagacity, as well as of noble, patriotic feeling." "If the moribund Democratic organization could be withdrawn, a new and far more powerful National party would immediately take its place, comprising the wisest statesmen and purest men of both the Democratic and Republican parties, banded together for the execution of such measures of public policy as should be for the best interests of the whole country, working for an honest and high-toned administration of the laws in conscientious conformity to the obligations of the Constitution, and for the overthrow of robbery, injustice, and corruption in the North and the South alike. Would not such a party by backed by the suffrages of an immense majority of the honest men of both sections and all existing organizations? And would not its continued supremacy for many years be assured beyond a doubt?"

976 “The Newest Departure,” The Sun (N.Y.), November 24, 1871.

977 “Greeley and Groesbeck—Why Not?,” The Sun (N.Y.), July 21, 1871.

978 “A New Departure in Earnest,” The Sun (N.Y.), June 26, 1871. This turned out to be one of the most incorrect predictions that Dana would ever make.

979 Ibid.

980 "Is it a Joke?," The Sun (N.Y.), June 28, 1871. "Mr. Greeley in the Tribune declares that he will not be dragged or driven into a premature discussion of Presidential candidates. This is very proper on his part. He has already announced that he will not decline the nomination, and that is all it was necessary for him to say. All the rest belongs to the farmers and mechanics, and the people generally. Mr. Greeley stands 
Dana had a public break with Greeley during the Civil War, which added to the perception that his spite encouraged Dana to act less than seriously in some of his editorial positions in this period. One July 1871 response to claims that The Sun offered "mock praise" for Greeley featured a history of Dana's close connection to Greeley, and The Sun's support of Greeley's recent candidacies, economic nationalism and political ideas. ${ }^{981}$ To reiterate his position on his former boss, Dana spoke for The Sun staff in declaring that "it is our decided and well-founded conviction that Mr. Greeley is immensely the superior of Grant in every particular except fighting and indifference to the destruction of human life." ${ }^{982}$ Dana added his name to the growing list of Grant critics using the general's war record to critique his fitness for political office. Dana's use of the contentious critique only reinforced the level to which the president's vision for the nation had enflamed the editor.

pledged to the one-term principle, and that is a very popular foundation plank for a platform. The Sun which shines for all shines with peculiar warmth on Mr. Greeley. Mr. Greeley's recollections of a busy life furnish an excellent campaign biography. A cheap edition should at once be got out, and we advice every voter to buy the book and read it. The Times affects to regard Mr. Greeley's nomination as a huge joke. The Times does well, in calling it a joke, to call it a huge one. We apprehend that Gen. Grant will find it so huge in his pathway that he will be unable to surmount it. Mr. Greeley's is not the first nomination for President has been treated as a joke..."

981 "A Blunder Set Right," The Sun (N.Y.), July 4, 1871. "How does the Lawrence Journal know that the editor of The Sun 'hates Greeley'? In what way was such hatred ever manifested? Have we ever said anything about Mr. Greeley that was not true? Have we ever got out of our way to malign him? Have we failed on any occasion to do justice to his merits? Have we not always supported him when he has been a candidate for office? And did not we not give him in the contest in this State in 1869, when he was running for Comptroller, fully ten thousand votes that he could not have received without the friendship and the earnest advocacy of The Sun? Was there any mockery about these ten thousand extra votes? And when the present administration came in, did we ask anything else of its head except that Mr. Greeley should be appointed Minister to England?"

${ }^{982}$ Ibid. Dana's editorial page wrote that "Mr. Greeley is not given to taking presents. He would never appoint incompetent men to office because they had given him presents. He would neither make a fivethousand-dollar man a member of the Cabinet, nor a bull-pup man a postmaster. Nor would he keel any convicted bribe-takers in high positions about him. Nor would he give offices to any worthless relatives of his own. Nor would he betray the cause of freedom in Cuba or elsewhere, or degrade himself to support Spanish slavery and the slave trade because Spanish agents had paid somebody's son-in-law large sums of money. In short his superiority to Grant is so great that, as we have ever said, there is no comparison between them. 
The Sun maintained that Grant's change in character had helped merit this transformation of opinion regarding the president, and Dana's renewed support for another Greeley candidacy. Dana reminded critics that he supported Grant resolutely during the Civil War, had "saved him from being relieved," and even wrote a campaign biography advocating his election of $1868 .{ }^{983}$ "But immediately after his elevation to the Presidency," one Sun editorial explained, "Gen. Grant began to manifest a change, almost incredible, which sudden and enormous prosperity, unbounded flattery, and a childish admiration of wealth and wealthy men, had wrought his character." $" 984$ The Sun reminded readers of its attempts to trust the president in April and May of 1869 , but had quickly after began "to have serious misgivings." After a long recounting of the scandals of the previous two years, Dana's paper admitted to a "certain inexpressible regret that he has so demeaned himself." ${ }^{985}$ A later August 1871 editorial made a similar point. The Sun argued that the claim that Grant "would prove fully as capable in civil administration as he had been in military matters... is now completely dissipated. ${ }^{" 986}$ By early 1872 , Dana was prepared to support a range of candidates that had come forward to confront the president, as Dana had set his mind to the argument that Grant had "used his power as if it were his own private property to be employed to enrich himself, his family and his favorites." 987 Grant had been "elected President by

983 “The Change in Grant's Character," The Sun (N.Y.), April 12, 1871. "During the war we stood by Gen. Grant from first to last. It was our fortune to render him such service a perhaps it happened to no other man to be able to render."

984 Ibid.

985 Ibid.

986 “The Only Reasons why Grant should be Nominated," The Sun (N.Y.), August 30, 1871. "In 1868 Grant was elected because the people remembered with gratitude his services during the war..."

987 “The Epoch of Corruption," The Sun (N.Y.), February 19, 1872; “The Epoch of Corruption," The Sun (N.Y.), February 19, 1872. "Who is mainly responsible for this universal corruption, for this unprecedented and prevailing wickedness? It is Ulysses S. Grant, the President of the United States. He has set the example. He is the most guilty of all. Elected President by a grateful and confiding people, he has used his power as if it were his own private property to be employed to enrich himself, his family and his favorites. Accepting presents and giving offices in return, begging from munificent citizens a donations of $\$ 100,000$ 
a grateful and confiding people," The Sun continued to contend, but had fouled his own chances for an easy reelection in 1872 . The paper argued that it had been "Grant's own hand" that "struck down the popular confidence in him," and that the editorial page of The Sun was simply spreading the word. ${ }^{988}$

\section{Conclusion}

This dissertation has argued that Dana's republican visions for the nation sharply clashed with President Grant and the Congressional Republican Party's initiatives and policies between 1869 and 1872. By the end of 1871, and into early 1872, Dana's sense of estrangement from the mainstream Republican Party intensified to the point of spurring Dana's public rebuke of the president and his allies. By early 1872, Dana had clearly set himself against the nomination of Grant for another term in office, and made every effort to discredit the Republican Party's recent turn toward patronage and organizational politics. "There are now two parties in the country claiming the title of Republicans. One is the real Republican Party; the other the party of Grant's officeholders," The Sun summarized of its recent study of American party politics since $1869 .{ }^{989}$ The structure of this statement, that overtly split the Republican Party, illustrated how Dana interpreted his own place within the political system. As previous chapters have explained, Dana already thought of himself as an independent newspaperman freed from political direction by leaders from either major party, and happened to know that President Grant did not like The Sun

to Gen. Sherman in order that he might get $\$ 65,000$ for a house which he had just sold to another man for $\$ 40,000 \ldots$. ... "Had Grant been a pure man, with a high moral sense, a delicate feeling of honesty, and a just conscience, his example, his influence, and his power would long since have sufficed to turn back the rising tide of corruption, and to rescue the Government from the dangerous evils with which it is struggling."

988 “The Only Reasons why Grant should be Nominated," The Sun (N.Y.), August 30, 1871.

989 “The Republican Party," The Sun (N.Y.), November 29, 1871. "At the head of one is Mr. Greeley, who founded the party in 1854, and has been its ablest leader in the press. At the head of the other is Gen. Grant, who never voted a Republican ticket until he voted for himself for President, and who in 1856, when the real Republicans rallied for their principles with Fremont as their leader, voted for Buchanan and the proslavery Democracy." 
for its coverage of the administration and the Republican Party. Dana noted that "Dr. Greeley is hated by Grant's officeholders with the most cordial malignity." ${ }^{990}$ By 1872 Dana had been distinguishing himself from the Grant portion of the Republican Party, and in so doing marked the change in political party affiliation, driven by a decades-long commitment to republicanism, that this dissertation has been analyzing. The early campaigns working in preparation for the national elections of that year left Dana convinced that his embrace of self-government, equality before the law, civic virtue, and labor rights placed him at the center of a political insurgency against Grantism and machine politics. Editorials in his newspaper reflected Dana's conviction that President Grant had amassed such an opposition, that these ideals could unite a broad coalition to defeat Grant's "officeholders." announced that it would hold its own convention in May of 1872, Dana interpreted this as the culmination of the growing solidarity in the opposition group he saw himself a part of. When the new party's convention was announced in early 1872 , he declared that it represented the seminal moment for the never-Grant movement. "In a certain class of political crises words are things, and declarations are equivalent to actions," the paper explained. "By the calling of the Cincinnati Convention the Liberal Republicans," The Sun wrote in 1872, "have evinced a disposition to cooperate with the Reform Democrats in delivering the country from the follies and crimes of the money-making administration of General Grant." ${ }^{\text {992 }}$

\footnotetext{
${ }^{990}$ Ibid. "Great efforts have been made to compel Dr. Greeley to abandon the old Republican Party and to suffer himself to be carried over into the Grant party. Up to the present time these efforts have met with no success; and Dr. Greeley is hated by Grant's officeholders with the most cordial malignity."

${ }^{991}$ The Sun (N.Y.), November 29, 1871. "Unpleasant to the Grant Officeholders-The idea that the Democrats will not run any candidate for the Presidency, but will give their support to the candidate of the National Reformers."

992 “The Connecticut Democracy,” The Sun (N.Y.), February 2, 1872.
} 
This is a period that political historians know well because of the shifts in the Republican Party, as well as the developments of the new organizations that began to take shape that replaced the Democratic Party in the elections in November 1872 to challenge the president. Andrew Slap's book, The Doom of Reconstruction, has made the most convincing argument about the nature of the party that came to challenge President Grant in the election of 1872, and the candidate that became its eventual nominee in Greeley. Slap overturned decades of historiography that suggested that only "gentleman reformers" made up the party's membership. ${ }^{993}$ As this chapter argues, and as Slap explains, a broader coalition of anti-Grant, anti-Republican Party establishment joined unhappy elements in the Democratic Party to win the right to face Grant. The Liberal Republican Party became the first party to replace the Democratic Party in a presidential election since the latter's founding. This chapter has argued that Charles A. Dana stood at the center of this insurgency across the second half of 1870 and the whole of 1871 even if he never formally joined the party that nominated his candidate. ${ }^{994}$ The men who formed the Liberal Republican Party were men that Dana remained politically close with, many of whom

\footnotetext{
${ }^{993}$ Slap, The Doom of Reconstruction, $\mathrm{xi}-\mathrm{xxv}$.

${ }^{994}$ While the impression of Dana's support for Greeley was sometimes treated as an initial joke by the editor, There are sources that do equate Dana's support to Greeley as being genuine. The best representative of this class includes Dana's first biographer James Harrison Wilson in The Life of Charles A. Dana, 428. "(Dana) and those who stood with him, believed thoroughly in the necessity of taking the government out of the hands of the Republican Party, as well as in the honesty and capacity of Greeley, and spared no effort to make the country believe in him as well." To the claims that Dana did not take Greeley seriously, Wilson says the following, "it has been suggested that Dana's earlier advocacy of 'the Philosopher of the Tribune' began in a spirit of fun and that it could not be sincere, and that the campaign for his election was hopeless from the start. To this Dana paid little attention till after the campaign had ended in Greeley's defeat and death." Wilson also provided the following regarding Dana's place in supporting Greeley, and the larger movement to reform the party: "To such as look below the surface, Dana's course at this time appears to have been not only genuine and disinterested, but exceedingly useful to the country at large. In the light of subsequent events, it must be conceded that it was significantly vindicated by the Independent Republican movement, which not only selected Greely, whom Dana had first nominated, but compelled the Democratic Party to select him also, and to adopt a policy on which it ultimately went to power. While the movement at first was defeated at the ballot-box, the Sun's part in it received an amount of non-partisan and even of Republican approval that has rarely ever been accorded to independent journalism." Sentiments of this sort sentiments don't appear in the more recent treatments of Dana's support for Greeley in the late 1860s and early 1870s.
} 
have been featured in this chapter. This list included men like Carl Schurz, Josef Pulitzer, Samuel

Bowles, Benjamin Gratz Brown, Lyman Trumbull, Francis Adams, Murat Halstead, and others.

The one man who overwhelmed these founders of the party in May of 1872 at the Liberal

Republican Convention - Horace Greeley - had received Dana's support for office since 1868.

The facts of the campaign of 1872 - and Dana's participation in it, largely fit with the proceeding

trends that this chapter covered. Dana supported the Liberal Republicans and Greeley as far as his

established ideologies took him, which meant supporting Greeley, but not following the party

entirely. The Liberal Republicans aligned with Dana's pleas for reform in the civil service and

less militarism in the administration's Reconstruction policy. Many Liberal Republicans also

thought of these issues in terms of classically liberal and republican ways. Dana, like leading

Liberals, thought that the president and the Republican majority threatened liberty, encouraged

tyranny, and invited despotism. Dana however, never formally joined the Liberal Republican

Party (and got closest only when Greeley became the party's nominee). ${ }^{995}$ Part of Dana's

995 "Issues for the Campaign," The Sun (N.Y.), December 1, 1871. In an editorial from December 1871, Dana revealed The Sun's formal platform that had driven his political commitments so far from the President and the Republicans. Here he again reiterated the now matured platform for the nation's politics, economic, and social questions built with a vision for the nation in conflict with the administration. The first point of Dana's platform called for "one term of office for the President, and no more; the Constitution to be amended to secure this reform." The various Sun editorials across the previous three years decrying the President's growing influence makes Dana's hesitancy at allowing a multi-term "tyrant" easier to see. The second point of Dana's platform called for "both Grantism and Tweedism to be abolished in national affairs by laws for the summary punishment of present-taking and bribe-taking as well as public robbery." To strengthen this second point, Dana proposed initiatives to stem the exact type of supposed corruption that Dana saw Tweed and Grant overseeing in places like New York City and state. Dana wanted "legislation to prevent the levy of blackmail upon clerks and other public officers for party political purposes, and for the summary punishment alike of those who demand and those who pay such contributions." In memoriam of the Young Democracy and Greeley candidacies sunk in previous years, this platform reproduced The Sun's language from 1869 and 1870. This plank also reverberated with the paper's reporting and editorial work that decried the administration's connection to fraud and graft in the Southern states still subject to Reconstruction. Dana's insistence that the President and his Republican allies continued to exacerbate the issues in the South informed his next concern. Dana advocated his ameliorative policy for the South, universal amnesty and restoration of political rights to all persons concerned in the late rebellion" - as his third platform point. Dana's fourth platform point illustrated the struggle between the editor's hope for a humble, virtuous federal government and the reality of the Grant administration's conflict with that very objective. This point asked for "reform in the Civil Service, so that appointment to office will no longer depend on party patronage, and cannot be used as a means of corrupting the politics of the country and perpetuating unworthy men in high places." Furthermore, Dana 
justification for not joining the Liberal Republican Party was that it was mostly in favor of free trade and had some connection to anti-labor and pro-tax policies that the White House favored. Particularly relevant to Dana, Liberal Republicans, according to Slap, were not Burkean conservatives, but aspired to classic American republicanism in politics, and, most critically to Dana, in economics tended towards classic liberalism and free trade. ${ }^{996}$ For this reason, a large portion of Liberal Republicans supported the free-market oriented nominees and were unhappy that Greeley, the protectionist, had gained the nomination. These liberal Liberals opposed Greeley’s economic nationalism and cooperationist approach to ending Reconstruction. ${ }^{997}$ Dana backed his ally, whose protectionism and staunch pro-labor outlook had preserved The Sun's dedicated support. At the Cincinnati Convention of 1872, when the Liberals chose their candidate, these factions fought for influence, with Greeley eventually defeating Francis Adams for the nomination. These developments paralleled Dana's previous attempts to find political

clarified that the platform needed to be amended to make sure that "the President cannot appoint his own relations of those of his wife to any office whatever." Against all the free traders in the Republican Party Liberal or otherwise-Dana advocated his five platform plank "reform of the revenue" and the "abolition of unconstitutional and superfluous internal taxes." The platform included a strong majority of all of Dana's domestic hopes for the nation. They also illustrate the way that he crafted direct policy proscriptions through which to realize some of these visions for the country in lieu of the obstructions introduced by the President and the Republican majority in Congress.

${ }^{996}$ Slap, xxi.

997 “A Word to the National Reformers," The Sun (N.Y.), February 2, 1872. "This touches upon a matter which the promoters of the Cincinnati Convention cannot too earnestly consider. Why should they bring up in this campaign the issue of free trade and protection? No doubt many of them are free traders from conviction, while others of them are protectionists; but neither one nor the other class can regard the question as practically important. Whatever may be our opinions, we must, as long as the public debt is as large as it is, levy an average of forty per cent import duties upon all foreign productions; and while this is the case protection is unavoidable, and free trade impossible. Why then engage in a controversy about it which may distract the reform movement? Or why take up a position which may at the start repel so powerful an ally as Dr. Greeley? Can it be wise of politic when the issue is the radical reform of the whole administration to weaken our cause by alienating from it men whose zeal and sincerity in support of reform cannot be questioned... Thirty or forty years hence the question of protection or free trade will be in order, for by that time the public debt will be so far reduced that it will be a legitimate subject of practical discussion. Let the men who are then living take hold of it in earnest, and make it a basis of political organization and party action; but let not the Reformers of the present day imperil the momentous interests that are in their charge by setting up as a test of political orthodoxy a doctrine which can have little or nothing to do with the present action of the Government." 
avenues most amenable to realizing his vision for the nation. In form, tone, and substance, Dana's participation in the campaign of 1872 mirrored this chapter's focus. It also mirrors this chapter's major argument: that the conflict between Dana's republican concept for the country and the policy alternatives executed by the president and the Republican majority best explain his continued hostility to his former political allies.

This chapter has reiterated how Dana's public life illustrated his ability to place his ideas before his professional desires for patronage, or his broader dedication to individual parties. The period, from the middle of 1870 through the end of 1871, invited widespread change across the nation's political economy, political communities, and larger political culture. This chapter argues that Dana confronted rapid industrial change and the escalation of government power with arguments inspired by the republicanism of his past. Dana's interpretations of the philosophies of self-government, civic virtue, equal rights and free labor made him protectionist, pro-labor, small government, and for equal protection. In the period, finding candidates to match his ideology took Dana further away from the president, his allies, and the Radical Republicans. His ideology instead took him closer to third parties, and even the rival Democratic Party, to develop new movements to realize his vision for the nation, and confront the president. Dana's support for Lyman Trumbull and the National Reform and National Workingmen's party, the candidates of the Young Democracy in New York City and state, and all of Horace Greeley's independent candidacies, revealed his willingness to disavow party allegiances to advance his ideas. Dana's opinions on economics, trade, currency, labor, immigration, and Reconstruction policy drove his political affiliations in this period. This chapter, and the four before it, have collated the evidence to show that Dana advocated a unified commitment to classically American, republican, and transatlantic, ideas whose influence was visible in his public words and newspaper's editorial policy. Between the summer of 1870 through early 1872 this characteristic remained one of the guiding features of Dana's continued advocacy for policies that were both reminiscent of earlier 
republican commitments and categorically against government policy. In this analysis, what stands out is the persistence with which Dana persistently uses a republican framework to evaluate Grant's administration, the nation, and broader geopolitics. 
VII. CHAPTER SEVEN

\section{REPUBLICAN VISIONS IN FOREIGN POLICY INFLUENCE}

\section{AMERICAN PARTY POLITICS}

(MID - $1870-1872)$

By the summer of 1870, and through 1871, Dana's dedication to self-government, egalitarianism, and equality before the law, had proven to be a formidable motivation for his rejection of his former allies in the Republican Party. This dissertation has attempted to show that Dana developed serious critiques of the nation's domestic and foreign policy motivated by his republican ideas. The preceding chapters have explained his capacity to see the intersections between domestic and foreign policy with a transatlantic perspective that he had employed since his youth. This chapter enriches the argument that Dana's international, and republican, frame of reference influenced his disillusionment with his former political allies in the lead up to the election of 1872. It argues that Dana again continued to see the problems of the administration and the Republican Party's commitment to Eric Foner's conceptualization of the organizational mode of patronage-centered politics comparable to other international examples. The results of this transformation in the party, according to him, hurt the United States' foreign interests, the future success of the president's party, and made Grant and the Republicans comparable to corrupt Old World governments. ${ }^{998}$ Between the summer of 1870 and early 1872, Dana's

\footnotetext{
${ }^{998}$ In an editorial in December of 1871, the end of the chronological range of the chapter, Dana recapped this argument. He argued that "as the civil service is now carried on, it is one enormous engine to corrupt public and private morals, to promote the personal designs of the President, to secure his renomination, and make him absolute master of the political party of which he belongs." See: "Grant's Notion of Civil Service Reform," The Sun (N.Y.), December 6, 1871. Dana's reaction to Grant's changes to the Republican Party, away from its ideological roots and towards a new "organizational mode" centered around patronage in the early 1870 s, illustrated this point. This transition in modes, as Dana interpreted it, encouraged corruption and the growth of an activist, self-preserving, federal government to preserve political power for Grant's allies within the Republican Party.
} 
newspaper illustrated how world affairs in Europe and the Caribbean continued to inform the editor's anti-Grantism. Dana insisted that the party selectively failed to defend republican values and anti-slavery in the early 1870 s, which was evident in the shadows of two complicated Atlantic processes: 1) the unification of Germany, the downfall of Napoleon III's reign during the Franco-Prussian War, and the course of the Paris Commune, and 2) the regime change in Spain, the crowning of a new Spanish king in 1871, and the Cuban demands for self-government during the ongoing Ten Years War. The intersections between the results of the Franco-Prussian War and Caribbean politics, especially in Cuba, provides an interesting perspective to study the antiGrant platform developing in the lead up to the national election of 1872 . This chapter will explain how these conflicts fit in with the editor's continued opposition to the president, his allies in the Republican Party. Before doing so, the chapter will first introduce how Charles A. Dana, editor of the now very popular New York newspaper, questioned the political health of the government and the Republican Party in response to a conflict the U.S. did not participate militarily in: the Franco-Prussian War and Paris Commune.

Dana's responses to the ongoing Cuban Revolution, the war in Europe, and the Grant White House's policy towards these events, are notable for a host of reasons. As this project has argued in previous chapters, Dana's responses to Europe and the Caribbean similarly help show how he refused to draw strict boundaries between internal and foreign affairs. ${ }^{999}$ The editorials from The Sun in late 1870 and 1871 particularly show how this transatlantic perspective animated Dana's opposition to Grant's initiatives, and the perception of impropriety these policies encouraged. The Ten Years War, the Franco-Prussian War and Paris Commune do not feature

\footnotetext{
${ }^{999}$ The last chapter explained that Dana's domestic policy vision helped inform his continued opposition to the President, his allies, and their policies across 1871. That chapter specified that Dana's republican motivations helped encourage both his policy hopes for the nation and criticism of the administration.
} 
often in treatments of Dana's opposition to the president and his supporters. ${ }^{1000}$ The editor, however, had illustrated a close ideological connection to both Caribbean and Franco-German politics since at least the 1840 s and 1850 s, not to mention the years of coverage that The Sun had given the Ten Years War since its commencement in October $1868 .{ }^{1001}$ As had consistently been the case since his early adulthood, Dana filtered his understanding of these events through an ideologically republican lens, a filter that translated the meaning of the present with the lessons Dana learned from the American Revolution, the American Civil War, and the annals of European and transatlantic history. Dana viewed the foreign affairs of the United States in the early 1870 s as being necessarily imbued with a republican promise, and duty. This idea was part of a much larger hemispheric and transatlantic initiative meant to foster self-government, liberal egalitarianism, legal equality, anti-slavery, and free labor. Dana responded to the Grant administration's foreign policy towards the wars in the Caribbean and Europe by highlighting the metaphors with Atlantic politics that the president's behavior helped create. Dana argued that the president encouraged his critics to compare Grant with the misadministration of Old World Europe. Particularly, Dana's editorials implored the president and the major political parties to support Cuban independence and regretted that the White House's foreign and domestic affairs compared to those European despots. This chapter will explain that the Cuban and broader Caribbean question continued to represent an influential part of his decision to break with Grant and the Republicans across 1871 and early 1872 and embrace alternative parties and candidates.

When war broke out between France and the North German Confederation in July 1870, Charles Dana and his Sun were not surprised, immediately interpreting the conflict in characteristically republican terms. The paper had expected Napoleon III's rush to war against

\footnotetext{
${ }^{1000}$ For more on the historiography surrounding Dana, his ideas, but also the connections of these ideas to the Caribbean, see the introduction to this dissertation.

${ }^{1001}$ For more on Dana's previous opinions about France, the German States, and Europe, see chapter 1 of this dissertation.
} 
Bismarck's Germany. Dana insisted that the economic struggles of Napoleon's financial policy, his bureaucratic corruption sapping French coffers, combined with the economic and military threat of the unifying German states, would push the French monarch to act preemptively in preservation of his waning power. ${ }^{1002}$ Sun editorials described a French society ruled by Napoleon's "personal" and nepotistic rule, highlighted the monarch's restriction, and even murder, of the French republican press, strong reprisals against the French labor movement, the protection of the Pope in Rome from Italian nationalists by French troops, and other examples of the curtailments of progressive liberties. ${ }^{1003}$ Dana argued that the United States had played a part in his frustration during Napoleon's abortive attempt to invade Mexico during the American Civil War when the Sun noted that the United States had “driven [Napoleon's] legions out of Mexico, and we have brought the Bonaparte eagle to crouch before the eagle of America." ${ }^{1004}$ Napoleon's failed adventure in Mexico, Dana maintained, remained one of the blights of mid-century Europe unhappy with the spread of republican, populist, and federalist ideas across the Atlantic world. An unpopular Napoleon III who feared rising German influence in Europe and the Americas, as The Sun described him to readers, predictably did not appreciate Prussian Chancellor Otto von

\footnotetext{
1002 "Wisdom for the Day," The Sun (N.Y.), September 17, 1870. The degradation of the people, the demoralization of the upper and middle classes, and the benighted condition of the laborers constituted the cause of Napoleon's successful usurpation of absolute power for nearly a generation, as well as of the defects of the French armies. Soldiers are drawn from the people; and the German people are educated and the French are not. How then could they hope to cope against an immensely superior array of numbers as well as of knowledge? The secret of success is in our civil war - was it not rather in the intelligence and spirit of the masses of our citizen soldiers than in the prowess of one or the other general? It is evident that nations are strong and powerful only in proportion as enlightenment, prosperity, and the spirit, of independence pervade the whole people."

1003 “Is There Going To Be War In Europe?," The Sun (N.Y.), April 8, 1869.

1004 “The Luck of Louis Napoleon,” The Sun (N.Y.), August 8, 1870. Dana appreciated the part that Grant and the United States played in previously helping check Napoleon III's attempt to take Mexico in 1863. He similarly appreciated that the United States had an overwhelming amount of support for Prussia in the first months of the war. "We have driven his legions out of Mexico, and we have brought the Bonaparte eagle to crouch before the eagle of America."
} 
Bismarck's encroaching influence on Spanish politics. ${ }^{1005}$ The principal insult was the offering of the German Hohenzollern prince Leopold to the Spanish throne in early $1870 .{ }^{1006}$ When the war began, Dana's paper hired the famous journalist Dr. William Howard Russell, the veteran reporter who made his name during the Crimean War, and one of the earliest war correspondents, who then became the only correspondent for an American newspaper embedded with Gen. Helmuth von Moltke's Prussian army at the start of the war in $1870 .{ }^{1007}$ Dana used Russell's expansive reports from France, about the battles at Wissembourg, Mars-La-Tour, Gravelotte, Metz and Sedan to craft metaphors for a struggle between two nations moving in different ideological directions. ${ }^{1008}$ Germany was the aggrieved nation, Dana argued, as it was Napoleon who started the war and exhibited the most evidence of illiberal and un-republican characteristics. ${ }^{1009}$ This judgment on Dana's part reinforced the larger ideological differences he saw between Germany's recent liberal reforms and Napoleon III's more conservative, nepotistic, and corrupt rule. ${ }^{1010}$

\footnotetext{
1005 “Is There Going To Be War In Europe?," The Sun (N.Y.), April 8, 1869.

1006 “Napoleon And The War He Has Begun,” The Sun (N.Y.), July 27, 1870.

1007 The Sun (N.Y.), August 5, 1870. “...Mr. Maverick will take rank next after Dr. William Howard Russell, the war correspondent of The Sun." Russell was an interesting character, who was at the Battle of Sevastopol during the Crimean War and saw the Charge of the Light Brigade. Russell was also present during the American Civil War, and covered the Austro-Prussian War. Russell was the premier war reporter, and Dana's hiring of the veteran signaled the place that The Sun held in American journalism.
}

1008 "German Civilization Entitled to Rule Europe," The Sun (N.Y.), July 23, 1870; "Will it be a Useless War?," The Sun (N.Y.), August 4, 1870. "The rising power of German civilization, while it excites the jealousy of the Gauls, and lures them into the present conflict, will thus have for its first effect to wipe out the last remnant of mediaeval institutions by extinguishing the temporal sovereignty of the Papacy. This now nearly certain triumph of humanity is mainly due to German influence. The cooperation of Italy with Prussia, which culminated in the extinction of the Austrian power in Germany as well as Italy, is now crowned by the necessity in which France finds herself of purchasing the neutrality or the alliance of Italy by sacrificing the temporal sovereignty of the Pontiff. What far-seeing statesmen have long expected is now on the point of coming to pass; and in this conflict of two highly civilized nation, the last remains of the middle ages will be crushed to death."

1009 "Napoleon and the War he has Begun," The Sun (N.Y.), July 27, 1870.

${ }^{1010}$ The Sun (N.Y.), July 25, 1870. 
Dana made clear that his critique of the French ruler, and early praise for the liberal movement in German society, was not an indictment against the liberal common people of France. ${ }^{1011}$ Dana here emphasized that like the working classes in the United States that appreciated equality and self-government, so too did the French people love the same values but were stifled by the corruption, adventurism, and illiberal power of Bonapartism. This compassion remained one of the features of Dana's argument that the Atlantic world remained one of peoples connected to each other by a commitment to republican ideas.

Dana's call on Americans, and the larger Atlantic world, to remain sympathetic with the republican aims of the French people reflected his broad geographical outlook. In many regards, Dana's Atlantic hopes fit comfortably with what some historians have explained as a global movement in support of self-government and local representation during this period. ${ }^{1012}$ Previous chapters have explained that Dana had held, and publicly argued for, the hemispheric applicability of republican ideas whilst reporting from Europe in $1848 .{ }^{1013}$ Now in the summer of 1870 , as the war reached a climax, Dana again made these commitments to those in support of self-government, nationalism, and anti-monarchism. ${ }^{1014}$ He maintained that he was not supporting

1011 “The Luck of Louis Napoleon,” The Sun (N.Y.), August 8, 1870.

1012 Katz, From Appomattox to Montmartre; Kilbride, The U.S. South and Europe: Transatlantic Relations in the Nineteenth and Twentieth Centuries (Lexington: University of Kentucky Press, 2013).

${ }^{1013}$ For more regarding Dana's opinions on the Revolutions of 1848 and their application for the American labor movement, see chapter two of this dissertation.

1014 “Wisdom for the Day," The Sun (N.Y.), September 17, 1870. "The downfall of slavery in America, of serfdom in Russia, and of imperialism in France, are the three great humanitarian achievements of the century, majestical landmarks in the progress of the rights of man. The degradation of labor and of the working classes of mankind is the alpha and the omega of all tyranny, whether of the landed monopolists in Russia or in England, or the despot who now bites the dust before German civilization. Wars like those fought in our country, and like the one now progressing in Europe, are redeemed from barbarism by extirpating the enemies of human progress, and by culminating in positive conquests for the emancipation of the masses from the thralldom of oppression and ignorance. The feudal theory of vesting of knowledge and culture, in a few powerful, fashionable, and privileged people, still lingers on in the world, and holds its place in the traditions of politics and legislation. It is intimately interwoven with human selfishness, and commends itself to the imagination by the glitter and the power of the privileged classes." 
the Prussian Army to spite the French people, but instead had the best intentions of the French people in mind. The French working masses, he wrote in his paper, needed to be rid of Bonapartism to have again the right to run their own government without corruption, family-rule, and political despotism. ${ }^{1015}$ One August 1870 editorial reinforced this claim, arguing that "in this country we are friendly to the French" and are "hostile only to Bonaparte."1016 Dana's editorials called Napoleon a "crapulous adventurer" while reaffirming the editor's commitment to the spread of self-government and egalitarian democracy. The paper called out for solidarity with the "the French people that we wish to see great, glorious, and prosperous." ${ }^{1017}$ In a broad ideological sense, Dana and his paper insisted that the war could help end the French monarchy and serve as an example for Americans of the ascendancy of liberal and republican ideas. The war "forshadowed [sic] ...portentous changes," one Sun editorial began in the first days of the war, "and which are no doubt destined to perfect the progress of this country by extinguishing dynastics which have outlived themselves." ${ }^{1018}$ A French defeat at the hands of a unifying Germany could suggest to Americans that they too "must make place for a different and better order of things, in which the Rights of Man and the principle of self-government will be duly

1015 "Wisdom for the Day," The Sun (N.Y.), September 17, 1870. "Whatever may be the future complications of the Franco-German contest, this much is certain, that the ruling classes all over the world are sternly admonished by the collapse of their fellows in France to pause in their selfish and grasping career, and to do justice to the masses of the people before they too are overtaken by providential justice, like the Emperor Bonaparte and his innumerable parasites."

1016 “The Luck of Louis Napoleon,” The Sun (N.Y.), August 8, 1870.

${ }^{1017}$ Ibid. Dana appreciated the part that Grant and the United States played in previously helping check Napoleon III's attempt to take Mexico in 1863. He similarly appreciated that the United States had an overwhelming amount of support for Prussia in the first months of the war... So far he has been decisively checkmated only by the United States. We have driven his legions out of Mexico, and we have brought the Bonaparte eagle to crouch before the eagle of America. And in the present war the Prussian sympathies of a country which has dealt such a fearful blow to the pride of the Bonapartes must be especially galling to the Emperor. It is true, he pretends that he does not make war upon the Prussian people, but only upon Bismarck."

1018 The Sun (N.Y.), July 22, 1870. 
recognized and revered." ${ }^{1019}$ Dana contended that the war in France between the forces of selfgovernment and equality for all under the law against monarchy and militarism necessarily influenced American politics and culture.

The Sun's analysis of the outbreak of the Franco-Prussian War included exhortations for the major American political parties to properly understand the importance of the war to voters in the United States. In his newspaper, Dana argued that the Franco-Prussian War and the Paris Commune represented a critical juncture that would impact the political affiliations of American voters. The war, the siege of Paris, and the following workers' revolt, produced a model for Grant's critics like Dana to use when showing how these events compared with the administration's domestic Reconstruction policy and its foreign policy. ${ }^{1020}$ The first group Dana had in mind that would look closely as to how the United States approached the European war were the nation's German-speaking immigrants. Dana witnessed the rising levels of immigration from the German states since the early nineteenth century, and participation in American society at the highest levels during the $1850 \mathrm{~s}$ and $1860 \mathrm{~s}$. He understood that their sheer numbers, political engagement, and progressive beliefs made the German American population a large, and influential, political lobby. ${ }^{1021}$ In July 1870 , various Sun editorials reminded readers of the

1019 “Caesar, Sultan, and Pope,” The Sun (N.Y.), July 22, 1870.

${ }^{1020}$ For one example of how these various issues, especially the Atlantic spread of republicanism, often came together within individual editorials of The Sun, see: "Complications and Anomalies," The Sun (N.Y.), September 17, 1870. "Spain kicks a Queen out and wants a King. Napoleon says one German shall not have the Spanish crown, and another German takes off Napoleon's crown. Germany says she is fighting against Napoleon, captures him, and then fights the French because they depose him. Russia and Austria protest against the dismemberment of republican France. Catholic Italy invades the Holy See, and Protestant England sends a frigate for the Pope. Spain, a kingdom without a King, sends troops to conquer republican Cuba and restore monarchical institutions in America. President Grant and Hamilton Fish pretend to be Republicans and Abolitionists; and they help Spain to subdue Cuba and restore slavery and the slave trade. All these vast results have been secured to mankind at the trifling cost, so far, of the creation of some 500,000 widows and 2,000,000 orphans. The establishment of the French Republic is as yet the only ray of sunlight on the gloomy picture."

${ }^{1021}$ In cities across the Midwest like St. Louis, Chicago, Cincinnati, and Memphis, and in the Northeast in places like New York City, Buffalo, and Hoboken, Germans formed large communities with influence in these cities' political, cultural, and journalistic circles. For more on this support of immigrant groups within 
political influence of these German communities across the country. One of these editorials began by conceding that there had been a time "when European wars affected us only indirectly.", 1022 To those readers that still may have felt this way, the editorial responded that the United States had changed in demographics and identity to "become the most cosmopolitan of nations." 1023 The best reflection of this was the sheer size of the German communities in the United States. "German America," the paper reminded readers, "is more populous than Baden and Saxony." ${ }^{1024}$ Dana even claimed the German-American community was politically "more stirring than all the German States together." ${ }^{1025}$ He presented the vast numbers of Germans in politics, and also who formed major political interest groups, as evidence of how "stirring" the German Americans had become since the 1840s, through the Civil War, and into the early 1870s. Dana understood that the Franco-Prussian War was a staggering event for German-speaking peoples around the world, and especially in the United States. ${ }^{1026}$ "Here are millions of Germans owing allegiance to the American Government, but all absorbed, at present, in the fate of their native country," one editorial noted. ${ }^{1027}$ "They are a great political force," the paper continued, "both in the country in

\footnotetext{
the reform impulses in the Republican Party, see: Kristen L. Anderson, "German Americans, African Americans, and the Republican Party in St. Louis, 1865 - 1872," Journal of American Ethnic History, 28, no. 1 (Fall 2008): 34- 51; Rowan, Steven W. "The Continuation of the German Revolutionary Tradition on American Soil," in Germans for a Free Missouri: Translation from the St. Louis Radical Press, 1857 1862, ed. Steven W. Rowan and James Neal Primm (Columbia: University of Missouri Press, 1983): 23 45.

1022 “Germans in America,” The Sun (N.Y.), July 22, 1870.

${ }^{1023}$ Ibid.

${ }^{1024}$ Ibid.

${ }^{1025}$ Ibid.

1026 "The War in the City. Enthusiastic Rally for Fatherland in Steinway Hall," The Sun (N.Y.), July 21, 1870.

1027 “Germans in America," The Sun (N.Y.), July 22, 1870.
} 
which they live and in what they have forsaken."1028 The fact remained, the Sun wrote in an article measuring the "effect of the war on American politics," that the "German vote of this country is very heavy."1029 To local readers unfamiliar with the strength of the German lobby in the mid-Atlantic states and across the northeast, the paper noted that their votes were "strong enough to control the politics of New York and New Jersey."1030 Germans in the U.S. "detest France, and have no friendship for those politicians in the United States who incline to the Bonaparte side of the conflict," the paper warned. ${ }^{1031}$ American political organization, then, needed to make sure that the influence of the war remained keen to Americans of all nationalities. Dana insisted that the political stakes of the European conflict within the United States could be quite high. By showing themselves fully against Bonapartism, Dana argued, the Republican Party might be able to reform its ailing reputation. Courting the "Teutons" in the U.S. during the European war, he wrote, could help the Republican Party "certainly carry Connecticut and New Jersey over to the Republicans," "put to hazard Democratic ascendancy in New York," and "leave [the Democrats] a meagre following in all the Central and Western States." ${ }^{1032}$ Dana used the German support of Prussia during the Franco-Prussian War as a bellwether for their potential value for domestic political parties. His employment of the conflict as a measuring tool for American political parties helps illustrate how seriously Dana measured transatlantic events as major influences on the American political order.

\footnotetext{
${ }^{1028}$ Ibid.

1029 “Effect of the War on American Politics—Teutons and Fenians," The Sun (N.Y.), July 22, 1870.

${ }^{1030}$ Ibid.

1031 “The Democrats and the War," The Sun (N.Y.), July 29, 1870.

${ }^{1032}$ Ibid.
} 
Considering the existing fractures in the Republican Party, and the way Dana viewed the potential influence of a long conflict in Europe on American politics, The Sun took care to find the opinion of the president on the fighting between Prussia and France in the middle of 1870. Dana directed his reporters to put to the record what leading Republicans thought about the European war days after he chastised the Republican conference in the House of Representatives for refusing to offer belligerent rights to the Cuban revolutionaries. ${ }^{1033}$ Many Republicans across the country, like Dana, had already made declarations of fealty with the Prussian cause, citing the close ties of American and German economics, politics, and social values. ${ }^{1034}$ Many Americans understood that German unification, and the recent liberal reforms that preceded it, portended the potential for a new phase in European politics that deserved American support. ${ }^{1035}$ The White House had not taken a clear position, though, and observers like Dana, already angry over the foreign policy issues in places such as the Caribbean in the year and half prior, wanted clarity. Dana insisted that any sign of sympathy towards France (or even Bonapartist values) by the administration would only reinforce the idea that Grant and his advisors bowed to monarchs and Old World dynasties, as was already happening over their support of the continued Spanish military activity in Cuba. In an early August 1870 interview with a Sun correspondent at his Long Branch, New York home, Grant affirmed that he shared what he believed to be the strong American sympathy for Germany over France visible elsewhere. ${ }^{1036}$ Dana explained that Grant

\footnotetext{
1033 “The Fatal Blunder," The Sun (N.Y.), June 18, 1870. “The halting of the Republicans in Congress will not arrest the march of American principles on this continent. The sons of Cuba will achieve their freedom by themselves, amid bloodshed and desolation. The movement for human rights will go on and triumph, but the Republican Party will be left far in the rear, with Grant and Fish and a mass of such dead material on its decaying hands."

1034 “The Republican Party of New York and the European War," The Sun (N.Y.), July 21, 1870

1035 "The War in the City. The Union Republican General Committee's War Meeting-The Republican Party Espouses the Cause of Germany," The Sun (N.Y.), July 22, 1870.

1036 "President Grant Talking - The European War a Disguised Blessing to America-Why Americans Sympathize with the Prussians," The Sun (N.Y.), August 5, 1870.
} 
cited that ideological, political, and economic similarities between the United States and Prussia especially the ties of "commerce, German emigration, and because the Germans took our bonds and stood with us during our war." ${ }^{1037}$ By informally aligning with Prussia's efforts to defeat Napoleon, President Grant avoided a further point of criticism for Dana and others to add to their long indictment of the administration. For the time being, Dana agreed with the president. Grant's Prussian sympathies did not bring him and other disaffected Americans back into the Republican fold, though. The very war itself, and the political ideologies represented by their major actors, instead produced a new model for Dana to use in his questioning of American foreign policy and the larger state of the political party landscape.

The nation's sympathy for the North German Confederation's mission to topple Napoleon, and the president's military experience, did not strengthen Dana's faith in the administration's handling of any potential spread of the Franco-Prussian War into American spheres of influence. Dana could not ignore the previous issues with corruption, nepotism, and poor management of the administration and used these reasons to doubt that the president could handle any expansion of the war to North America. The war, the siege of Paris, and the following Commune in that city produced a model for Grant critics to use when showing how these events compared with the administration's domestic Reconstruction policy and its foreign policy. "It is scarcely to be apprehended that the United States can be drawn into the general quarrel in which Europe is soon to be involved," The Sun wrote in one editorial. In the case that it did happen, though, the paper maintained that "grave complications will necessarily arise, requiring the greatest honest, discretion, wisdom, and statesmanship in their treatment." ${ }^{\text {"038 }}$ Unfortunately, the

\footnotetext{
1037 "President Grant Talking-The European War a Disguised Blessing to America_-Why Americans Sympathize with the Prussians," The Sun (N.Y.), August 5, 1870.

1038 “The Administration Must be Reconstructed," The Sun (N.Y.), July 29, 1870. "Fish with his speculation in the purchase of Cuba. Bancroft Davis with his lust for bribes, Robeson with his
} 
paper noted, "there is not a man of common sense and understanding in the land who will undertake to maintain that Grant and the incapables of his administration are adequate to this emergency." The president's track record did not leave the paper, Dana reasoned, much room to suggest that the "people can feel a sense of security while the Government is in such hands."1039 The paper maintained that the "present disgraced and ridiculous administration might be endured in an ordinary time; but now the people will demand a change..." ${ }^{1040}$ If Dana's anxiety about Grant's ability to lead the nation in the case that the European war expanded into a larger war, Bismarck’s foreign policy only amplified these anxieties.

Editorials in The Sun also alleged that Grant was not a strong enough statesman to ward off Bismarck's acquisitive intentions over Cuba. Germany's rapidly growing influence in Europe during the war, Dana explained, gave Bismarck a diplomatic advantage with the Spaniards that could result in the potential German purchase of Cuba as part of larger Prussian expansion plans. Reports from Sun correspondents in Europe informed Dana of rumors circulating in London that Spain's General Prim and Bismarck were in negotiations that included Prussian territorial acquisitions in the Caribbean. Dana explained that Spain and the North German Confederation were near to terms for an exchange of Prussian money for a slice of the Spanish Empire. Dana's paper reported rumors that Bismarck might pay the steep Spanish revolutionary debt in exchange for the ability to place King John of Saxony on the Spanish throne, the ceding territory in Spanish Algeria, the fortress at Gibraltar, and the whole of Cuba. ${ }^{1041}$ The paper's editorials noted how "very much out of place" a Saxon king would be in "attempting to rule a country so torn by

\footnotetext{
submissiveness to Admiral Porter, Akerman the unknown rebel officer, must all go, and men of honesty, character, and capacity must be put in their places."

1039 “The Administration Must be Reconstructed,” The Sun (N.Y.), July 29, 1870.

${ }^{1040}$ Ibid.

${ }^{1041}$ The Sun (N.Y.), September 29, 1870.
} 
faction and broken by financial distress as Spain." In these editorials, Dana insisted that "secret negotiations have long been going on between Prim and Bismarck" about the Prussian acquisition of Cuba from Spain and confirmed the threat that Prussia posed to the problematic Grant administration. ${ }^{1042}$ This news came to light in the weeks and months after the start of the FrancoPrussian War, and enflamed Dana's criticisms of the American diplomatic corps. The Sun explained that Bismarck was "anxious to add to its great naval development" and highlighted that German agents were already active in Havana and Santiago, Cuba, to "ascertain whether it would be judicious to bargain for it." ${ }^{043}$ Dana argued that if not for the stumblings of the White House, the State Department, and their foreign policy, Bismarck would have had no practical interest in Cuba in late 1870. "If there was a strong administration at Washington, animated by a decided American feeling, and endowed with a sense of courage sufficient to act accordingly, this scheme would never have entered into Bismarck's head," the paper maintained. ${ }^{1044}$ The German Chancellor, The Sun wrote, could "well afford" to look past the public sentiment in support of Cuba by Americans because of the administration's trepidation in acting with force, to defend republicanism diplomatically or militarily. ${ }^{1045}$ "He means to have Cuba," the editorial continued of Bismarck's reported plans, noting that "with such persons as Fish, Grant, and Bancroft Davis to direct the action of the United States," the Chancellor was right in thinking that "all the noisy opposition that may be expected from the United States will amount to little."1046 "Perhaps," Dana's editorial page considered, the only hopes for the island were that "the republican

\footnotetext{
1042 The Sun (N.Y.), September 29, 1870.

${ }^{1043}$ Ibid.

1044 "Bismarck Means to Have Cuba," The Sun (N.Y.), October 14, 1870.

${ }^{1045}$ Ibid.

${ }^{1046}$ Ibid.
} 
sentiment of the Cuban people, and their heroic resolution to separate themselves from Europe forever, may be sufficient to defeat him." ${ }^{\text {1047 }}$ Dana's objection to the Grant administration's supposed weakness (in allowing Bismarck to believe that he could potentially have Cuba) occurred against the backdrop of major changes in the editor's perception of Bismarck, the German siege of Paris, the Third Republic, and the Paris Commune.

Dana's reaction to the European crisis in 1871 continued to illustrate how his interpretation of these conflicts was filtered through a republican prism. At first, Dana's explanation of the early parts of the Paris Commune, as being in search of a unifying message and too tied to violence, led him to think that Thiers and the Third Republic were the best options for a stable, Bonaparte-less France. ${ }^{1048}$ Editorials in The Sun in these early months of the Commune argued, for instance, that the only way for the Republic to live was for the French to "avoid all internal conflicts, and to maintain the Government of which Mr. Thiers is the head." ${ }^{1049}$ Dana also initially thought that the Commune did not look like it could succeed, and instead maintained that (like the American South), it needed to cooperate with the leaders of the nation after a major war. One late March 1871 editorial put it frankly that The Sun editorial staff "do not believe that this insurrection can become a revolution." ${ }^{1050}$ Dana's paper continued explaining that the only practical way to preserve the unity of the French progressives was for Thiers to work with the radical left and bring them into the government with a policy of amnesty and reconciliation. The Sun editorial maintained that beginning the process of a French version of Reconstruction would help Thiers's cause. Historian Mark Katz has shown that this comparison saturated the way that

\footnotetext{
1047 "Bismarck Means to Have Cuba," The Sun (N.Y.), October 14, 1870.

1048 The Sun (N.Y.), April 1, 1871.

1049 “Who Can Tell," The Sun (N.Y.), March 21, 1871.

${ }^{1050}$ Ibid.
} 
Americans interpreted the Paris Commune, and Dana's opinions of the Commune's possible resolution reflected this trend. ${ }^{1051}$ As Dana had counselled the White House and the Republican Party to approach the American South, his newspaper wrote that Thiers owed it to the Parisians that "clemency and forbearance [were] the only wise policy." "1052 This never happened, of course, and Thiers and the Commune went to war over the right of the city of Paris to govern, and defend, itself (as well as get a seat at the table during the treaty negotiations with Germany). Dana, though, hoped that he would undertake the same type of policy in France that he wished to see embraced in the American South — peaceful, egalitarian, and republican approaches to rebuilding after war. As the Commune progressed, and the National Guard joined the Commune against Thiers (who were also unhappy with Thiers' conditions of armistice with Germany), Dana's impression of Thiers and his potential to protect republicanism in France was deflated. The change in the Commune's goals shifted his perception of each of the relevant actors in the larger European conflict. Bismarck and Thiers both developed the characteristics of the oppressor in The Sun, the Paris Commune developed the characteristics of a burgeoning, if problematic, republican experiment. To Dana, the Grant administration again seemed to be shirking their duties to defend his understanding of American values. This all built to an alteration in Dana's analysis of the political character of Germany.

Dana contended that Germany's behavior during the war verified his previous characterization of the development of German Unification as being premature. In the shadow of

\footnotetext{
${ }^{1051}$ Philip Mark Katz, From Appomattox to Montmarte: Americans and the Paris Commune (Cambridge: Harvard University Press, 1998).

1052 "Ferocity in France," The Sun (N.Y.), June 1, 1871. "The men who control the Versailles Government are more barbarous and blood-thirsty than the much condemned Communists. In the heat and fury of the contest Communists put to death the hostages whom they help to secure the safety of their captured and executed comrades; but the Government deliberately slaughters men after the strife is over, and when there can be no object in slaying them except the gratification of a relentless vengeance. While the battle is raging any necessary degree of severity is justifiable; but when it is all over and the victory gained, clemency and forbearance are the only wise policy. The French rulers may yet live long enough to appreciate this most bitterly from experience of their own."
} 
the Paris Commune, Dana remained disappointed in Germany's un-republican turn as it consolidated power into a new empire. Where Dana previously argued that Germany had been ascendant in its liberalism and nationalism and refined civilization, he now maintained that the war proved that Germany had instead chosen to refuse this republican track. The decision to continue the Siege of Paris, one of the principal causes of the Paris Commune, stained their ideological credentials in Dana's estimation. One editorial explained that the recent developments illustrated that "among the Germans the principle of feudalism, of divine right, and of obedience to an irresponsible sovereign have undoubtedly been much strengthened in these six months of warfare." 1053 The results of the war in France and Germany, the paper explained, demonstrated that "the poles of the political world have shifted a little." Undoubtedly, this editorial wrote, "the result of the war is in favor of despotism." ${ }^{1054}$ No matter that Germany had "overthrown" the "imperial fraud" in France. Dana argued that something worse, "a real Emperor," "has been made in Germany," because of the Franco-Prussian War. ${ }^{1055}$ Dana insisted that it was important for the world to know that Germany was not the liberalizing force that it had appeared to be. The end of the war, the paper explained, had "put truth in their place... in the most marvelous and astonishing fashion.”1056 Germany’s decision to uphold its siege of Paris, crown Wilhelm, and establish the German Empire, soured Dana's confidence that a German defeat of Bonapartism could embolden the spread of republicanism in Europe.

\footnotetext{
1053 “The End of the War,” The Sun (N.Y.), March 6, 1871.

1054 Ibid.

1055 Ibid.

1056 Ibid. All hope was not lost, however, for the editor of The Sun. Dana argued that "democratic ideas are strong enough to take care of themselves" and that "upon the whole we may hope and believe that the world will not be worse but better for all this waste and bloodshed."
} 
Dana's changing impressions of the significance of the Franco-Prussian War, and the early Paris Commune, also grew from his maturing understanding of the motivations that animated the Commune. Dana's attuned impressions of the Commune came with a recognition of its ideological commitments —republicanism, anti-centralization, expanded labor rights, and independent municipal control. "At the bottom of their movement," one early April editorial explained, was "a great and sacred principle which they [the Communards] are defending." The principle remained a familiar one for The Sun, especially considering the paper's editorial platform. The paper called on its republican program when insisting that the Communards called on these principles of self-government, collectivism, and egalitarianism to "die for the Republic in a bootless effort to put down a monarchist conspiracy." 1057 Another editorial insisted that "the men of the Commune have fought for a true idea." Reminiscent of the paper's response to the domestic political crisis of Reconstruction in the United States, The Sun wrote that the Commune's animating idea was "local self-government, the independence of every town or commune in the management of its own affairs by its own people." ${ }^{\prime 1058}$ Dana argued that it simply could not be that the Communards were "being actuated by nothing but unreasoning political fanaticism, and a barbarous desire to rob and murder." His paper's editorials insisted that even though "the so-called mob and the vicious classes are, for the time, acting with them," the generalizations of the true republicans could not be overshadowed by critics in the United States and around the world. ${ }^{1059}$ Dana wanted readers to understand that the Commune involved an intensely more complicated ideological struggle than other writers had allowed. Dana had personal experience with how attempts at practical reform develop, and Brook Farm ended in

\footnotetext{
1057 “The Reason Why,” The Sun (N.Y.), April 10, 1871.

${ }^{1058}$ Ibid.

${ }^{1059}$ Ibid.
} 
literal flames and its ideological inspirations, Associationism, never gained a national reputation. Critics had joked of Dana's endearment to the cooperationist ideas of associationism. As he did in the 1850 s, Dana insisted that these ideas were not so radical, and instead had, at their core, purely republican ideas that could help the United States. Dana wanted his readers to see the larger, if hidden, ideological meaning of the Paris Commune, and its potential relevance to the United States.

Dana trumpeted the virtues of the republican values of the Commune in the face of the realities of the its more troubling policies. Editorials in The Sun instructed readers to contemplate the American applicability of the Paris Commune's principal aim of creating "a labor-centered republic that confronted centralization" and "the despotic control of all provinces and cities by the central authority." 1060 Make no question, though, at every stage Dana qualified his developing sympathy for the ideology of the Commune with pleas for non-violent, moderate political resolutions in favor of municipal rule and rights for the working classes. One of the paper's reviews of the Commune, after it ended in late May, described the three months as ones of "much bloodshed, great destruction of property, and various political eccentricities." ${ }^{1061}$ Reporting for the Tribune during the 1848 Revolutions, Dana had of course concluded that the violence that grew from the republicanism and anti-monarchism of those revolutions was one of the main reasons the revolutions failed. This violence, a previous chapter has explained, influenced Dana's conclusion that Americans would reject the mob-centered revolutionary viciousness of the Revolutions of 1848 in favor of the stability of the expanding American voting system. Dana had of course argued that American institutions were more stable and representative than those in Europe, and could help laborers, republicans, and liberals obtain the reforms of the system that

\footnotetext{
1060 "The End of the Paris Insurrection," The Sun (N.Y.), May 24, 1871.

${ }^{1061}$ Ibid.
} 
they desired. ${ }^{1062}$ Dana's suspicions of the Commune began with its penchant for this violence and destruction of property. But even then, as when the Commune government voted to topple the column in the Place Vendôme, Dana appreciated how the act "express[ed] the detestation of the Parisian Commune and people for the Bonaparte rule and system." ${ }^{1063} \mathrm{He}$ also explained that once Thiers decided to begin a second siege of Paris based from the palace at Versailles miles outside of Paris, that the Communards held the right to defend themselves. Of the Commune's "barbarous and blood-thirsty" outrages by the "communists" Dana argued that "when the battle is raging any necessary degree of severity is justifiable." ${ }^{1064}$ Part of Dana's rationalization of the violence of the "Bloody Days," is that the Commune had become a much clearer conflict with an objective that Dana better recognized, and which he described as pure republicanism. He wrote that the Parisians knew were fighting "a desperate battle" to stave off the impending "restoration of the old Bourbon monarchy." 1065 This goal, to fight monarchism and reintroduce republicanism and labor rights, was enough for Dana to provide his sympathy for the Commune's ideals.

Dana's faith in the power of republican self-government to spread across the transatlantic world never remained far from his judgment of Grant's tenure. Dana pointed to problematic reports that made the front page of The Sun in late 1871 of the American Ambassador to France, Elihu Washburne's, suspicious behavior against the Commune as evidence of continued malfeasances by America's leaders. The paper presented readers with accounts that the Grant administration, and especially its Minister to France, shared the Old World's distaste with the

\footnotetext{
1062 Ibid.

1063 The Sun (N.Y.), May 18, 1871.

1064 "Ferocity in France," The Sun (N.Y.), June 1, 1871.

1065 "The Reason Why," The Sun (N.Y.), April 10, 1871. "The motives that have impelled the Republicans of Paris to take up arms and fight a desperate battle are becoming evident to the world outside. They are approaching restoration of the old Bourbon monarchy, with Henry V. as King of France."
} 
Paris Commune and its republicanism. In a curious set of circumstances, The Sun received a letter from the International Workingmen's Union, of whom Karl Marx and Friedrich Engels were secretaries, that the American Minister to France poorly represented the United States during the Commune. ${ }^{1066}$ The charge was that Washburne bore no sympathy with the Communards, and was reported to have said in Paris, in heat of the Bloody Days, that "all who belong to the Commune, and those that sympathize with them, will be shot." Washburne, the report noted, was heard "repeating this sanguinary phrase" as Thiers' soldiers "were killing old and young for the crime of sympathy with them [the Commune]. ${ }^{, 1067}$ Dana noted that the fact that Washburne would then immediately attempt to negotiate an end to the hostilities between the Commune, the Third Republic, and the new German Empire, presented a horrible picture of American conflicts of interest, and hypocrisy. If the charges were true, Dana's analysis of this letter from the International Workingmen's Association concluded, that Washburne had defrauded the values of the nation. Dana called Washburne's “duplicity” a feature of the Republican Party's broader "anti-republicanism" in foreign policy. ${ }^{1068}$ The paper boldly reprinted another note from the North American Central Committee of the International Workingmen's Association that indicted Washburne as belonging to "that large family of State parasites feeding upon the public crib, and stumbled over in almost all the Northern States." ${ }^{, 069}$ Dana came to question whether the Grant

\footnotetext{
1066 Dana, Marx, and Engels retained a professional relationship from Dana's first encounter with Marx in 1848 through to Marx's death in 1871. For more on their professional correspondence, see The Sun (N.Y.), September 6, 1871, for a letter that Marx sent Dana and The Sun just days before his death updating the American paper on the work of the International Working Men's Association in the shadow of the late Paris Commune.

1067 “Washburne's Duplicity. The Nation Misrepresented Before The Commune," The Sun (N.Y.), August $1,1871$.

${ }^{1068}$ Ibid. Washburne's "anti-republicanism" is noted here by Dana, and article includes larger letter sent to The Sun from Council of the International Workingmen's Union, of which Marx and Engels sat as corresponding secretaries, and includes note from the North American branch of the I.W.A."

${ }^{1069}$ Ibid.
} 
administration had become so close to the Thiers' administration so as to clash with those fighting for pure republicanism, as opposed to Thiers who resorted to force, siege, and invasion to coerce the entrance of Paris into the National Assembly of the Third Republic. The United States had been the first nation to recognize Thiers's government in 1870, but to Dana, by 1871, the Third Republic was the antagonist to the Commune.

Dana explained that Grant and Thiers both faced stiff resistance to their approaches to their respective insurgent populations. The folly in either of them responding aggressively to groups asking for republican rights, Dana explained, would result in the weakening of recent gains for both men, like the threat of a Bourbon monarchy returning to France, or the Republican Party descending into a party dictated mainly by patronage and force. As Dana had done in the past, he advocated a policy of cooperation amongst the competing classes to reach the critical level of egalitarianism needed to create and sustain actual republican government. In Dana's estimation, both Grant and Thiers exposed their straying from these types of values with their uses of the regular military to enforce political behavior. For instance, Dana stood convinced that a majority of the National Assembly had the "desire in their hearts of the restoration of the Bourbons" that overwhelmed the Communards. ${ }^{1070}$ This political reality, and some of the other weaknesses of the Commune motivated Dana's analysis of the conservative counter-revolution in Europe. The Sun reported that the National Assembly, and even the Orleanist challengers to the throne, supported the claim of Henri V on a platform of stability and law and order. ${ }^{1071}$ This, the worst of all possibilities at the end of the Franco-Prussia War for Dana, the reinstatement of monarchy, crushed the editor's hopes in the upward trajectory of republicanism in the Atlantic

\footnotetext{
1070 "The End of the Paris Insurrection," The Sun (N.Y.), May 24, 1871. "The question of perpetuating the Republic in France will now be decided. No doubt Mr. Thiers will endeavor to be faithful to the pledges he has given to the Republicans. But will he be able to keep those promises? It is doubtful. The assembly desire in their hearts the restoration of the Bourbons; and sooner or later that object is likely to be attained." 1071 “The King that Is To Be,” The Sun (N.Y.), June 1, 1871.
} 
world. ${ }^{1072}$ European revanchism, Dana knew, was no friend to his favored ideas regarding cooperation. In not being more welcoming or less forceful, Dana argued that Thiers had committed a political crime more egregious, but similar, to Grant's in the American state party nominating conventions in 1871. For example, Mark Katz explained that part of what allowed critics to compare the Radical Republicans to both the Germans during the Franco-Prussian War, and Theirs's Third Republic during the Commune, was the claim by each to be able to proclaim when and where republics could exist. Dana's developing critique of the president's Reconstruction policy, of course, grew from a very similar sentiment. To that end, Dana argued that of all the possible things that could ruin Thiers, it was his inability to coordinate with Paris, and the Commune that would prove most telling. "The Government of Mr. Thiers," one April article explained, "will be broken down by its success in suppressing the Parisian Red."1073 The Sun's editorial page instructed readers that the conquest of Paris had proven too brutal to endear Thiers to the republicans around France and would keep him from uniting the National Assembly behind him. Both the policy and the result, the paper argued, aligned the Grant administration and

\footnotetext{
1072 Ibid. "The Count de Chambord, more commonly known as Henri V., has just put forth the programme upon which he expects to be raised to the throne of France. It was sent as a letter to a Legitimist member of the National Assembly, who has published it." "The future King says that France will be saved "when she ceases to look for security from haphazard Governments which, after a few years of fancied peace, leave her in difficulties truly deplorable.' This, though rather obscure, means the Republic and the Verhuel Empire; but it is equally applicable to the Government which ended with the flight of Charles X from Paris in 1830, and that which terminated when Louis Phillippe fled in 1848. Considering that about threequarters of the National Assembly are in favor of the restoration, and that the power is in the hands of his friends, this language on the part of the Count de Chambord is not vainglorious, and his expectations are not groundless. After forty years of revolt against the rights of the elder branch, the family of Orleans have now given him their adhesion; and if the plan of making him King should be defeated, it will only be by a more desperate revolution than that just extinguished in Paris. But though a King of France may once more be proclaimed, let us thank God he cannot reign in the Tuileries. That, at least, the Commune has rendered impossible."

1073 “The Prospect in France,” The Sun (N.Y.), April 5, 1871. "The Government of Mr. Thiers will, however, be broken down by its success in suppressing the Parisian Red. This even will settle the question of the duration of the present republic. We may look at no distant day for the establishment of a new monarchy; and the facts indicate very strongly that this monarchy will very possible be one which nobody has expected."
} 
Thiers, and would reintroduce conservatism to France. As he came to argue (for the United States as much as France), that "when it is all over and the victory gained" it was clemency and forbearance that were required. ${ }^{1074}$ By suppressing the desires of the working class radicals with the military, Dana argued the French Republic could not be held together. ${ }^{1075}$ "We may look at no distant day for the establishment of a new monarchy," the paper had written, "and the facts indicate very strongly that this monarchy will very possibly be one which nobody has expected." ${ }^{1076}$ Dana's disillusionment with Thiers as the figure to unify the nation developed from the Third Republic's strong repression of the Commune. Dana carried this same disappointment with the obstacles to reform when discussing other conflicts he felt were important for his American readers to understand.

When the Paris Commune began in the summer of 1871, what later became known as the Ten Years War between Cuba and Spain was still very active in its third year. Dana reminded readers that this other conflict (that he had covered since its beginnings in 1868) remained just as brutal and as critical to the spread of republicanism across the transatlantic world. In one editorial from June of 1871, The Sun went so far as to argue that "the atrocities of the Commune in Paris

1074 "Ferocity in France," The Sun (N.Y.), June 1, 1871.

1075 “The Prospect in France," The Sun (N.Y.), April 5, 1871. "The National Assembly contains about six hundred and fifty members. Of these, three hundred are Legitimists and one hundred and fifty Orleanists. A reconciliation between those two parties has probably been already arranged; indeed, from information which has reached this country, we know that such a measure has for some time been in preparation. Of the two factions, the Legitimists are not only the stronger in numbers, but the more resolute in their opinions. The have gained also in power in the war with Prussia, for the best fighting has been done by them. Besides, the Orleanists can lose little by making the combination. If the Count de Chambord is placed upon the throne, the heir to the crown will be the Count de Paris, Chambord, who is now fifty-one years old, fat and apoplectic, has no children and will not have any; and the adherents of the Orleans family are not so foolish as to sacrifice the chance of coming into power in the course of a few years, to an empty animosity against the last representative of the older branch of the Bourbons. The coalition of those two parties will form a majority of more than two thirds of the Assembly. Mere conservatives and men of no fixed opinions, who only desire the safest and best escape from the present complications, will join them, leaving the Republicans in the Assembly in a small minority. After that the rest will be easy."

${ }^{1076}$ Ibid. 
are insignificant in comparison with those of the Spaniards in Cuba. The eyes of the world were on the former. Cuba seems to be utterly ignored." ${ }^{1077}$ He squarely accused the Republican leadership in Washington for this fact. ${ }^{1078}$ Dana continued to use his favored ideological themes to guide The Sun's analysis of the Franco-Prussian War and the Commune to explain the broader ideas and values that connected the Ten Years War to American politics. This was especially the case as Dana transitioned his attention from the Paris Commune to the summer 1871 campaigning season in Cuba. The main issue of the Commune, the demand for self-government and labor rights, which Dana interpreted as the right to nationalism, equality, free labor and anti-slavery, continued to apply directly to his understanding of the Ten Years War and the coming presidential election of 1872 in the United States. ${ }^{1079}$ The first of these interconnections within

1077 The Sun (N.Y.), June 30, 1871. "A late number of the Voz de Cuba, the organ of these scoundrels, actually proposed the organization of a joint stock company for the raising of a fund wherewith to pay assassins of all the patriot leaders. If Spain still insists upon retaining nominal sovereignty over the island, she must accept the ignominy of acts done in her name."

1078 "A Sound Platform, but An Unsound Executive," The Sun (N.Y.), August 1, 1870. "The Convention which nominated Gen. Grant for the Presidency set up a platform for him to stand on, and one of its planks was the following: 'This Convention declares itself in sympathy with all oppressed peoples struggling for their rights.' This declaration was made in May, 1868, and in the October following the people of Cuba, desiring to obtain their rights, and relying upon the professions of that great party which had governed the United States for eight years, rose in rebellion against their Spanish oppressors. Thus they began that brave struggle for freedom, for the abolition of slavery, and the equal rights of man, in which they still persevere in the face of obstacles that only the most devotion could contend with. If the Republican National Convention of 1868 felt such sympathy for oppressed peoples struggles for their rights, how deplorably the Republican Congress and the Republican Executive have fallen away from that noble declaration! Instead of aiding the Cubans, they have aided their enemies; and at this very moment there are men at the head of the State Department, kept there by this Republican Congress and Republican Executive, who are engaged in a scheme to make money by the purchase and sale of Cuba, and who have protracted their sufferings of her devoted people, in the hope that their profits might thus be larger! And more than this, as if to intensify the wrong, this same Congress and this same Executive maintain in office as their Assistant Secretary of State a man who is in the interest of Spain, and whom the Legislature of Massachusetts has publicly branded with the shame of receiving bribes to betray those who had confided in him! Of course he will receive bribes again whenever they are offered. Such is the sympathy of the Republican Party, the Republican Congress, and the Republican Executive with oppressed peoples struggling for their rights!"

1079 "Managing the Cuban Revolution," The Sun (N.Y.), February 1871. "But with all the perseverance of their race the Cubans still maintain the struggle, and the history of the other Spanish-American colonies shows that the hasty mind of Gen. Ryan misleads him widely when he supposes that it is likely to be abandoned. It took New Granada to gain her independence; the struggle of Chili (sic) lasted seven years; that in Venezuela eleven years; that in Mexico fourteen years. In Cuba it is not yet two years and a half since the standard of independence was raised; and while we desire as earnestly as any one can that the war should be brought to an early close by the victory of the Cubans, we do not propose to abandon it in despair 
Dana's transatlantic approach was his claim that the president had turned his back on traditionally republican principles by continuing to allow Spain to perpetuate slavery, and frustrate nationalism, in Cuba. The editor critiqued the administration's Cuba policy because the president had turned his back on free labor in Cuba for the last three years. The Sun reported constantly on the state of slavery in Cuba, and the fact that Spain remained unwilling to end the practice entirely. ${ }^{1080}$ The Sun lamented that chattel slavery was still the major labor force on the island. He remained convinced that the American executive branch retained complicity in the slaughter for its continued preservation for the sake of stability elsewhere. As previous chapters explained, Dana had a strong desire to see the United States intervene in Cuba to end the practice. The language that Dana used two and three years after President Grant and Secretary Fish took control of the nation's foreign policy remained very similar in this period. In one July 1871 editorial, after an announcement that Spain was not willing to accept British mediation in the sale of Cuba to the Cuban rebels, he lamented that the White House would not do more to assist. Dejected after months of repeating the same exhortation to Grant and "Don Hamilton Fish," Dana's paper wrote that "we have long ceased to hope for any American action in this matter from our present Executive, on the score of duty, patriotism, or any noble sympathy with a noble cause." ${ }^{1081}$ Dana argued that this was one of the more anomalous positions of the president's current policy towards the Cuban Revolution. Grant's election to the executive, The Sun wrote late in 1871,

if it is not finished at an early day. Meanwhile we have this advice for Gen. Ryan, and for all other friends of Cuban freedom: Let them cooperate together as much as possible, avoiding dissensions and public disputes, and making the best of everything that can in any manner advance the good cause."

1080 "Slavery in Cuba," The Sun (N.Y.), July 7, 1871. "The noncompliance on the part of the Spanish Government with its promise that slavery should be abolished in the colonies, is not the least of the difficulties which the Cabinet of Madrid is called upon to solve."

${ }^{1081}$ Ibid. "Spain cannot wrest the control of the island from the volunteers; and as long as the slave-traders squander money in Madrid, no Government will be found bold enough to cede Cuba to the Cubans, from a treaty with whom alone any future benefit can possibly only accrue to Spain.” 
"owes its existence to the abolition of slavery," but he "has systematically endeavored to thwart abolition in Cuba" since $1868 .^{1082}$

To contextualize the anomaly of the United States' position on the slave question in Cuba, Dana clarified that many members of the Republican Party (within and without the administration) continued to insist on prioritizing the status quo in Cuba as a way to preserve American economic interests there. Editorials in his newspaper argued that "although many, if not all, of these merchants are to-day good anti-slavery champions in the halls of the Union League, they foolishly thought that the only way to secure their Cuban interests was to assist the Spaniards in preserving slavery, and for this and they used all their influence."1083 Dana's argument that Grant and the Republicans had turned their backs on the idea of free labor in Cuba remained as consistent in late 1870 and 1871 as it had been earlier. He continued to chastise the Republican anti-slavery establishment's geographic myopia in supporting abolitionism and noted that "for such philanthropy as theirs we have very little sympathy indeed." ${ }^{084}$ Dana demanded that the administration show its commitment to anti-slavery policies in the Caribbean by allowing Americans to help on their own. "It is never too late for them to mend," the paper explained of American abolitionists. "Let them hurry and secure from the Government satisfactory proofs that the lives of the blockade-runners shall be protected," citing the filibusterers employed by the Cuban Junta, "and then let them, in defend of their own interests, send whole cargoes of arms and ammunition to the ever-faithful island." ${ }^{1085}$ Dana argued that if the Republican industrialists in the Union League wanted to protect any economic stability on the island, they needed to change their

\footnotetext{
1082 “The Spanish Bank of Havana,” The Sun (N.Y.), November 17, 1871.

1083 "Interest and Principle," The Sun (N.Y.), June 3, 1871.

1084 Ibid.

1085 Ibid.
} 
minds over their convictions that neutrality was the policy to achieve that. He explained that rather than preserve any sort of economic vitality on the island, they had instead encouraged the prolongation of Cuban slavery. The result was an island wrecked of its economic value by the total war engulfing its major sugar and produce centers, and embracing forced labor as a means to preserve power. ${ }^{1086}$ "Had they listened either to the voice of their own consciences or to that of The Sun," the editorial page concluded, "Cuba would have been free two years ago, and the estates upon which they had loaned their money, in lieu of being devastated by fire and sword, would to-day producing the wherewithal to return their advantages." 1087 As was typical of Dana's paper, The Sun's editorial page made sure to remind readers of its previous recommendations in light of the existing issues.

The Cuban question illustrated how Dana's Atlantic perspective motivated his stance that the president and the Republican Party in Congress appeased monarchists in seeming to assist Spain's suppression of the Cuban rebellion. The basis of Dana's claim that the Republicans had allied with the Old World was the contention that the White House had refused to affirm their republican responsibilities within the hemisphere, by continuing to allow a monarchist state to perpetuate slavery ninety miles off the American coast into the early 1870 s. To Dana's perception of the world, this was the behavior of Bonapartists, Bourbons, and Orleanists. Dana argued that

\footnotetext{
1086 "Spain and Cuba," The Sun (N.Y.), July 14, 1871. "The continuation of the war means the utter desolation of one of the fairest gardens of the earth. Cuba, producing as she does one-fifth of the sugar of the world, is to-day a commercial necessity; and this country, the largest sugar consumer of the world, is especially interested in its preservation In the ensuing campaign the torch will surely be carried westward into the heart of the richest sugar districts of the island. We have long ceased to hope for any American action in this matter from our present Executive, on the score of duty, patriotism, or any noble sympathy with a noble cause. Is it too much to ask of the successor of Don Hamilton Fish, whoever he may be, that he should - not in deference to the wishes or interest of the American people, but simply as an act of kindness to that highly respected class of American merchants who owe their fortunes to commissions on Cuban produce - signalize his accession to office by some act which will prevent the utter ruin of the island?"

${ }^{1087}$ Ibid.
} 
the evidence for this thesis was strongest when the president neglected to change his position across 1871 in the face of increasing abuses perpetrated by the Volunteers on the island and condoned by the Spanish Crown. The actions of the Volunteers, the paramilitary units of Cubans who supported staying a Spanish colony, had remained extremely controversial to Dana, who saw them as a critical reason for the expansive violence against sympathizers of independence in Western Cuba and the continued existence of slavery on the island. ${ }^{1088}$ When the new king of Spain, Amadeo I, decided to commission a new medal for exceptional Volunteers in Cuba, Dana highlighted that the monarch's rewarding of violence made the Grant administration's decision to remain neutral stand out all the more. "The insignia... of the new order," Dana explained, "will doubtless be ingeniously devised to represent the outrage, the torture, and the slaughter" of Cuban republicans by the Volunteers. ${ }^{1089}$ The Volunteers, the paper wrote, had engineered the murder of medical students in late 1871, the continued arrest and theft of American property, and the reindenture of most of the Chinese immigrant labor on the island. ${ }^{1090}$ The Sun contended that these royalists in Cuba were no friends of American interests, yet were being empowered by American weapons and neutrality. The editorials of The Sun, responding to the news of the new medal, cited the "cowardly brutality" of the Volunteers and the unfortunate support of the Spanish authorities for their activities. ${ }^{1091}$ An editorial describing the nature of the counter-revolutionary military award noted that, "not only does the King of Spain reward the acts of cruelty and brutality which

\footnotetext{
${ }^{1088}$ For Dana's previous judgments about the Volunteers and the Spanish party on the island, see chapter three of this dissertation. Also see: "The Havana Savages Dictating to their Countrymen in Spain-Slave Trade to be Revived - Caution to Cubans," The Sun (N.Y.), January 27, 1872. (N.Y.), January 1, 1872.

1091 "The Atrocity of the Spanish Volunteers," The Sun (N.Y.), November 29, 1871. "The shooting of these thoughtless lads is a fair example of the cowardly brutality of the Spanish volunteers who rule Havana."
} 
he pretends to regret, but he disgraces all who refuse to assist in the extermination of the Cubans." ${ }^{1092}$ Dana argued that Secretary of State Fish also deserved to have a medal offered personally by Amadeo to reflect his assistance for the Spanish effort to preserve slavery on the island. In in its characteristic sarcasm, the paper wrote that while "the ordinary Crosses will, we presume, be reserved for the rank and file," "one of the richest will, we trust, be conferred upon Don Hamilton Fish, who, although a foreigner, has done more toward the indiscriminate murder of Cuban women and children than 'the noblest Roman of them all."' Such a prize, Dana suggested, would serve as an "emblem of his subserviency to Spain," and a model for the White House's approach toward republican values across the world. ${ }^{1093}$

Dana drew on the interconnections between his anti-Grantism and transatlantic focus in drawing parallels between the president, his ministers, and the problematic Old World governments of Europe. Particularly, Dana argued that Grant's government bore a resemblance to Bismarck's bureaucratic style and realpolitik approach, as well as the nepotistic and corrupt bureaucracy of the ministries of the toppled Napoleon III. Following this pattern, Dana specifically equated the Grant administration's recent behavior as being a direct tilt toward the vicissitudes of European governments unfriendly to republicanism. One editorial made the case that the secretary of state had subverted self-government in Cuba for personal reasons. "Gen. Prim's representative at Washington, Don Hamilton Fish," an October 1870 editorial began "does not like the news of republican victories in France." "1094 Secretary Fish "fears" that French

\footnotetext{
1092 "Spain Drops The Mask," The Sun (N.Y.), November 29, 1871. Dana argued that it was precisely the objective of obstructing the allies of republicanism that gained the King of Spain's favor; "Spain Drops The Mask," The Sun (N.Y.), November 29, 1871. "Rewards have been showered by the King of Spain on all, high and low, in the Spanish army in Cuba, exactly in proportion to the brutality evinced by them. Count Valmaseda was appointed Captain-General of the Island solely by reason of a decree of his which has been universally stigmatized as a disgrace to the civilization of the age."

1093“"The Cross of Cuba,” The Sun (N.Y.), November 16, 1871.

${ }^{1094}$ The Sun (N.Y.), October 17, 1870. "Don” Hamilton Fish was Dana's favorite Spanish nickname for the Secretary of State.
} 
successes "may revive the republican spirit in Cuba," and he did not want to "place in jeopardy the income which his son-in law Webster derives from the stability of the Spanish dictatorship." ${ }^{1095}$ Webster's earlier connections to the Spanish government as legal counsel, and to Secretary Fish as his daughter's husband, only reinforced The Sun's claims of nepotism and corruption saturating American foreign policy. ${ }^{1096}$ So did the appointment of Caleb Cushing as lead negotiator for the United States with Spain regarding the contested claims arising from the Ten Years War. To Dana, Cushing's appointment (and previous role as an informal advisor to the State Department) embodied some of the ironies of the Grant administration's foreign policy connections to malpractice and illiberalism towards slavery. ${ }^{1097}$ The former attorney general and minister to Peru and China, The Sun explained, had been brought in by the Grant to assist Secretary of State Fish in 1870, as well as to help advance American interests with Spain. ${ }^{1098}$

1095 Ibid.

${ }^{1096}$ The Sun (N.Y.), April 24, 1871. "We have reports from Cuba of the continued murder of prisoners taken in battle by the Spanish troops. How much longer is this thing to go on? When will Don. Hamilton Fish begin that intervention that he threatened at the commencement of his official career, when he notified the Spanish Government that such excesses were a disgrace to humanity? "Since that notification, however, Fish's son-in-law has been paid $\$ 50,000$ by the agents of the Spanish slave traders in Havana, and all is right."

${ }^{1097}$ New York Sun, May 6, 1871. "We learn from Washington that Hon. Caleb Cushing has been appointed - by President Grant of course - attorney for the prosecution of the claims of United States Citizens against Spain. These claims are to be adjudicated on the basis of an arrangement recently made in Madrid by Gen. Sickles. But considering that Mr. Cushing has long been professionally in the service of Spain, is it not rather rough in Gen. Grant to appoint him as the legal representative of claims against that Government?"

1098 “Caleb Cushing,” The Sun (N.Y.), September 27, 1871. “...Grant's administration has constantly called upon him for assistance. The most important documents of the State Department under Hamilton Fish have been his work."; "Caleb Cushing Secretary of State," The Sun (N.Y.) November 10, 1870. "The position of Gen. Cushing at Washington is not well understood by the people at large. Though a Democrat in politics, he is really Secretary of State. President Grant having appointed a man to that office who is not able to do its work, Gen. Cushing is called in when there is anything to be done requiring talent and information. He writes all important despatches that Mr. Fish signs, and advises Mr. Fish generally what to do. In a word, Gen. Cushing is really the Secretary of State, while Mr. Fish and Mr. Bancroft Davis, the bribe-taker, are mere show figures; and except where there is a prospect of making money, as in the scheme for the purchase and sale of Cuba, and in preventing the export of arms to the patriots of that country, while supplying them freely to the Spaniards, they move only as he advises. Would it not be better for the sham Secretary of State to go out, and the real Secretary of State to take his place? Ought there to be any humbug 
Cushing's relationship with Spain, dating from his previous employment for that government, and through his work for the State Department, in charge of the nation's policy towards Cuba, was suspicious to Dana. Sun editorials argued that "at the same time he has been the counsel and adviser of the Spanish Minister at Washington," Cushing "ha[d] exercised a great influence in directing that part of the Spanish campaign against Cuba which has been fought in the White House, the State Department, and the Capitol." ${ }^{1099}$ If the administration did not already look a bit like an Old World government to Dana, Cushing's checkered relationship with slavery only reinforced this caricature. "First an extreme abolitionist, and then for a quarter of a century a thoroughgoing partisan of slavery in this century, there is no inconsistency in his serving Grant's administration at Geneva as he has served it in Washington," the paper wrote. ${ }^{1100}$ For Dana, Cushing represented the White House's attempts to appear as the champion of New World values of abolition and equality in the United States while similarly allowing opposing Old World values to thrive in Cuba.

Dana's negative assessment of Cushing joined his broader indictments about the ideological character of Grant's foreign policy team. Dana explained that the State Department appeared as a group of advisors such as Napoleon III might have constructed out of family and friends, and who also acted as aggressively and cynically as Bismarck had in unifying a new empire in Europe. The State Department, The Sun made clear in late 1870, did not help the progress of republican values across the world. ${ }^{1101}$ How could they, Dana often inquired in

in such a matter? It is true that Gen. Cushing is a Democrat; but that might be made up by his giving a house or a horse or a cottage by the seaside to the President."

1099 Ibid.

1100 Ibid.

1101 "What Wonder?," The Sun (N.Y.), November 29, 1871. "What else can be expected from the Washington firm of Roberts, Fish, Sidney Webster \& Co., in which President Grant is only a sleeping partner?" 
editorials in late 1871 , when the assistant secretary of state would be found to be corrupt by an American jury. The Sun noted that the hiring of Davis, a convicted bribe-taker, as Fish's subordinate, exacerbated the negative perception of the controversial White House policy towards Cuba and Spain. One editorial made the direct connection of the response to the politics of the Iberian Peninsula and the Caribbean to those of these "Old World" tendencies of corruption, nepotism, aggression, and cronyism in foreign policy. "Bribe-taker [Assistant Sec. of State Bancroft] Davis has also been induced to Bismarckize the State Department," these comparisons explained, suggesting the parallels in self-serving German and American policy towards fledgling republican movements. ${ }^{102}$ The neutrality of the government toward Cuba, the Sun editorial continued, "is the more agreeable to the Secretary, as it tends to crush republican aspirations and give to his son-in-law in the paw of Prim a further lease of fees," renewing Dana's claims of fraud from the American and Spanish diplomatic corps. ${ }^{1103}$ The Sun editorial rooms joined the anti-Grant press in equating the president with Napoleon III. One of Dana's articles made the broad declaration that "those who denounce the condition of France under Louis Napoleon are repeatedly reminded by Gen. Grant's acts of the familiar proverb respecting people who live in

1102 "Grant and Fish in Favor of Slavery in Cuba," The Sun (N.Y.), October 14, 1870; "Another BribeTaker-Offices in Exchange for Presents," The Sun (N.Y.), June 16, 1871; "Ought Consul Butler to be Removed?," The Sun, June 19, 1871. For more on Dana's argument that Bancroft Davis represented the pinnacle of State Department corruption, see: "Bancroft Davis - The Right Man in the Right Place," The Sun (N.Y.), February 20, 1871. This editorial argues that "if anybody doubts Mr. Davis' qualifications" for his various diplomatic posts, "let him procure a copy of Senate document No. 1333, published by the Legislature of Massachusetts in March, 1870. That document relates to certain doings between the Boston, Hartford and Erie Railroad Company and the Erie Railroad Company, by which the latter was induced to guarantee five millions of Boston, Hartford and Erie bonds." (...) "We are glad that President Grant and Mr. Fish are going to recognize the merits of Mr. Davis by putting him in with Lord Tenterden as one of the Secretaries of the Commission. It shows a noble appreciation of smartness and financial talent on their part, and a heroic contempt for the opinions of narrow-minded old-fashioned puritans who believe in honesty and foolishly revolt at bribe-taking. The Sun is sometimes counted among the opponents of the present administration; but henceforth let no one deny that we admire its consistency, and give it a generous and intelligent support."

${ }^{1103}$ The Sun (N.Y.), October 17, 1870. 
glass houses." 1104 These parallels between the American head of state and aggressive European leaders help illustrate the urgency with which Dana interpreted what he argued were antirepublican trends. "How can anything else be expected" from the Grant's leadership, his paper concluded, "than complicity with all other species of wrong and injustice, including contempt for the rights of man, whether in Cuba or anywhere else?"1105 The track record of the administration, and the continued equation between the State Department and the foreign policy style of the Old World, sustained this parallel in the pages of The Sun. Dana, unfortunately for him, continued to find reason to deepen his growing distaste for the president, his aides, and their party.

Dana pointed to the White House's Bismarckian or Bonapartist tendencies, citing the secrecy with which the State Department handled its business towards Cuba. Chapter five has already noted that Dana's negative reaction to news that Congress had forced Secretary of State Fish to hand over all its communications with Spain because of similar concerns. Historian Peter Cozzens has contextualized Fish's 1871 attempt to discontinue the publication of these messages in the Department of State's periodically published summary of relevant communications titled Papers Relating to the Foreign Relations of the United States (FRUS), a publication that Congress often used to inform its foreign policy debates. ${ }^{1106}$ These very issues over secrecy and lack of unaccountability in 1869 and 1870 were, The Sun estimated, part of the larger reason why Fish had an "ambiguous position in the Cabinet" in late 1871 and $1872 .{ }^{1107}$ The secretary of state

\footnotetext{
1104 “1870," The Sun (N.Y.), January 2, 1871. "While the President urges in his annual message to Congress the reform of the civil service, he has opened the doors to hypocrisy and corruption by disregarding fitness and propriety in his appointments and regarding only the claims which persons who are related to his family, or who make him presents, or who assist him in his personal schemes, may have upon his recognition."

1105 "Grant and Fish in Favor of Slavery in Cuba," The Sun (N.Y.), October 14, 1870.

${ }^{1106}$ Peter Cozzens, ““A Surprising Manifestation of Backbone': The 1872 Foreign Relations Affair,” Office of the Historian, U.S. Department of State (June 21, 2011): 1 - 7.

1107 "The Hundred and Fifty Millions Due for Spanish Confiscations in Cuba," The Sun (N.Y.), June 10, 1871.
} 
could not quickly gain concessions from the Spanish government relative to American interests in the Cuba, and attempting to keep the negotiations outside of the press enflamed Dana's sense of Fish's suspicious motives. Dana blamed Fish for the lack of respect for the American flag in Cuba by failing to follow through on threats, ${ }^{1108}$ and now this secrecy only amplified the picture of impropriety. Bismarck had a widely known reputation for using backroom deals filled with cunning and suspicious diplomatic practices to press his preferred policies, The Sun had explained. Dana's characterization of the administration's foreign policy into 1871 continued to feature his judgment that it appeared increasingly un-republican. Dana had previously indicted the federal government for excessive secrecy regarding the treaty with England currently being negotiated to resolve the Alabama claims. ${ }^{1109}$ The editor now insisted that the White House did not have enough political capital with the nation, and the political classes, to keep treaty negotiations like these secret without appearing suspicious. ${ }^{110}$ Dana noted that "President Grant has done few things that have been popular," and that by publicizing the progress of the negotiations, he would improve his weak reputation and that of his State Department. ${ }^{111}$ The point, he argued, was that a nation governed by the principles of self-government, equality, and civil virtue should not handle its foreign policy without open and extensive Congressional debate.

\footnotetext{
1108 "Spain Not Responsible," The Sun (N.Y.), June 8, 1871. "The absurdity of looking to Madrid for redress for any outrage committed in Cuba has been for the last two years so self-evident that the representatives, both naval and consular, of all other nations except our own have long since adopted the system of exacting immediate reparation from the local authorities. The consequence has been that the flags of such nations and the lives of their citizens have been respected."

1109 "Publish the Treaty!,” The Sun, May 6, 1871; "Fishermen's Wrongs," The Sun (N.Y.), February 22, 1872; "Canadian Opposition to the Treaty," The Sun (N.Y.), January 11, 1872.

1110 “Away with Secret Diplomacy?," The Sun (N.Y.), May 3, 1871. "To Gen. Grant's administration it is especially necessary that this treaty should be made public and be acted upon publicly."

${ }^{1111}$ Ibid. "He could not make a better beginning in that direction than by giving this treaty to the public at the same time he gives it to the Senate."
} 
Dana insisted that "secrecy in such matters must always be hateful to a free people." 1112

Editorials in the paper explained that the appearance of non-republican secrecy similarly characterized the administration's foreign policy towards Cuba. The Sun editor wrote that Americans deserve to have the negotiations about the financial claims of the property lost in Cuba carried over in their public forum. Dana feared that secrecy from the State Department meant that a bureaucracy with a reputation for questionable ethics continued to act without oversight and accountability. ${ }^{1113}$ This, Dana explained, represented a problem for the nation's reputation concerning nationalism and abolitionism across the Atlantic.

Dana contended that these interconnections with the White House's foreign policy, and the comparisons with the un-republican approach of some of Europe's leaders, hurt America's standing in the world. Editorials in The Sun argued that the president's Caribbean policy could not have been any more antithetical to the Civil War goals of self-government and anti-slavery

1112 “Away with Secret Diplomacy?," The Sun (N.Y.), May 3, 1871. Also see: "The Treaty," The Sun (N.Y.), May 10, 1871. In this editorial Dana applauded that it could help compel the publication of treaty which marks different from less democratic forms of secret diplomacy.

1113 "The Hundred and Fifty Millions Due for Spanish Confiscations in Cuba," The Sun (N.Y.), June 10, 1871. "It is reported that Gen. Grant presented to the Cabinet some days ago since various papers relating to the claims of American citizens for confiscation on their property in Cuba, and damage to the same. These claims amount to about one hundred and fifty millions of dollars, and as Spain has long been bankrupt, and declines even to acknowledge as a debt of the nation her small indebtment for sixty millions of dollars, furnished her by the Spanish Bank of Havana for the prosecution of the war in Cuba, it is not likely that our Executive has the remotest idea that she will ever pay these claims. Spain cannot even restore to American citizens their estates confiscated in Cuba. The volunteers, so far as Spain is concerned, are masters of the situation in Cuba." "Does President Grant really expect to make of these claims a lever to lift Cuba out of all relations to Spain and bring her over to the United States?"; "Spain Not Responsible," The Sun (N.Y.), June 8, 1871. "While American citizens who happen to be obnoxious to the volunteers are denied admission into Cuba, and while their property are confiscated and destroyed, Hamilton Fish, in lieu of accepting the responsibility and ordering our vessels of war to act in the premises, wastes time and money in telegraphing to Madrid and demanding the publication of orders by the Spanish Government which he knows full well Spain has no power to enforce... Two years ago Gen. Prim assured Gen. Sickles that De Rodas had orders to shoot down any refractory volunteers. Since then the volunteers have packed De Rodas off to Spain; and the last steamer brings us news that they have deposed the Governor of Cienfuegos - the most important point on the Southern coast — simply because he thwarted their will in protecting from their fury a small boy, whose crime was the possession of a handkerchief embroidered with a red star." 
for which the United States had recently gained international notice. When the Cubans decided to look towards England as a potential ally in 1871, Dana indicted the president for providing the British with an opportunity to upstage the American republic in its duties to protect republicanism in the Caribbean. Dana called to evidence British public opinion from the pro-Cuban and antiGrant sympathies of the British press as confirmation of his argument. Specifically citing articles from "several leading journals" from London like the Times, Standard, and Cosmopolitan, Dana argued that "all of them maintain the justice of the cause of Cuba." More relevant still to the importance of Dana's attempts to frame the administration's wrong-headed approach, was his noting that many of these papers "handle Grant's Cabinet without gloves for its inexplicable apathy in this matter." 1114 Dana regretted that the "agents of the Cuban Republic" had met with "so ungracious and unexpected reception at the hands of our Executive" and had to appeal instead to England. ${ }^{115} \mathrm{He}$ lamented that Britain had become a more forceful advocate of abolitionism in Cuba than the United States Government appeared to be. ${ }^{116}$ He also bemoaned that the British government had more initiative to end slavery in Cuba, and help the rebels gain their

\footnotetext{
1114 “Cuba in England," The Sun (N.Y.), May 4, 1871; The Sun (N.Y.), June 12, 1871. "In a late number of the London Cosmopolitan, the editor devotes three columns to a leading article on Cuban independence. The subject matter is chiefly statistical and historical, and consequently would not be new to the readers of The Sun; but so strange a hope is expressed at the close of the article that we quote it, as follows: 'We believe that the time is fast approaching when Gen. Grant would do a noble and a graceful thing to propose, for the sake of humanity and progress, a joint recognition by Great Britain and the United States of this long-struggling Republic. We know, if the question were left to the people of Great Britain and the United States, it would not be long in abeyance. We have faith in Gen. Grant, and this Cuban question should not be used for political clap trap. The cause of a people who have struggled for liberty for fifty years is too sacred a thing for that; and since Grant has so ably moved the Alabama question out of the dirty arena of party politics, why not do the same with Cuba by acknowledging her independence?' The writer of the above is either unacquainted with President Grant, or he has never heard of that Japanese proverb with which the late Sir Robert Peel opened his celebrated speech in favor of the repeal of the Corn Laws, and which says that 'a wise man changes his mind often, a man without wisdom never."

${ }^{1115}$ Ibid.

1116 “Cuban Slavery in the British Commons," The Sun (N.Y.), August 2, 1871.
} 
independence, than did the United States. ${ }^{1117}$ In Dana's understanding, this fact made the United States appear to be in league with the controversial governments of the world. "Nowhere in the whole world, not even at the Court of the Czar or the Sultan," the paper insisted, describing the neutral policy toward Cuba, "could there have been such rejoicing over the triumphs of tyranny and statecraft as in the capital of the American Republic." ${ }^{1118}$ By such pronouncements, Dana continued to maintain that these initiatives by the administration to preserve stability in the Caribbean, over the republican imperative to intervene, diminished the reputation of the nation around the Atlantic world. How could the nation have fought a war that ended with the abolition of slavery, he argued, and allow it to exist so profitably ninety miles from American soil?

Dana maintained that the nation was made to look worse on the international stage by the administration because of its anomalous behavior towards slavery, and prosecution of filibustering in the early 1870s. Another example of this was Dana's comparison of the United States commitment to self-government and abolitionism, in contrast to other American states, like Venezuela. The recently founded republic in South America had been one of the primary friends of the Cuban rebels since 1868, and Dana noted their much closer commitment to republicanism than the current administration. One 1871 editorial supporting Venezuela's outfitting of various filibustering missions made just this case. Dana's paper highlighted how another “American republic" like Venezuela had acted as a "noble example" for those looking defend republican values, and thus exposed the United States" "dereliction of duty." ${ }^{1119}$ Venezuela, the editorial maintained, deserved praise for its continued support of Cuba, a praise "to which we as America

1117 "Spain Acknowledges her Loss of Cuba," The Sun (N.Y.), July 18, 1871. "If the truth is elicited, it will be shown that fully two thirds of the slaves now held in the island are retained in direct violation of the treaty with England. After this debate, Spain will probably reconsider her determination of last week. She long ago learned that though American threats may be derided, and American Secretaries of State cajoled, suggestions from the British Foreign Office must be religiously complied with."

1118 “Gen. Grant's Cuban and Dominican Policy,” The Sun (N.Y.), October 13, 1870.

1119 “Venezuela’s Glorious Example," The Sun (N.Y.), July 15, 1871. 
are not entitled." ${ }^{1120}$ Calling it "Venezuela's glorious example," the editorial contended that the young South American republic had provided yet another point of evidence to isolate the reality of the "criminal inaction of [the] Executive in assisting Cuba..."1121 Dana explained that other newspapers had failed to recognize the outside assistance given to Cuba by outside nations (or indeed private individuals) in the same way that he had in this period. The Sun noted that the New York Tribune had called the expedition "'a filibustering affair, without palliation or excuse; of no possible assistance to the Cubans, and probably only a new source of trouble to them."” Dana claimed that newspaper editorials such as these "stigmatized" the military efforts of sympathetic nations like Venezuela and ignored the value of the supplies, men, guns, ammunition, artillery stocks, cannon, and mules that landed in Cuba. ${ }^{122}$ This, an old argument Dana made regarding the Cuban insurrection (that the rebels merely needed guns and supplies to win), ${ }^{1123}$ joined another old argument of his (that the idea of filibustering to help insurgent republics, and the struggle in Cuba more generally, resembled the clandestine efforts of the heroes of the American Revolution), in continuing to defend any attempt to help the Cubans by Americans or others. ${ }^{1124}$

\footnotetext{
1120 “Venezuela’s Glorious Example," The Sun (N.Y.), July 15, 1871.

${ }^{1121}$ Ibid. "The Tribune yesterday stigmatized the landing as 'a filibustering affair, without palliation or excuse; of no possible assistance to the Cubans, and probably only a new source of trouble to them.' Our contemporary is not well informed... We can readily see how galling it must be to any Americans who have supported the criminal inaction of our Executive in assisting Cuba, that any American republics should by their noble example prove our dereliction of duty; but that is no reason why any honest journalist should seek to disguise or pervert the truth, or fail to accord to others that just praise to which we as Americans are not entitled."

1122 Ibid. "Of the Venezuelan example of June $19^{\text {th }}$, “...it did not consist of two hundred, but of three hundred and sixty Venezuelan soldiers. Each man carried two Remington rifles, and there were landed besides the above two pieces of field artillery, twenty mules for dragging them, and forty pack jackasses wherewith to convey the extra ammunition for the guns and rifles to the interior..."

${ }^{1123}$ Ibid. "The Cubans have, ever since October, 1868, been short of arms and of disciplined men, and the advent of the Virgin will undoubtedly be most valuable. With a few more such 'sources of trouble to the Cubans,' the Spaniards may pack up their trunks and abandon the island."

${ }^{1124}$ Ibid. "“The Venezuelan Government is most friendly to the Cuban cause, and if Gen. Garrido and Rafael Quesada, who commanded the expedition are filibusters, Gen. LaFayette was equally so."
} 
The fact that the Grant administration had so frustrated the Cuban effort, Dana insisted, and had been made to look an enemy of historic American value by other nations could not be forgiven. ${ }^{125}$ Dana's continued persistence on this issue of Atlantic politics also reflected how broadly he continued to frame the desire to help Cuba obtain independence as a domestic political party issue in 1871 and 1871.

Dana ultimately concluded current American foreign policy did damage to the nation's reputation overseas, hurting the president and the Republican Party's standing with the American electorate. Previous chapters have provided a host of reasons why Dana found the president and the administration to be harmful to the health of the Republican Party, and how he subsequently rescinded his own support. An analysis of Dana's reaction to the party's policy toward the Caribbean, of course, made up a large part of chapter three of this dissertation's argument. In 1871 and early 1872, as then, the policy remained a major feature of Dana's criticism of the party. For example, in one 1871 editorial, The Sun offered a review of the updated state of public opinion of the president's overall performance. The White House's evaluation, by the paper's estimation remained poor and foreign policy concerns persisted as a major reason for this. Dana argued that the president's continued attempts to annex the Dominican Republic stood out, alongside Cuba, as one of these foreign policy bungles that continued to frustrate the president's

\footnotetext{
${ }^{1125}$ Ibid. "The Spaniards in Havana are brimful of wrath against the Government of Venezuela, for allowing the expedition under Gen. Rafael Quesada to sail for Cuba from Puerto Cabello. They demand that all Venezuelan ports be at once blockaded by the Spanish navy, and that full reparation be exacted for the outrage... All this bluster will end in smoke. When the United States of Colombia acknowledged the belligerency of the Cubans, and thereby gave the patriots the use of their ports, the Captain-General in Havana despatched the frigate Gerona (just refitted at the Brooklyn Navy Yard) to Carthagena replied by sending to the captain of the Gerona an official copy of the proclamation conceding the rights of belligerents to the Cubans, which he had just received from Bogota. The Gerona did not open fire, and Carthagena still stands...The only foreign nation which Spain succeeded in frightening is our own. Her threat of declaring war if we recognized the belligerency of the Cubans cowed Hamilton Fish. But the Spaniards are good judges of human nature, and better diplomatists. Hamilton Fish had sworn that he would proclaim the belligerency of the Cubans if the terms proposed by him through Gen. Sickles were not accepted. The Spaniards doubted his pluck, and indignantly spurned his proposal. He then failed to carry out his threat, and the Spaniards dared him to do it. They knew he was nothing but a frothy blusterer."
} 
popularity in the United States. Previous chapters have mentioned that The Sun helped identify the administration's policy towards the Dominican Republic as one of the major issues for those in opposition to Grant to use to defeat him in the domestic elections between 1870 and 1872 . To that effect, the paper wrote in June of 1871 that "the San Domingo bubble has so effectually collapsed that none but an idiot would attempt to inflate it again." ${ }^{1126}$ The times that Dana implied that Grant was the idiot radically increased across the early 1870 s.

Dana explained that Grant had hurt his popularity all the more in the spring of 1871 when he personally corresponded with Dominican President Baez, removed Sumner from the Chairmanship of the Senate Committee on Foreign Relations, and attempted another legislative initiative to authorize the annexation of the Dominican Republic. Dana's paper was reporting that Grant had left U.S. Navy schooners in Baez's nominal control around Hispaniola so as to help Baez in a civil war against Dominican nationalists and Haitian freedom fighters. Sun editorials argued that this intelligence helped confirm the claims that Grant was pushing the party further into its patronage-centered, organizational mode, in ways that voters and the independent press could not accept further. ${ }^{1127}$ For one, the president appeared to have a personal relationship with the embattled Dominican president that contextualized his continued faith that he could annex the nation over Congress's latest disapproval. Sun editorials argued that the Dominican policy had

\footnotetext{
1126 “The Opportunity of the Democrats," The Sun (N.Y.), June 26, 1871.

1127 "The Ostracism of Sumner," The Sun (N.Y.), March 10, 1871. "Mr. Sumner is one of the founders of the Republican Party. Always its most learned advocate, he has stood foremost among its eloquent representatives both in Congress and in the forum of the people. In the early days, when to be an advocate of its radical doctrines was to invoke social proscription and provoke personal assault, he lost caste among his literary compeers, and was subjected to a brutal assault in the Senate Chamber, which sprinkled the floor with his blood and came near terminating his life. And why is such a man now sacrificed by the Republican majority of the Senate, the most of whom rose to their present positions after he had won fame in the public councils? The avowed reason is that he differs with Gen. Grant on the subject of the annexation of San Domingo to the United States." Also see: "Samana," The Sun (N.Y.), April 18, 1871; "He is Still True," The Sun (N.Y.), May 12, 1871; "Grant's Foolish Experiments," The Sun (N.Y.), May 25, 1871; "Why Not Reward Them All?," The Sun (N.Y.), May 26, 1871.
} 
already proven harmful to the president and the Republican Party's upcoming electoral hopes.

The paper claimed that a recent contest for the nomination for the party's candidate for Governor of Ohio represented a weathervane as to the Republican Party's cloudy future. One editorial argued that the contest was a "trial of strength between the San Domingo party and the officeholders on one side, and the independent press on the other." ${ }^{1128}$ Describing the results of the state election, where Dana's candidate won, The Sun explained that "Grant, and the officeholders, and the San Domingo jobbers were nowhere. The independent press cleared them out of the field." ${ }^{1129}$ Dana predicted that moderates and independents within the American political order could defeat Grant, "and all the officeholders and the San Domingo speculators" that "encourage him." 1130 The Dominican annexation issue remained for Dana one of these "circumstances which will mainly earn for [President Grant] such unenviable remembrance," and the other was "preventing the independence of Cuba." 1131 Combined with the clumsy efforts to lobby for Dominican annexation, Dana argued that the Cuban policy of the administration characterized the unpopular "lethargy forming the chief characteristic of his civil career," and editorials in The Sun insisted that the president's Caribbean policy could leave his reputation "in complete oblivion." 1132 If somehow it never reached that level, Dana reasoned that "posterity" would only remember the Grant as "the Great American Fizzle." "1133 The president had entered the

\footnotetext{
1128 “A Trial of Strength," The Sun (N.Y.), June 26, 1871. "President Grant and the San Domingo speculators were resolved that Ben Wade should be the candidate for Governor. The independent press were for Gen. Noyes; and when the Convention met, Ben Wade was so powerless in that he had to withdraw without a ballot, leaving Noyes to be nominated by acclimation."

1129 “A Trial of Strength,” The Sun (N.Y.), June 26, 1871.

${ }^{1130}$ Ibid.

1131 “The Opportunity of the Democrats," The Sun (N.Y.), June 26, 1871.

1132 Ibid.

${ }^{1133}$ Ibid.
} 
White House with a reputation for the preservation of republican government, Dana remembered in these editorials, noting the president's legacy even on the international scene contesting Napoleon III at the Mexican border in 1865. Dana argued that the result of the president's performance in the White House had similarly stained the Republican Party he led. The party, The Sun argued, acted out of cowardly deference to a president and base fear for the safety of a party," and "have thwarted the wish of the people" to see Cuba free of Spain. ${ }^{1134}$

Dana continued to use republican language to explain his contention that the Republican Party's Cuban position could harm the president's party and aid his opponents in 1872. Echoing comparisons with American history, Dana's Sun argued that "no President and no Cabinet from the days of Washington to the present time could have played so anti-American a part as has been played in regard to Cuba by this Great American Fizzle." 1135 Dana argued that the Republican Party needed to finally discontinue their blind commitment to economic stability in the Caribbean, and support Cuban independence for its ideological and strategic value. Reform of policy in this direction, Dana maintained, would present a welcome picture of American leaders projecting American values onto the world, as opposed to stifling them - as was the case of current policy. ${ }^{1136}$ To that end, the editor continued to motivate Democrats to "organize and furnish the Cuban patriots with the means — not much is needed - of speedily winding up their war of independence." ${ }^{1137}$ He argued that the Democratic Party would win future elections by doing so, and could threaten the Republican majority in Congress in 1872 . The Democrats, these

\footnotetext{
${ }^{1134}$ Ibid.

${ }^{1135}$ Ibid.

1136 “The Opportunity of the Democrats," The Sun (N.Y.), June 26, 1871. "Cuba is close upon her final triumph. Her cause is just, noble, humane, essentially American, and deservedly popular in this country; and none but the most short sighted or the most perverse would ever have attempted to impede it."

${ }^{1137}$ Ibid.
} 
Sun editorials noted, needed to explain to voters that they "will find that Grant has one law and one practice for the poor and almost helpless Cuban exiles." That would prove to be a strong contrast, he argued, to the picture Democrats hoped to present the American people — that they were ready to support the Fifteenth Amendment and become a progressive party in both domestic and foreign policy. Dana insisted that "there can be no better ground for" the Democrats' "claiming the suffrages of the American people than having extended democratic institutions to a near neighbor in the very teeth of Grant and of his satellites." 1138 "Let the Democracy then seize the opportunity and free Cuba," the paper implored the leaders of the anti-Grant opposition in that party. ${ }^{1139}$ By Dana's estimation, the advantages of making continued public affirmations by the party in support of Cuba were great for the Democrats and tapped into the purest veins of American ideological values.

The escalation of the war in Cuba in late 1871 and early 1872 did not change Dana's judgment that the administration and the Republican Party had turned their backs on republicanism in Cuba. The despatches Dana received from the island noted that the rebellion continued to make gains in central Cuba and remained successful in attacking Spanish Army and Volunteer positions. ${ }^{1140}$ Editorials in The Sun in late 1871 and early 1872 trumpeted the importance of these recent victories and used as evidence the increased momentum of the rebels against desperate Spanish ranks on the island. The newspaper, for instance, had gathered intelligence that the Spanish authorities in Cuba had restarted the slave trade to continue funding

\footnotetext{
${ }^{1138}$ Ibid.

${ }^{1139}$ Ibid.

1140 The Sun (N.Y.), November 15, 1871. Dana making joke about "occasional bullet" quip from years back. Says Spaniards have a "fever" from it since the Cubans doing so well; "News from Havana," The Sun (N.Y.), December 14, 1871.
} 
their exhausted defense of the colony. ${ }^{1141}$ Other reports cited that the royalists on the island had threatened to exterminate every Cuban sympathizer. ${ }^{1142}$ When this aggressive Spanish policy in Cuba resulted in the arrest of another American ship in late December 1871 (again the Florida), Dana feared that the White House might change policy towards the island for their political advantage. ${ }^{1143}$ The proximity of another potential foreign policy crisis in Cuba could be manipulated to benefit Republicans in the coming national elections in ways advantageous to the president, Dana suggested. Sun editorials of the scandal noted that "like the whole action of Gen. Grant toward Spain and Cuba, this affair of the Florida exhibits many incongruous and contradictory features, and it is difficult to tell what to make of it." ${ }^{\text {1144 }}$ Dana wondered in the paper if Grant would simply demand financial compensation for the disrespect of the American flag as he had since 1869 . Or, the paper asked, would he press more aggressively for action in Cuba to finally obtain the island as he had wanted to do in 1868 , and which Secretary of State

1141 "Slave Cargoes for Cuba. Spain Again Trading in Kidnapped Africans," The Sun (N.Y.), January 8, 1872.

${ }^{1142}$ The Sun (N.Y.), January 12, 1872.

1143 The Florida was arrested in what would today be international waters, 500 miles from the coast of Cuba, dana argued. Because of this, Dana and others suspected that the Spanish had been given intelligence about when the Florida would have left its American port. This remained highly irregular in dana's eyes, and he did not put it past the President, his secretary of state, and government lawyer Sidney Webster, to take such a step to harass a filibustering ship that had previously skirted the government's reach. This ship was the ship at the center of the Florida case where Judge Blatchford of the Federal District Court of New York City found that the ship was legally allowed to carry weapons and ammunition on board within international waters without question. Dana, in moments of high suspicion, thought that the administration held a clear grudge against the ship and its proprietors, thus arranging for its arrest, and thus creating the pretext for a "provoked defensive war" with Spain in defense of the Florida.

1144 “The Flag Outraged," The Sun (N.Y.), January 1, 1872. "Like the whole action of Gen. Grant toward Spain and Cuba, this affair of the Florida exhibits many incongruous and contradictory features, and it is difficult to tell what to make of it. If his purpose be to continue to truckle Spain, and to submit with patience to every insult that Spanish insolence may be put upon us, here is an excellent opportunity for him to illustrate anew the virtue of weakness and submission; or if his is purpose be to bring on a war with Spain for the possession of Cuba, here is an ample occasion. There is no reason to suppose that a war for the freedom of Cuba and the abolition of slavery there would not be favored and supported by our people; and we have yet to find any intimation, either in the press or in the utterances of public men, that it is impossible or even improbable that such a war should render certain the renomination and reelection of Gen. Grant." 
Fish had prevented him from doing since then. Dana remained incredibly cynical and suspicious of Grant's motives regarding Cuba as late as early 1872, when there were reports that the administration was selling weapons and ammunition for use in Cuba by the controversial volunteers to kill Cuban republicans. ${ }^{1145}$ Grant and his subordinates remained incredibly hostile to the press, especially Dana, for the publishing of sensitive information about filibustering expeditions. ${ }^{1146}$ Dana explained to readers that Caleb Cushing had been put on the record claiming that he wanted to prosecute telegraph companies who transmitted these first-hand accounts, and "suppress" newspapers like The Sun which published editorials about these filibustering expeditions. Such a posture only reinforced the claims of the un-republican, Bonapartist, realpolitik-like tendencies of an administration willing to stifle free speech and republican values. ${ }^{1147}$ Considered alongside the larger context of this dissertation, and Dana's four

1145 "Arms for the Spaniards in Cuba," The Sun (N.Y.), January 19, 1872. "The Spanish requisitions for American firearm and ammunitions still continue, and if the shipments of these articles hence to Cuba have not of late been more important, the fact is due solely to the scarcity of funds at the disposal of the purchasers. Spain has important interest in Cuba for the use of her regular and volunteer soldiery since the commencement of the revolution about ninety thousand rifles and muskets of American manufacture. Of these, according to official statements on the books of the Sub-Inspector-General of Artillery in Havana, 18,930 have been lost. Her present requisitions exceed this number... We observe, moreover, that Spain is strengthening her fleet in Cuban waters by sending thither her best iron clads. She has several there already, and others are on the way. It is absurd of course to imagine that the presence of vessels of this class can be intended to operate against the Cubans, and as by last reports from Madrid that will of the volunteers appears to be paramount even to that of the wealthy slave traders - for telegrams say Valmaseda is not to be removed - the iron-clads cannot be considered as [missing word] for the disarmament of the brutal savages whose every act Spain has approved... The spirit of hostility to this country which animated the Spaniards of Cuba from 1861 till 1865 burns to-day as fierce as ever. During our civil war it was manifested by the indecent joy with which the Digby, the Susannah, and other blockade runners were jailed on their arrival in Havana; by the haste which the Spanish Government slowed to empty the arsenals in Cuba for the benefit of the Confederates; by the shouts of Death to Lincoln! And the like, which resounded day and night through the streets of every city. The Cubans, on the other hand, were always our friends. A subscription which they raised for the soldiers who first placed the stars and stripes at Richmond, and which contained the names of none but Cubans, was ordered to be [aborted?] by the Captain-General because it displeased the Spaniards...It seems strange in view of such facts as these that our enemies should be applied with arms here and our friends denied similar privileges. But we have become used to very singular things during the past three years."

1146 "Why Not Gag the Press?," The Sun (N.Y.), December 9, 1871.

1147 "The Florida and Hornet. The Administration in a Quandary — Caleb Cushing Wants the Sun Suppressed and a Telegraph Company Proscribed," The Sun (N.Y.), February 1, 1872. 
years of frustration with the president, his reaction remained wholly questioning as to what the genuine motives on the part of the administration and the Republican Party happened to be. The administration, at least by The Sun's estimation, appeared more in league with Captain-General Valmaseda, the Volunteers, and the slave-traders, than with the Cuban republicans. The possibility of potential war with Spain over Cuba also reminded Dana of the broader criticisms he had made of the president's use of the regular army across the country to help strengthen his political chances in the coming elections. The idea that Grant would also begin a war for political and economic gain, Dana continued, only made the president look, sound, and act like the Bonapartes, Cromwell, Caesar, and Bismarck. Editorials in the paper argued that White House could attempt to realize its annexationist goals by provoking war with Spain, in a way comparable to Bismarck's actions with Napoleon III in 1870, in what historians have since called a "provoked defensive war." ${ }^{1148}$ By Dana's measure, the president had shown no hesitation in using the military in political ways in recent party nominating conventions, or to tilt the Dominican situation in his favor, and a new war in Cuba could serve a similar political purpose for the White House's strategy. Because he had not shown any strong concern in any of the previous cases of commandeered ships, or used his political capital to press for congressional approval of

\footnotetext{
1148 "War with Spain Imminent-The Tribune fully Committed to It," The Sun (N.Y.), December 27, 1871. "In striking confirmation of our position, we observe that the New York Tribune - most conspicuous among the Republican journals of the country hitherto for its opposition to Gen. Grant - in commenting upon our article, takes the ground - and we quote its own words...The wrongs, therefore, which citizens of the United States have suffered at the hands of Spain are not to be borne or endured. What is not to be borne, it follows, is in some way to be redressed. These wrongs, then, are to be redressed... The Tribune goes on to say that these wrongs are virtually admitted to be gross and intolerable "by the Department of Foreign Affairs in Madrid." Having satisfactorily established these two points, namely, that these wrongs are "gross and intolerable" and not to be endured, and that "They have been virtually admitted to be so by the Department of Foreign Affairs in Madrid," the Tribune next comes to the discussion of the manner in which these wrongs are to be righted... The Tribune shows plainly the occasion —-the necessity —of a war with Spain. How easy it will be to progress from this one step further, to the conclusion that Gen. Grant is the best man to conduct this war! See how suddenly this war-cry has made a distinguished rival candidate for President a half-convert to Grantism! Does not this indicate that a war with Spain will be popular?"
} 
belligerent rights for Cuba, Dana did not imagine that the president's approach to Cuba in early 1872 was anything more than merely opportunistic. ${ }^{1149}$

Dana's evaluation of Grant, and his previous assessment of Bismarck's foreign policy and governing style, continued to provide insights into the editor's reaction to the nation's foreign policy in the first months of 1872 . The editor had previously made the claim that the State Department had become "Bismarckized," reflected in part through the use of the army to realize political ends. This only strengthened the connections he saw in both Grant and the German Chancellor's use of realpolitik in both domestic and foreign policy. ${ }^{1150}$ The drama surrounding the capture of the reoutfitted filibustering vessel the Florida, had for Dana, also reinforced his sense that the president had a predilection for self-serving behavior in the preservation of his political power. Dana further explained to readers that the administration had continued to sell weapons and ammunition to the Volunteers in Cuba in 1871, the group that persisted as the main defender of continuing slavery in Cuba, supported the re-indenture of former-Chinese contract workers on the island, committed various controversial, extra-legal executions of prisoners, and were reportedly associated with the assassination of the former leader of Spain, General Juan Prim. ${ }^{1151}$ The executive favored monarchists over republicans, he bellowed, and it was time that the American people realized it. Dana argued that the president would only use war now to help coalesce public opinion behind patriotism, distract from his previous status quo policy, gain strategic additions to the nation, and add to his own power by gaining re-election in 1872 on the back of war mobilization and military patronage. In the process, Grant armed the true murderers

\footnotetext{
1149 The Sun (N.Y.), January 6, 1872. "We have already had occasion to comment upon the manner in which a war with Spain on account of Cuba would be received by men of all parties. Our opinion is confirmed by a protest from Hon. George Francis Train, the only candidate against Grant who is now making a decided canvass...."

1150 "Grant and Fish in Favor of Slavery in Cuba," The Sun (N.Y.), October 14, 1870.

1151 “Talk about Buying Cuba,” The Sun (N.Y.), January 24, 1872.
} 
in Cuba, Dana explained, and smothered American values in their infancy off the American coast.

The White House might have devised a plot, in real Bismarckian fashion, to arrange for the seizure of the Florida "as a ploy to get Cuba," The Sun wrote. ${ }^{1152}$ Dana implored readers to remember that any war that Grant now attempted to start with Spain would not have been started in defense of republicanism. "After all," one Sun editorial wrote, "a war is always the desperate resort of incompetent rulers whose people have resolved to repudiate them." ${ }^{\prime 153}$ This behavior, the paper reminded readers, is "the tradition of European despots" who are "very near the bottom of the hill, if not quite there." ${ }^{1154}$ Dana predicted that war with Spain would become "an important part of the Grant programme for the present year - the year of the Presidential election." 1155 Editorials in The Sun argued that a Spanish-American war brought on by the

\footnotetext{
1152 The Sun (N.Y.), January 6, 1872.

${ }^{1153}$ Ibid.

${ }^{1154}$ Ibid.
}

1155 “The Sun's Prediction Verified," The Sun (N.Y.), January 3, 1872. "It is hoped that the recognition of belligerency may suffice to satisfy the public feeling of the country. War is expensive, and new war taxes are dreaded everywhere. But having taken this first step, Grant will not hesitate to take those which may be thought necessary hereafter. Under present circumstances and with such a man as Sagosta at the head of the Spanish Government, the recognition of belligerency, instead of preventing war, will only render it more probably." Also see: "War at Hand," The Sun (N.Y.), January 9, 1872. "The probabilities, so often demonstrated in The Sun of late that war between the United States and Spain will begin at an early day, are confirmed by the subjoined report published in yesterday's Herald: (...) There can be no question that in exacting such an apology President Grant will be sustained by the entire public sentiment of the United States. Will Spain make this apology? It is not likely, but it is possible. If she makes it, will all causes for war be removed? By no means... The insult of Gen. Torbert, which is spoken of both in the letter of The Sun and in that of the Tribune, is, if possible, more grave than that for which President Grant has peremptorily demanded an explanation. Added to the outrage inflicted upon Consul Phillips in Santiago de Cuba more than a year ago, to the imprisonment of Dr. Howard at Cienfuegos, and to other notorious facts of this kind, it makes, under present circumstances, ample cause for war, even if the most submissive apology should be made for searching the Florida. It is thus more than ever probable that we are on the eve of a war with Spain. How will that war be waged, and what will be its results? In the first place, it must be fought on the ocean, and for such a contest no nation could be worse prepared than the United States at present. We have no navy that is worth speaking of. Our fighting must therefore be done mainly by privateers, and a great number of these will at once be let loose against Spanish commerce. Spain still has an important foreign trade, and it will be swept from the ocean. We, on our part, have none, so that so far as liability to damage is concerned the advantage is on our side. Besides, we shall immediately begin to build and fit out ships of war, and in the course of a few months we shall doubtless be able to send to sea a respectable force of naval vessels. To our regular army no addition will be necessary. It may be advantageous, however, to enlist a few regiments of volunteers for service in the sea-coast fortification. 
president "will not be for the purpose of making money for the sale of Cuba to the United States for one hundred and fifty millions, but for the purpose of electing Grant." ${ }^{1156}$ Dana had a keen sense for the ways that organizing a war effort, and staffing an army, could have political implications. As Assistant Secretary of War during the late Civil War, Dana had direct experience of how political allegiances could be strengthened by the bureaucracy and wages of an army. Not many knew it more directly than he. One Sun editorial, written in the midst of the January 1872 war panic, further explained Dana's point when it explained that "with the great number of quartermasters, purchasing agents, and contractors who would at once be called into being in reconstructing the navy and calling into service a volunteer land force, and with the power of millions which they would have to pay out, an immense addition would at once be made to the already formidable array of officeholders who are bound to do Grant's bidding and secure the gratification of his ambition." ${ }^{1157}$ Editorials in The Sun asked readers "will not Grant's chances of renomination and reelection be immensely increased by the adoption of the new project?" ${ }^{1158}$ This

The expenses of this, however, need not be great, and there is no reason why this war should cost more than two hundred and fifty millions, even if it costs as much as that...The Cuban revolution will at once receive new proportions. The moral and material support which it will receive from the United States must bring it speedily to a conclusion. There will be no need of our sending an army to Cuba. There are fighting men enough there already, and all that they require is a sufficient supply of arms and ammunition. But of course the Cuban Republic would at once be allowed to enlist recruits in this country, and the transports carrying them to Cuba would be protected by what men-of-war we have. A force of ten thousand Yankee soldiers, experienced and skilled in fighting, added to the armies of Cuba, would soon finish the business, and the Spanish flag would take its final leave of the Western Hemisphere; Cuba would be free, slavery and the slave trade would be abolished, and the question of annexation or of independent existence under the protectorate of the United States would then be in order... A subject of great interest is the effect which such a war would have upon the pending political struggle in this country. Would it render the renomination and re-election of Gen. Grant certain? We don't know... There are causes at work that might turn the tide in the opposite direction; but will anybody deny that the probabilities in such a case would be altogether in favor of Grant?"

${ }^{1156}$ The Sun (N.Y.), January 6, 1872.

1157 "War at Hand," The Sun (N.Y.), January 9, 1872.

1158 "The Sun's Prediction Verified - Radical Measures toward Spain-Hamilton Fish Going Out in Earnest," The Sun (N.Y.), January 3, 1872. 
awareness, that the rebellion in Cuba could finally become a politically valuable option for the president before the next election, was widely shared in this period.

Amid the public outcry surrounding the seizure of the Florida, politicians in the antiGrant opposition in Congress attempted again to get legislation passed affirming the belligerent rights of the Cubans, drawing forth Dana's prediction that the failure to defend Cuban republicanism and abolitionism would prove damaging the president and the Republican Party in 1872. The joint resolutions presented to the House by Rep. Samuel "Sunset" Cox (D - NY), and Rep. Daniel Voorhees (D - IN) produced reactions from Dana that reproduced the arguments the editor had made about Cuban independence and the Grant administration since 1869. ${ }^{1159}$ Both proposed bills to recognize the belligerency rights of the Cuban rebels which Dana, of course, welcomed. Editorials in The Sun in January betrayed an unfamiliar confidence that the rights of belligerents would be finally conceded, and that the federal government would finally admit that

\footnotetext{
${ }^{1159}$ The Sun (N.Y.), January 10, 1872. Also see: "Joint Resolution for the Concession of Belligerency to the Cuban Patriots Presented to Congress by the Hon. S.S. Cox," The Sun (N.Y.), January 10, 1872; The Sun (N.Y.), January 30, 1872; "Are These Men Americans. Congressman Who Deliberately Disgrace the Nation," The Sun (N.Y.), February 2, 1872. "Let the People Look at their Representatives and Blush with Shame-Men who Deny that Spain is Waging War in Flagrant Violation of the Rules of Civilized Warfare, and who Declare that Spain has a Right to Search American Vessels in Time of Peace." After printing Voorhees' resolution in full, the paper wrote the following: "The following members of Congress, who call themselves Americans, voted against the joint resolution. By their vote they distinctly deny that there is a war in Cuba, and assert that Spain is not waging a war 'in flagrant violation of the rules of civilized warfare.' They go further, and declare that Spain has, in time of peace, a right to search American vessels. Let the people preserve this list of shame for future reference..." For more on the resolutions themselves, see: Cox's resolution: H.R. 66, "Joint resolution for the recognition of belligerent rights between the kingdom of Spain and the so-called republic of Cuba," Index to the Congressional Globe for the Second Session Forty-Second Congress (Washington, D.C., Office of the Congressional Globe, F.\&J. Rives \& George R. Bailey, 1872): clxxviii. The bill was read, and referred to committee, but never progressed to a vote; Voorhees's resolution: H.R. 93, "Joint resolution for the recognition of belligerent rights on the part of the people of the island of Cuba in their civil war against the kingdom of Spain," Index to the Congressional Globe for the Second Session Forty-Second Congress (Washington, D.C., Office of the Congressional Globe, F.\&J. Rives \& George R. Bailey, 1872): ccciii. Motion was offered to suspend the rules and pass the resolution without being referred to committee, avoiding Grant's allies in the House Committee on Foreign Relations, failed 73 to 109. The bill was referred to committee, and never progressed to a vote.
} 
a formal war existed in Cuba. ${ }^{1160}$ He understood that elements within the government had gossiped that a declaration of war could be imminent. ${ }^{1161}$ Sickles had been one of these, and The Sun took note of Sickles' recent comments that the Cubans even deserved the recognition of the United States. ${ }^{1162}$ The paper told readers that Sickles repeated the paper's claims that the Cubans remained wholly more virtuous than the Confederate States during the American Civil War, and were in full support of republican values. "And when Gen. Sickles says that the Cuban patriots

1160 "The Sun's Prediction Verified - Radical Measures toward Spain-Hamilton Fish Going Out in Earnest," The Sun (N.Y.), January 3, 1872. "It has been determined by those who direct the policy and action of Gen. Grant that the fact of a revolutionary war in Cuba shall be officially recognized by the Government of the United States...Along with this it is decided that Don Hamilton Fish, our Spanish Secretary of State, must leave the Cabinet. In regard to the special time of his resignation or dismissal his wishes will, to a certain extent, be consulted; but go he must. No new memorial which he may get up to be signed by Senators and members of Congress will save him from decapitation. This business will be completed within the next week or ten days."

1161 "The Sun's Prediction Verified - Radical Measures toward Spain-Hamilton Fish Going Out in Earnest," The Sun (N.Y.), January 3, 1872. "The formal concession to the Cuban patriots of the rights of belligerents will doubtless be made within a week from the present time."

1162 The Sun (N.Y.), January 17, 1872. "We publish elsewhere some very important opinions of Gen. Sickles on the Cuban question. They were given to our reporter since the return of Gen. Sickles from Washington."; "Gen. Sickles on the Situation in Cuba - The Recall of Minister Roberts," The Sun (N.Y.), January 17, 1872. "Gen. Sickles thinks that Spain would not go to war with the United States if we should recognize the insurgents as belligerents. He views the relations between the United States and Spain as of a very different character from those existing between the United States and England, when the latter Government recognized the Southern rebels as belligerents. England acted early in the war, at a time when the rebels were begging for sympathy, to give watch was anything but international friendship toward the Government of the United States. (...) The belligerents in Cuba he thinks are entitled to respect and sympathy from several causes, which did not apply to the Southern rebels. The Cubans, although perhaps they have not established themselves as the permanent holders of any particular portion of the island or occupied forts, yet their great endurance has forced Spain to keep a standing army of 100,000 men on the island, 60,000 of which number was sent from Spain, showing that the insurgents are so formidable that the Spanish Government can hold possession of the island only by such an expensive are formidable military array. (...) The insurgents are entitled to the regard of the people and governments of all civilized nations on account of the barbarity with which the Spanish Government has carried on the war. The assassination of prominent persons known to sympathize with the insurgents, the cruel slaughter of the students, and similar acts, have been sufficient to warrant the official action of the United States in recognizing the insurgents as belligerents." 
are entitled to the rights of belligerents," the editorial page emphasized, "he confirms the judgment of every American citizen, the Secretary of State alone excepted.”1163

The failures of both resolutions, each stalled in committee, further illustrated the resoluteness of Dana's anti-Grantism in 1872, as well as his enduring commitment to republicanism in the Atlantic world. The news of Representative Voorhees' attempt to get his resolution passed outside of the regular committee order of the House, to avoid the president's allies in the House Committee on Foreign Relations (where the resolution would be referred and heard), continued The Sun's analysis. The paper reported that the resolution failed with only 79 votes for, and 109 against. ${ }^{1164}$ Republicans and Grant supporters made up the difference within the House of Representatives to refuse the rights of belligerents to the Cuban rebels. The Sun's strong reaction to the vote came in part because other newspapers, like the New York Post, argued that the election would be a "test vote and a direct and positive endorsement of the policy pursued by the administration in reference to Cuba." 1165 Dana's own conceptions of the character of the American people made him protest that the referendum stood instead as confirmation for the level of corruption, party despotism, and patronage-centered politics dominating the Republican Congress. ${ }^{1166}$ Editorials in The Sun argued that the American people could not possibly "wish to see Spain victorious, perpetuating slavery and reviving the slave trade, and the gallant Cubans

\footnotetext{
${ }^{1163}$ The Sun (N.Y.), January 17, 1872. "No man is probably better informed upon the questions of which he speaks than one to whom the different Spanish Cabinets have, for the past three years, confided their opinions and intentions about Cuba."

${ }^{1164}$ The Sun (N.Y.), January 30, 1872.

${ }^{1165}$ Ibid.

${ }^{1166}$ Ibid. "Are we from this to deduce that the American people endorse the brutal system of warfare waged by the Spaniards against the Cubans? That they have no sympathy for a people who under infinitely greater oppression rebel, as did our ancestors, and fight for the rights of man? That they approve and invite the dishonoring of our flag, as it is being dishonored?"
} 
exterminated..." ${ }^{167}$ Using language that had escalated quite dramatically from that of 1869 , Dana insisted that the American people, no matter the vote of Congress, had to have a "sympathy for a people who under infinitely greater oppression rebel, as did our ancestors, and fight for the rights of man..."1168 The editor could not accept that the vote of the House of Representatives reflected the actual desires of the American people, whom he always suggested held thoroughly republican sympathies. Instead, he reasoned that the failed vote had to have been also the product of political corruption and machine politics. The very same editorial reflected the sentiment when it concluded that "if the Post is correct, either the American people are false to their inherited freedom or their representatives are false to them." ${ }^{1169}$ The last few years of coverage of the Grant administration would have left daily Sun readers confident that Dana had already judged it the latter. Dana's very strong repulsion with Grant's new organizational mode for the Republican Party left the editor incurably suspicious that the party was only beholden to the president because he dispensed the patronage. Dana insisted that Grant's despotism over the Republican Party in Congress had whipped members into line behind the president's willful rejection of American republican values in the Caribbean.

As the opposition groups to the president began citing Cuban independence as a necessary part of their political platforms for 1872, Dana and his newspaper invoked republican themes to applaud the development. Dana interpreted the growing Democratic support for Cuba as a manifestation of the party's progressive reform efforts across its domestic and foreign policy program. The case of the Connecticut Democratic Party platform's embrace of Cuban independence in 1872 elicited Dana's encouragement and reinforced his perception that the issue

\footnotetext{
${ }^{1167}$ Ibid.

${ }^{1168}$ The Sun (N.Y.), January 30, 1872.

${ }^{1169}$ Ibid.
} 
would strengthen the Democratic Party's perceived connection to transatlantic republican values. A February 27, 1872 Sun editorial noted that the resolution was "not only sound in principle," but also "hearty in its defense of republican institutions in the Western Hemisphere..." ${ }^{1170}$ When put up against the policy of the White House, Dana explained, these Democratic platform proposals appeared vastly more progressive than the government's policy and that of Republicans in Congress. As he had done in earlier chapters, Dana again compared the plight of the Cubans and their diplomatic treatment by the United States with the behavior of previous American administrations. As the Grant White House prevented the rights of belligerents being granted for the Cubans, Dana explored how those who crafted these policy choices compared with famous foreign relations teams of American history. Dana wrote that the Connecticut Democrats of 1872 threw their support behind the Cuban republic in the same way that President James Monroe, Secretary of State John Quincy Adams, and Congressman Henry Clay had done in support of the independence of the South American nations rebelling from Spain half a century earlier. ${ }^{1171}$ The policy that developed as part of this American effort, Dana explained, became a "famous doctrine" that aggressively "opposed the future extension and the longer continuation of European institutions in this hemisphere."1172 Dana argued that these leaders of the Whig party in the late 1810 s and early 1820 s established for that political organization the fame of "having settled the question." These 1872 editorials reiterated claims that Dana had been making since the first months of the Grant administration. The paper characterized the government's policy towards Cuba as a "skulking, evasive, cowardly course." Dana ripped into the president and his allies in the party for their "base bowing of the knee before the crumbling throne of Spain." 1173 In

\footnotetext{
1170 “Connecticut on Cuba,” The Sun (N.Y.), February 27, 1872.

${ }^{1171}$ Ibid.

${ }^{1172}$ Ibid.

${ }^{1173}$ Ibid.
} 
February of 1871, a year earlier, The Sun's editorial page had argued that "by some means of another, Spain obtained control of the Republican Party in Congress which had not the energy enough to differ with the benighted President." Not much had changed in his impression of the issue a year later. Then Dana had argued that at the foot of the Republican Party sat "the massacre of thousands of innocent people in Cuba, and the devastation of a vast extent of cultivated and fruitful country.” By 1872, after almost four full years of fighting in Cuba, and Dana abortively calling on the president and the Republican Party to help, his estimation of his former allies' commitment to republican values in the Caribbean remained unimproved. In some sense, to him it was if the victory in the Civil War was cheapened if it could not encourage American foreign policy to more aggressively scrub slavery from the American continent. Why all the effort? Dana's support of Democrats and disenchanted Republicans acting within Congress to bring about change represented just how far from the White House that the editor's commitment to worldwide republican values had taken him. The fact that he had also come to see the administration's larger foreign policy as an illustration of its similarity to some of history's most controversial leaders like Caesar, Oliver Cromwell, Napoleon Bonaparte, Napoleon III, and Chancellor Bismarck further highlighted Dana's complete estrangement from the president and the Republican Party leading up to the election of 1872 . The process began in 1869 , crystallizing into open ideological rebellion on Dana's part against the agenda of his former allies in 1872. While some may point to Dana's personal rivalries with President Grant, and his failed attempt to obtain patronage from him, the editor's commitment to a specific set of political, economic, and social values, framed in a clear transatlantic perspective, dominated his intellectual and ideological life in this period.

\section{Conclusion}

Between the summer of 1870 and early 1872 , Dana continued to be motivated by a transatlantic republicanism that inspired his opposition to the president and the Republican Party. 
In previous chapters, Dana's belief in self-government, abolitionism, racial equality before the law, civic virtue, and labor rights confronted the president and the Republican Party's policies in various domestic and foreign arenas. While Dana had found reason to oppose the "Grantism" and corruption of the administration and the Republican Party, the use of the military to interfere in political party conventions, and the aggressive use of the Reconstruction Acts to interfere in state politics in states like New York, he also continued to explain his rejection of both the Grant administration and Republican Party through the lens of foreign affairs. In these early years of the 1870s, Dana's interpretation of the wars in Europe and the Caribbean continued to illustrate how issues of foreign policy could serve as points of comparison between the major events and characters of transatlantic politics and those of the United States. In that period Grant's worst proclivities, by Dana's estimation, resulted in suspicious interconnections between the corrupt tendencies of Old World Europe and the diminishing commitment of the United States government to republican principles. The Franco-Prussian War provided Dana with examples of an illiberal and un-republican monarch in Napoleon III, and the similar embrace of corruption and party despotism between the Bonapartist king, the White House and its Republican allies. Although the swift German victory over the French armies, the arrest of Napoleon, and the declaration of a French Third Republic, appeared to portend the expansion of self-government, unionism, and liberal rights in Europe, much the opposite happened. Dana's reaction to the German siege of Paris, the establishment of the German Empire with the coronation of Wilhelm I as emperor, the declaration of the Paris Commune, and the new French leader Adolphe Thiers's decision to put Paris under a second siege with the armies of the new Third Republic stationed at Versailles, clouded Dana's impressions about the future of republicanism in Europe. It also further problematized his impression of domestic American politics as the president, his diplomats, and the Republican Party adopted hostile positions against the Commune. In the pages of The Sun, President Grant often appeared alongside a parallel example from Europe that Dana 
thought was similarly stifling republican values as epitomized by the controversial Commune.

Dana's insistence to view the politics of the transatlantic world as interwoven, led him to evaluate the administration and its allies by the way that they defended, or critiqued, the advancement of republicanism in France. Dana's views that the lessons of the Commune, but not its violence, could have valuable resonance for American politics, helped motivate Dana's search for political alternatives to President Grant in the election of 1872. The ongoing revolution in Cuba, as well Grant's policy toward the Dominican Republic, also provided Dana with critical examples of the White House's problematic defense of republicanism in the Atlantic world.

Dana's analysis of the foreign affairs of the United States in Cuba and the broader Caribbean reflected his republican and transatlantic perspective, and continued to dominate the editorial pages of The Sun in 1871 and 1872. As he had done earlier, and as he did in response to the Paris Commune and German Unification, Dana challenged the Grant administration's approach to republican values between the late summer of 1870 and the early months of 1872 . This chapter has explained that Dana strongly opposed how the White House intensified its prosecution of the Cuban rebels on the high seas, and in the federal courts. This chapter has also shown that Dana rejected the administration's refusal to antagonize Spain over Cuba out of fear of destabilizing the Atlantic geopolitical order (and disturbing American economic interests in the Caribbean). Dana's strong passion for Cuban independence, and confidence in the justice of that cause, continued to saturate his understanding of the rebellion in $1872 .{ }^{1174}$

This chapter reinforces the dissertation's larger argument that in Dana's eyes, the transatlantic movement for republicanism had dire political ramifications for his growing

\footnotetext{
1174 "Cuba and Spaniards," The Sun (N.Y.), February 19, 1872. "They well deserve the consideration of every civilized Government. The Christian spirit which breathes through them offers an impressive contrast with the barbarous, bloodthirsty, and relentless ferocity which have made the proclamations of Valmaseda the disgrace of the country. These decrees from the elected ruler of a people who are fully justified in making reprisals for the countless horrors which the Spaniards glory in committing are worth in a reality a hundred victories, and inevitably foreshadow the speedy triumph of their cause." Dana frankly supported the "civilized and human principles on which the Cuban Republic is founded"
} 
disaffection towards President Grant, his administration, and the Republican Party. This perspective played a clear part in Dana's understanding of the nation's political identity, ideological history, and republican duty in the Atlantic world. The wars and rebellions in Europe, and in Cuba, occurred during a critical period in American politics. The continuation of Reconstruction across the first Grant administration influenced every aspect of Dana's understanding of the period. The changing nature of Dana's political sympathies in 1871 and 1872 , and the editorial policy and tools used to justify his position, remain critical because of the role he played in the lead-up to the November 1872 national elections. This, however, has received considerable attention both then and since. Instead, this chapter's historiographical contribution was explaining that Dana's decision not to formally join the Liberal Republican Party that ran against Grant in 1872 with the blessing of the Democrats, but still vote for their candidate Horace Greeley, reflected his enduring transatlantic republican perspective and continued flirtation with the Democratic Party. The Cuban issue, alongside those in Europe, played critical parts in the ways that Dana analyzed, and understood American politics. In the lead up to 1872, this perspective helped explain Dana's sympathy for the Democratic Party (a group he had never openly supported in his life until 1870-71) in this period.

This chapter has shown that Dana implored Grant, his Department of State, the broader executive branch bureaucracy, and the Republicans in Congress to support republicanism across the transatlantic world, but especially in Cuba and France. It has also clarified the prominence of his claim that when they neglected to, this would hurt the democratic reputation of the United States across the world and helped justify the editor's rejection of Grant and the party. The Democratic Party's new willingness to follow progressive policies, and growing support for Cuban independence and the rights of labor in 1871 and 1872, attracted Dana. The addition of other anti-Grant groups like the Liberal Republicans and National Reformers also publicizing support for republican movements like these further drew Dana away from his former allies. 
Dana had argued that with the Grant administration's failure to defend republican values in Cuba that it became the duty of this anti-Grant opposition (the Democrats behind Francis Blair and Samuel Cox, the Liberal Republicans behind Charles Sumner, Francis Adams, B. Gratz Brown and Carl Schurz, and the National Reformers behind Lyman Trumbull) to support the cause of transatlantic republicanism, and confront the White House's foreign policy. Perhaps we can now call them "never-Granters." On the back of support for Cuba, as well as the reform in the nation's domestic affairs, Dana argued that independent reformers could band together to champion republican values in the coming elections of November $1872 .{ }^{1175}$ Like the creation of the Republican Party in the 1850 s, Dana understood that a similar breakaway political movement had grown in opposition to Grant administration policies in 1871 and $1872 .{ }^{1176}$ "His support of the

1175 The Democratic Party had initially been breaking apart, just as the Whigs, and Know-Nothings were, and thus sent many to join the Republican Party. "How the Democracy Can Win," The Sun (N.Y.), January 3, 1872. "The Republican Party was originally a coalition, made up of Whigs, Democrats, Know-Nothings, and Abolitionists. The Whigs contributed the greatest numbers of the rank and file to the new organization, but the Democrats furnished to it most important elements, especially in the department of leadership. New England gave to the party Hamlin, Banks, and Boutwell. Among the many conspicuous names in New York we may specify Preston King, Gov. Fenton, and Gen. Wadsworth, Wilmot, of Proviso celebrity, Speaker Grow, and the veteran Cameron, were contributed by Pennsylvania. In the Northwest there were Chase, Trumbull, Doolittle, and Gratz Brown. Gen. Fremont fitly typified the enterprise and daring of the Pacific coast, while the adhesion to the new organization of the ubiquitous Blair family gave it to something of the prestige of the Jacksonian epoch."; "Do the Democrats Comprehend the Situation," The Sun (N.Y.), February 1, 1872 "Grant's partisans may disparage the honesty and ability of the malcontents in the Republican Party, belittling their numbers and influence, while they asperse their motives; but the fact remains, and no intelligent man will gainsay it, that the Democracy, reinforced by the men of whom Messrs. Trumbull, Schurz, Sumner, and Greeley are the representatives, are numerically strong enough to overcome their opponents, both in the popular vote and in the Electoral College...It seems to be a selfevident proposition that a cordial union of the Democrats with the Republicans who are opposed to the renomination of Grant, and their effective cooperation at the polls, will insure the election of a competent, dignified, and patriotic President... Probably there is no supporter of the administration sufficiently addleheaded to controvert this proposition, unless it be some foolish officeholder, or the editor of the Times."

1176 “How the Democracy Can Win," The Sun (N.Y.), January 3, 1872. “As it was with the Democratic Party then, so it is with the Republican Party now. There are many great distinguished leaders among the Republicans who are utterly opposed to Grant's administration, and especially to his renomination, and who, under no conceivable circumstances, will vote for his reelection. But they bear no proportion to the Republican masses who cherish the same sentiments, and if the occasion arises will carry out their convictions at the polls. Grant is weak among the Republicans in the Senate, as the debate on Trumbull's resolution demonstrated. He is weak in the House, as the discussion and vote on the San Domingo and telegraph swindles proved. But he is far weaker with that solid body of Republicans who neither hold nor desire office, than with their independent representatives in the two branches of Congress." 
slave-traders of Cuba against the patriots who are struggling for their own freedom and that of half a million of enslaved Africans," Dana explained, with all the other issues, "combined to produce a revulsion in public feeling which will make itself manifest at the proper time in a most effectual manner."1177

1177 “The Newest Departure,” The Sun (N.Y.), November 24, 1871. 


\section{CONCLUSION}

"... we feel that we have done our duty in advocating the great doctrine of equal rights which lies at the foundation of the prosperity of the land. The voice of the courtiers would fain have persuaded us to seat the King on the throne, with his feet on the neck of Liberty prostrate and slain. We have preferred the side of the people. We would rather be their faithful advocate, with an open field for a dwelling and soldier's blanket for a covering, than to sleep on a bed of down in a palace, inhaling the odors of flowers, enjoying the honors and emoluments of office, as the price for singing the praises of a king. Office, instead of being an honorable distinction, becomes the badge of infamy when it is purchased by sacrificing the rights of the people. Come weal or come woe, come success or come defeat, come prosperity or come adversity-we shall be found in future campaigns as we have been in this, we shall live and we shall die, the unswerving, unchanging, unfaltering advocate of equal rights and of the rule of the people."

- "The Sun and the People," The Sun (N.Y.), November 4, 1878.

Between 1813 and 1872 Dana developed into a major figure in American public life. His commitment to a certain understanding of republican ideals — civic virtue, egalitarianism, cooperationism, and federalism - helped him gain this standing. This dissertation covered the first half of Dana's professional journey, providing an updated analysis of the influence on this period in his life. Previous historians have studied Dana closely, and produced a somewhat muddied picture of the man, his ideas, and his influence. Some describe him much like this dissertation does, as a committed idealist turned pragmatist committed to republican ideas, while many historians emphasize Dana's frustrated patronage hopes to paint over these characterizations with claims of selfish aggrandizement, raw power seeking, and yellow journalism. This dissertation sought to make the case that the former attribution is more accurate and charts Dana's life from his teenage years in Buffalo, New York, throughout the antebellum period, through the Civil War, to his initial support of Ulysses S. Grant for president, and his subsequent rejection of the man. The episode with Grant — a rejected patronage request by Dana after the election of 1868 - produced an outsized reaction from observers and historians as a 
reflection of Dana's selfishness and fickle political character. ${ }^{1178}$ He was just one of those office seekers who had sucked at the proverbial teat of the government salary pool, as the caricature went. This dissertation hopes to shine light on the intellectual buildup that contextualized Dana's thought in this period toward Grant. This project has added to this analysis of the influence of Dana's republicanism the added lens of his transatlantic perspective and focus on foreign policy. The seven chapters of this study argued that Dana obtained a specifically republican, and pacifist, ideology in his youth, which matured into an aggressive political outlook that best explain his behavior during the Civil War and first administration of U.S. Grant (1868-1872). ${ }^{1179}$ This conclusion will briefly summarize the dissertation's principal findings, and then show how the project's conclusions of Dana's intellectual progression also help explain the next few decades in his life until his death in 1897.

This dissertation has made several interwoven arguments about the first half of Dana's life and its impact on his intellectual biography. The integral thread of the project's thesis is that Dana developed a republican worldview in the 1820 s and 30s that he kept for the rest of his life. Another fiber of the thesis holds that Dana transitioned from a pacifist understanding of this ideology into a belligerent one after witnessing, first hand, the European Revolutions of 1848 , that motivated his interpretation of the American Civil War. The project also argues that Dana

\footnotetext{
1178 "The Pirate of the Press," Washington Daily Journal, March 22, 1872. One of Dana's rival papers made the description this way: "It is a matter of regret to be obliged to speak of one in our profession in these terms, but in the case of Dana there is no alterative. It would be a pleasure to write of this man in the kindest and most courteous way, but Charles A. Dana has placed himself beyond the pale of ordinary courtesy. His hand is against every man of honor and integrity, and in self-defense every man's head must be against him. He has warred against women, and for years acted the part of a blackmailer, a spy and a thief of public and private character. He has surrounded himself in the publication of his paper with a gang of bad and desperate men, who have made themselves the terror of society, the free-booters and free-lances of journalism.

${ }^{1179}$ The idealist atmosphere of Harvard College and the Brook Farm Commune of the 1840s instilled in Dana a faith in pacifism and reform-minded social Protestantism. See: Wilson, Charles A. Dana, 517 534. Here Wilson provides a transcript of an address Dana gave at the University of Michigan in January of 1895.
} 
embraced an explicitly transatlantic application of this ideology, drawing him to support nationalist movements in places like Cuba, and apply lessons from international movements to American politics. Last, this dissertation finds that Dana took the last three points to explain how, in $1868-9$, he could go from so forcefully supporting a candidate for president like U.S. Grant, to so virulently rejecting his administration's domestic and foreign policy. Dana's republicanism remained the stable pole in his intellectual universe, even if different parts of it were accentuated in the course of the nineteenth century.

Clear signs of adjustments in Dana's thought and his understanding of the United States are visible in the immediate aftermath of the election of 1872. Dana's mentor Horace Greeley suffered one of the most historic losses in a presidential election in American history in 1872. Dana's support for Greeley as the candidate to defeat Grant proved to be the culmination of a critical strain in Dana's intellectual biography dating back to the 1830 s. He rejected the Grant administration's connection to corruption and nepotism, use of the military for political purposes, trading of economic progress for social or political progress, and foreign policy blunders like the failure to support Cuban independence or the support for a coup in the Dominican Republic. Dana's support of Greeley represented a sign of protest for Dana, a founding member of the Republican Party, and a supporter of Grant's candidacy in 1868. Grant's second inaugural address in 1873 did not impress Dana, describing that "neither the word honesty nor the idea of honesty is set forth or suggested in the whole of this inaugural address". ${ }^{1180}$ Dana argued that unless "integrity" was "restored" during Grant's second term, that "our experiment will end in ruin, and that he shall exert himself by precept and example to prevent such a catastrophe." 1181 Much had changed for Dana's political affiliations, not just four years ago having proclaimed

\footnotetext{
1180 "What He Did Not Say," The Sun (N.Y.), March 20, 1873.

${ }^{1181}$ Ibid.
} 
Grant to be the protector of the republic. The threads of Dana's ideological heritage remained clear, however, in a period of massive transition for the nation.

Grant's second term occurred in a changing economic and political landscape that set Dana's public defense of republicanism on a different course. The Panic of 1873 lasted deep into the decade, and destroyed the economic progress that had occurred since the end of the war in 1865. Americans lived in a booming nation up to 1873 with space to move - economically and geographically. As many went west over the next few decades, however, they felt the economic burdens imposed on them by the "Long Depression" of the 1870s. High Civil War taxes, fluctuating currency prices, and new debates about trade tariffs now consumed Dana's attention along with that of many other citizens. New reports of corruption in the Grant White House got attention too — the Credit Mobilier scandal and Washington Ring scandal alleged connections between Republican apparatchiks and railroad speculators as well as bribes by robber barons and political machine bosses. Could anything go right for the president, critics like Dana questioned? Southern Democrats had also succeeded in rolling back Republican Party legislatures in supposedly reconstructed Southern states in the mid-1870s. This movement by Southerners to "redeem" states formerly held by Northern, “carpetbag," installed legislatures passed "black codes" meant to roll back the rights of freed slaves. A small handful of states, like Louisiana, remained under federal supervision, and served as the continued example of the complications that using the army to reconstruct states could produce. ${ }^{1182}$ Both major parties were torn by

\footnotetext{
1182 "A Record of Party Infamy," The Sun (N.Y.), August 5, 1874. "It is admitted by Matt Carpenter and the most accomplished lawyers and politicians of his party in Congress, that Louisiana was seized by the President and turned over to Casey as a mere personal conquest; and that so far from being republican in form or quality, the present government is a pure despotism, originating in a base-born conspiracy between a parcel of infamous carpet-baggers and scalawags, backed by Grant, on the one hand, and an abandoned, drunken wretch of a Judge on the other. The result is a complete revolution in the order of society. A plain statement of this single case ought to be sufficient to condemn the Republican Party through all time. The President at the special instigation of his brother-in-law, took up a notorious carpet-bagger named Kellogg and installed him Governor at the point of the bayonet, Kellogg having no more title to the office than Casey himself. Kellogg is surrounded by his kind, and Louisiana lies prostrate and ruined; while these heartless knaves revel in the spoils."
} 
factionalism. Witnessing this process during Grant's first term irrevocably disillusioned Dana to Reconstruction and establishment politics. Republicans were fractured between those "Stalwart" party members siding with the president and the developing anti-corruption "Half Breed" faction, as the Liberals (as a political organization) disappeared post-election. Democrats had under their banner states-rights' Southerners, pro-business, conservative "Bourbons," "redeemers," the Southern Bourbon offshoot, and those falling behind the "New Departure" reform movement for disaffected Republicans and moderates. Major splits also developed between free traders and protectionists. The political situation was not like it was years earlier, and Dana would no longer judge the nation in the same way. Especially when it came to analyzing domestic policy, the passage of time had made Dana more conservative - a sign of a maturing interpretation of the role of republican values and their role in Grant's America and beyond.

Dana found the developing policy of the reconstruction of the Southern states to be highly problematic, and a threat to republican values. Like so many other Americans, he began removing his rhetorical support for the federal intervention in the politics of the Southern states, and the federal defense of black rights by threat of military force. ${ }^{1183}$ Dana simply grew tired of having the northern states pay, through taxes, for the propping up of struggling Southern economies and still invalidated former-Confederate state governments. After the economically destructive Panic of 1873, Dana did not think that it could be possible to reconstruct the south in the middle of a profound recession. One October 4, 1876 editorial in the Sun insisted that the "the

\footnotetext{
1183 “A Record of Party Infamy," The Sun (N.Y.), August 5, 1874. "When the continued ascendancy of the Republicans required that the Southern States should be gagged and bound and given over to the Government of the army first, and subsequently to the government of the negroes and carpet-baggers, it was done, as Mr. Stevens boldly avowed, 'outside the Constitution,' and in defiance of it. Neither the President nor his partisans in Congress have ever stopped to consider constitutional inhibitions which happened to be in the least inconvenient. It has been their practice ever since the war to crush with the force of the Federal Government all opposition in the Southern States. The reconstruction measures were framed for that very purpose and were carried into execution with merciless severity." The editorial concluded that "the truth is, the Republican Party has spent ten mortal years in the open, shameless, unrelenting struggle to keep those States from being restored to the protection of the Constitution."
} 
whole country is financially prostrate" and "our taxes are eating us up already." 1184 Dana argued that he wanted "the South in a condition to bear its share of the burdens..."1185 Feeding it money and the regular army to accomplish this was not within the spirit of traditional American republicanism. Conditions in the nation had changed and in Dana's opinion Grant and the federal government had proven themselves incapable of honestly executing any sort of statist vision for reconstruction. ${ }^{1186}$ A growing track record of corruption that The Sun sometimes had a hand in revealing, reinforced Dana's cynicism towards Grant's administration. ${ }^{1187}$ "The state of things, the Republicans tell us, must be perpetuated, and they take our army and use it in order to accomplish this purpose," the paper complained to its readers. ${ }^{1188}$ Using its trademarked republican language, tinged with the filter of Reconstruction, it indicted the president: "when the people vote the robber Government down, Grant sets it up again, and props with the bayonets of the army which we are taxed to support."

\footnotetext{
1184 “The Way Mr. Randall Puts It,” The Sun (N.Y.), October 4, 1876.

${ }^{1185}$ Ibid.
}

1186 “A Record of Party Infamy,” The Sun (N.Y.), August 5, 1874. "No state has ever been practically restored to the Union by the present Republican Party. No State has ever been permitted to cast off the carpet-baggers and other thieves, without first repudiating finally and effectually the party which fosters and encourages them. Whenever the 'the protection of the Constitution' shall be extended to one of these long harried and suffering communities, it will be not by the Republican Party as it is now constituted, but in spite of it."

1187 “The Sun Again Sustained," The Sun (N.Y.), April 12, 1876. "The rogues at Washington have fallen out, and honest men are at last likely to get their dues. When The Sun years ago charged that the safe burglary was concocted for the Washington Ring; that the details were planned and carried out by the Secret Service of the Treasury and with a free use of public money; that the conspirators were high in the confidence of the Administration, and were protected by the influence of the White House, every statement was denounced as a calumny by the organs of the Republican Party. Time and truth have again justified The Sun by confirming every one of these charges before a committee of investigation, and by adding testimony which astound and appalls the public mind."

1188 “The Way Mr. Randall Puts It,” The Sun (N.Y.), October 4, 1876.

${ }^{1189}$ Ibid. 
Dana's reinterpretations of republican values in American politics took him towards the Democratic Party. He could no longer stomach the Republican Party's attempts to use federal power to accomplish policy goals in the mid 1870s. He abhorred its foreign policy agenda and used his paper to rally opposition against it in that decade and the next. ${ }^{190}$ The Democrats were using republican language to criticize Grant's corruption of civic virtue, despotic use of military power, abuse of federal power in constitutionally mandated state responsibilities, and preference for economic progress over cooperation between the forces of capital and labor. Dana was attracted by the moderate "New Departure" faction of the party that called for a nationwide acceptance of the Fourteenth and Fifteenth amendments, civil service reform, Whiggish protectionist trade policies, a conservative winddown of reconstruction, pro-labor policies (i.e. the eight-hour work day and workingmen's insurance), and intervention in the Cuban Revolution. ${ }^{1191}$ Dana's continued support for the New Departure illustrates how far the American political system had destabilized since the Civil War. Many New Departure Democrats were disaffected Republicans like Dana, but many had been Union Democrats during the war (Copperheads like

\footnotetext{
${ }^{1190}$ For a sample of the paper's turn of sympathy, see an editorial in the wake of the paper's increasing support for the Democrat Gen. Winfield Hancock after receiving the nomination against Republican, and Grant ally, James Garfield: "Signs of Promise," The Sun (N.Y.), October 21, 1880. "There is no knowing what may be the result of the thorough shaking up of the Democracy in which we have taken a slight hand for a few days past. The greatest pains had been taken to create the impression that the Democratic Party was tainted with secession, and that a change in the tariff injurious to workingmen would be made in the event of Gen. Hancock's election. We have done what we could to disabuse the minds of our readers of these two fallacies. Gen. Hancock is as thorough a Union man as lives. If elected, he would surround himself with a thoroughly loyal Cabinet. We knew the country required to be assured on this point to preserve any chance of Gen. Hancock's election. We think the truth is now pretty well understood... In making these points clear, we are aware that we have created no little excitement and frightened some timid people. But the party had become listless and discouraged, and nothing but a thunderbolt would clear the murky atmosphere by which it was surrounded. Already, as the clouds lift, the brilliant rainbow of hope begins to appear. The party in this State is in a healthier and heartier condition than it has been in before. There is great reason to feel encouraged."

1191 "Is the New Departure an Old Departure," The Sun (N.Y.), July 28, 1871. "We have never doubted the wisdom of the now accepted policy of the Democratic Party. It was the last step in the process of a development that has been going on ever since the close of the war, and which has now reached its climax... in truth these are but the accumulated wisdom of each of the opposite political camps, between which the warfare ever rages, though the standards and watchwords vary with the warriors."
} 
Maryland Congressman Clement Vallandigham with checkered opinions on race), and Speaker of the House Sam Randall, an economic nationalist eager to move past issues of race to implement trade protectionism, lower taxes, and devolve powers taken by the federal government during the late war back to the states. In the decade since the end of the Civil War, Dana associated less and less with Radical Republicans, and proved that he was, indeed, more comfortable with moderates and conservatives like Democrat Edwin Stanton and Republican Abraham Lincoln. The Sun made public friendships with Democrat political leaders like Randall and others to suggest which leaders might best reflect its ideas. By the mid-1870s, Dana had come to believe that Grant's Republican Party was not the best vessel to expand civic virtue and egalitarianism. If anything, Grant had contracted the nationwide reach of some of these values in his eyes.

One the places Dana continued to point to as evidence of the nation's continued problematic relationship with republican values was the revolution in Cuba. His commitment to Cuban independence had not wavered and he hoped to see a republic established on that island. On February 25, 1873, the Sun reprinted a manifesto of a commission of Cuban refugees, and provided a reaction summarizing its support for the revolt. Titled, "Cuba Must Be Independent", the program argued that there could be no Union between Cuba and Spain. It began, "it is not convenient in any sense to America that an ambitious nation, bound by various and most ancient relations of friendship and similarity to the European system of nations, should continue to rule or even to influence the key of the Mexican Gulf. ${ }^{1192}$ To the republican legacy, dating from the European system of nations," Dana responded, "we say advisedly that Cuba enters to-day upon the third year of her independence, remembering that we are in the ninety fifth year of our own, and that on the $4^{\text {th }}$ of July $1778 . " 1193$ This independence reinforced the many principles that drove

1192 "Cuba and the Republic: Nothing Short of Absolute Independence For Cuba," The Sun (N.Y.), February 251873.

1193 “The Tenth of October", The Sun (N.Y.), October 10, 1870. 
his break with Grant and the Republicans. Following the election of 1872, the continuing Ten Years War gave Dana further ammunition to berate Grant. The numerous developments of the war brought Dana's ire - the volatile Virginius Affair of 1873-75 between the United States and Spain particularly animated him and the newspaper's editorial page (in this episode, Spain confiscated an American vessel, a filibustering ship, the U.S.S. Virginius, and executed the crew). Dana implored on the White House to intervene militarily. These entreaties were saturated with the same American-centric themes of republican brotherhood and national sovereignty. ${ }^{1194}$ Dana would never forgive the president for his administration's policy towards Cuba which, by disallowing any assistance from reaching the island, helped contribute to the insurgency's disintegration in 1878 . For the ten years of its course, the Cuban rebellion against Spain had been a foil for Dana to use to judge American politics and the Republican Party. Dana's full-throated support of Cuban independence, and abolitionism, helped show his enduring opposition to slavery through the 1870s. As his opinions about Reconstruction changed, his abolitionism shows that he was emphatically against slavery, if even also spending more editorial space demanding that federal troops leave the South and return power over elections to state legislatures. Focusing on Dana's transatlantic interests in places like Cuba has provided a contextualizing perspective through which to understand his ideas and understanding of the nation. Issues of foreign policy thoroughly motivated his opposition Reconstruction policy.

Critical themes from his youthful republicanism endured in Dana's interpretation of national politics. To the unfamiliar reader Dana's editorial stances appeared to reject much of the policies he supported since the end of the Civil War. Dana could realistically be called a states' rights advocate when it came to Reconstruction and civil rights issues, a moniker with a

\footnotetext{
1194 "More Butchery in Cuba," The Sun (N.Y.), November 13, 1873; “The Spanish Butcheries," New York Sun, November 23, 1873; "The End of the Virginius," New York Sun, December 31, 1873.
} 
controversial history and connected with the pro-Confederate Lost Cause mythology. To Dana it was a realistic solution to rectifying the problems of Reconstruction in an era where the executive branch was ethically suspect and quick to use the military to accomplish political goals. Those hoping to run in the election of 1876 and gain Dana's support would need to provide an image of civic republicanism that Grant and the Republican Party could not hope to demonstrate to the editor. As usual, Dana made recommendations to the parties about how best to accommodate his vision for the nation. Editorials from The Sun show Dana calling on the nation to reject militarism, for instance, by avoiding generals as suitable candidates for president in $1876 .{ }^{1195}$ The Democrats could not nominate General Winfield S. Hancock, the paper explained, because "the country has had enough of military presidents for the present century." ${ }^{\prime 196}$ No longer interested in what the Republicans were doing in the leadup to the election, as their nominee Rutherford B. Hayes publicized his close connection with the Grant White House (which got him folded into Dana's critique of Grant in 1875 and 76), Dana publicized the New Departure Democrats and their recommendations for the nation's future. Dana supported Speaker Randall's close friend, long time Democrat lawyer and apparatchik Samuel J. Tilden to run for president. From New York City, Tilden elevated his national profile by helping break up the Tammany Ring in 1871 (in alliance with Dana and The Sun), and winning election as the state's governor in 1874. Moderate Democratic and Republican exiles found Tilden to be a welcome compromise candidate for 1876 capable of winning votes in the north, west, and south. Not a card-carrying Democrat, but a Tilden supporter, Dana used The Sun to communicate to New Yorkers and Americans alike that the party appeared to be changing for the better - away from their Civil

\footnotetext{
1195 "No More Military Presidents," The Sun (N.Y.), April 12, 1876. "Unlike many of our prominent military commanders, he [Gen. Winfield S. Hancock] believes it is his duty to obey the laws, and he has a respect for the ideas of civil right. He would certainly make a great deal better President than Grant has been, or than Sheridan or Sherman would be... The country has had enough of military Presidents for the present century. The President elected in the centennial year should not be a military man.”

${ }^{1196}$ Ibid.
} 
War era ideology accommodating slavery's existence and towards cooperation. This association illustrates a major shift for Dana, but if viewed ideologically, and not in the realm of party identification, not much had changed for him. As this dissertation has attempted to argue, to understand Dana's choices it is important to understand the context influencing his interpretation of his preferred republican values.

The drama surrounding the clouded result of the election of 1876 redirected the intellectual trajectory of the last decades of Dana's life. This is easy to understand, as the election is easily one of the most controversial and influential in all of American history. Tilden, Dana's favored candidate, opposed the Republican Governor from Ohio, Rutherford B. Hayes. Tilden campaigned on proposals to reform the nation's civil service, resuscitate the reputation of the executive branch, remove corrupt Republican governments from Southern states, and limit the influence of corporations. Hayes, a relatively unknown Midwesterner but a Grant stalwart, surprised many by taking the nomination. There had been a decent chance that U.S. Grant would seek a third term, a reality that Dana campaigned heartily against, and James G. Blaine from Maine was widely expected to be handed the nomination if Grant did not run again. While Dana did not dislike Blaine as a candidate, he preferred Tilden, as he thought Grant and Hayes were part of the same Grantist circle (Hayes' was rumored to have been connected to scandal associated with Grant) and Blaine was too bland and regionally popular to win a national election. Hayes's presidential campaign on the status quo regarding race relations with an eye towards economic growth, did better than most expected and kept the race close enough. Tilden won the popular vote by a margin of more than 250,000 votes, with a spread of $50.9 \%$ to $47.9 \%$. In the electoral college, however, the results remained undecided. In the days after election night, the count stood 184 for Tilden and 165 for Hayes, with 20 votes left unattributed. These uncounted votes came from Florida, Louisiana, and South Carolina, states that had a checkered past with voting rights relative to Reconstruction policy. The Sun called the election results a conspiracy 
executed by Republican political machines in Southern states. ${ }^{197}$ Not assuaged by the electoral commission created by the House of Representatives to certify the recount in these states, Dana joined a chorus of critics calling into question the election result's validity. This impression was not improved when Democrats and Republicans in the House of Representatives made a pact, remembered as the Compromise of 1877 , which gave the Republican candidate the disputed twenty electoral college votes in exchange for the removal of all federal troops from Southern states. Dana continued to use the most extreme of allusions to make his case that what was occurring was of the utmost concern to the fate of the republic. ${ }^{1198}$ The election, in his eyes, had been stolen by Republicans.

The trajectory of Dana's intellectual life became more complicated as the nineteenth century progressed. National politics had proven intensely frustrating to him, as Dana would not have a highly favored candidate win the White House until the 1890s and he would never again find a consistent home in one of the major parties. He realized, like so many others, that issues that were popular in the 1840 s had less salience in the 1860 s and less still into the 1880 s and 90 s. Rampant railroad speculation had helped cause the Panic of 1873 , monetary and trade policy took national prominence as an ameliorative to ease the economic depression, and tax rates became more important issues for some than civil rights violations in the South. Industrialization and corporatization had ushered the nation into the Gilded Age, factories spread across the north and

1197 "The Conspiracy Broadly Developed," The Sun (N.Y.), November 15, 1876. "Though the returns from all parts of the country received on the night of the election proved clearly that Mr. Tilden was the choice of the people, the Republican managers, with Zach[ariah] Chandler at their head, would not admit it, but stubbornly maintained that Hayes was elected. Since then they have persisted in this declaration in the face of authentic figures from the counties and parishes of the disputed States, fully proving that the majority of their citizens have given their votes to Mr. Tilden; and to-day they persist in this with a greater show of determination and confidence than ever."

${ }^{1198}$ Ibid. "If this scheme is carried through, will it not be a military revolution? Of course it will; but does that fact constitute any safeguard for the Republic? Will Grant, or [Zachariah] Chandler, or Phil Sheridan be afraid of it?" 
west at unprecedented rates, and newspapers like The Sun were competing with industrial scale operations run by Pulitzer and Hearst with printers triple the size of Dana's. Corporations of all variety spread nationwide, their influence spreading through the political system. The relationship between workers and their employers worsened, strikers criticized the scope of industrial consolidation, and Dana's ideas were no longer the standard for the working man. Explaining the role this context played in his life would require another volume's worth of text — another dissertation even. There are many subjects relative to Dana that fall into that category.

In the 1880s Dana argued that the nation needed to move past the struggles of Reconstruction to address the financial and political issues plaguing the nation. This produced the effect of The Sun's editorial page prioritizing issues in the 1880s that it had not emphasized so vigorously in the past. For instance, Dana continued to suggest that realizing true progress required states from all parts of the nation accept the Fourteenth and Fifteenth amendments, that the military should not be used for political purposes, ${ }^{1199}$ and that political and financial corruption needed to be expelled from the federal government. ${ }^{1200}$ During the 1880 s, Dana also

1199 “Do You Really Want a Strong Government?" The Sun (N.Y.), April 25, 1879. "The common answer to the inquiry, Why are you in favor of Gen. Grant? Is, We want a strong government. Now, it is worth while to ponder somewhat over this proposition, and consider whether a strong government is really desirable. What is a strong government? People in this country who mention it so cavalierly labor under the mistake that it is a government strong to protect its citizens in their rights. Practically, such is seldom, if ever, the case. A strong government is strong to oppress. So far as protection is concerned, it is only strong to protect itself by the oppression of others... It is meant that he would make an administration strong for the negroes at the expense of the whites; strong for the carpet-bagger at the expense of the substantial and permanent resident; and administration strong in the cohesive power of public power. It would be an administration strong in military support and despotic tendencies. Strong governments make themselves strong at the cost of the blood and the liberties of the people. A strong government would be out of place in the United States."

1200 "The Sun and the People," The Sun (N.Y.), November 4, 1878. "Whatever may be the result of tomorrow's election, we feel that we have done our duty in advocating the great doctrine of equal rights which lies at the foundation of the prosperity of the land. The voice of the courtiers would fain have persuaded us to seat the King on the throne, with his feet on the neck of Liberty prostrate and slain. We have preferred the side of the people. We would rather be their faithful advocate, with an open field for a dwelling and soldier's blanket for a covering, than to sleep on a bed of down in a palace, inhaling the odors of flowers, enjoying the honors and emoluments of office, as the price for singing the praises of a king. Office, instead of being an honorable distinction, becomes the badge of infamy when it is purchased by sacrificing the rights of the people. Come weal or come woe, come success or come defeat, come 
began prioritizing economic issues related to republicanism versus some of the others that took more of his attention in the Civil War era. These economic issues included: the need to back currency in gold, rather than silver, the need to phase out Civil War paper currency (or greenbacks), and the need to raise tariffs to better protect American industries and workers. This movement coincided with his leaning towards the Democratic Party and candidates like Tilden, Winfield, and Massachusetts Democrat Benjamin Butler in 1884. ${ }^{1201}$ This reprioritizing of economic issues over others restructured how Dana organized himself within the nation's political atmosphere. He began to find new allies like Ohio Congressman Samuel J. Randall and championed them in the paper. ${ }^{1202}$ He actively campaigned for Democrat candidates across the decade, even supporting third party candidates who aligned with some of these new postReconstruction issues. ${ }^{1203}$ Dana perceived the Republican Party to be a pro-corporate party that embraced government power and free trade to achieve its goals. The Democrats offered a more attractive platform to protect the rights of labor through a protectionist policy. Any alternative

prosperity or come adversity - we shall be found in future campaigns as we have been in this, we shall live and we shall die, the unswerving, unchanging, unfaltering advocate of equal rights and of the rule of the people."

${ }^{1201}$ For a sample of his fevered support for candidates like Butler, see this concentration of articles, The Sun (N.Y.), July 11, 16-17, 20, 1884.

1202 "What Some People Don't See," The Sun (N.Y.), June 24, 1886. "In every calculation upon the Presidential campaign of 1884, the most conspicuous factor is Randall. He was absolutely the only great leader of the Democracy who entered New York and took a hand in carrying this state for the Democratic ticket... the mainstay of the Democratic Party is Samuel J. Randall."; The Sun (N.Y.), June 18, 1884. "Mr. Randall is always posing himself and his friends with the purpose of advancing the cause of true Democracy for 1888, and subsequent years besides." Also see: "Samuel J. Randall," The Sun (N.Y.), September, 5, 1884; November 11, 1886; July 17, 1888.

1203 "Signs of Promise," The Sun (N.Y.), October 21, 1880. Dana emphasized that his paper had done whatever it could to prove Hancock's fitness as a Democrat: "we have done what we could to disabuse the minds of our readers of these two fallacies. Gen. Hancock is as thorough a Union man as lives. If elected, he would surround himself with a thoroughly loyal Cabinet." He explained that The Sun was aggressive in making these points about the history of the Democratic Party because "it had become listless and discouraged, and nothing but a thunderbolt would clear the murky atmosphere by which it was surrounded." 
organization would have served as a better vehicle for Dana's ideology in his older age. While this is not to say that he rejected the republicanism of his past in exchange for a focus on economics, but that instead he began to emphasize those parts of his republicanism that accentuated economic nationalism, conservative currency manipulation, and egalitarian monetary policies meant to help the laboring and capitalist classes cooperate. Dana's movement from concentrating on the economic, political, and social issues related to civil rights during the Civil War era, to those more pressing in the 1880 s, signals the way the waning decades of the nineteenth century changed him prior to his death in 1897.

Dana is a rich historical source and the parts of his intellectual biography between 1813 and 1872 , not to mention in the next two decades of his life, provide opportunities through which to enrich our understanding of Dana himself but also more about the geographical interconnectedness of the period in which he lived. One of these subjects is Dana's interest in the rest of the world, and the influence of issues like the 1848 Revolutions, the Ten Years War of 1868 - 78, the Franco-Prussian War $(1870-71)$ and the Paris Commune of 1871 on transatlantic politics. His analysis of these conflicts helped him better understand American politics. This analysis helped him better understand his opinions about the role of republicanism in the Atlantic world. They helped motivate his joining of the Republican Party in 1854 and exit from it in 1870, acting as a filter for Dana to use to judge American politics. He had been doing this since the 1830 s and continued to do so until his death in 1897 . Ideologically republican-inspired analyses of these events permeated The Sun's editorial pages after this study ends in 1872. For instance, Dana's commitment to the cause of "Home Rule" for Ireland often influenced his national politics but was not a major feature of this dissertation. Dana was an early supporter of the Fenian movement in the late 1860s and chastised the Grant White House for not affirming the value of Irish independence from England. This Anglophilia on the part of the administration made it look the enemy of republican values. Dana would move closer to the Democrats into the $1890 \mathrm{~s}$ 
because of their sympathy with Irish nationalism. Dana's support for the Fenian Brotherhood would cool, but his support for Home Rule would not. He was one of the best-connected Americans helping organize Home Rule meetings in the United States. ${ }^{1204}$ For reasons of space, Dana's Irish passion is not dealt with fully in this study. His place in the Home Rule movement merits a dissertation of its own.

More attention can be offered to a host of various major international issues that Dana connected to republicanism and used as filters through which to measure the United States, such as the Italian Risorgimento, the Canadian separatist movement, the wars on Hispaniola, Puerto Rican independence, the "Great Game" rivalry between England and Russia in the Middle East, the "opening" of Asia in the 1880s and 1890s, and Dana's role in the Spanish-American War in Cuba (1898) and the Philippines (1899) that began the years after he died in 1897. We do not know enough, for instance, about Dana's close relationship with Jose Marti, the famed Cuban revolutionary hero. Marti often stayed in New York City with Dana, wrote for The Sun, and kept Dana connected to the brain trust of the newest Cuban revolution started in 1895. Marti died that year in battle, however, hurting Dana deeply. At a November meeting of Cuban sympathizers at New York City's Cooper Union that year, he eulogized Marti. To the crowd he said that "it was one of the pieces of great good fortune that I knew Jose Marti, whom I knew intimately. I gathered inspiration from the ideas of the man of genius, who sought for everyone, as he did for himself, liberty. He died worthily and in the cause of his life, and we are here tonight to pay a just tribute to his memory. No man perishes who follows ideas such as he had." ${ }^{1205}$ As he had done for decades, Dana emphasized that he had a transatlantic vision for freedom, continuing to affirm his

\footnotetext{
1204 “A Very Spirited—England's Threatened Policy of Coercion in Ireland," The Sun (N.Y.), March 22, 1887. Dana served as chairman of a "mass meeting of American citizens denounc[ing] England's acts of oppression toward Ireland" known as the Irish National League. Also see: "Patrick's Day at Evening," The Sun (N.Y.), March 18, 1888; “Aid for Home Rule,” Arizona Republic, November 11, 1890.

1205 "In Aid of the Patriots," Lebanon Daily News, November 27, 1895.
} 
connection to the values that had animated him for decades. "Wherever a hand is raised or blow is struck for liberty and freedom," he said, "there is where my sympathy and heart lies, and all I can ever do in assisting my oppressed brethren will done by me."1206 When the president did not send a frontline Navy vessel to Cuba in 1897 to show American support for the new revolution during his lame-duck session, The Sun called the outgoing executive a "faithless creature."1207 Not much had changed from 1869, when the very same paper was pushing President U.S. Grant to intervene in the Ten Years War. There is considerable room for studies of American sympathy for the Cuban Revolution in the figure of Dana and others like him. Dana's transatlantic interests are a rich source, and his advocacy for Cuba serves as one of the best examples of the impact of these ideas on his thought, and their lasting influence on the memory of the transatlantic world. Dana did, after all, get memorialized on the island of Cuba, in the province of Camaguey, with a plaza and street named after him that remains to this day - a signal of how close the relationship between Dana and the revolutionaries were, and partially still are. Dana's foreign policy interests were so broad that there is, in some form, an editorial trail of his analysis of most of the nineteenth century's international affairs after 1840 to analyze.

The overarching republicanism of Dana's opinions on issues between nation-states is a subject also meriting an extended study. This dissertation looked to both domestic and foreign policy to show how republican ideals permeated his thought in the Civil War era. His republican expectations for American foreign policy focus almost became the subject of this project. These themes permeated his thought and had since his earliest published record at Brook Farm. He continued to have a fear of militarism on ideological and class grounds. Dana asked readers what the "quarrels of courts, disputes over boundary lines, and the rivalries of ambitious princes and

\footnotetext{
${ }^{1206}$ Ibid.

1207 “Defend the Flag,” The Sun (N.Y.), February 27, 1897.
} 
premiers," were worth, "except [as] excuses for laying fresh burdens on the people?"1208 Dana never liked the idea of standing armies in peacetime, thus his revulsion with the use of the military during Reconstruction. The Revolutions of 1848, the reconstruction of the Southern states, and the Paris Commune of 1871 (among other things) helped convince Dana, in his older age, that government needed to remain efficient, small and demilitarized, yet always beholden to the Constitution. Dana's general avoidance of war illustrates the place that republican fears of overpowered governments and military coups link in the history of American isolationism. ${ }^{1209}$ The New York Tribune and the New York Sun took on important roles in attempting to educate Americans regarding when and where war was just. In the Civil War era Dana's threshold for violence and war stand out as exceptions to his largely consistent argument that war wastes men and resources that could be better spent at home. Militarism threatened the stability of nations like the United States as well as that of the international system. Dana anticipated that a "general war" would come to Europe in the 1880 s as a result of it. ${ }^{1210}$ While Dana was not always a successful prognosticator (once claiming that "the day of great navies was over" in $1877^{1211}$ ), he was not incorrect that militarism would lead to widespread war in the near future. Closer study of Dana's anti-militarism would provide additional contours to the complicated American opinion with war at the turn of the century.

Dana's insistence that economic classes could cooperate in the United States is a major feature of his understanding of American and transatlantic politics and this aspect too deserves

\footnotetext{
1208 “The Scourge of Militarism,” The Sun (N.Y.), July 10, 1880.

1209 "What Is Going On In Europe," The Sun (N.Y.), June 20, 1880. Dana applauded the spread of the "prevailing tendency of peoples to dispute the divine right of their kings."

1210 "General War Coming in Europe," The Sun (N.Y.), July 20, 1880; “Europe's Danger," The Sun (N.Y.), December 12, 1880.

1211 “The Day of Great Navies Over," The Sun (N.Y.), March 3, 1877.
} 
more attention than this dissertation can offer. His belief that there could be a middle ground between capital and labor provides a glimpse into the gradations of beliefs into how far to reform American capitalism, and to what extent the owners of capital should dictate that reform. Dana had an understanding of American political economy that sought mediation between socialism and capitalism. He cultivated this understanding of political economy at Harvard and Brook Farm and in revolutionary Europe of 1848. Realizing these policies in the 1840s meant creating utopian experiments like Brook Farm, popularizing early proposals for health and unemployment insurance, joint-stock corporations to look after workers, and a federally mandated eight-hour work day. Dana called for "association" and "cooperation" between labor and capital in the antebellum period and continued to advocate for similar policies in the decades that followed. ${ }^{1212}$ He thought that the nation's decentralization of power made Marxist revolutions difficult, a tool that strengthened American constitutional order and moderated labor politics toward cooperation rather than growth through destruction. ${ }^{1213} \mathrm{He}$ often described his efforts to reform capitalism in this way as a particularly American form of socialism, one without the violence of Europe.

American socialism could be volatile, he continued to argue, but it was not interested in coup d'état, seizing Washington D.C., and realizing a belligerent worker's revolution. In the middle of the sharp depression that followed the Panic of 1873, these types of arguments illustrate

1212 “Co-operative House Building,” The Sun (N.Y.), August 14, 1868.

1213 "The Stranger's Note Book: Some Meditations Respecting the Riots," The Sun (N.Y.), July $28,1877$. Dana explains that a peculiarity of the United States that makes it resistant to violent revolution "is the decentralization of power. The fact that there is no main point for the attack necessarily disables the assailant. Every state being self-supporting and self-protecting, what substantial differences would it have made had the rioters marched on Washington and captured Hayes, Evarts, Schurz, and toute la boutique? Suppose citizens Justus Schwab and David Conroy had the pluck to take possession of the Capitol and proclaim themselves dictators. Who would have taken notice of them? They would have to wage war on every count one of the States and conquer every one of them. In Europe, on the country, the moment the central power is seized, everything is seized with it. This is the chief reason why revolutions are liable to take place at any moment in any of the European countries, and can never take place in the North American Union." 
Dana's place as a labor rights moderate, but one who could also be called socialist. Dana made this argument explicitly surrounding the Great Railroad Strike of 1877, a massive shutdown of rail service when workers struck after a third wage cut by management. Allusions to European radicalism followed striking workers up and down the length of the Baltimore and Ohio Railroad. Federal troops and state militiamen were dispatched to Buffalo, Peoria, and St. Louis, and around the major cities of Pennsylvania. ${ }^{1214}$ The strike lasted forty five days and resulted in the death of close to one hundred protesters. Dana attempted to soothe calls from conservative Americans that reports of violence by frustrated workers were bringing the Paris Commune to the United States by comparing the hard ideology of European Marxism to the practicality of American socialism. ${ }^{1215}$ Stemming from his own knowledge of the spectrum of American versions of socialism and its history, he clarified to concerned readers that these protesters were intensely pragmatic. "The rioters and strikers here did not bring forward any vague principle or any 1214 One of the classic summaries of the strike and its place in late nineteenth century history is Robert
Wiebe's in The Search for Order, 1877-1920 (New York: Hill and Wang, 1967): 1 - 10.

1215 "The Stranger's Note Book: Some Meditations Respecting the Riots," The Sun (N.Y.), July 28, 1877. "The consciousness of this peculiarity of the social edifice of this country has made people naturally lenient here. A Danton or a Robespierre, a Mazzini or a Karl Marx, may be, or seem to be, very dangerous in Europe, but they would have been harmless here, for in no case could they have seized the power and imposed their theories of caprice upon the country. Consequently, if it may appear desirable in Europe to rid of them by means of execution, banishment, or any similar expedient, it would be cowardice to do so here. It is cowardice, too, and stupidity in the bargain, to cry out, as many people do just now, for the increase of the Federal army, and the strengthening of the Federal power. The men who do so want simply to shift their duty on somebody else's shoulders. They ought to understand that the weakness of the central power, and the strength of ever one of the States, form the best guarantee of liberty. They forget the old saying that what is sauce to the goose is sauce to the gander. A regular army of the hundred thousand men might have prevented the strikes, or made a more sanguinary execution of the rioters. But the same army might have made Grant an Emperor and Belknap a Marshal. "Another happy peculiarity of this country is that the minds of its people are not theoretical. The protracted and fierce struggle for existence carried on in Europe for centuries past, has rendered people there meditative and fanatical. Men think altogether too much in Europe. Here a man acts first and thinks afterward. His action is, therefore, determined by purely practical, business considerations of the moment. If he constructs and theory at all, he constructs it $a$ posteriori, and in analyzing the results of his action, he is just as ready to acknowledge that he acted like a fool, as he is ready to take credit to himself. He will not fight for an idea. He fights for a concrete, tangible experience of it. He fights fiercely, but not fanatically, and is ready at any moment to accept a reasonable compromise." 
socialistic theory," The Sun argued. "They simply wanted an increase of ten percent in their wages. The struggle could therefore never become as fanatical a one as it would have been in Europe...," the paper explained. ${ }^{1216}$ Even professed American socialists and Communists, this editorial wrote, acted for practical ends that even non-ideological workers asked for. "All they seem to want is that Government should take possessions of the railroads," the paper wrote, "as had been done in Belgium and Germany, and as will undoubtedly soon be done in France and England, and that the workingmen should be admitted to partial copartnership in great industrial terms." ${ }^{1217}$ Dana's incessant desire for moderation between extremes, between a fully capitalist society favoring owners or the world of the Commune where workers hold the upper hand, helped create a very specific understanding of socialism and capitalism in the United States. This characteristic provides an important variable in the history of American socialism. Analyzing the history of labor through the prism of someone like Charles A. Dana, and the opinion of newspapers like The Sun regarding critical strikes like the one in Carnegie's U.S Steel plant in Homestead, Pennsylvania in 1894, for instance, or the Haymarket Riot of 1884, would require a much more comprehensive study than the one undertaken here.

The role of Dana's opinions about race and their influence on his larger worldview are also not effectively analyzed in this dissertation. Any future study of Dana's intellectual biography must account for Dana's initial opposition to the Fifteenth Amendment. In its singular focus on the points that drove Dana's displeasure with President Grant related to corruption, overuse of power, and having a misdirected foreign policy, this dissertation did not analyze the major difference in Dana's opposition to slavery, and his opinions about the feasibility of offering voting rights to African Americans. While Dana believed that slavery was categorically wrong,

\footnotetext{
${ }^{1216}$ Ibid.

1217 "The Stranger's Note Book: Some Meditations Respecting the Riots," The Sun (N.Y.), July 28, 1877.
} 
and supported the Thirteenth and Fourteenth Amendments, the proposed Fifteenth Amendment, debated across 1869, and ratified on February 3, 1870, barring discrimination in voting rights on account of race, color, or previous condition of servitude, did not receive his initial, full-throated, endorsement. Where these other amendments outlawed slavery and guaranteed equal protection and citizenship for freed slaves and naturalized immigrations, basic republican goals, the Fifteenth amendment would be more controversial. "As The Sun has again repeated," one March 11,1869 editorial wrote of the issue of black suffrage, "this giving the suffrage to the negro is not a matter upon which an issue of national interest can be raised, and the party which attempts to make it such commits a serious blunder."1218 Dana alleged that "the people have...long ago got tired of hearing it discussed," that it was a "dead question," and was "a position which is every day becoming less tenable!" 1219 Yet, just a month earlier another editorial trumpeted how extensive the proposed amendment's suffrage reforms were when comparing them with the pace of reform in the United Kingdom, and the potential for the amendment to end the strife of the war for good. ${ }^{1220}$ There was an inconsistency in the newspaper's editorial policy on issues of race that did not always trend towards progressivism that requires addressing to fully contextualize the nuances of Dana's thought and places where intolerance polluted his supposed commitments to republican values like egalitarianism.

Dana's increased penchant to trade practical goals for ideological ones was especially clear through the 1870 s and 1880 s, when economic downturns soured the desires of many Americans to use federal power to extend further rights to African Americans. Like so many others in the 1870s, Dana appeared to forsake the freedman for a different American future focused on finances, political economy, and class cooperation. His doubts about the Fifteenth

\footnotetext{
1218 “The Indian Democrats," The Sun (N.Y.), March 11, 1869. ${ }^{1219}$ Ibid.

1220 “The Fifteenth Amendment—End of a Protracted Controversy," The Sun (N.Y.), February 4, 1869.
} 
Amendment often centered around its political tenability and futures Constitutional implications. He feared the power of the federal government when controlled by individuals and groups he did not trust, like Grant and his Republican supporters. Because voting rights were reserved powers given to the states in the Constitution, the Fifteenth Amendment radically expanded the federal government's ability to influence voting rights. The three Enforcement Acts of 1870-71 had proven for Dana the danger to elections and state sovereignty presented by laws that allowed the government to use force to enforce civil rights. The rest of the 1870s and 1880s entrenched Dana fully into the argument that further government investment in guaranteeing these rights through potential military coercion was no longer politically and economically justifiable. Many of these arguments were being made by segregationists and Lost Cause advocates hoping to roll back many of the rights given to freed slaves and immigrants during Reconstruction. One April 1879 editorial complaining about the previous cost of Reconstruction, the continued burden of the Lincoln-era taxes, and the threat of another Grant presidency threatened that "he would make an administration strong for the negroes at the expense of the whites."1221 Dana might have argued that he always blamed Southerners for their backwardness and vice for not embracing the freed slave on their own, but really could have done more to use his newspaper to elevate the political standing of the black community in this period. Dana wanted to fight corruption and his perception of tyranny so fervently that he would allow for the existence of the black codes aimed to curtail voting rights in Southern states. He was not the friend to freedmen he could have been, and that deserves additional study in any full-length intellectual biography of the man. Like so many others, Dana exhibited a clear hesitancy to protect full rights to freed slaves as the distance from the end of the Civil War grew. By the 1890s he was offering biological explanations of race

\footnotetext{
1221 “Do You Really Want a Strong Government?” The Sun (N.Y.), April 25, 1879.
} 
that the civil rights Dana of the Wide Awake period may never have advanced. These beliefs were in line with many race theories emphasizing the need for African Americans to obtain additional training in civilization to match that of whites. ${ }^{1222}$ Dana was not the progressive on race that he was on other issues - a fact requiring more attention.

Regardless of areas that might reward further inquiry, this dissertation presents an argument about the ways that ideology and geographic orientation can influence judgements about American nationalism in the nineteenth century. Charles A. Dana lived through one of the most critical phases in American history. Only a few generations removed from the nation's founding, Dana carried with him the republican strain from that period that enabled him to judge the transatlantic world and the United States. Clear evidence of this outlook connect to his intellectual biography at every critical stage. Looking back and forth between the politics of New York, Havana, Washington D.C., Paris, Chicago, London, and the larger transatlantic world made Dana's opinions about his life between 1819 and 1872, and especially Reconstruction and the first Grant administration, dynamic. His ability to compare and contrast the politics of the Old World and the New constantly provided him with ammunition through which to judge his surroundings. His commitment to civic virtue, egalitarianism, communitarianism, federalism, and national sovereignty served as the central ideological pillar across these years. Dana had his shortcomings, and reports that his failed attempts to receive a patronage job from the Johnson and Grant White Houses no doubt played their part in his life. He followed a republican worldview nonetheless. Abrupt shifts in his surroundings created the appearance that he compromised his

\footnotetext{
1222 “Negro Progress,” San Francisco Call, March 25, 1891. “Jacksonville (Fla.), March 24 - In an interview here to-day Charles A. Dana was asked: 'Have you noticed any progress among the negroes?' He replied: 'I think they have improved immensely. One great improvement is in the purification of the race. An evidence that freedom produces purity.' 'Will the negro catch up with the whites in civilization, and some day stand on the same footing?' 'You must remember white men have been engaged in political amelioration and intellectual pursuits for more than 5000 years. The negro has been engaged in these only a little over a century - 125 years. If you expect them to achieve a degree of progress in the character and refinement in 125 years that the whites have used 5000 to accomplish you will be greatly disappointed. At the end of the 2000 years he will be up to us in everything."
} 
values, or turned his back on decades-long commitments to specific mores. His worldview remained consistent, however, all the while, helping provide context to Dana's very quick changes of mind, for instance, about the potential and performance of Ulysses S. Grant. In the process he had made many political enemies. Henry Adams famously called him a blackguard. ${ }^{1223}$ The Washington Daily Republican once went so far as featuring Dana alone on its front page in a cartoon depicting him as "the pirate of the press." ${ }^{1224}$ President Grover Cleveland once called him an "old senile liar and thief." 1225 Scandals covered by The Sun exposed Dana to the ire of prominent figures. From President Grant, his Secretary of State Fish, Tammany Hall's William "Boss" Tweed and John T. Kelly, writer and Grant ally Mark Twain, political cartoonist Thomas Nast, controversially elected President Rutherford B. Hayes, twice elected President Cleveland, famous reverend Henry Ward Beecher, World publisher Pulitzer, new Tribune editor Whitelaw

${ }^{1223}$ Henry Adams, Ira B. Nadel, ed. The Education of Henry Adams (Oxford: Oxford University Press, 1999): 206.

1224 “Charles A. Dana," Washington Daily Republican, March 22, 1872. The feature story was meant to be a "brief sketch of his life - his career as a Fourierite, a Journalist and a "Maligner of Men." The report described the "arrival of so notorious a person" as Dana as a newsworthy event. Dana, who the Daily Republican did not like, was described as "being the most disreputable, bad, unscrupulous, and wicked editor wo ever controlled the columns of a criminal or any other newspaper." They wrote to readers that were writing this report so that the public about such an "infamous person" of whom they "should be on their guard."

1225 "Senile Liar and Thief," Harrisburg Telegraph, April 17, 1890. In response to a Sun report that the present was undergoing treatments for "reducing flesh," the ex-President reacted by criticizing the paper's reporting on his personal life. In the process he described Dana in colorful language. "I have not... seen the article you refer to, and if it appeared nowhere else but in the Sun, there is not the least chance of my seeing it. Of course the entire thing is a lie, without the slightest pretext to it. I judge from what you say that the venerable editor of the Sun supposes that he has at last hit upon a subject which can be used to annoy me. In that he is mistaken. He must be his own judge of social decencies and proprieties. I am not sure that he should at his time of life and in his apparently peculiar mental condition be molested in his amusement... Whenever I receive those cracks' letters I know that the senile old liar and thief, Dana, has been at it again. That is the only I keep tracking his mental ravings. The object, I suppose, is to annoy me and my friends." Dana and Cleveland had a very problematic relationship, dating principally to Dana's controversial reports on Cleveland's wife. The rest of this article continues Cleveland's broadside against Dana by making reference to that point - one that no doubt contributed to Dana's falling public image into the 1890s. He was controversial, in part, because his muckraking strategy did not always unearth stories that were felicitous or graceful. For a summary of Dana and Cleveland's fluctuating relationship, see: "Cleveland-His Rise and Fall," The Sun (N.Y.), March 3, 1895. 
Reid, and a host of well-known Americans, had, at some point in the second half of the nineteenth century, a very public, and often personal, rivalry with the outspoken editor. ${ }^{1226}$ He was a controversial figure, was on many occasions called into court to defend himself against charges of libel, only encouraging this reputation of roguery. ${ }^{1227}$ Dana, though, was a titan of journalism, evaded libel charges, and eulogized as having a formidable reputation as a journalist and transatlantic republican. ${ }^{1228}$ These values have made it easier to understand many of the choices Dana made in his career and the beliefs that animated them between the 1830 s and the end of the nineteenth century.

\footnotetext{
1226 "Charles A. Dana," San Francisco Call, April 19, 1891. "When Charles A. Dana of the Sun is in New York he goes to his office every day and puts in a stiff day's work, just as if he wasn't 71 years old and a millionaire. He is a kindly, brusque old fellow, who beams upon everybody through his two-moon spectacles, and bustles and buzzes about more like a big bluebottle fly on a windowpane than the traditional office cat. But when he settles himself at the business ear of his stenographer loaded for a column or so of leaded brevier the fur begins to fly in earnest. It's queer that a man who has more warm personal friends than any other editor in New York should also have such a host of bitter enemies. Probably the reason is that most of them have never seen him."

1227 “Charles A. Dana Arrested For Libel," The (Washington D.C.) Evening Star, June 27, 1873; "NoyesLibel Case," The Sun (N.Y.), March 19-21, 1895; “The Victory of the Press," The Sun (N.Y.), June 28, 1895.

1228 “Smith Speaks of Dana," Philadelphia Times, October 22, 1897.
} 


\section{LIST OF REFERENCES}

Abbenhuis, Maartje. An Age of Neutrals: Great Power Politics, 1815-1914. Cambridge: Cambridge University Press, 2014.

Ackerman, Kenneth D. The Gold Ring: Jim Fisk, Jay Gould, and Black Friday, 1869. New York: Dodd, Mead, \& Co., 1988.

- Boss Tweed: The Rise and Fall of the Corrupt Pol Who Conceived the Soul of Modern New York. New York: Carroll \& Graf, 2006.

Adams, Henry and Ira B. Nadel, ed. The Education of Henry Adams. Oxford: Oxford University Press, 1999.

Ahern, William H. "Laissez Faire vs. Equal Rights: Liberal Republicans and Limits to Reconstruction." Phylon 40, no. 1 (1 ${ }^{\text {st }}$ Qtr., 1979): 53- 65.

Alexander, Erik B. "The Fate of Northern Democrats after the Civil War: Another Look at the Presidential Election of 1868." In A Political Nation: New Directions in Mid-Nineteenth Century American Political History, by Gary W. Gallagher and Rachel A. Shelden, 16795. Chancellorsville: University of Virginia Press, 2012.

Allen, Austin. Origins of the Dred Scott Case: Jacksonian Jurisprudence and the Supreme Court, 1837 - 1857. Athens: University of Georgia Press, 2006.

Altschuler, Glenn and Jan M. Saltzgaber. Revivalism, Social Conscience and Community in the Burned-Over District: The Trial of Rhoda Bement. Ithaca: Cornell University Press, 1983.

Alvarez-Lopez, Luis. The Dominican-Republic and the Beginning of a Revolutionary Cycle in the Spanish Caribbean, 1861-1898. Lanham: University Press of America, 2009.

Anderson, Douglas Firth. “"More Conscience Than Force,': U.S. Inspector William Vandever, Grant's Peace Policy, and Protestant Witness." The Journal of the Gilded Age and Progressive Era 9, no. 2 (April 2010): 167-196.

Anderson, Hannah L. "That Settles It: The Debate and Consequences of the Homestead Act of 1862." The History Teacher 45, no. 1 (November 2011): 117-137.

Anderson, Kristen L. "German Americans, African Americans, and the Republican Party in St. Louis, 1865 - 1872.” Journal of American Ethnic History 28, no. 1 (Fall 2008): 34- 51.

Appleby, Joyce. Liberalism and Republicanism in the Historical Imagination. Cambridge: Harvard University Press, 1992.

Arenson, Adam. The Dred Scott Case: Historical and Contemporary Perspectives on Race and Law. Athens: Ohio University Press, 2010. 
Arieli, Yehoshua. Individualism and Nationalism in American Ideology. Cambridge: Harvard University Press, 1964.

Arnold, Andrew. Fueling the Gilded Age. New York: New York University Press, 2014.

Ayers, Edward L. "The American Civil War, Emancipation, and Reconstruction on the World Stage.” OAH Magazine of History 20 (January 2006): 54 - 60.

Babun, Teo A. and Victor Andrew Triay. The Cuban Revolution: Years of Promise. Gainesville: University Press of Florida, 2005.

Backhaus, J.G. "Friedrich List and the political Economy of Protective Tariffs." In Perspectives on the History of Economic Thought, vol. 7, edited by T. Lowry, 167-95. Vermont: Edward Elgar for the History of Economics Society, 1992.

Baggett, James Alex. The Scalawags: Southern Dissenters in the Civil War and Reconstruction. Baton Rouge: Louisiana State University Press, 2003.

Bailey, Brigitte, et al. Margaret Fuller and Her Circles. Durham: University of New Hampshire Press, 2013.

Bailyn, Bernard. The Ideological Origins of the American Revolution. Cambridge: Belknap Press of Harvard University Press, 1967.

Baker, E. and Brian Kelly, eds.. After Slavery: Race, Labor, and Citizenship in the Reconstruction South. Gainesville: University Press of Florida, 2013.

Baker, Jean Harvey. Affairs of Party: The Political Culture of Northern Democrats in the MidNineteenth Century. New York: Fordham University Press, 1998.

—. James Buchanan. New York: Times Books, 2004.

Baldasty, Gerald. The Commercialization of News in the Nineteenth Century. Madison: University of Wisconsin Press, 1992.

Ballard, Michael B. The Civil War in Mississippi: Major Campaigns and Battles. Jackson: University Press of Mississippi, 2011.

Balsamo, Larry T. “'We Cannot Have Free Government without Elections': Abraham Lincoln and the Election of 1864." Journal of the Illinois State Historical Society 94, no. 2 (Summer, 2001): 181-199.

Banning, Lance. The Jeffersonian Persuasion: Evolution of a Party Ideology. Ithaca: Cornell University Press, 1978.

Baptist, Edward E. The Half Has Never Been Told: Slavery and the Making of American Capitalism. New York: Basic Books, 2014. 
Baggett, James Alex. The Scalawags: Southern Dissenters in the Civil War and Reconstruction. Baton Rouge: Louisiana State University Press, 2003.

Bartlett, Christopher J. "British Reaction to the Cuban Insurrection of 1868-1878." The Hispanic American Historical Review 37, no. 3 (Aug., 1957): 296-312.

- Defense and Diplomacy: Britain and the Great Powers, 1815-1914 (Manchester: Manchester University Press, 1993).

Barkan, Elliot R. "The Emergence of a Whig Persuasion: Conservatism, Democratism, and the New York State Whigs.” New York History 52, no. 4 (October 1871): 367 - 395.

Barker, Nancy N. "Napoleon III and The Hohenzollern Candidacy for The Spanish Throne." The Historian 29, no. 3 (May 1967).

Barkun, Michael. Crucible of the Millennium: The Burned-Over District of New York in the 1840s. Syracuse: Syracuse University Press, 1986.

Bass, Gary. Freedom's Battle: The Origins of Humanitarian Intervention. New York: Vintage Books, 2008.

Bate, Walter Jackson. Coleridge. Cambridge: Harvard University Press, 1973.

Bateman, Alfredo D. Francisco Javier Cisneros. Bogota: Editorial Kelly, 1970.

Baxter, Maurice G. Henry Clay and the American System. Lexington: University Press of Kentucky, 1995.

Baum, Dale and Dale T. Knobel, “Anatomy of a Realignment: New York Presidential Politics, 1848-1860.” New York History 65, no. 1 (January 1984): 60-81.

Bayly, C.A. The Birth of the Modern World, 1780 - 1914. New York: Wiley-Blackwell, 2003.

-., et al. "AHR Conversation: On Transnational History." The American Historical Review 111, no. 5 (December 2006): 1441-1464.

Bean, Judith Mattson and Joel Myerson. Margaret Fuller, Critic: Writings from the New York Tribune, 1844-46. New York: Columbia University Press, 2000.

Beaver, Daniel R. Modernizing the American War Department: Change and Continuity in a Turbulent Era, 1885 - 1920. Kent: Kent State University Press, 2006.

Beck, Colin J. "The World-Cultural Origins of Revolutionary Waves: Five Centuries of European Contention." in Social Science History 35, no. 2 (Summer 2011): 167-207.

Beckel, Deborah. Radical Reform: Interracial Politics in Post-Emancipation North Carolina. Charlottesville: University of Virginia Press, 2011. 
Becker, Josef. "The Franco-Prussian Conflict of 1870 and Bismarck's Concept of a 'Provoked Defensive War': A Response to David Wetzel." Central European History 41, no. 1 (Jan., 2008): 93-109.

Beckert, Sven. Empire of Cotton: A Global History. New York: Knopf, 2015.

- Slavery's Capitalism: A New History of American Economic Development. Philadelphia: University of Pennsylvania Press, 2016.

Beck Block, Marguerite. The New Church in the New World: A Study of Swedenborgianism in America. New York: Holt, Rinehart and Winston, 1932.

Beecher, Jonathan. Charles Fourier: The Visionary and His World. Berkeley: University of California Press, 1986.

- Victor Considerant and the Rise and Fall of French Romantic Socialism. Berkeley: University of California Press, 2001.

Beilein, Jr. Joseph M. and Matthew C. Hulbert. The Civil War Guerilla: Unfolding the Black Flag in History, Memory, and Myth. Lexington: University Press of Kentucky, 2015.

Bell, Daniel A. Communitarianism and Its Critics. Oxford: Clarendon Press, 1995.

- Victorian Visions of Global Order: Empire and International Relations in Nineteenth Century Political Thought. Cambridge: Cambridge University Press, 2007.

Belz, Herman. "Salmon P. Chase and the Politics of Reform." Journal of the Abraham Lincoln Association 17, no. 2 (Summer 1999): 22 - 40.

Bellia Jr., Anthony J. and Bradford R. Clark. "The Law of Nations as Constitutional Law," Virginia Law Review, 98, no. 4 (June 2012): 729-838.

Benedict, Michael Les. The Impeachment of Andrew Johnson. New York: W.W. Norton, 1973.

- Preserving the Constitution: Essays on Politics and the Constitution in the Reconstruction Era. New York: Fordham Univ. Press, 2006.

Benjamin, Jules R. The United States and the Origins of the Cuban Revolution: An Empire of Liberty in an Age of National Liberation. Princeton: Princeton University Press, 1990.

Bensel, Richard F. Yankee Leviathan: The Origins of Central State Authority in America, 18591977. Cambridge: Cambridge University Press, 2003.

Berlin, Isaiah and Alan Ryan, Karl Marx: His Life and Environment. New York: Oxford University Press, 1996.

Bergmann, Peter. “American Exceptionalism and German 'Sonderweg' in Tandem.” The International History Review 23, no. 3 (Sep., 2001): 505-534. 
Berman, Jacob Rama. American Arabesque: Arabs, Islam and the Nineteenth-Century Imaginary. New York: New York University Press, 2012.

Bernstein, Peter L. Wedding of the Waters: The Erie Canal and the Making of a Great Nation. New York: W.W. Norton, 2005.

Besada Ramos, Benito. “Antecedentes Económicos de la Guerra de los Diez Años.” Economia y Desarollo 13 (September - October, 1972): 155 - 162.

Bestor, Arthur. Backwoods Utopias: The Sectarian Origins and the Owenite Phase of Communitarian Socialism in America, 1663-1829, $2^{\text {nd }}$ Edition. Philadelphia: University of Pennsylvania Press, 1970.

Bicknell, John. Lincoln's Pathfinder: John C. Fremont and the Violent Election of 1856. Chicago: Chicago Review Press, 2017.

Bingham, Tom. "The Alabama Claims Arbitration." The International and Comparative Law Quarterly" 54, no.1 (Jan., 2005): 1-25.

Blake, E. Vale. History of the Tammany Society, or, Columbian Order, From its Organization to the Present Time. Souvenir Publishing, 1901.

Blantz, Thomas E. "James Gillespie Blaine, His Family and "Romanism." The Catholic Historical Review 94, no. 4 (Oct., 2008): 695 - 716.

Blight, David. Race and Reunion: The Civil War in American Memory. Cambridge: Harvard University Press, 2001.

Bogue, Allan G. The Earnest Men: Republicans of the Civil War Senate. Ithaca: Cornell University Press, 1981.

—. The Congressman's Civil War. New York: Cambridge University Press, 1989.

Bolkhovitinov, Nikolay N. "The Crimean War and the Emergence of Proposals for the Sale of Russian America, 1853-1861.” Pacific Historical Review 59, no.1 (Feb., 1990): 15-49.

Bonilla, Raúl Cepero. Escritos Históricos. La Habana: Editorial de Ciencias Sociales, 1989.

Borden, Morten, ed. "Five Letters of Charles A. Dana to Karl Marx." Journalism Quarterly 36 (Summer 1959).

Bosco, David. "Moral Principle vs. Military Necessity: The First Code of Conduct During Warfare, Created by a Civil War-Era Prussian Immigrant, Reflected Ambiguities We Struggle With To This Day." The American Scholar 77, no.1 (Winter 2008): 25-34.

Bradford, George P. "Reminiscences of Brook Farm" Century Magazine 45 (Nov., 1892): 141148.

Bradford, Richard H. The Virginius Affair. Boulder: Colorado Associated University Press, 1980. 
Bradley, Mark L. Bluecoats \& Tar Heels: Soldiers and Civilians in Reconstruction North Carolina. Lexington: The University Press of Kentucky, 2009.

Brancaforte, Charlotte L. The German Forty-Eighters in the United States. New York: Peter Lang, 1989.

Brauer, Kinley J. "Seward's 'Foreign War Panacea': An Interpretation.” New York History 55, no. 2 (April 1974): $132-157$.

Breckman, Warren. Marx, the Young Hegelians, and the Origins of Radical Social Theory. Cambridge: Cambridge University Press, 1998.

Bresler, Fenton S. Napoleon III: A Life. London: Harper Collins. 2000.

Bridges, Amy. "Managing the Periphery in the Gilded Age: Writing Constitutions for the Western States." Studies in American Political Development 22 (Spring 2008): 32-58.

Brisson, Jim D. “'Civil Government Was Crumbling Around Me': The Kirk-Holden War of 1870." The North Carolina Review 88, no. 2 (April 2011): 123 - 163.

Britton, John A. “"The Confusion Provoked by Instantaneous Discussion;” The New International Communications Networks and the Chilean Crisis of 1891-1892 in the United States." Technology and Culture 48, no. 4 (Oct., 2007): 729-757.

Broadberry, Stephen. "Relative per Capita Income Levels in the United Kingdom and the United States since 1870: Reconciling Time-Series Projections and Direct Benchmark Estimates." The Journal of Economic History 63, no. 3 (Sept., 2003): 852 - 863.

Brody, David. "Reconciling the Old Labor History and the New." Pacific Historical Review 62, no. 1 (Feb., 1993): 1-18.

Brooke, John. "Cultures of Nationalism, Movements of Reform, and the Composite-Federal Polity: From Revolutionary Settlement to Antebellum Crisis." Journal of the Early Republic 29, no. 1 (Spring 2009): 1-33.

Brooks, Corey. "Stoking the 'Abolition Fire in the Capitol': Liberty Party Lobbying and Antislavery in Congress," Journal of the Early Republic 33, no.3 (Fall 2013): 523-547.

Brose, Eric Dorn. The Kaiser's Army: The Politics of Military Technology in Germany During the Machine Age, 1870-1918. New York: Oxford University Press, 2001.

- "The Revolutions of 1848-1849 and Their Aftermath." In German History, 1789-1871. New York: Berghan Books, 2013.

Browder, Clifford. The Money Game in Old New York. Lexington: University Press of Kentucky, 1986. 
Brown, David. "Jeffersonian Ideology and the Second Party System." The Historian 62, no. 1 (Fall 1999): 17-30.

Brownlee, W. Eliot. Federal Taxation in America: A Short History. New York: Cambridge University Press, 1996.

Burg, Robert W. "Amnesty, Civil Rights, and the Meaning of Liberal Republicanism, 18621872.” American Nineteenth-Century History 4 (Fall 2003).

Burt, John. Lincoln's Tragic Pragmatism. Cambridge: Harvard University Press, 2013.

Burton, Katherine. Paradise Planners: The Story of Brook Farm (New York: Longmans, Green and Co., 1939).

Butler, Jon. Awash in the Sea of Faith: Christianizing the American People. Cambridge: Harvard University Press, 1990.

Butler, Leslie. Critical Americans: Victorian Intellectuals and Transatlantic Liberal Reform. Chapel Hill: University of North Carolina Press, 2007.

Cain, Patricia Mary. "Capitalism, War and Internationalism in the Thought of Richard Cobden." British Journal of International Studies 5 (1979): 229-47.

Calhoun, Charles W. "Major Party Conflict in the Gilded Age: A Hundred Years of Interpretation." OAH Magazine of History 13, no. 4 (Summer, 1999): 5 - 10.

- Conceiving a New Republic: The Republican Party and the Southern Question, 18691900. Lawrence: University Press of Kansas, 2006.

Callahan, James Morton. American-Canadian Relations Concerning Annexation, 1846-1871. Bloomington: Indiana University Press, 1925.

Callahan, James Morton. American Foreign Policy in Canadian Relations. New York, 1937.

Campbell, W. Joseph. Yellow Journalism: Puncturing the Myths, Defining the Legacies. Westport: Praeger, 2001.

—. The Gilded Age Press, 1865-1900. Westport: Praeger, 2003.

Campbell, Randolph B. "The Spanish American Aspect of Henry Clay's American System." The Americans 24, no. 1 (Jul., 1967): 3-17.

Canaday, Margot. "Thinking Sex in the Transnational Turn: An Introduction." The American Historical Review 114, no. 5 (December, 2009): 1250-1257.

Carp, Roger E. "The Limits of Reform: Labor and Discipline on the Erie Canal." Journal of the Early Republic 10, no. 2 (Summer 1990): 191-219.

Carr, William. The Origins of the Wars of German Unification. London: Longman, 1985. 
Carwadine, Richard and Jay Sexton. The Global Lincoln. New York: Oxford University Press, 2011.

Casanovas, Joan. "The Cuban Labor Movement of the 1860s and Spain's Search for a New Colonial Policy." Cuban Studies 25 (1995): 83 - 99.

Casper, Henry W. "American Attitudes Toward the Rise of Napoleon III; A Cross Section of Public Opinion” PhD diss. Catholic University of America Press, 1947.

Castel, Albert and Brooks D. Simpson. Victors in Blue. Lawrence: University Press of Kansas, 2011.

Catton, Bruce. U.S. Grant and the American Military Tradition. Boston: Little \& Brown, 1954.

Cavallar, Georg. "The Law of Nations in the Age of Enlightenment: Moral and Legal Principles." Annual Review of Law and Ethics 12 (2004): 213-229.

Ceaser, James W. "The Origins and Character of American Exceptionalism." American Political Thought 1, no.1 (Spring 2012): 3-28.

Chaffin, Tom. "'Sons of Washington': Narciso López, Filibustering, and U.S. Nationalism, 1848 - 1851." Journal of the Early Republic 15, no. 1 (Spring 1995): 79 - 108.

Chalmers, David M. Hooded Americanism: The History of the Ku Klux Klan. Durham: Duke University Press, 1965.

Chamberlain, Ryan. Pistols, Politics, and the Press: Dueling in $19^{\text {th }}$ Century American Journalism. Jefferson, NC: McFarland \& Co., 2009.

Cheng, Eileen Ka-May. "Exceptional History? The Origins of Historiography in the United States." History and Theory 47, no. 2 (May, 2008): 200-228.

Christman, Henry M. ed. The American Journalism of Marx and Engels: A Selection from the New York Daily Tribune. New York: New American Library, 1966.

Cimbala, Paul A. Under the Guardianship of the Nation: The Freedman's Bureau and the Reconstruction of Georgia, 1865 - 1870. Athens: University of Georgia Press, 1997.

—. and Randall Miller, eds. The Great Task Remaining Before Us: Reconstruction as America's Continuing Civil War. New York: Fordham University Press, 2010.

Claeys, Gregory. "John Adolphus Etzler, Technological Utopianism, and British Socialism: The Tropical Emigration Society's Venezuelan Mission and Its Social Context, 1833-1848." The English Historical Review 101, no. 399 (Apr., 1986): 351-375.

Cleaver, Nick. Grover Cleveland's New American Foreign Policy: Arbitration, Neutrality, and the Dawn of American Empire. New York: Palgrave MacMillan, 2014. 
Coghlan, J. Michelle. Sensational Internationalism: the Paris Commune and the Remapping of American Memory in the Long Nineteenth Century. Edinburgh: Edinburgh University Press, 2018.

Cohen, Andrew Wender. The Right and Labor in America: Politics, Ideology, and Imagination. Philadelphia: University of Pennsylvania Press, 2012.

Cohen, Michael David. Reconstructing the Campus: Higher Education and the American Civil War. Charlottesville: University of Virginia Press, 2012.

Cohen, Nancy. The Reconstruction of American Liberalism, 1865-1914. Chapel Hill: University of North Carolina Press, 2002.

Cohn, Raymond L. Mass Migration Under Sail: European Immigration to the Antebellum United States. Cambridge: Cambridge University Press, 2010.

Coleman, Charles H. The Election of 1868: The Democratic Effort to Regain Control. New York: Columbia University Press, 1933.

Collazo, Enrique. Desde Yara Hasta el Zanjón: Apuntaciones Históricas. Havana: Instituto del Libro, 1967.

Commons, John R. "Horace Greeley and the Working-Class Origins of the Republican Party." Political Science Quarterly 24, no. 3 (Sept., 1909): 468-488.

Conlin, Michael F. "The Dangerous 'isms' and the Fanatical 'ists': Antebellum Conservatives in the South and the North Confront the Modernity Conspiracy." Journal of the Civil War Era 4, no. 2 (June 2014): 205-233.

Connolly, James. An Elusive Unity: Urban Democracy and Machine Politics in Industrializing America. Ithaca: Cornell University Press, 2011.

Cook, Adrian. The Alabama Claims: American Politics and Anglo-American Relations, $1865-$ 1872. Ithaca: Cornell University Press, 1975.

Cooke, George Willis. John Sullivan Dwight: Brook Farmer, Editor, and Critic of Music. Boston: Small \& Maynard, 1898.

Cooper, Matthew. "Relations of Modes of Production in Nineteenth Century America: The Shakers and Oneida." Ethnology 26, no. 1 (Jan., 1987): 1-16.

Cope, Rachel. "From Smouldering Fires to Revitalizing Showers: A Historiographical Overview of Revivalism in Nineteenth-Century New York." Wesley and Methodist Studies 4 (2012): 25-49.

Corbett, Percy E. Law in Diplomacy (Princeton: Princeton University Press, 1959).

Corcoran, Paul E. Before Marx: Socialism and Communism in France, 1830-1848 (London: MacMillan, 1983). 
Cortada, James W. "The New York Times, Spain and Cuba, 1851-1869." Revista de Historia de América 77/78 (Jan. - Dec., 1974): 61-75.

— . "A Case of International Rivalry in Latin America: Spain's Occupation of Santo Domingo, 1853-1865." Revista de Historia de América 82 (July - December, 1976).

Corwin, Arthur F. Spain and the Abolition of Slavery in Cuba, 1817-1886 (Austin: University of Texas Press, 1967.

Crapol, Edward. James G. Blaine: Architect of Empire (Lanham: Rowman \& Littlefield Publishers, 1999.

Craton, Michael and Gail Saunders. The History of the Bahamian People: From the Ending of Slavery to the Twenty-First Century. Athens: University of Georgia Press, 2000.

Crofts, Daniel W. Reluctant Confederates: Upper South Unionists in the Secession Crisis. Chapel Hill: The University of North Carolina Press, 1988.

Cronin, James E. Global Rules: America, Britain and a Disordered World. New Haven: Yale University Press, 2014.

Cross, Anthony. "The Crimean War and the Caricature War." The Slavonic and East European Review 84, no. 3 (Jul., 2006): 460-480.

Cross, Whitney. The Burned-Over District: The Social and Intellectual History of EnthusiasticReligion in Western New York, 1800-1850. New York: Harper \& Row, 1950.

Cross II, Coy F. Go West Young Man! Horace Greeley’s Vision for America. Albuquerque: University of New Mexico Press, 1995.

Crowe, Charles. George Ripley. Athens: University of Georgia Press, 1967.

Crowell, Jackson. "The United States and a Central American Canal, 1869-1877." The Hispanic American Historical Review 49, no. 1 (Feb., 1969): 27-52.

Cuncliffe, Marcus. Chattel Slavery and Wage Slavery: The Anglo-American Context, 1830-1860. Athens: University of Georgia Press, 2008.

Curl, Donald. Murat Halstead and the Cincinnati Commercial. Boca Raton: University Press of Florida, 1980.

Currarino, Rosanne. The Labor Question in America: Economic Democracy in the Gilded Age. Urbana: University of Illinois Press, 2011.

Currie, David P. The Constitution in Congress: Democrats and Whigs, 1829-1861. Chicago: Chicago University Press, 2005. 
Curry, Leonard. Blueprint for Modern America: Nonmilitary Legislation of the First Civil War Congress. Nashville: Vanderbilt University Press, 1968.

Dailey, Jane and Bryant Simone, eds.. Jumpin' Jim Crow: Southern Politics from Civil War to Civil Rights. Princeton: Princeton University Press, 2000.

Davidson, Rondel V. "Victor Considerant and the Failure of La Réunion." The Southwestern Historical Quarterly 76, no. 3 (Jan., 1973): 277-296.

Davis, Hugh. "We Will Be Satisfied With Nothing Less:” The African American Struggle for Equal Rights in the North During Reconstruction. Ithaca: Cornell University Press, 2011.

Davis, Thomas J. John Calvin's American Legacy. New York: Oxford University Press, 2010.

Davis, Rodney O. and Douglas L. Wilson, eds. The Lincoln-Douglas Debate. Urbana and Chicago: Knox College Lincoln Center and University of Illinois Press, 2008.

Dawson, Andrew. "Reassessing Henry Carey (1793-1879): The Problems of Writing Political Economy in Nineteenth Century in Nineteenth-Century America." Journal of American Studies 34, no. 3 (Dec., 2000): 465-485.

Dauphine, James G. "The Knights of the White Camelia and the Election of 1868: Louisiana's White Terrorists." Louisiana Territory: The Journal of the Louisiana Historical Association 30, no. 2 (Spring 1989): 173-190.

De Céspedes, Carlos Manuel and Fernando Portuondo, ed. Escritos, vol. 1. Havana: Editorial de Ciencias Sociales, 1974.

De la Cova, Antonio Rafael. "Cuban Exiles in Key West during the Ten Years' War, 1868-1878," The Florida Historical Quarterly 89, no. 3 (Winter 2011): 287-319.

DeCanio, Samuel. Democracy and the Origins of the American Regulatory State. New Haven: Yale University Press, 2015.

DeCaro Jr., Louis A. Fire From the Midst of You: A Religious Life of John Brown. New York: New York University Press, 2002.

Delano, Sterling. "French Utopianism on American Soil: Six Unpublished Letters by Victor Considerant." Nineteenth-Century French Studies 13, no. 2/3 (Winter-Spring, 1985): 59-64.

—. Toward a Genealogy of Transcendentalism. Athens: University of Georgia Press, 2014.

Dennis, Matthew. Seneca Possessed. Philadelphia: University of Pennsylvania Press, 2010.

- Dreams, Dreamers, and Visions: The Early Modern Atlantic World. Philadelphia: University of Pennsylvania Press, 2013. 
Dibble, Ernest F. "'We Could Have Sent the Old Barbarian Back to the Hermitage': Joseph M. White and Anti-Jacksonianism in Territorial Florida, 1821 - 1839." The Florida Historical Quarterly 75, no. 2 (Fall, 1996): 167 - 182).

Dickinson, Edwin D. "The Law of Nations as Part of the National Law of the United States." University of Pennsylvania Law Review 101, no. 1 (Oct., 1952): 26 - 56.

Diethe, Carol. Exiles from European Revolutions: Refugees in Mid-Victorian England. Berghan Books, 2003.

Di Nunzio, Mario N. "Lyman Trumbull, the States' Rights Issue, and the Liberal Republican Revolt.” Journal of Illinois State Historical Society 66, no. 4 (Winter, 1973): 364 - 375.

Dodd, Dorothy. "Henry J. Raymond and the New York Times during Reconstruction," PhD diss., University of Chicago, 1933.

Donald, David, ed. Inside Lincoln's Cabinet: The Civil War Diaries of Salmon P. Chase. New York: Longmans, Green and Company, 1954.

- The Politics of Reconstruction, 1863-1867. Baton Rouge, Louisiana State University Press, 1965.

Dowling, David. Emerson's Protégés: Mentoring and Marketing Transcendentalism's Future. New Haven: Yale University Press, 2014.

Downs, Gregory P. Declarations of Dependence: The Long Reconstruction of Popular Politics in the South, 1861-1908. Chapel Hill: University of North Carolina Press, 2011.

—. "The Mexicanization of American Politics: The United States' Transnational Path from Civil War to Stabilization." American Historical Review 117 (April 2012): 387- 409.

- The Politics of Reconstruction, 1863-1867. Baton Rouge, Louisiana State University Press, 1965.

- After Appomattox: Military Occupation and the Ends of War. Cambridge: Harvard University Press, 2015. . and Kate Masur. The World the Civil War Made. Chapel Hill: University of North Carolina Press, 2015.

Dowty, Alan. The Limits of American Isolation: The United States And The Crimean War. New York: New York University Press, 1971.

Doyle, Don H. The Cause of All Nations: An International History of the American Civil War. New York: Basic Books, 2015.

—., Jörg Nagler and Marcus Gräser. The Transnational Significance of the American Civil War. Basingstroke: Palgrave-MacMillan, 2016. 
ed. American Civil Wars: The United States, Latin America, Europe, and the Crisis of the 1860s. Chapel Hill: University of North Carolina Press, 2017.

Drescher, Seymour. “John Brown's Body in Europe.” In His Soul Goes Marching On: Responses to John Brown and the Harper's Ferry Raid, edited by Paul Finkelman. Charlottesville: University Press of Virginia, 1995.

Dudden, Faye E. Fighting Chance: The Struggle over Women's Suffrage and Black Suffrage in Reconstruction America. New York: Oxford University Press, 2011.

Dueholm, James A. "Lincoln's Suspension of the Writ of Habeas Corpus: An Historical and Constitutional Analysis." Journal of the Abraham Lincoln Association 29, no. 2 (Summer 2008): $47-66$.

Duran, Jane. "Margaret Fuller and Transcendental Feminism." The Pluralist, 5, no. 1 (Spring 2010): $65-72$.

Durden, Robert F. James Shepard Pike: Republicanism and the American Negro, 1850 - 1882. Durham: Duke University Press, 1957.

Durning, Russell E. "Margaret Fuller's Translation of Goethe's "Prometheus." Harbuch für Amerikastudien 12 (1967): 240-245.

Earle, Johnathan H. Jacksonian Antislavery \& the Politics of Free Soil, 1824-1854. Chapel Hill: University of North Carolina Press, 2004.

- Bleeding Kansas, Bleeding Missouri: The Long Civil War on the Border. Lawrence: University of Kansas, 2013.

Echard, William E. "Conference Diplomacy in the German Policy of Napoleon III, 1868-1869." French Historical Studies 4, no. 3 (Spring, 1966).

- Napoleon III and the Concert of Europe. Baton Rouge: Louisiana State University Press, 1983.

Edling, Max. A Hercules in the Cradle: War, Money, and the American State, 1783 - 1867. Chicago: The University of Chicago Press, 2015.

Edmunds, Sterling E. "The Law of Nations: A Science That Has Stood Still." Virginia Law Review 14, no. 1 (Nov., 1927), 19-30.

Edsall, Nicolas. Richard Cobden: Independent Radical. Cambridge: Harvard University Press, 2014.

Edwards, Rebecca. New Spirits: Americans in the “Gilded Age.” Oxford: Oxford University Press, 2015.

Egerton, Douglas R. The Wars of Reconstruction: The Brief, Violent History of America's Most Progressive Era. New York: Bloomsbury Press, 2014. 
Egnal, Marc. "The Beards Were Right: Parties in the North, 1840-1860." Civil War History 47, no. 1 (March 2001): 30-56.

Eisenhower, John S.D. So Far From God: The U.S. War With Mexico, 1846-1848. New York: Random House, 1989.

Emberton, Carole. "Defining Postwar Republicanism: Congressional Republicans and the Boundaries of Citizenship.” In The Republicans' First Generation, edited by Robert F. Engs and Randall M. Miller, 128-147. Philadelphia: University of Pennsylvania Press, 2011.

- Beyond Redemption, Race, Violence, and the American South after the Civil War. Chicago: University of Chicago Press, 2013.

Embree, Michael. Bismarck's First War: The Campaign of Schleswig and Jutland 1864. Solihull: Helion, 2006.

Engs, Robert F. and Randall M. Miller. The Republicans' First Generation. Philadelphia: University of Pennsylvania Press, 2011.

Erie, Steven. Rainbow's End: Irish-Americans and the Dilemmas of Machine Politics, 18401985. Berkeley: University of California Press, 1988.

Escott, Paul D. North Carolinians in the Era of the Civil War and Reconstruction. Chapel Hill: The University Press of North Carolina, 2008.

Esh, Christian. "Martin Van Buren as Statesman: States Rights and the Rise of the 'Free Soil' Party." In Constitutionalism in the Approach and Aftermath of the Civil War, edited by Paul D. Moreno and Johnathan O’Neill. New York: Fordham University Press, 2013.

Eyal, Yonatan. The Young America Movement and the Transformation of the Democratic Party, 1828-61. New York: Cambridge University Press, 2007.

Farber, Daniel A. Lincoln's Constitution. Chicago: The University of Chicago Press, 2011.

Farmer-Kaiser, Mary. Freedwomen and the Freedmen's Bureau. Fordham University Press, 2010.

Faulkner, Carol. Women's Radical Reconstruction: the Freedmen's Aid Movement. Philadelphia: University of Pennsylvania Press, 2006.

Fellman, Michael. The Unbounded Frame: Freedom and Community in Nineteenth Century American Utopianism. Westport: Greenwood Press, 1973.

- In the Name of God and Country: Reconsidering Terrorism in American History. New Haven: Yale University Press, 2010. 
Fenton, Laurence. Palmerston and The Times: Foreign Policy, The Press and Public Opinion in mid-Victorian Britain. London: I.B. Tauris, 2013.

—. Frederick Douglass in Ireland: the “Black O'Connell.” Leicester: Thorpe, 2015.

Ferrer, Ada and M. Ferrandis Gerrayo, "Esclavitud, Ciudanía, los Límites de la Nacioladidad Cubana: la Guerra de los Diez Años.” Historia Social 22 (1995).

- Insurgent Cuba: Race, Nation, and Revolution, 1868-1898. Chapel Hill: University of North Carolina, 1999.

_. "Armed Slaves and Anticolonial Insurgency in Late Nineteenth-Century Cuba." In Arming Slaves: From Classical Times to the Modern Age, edited by Christopher Leslie Brown and Philip D. Morgan, 304 - 329. New Haven: Yale University Press, 2006.

Ferrie, Joseph P. Yankees Now: Immigrants in the Antebellum United States, 1840 - 1860. New York: Oxford University Press, 1999.

Ferris, Norman B. Desperate Diplomacy: William H. Seward's Foreign Policy, 1861. Knoxville: University of Tennessee Press, 1976.

Filler, Louis. The Muckrakers. University Park: Pennsylvania State University, 1976.

Fink, Leon. The Long Gilded Age. Philadelphia: University of Pennsylvania Press, 2015.

Flandreau, Marc and Juan H. Flores, "The Peaceful Conspiracy: Bond Markets and International Relations During the Pax Britannica.” International Relations 66, no. 2 (Spring 2012): $211-241$.

Fleche, Andre M. The Revolution of 1861: The American Civil War in the Age of Nationalist Conflict. Chapel Hill: Univ. of North Carolina Press, 2012.

Flint, Kate. The Transatlantic Indian, 1776-1930. Princeton: Princeton University Press, 2008.

Folts, James D. "The Fanatic and the Prophetess: Religious Perfectionism in Western New York, 1835-1839." New York History 72, no. 4 (October 1991): 357-387.

Foner, Eric. "The Wilmot Proviso Revisited." The Journal of American History 56, no. 2 (Sep., 1969): 262-279.

- "Why Is There No Socialism in the United States?" History Workshop 17 (Spring, 1984).

- Reconstruction: America's Unfinished Revolution, 1863-1877. New York: Harper and Row, 1988.

- Nothing But Freedom: Emancipation and Its Legacy. Baton Rouge: Louisiana State University Press, 1993. 
- Free Soil, Free Labor, Free Men: The Ideology of the Republican Party Before the Civil War. New York: Oxford University Press, 1995.

Foner, Philip. A History of Cuba and Its Relations with the United States, 2 vols. New York, 1962.

Formisano, Ronald P. For The People: American Populist Movements from the Revolution to the 1850s. Chapel Hill: University of North Carolina Press, 2008.

Förster, Stig and Jörg Nagler, eds. On The Road To Total War: The American Civil War and the German Wars of Unification, 1861-1871. New York: Cambridge University Press, 1997.

Fowler, William M. Steam Titans: Cunard, Collins, and the Epic Battle for Commerce on the North Atlantic. New York: Bloomsbury Press, 2017.

Franco, José Luciano. La Revolución de Yara y la Constituyente de Gúaimaro. Cárdenas, Cuba, 1950.

Franklin, John Hope. Reconstruction: After the Civil War. Chicago: University of Chicago Press, 1961.

Frasca, Ralph. The Rise and Fall of the Saturday Globe. Selinsgrove: Susquehanna University Press, 1992.

Freeman, Joanne. The Field of Blood: Violence in Congress and the Road to Civil War. New York: Farrar, Straus and Giroux, 2018.

Frei, Hans W. ed. The Eclipse of Biblical Narrative: A Study in Eighteenth and Nineteenth Century Hermeneutics. New Haven: Yale University Press, 1980.

Freitag, Sabine. Exiles from European Revolutions: Refugees in Mid-Victorian England. Berghahn Books, 2003.

Fry, Joseph A. Dixie Looks Abroad: the U.S. South and U.S. Foreign Relations, $1789-1973$. Baton Rouge: Louisiana State University, 2002.

Fuller, A. James. The Election of 1860 Reconsidered. Kent: Kent State University Press, 2013.

Gabaccia, Donna R. Foreign Relations: American Immigration in Global Perspective. Princeton: Princeton University Press, 2012.

Gambill, Edward L. Conservative Ordeal: Northern Democrats and Reconstruction, 1865-1869. Ames: Iowa State University, 1981.

Gardbaun, Stephen. "The Myth and the Reality of American Constitutional Exceptionalism." Michigan Law Review 107, no. 3 (Dec., 2008): 391-466.

Garrett, Clarke. "Swedenborg and the Mystical Enlightenment in Late Eighteenth-Century England." Journal of the History of the Ideas 45, no.1 (Jan., - Mar., 1984): 67 - 81. 
Gemme, Paola. Domesticating Foreign Struggles: The Italian Risorgimento and antebellum American Identity. Athens: University of Georgia Press, 2012.

Gerber, David A. The Making of an American Pluralism: Buffalo, New York, 1825-60. Champaign: University of Illinois Press, 1989.

Gerber, Larry G. "Shifting Perspectives on American Exceptionalism: Recent Literature on American Labor Relations and Labor Politics." Journal of American Studies 31, no. 2 (Aug., 1997): 253-274.

Gerber, Richard Allen. "The Liberal Republicans of 1872 in Historiographical Perspective." The Journal of American History 62, no. 1 (June 1975): 40-73.

Gerrish, B.A. A Prince of the Church: Schleiermacher and the Beginnings of Modern Theology. Eugene: Wipf and Stock, 2001.

Gerteis, Louis. "Salmon P. Chase, Radicalism, and the Politics of Emancipation, 1861 - 1864." Journal of American History 60, no. 1 (June 1973).

Gertz, Elmer. "Charles A. Dana and the Chicago Republican." Journal of the Illinois State Historical Society 45 (1962).

Geyer, Michael and Charles Bright. "World History in a Global Age." American Historical Review 100 (1995): 1034-1060.

Gienapp, William E. The Origins of the Republican Party, 1852-1856. New York: Oxford University Press, 1987.

Giladi, Rotem. "Francis Lieber on Public War." Gottingen Journal of International Law 4 (2012) $2,447-477$.

Gillette, William. Right to Vote: Politics and the Passage of the Fifteenth Amendment. Baltimore: Johns Hopkins University Press, 1965.

- Retreat from Reconstruction, 1869-1879. Baton Rouge: Louisiana State Univ. Press, 1979.

Gilmore, Michael T. American Romanticism and the Marketplace. Chicago: University of Chicago Press, 1985.

Gilpin, R. Blakeslee. John Brown Still Lives!: America's Long Reckoning with Violence, Equality, and Change. Chapel Hill: University of North Carolina Press, 2011.

Gilpin, Robert. The Political Economy of International Relations. Princeton: Princeton University Press, 1987.

Glasco, Laurence. "Migration and Adjustment in the Nineteenth-Century City: Occupation, Property, and Household Structure of Native-born Whites, Buffalo, New York, 1855." In 
Family and Population in $19^{\text {th }}$ Century America, edited by Hareven and Vinovskis. Princeton: Princeton University Press, 1978.

Gleeson, David T. and Simon Lewis, eds. The Civil War as Global Conflict: Transnational Meanings of the American Civil War. Columbia: University of South Carolina Press, 2014.

Glickstein, Jonathan A. American Exceptionalism, American Anxiety: Wages, Competition, and Degraded Labor in the Antebellum United States. Charlottesville: University of Virginia Press, 2002.

Goddard, Stacie E. "When Might Makes Right: How Prussia Overturned the European Balance of Power." International Security 33 no. 3 (Winter 2008/2009): 110-142.

Goff, Patricia Mary. "Invisible Borders: Economic Liberalization and National Identity," International Studies Quarterly 44, no. 4 (2000): 533-562.

Gohdes, Clarence. "Getting Ready for Brook Farm.” Modern Language Notes 49, no. 1 (Jan., 1934): 36-39.

Goldin, Claudia D. and Frank D. Lewis. "The Economic Cost of the American Civil War: Estimates and Implications" Journal of Economic History 35 (1970): 299 - 326.

Golway, Terry. Machine Made: Tammany Hall and the Creation of Modern American Politics. New York: W.W. Norton/Liveright Publishing, 2014.

González Barrios, Réne. Los Capitanes Generals en Cuba (1868 -1878). Havana: Ediciones Verde Olivo, 1999.

Goodheart, Lawrence B. Abolitionist, Actuary, Atheist: Elizur Wright and the Reform Impulse. Kent: Kent State University Press, 1990.

Goodman, Paul. "The Emergence of Homestead Exemption in the United States: Accommodation and Resistance to the Market Revolution, 1840 - 1880." The Journal of American History 80, no. 2 (Sept., 1993): 470-498.

Goodwin, Daniel C. Into Deep Waters: Evangelical Spirituality and Maritime Calvinistic Baptist Ministers, 1790-1855. Montreal: McGill-Queen's University Press, 2010.

Gordon, Robert J. The Rise and Fall of American Growth: The U.S. Standard of Living since the Civil War. Princeton: Princeton University Press, 2016.

Goss, Thomas J. The War for the Union High Command. Lawrence: University Press of Kansas, 2003.

Gould, Eliga H. Among the Powers of the Earth: The American Revolution and the Making of a New World Empire. Cambridge: Harvard University Press, 2012. 
Gourevitch, Alex. From Slavery to the Cooperative Commonwealth: Labor and Republican Liberty in the Nineteenth Century. Cambridge: Cambridge University Press, 2014.

Gräser, Marcus, "World History in a Nation-State: The Transnational Disposition in Historical Writing in the United States." The Journal of American History 95, no. 4 (Mar., 2009): 1038-1052.

Green, Arnold W. Henry Charles Carey: Nineteenth Century Sociologist. Philadelphia: University of Pennsylvania Press, 1951.

Green, Hilary. Education Reconstruction: African American Schools in the Urban South, 18651890. Fordham University Press, 2016.

Green, Michael S. Freedom, Union, and Power: Lincoln and His party in the Civil War. New York: Fordham University Press, 2004.

- Lincoln and the Election of 1860. Carbondale: Southern Illinois University Press, 2011.

Greenberg, Amy. A Wicked War: Polk, Clay, Lincoln, and the 1846 U.S. Invasion of Mexico. New York: Knopf, 2012.

Greenberg, Ethan. Dred Scott and the Dangers of a Political Court. Lanham: Lexington Books, 2010.

Greenberg, Joshua R. "'Powerful—Very Powerful is the Parental Feeling”: Fatherhood, Domestic Politics, and the New York City Working Men's Party." Early American Studies 2, no. 1 (Spring 2004): $192-227$.

Greenstone, J. David. The Lincoln Persuasion: Remaking American Liberalism. Princeton: Princeton University Press, 1993.

Gregory, James N. The Southern Diaspora: How the Great Migrations of Black and White Southerners Transformed America. Chapel Hill: University of North Carolina Press, 2007.

Grinde, Donald A. and Quintard Taylor. "Red vs. Black: Conflict and Accommodation in the Post-Civil War Indian Territory, 1965-1907.” American Indian Quarterly 8, no. 3 (Summer 1984).

Grinspan, Jon. "Young Men For War," The Wide Awakes and Lincoln's 1860 Presidential Campaign." The Journal of American History 96, no. 2 (Sep., 2009): 357-378.

- The Virgin Vote: How Young Americans Made Democracy Social, Politics Personal, and Voting Popular in the Nineteenth Century. Chapel Hill: University of North Carolina, 2017.

Grossman, Lawrence. The Democratic Party and the Negro: Northern and National Politics, 1868-1892. Urbana: University of Illinois Press, 1976. 
Grove, John G. John C. Calhoun's Theory of Republicanism. Lawrence: University Press of Kansas, 2016.

Grusin, Richard A. Transcendentalist Hermeneutics: Institutional Authority and the Higher Criticism of the Bible. Durham: Duke University Press, 1990.

Guardino, Peter. A Dead March: A History of the Mexican-American War. Cambridge: Harvard University Press, 2017.

Guarneri, Carl J. "Utopian Socialism as a Transatlantic Movement," paper presented to Charles Warren Seminar for Boston Area Historians of American History, Harvard Univ., April 7, 1982.

- The Utopian Alternative: Fourierism in Nineteenth-Century America. Ithaca: Cornell University Press, 1994.

_. "Reconstructing the Antebellum Communitarian Movement: Oneida and Fourierism." Journal of the Early Republic 16, no. 3 (Autumn, 1996): 463-488.

Guerra y Sanchez. Guerra de Loz Diez Años, 1868-1878, 2 vols. Habana, 1950.

Guterl, Matthew Pratt. American Mediterranean: Southern Slaveholders in the Age of Emancipation. Cambridge: Harvard University Press, 2008.

Gutman, Herbert. Work, Culture, and Society in Industrializing America. New York: Verso, 1976.

Guyatt, Nicholas. "America's Conservatory: Race, Reconstruction, and the Santo Domingo Debate.” Journal of American History 97 (March 2011): 974-1000.

Hahamovitch, Cindy. The Fruits of their Labor: Atlantic Coast Farmworkers and the Making of Migrant Poverty, 1870-1945. Chapel Hill: University of North Carolina Press, 1997.

Hahn, Stephen. A Nation Under Our Feet: Black Political Struggles in the Rural South from Slavery to the Great Migration. Cambridge: Belknap Press of Harvard University Press, 2003.

- A Nation Without Borders: The United States and Its World in an Age of Civil Wars, 1830 - 1910. New York: Penguin Books, 2017.

Halmi, Nicholas. “Coleridge's Ecumenical Spinoza.” In Spinoza Beyond Philosophy, by Beth Lord. Edinburgh: University of Edinburgh, 2012.

Hanagan, Michael. "Response to Sean Wilentz, 'Against Exceptionalism: Class Consciousness and the American Labor Movement, 1790 - 1920." International Labor and WorkingClass History 26 (Fall, 1984): 31 - 36.

Hanlon, Christopher. America's England: Antebellum Literature and Atlantic Sectionalism. New York: Oxford University Press, 2013). 
Harlow, Ralph Volney. "The Rise and Fall of the Kansas Aid Movement.” The American Historical Review 41, no. 1 (Oct., 1935): 1-25.

Harris, William C. Two Against Lincoln: Reverdy Johnson and Horatio Seymour-Champions of the Loyal Opposition. Lawrence: University Press of Kansas, 2017.

Harrison, Brady. Agent of Empire: William Walker and the Imperial Self in American Literature. Athens: University of Georgia, 2004.

Harvey, A.D. "Was the American Civil War the First Modern War?" History 97, no. 2 (April 2012): $272-280$.

Harvey, Samantha C. Transatlantic Transcendentalism: Coleridge, Emerson and Nature. Edinburgh: Edinburgh University Press, 2013.

Hattam, Victoria C. Labor Visions and State Power: The Origins of Business Unionism in the United States. Princeton: Princeton University Press, 1993.

Hauhart, Robert C. " $19^{\text {th }}$ Century Labor Money Schemes, Self-Realization Through Labor, and the Utopian Idea." World Review of Political Economy 3, no. 2 (Summer 2012): 177 190.

Hawgood, John A. "John C. Frémont and the Bear Flag Revolution: A Reappraisal." Southern California Quarterly 44, no. 2 (June, 1962): 67 - 96.

Hazeltine, Mayo W. "Charles Anderson Dana." The North American Review 185, no. 618 (1907): 505-514.

Healy, David. James G. Blaine and Latin America. Columbia: University of Missouri Press, 2002.

Heath, Andrew. "'Let the Empire Come': Imperialism and the Reconstruction South." Civil War History 60, no. 2 (June 2014) 152-189.

Heidler, David and Jeanne. Henry Clay: the Essential American. New York: Random House, 2011.

Heinrici, Max. Das Buch Der Deutschen in Amerika. Philadelphia: Walther, 1909.

Heise, Bernard. Karl Marx: An Intellectual Biography. Translated by Rolf Hosfeld. New York: Bergahn Books, 2013.

Heizen, Jasper. "Transnational Affinities and Invented Traditions: The Napoleonic Wars in British and Hanoverian Memory, 1815-1915." The English Historical Review 127, no. 529 (December 2012): 1404-1434.

Helg, Aline. Our Rightful Share: The Afro-Cuban Struggle for Equality, 1886 - 1912. Chapel Hill: University of North Carolina Press, 2000. 
Helleiner, Eric. "Economic Nationalism as a Challenge to Neoliberalism? Lessons from the $19^{\text {th }}$ Century.” International Studies Quarterly 46, no. 3 (2002): 307-329

Helleiner, Eric. "Economic Liberalism and Its Critics: The Past as Prologue?" Review of International Political Economy 10, no. 4 (Nov., 2003): 685 - 696.

Henderson, W.O. "Friedrich List and the French Protectionists." Journal of Institutional and Theoretical Economics 138, no. 2 (Jun 1982): 262-275.

—. Friedrich List: Economist and Visionary, 1789-1846. London: Cass, 1983.

Henderson, W.O. and Hemel Hempstead, "Friedrich List and England." Journal of Economics and Statistics 203, no. 5/6 (October 1987): $532-546$.

Hendrickson, David C. Union, Nation, or Empire: the American Debate over International Relations, 1789 - 1941. Lawrence: University Press of Kansas, 2009.

Henson, D. Leigh. "Classical Rhetoric as a Lens for Reading the Key Speeches of Lincoln's Political Rise, 1852-1856." Journal of the Abraham Lincoln Association 35, no. 1 (Winter 2014): 1-25.

Hernandez, Jose M. Cuba and the United States: Intervention and Militarism, $1868-1933$. University of Texas Press, 2010.

Hettle, Wallace. The Peculiar Democracy: Southern Democrats in Peace and Civil War. Athens: University of Georgia Press, 2001.

Heuser, Beatrice. The Evolution of Strategy: Thinking War From Antiquity To The Present. New York: Cambridge University Press, 2010.

Hicks, Geoffrey. Peace, War, and Party Politics- The Conservatives and Europe, 1846-1859. Manchester: Manchester University Press, 2007.

Hilfrich, Fabian. Debating American Exceptionalism: Empire and Democracy in the Wake of the Spanish-American War. New York: Palgrave, 2012.

Hill, Michael. Elihu Washburne: The Diary and Letters of America's Minister to France During the Siege and Commune of Paris. New York: Simon and Schuster, 2012.

Hinde, Wendy. Richard Cobden: a Victorian Outsider. New Haven: Yale University Press, 1987.

Hirota, Hidetaka. Expelling the Poor: Atlantic Seaboard States and the Nineteenth Century Origins of American Immigration Policy. New York: Oxford University Press, 2017.

Ho, P. Sai-wing. "Distortions in the Trade Policy for Development Debate: A Re-examination of Friedrich List." Cambridge Journal of Economics 29, no. 5 (September 2005): 729 - 745.

Hobsbawn, Eric. The Age of Revolution: Europe, 1789 - 1848. London: Abacus, 1977. 
- The Age of Capital: 1848 - 1875. New York: Vintage, 1996.

Hodes, Martha. "The Sexualization of Reconstruction Politics: White Women and Black Men in the South After the Civil War." Journal of the History of Sexuality 3, no. 3 (January 1993): 402-417.

Hoffman, Elizabeth Cobbs. American Umpire. Cambridge: Harvard University Press, 2013.

Hofstadter, Richard. The American Political Tradition and the Men Who Made It. New York, 1948.

- The Age of Reform: from Bryan to F.D.R. New York: Alfred A. Knopf, 1955).

- The Paranoid Style in American Politics and Other Essays. New York: Vintage Books, 1967.

Holifield, E. Brooks. Theology in America: Christian Thought from the Age of the Puritans to the Civil War. New Haven: Yale University Press, 2003.

Holmes, Richard. Coleridge. New York: Pantheon Books, 1999.

Holt, Michael F. The Political Crisis of the 1850s. New York: Wiley, 1978.

- Political Parties and American Political Development: From the Age of Jackson to the Age of Lincoln. Baton Rouge: Louisiana State University Press, 1992.

- The Rise and Fall of the American Whig Party: Jacksonian Politics and the Onset of the Civil War. New York: Oxford University Press, 1999.

—_. "A Time of Uncertainty: The Civil War Era and America's Two-Party System," 42 nd Annual Robert Fortenbaugh Memorial Lecture. Gettysburg College, 2003.

Honeck, Mischa. We Are the Revolutionists: German-Speaking Immigrants and American Abolitionists after 1848. Athens: University of Georgia, 2011.

Horne, Alistair. The Fall of Paris: The Siege and the Commune, 1870-71. New York: St. Martin's Press, 1966.

Horne, Gerald. Confronting Black Jacobins: The U.S., the Haitian Revolution, and the Origins of the Dominican Republic. New York University Press, 2015.

Horton, Carol. A. Race and the Making of American Liberalism. New York: Oxford University Press, 2005.

House, Albert V. "Republicans and Democrats Search for New Identities, 1870 - 1890." The Review of Politics 31, no. 4 (Oct., 1969): 466 - 476. 
Hovenkamp, Herbert. "Regulatory Conflict in the Gilded Age: Federalism and the Railroad Problem.” The Yale Lay Journal 97, no. 6 (May, 1988): 1017 - 1072.

Howard, Michael. The Franco-Prussian War: The German Invasion of France, 1870-1871. New York: MacMillan, 1962.

Howard, Thomas A. Religion and the Rise of Historicism: W.M.L. de Wette, Jacob Burckhardt, and the Theological Origins of Nineteenth-Century Historical Consciousness. New York: Cambridge University Press, 1999.

Howard, Victor B. Religion and the Radical Republican Movement, 1860-1870. Lexington: University Press of Kentucky, 1990.

Howe, Anthony. Free Trade and Liberal England, 1846 - 1946. Oxford, Oxford University Press, 1997.

—. "Free Trade and Global Order: The Rise and Fall of a Victorian Vision," in Victorian Visions of a Global Order, edited by Duncan S.A. Bell. Cambridge: Harvard University Press, 2007.

Howe, Daniel Walker. The Unitarian Conscience: Harvard Moral Philosophy, 1805 - 1861. Cambridge: Harvard University Press, 1970.

- The Political Culture of the American Whigs. Chicago: University of Chicago Press, 1979.

Howe, Irving. Socialism and America. San Diego: Harcourt Brace, 1985.

Hsieh, Wayne Wei-Siang. "Total War and the American Civil War Reconsidered: The End of an Outdated 'Master Narrative.'" Journal of the Civil War Era 1, no. 3 (September 2011): $394-408$.

Hugill, Peter J. "The American Challenge to British Hegemony, 1861-1947.” Geographical Review 99, no. 3 (July 2009): 403-425.

Huston, James L. "A Political Response to Industrialism: The Republican Embrace of Protectionist Labor Doctrines." The Journal of American History 70, no. 1 (June 1983): $35-57$.

Huston, Reeve. "The Parties and 'The People': The New York Anti-Rent Wars and the Contours of Jacksonian Politics." Journal of the Early Republic 20, no. 2 (Summer 2000): 241-271.

Hume, Richard L. and Jerry B. Gough. Blacks, Carpetbaggers, and Scalawags: The Constitutional Conventions of Radical Reconstruction. Baton Rouge: Louisiana State University Press, 2008.

Huzzey, Richard. Freedom Burning: Anti-Slavery and Empire in Victorian Britain. Ithaca: Cornell University Press, 2012. 
Isabella, Maurizio and Konstantina Zanou, Mediterranean Diasporas: Politics and Ideas in the Long $19^{\text {th }}$ Century. London: Bloomsbury Academic, 2016.

Jacobson, Matthew Frye. Whiteness Of A Different Color: European Immigrants and the Alchemy of Race. Cambridge: Harvard University Press, 1999.

Jacoby, Sanford M. Masters to Managers: Historical and Comparative Perspectives on American Employers. New York: Columbia University Press, 1991.

James, Scott C. and Brian C. Lawson. "The Political Economy of Voting Rights Enforcement in America's Gilded Age: Electoral College Competition, Partisan Commitment, and the Federal Election Law.” The American Political Science Review 93, no. 1 (Mar., 1999): $115-131$.

Janis, Ely M. A Greater Ireland: The Land League and Transatlantic Nationalism in Gilded Age America. Madison: University of Wisconsin Press, 2015.

Jenkins, Lloyd. "Fourierism, Colonization and Discourses of Associative Emigration." Area 35, no. 1 (Mar., 2003): 84-91.

Jentz, John B. and Richard Schneirov. Chicago in the Age of Capital: Class, Politics, and Democracy during the Civil War and Reconstruction. Urbana: University of Illinois Press, 2015.

Jiménez, Hugo Murillo. "La Controversia de Limites entre Costa Rica Y Nicaragua. El Laudo Cleveland y los Derechos Canaleros, 1821-1903." Anuario de Estudios Centroamericanos 12, no. 2 (1986): 45-58.

Johnson, Curtis D. Islands of Holiness: Rural Religion in Upstate New York, 1790-1860. Ithaca: Cornell University Press, 1989.

Johnson, Kendall. The New Middle Kingdom: China and the Early American Romance of Free Trade. Baltimore: Johns Hopkins University Press, 2017.

Johnson, Martin P. The Paradise of Association: Political Culture and Popular Organizations in the Paris Commune of 1871. Ann Arbor: University of Michigan Press, 1996.

Johnson, Paul E. A Shopkeeper's Millennium: Society and Revivals in Rochester, New York, 1815-1837. New York: Hill and Wang, 2004.

Jordan, Ryan. "Quakers, 'Comeouters,' and the Meaning of Abolitionism in the Antebellum Free States." Journal of the Early Republic 24, no. 4 (Winter, 2004): 587-608.

Jones, Peter. The 1848 Revolutions. London: Routledge, 2014.

Juergens, George. Joseph Pulitzer and the New York World. Princeton: Princeton University Press, 1966. 
Jung, Moon-Ho. Coolies and Cane: Race, Labor, and Sugar in the Age of Emancipation. Baltimore: Johns Hopkins University Press, 2006.

Kaczorowski, Robert J. "To Begin the Nation Anew: Congress, Citizenship, and Civil Rights after the Civil War.” American Historical Review 92 (February 1987): 45-68.

- The Politics of Judicial Interpretation: The Federal Courts, Department of Justice, and Civil Rights, 1866 -1876. New York: Fordham University Press, 2005.

Kammen, Michael. "The Problem of American Exceptionalism: A Reconsideration." American Quarterly 45 (1993): 1-43.

Kantrowitz, Stephen. More Than Freedom: Fighting for Black Citizenship in a White Republic, 1829-1889. New York: Penguin, 2012.

Kaplan, A.D.H. Henry Charles Carey. Baltimore: Johns Hopkins University Press, 1931.

Kaplan, Amy. The Anarchy of Empire in the Making of U.S. Culture. Cambridge: Harvard University Press, 2002.

Kaplan, Richard L. Politics and the American Press: The Rise of Objectivity, $1865-1920$. New York: Cambridge University Press, 2002.

Kasaba, Resat. The Ottoman Empire and the World Economy: the Nineteenth Century. Albany: State University of New York Press, 1988.

Katz, Phillip Mark. From Appomattox to Montmartre: Americans and the Paris Commune. Cambridge: Harvard University Press, 1998.

Katznelson, Ira and Martin Shefter, eds. International Influences on American Political Development. Princeton: Princeton University Press, 2002.

Keil, Hartmut. "Francis Lieber's Attitudes on Race, Slavery, and Abolition." Journal of American Ethnic History 28, no. 1 (Fall 2008): 13 - 33.

Kellow, Geoffey C. and Neven Leddy, eds. On Civic Republicanism: Ancient Lessons for Global Politics. Toronto: University of Toronto Press, 2016.

Kennan, George F. The Decline of Bismarck's European Order: Franco-Russian Relations, 18751890. Princeton: Princeton University Press, 1979.

Kidd, Thomas. The Great Awakening: The Roots of Evangelical Christianity in Early America. New Haven: Yale University Press, 2007.

Kilbride, Daniel. Being American in Europe, 1750-1860. Baltimore: The Johns Hopkins University Press, 2013.

Kloppenberg, James T. Uncertain Victory: Social Democracy and Progressivism in European and American Thought, 1870-1920. New York: Oxford University Press, 1986. 
Knight, Franklin. Slave Society in Cuba during the Nineteenth Century. Madison: University of Wisconsin Press, 1986.

Koeppel, Gerard. Bond of Union: Building the Erie Canal and the American Empire. Cambridge: Da Capo Press, 2009.

Mach, Thomas S. "Gentleman George” Hunt Pendleton: Party Politics and Ideological Identity in Nineteenth-Century America. Kent: Kent State University Press, 2007.

Maihafer, Harry J. The General and the Journalists. London: Brasseys, 1998.

Maizlish, Stephen E. "Salmon P. Chase: The Roots of Ambition and the Origins of Reform." Journal of the Early Republic 18, no. 1 (Spring, 1998): 47 - 70.

Maltz, Earl M. The Fourteenth Amendment and the Law of the Constitution. Durham: Carolina Academic Press, 2003.

Mandel, Bernard. Labor, Free and Slave: Workingmen and the Anti-Slavery Movement in the United States. New York: Associated Authors, 1955.

Mantell, Martin E. Johnson, Grant, and the Politics of Reconstruction. New York: Columbia University Press, 1973.

Margolies, Daniel S. Henry Watterson and the New South. Lexington: University of Kentucky, 2006.

Mariña, Jacqueline. The Cambridge Companion to Friedrich Schleiermacher. New York: Cambridge University Press, 2005.

Markovits, Stefanie. The Crimean War and the British Imagination. Cambridge: Cambridge University Press, 2009.

Marques, Leonardo. The United States and the Transatlantic Slave Trade to the Americas, 1776 1867. New Haven: Yale University Press, 2016.

Marsden, George. The Soul of the American University: From Protestant Establishment to Established Nonbelief. New York: Oxford University Press, 1994.

Martin, David L. "When Lincoln Suspended Habeas Corpus." American Bar Association Journal 60, no. 1 (January 1974): 99-102.

Marvel, William. Lincoln's Autocrat: The Life of Edwin Stanton. Chapel Hill: The University of North Carolina Press, 2015.

Marx, Karl and Friedrich Engels., ed. Andrew Zimmerman, The Civil War in the United States. New York: International Publishing Company, 2016.

Marx, Karl and Friedrich Engels. Collected Works. New York: International Publishers, 1975. 
Massey, Douglas S. "Globalization and Inequality: Explaining American Exceptionalism." European Sociological Review 25, no. 1 (February 2009): 9-23.

Masur, Kate. An Example for All the Land: Emancipation and the Struggle over Equality in Washington, D.C. Chapel Hill: University of North Carolina Press, 2010.

May, Robert E., ed., The Union, the Confederacy, and the Atlantic Rim. West Lafayette: Purdue University Press, 1996.

- Manifest Destiny's Underworld: Filibustering in Antebellum America. Chapel Hill: University of North Carolina Press, 2002.

Mazaar, Michael J. Semper Fidel, America and Cuba, 1776-1988. Baltimore: Johns Hopkins University Press, 1988.

McCaffrey, James M. Army of Manifest Destiny: the American Soldier in the Mexican-American War, 1846-1848. New York: New York University Press, 1992.

McCammon, Holly J. "The Politics of Protection: State Minimum Wage and Maximum Hour Laws for Women in the United States, 1870 - 1930.” The Sociological Quarterly 36, no. 2 (Spring, 1995): $217-249$.

McClellan, David. The Young Hegelians and Karl Marx. New York: Praeger, 1969.

McClintock, Russell. Lincoln and the Decision for War: The Northern Response to Secession. Chapel Hill: University of North Carolina Press, 2008.

McCormick, Richard P. The Second American Party System: Party Formation in the Jacksonian Era. Chapel Hill: University of North Carolina Press, 1966.

- The Presidential Game: The Origins of American Presidential Politics. New York: Oxford University Press, 1982.

McCoy, Drew R. Elusive Republic: Political Economy in Jeffersonian America. Chapel Hill: University of North Carolina Press, 2012.

McCurry, Stephanie. Confederate Reckoning: Power and Politics in the Civil War South. Cambridge: Harvard University Press, 2010.

McCusker, John J. "The Demise of Distance: The Business Press and the Origins of the Information Revolution in the Early Modern Atlantic World." The American Historical View 110, no. 2 (April, 2005): 295-321.

McCullough, Stephen. "Foreshadowing of Informal Empire: Ulysses S. Grant and Hamilton Fish's Caribbean Policy, 1869 - 1877.” PhD. diss., University of Alabama, 2007.

McDaniel, W. Caleb. The Problem of Democracy in the Age of Slavery: Garrisonian Abolitionists and Transatlantic Reform. Baton Rouge: Louisiana State University Press, 2013. 
McFarland, Gerald W. Mugwumps, Morals \& Politics, 1884-1920. Amherst: University of Massachusetts Press, 1975.

McFeely, William S. Grant: A Biography. New York: Norton, 1982.

McGerr, Michael. The Decline of Popular Politics: The American North, 1865-1928. New York: Oxford University Press, 1986.

—_. "The Price of the New Transnational History." American Historical Review 96 (Oct. 1991): 1056-67.

McGinty, Brian. Lincoln and the Court. Cambridge: Harvard University Press, 2008.

McGreevy, Patrick V. Stairway to Empire: Lockport, the Erie Canal, and the Shaping of America. Albany: State University of New York Press, 2009.

McKitrick, Eric L. Andrew Johnson and Reconstruction. New York: Oxford University Press, 1988.

McPherson, Alan L. The Invaded: How Latin Americans and their Allies Fought and Ended U.S. Occupations. New York: Oxford University Press, 2013.

McPherson, James M. The Struggle for Equality: Abolitionists and the Negro in the Civil War and Reconstruction. Princeton: Princeton University Press, 1965.

—. "Grant or Greeley? The Abolitionist Dilemma in the Election of 1872." The American Historical Review 71, no. 1 (Oct., 1965): 43 - 61.

Mehta, Uday Singh. Liberalism and Empire: A Study in Nineteenth Century British Liberal Thought. Chicago: University of Chicago Press, 1999.

Mehta, N.J, Mehta, R.N. and I.A. Khan. "Austin Flint: Clinician, Teacher, and Visionary.” Texas Heart Institute Journal 27, no. 4 (2000) 386-389.

Meier, Kenneth J. and Thomas M. Holbrook. "'I Seen My Opportunities and I Took 'Em:' Political Corruption in the American States." The Journal of Politics 54 (February 1992): 133-55.

Merrill, Horace S. Bourbon Democracy of the Middle West, 1865-1896. Baton Rouge: Louisiana State University Press, 1953.

Messer-Kruse, Timothy. The Yankee International: Marxism and the American reform tradition, 1848 - 1876. Chapel Hill: University of North Carolina Press, 1998.

Mexal, Stephen J. Reading for Liberalism: the Overland Monthly and the Writing of the Modern American West. Lincoln: University of Nebraska Press, 2013. 
Milanovich, Branco. Global Inequality: A New Approach for the Age of Globalization. Cambridge: Belknap Press of Harvard University Press, 2016.

Miller, Bonnie M. From Liberation to Conquest: The Visual and Popular Cultures of the Spanish-American War of 1898. Amherst: University of Massachusetts Press, 2012.

Mirriam, George Mirriam. The Life and Times of Samuel Bowles. New York: Johnson, 1969.

Milton, Joyce. The Yellow Kids: Foreign Correspondents in the Heyday of Yellow Journalism. New York: Harper \& Row, 1989.

Mitchell, Edward P. Memoirs of an Editor: Fifty Years of American Journalism. New York: C. Scribner's Sons, 1924.

Moggach, Douglas. The Philosophy and Politics of Bruno Bauer. Cambridge: Cambridge University Press, 2003.

- The New Hegelians: Politics and Philosophy in the Hegelian School. New York: Cambridge University Press, 2006.

—_. "Bruno Bauer." The Stanford Encyclopedia of Philosophy (Winter 2017 Edition). https://plato.stanford.edu/archives/win2017/entries/bauer/.

- On Civil Republicanism: Ancient Lessons for Global Politics. Toronto: University of Toronto Press, 2016.

Mohr, James C. The Radical Republicans in New York during Reconstruction. Ithaca: Cornell University Press, 1973.

Montgomery, David. Beyond Equality: Labor and the Radical Republicans, 1862-1872. Urbana: University of Illinois Press, 1981.

- The Fall of the House of Labor: The Workplace, The State, and American Labor Activism, 1865-1925. Cambridge: Cambridge University Press, 1993.

Moore, R. Laurence. Religious Outsiders and the Making of Americans. New York: Oxford University Press, 1986.

Moreno, Paul D. and Johnathan O'Neill, eds. Constitutionalism in the Approach and Aftermath of the Civil War. New York: Fordham University Press, 2013.

Morgan, Edmund American Slavery, American Freedom: the Ordeal of Colonial Virginia. New York: Norton, 1975.

Morgan, Simon. "The Anti-Corn-Law League and British Anti-Slavery in Transatlantic Perspective, 1838 - 1846.” The Historical Journal 52, no. 1 (Mar., 2009): 87-107.

Morgan, Simon and Anthony Howe. Rethinking Nineteenth Century-Liberalism: Richard Cobden Bicentury Essays. New York: Routledge, 2009. 
Morison, Samuel Eliot. Three Centuries of Harvard. Cambridge: Harvard University Press, 1936.

Morris, James McGrath. Pulitzer: A Life in Politics, Print, and Power. New York: Harper, 2010.

Morris, Robert Charles. Reading, 'Righting, and Reconstruction: The Education of Freedmen in the South, 1861-1870. Chicago: University of Chicago Press, 1981.

Morrison, Chaplain W. Democratic Politics and Sectionalism: The Wilmot Proviso Controversy. Chapel Hill: University of North Carolina Press, 1967.

Morrison, Michael A. Slavery and the American West: The Eclipse of Manifest Destiny and the Coming of the Civil War. Chapel Hill: University of North Carolina Press, 1997.

Morrison, Rodney J. "Henry C. Carey and American Economic Development." Explorations in Entrepreneurial History 5 (Winter 1968): 132-144.

Morrow, John. Thomas Carlyle. New York: Bloomsbury Academic Press, 2007.

Morse, David. American Romanticism. London: Palgrave MacMillan, 2014.

Mulanax, Richard B. The Boer War in American Politics and Diplomacy. Lanham: University Press of America, 1994.

Müller, Frank Lorenz. "The Spectre of a People in Arms: The Prussian Government and the Militarisation of German Nationalism, 1859-1864." The English Historical Review 122, no. 495 (Feb. 2007): 82-104.

Murray, Meg McGavran. Margaret Fuller, Wandering Pilgrim. Athens: University of Georgia Press, 2008.

Mushkat, Jerome. The Reconstruction of the New York Democracy, 1861- 1874. Rutherford: Farleigh Dickinson Press, 1981.

Myers, Gustavus. The History of Tammany Hall. New York: Burt Franklin, 1968.

Myerson, Joel. "New Light on George Ripley and the Harbinger's New York Years." Harvard Library Bulletin 32 (Summer 1985): 313 - 336.

Namier, Lewis. 1848: The Revolution of the Intellectuals. Oxford: Oxford University Press, 1993.

Nayak, Meghana V. and Christopher Malone. "American Orientalism and American Exceptionalism: A Critical Rethinking of U.S. Hegemony.” International Studies Review 11, no. 2 (Jun., 2009): 253-276.

Neely, Jeremy. The Border Between Them: Violence and Reconciliation on the Kansas-Missouri Line. Columbia: University of Missouri Press, 2007. 
Neely, Jr., Mark E. The Fate of Liberty: Abraham Lincoln and Civil Liberties. New York: Oxford University Press, 1991.

- The Union Divided: Party Conflict in the Civil War North. Cambridge: Harvard University Press, 2002.

- The Boundaries of American Political Culture in the Civil War Era. Chapel Hill: University of North Carolina Press, 2005.

_. "American Nationalism in the Image of Henry Clay: Abraham Lincoln's Eulogy on Henry Clay in Context." The Register of the Kentucky Historical Society 106, no. 3/4 (Summer/Autumn 2008): 537-570.

Neem, Johann N. “American History in a Global Age." History and Theory 50 (February 2011): 41-70.

Neidhardt, Wilfried S. Fenianism in North America. University Park: Pennsylvania State University Press, 1975.

Nelson, Scott Reynolds. Iron Confederacies: Southern Railways, Klan Violence, and Reconstruction. Chapel Hill: University of North Carolina Press, 1999.

Neufeld, Maurice F. "The Persistence of Ideas in the American Labor Movement: The Heritage of the 1830s." Industrial and Labor Relations Review 35, no. 2 (Jan., 1982): 207-220

Nevins, Allan. Hamilton Fish: The Inner History of the Grant Administration. New York: F. Ungar Publishing, 1957.

- Ordeal of the Union: A House Dividing (1852 - 1857). New York: Scribner's and Sons, 1947.

Ngai, Mae M. Impossible Subjects: Illegal Aliens and the Making of Modern America. Princeton: Princeton University Press, 2004.

Niven, John. Salmon P. Chase: A Biography. New York: Oxford University Press, 1995.

Nichol, John. Thomas Carlyle. Cambridge: Cambridge University Press, 2011.

Northup, Cynthia Clark. Encyclopedia of Tariffs and Trade in U.S. History, 3 Vols. Westport, CN: Greenwood Press, 2003.

Notz, W. "Fredrick List in America." American Economic Review 16 (1925): 249 - 265.

O’Brien, Frank M. The Story of the Sun. New York: D. Appleton \& Company, 1918.

O'Harrow, Jr., Robert. The Quartermaster: Montgomery C. Meigs, Lincoln's General, Master Builder of the Union Army. New York: Simon \& Schuster, 2016. 
O'Roarke, Kevin and Jeffrey G. Williamson. Globalization and History: The Evolution of a Nineteenth-Century Atlantic Economy. Boston: MIT Press, 2000.

Ogelsby, J.C.M. "The Cuban Autonomist Movement's Perception of Canada, 1865-1898: Its Implication." The Americas 48, no. 4 (Apr., 1992): 445- 461.

Olson, Otto H. "The Ku Klux Klan: A Study in Reconstruction Politics and Propaganda." The North Carolina Historical Review 39, no. 3 (July 1962): 340-362.

Onuf, Peter and Nicholas. Federal Union, Modern World: The Law of Nations in an Age of Revolutions, 1776 - 1814. Madison: Madison House, 1993.

Onuf, Peter S. "American Exceptionalism and National Identity." American Political Thought 1, no. 1 (Spring 2012): 77-110.

Ormerod, R.J. "The History and Ideas of Marxism." The Journal of the Operational Research Society 59, no. 12 (Dec., 2008): 1573 - 1590.

Orser, Jr., Charles E. "Beneath the Surface of Tenement Life: The Dialectics of Race and Poverty during America's First Gilded Age." Historical Archeology 45, no. 3 (2011): 151 - 165.

Orum, Thomas. "The Politics of Color: The Racial Dimension of Cuban Politics During the Early Republican Years.” PhD diss., New York University, 1975.

Osterhammel, Jürgen and Patrick Camiller. The Transformation of the World: A Global History of the Nineteenth Century. Princeton: Princeton University Press, 2014.

Otte, T.G. The Foreign Office Mind: The Making of British Foreign Policy, 1865-1914. New York: Cambridge University Press, 2013.

Owens, Mackubin T. Abraham Lincoln's, Esq.: The Legal Career of America's Greatest President. Lexington: University Press of Kentucky, 2010.

Painter, Levinus K. "Quaker Settlements in Erie County, New York.” Quaker History 55, no. 1 (Spring 1966): 24-37.

Palen, Marc-William. "The Civil War's Forgotten Transatlantic Tariff Debate and the Confederacy's Free Trade Diplomacy." Journal of the Civil War Era 3, no. 1 (March 2013): 35-61.

- The "Conspiracy" of Free Trade: the Anglo-American Struggle over Empire and Economic Globalization, 1846 - 1896. Cambridge: Cambridge University Press, 2016.

Paolino, Ernest N. The Foundations of the American Empire: William Henry Seward and U.S. Foreign Policy. Ithaca: Cornell University Press, 1973.

Parkerson, Donald H. "The Structure of New York Society: Basic Themes in Nineteenth-Century Social History." New York History 65, no. 2 (April 1984): 159-187. 
Parsons, Elaine Frantz. Ku-Klux: The Birth of the Klan During Reconstruction. Chapel Hill: University of North Carolina Press, 2015.

Parsons, Lynn Hudson. The Birth of Modern Politics: Andrew Jackson, John Quincy Adams and the Election of 1828. New York: Oxford University Press, 2009.

—. "Midnight Rangers: Costume and Performance in the Reconstruction-Era Ku Klux Klan.” The Journal of American History 92, no. 3 (December 2005): 811-836.

Parsons, Elaine Frantz. Ku-Klux: The Birth of the Klan During Reconstruction. Chapel Hill: University of North Carolina Press, 2015.

Peek, Ralph L. "Election of 1870 and the End of Reconstruction in Florida." The Florida Historical Quarterly 45, no. 4 (Apr., 1967): 352 - 268.

Pérez, Jr., Louis A. Cuba, Between Reform and Revolution. Oxford: Oxford University Press, 1988.

. "We Are the World: Internationalizing the National, Nationalizing the International," Review of Rethinking American History in a Global Age, edited by Thomas Bender. The Journal of American History. 89, no. 2 (Sep., 2002): 558-566.

- Cuba and the United States: Ties of a Singular Infancy. Athens: University of Georgia Press, 2003.

—. The Structure of Cuban History. Chapel Hill: University of North Carolina Press, 2013.

Pérez-Stable, Marifeli. The Cuban Revolution: Origins, Course and Legacy. New York: Oxford University Press, 2012.

Perlman, Selig. A Theory of the Labor Movement. Philadelphia: Porcupine Press, 1979, 1922.

Perman, Michael. The Road to Redemption: Southern Politics, 1869-1879. Chapel Hill: University of North Carolina Press, 1984.

- Pursuit of Unity: A Political History of the American South. Chapel Hill: University of North Carolina Press, 2009.

Perkins, Dexter. The Monroe Doctrine, 1826 - 1907. Baltimore: Johns Hopkins University Press, 1937.

Periaccante, Marianne. Calling Down Fire: Charles Grandison Finney and Revivalism in Jefferson County, New York, 1800-1840. Albany: State University of New York Press, 2003.

Pessen, Edward. "A Variety of Panaceas: The 'Social Problem' and Proposed Solutions to it in Mid-Nineteenth Century New York State.” New York History 59, no. 2 (April 1978): 198-222. 
Peterson, Merrill D. The Great Triumvirate: Webster, Clay and Calhoun. New York: Oxford University Press, 1987.

_. John Brown: The Legend Revisited. Charlottesville: University of Virginia Press, 2002.

Pfaff, Daniel W. Joseph Pulitzer II and the Post-Dispatch: A Newspaperman's Life. University Park, Pa.: Pennsylvania State University Press, 1991.

Pfau, Michael W. The Political Style of Conspiracy: Chase, Summer, and Lincoln. Lansing: Michigan State University Press, 2005.

Phillips, Sarah T. “Antebellum Agricultural Reform, Republican Ideology, and Sectional Tension." Agricultural History 74, no. 4 (Autumn, 2000): 799-822.

Pierce, Jason E. Making the White Man's West: Whiteness and the Creation of the American West. Boulder: University Press of Colorado, 2016.

Pilbeam, Pamela. French Socialists before Marx. Montreal: McGill-Queen's University Press, 2000.

Pinkett, Harold T. "Efforts to Annex Santo Domingo to the United States, 1866-1871." Journal of Negro History 26, no. 1 (January 1941).

Pirala, Antonio. Anales de la Guerra en Cuba, 3 vols. Madrid: F. González Rojas, 1895 - 1898.

Pitre, Althea D. “The Collapse of the Warmoth Regime, 1870 - 72." Louisiana History 6, no. 2 (Spring, 1965): $161-187$.

Pitts, Jennifer. A Turn to Empire: The Rise of Imperial Liberalism in Britain and France. Princeton: Princeton University Press, 2006.

Pletcher, David M. The Diplomacy of Trade and Investment: American Economic Expansion in the Hemisphere, 1865 - 1900. Columbia: University of Missouri Press, 1998.

Pocock, J.G.A. "Virtue and Commerce in the Eighteenth Century." Journal of Interdisciplinary History 3 (1972).

—. The Machiavellian Moment: Florentine Political Thought and the Atlantic Republican Tradition. Princeton: Princeton University Press, 1975.

Polasky, Janet. Revolutions without Borders: The Call to Liberty in the Atlantic World. New Haven: Yale University Press, 2016.

Pollack, Sheldon D. War, Revenue, and State Building: Financing the Development of the American State. Ithaca: Cornell University Press, 2009.

Polyné, Millery. "Expansion Now!: Haiti, 'Santo Domingo,' and Frederick Douglass at the Intersection of U.S. and Caribbean Pan-Americanism." Caribbean Studies 34, no. 2 (Jul. - Dec., 2006): 3-45. 
Ponce, Pearl T. Bleeding Kansas, Bleeding Missouri: The Long Civil War on the Border. Lawrence: University of Kansas, 2013.

Porter, Laura Smith. “"The Last, Best Hope of Earth,': Abraham Lincoln's Perception of the Mission of America, 1834 - 1854." Illinois Historical Journal 78, no. 3 (Autumn, 1985): $207-216$.

Potter, David M. "Horace Greeley and Peaceable Secession." The Journal of Southern History, 7, no. 2 (May, 1941): 145-159.

Poyo, Gerald. "Evolution of Cuban Separatist Thought in the Emigré Communities of the United States, 1848-1895." Hispanic American Historical Review 66, no. 3 (Aug., 1986) 485507.

- "With All, and the Good of All:" The Emergence of Popular Nationalism in the Cuban Communities of the United States, 1848 - 1898. Durham: Duke University Press, 1989.

Price, Daniel O. "Estimates of Net Migration in the United States, 1870 - 1940." American Sociological Review 18, no. 1 (Feb., 1953): 35 - 39.

Prickett, Stephen. Origins of Narrative: The Romantic Appropriation of the Bible. Cambridge: Cambridge University Press, 1996.

Prichard, Alex. Justice, Order and Anarchy: The International Political Theory of Pierre-Joseph Proudhon. Toronto: Routledge, 2015.

Priest, Loring Benson. Uncle Sam's Stepchildren: The Reformation of United States Indian Policy, 1865-1887. Lincoln: University of Nebraska Press, 1942.

Pritchard, Linda K. "The Burned-Over District Reconsidered: A Portent of Evolving Religious Pluralism in the United States." Social Science History 8, no. 3 (Summer 1984): 243-265.

Prochaska, Frank. The Eagle and the Crown: Americans and the British Monarchy. New Haven: Yale University Press, 2008.

Quigley, David. "Acts of Enforcement: The New York City Election of 1870.” New York City History 83, no. 3 (Summer 2002): 271 - 292.

—_. "The Department of Justice and Civil Rights Enforcement, 1870 - 1871." In The Politics of Judicial Interpretation: The Federal Courts, Department of Justice, and Civil Rights, $1866-1876$, by Robert J. Kaczorowski, $62-79$. New York: Fordham University Press, 2005.

- Second Founding: New York City, Reconstruction, and the Making of American Democracy. New York: Hill and Wang, 2005.

Rabkin, Jeremy A. Law Without Nations?: Why Constitutional Government Requires Sovereign States. Princeton: Princeton University Press, 2005. 
Rable, George C. But There Was No Peace: The Role of Violence in the Politics of Reconstruction. Athens: University of Georgia Press, 1984.

Ragsdale, Lyn. Vital Statistics on the Presidency. Washington, D.C.: Congressional Quarterly Press, 1998.

Raimond, Jean and J.R. Watson. A Handbook to English Romanticism. New York: St. Martin's Press, 1992.

Ramage, James A. and Kristopher A. Teters. "Public Reactions to Ulysses S. Grant's Vicksburg Campaign in Kentucky, Cincinnati, and Across the Union." The Register of the Kentucky Historical Society 103, no. 4 (Autumn 2005): 627-660.

Rammelkamp, Julian S. Pulitzer's Post Dispatch, 1878-1883. Princeton: Princeton University Press, 1967.

Randers-Pehrson, Justine Davis. Adolf Douai, 1819-1888: The Turbulent Life of a German-FortyEighter in the Homeland and in the United States. New York: Peter Lang, 2000.

Ranney, Joseph A. In the Wake of Slavery: Civil War, Civil Rights, and the Reconstruction of Southern Law. Westport: Praeger, 2006.

Raper, Horace W. William W. Holden: North Carolina's Political Enigma. Chapel Hill: University of North Carolina Press, 1985.

Rapport, Michael. 1848: Year of Revolution. New York: Basic Books, 2010.

Rappaport, Armin. A History of American Diplomacy. New York, 1975.

Rauch, Basil. American Interest in Cuba, 1848 - 1855. New York, 1974.

Rawley, James A. The Kansas-Nebraska Act of 1854. Lincoln: University of Nebraska Press, 2008 .

Redeker, Martin. Schleiermacher: Life and Thought. Philadelphia: Fortress Press, 1973.

Reeves, Jesse S. "The Influence of the Law of Nature Upon International Law in the United States." The American Journal of International Law 3, no. 3 (Jul., 1909): 547-561.

Reilly, Elizabeth, ed. Infinite Hope and Disappointment: The Story of the First Interpreters of the Fourteenth Amendment. Akron: University of Akron Press, 2011.

Reisman, David A. James Buchanan. Basingstroke: Palgrave-Macmillan, 2015.

Reuben, Julie. The Making of the Modern University: Intellectual Transformation and the Marginalization of Morality. Chicago: University of Chicago Press, 1996. 
Richards, Leonard. The Free North and Southern Domination, 1780-1860. Baton Rouge: Louisiana State University, 2000.

Richardson, Heather Cox. The Greatest Nation of the Earth: Republican Economic Policies during the Civil War. Cambridge: Harvard University Press, 1997.

- The Death of Reconstruction: Race, Labor, and Politics in the Post-Civil War North, 1865-1901. Cambridge: Harvard University Press, 2002.

—. To Make Men Free: A History of the Republican Party. New York: Basic Books, 2014.

Roark, James L. Masters without Slaves: Southern Planters in the Civil War and Reconstruction. New York: Norton, 1977.

Robert, Karen. "Slavery and Freedom in the Ten Years War, Cuba, 1868 - 1878." Slavery \& Abolition 13, no. 3 (1992): $181-200$.

Roberts, Alasdair. America's First Great Depression: Economic Crisis and Political Disorder after the Panic of 1837. Ithaca: Cornell University Press, 2013.

Roberts, David. A Newer World: Kit Carson, John C. Frémont, and the Claiming of the American West. New York: Simon and Schuster Books, 2000.

Roberts, Timothy Mason. Distant Revolutionaries: 1848 and the Challenge to American Exceptionalism. Charlottesville: University of Virginia Press, 2009.

Rockman, Seth and Cathy Matson. Scraping By: Wage Labor, Slavery, and Survival in Early Baltimore. Baltimore: Johns Hopkins University, 2009.

Rodgers, Daniel T. Atlantic Crossings: Social Politics in a Progressive Age. Cambridge: Harvard University Press, 1998.

Rodgers, Thomas E. "Copperheads or a Respectable Minority: Current Approaches to the Study of Civil War-Era Democrats." Indiana Magazine of History 109, no. 2 (June 2013): 114146.

Rolle, Andrew. John Charles Frémont-Character as Destiny. Norman: University of Oklahoma Press, 1991.

Rothman, Adam. "Slavery and National Expansion in the United States." OAH Magazine of History 23, no. 2 (April 2009): 23 - 29.

Rogers, Richard Lee. "The Urban Threshold and the Second Great Awakening: Revivalism in New York State, 1825-1835." Journal for the Scientific Study of Religion 49, no. 4 (December 2010): 694-709.

Rogerson, John W. W.M.L. de Wette: Founder of Modern Biblical Criticism, An Intellectual Biography. Sheffield: Sheffield Academic Press, 1992. 
Rosebault, Charles J. When Dana Was The Sun. New York: Robert M. McBride \& Company, 1931.

Rosen, Hannah. Terror in the Heart of Freedom: Citizenship, Sexual Violence, and the Meaning of Race in the Postemancipation South. Chapel Hill: University of North Carolina Press, 2009.

Rosenbloom, Joshua L. "The Extent of the Labor Market in the United States, 1870 - 1914." Social Science History 22, no. 3 (Autumn, 1998): 287 - 318.

Ross, Earle D. "Horace Greeley and the West." The Mississippi Valley Historical Review, 20, no. 1 (Jun., 1933): 63-74.

Rossbach, Jeff. Ambivalent Conspirators: John Brown, the Secret Six, and a Theory of Slave Violence. University of Pennsylvania Press, 1982.

Rothman, Adam. "Slavery and National Expansion in the United States." OAH Magazine of History 23, no. 2 (April 2009) $23-29$.

Rowan, Steven W. "The Continuation of the German Revolutionary Tradition on American Soil." In Germans for a Free Missouri: Translation from the St. Louis Radical Press, 1857 1862, edited by Steven W. Rowan and James Neal Primm, 23 - 45. Columbia: University of Missouri Press, 1983.

Rowe, David L. Thunder and Trumpets: Millerites and Dissenting Religion in Upstate New York, 1800-1850. Decatur: Scholars Press, 1985.

Rowe, Justin. "New Wine in Old Wineskins: Social Structure and the Making of $19^{\text {th }}$ Century American Calvinism.” PhD diss., Michigan State University, 2015.

Roy, Joaquin. The Cuban Revolution (1959 - 2009): Relations with Spain, the European Union and the United States. New York: Palgrave MacMillan, 2009.

Rubery, Matthew. The Novelty of Newspapers: Victorian Fiction after the Invention of the News. New York: Oxford University Press, 2009.

Rugemer, Edward Bartlett. The Problem of Emancipation: The Caribbean Roots of the American Civil War. Baton Rouge: Louisiana State University Press, 2008.

Ryan, Mary P. Cradle of the Middle Class: The Family in Oneida County, New York, 1790-1865. New York: Cambridge University Press, 1981.

Ryley, Peter. Making Another World Possible: Anarchism, Anti-Capitalism, and Ecology in Late $19^{\text {th }}$ and Early $20^{\text {th }}$ Century Britain. New York: Bloomsbury Academic, 2013.

Safranski, Rüdiger. Goethe: Life as a Work of Art. Translated by David Dollenmayer. London: Liveright, 2017. 
Samito, Christian, ed. Changes in Law and Society during the Civil War and Reconstruction. Carbondale: Southern Illinois University Press, 2014.

Samuels, Ernest. Henry Adams. Cambridge: Belknap Press of Harvard University Press, 1989.

Sandel, Michael J., "Liberalism and Republicanism: Friends or Foes? A Reply to Richard Dagger," The Review of Politics 61, no. 2 (Spring, 1999): 209 - 214.

Sands, Eric C. American Public Philosophy and the Mystery of Lincolnism. Columbia: University of Missouri Press, 2009.

Sarbaugh, Timothy J. Post-Civil War Fever and Adjustment: Fenianism in the Californian Context, 1858-1872. Boston: Northeastern University, 1992.

Saul, Norman. Concord and Conflict: The United States and Russia, 1867 - 1914. Lawrence: University of Kansas Press, 1996.

Saunt, Claudio. "The Paradox of Freedom: Tribal Sovereignty and Emancipation During the Reconstruction of Indian Territory." The Journal of Southern History 70, no. 1 (Feb. 2004): 63-94.

Shafer, David A. The Paris Commune: French Politics, Culture, and Society at the Crossroads of the Revolutionary Tradition and Revolutionary Socialism. New York: Palgrave MacMillan, 2005.

Schaefer, Richard T. "The Ku Klux Klan: Continuity and Change." Phylon 32, no. 2 ( ${ }^{\text {nd }}$ Quarter 1971): 143-157.

Schivelbusch, Wolfgang. The Railway Journey: The Industrialization of Time and Space in the Nineteenth Century. Berkeley: University of California Press, 2014.

Scnheirov, Richard. "Thoughts on Periodizing the Gilded Age: Capital Accumulation, Society, and Politics, 1873 - 1898." The Journal of the Gilded Age and Progressive Era 5, no. 3 (Jul., 2006): $189-224$.

Schoonover, Thomas. Uncle Sam's War and the Origins of Globalization. Lexington: The University Press of Kentucky, 2013.

Schudson, Michael. Discovering the News: A Social History of American Newspapers. New York: Basic Books, 1978.

—. The Good Citizen: A History of American Life. New York: The Free Press, 1998.

Schuler, Friedrich E. Secret Wars and Secret Policies in the Americas, $1842-1929$. Albuquerque: University of New Mexico Press, 2015.

Scott, Ivan. "Nineteenth Century Anarchism and Marxism." Social Science 47, no. 4 (Autumn 1972): 212-218. 
Scott, Rebecca J. Slave Emancipation in Cuba: The Transition to Free Labor, 1860- 1899. Princeton: Princeton University Press, 1985.

Seigel, Micol. "Beyond Compare: Comparative Method after the Transnational Turn." Radical History Review 91 (Winter 2005): 62-90.

Selinger, Jeffrey S. Embracing Dissent: Political Violence and Party Development in the United States. Philadelphia: University of Pennsylvania Press, 2016.

Senghaas, Dieter. "Friedrich List and the Basic Problems of Modern Development." Review 14, no. 3 (Summer, 1991): $451-467$.

Sewell, Mike. "Political Rhetoric and Policy Making: James G. Blaine and Britain," Journal of American Studies 24, no. 1 (Apr., 1990): $61-84$.

Sexton, Jay. "Toward a Synthesis of Foreign Relations in the Civil War Era." American Nineteenth Century History 5 (Fall 2004): 50-73.

—. "The Global View of the United States." The Historical Journal 48, no. 1 (March 2005): 261-276.

- Debtor Diplomacy: Finance and American Foreign Relations in the Civil War Era, 1837 - 1873. Oxford: Oxford University Press, 2005.

Shackel, Paul A. and Matthew M. Palus, "The Gilded Age and Working Class Industrial Communities." American Anthropologist 108, no. 4 (Dec., 2006): 828 - 841.

Shankman, Kimberly. Compromise and the Constitution: The Political Thought of Henry Clay. Lanham: Lexington, 1999.

Shaw, Ronald E. Canals for a Nation: The Canal Era in the United States, 1790-1869. Lexington: University Press of Kentucky, 1990.

_. Erie Water West: A History of the Erie Canal, 1792-1854. Lexington: University of Kentucky Press, 1990.

Shelden, Rachel A. Washington Brotherhood: Politics, Social Life, and the Coming of the Civil War. Chapel Hill: University of North Carolina Press, 2013.

Sheriff, Carol. The Artificial River: the Erie Canal and the Paradox of Progress, 1817-1862. New York: Hill and Wang, 1996.

Shi, David E. "Seward's Attempt to Annex British Columbia, 1865-1869." Pacific Historical Review 47, no. 2 (May, 1978): 217-238.

Shoemaker, Stephen. "The Emerging Distinction between Theology and Religion at NineteenthCentury Harvard University." The Harvard Theological Review 101, no. 3-4 (Jul. - Oct., 2008). 
Shook, John R., ed. Dictionary of Early American Philosophers, vol. 1. London: Continuum, 2012.

Shookman, Ellis. "Brook Farm and Beyond: German Thought and Literature in 'The Harbinger,' 1845 - 1849." German Studies Review 34, no. 3 (October 2011).

Shore, Eliot. The German-American Radical Press: The Shaping of a Left Political Culture, 1850 - 1940. Urbana: University of Illinois Press, 1992.

Showalter, Dennis E. "The Political Soldiers of Bismarck's Germany: Myths and Realities" German Studies Review 17, no. 1 (Feb., 1994): 59-77.

- The Wars of German Unification. London: Arnold, 1999..

Shookman, Ellis. "Brook Farm and Beyond: German Thought and Literature in 'The Harbinger,' 1845-1849." German Studies Review 34, no. 3 (October 2011).

Schrag, Peter. Not Fit For Our Society: Immigration and Nativism in America. Berkeley: University of California Press, 2010.

Silver, Beverly. Forces of Labor: Workers Movements and Globalization Since 1870. Cambridge: Cambridge University Press, 2003.

Simmons, Nancy C. “Coleridge's American Reputation, 1800-1853." The Journal of English and German Philology 87, no. 3 (Jul., 1988).

Simon, John, ed, The Papers of Ulysses S. Grant, vol. 24. Carbondale: Southern Illinois University Press, 2000.

Skocpol, Theda and Ellen Kay Trimberger. "Revolutions and the World-Historical Development of Capitalism.” Berkeley Journal of Sociology 22 (1977-78): 101-113.

Skocpol, Theda. Protecting Soldiers and Mothers: The Political Origins of Social Policy in the United States. Cambridge: Belknap Press of Harvard University Press, 1992.

Slotkin, Richard. The Fatal Environment: The Myth of the Frontier in the Age of Industrialization, 1800-1890. Norman: University of Oklahoma Press, 1998.

Silbey, Joel H. A Respectable Majority: The Democratic Party in the Civil War Era, 1860-1868. New York: W.W. Norton, 1977.

Simpson, Brooks. Let Us Have Peace: Ulysses S. Grant and the Politics of War and Reconstruction, 1861 - 1868. Chapel Hill: University of North Carolina Press, 2001.

Silver, Beverly. Forces of Labor: Workers Movements and Globalization Since 1870. Cambridge: Cambridge University Press, 2003.

Slap, Andrew. The Doom of Reconstruction: the liberal Republicans in the Civil War Era. New York: Fordham University Press, 2010. 
Slater, Joseph. "George Ripley and Thomas Carlyle." Proceedings of the Modern Language Association 67, no. 4 (June 1952): 341-349.

Slotkin, Richard. The Fatal Environment: The Myth of the Frontier in the Age of Industrialization, 1800-1890. Norman: University of Oklahoma Press, 1998.

Smith, Angel and Emma Aurora Dávila Cox, The Crisis of 1898: Colonial Redistribution and Nationalist Mobilization. New York: St. Martin's Press, 1999.

Smith, George Winston. Henry C. Carey and the American Sectional Conflict. Albuquerque: University of New Mexico Press, 1951.

Smith, Michael Thomas. The Enemy Within: Fears of Corruption in the Civil War North. Charlottesville: University of Virginia Press, 2011.

Smith, Rogers M. Civil Ideals: Conflicting Visions of Citizenship in U.S. History. New Haven: Yale University Press, 1997.

Snay, Mitchell. Fenians, Freedmen, and Southern Whites: Race and Nationalism in the Era of Reconstruction. Baton Rouge: Louisiana State University Press, 2007.

- Horace Greeley and the Politics of Reform in Nineteenth-Century America. Lanham: Rowman \& Littlefield, 2011.

Sombart, Werner. Why Is There No Socialism In The United States? Translated by C.T. Husbands. London: MacMillan, 1976, 1906.

Souza, Benigno. Máximo Gómez: El Generalísimo. Havana: Editorial de Ciencias Sociales, 1986.

Spann, Deward. Brotherly Tomorrow: Movements for a Cooperative Society in America, 1820 1920. New York: Columbia University Press, 1988.

Spencer, David R. The Yellow Journalism: The Press and America's Emergence as a World Power. Evanston: Northwestern University Press, 2007.

Sproat, John G. "The Best Men”: Liberal Reformers in the Gilded Age. New York: Oxford University Press, 1971.

Stedman-Jones, Gareth. "Radicalism and the extra-European world: the case of Karl Marx." In Victorian Visions of Global Order: Empire and International Relations in Nineteenth Century Political Thought, edited by Duncan Bell, 186 - 214. Cambridge: Cambridge University Press, 2007.

Steefel, Lawrence. Bismarck: The Hohenzollern Candidacy and the Origins of the FrancoGerman War of 1870. Cambridge: Harvard University Press, 1962.

Steele, Janet A. The Sun Shines For All: Journalism and Ideology in the life of Charles A. Dana. Syracuse University Press. Syracuse, New York. 1993. 
Stone, Candace. Dana and the Sun. New York: Dodd, Mead \& Company, 1938.

Stone, James. The War Scare of 1875: Bismarck and Europe in the Mid-1870s. Stuttgart: Franz Steiner Verlag, 2010.

Story, Ronald R. "Harvard Students, the Boston Elite, and the New England Preparatory System, 1800-1876." History of Education Quarterly 15, no. 3 (Autumn, 1975): 281-298.

Streeby, Shelley. American Sensations: Class, Empire, and the Production of Popular Culture. Berkeley: University of California Press, 2002.

—. "Labor, Memory, and the Boundaries of Print Culture: From Haymarket to the Mexican Revolution." American Literary History 19, no. 2 (Summer, 2007): 406-433.

Strong, Douglas. Perfectionist Politics: Abolitionism and the Religious Tensions of American Democracy. Syracuse: Syracuse University Press, 1999.

Summers, Mark Wahlgren. Railroads, Reconstruction, and the Gospel of Prosperity: Aid under the Radical Republicans, 1865-1877. Princeton: Princeton University Press, 1984.

- The Press Gang: Newspapers and Politics, 1868 - 1878. Chapel Hill: University of North Carolina Press, 1994.

- A Dangerous Stir: Fear, Paranoia, and the Making of Reconstruction. Chapel Hill: Univ. of North Carolina Press, 2009.

- The Ordeal of The Reunion: A New History of Reconstruction. Chapel Hill: University of North Carolina Press, 2014.

Sumner, Arthur. “A Boy’s Reflections of Brook Farm.” New England Magazine 10 (May 1894): 309-13.

Surdam, David G. "Traders or Traitors: Northern Cotton Trading During the Civil War." Business and Economic History 48, no. 2 (Winter 1999): 301-312.

Swanberg, W.A. Pulitzer. New York: Scribner, 1967.

Swift, Lindsay. Brook Farm: Its Members, Scholars, and Visitors. New York: MacMillan Company, 1900.

Sylla, Richard. "Finance and Capital in the United States, 1850 - 1900." The Journal of Economic History 27, no. 4 (Dec., 1967): 621 - 624.

Sylvest, Casper. British Liberal Internationalism, 1880-1930. Manchester: Manchester Univ. Press, 2009.

Szporluk, Roman. Communism and Nationalism: Karl Marx versus Friedrich List. Cambridge: Cambridge University Press, 1988. 
Taussig, Frank W. The Tariff History of the United States. New York: G.P. Putnam's Sons, 1931.

Taylor, Alan. "The Free Seekers: Religious Culture in Upstate New York, 1790-1835.” Journal of Mormon History 27, no. 1 (Spring 2001).

Taylor, Andrew. Thinking America: New England Intellectuals and the Varieties of American Identity. Durham, N.H.: University of New Hampshire Press, 2011.

Taylor, Quintard. In Search of the Racial Frontier: African Americans in the American West, 1528 - 1990. New York: Norton, 1998.

Thomas, Samuel J. "Mugwump Cartoonists, the Papacy, and Tammany Hall in America's Gilded Age." Religion and American Culture: A Journal of Interpretation 14, no. 2 (Summer 2004): $213-250$.

Thelen, David. "The Nation and Beyond: Transnational Perspectives on United States History." The Journal of American History 86, no. 3 (Dec., 1999): 965-975.

Thompson, Margaret Susan. "Corruption — or Confusion? Lobbying and Congressional Government in the Early Gilded Age." Congress and the Presidency 10 (August 1983): 169-93.

- The "Spider Web": Congress and Lobbying in the Age of Grant. Ithaca: Cornell University Press, 1985.

Timberlake, Richard H. Monetary Policy in the United States: An Intellectual History. Chicago: University of Chicago Press, 1993.

Tolley, Howard B. "The Domestic Applicability of International Treaties in the United States." Lawyer of the Americas 15, no. 1 (Spring, 1983): $71-88$.

Trask, Donald F. The War With Spain. Lincoln: University of Nebraska Press, 1981.

Trefousse, Hans L. Impeachment of a President: Andrew Johnson, the Blacks, and Reconstruction. New York: Fordham University Press, 1999.

Trelease, Allen W. White Terror: The Ku Klux Klan Conspiracy and Southern Reconstruction. New York: Harper \& Row, 1971.

Tribe, K. "Friedrich List and the Critique of 'Cosmopolitical Economy."” The Manchester School 56 (1988): $17-36$.

Trodd, Zoe. "Writ in Blood: John Brown's Charter of Humanity, The Tribunal of History, and the Think Link of American Political Protest." Journal for the Study of Radicalism 1, no. 1 (Spring 2007): 1-29.

Trubowitz, Peter. Politics and Strategy: Partisan Ambition \& American Statecraft. Princeton: Princeton University Press, 2009. 
Tuchinsky, Adam-Max. Horace Greeley's New York Tribune: Civil War-Era Socialism and the Crisis of Free Labor. Ithaca: Cornell University Press, 2009.

—. "'The Bourgeoisie Will Fall and Fall Forever:' The 'New-York Tribune,' the 1848 French Revolution, and American Social Democratic Discourse." The Journal of American History 92, no. 2 (Sep., 2005): 470-497

Tucker, David M. Mugwumps: Public Moralists of the Gilded Age. Columbia: University of Missouri Press, 1998.

Tyrell, Ian. "American Exceptionalism in an Age of International History." American Historical Review 96 (1991): 1031-1072.

Unger, Irwin. The Greenback Era: A Social and Political History of American Finance, $1865-$ 1879. Princeton: Princeton University Press, 1964.

Urban, C. Stanley. "The Abortive Quitman Filibustering Expedition, 1852 - 1855." The Journal of Mississippi History 18, no. 3 (July 1956): 175 - 196.

Utley, Robert M. The Indian Frontier of the American West, 1846- 1890. Albuquerque: University of New Mexico Press, 1984.

Vagts, Alfred. "Hopes of an American-German War, 1870 - 1915." Political Science Quarterly 54, no. 4 (1939): $514-535$.

Van der Linden, Marcel. "Transnationalizing American Labor History." The Journal of American History 86, no. 3 (Dec., 1999): 1078-1092.

—_ "The Promises and Challenges of Global Labor History." ILWCH 82 (Fall, 2012): 5776.

Vaughn, Gerald F. "Institutional Economics and Community Development: The Pioneering Roles of Henry C. Carey and Van Buren Denslow." Journal of Economic Issues 37, no. 3 (Sep., 2003): $681-696$.

Vila, Herminio Portell. Historia de Cuba en sus Relaciones con los Estados Unidos y España, vol. 2. Miami: Mnemosyne Publishing, Inc., 1969.

Villard, Oswald Garrison. John Brown, 1800-1859: A Biography Fifty Years After. New York: Houghton Mifflin, 1919.

Vincent, K. Steven. Pierre-Joseph Proudhon and the Rise of French Republican Socialism. Oxford: Oxford University Press, 1984.

Vogel, Stanley M. German Influences on the American Transcendentalists. New Haven: Yale University Press, 1955. 
Volk, Kyle G. "The Perils of 'Pure Democracy'- Minority Rights, Liquor Politics, and Popular Sovereignty in Antebellum America." Journal of the Early Republic 29, no. 4 (Winter 2009): 641-679.

Volpe, Vernon L. "The Origins of the Frémont Expeditions: John J. Abert and the Scientific Exploration of the Trans-Mississippi West." The Historian 62, no. 2 (Winter 2000): 245-263.

Voss-Hubbard, Mark. “The 'Third Party Tradition' Reconsidered: Third Parties and American Public Life, 1830-1900.” Journal of American History 86 (June 1999).

- Beyond Party: Cultures of Antipartisanship in Northern Politics Before The Civil War. Baltimore: Johns Hopkins University Press, 2002.

Voss, Kim. The Making of American Exceptionalism: The Knights of Labor and Class Formation in the Nineteenth Century. Ithaca: Cornell University Press, 1993.

Wade, Wyn Craig. The Fiery Cross: The Ku Klux Klan in America. New York: Simon and Schuster, 1987.

Wagner, Ulrike. "Transcendentalism and the Power of Philology: Herder, Schleiermacher, and the Transformation of Biblical Scholarship in New England." Amerikastudien/American Studies 57, no. 3 (2012): 419-445

Warner, Donald F. The Idea of Continental Union: Agitation for the Annexation of Canada to the United States, 1849-1893. Lexington: University Press of Kentucky, 1960.

Waldron, Jeremy. "Party Laws Common to All Mankind": Foreign Law in American Courts. New Haven: Yale University Press, 2012.

Walker, Amasa. "Senator Sumner and the Peace Cause." Advocate of Peace 3, no. 44 (August 1972).

Wang, Xi. The Trial of Democracy: Black Suffrage and Northern Republicans, 1860-1910. Athens: University of Georgia Press, 1997.

Warren, Kenneth. Triumphant Capitalism: Henry Clay Frick and the Industrial Capitalism of America. Pittsburgh: University of Pittsburgh Press, 1996.

Wawro, Geoffrey. The Austro-Prussian War: Austria's War With Prussia and Italy in 1866. New York: Cambridge University Press, 1966.

- The Franco-Prussian War: The German Conquest of France in 1870-1871. New York: Cambridge University Press, 1966.

Weber, Jennifer. Copperheads: The Rise and Fall of Lincoln's Opponents in the North. New York: Oxford University Press, 2008. 
Wehler, Hans-Ulrich. “Bismarck’s Imperialism, 1862 - 1890.” Past \& Present 48 (1970): 119 155.

Weinberg, Arthur and Lila Shaffer Weinberg, The Muckrakers. Urbana: University of Illinois Press, 2001.

Weisman, Steven R. The Great Tax Wars: Lincoln to Wilson. New York: Simon \& Schuster, 2002.

Weiss, Gerhard. "The Americanization of Franz Lieber and the Encyclopedia Americana." In German Culture in Nineteenth-Century America: Reception, Adaptation, Transformation, edited by Lynne Tatlock and Matt Erlin. Boydell \& Brewer, Camden House, 2005.

Weithman, Paul. "Political Republicanism and Perfectionist Republicanism," The Review of Politics 66, no.2 (Spring, 2004): 285-312.

Welch, Samuel Manning. Home History: Recollections of Buffalo During the Decade from 1830 to 1840 of Fifty Years Since. Buffalo: Peter Paul \& Bro., 1891e.

Wennersten, John R. “A Reformer's Odyssey: The Public Career of Parke Godwin of the New York Evening Post, 1837-1870.” PhD diss., University of Maryland, 1970.

Wesley, Thomas J. “John Sullivan Dwight: A Translator of German Romanticism.” American Literature 21, no. 4 (January 1950): 427-441.

Wetzel, David. The Crimean War: A Diplomatic History. New York: Columbia University Press, 1985.

Wetzel, David. A Duel of Nations: Germany, France, and the Diplomacy of the War of 18701871. Madison: University of Wisconsin Press, 2012.

White, Ashli. Encountering Revolution: Haiti and the Making of the Early Republic. Baltimore: Johns Hopkins University, 2012.

White, Ed. "The Ends of Republicanism," Journal of the Early Republic 30, no. 2 (Summer, 2010): $179-199$.

White, Richard. "Information, Markets, and Corruption: Transcontinental Railroads in the Gilded Age." The Journal of American History 90, no. 1 (June 2003): 19-43.

- Railroaded: The Transcontinentals and the Making of Modern America. New York: Norton, 2011.

White, Ronald C. American Ulysses: A Life of Ulysses S. Grant New York: Random House, 2016.

Whitelaw, Nancy. Joseph Pulitzer and the New York World. Greensboro: Morgan Reynolds, 2000 . 
Whitman, Roger, Scott G. Eberle and David A. Gerber. The Rise and Fall of a Frontier Entrepreneur: Benjamin Rathbun. Syracuse: Syracuse University Press and Erie County Historical Society, 1996.

Widmer, Edward L. Young America: The Flowering of Democracy in New York City. Oxford: Oxford University Press, 1999.

Widmer, Larry T. "The Gold Crisis of 1869: Stabilizing Speculation under Floating Exchange Rates?” Explorations in Economic History 12 (April 1975): 105-122.

Wilson, Mark R. "The Business of Civil War: Military Enterprise, the State, and Political Economy in the United States, 1850 - 1880." Enterprise \& Society 4, no. 4 (December 2003): $599-605$.

Wiener, Joel H. The Americanization of the British Press, 1830s-1914: Speed in the Age of Transatlantic Journalism. New York: Palgrave Macmillan, 2011.

Wilentz, Sean. Chants Democratic: New York City and the American Working Class 1788-1850, $2^{\text {nd }}$ ed. New York: Oxford University Press, 2004.

—. The Rise of American Democracy: Jefferson to Lincoln. New York: Norton, 2005.

Williams, John R. The Life of Goethe: A Critical Biography. New York: Wiley-Blackwell, 1998.

Williams, Robert C. Horace Greeley: Champion of American Freedom. New York: New York University Press, 2006.

Williamson, Joel. The Crucible of Race: Black-White Relations in the American South Since Emancipation. New York: Oxford University Press, 1984.

Wilson, Brian C. Yankees in Michigan. Lansing: Michigan State University Press, 2008.

Wilson, Brian. Heyday: the 1850s and the Dawn of the Global Age. New York: Basic Books, 2016.

Wilson, James Harrison. The Life of Charles A. Dana. New York: Harper, 1907.

Wilson, Jr., James D. "The Donaldsonville Incident of 1870: A Study of Local Party Dissension and Republican Infightwing in Reconstruction Louisiana." Louisiana History: The Journal of the Louisiana Historical Association 38, no. 3 (1997): 329 - 345.

Winders, Bill. "The Roller Coaster of Class Conflict: Class Segments, Mass Mobilization, and Voter Turnout in the U.S., 1840 - 1996." Social Forces 77, no. 3 (Mar., 1999): 833-862.

Winkelstein, Warren. “Austin Flint, Clinician Turned Epidemiologist.” Epidemiology 18, no. 2 (March 2007).

Witt, John Fabian. Lincoln's Code: The Laws of War in American History. New York: Free Press, 2014. 
Witte, John. The Reformation of Rights: Law, Religion, and Human Rights in Early Modern Calvinism. Cambridge: Cambridge University Press, 2007.

Wittke, Carl. Refugees of Revolution: The German Forty-Eighters in America. Philadelphia: University of Pennsylvania Press, 1952.

Wright, Carroll D. "The Course of Wages in the United States Since 1840." Publications of the American Statistical Association 3, no. 24 (Dec., 1893): 496 - 500.

Wood, Dennis B. "The Long Revolution: Class Relations and Political Conflict in Cuba, 1868 1968.” Science \& Society 34, no. 1 (Spring, 1970): 1-41.

Wood, Gordon S. The Creation of the American Republic, 1776-1787. Chapel Hill: University of North Carolina Press, 1969.

Wooster, Robert. The Military and United States Indian Policy, 1865-1903. New Haven: Yale University Press, 1988.

Yearley, Clifton K. The Money Machines: The Breakdown and Reform of Governmental and Party Finance in the North, 1860 - 1920. Albany: State University of New York Press, 1970.

Yox, Andrew P. “Bonds of Community: Buffalo's German Element, 1853-1871.” New York History 66, no. 2 (April 1985): 140-163.

Zakim, Michael and Gary J. Kornblith. Capitalism Takes Command. Chicago: University of Chicago Press, 2011.

Zarefsky, David. "Lincoln and the House Divided: Launching a National Political Career." Rhetoric and Public Affairs 13, no. 3 (Fall 2010): 421-453.

Ziegler, Vanessa Michelle. “"The Revolt of "the Ever-Faithful Isle': The Ten Years' War in Cuba, 1868 - 1878.” Ph.D. diss., University of California, Santa Barbara, 2007.

Zimmerman, Andrew. "From the Second American Revolution to the First International and Back Again: Marxism, the Popular Front, and the American Civil War." In Gregory P. Downs and Kate Masur. The World the Civil War Made. Chapel Hill: University of North Carolina Press, 2015.

- "From the Rhine to the Mississippi: Property, Democracy, and Socialism in the American Civil War.” The Journal of the Civil War Era 5, no. 1 (March 2015): 3 - 37.

Zolberg, Aristide. A Nation by Design: Immigration Policy in the Fashioning of America. Cambridge: Harvard University Press, 2006.

Zonderman, David A. “George Ripley's Unpublished Lecture on Charles Fourier." Studies in the American Renaissance (1982): 185-208. 
Zuczek, Richard. "The Federal Government's Attack on the Ku Klux Klan: A Reassessment." The South Carolina Historical Magazine 97, no. 1 (January 1996): 47-64.

\section{Primary Sources}

A Catalogue of the Officers and Students of Harvard University, for the Academic Year, 18391840. Cambridge: Folsom, Wells, and Thurston, 1839.

Correspondence of the United States Department of State in relation to The Seizure of American Vessels and Injuries to American Citizens during the Hostilities in Cuba. Transmitted to the Senate in Obedience to a Resolution. Washington: Government Printing Office, 1870.

Información sobre reformas en Cuba y Puerto Rico, vol, I and II. New York: Hallet \& Breen, 1867.

Benjamin, Charles F. "Recollections of Secretary Stanton," Century Magazine 33, no. 5 (March 1887): 758-768.

Blind, Karl. "The Spanish Revolution.” The North American Review 108, no. 223 (Apr., 1869).

Brisbane, Arthur. and Osborne Macdaniel. "Gradual Abasement of the Producing Classes." Phalanx 1 (March 1, 1844): 73.

Cleveland, John and Horace Greeley. A Political Textbook for 1860. New York: Tribune Association, 1860.

Channing, William A. “Labor for Wages.” Harbinger 2 (May 30, 1846): 396.

Dana, Elizabeth Ellery The Dana Family in America. Cambridge: Wright \& Potter Printing Company, 1956.

Dana, Richard Henry. "Francis Dana.” Magazine of History and Biography 1 (1877): 86 - 95.

Dana, Charles A. “A Lecture on Association, In Its Connection With Religion” Delivered before the New England Fourier Society in Boston on March 7, 1844. Boston: New England Fourier Society, 1844.

—. American Household Book of Poetry. New York: Appleton \& Co., 1859.

- and James Harrison Wilson. The Life of Ulysses S. Grant, General of the Armies of the United States. Springfield: G. Bill \& Co., 1868.

—. Lincoln And His Cabinet. New York: De Vinne Press, 1896.

- Reminiscences of Men and Events of the Civil War. New York: S.S. McClure, 1898.

Dulce, Domingo. Informe presentado por el Excmo. Se. D. Domingo Dulce, Marqués de Catellflorita, al Ministro de Ultramar en Enero de 1867. Madrid, 1867. 
Dwight, Timothy J. Select Minor Poems, translated from the German of Goethe and Schiller. Boston: Hilliard \& Gray, 1839.

First Annual Report of the Executive Committee of the Young Men's Association of the City of Buffalo. Buffalo: Press of Oliver V. Steele, 1837.

Godwin, Parke. "Wages Slavery.” Harbinger 6 (March 25, 1848): 146.

Goethe, Johann Wolfgang von. The Auto-biography of Goethe. Truth and Poetry: From my Life, 4 vols. Edited by Parke Godwin. Trans. By Godwin, John H. Hopkins, Charles A. Dana, and John S. Dwight. New York: Wiley and Putnam, 1847-8.

Grant, Ulysses S. Personal Memoirs of U.S. Grant, vol. 2. New York: Charles L. Webster \& Co., 1894.

Johnson, Albert E.H. "Reminiscences of the Hon. Edwin M. Stanton, Secretary of War." Records of the Columbia Historical Society 13 (1910): 88-89.

Lieber, Franz. Guerilla Parties Considered With Reference To The Laws And Usages Of War. Written at the request of Major-General Henry W. Halleck, General-in-Chief of the Army of the United States. New York, D. Van Nostrand, August 1862.

Menzel, Wolfgang and C.C. Felton, and George Ripley, German Literature. Boston: Hilliard, Gray, and Company, 1840.

Ripley, George. The Temptations of the Times: A Discourse Delivered in the Congregational Church in Purchase Street, on Sunday Morning, May 7, 1837. Boston: Hillard, Gray, and Company, 1837.

- Letters on The Latest Form of Infidelity, Including A View of the Opinions of Spinoza, Schleiermacher, and De Wette. Boston: James Munroe and Company, 1840.

Sheridan, Philip. "From Gravelotte to Sedan," Scribner's Magazine, 4, no. 5 (November 1888).

Sherman, William T. Memoirs of General William T. Sherman. New York: D. Appleton and Co., 1875 .

\section{$\underline{\text { Newspapers }}$}

\section{Chicago Tribune}

Christian Examiner

Cincinnati Commercial

Graham's Magazine

Harper's Weekly 
Monthly Review

North American Review

New York Herald

New York Evening Post

New York Tribune

Rochester Chronicle

Scientific American

Springfield (Mass.) Republican

The Harbinger

The Nation

The New York Times

The Sun (N.Y)

Troy Times 


\section{ERIC RIVAS}

Born, Miami, Florida

2011

$2012-2016$

B.A., Philosophy

Florida International University

Miami, Florida

M.A., History

Florida International University

Miami, Florida

$2012-2017$

Teaching Assistant

Florida International University

Miami, Florida

$2016-2019$

Doctoral Candidate

Florida International University

Miami, Florida

\section{PUBLICATIONS AND PRESENTATIONS}

Rivas, Eric. (March 2013). “The Mob of a Single City Will Plunge Us into War': The RussoJapanese War, California Racism and Public Memory's Influence on the War Scare of 1907." Paper presented at the annual conference of the Department of History Graduate Student Association, Florida International University, Miami, Florida.

Rivas, Eric. (March 2015). “'The More I See of Europe, The More American I Become:' Joseph Pulitzer and an International World, A Methodological Case Study." Paper presented at the annual conference of the Department of History Graduate Student Association, Florida International University, Miami, Florida.

Rivas, Eric. (2015) Book review of Terry Golway, Machine Made: Tammany Hall and The Creation of Modern American Politics (New York: Liveright (W.W. Norton), 2014) in Atlantic Millennium 13 (2014-15) 44-46.

Rivas, Eric. (March 2017). "Charles A. Dana's New York Sun and the Role of the Cuban Revolution on American Party Politics, 1869 - 1870." Paper presented at the annual conference of the Department of History Graduate Student Association, Florida International University, Miami, Florida. 